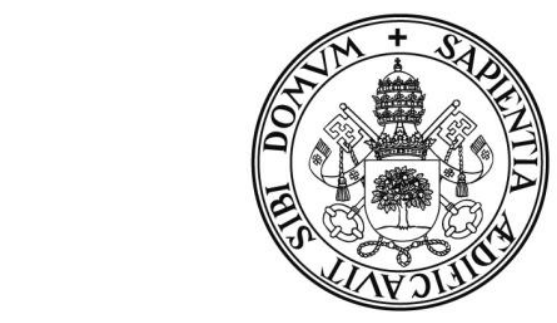

Universidad deValladolid

FACULTAD DE FILOSOFÍA Y LETRAS

DEPARTAMENTO DE GEOGRAFÍA

TESIS DOCTORAL:

\title{
La Interpretación del Patrimonio Geomorfológico en los Picos de Europa: una propuesta para su aprovechamiento didáctico y geoturístico
}

Presentada por Héctor Bazán para optar al grado de doctor por la Universidad de Valladolid

Dirigida por el Dr. Enrique Serrano Cañadas y la Dra. Purificación Ruíz Flaño 



\section{Agradecimientos}

La presente Tesis de Doctorado fue realizada gracias a una beca de movilidad EADIC II Erasmus Mundus. Es un esfuerzo en el cual, directa o indirectamente, participaron varias personas leyendo, opinando, corrigiendo, dando ánimo, teniéndome paciencia o acompañándome en los momentos de crisis como en los de felicidad.

De forma puntual quiero agradecer a mis directores de tesis, el Dr. Enrique Serrano Cañadas y la Dra. Purificación Ruiz Flaño, por haber confiado en mi voluntad de trabajo para realizar este estudio. Su constante guía de lecturas y enfoques, la exhaustiva corrección de todo el trabajo y la aportación de ideas, han hecho posible que haya llegado hasta aquí. Gracias por los conocimientos y el tiempo dedicados a mi formación, y por la paciencia y generosidad de su tutela hacia mi persona.

A mis dos familias, la biológica y la construida por los afectos encontrados durante mi estancia vallisoletana, porque han sabido estar en los momentos más críticos, procurándome cariño, compañía y ayuda, y sobre todo han vivido este proyecto casi con la misma ilusión que yo.

Al Departamento de Geografía de la Universidad de Valladolid por su colaboración para la realización de la presente investigación. 



\section{Índice general}

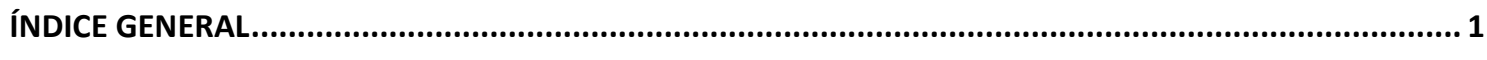

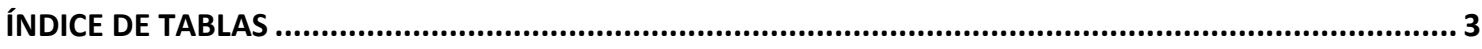

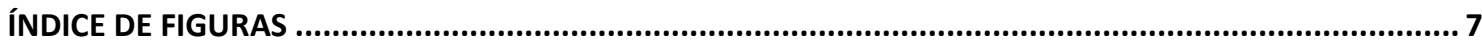

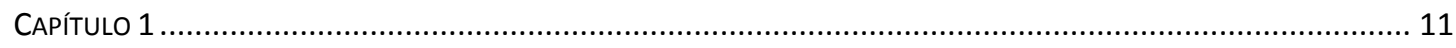

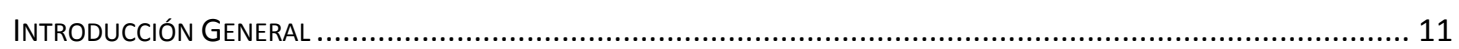

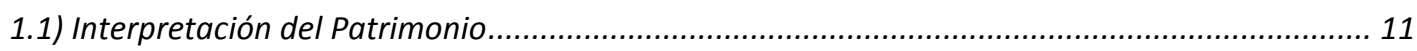

1.2) Lugares de interés geomorfológico................................................................................ 13

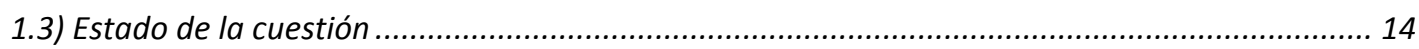

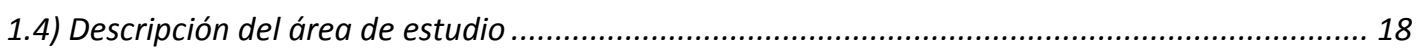

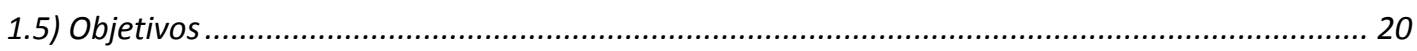

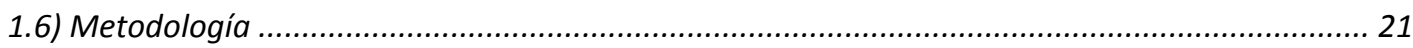

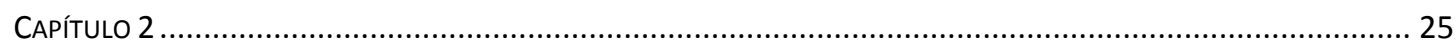

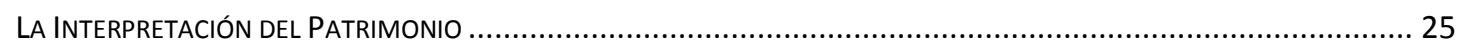

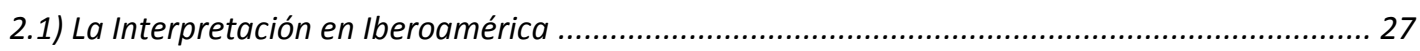

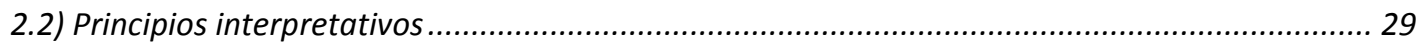

2.3) Características y elementos de una Interpretación exitosa ................................................. 37

2.4) Investigación sobre Interpretación .................................................................................... 42

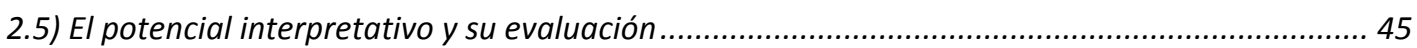

2.6) Los cambios en la definición de Interpretación del Patrimonio .............................................. 47

2.7) La importancia de la planificación en Interpretación. Modelos de planificación interpretativa 59

2.8) Técnicas y medios en Interpretación ................................................................................. 90

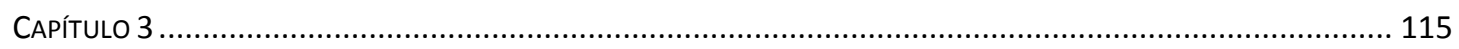

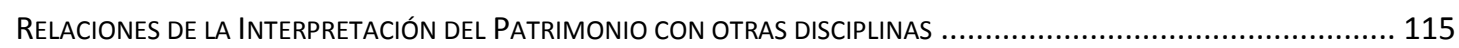

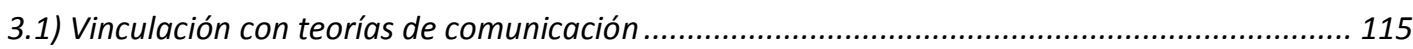

3.2) Vinculación con estudios cognitivos y conductuales.......................................................... 119

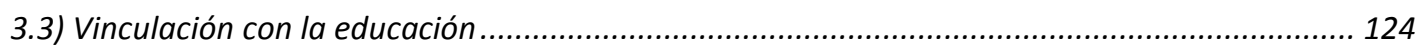

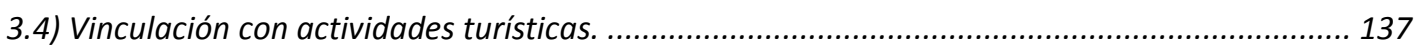

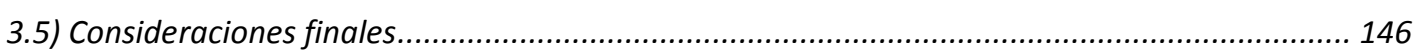

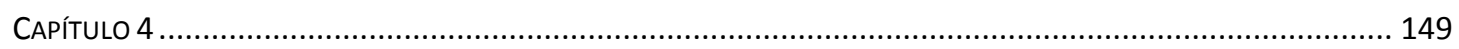

LUGARES DE INTERÉS GEOMORFOLÓGICO (LIGM) Y SU APROVECHAMIENTO DIDÁCTICO........................................ 149

4.1) Lugares de Interés Geomorfológico ................................................................................ 150

4.2) Evaluación de LIGm y de su aprovechamiento didáctico ...................................................... 152

4.3) Elaboración de fichas para la valoración didáctica de LIGm ................................................ 161

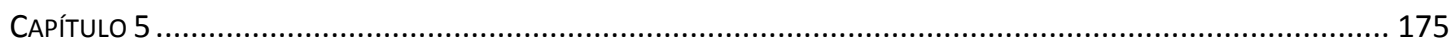

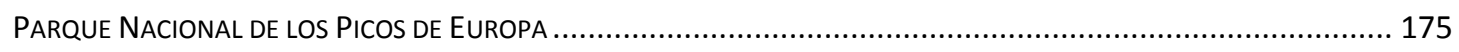

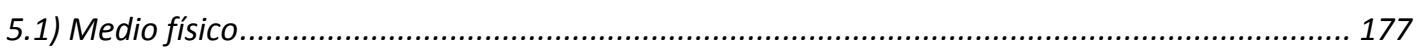

5.2) Picos de Europa como punto de atracción de visitantes................................................... 184

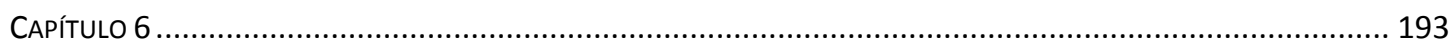

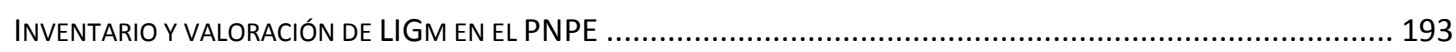

6.1) El método de valoración de LIGm utilizado en el Parque Nacional de los Picos de Europa ...... 194

6.2) Análisis de los LIGm de los Picos de Europa ................................................................... 201 
CAPÍTULO 7

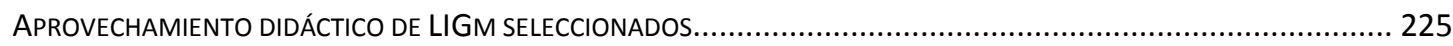

7.1) Selección de LIGm para su aprovechamiento didáctico y turístico ........................................... 225

7.2) Identificación de elementos y atributos tangibles en los LIGm seleccionados........................... 228

7.3) Elaboración de tópicos, temas y paneles interpretativos .................................................. 237

7.4) Propuestas para el uso didáctico y geoturístico de paneles y LIGm. .................................... 251

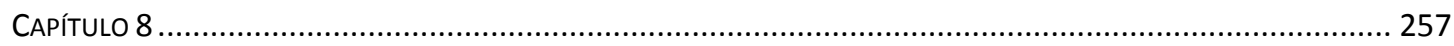

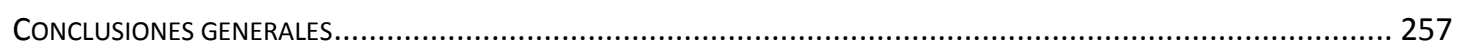

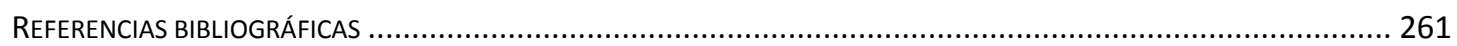

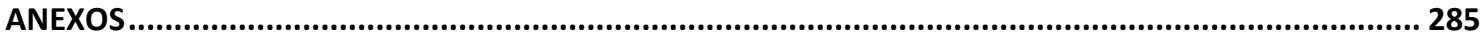

A.1) Currículos oficiales de Educación Primaria, ESO y Bachillerato de Asturias .......................... 287

A.2) Currículos oficiales de Educación Primaria, ESO y Bachillerato de Cantabria ......................... 291

A.3) Currículos oficiales de Educación Primaria, ESO y Bachillerato de Castilla y León .................... 296

A.4) Grados oficiales de la Universidad de Asturias relacionados con contenidos geomorfológicos.

A.5) Grados oficiales de la Universidad de Cantabria relacionados con contenidos geomorfológicos. 303

A.6) Grados oficiales de Universidades Públicas de Castilla y León relacionados con contenidos geomorfológicos. 304

A.7) Bibliografía de consulta sobre geomorfología glaciar...................................................... 306

A.8) Bibliografía de consulta sobre geomorfología periglaciar. ................................................... 313

A.9) Bibliografía de consulta sobre geomorfología exokárstica ................................................... 321

A.10) Fichas de LIGm de los Picos de Europa ............................................................................... 323

A.11) Fichas de valoración de LIGm de los Picos de Europa ...................................................... 373 


\section{Índice de Tablas}

Tabla 1. Tesis doctorales realizadas en España sobre Interpretación del Patrimonio 15

Tabla 2. Tesis doctorales realizadas en España sobre Patrimonio Geomorfológico del Parque Nacional de los Picos de Europa

Tabla 3. Correspondencia entre los principios enunciados por Tilden (2006) y Beck y Cable (1998) con elementos interpretativos.

Tabla 4. Correspondencia entre los principios enunciados por Beck y Cable (1998) y los GIFT mencionados por los mismos autores en 2011.

Tabla 5. Recomendaciones para elaborar mensajes interpretativos.................................................... 38

Tabla 6. Evolución de la investigación sobre Interpretación del Patrimonio. ........................................... 43

Tabla 7. Principales áreas de investigación en Interpretación del Patrimonio. ....................................... 44

Tabla 8. Matriz para la evaluación del potencial interpretativo.............................................................. 45

Tabla 9. Análisis de definiciones de Interpretación del Patrimonio y/o Ambiental. ................................... 54

Tabla 10. Interrogantes que guían el proceso de la planificación de tareas............................................. 59

Tabla 11. Esquema General de un Plan Maestro Interpretativo Escrito (Veverka, 1994)....................... 66

Tabla 12. Plan interpretativo propuesto por el Servicio de Parques Nacionales (NPS, 2000).................. 74

Tabla 13. Planificación y diseño de actividades interpretativas (Levy Hynes, 2002). ................................ 77

Tabla 14. Detalle de una matriz elaborada para un campo de producción forestal en la Patagonia

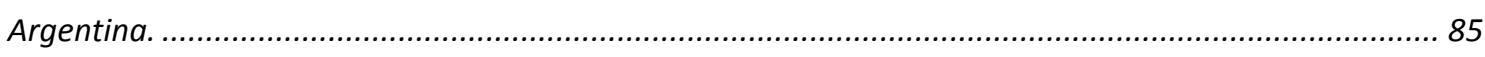

Tabla 15. Detalle de una matriz elaborada para inventariar tópicos. .................................................... 85

Tabla 16. Etapas de un plan interpretativo (Morales, 2007). ........................................................... 87

Tabla 17. Planificación de un programa interpretativo (Guerra et al., 2008)........................................ 88

Tabla 18. Características e investigaciones sobre medios interpretativos............................................ 91

Tabla 19. Tipos de senderos interpretativos .................................................................................. 94

Tabla 20. Principales ventajas y desventajas en el uso de paneles interpretativos. ..................................96

Tabla 21. Matriz para el análisis de paneles interpretativos. .............................................................. 100

Tabla 22. Análisis de panel interpretativo del Centro de Interpretación de Sotama (Parque Nacional de los Picos de Europa, España)................................................................................................................ 102

Tabla 23. Análisis de panel interpretativo en Parque Provincial Ischigualasto (Argentina). ................... 104

Tabla 24. Análisis de panel interpretativo en Colorado National Monument (Estados Unidos).............. 106

Tabla 25. Análisis de Panel informativo en Monumento Natural Puente del Inca (Argentina). ............. 108

Tabla 26. Análisis de panel informativo en sendero autoguiado de Murcia (España)........................... 110

Tabla 27. Análisis de panel interpretativo en el Centro de visitantes Pedro Pidal (Parque Nacional de los

Picos de Europa, España).................................................................................................................. 112

Tabla 28. Teorías de cambio conductual relacionadas con la Interpretación........................................... 119

Tabla 29. Diferencias y similitudes entre Didáctica del Patrimonio, Educación Ambiental e Interpretación

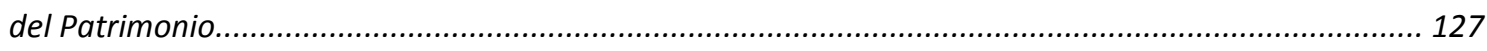

Tabla 30. Primer Principio Interpretativo y su relación con la educación. .............................................. 128

Tabla 31. Segundo Principio Interpretativo y su relación con la educación............................................. 130

Tabla 32. Tercer Principio Interpretativo y su relación con la educación................................................ 131

Tabla 33. Cuarto Principio Interpretativo y su relación con la educación............................................... 132

Tabla 34. Quinto Principio Interpretativo y su relación con la educación............................................... 134

Tabla 35. Sexto Principio Interpretativo y su relación con la educación................................................ 135 
Tabla 36. La Interpretación y el desarrollo infantil.

Tabla 37. Evolución de la relación entre el turismo y el ambiente....................................................... 137

Tabla 38. Términos relacionados al ecoturismo .................................................................................. 140

Tabla 39. Definiciones de Geoturismo. ............................................................................................. 142

Tabla 40. Definiciones de LIGm y términos similares....................................................................... 151

Tabla 41. Comparación de la valoración didáctica presente en métodos de valoración de lugares de interés geológico y/o geomorfológico.

Tabla 42. Instrumentos legales con los currículos oficiales de las Comunidades Autónomas seleccionadas.

Tabla 43. Ficha de valoración didáctica en Geomorfología de LIGm................................................... 165

Tabla 44. Criterios de valoración de factores condicionantes del aprendizaje de contenidos geomorfológicos en LIGm.

Tabla 45. Lista de planes de estudio consultados de las carreras de grado de Universidades Públicas de Asturias, Cantabria y Castilla y León.................................................................................................... 168

Tabla 46. Lista de la bibliografía consultada para el diseño de fichas de valoración. ............................. 169

Tabla 47. Ficha de valoración didáctica de geomorfología glaciar de montaña. ................................... 169

Tabla 48. Ficha valoración didáctica en geomorfología periglaciar en zona de montaña. ...................... 171

Tabla 49. Ficha de valoración didáctica en geomorfología exokárstica. ............................................... 173

Tabla 50. Entrada de visitantes al PNPE (2007-2012) según puntos de ingreso.................................... 186

Tabla 51. Entrada mensual de visitantes al PNPE (2007-2012) según puntos de ingreso. .................... 187

Tabla 52. Visitantes al PNPE con atención personalizada (VAP) 2008-2012. ....................................... 189

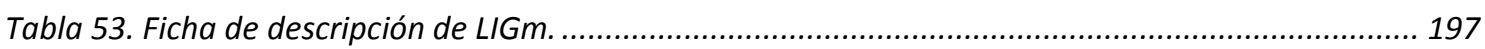

Tabla 54. Criterios de la valoración intrínseca.................................................................................... 198

Tabla 55. Puntuación total de la valoración intrínseca.......................................................................... 198

Tabla 56. Criterios de la valoración cultural o añadida. ................................................................... 198

Tabla 57. Puntuación total de la valoración cultural o añadida. ......................................................... 199

Tabla 58. Criterios de valoración de uso y gestión.......................................................................... 199

Tabla 59. Puntuación total de la valoración intrínseca...................................................................... 200

Tabla 60. LIGm de los tres macizos del Parque Nacional de los Picos de Europa. .................................. 203

Tabla 61. Resumen de las valoraciones de los LIGm de los tres macizos del PNPE................................. 204

Tabla 62. Valoraciones en orden descendente de los LIGm de los tres macizos del PNPE...................... 205

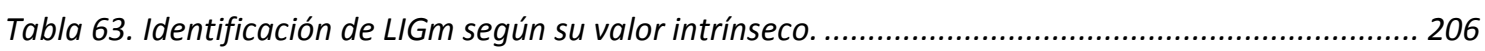

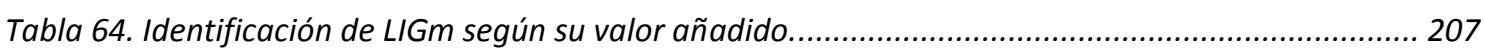

Tabla 65. Valoración de los aspectos del valor añadido según LIGm. ................................................... 207

Tabla 66. Identificación de LIGm según su valor de uso y gestión. ........................................................ 215

Tabla 67. Valoración de los aspectos del valor añadido según LIGm. ............................................... 215

Tabla 68. Identificación de LIGm según interrelación de valoraciones. ................................................. 222

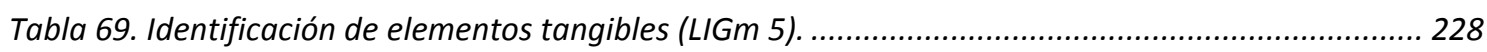

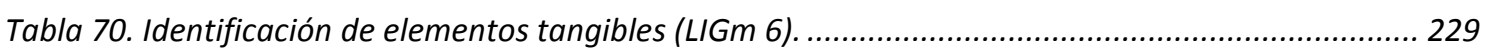

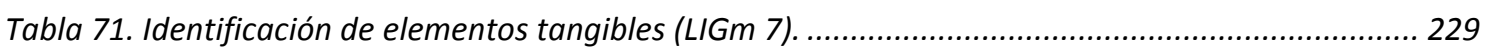

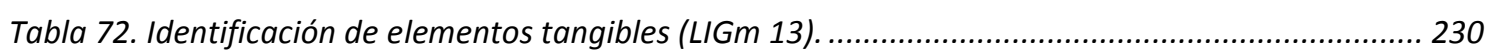

Tabla 73. Identificación de elementos tangibles (LIGm 14). ............................................................. 230

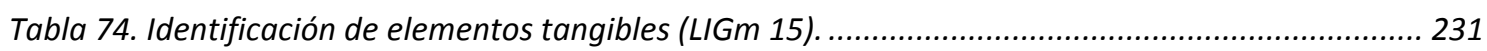

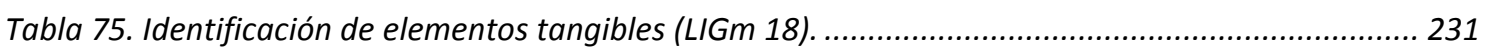

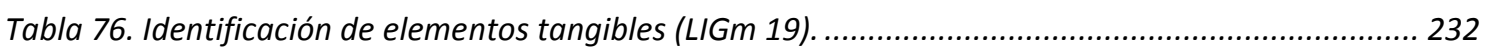

Tabla 77. Identificación de elementos tangibles (LIGm 26). ............................................................. 233

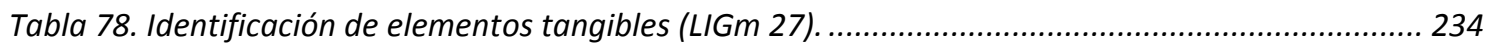


Tabla 79. Identificación de elementos tangibles (LIGm 31) 234

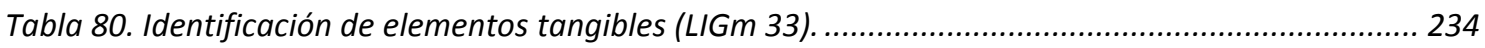

Tabla 81. Identificación de elementos tangibles (LIGm 34) ............................................................ 235

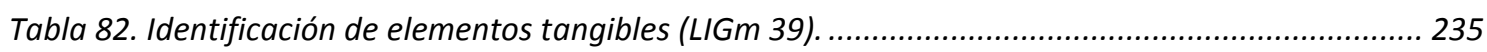

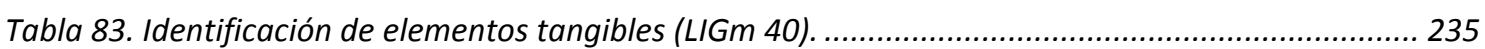

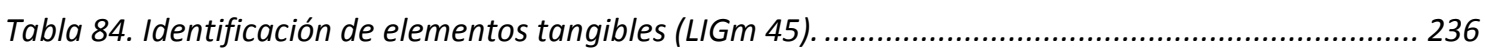

Tabla 85. Identificación de elementos tangibles (LIGm 46) ............................................................... 236

Tabla 86. Identificación de elementos tangibles (LIGm 49). .......................................................... 236

Tabla 87. Elaboración del tópico general, tópicos específicos y temas interpretativos en los LIGm

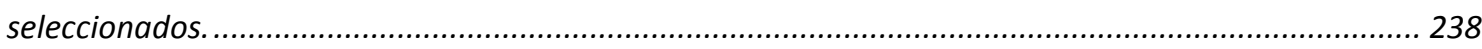

Tabla 88. Análisis de panel interpretativo sobre geomorfología kárstica. .......................................... 241

Tabla 89. Análisis de panel interpretativo sobre geomorfología periglaciar. ......................................... 245

Tabla 90. Análisis de panel interpretativo sobre geomorfología glaciar. ............................................ 250

Tabla 91. Relación de LIGm seleccionados para el uso didáctico y turístico con contenidos

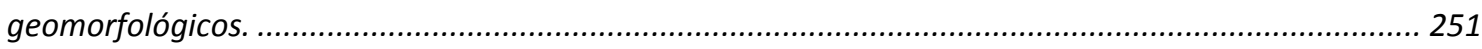

Tabla 92. Principales contenidos geológicos presentes en los currículos oficiales de Asturias de Educación

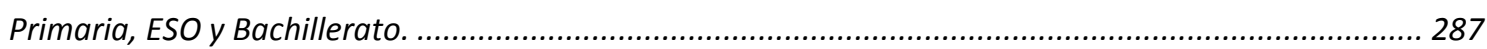

Tabla 93. Principales contenidos geológicos presentes en los currículos oficiales de Cantabria de Educación Primaria, ESO y Bachillerato............................................................................................ 291

Tabla 94. Principales contenidos geológicos presentes en los currículos oficiales de Castilla y León de Educación Primaria, ESO y Bachillerato.

Tabla 95. Principales contenidos geológicos y geomorfológicos presentes en grados oficiales de la Universidad de Asturias.

Tabla 96. Principales contenidos geológicos y geomorfológicos presentes en grados oficiales de la Universidad de Cantabria.

Tabla 97. Principales contenidos geológicos y geomorfológicos presentes en grados oficiales de la Universidad de Salamanca.

Tabla 98. Principales contenidos geológicos y geomorfológicos presentes en grados oficiales de la Universidad de León.

Tabla 99. Principales contenidos geológicos y geomorfológicos presentes en grados oficiales de la Universidad de Valladolid.

Tabla 100. Principales contenidos sobre geomorfología glaciar presentes en Gutiérrez, 2008 (Capítulo: Geomorfología glaciar I, p. 451-483).

Tabla 101. Principales contenidos sobre geomorfología glaciar presentes en Gutiérrez, 2008 (Capítulo: Geomorfología glaciar II, p. 485-515).

Tabla 102. Principales contenidos sobre geomorfología glaciar presentes en Gutiérrez, 2001. ............. 308

Tabla 103. Principales contenidos sobre geomorfología glaciar presentes en Pedraza, 1996. ............... 309

Tabla 104. Principales contenidos sobre geomorfología glaciar presentes en Sandoval, 1991.............. 311

Tabla 105. Principales contenidos sobre geomorfología glaciar presentes en Derruau, 1991. ............... 311

Tabla 106. Principales contenidos sobre geomorfología glaciar presentes en Tricart, 1963................... 312

Tabla 107. Principales contenidos sobre geomorfología periglaciar presentes en Gutiérrez, 2008. ....... 313

Tabla 108. Principales contenidos sobre geomorfología periglaciar presentes en Gutiérrez, 2001. ....... 314

Tabla 109. Principales contenidos sobre geomorfología periglaciar presentes en Pedraza, 1996. ......... 316

Tabla 110. Principales contenidos sobre geomorfología periglaciar presentes en Derruau, 1991.......... 317

Tabla 111. Principales contenidos sobre geomorfología periglaciar presentes en Washburn, 1973. ..... 317

Tabla 112. Principales contenidos sobre geomorfología periglaciar presentes en Tricart, 1963. ........... 320 
La Interpretación del Patrimonio Geomorfológico en los Picos de Europa: una propuesta para su aprovechamiento didáctico y geoturístico

Tabla 113. Principales contenidos sobre geomorfología kárstica presentes en Gutiérrez, 2008.

Tabla 114. Principales contenidos sobre geomorfología kárstica presentes en Gutiérrez, 2001. 322 


\section{Índice de Figuras}

Figura 1. Mapa del Parque Nacional de los Picos de Europa.

Figura 2. Diagrama descriptivo del abordaje de los objetivos del trabajo............................................ 20

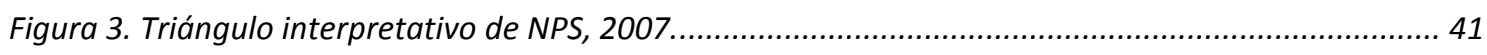

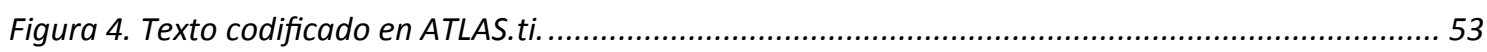

Figura 5. Análisis de definiciones. Respuestas a la pregunta ¿Qué es la Interpretación?........................ 55

Figura 6. Nube de palabras creada con la aplicación en línea Wordle, surgida de las definiciones analizadas.

Figura 7. Modelo de Comunicación para el Proceso de Planificación Interpretativa de Peart y Woods. .. 62

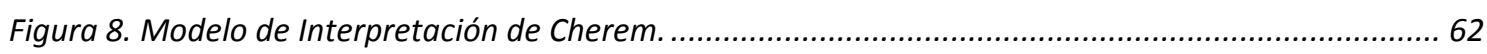

Figura 9. Fases de la planificación interpretativa de Bradley. ................................................................63

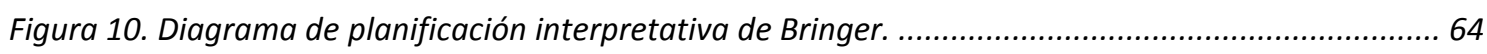

Figura 11. Diagrama de flujos del proceso de planificación interpretativa de Kuehn. .............................65

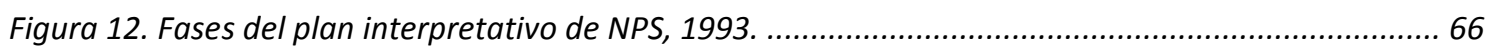

Figura 13. Plan Maestro de Interpretación de Veverka..........................................................................6 66

Figura 14. Modelo de Interpretación enfocado en la audiencia de Jacobson y Marynowski. .................. 70

Figura 15. Proceso de Planificación en Interpretación de ANZECC. ........................................................ 72

Figura 16. Modelo de los siete pasos de la comunicación ambiental de Castro (2002)............................ 76

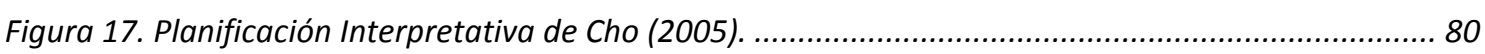

Figura 18. Trazado de recorridos interpretativos............................................................................. 94

Figura 19. Itinerario demarcado por rocas en el Parque Provincial Ischigualasto (Argentina). ............... 95

Figura 20. Medidas de seguridad para el uso de sendero en el Parque Los Terrones (Argentina). ........... 95

Figura 21. Panel con mensaje difícil de leer debido a condiciones climáticas (Murcia, España)............... 95

Figura 22. Panel interpretativo sobre un sendero del Parque Nacional de Yellowstone (EE.UU.) que provoca el uso del tacto................................................................................................................ 97

Figura 23. Panel que invita a descubrir "rostros en las rocas" en el Parque Nacional Paparoa (Nueva Zelanda).

Figura 24. Panel interpretativo del Centro de Interpretación de Sotama (Parque Nacional de los Picos de

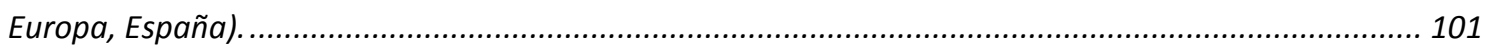

Figura 25. Detalle de figura 24. .................................................................................................... 101

Figura 26. Panel interpretativo en el Centro de Visitantes (Parque Provincial Ischigualasto, Argentina).

103

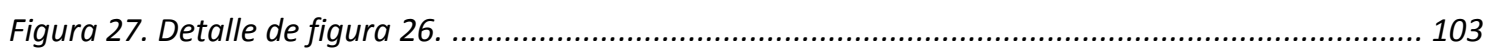

Figura 28. Panel interpretativo en Colorado National Monument (Estados Unidos). ............................ 105

Figura 29. Detalle de figura 28. ....................................................................................................... 105

Figura 30. Panel informativo en Monumento Natural Puente del Inca (Argentina).............................. 107

Figura 31. Detalle de figura 30. ................................................................................................... 107

Figura 32. Panel informativo en sendero autoguiado de Murcia (España). ...................................... 109

Figura 33. Detalle de figura 32. .................................................................................................... 109

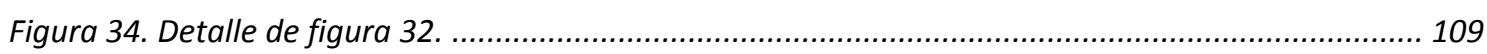

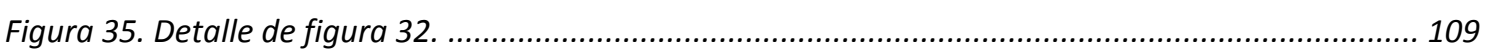

Figura 36. Panel interpretativo en el Centro de visitantes Pedro Pidal (Parque Nacional de los Picos de Europa, España). 
Figura 37. Detalle de figura 36.

Figura 38. Modelo general de comunicación................................................................................... 115

Figura 39. Modelo de comunicación de Jakobson. ............................................................................... 116

Figura 40. Modelo de comunicación de Shannon. ............................................................................... 117

Figura 41. Modelo de comunicación en Interpretación del Patrimonio................................................. 117

Figura 42. Modelo de comunicación de Eco..................................................................................... 118

Figura 43. Modelo de Probabilidad de Elaboración. .............................................................................. 121

Figura 44. Diagrama de la Teoría del Comportamiento Planificado..................................................... 122

Figura 45. Relación de los tres tipos de creencias, su interrelación y su comportamiento posterior, según

la Teoría del Comportamiento Planificado. ....................................................................................... 123

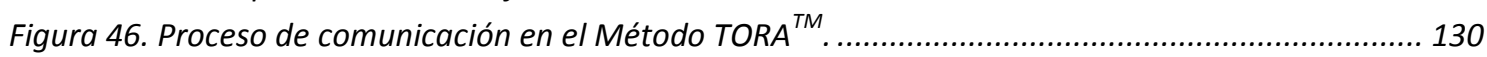

Figura 47. Proceso de comunicación en el acto didáctico.................................................................... 130

Figura 48. Relaciones entre los componentes del triángulo didáctico................................................. 133

Figura 49. Evolución del concepto de Turismo Sostenible. ............................................................. 138

Figura 50. Relación del turismo sostenible con términos similares. ..................................................... 139

Figura 51. Modalidades del mercado turístico según la Organización Mundial del Turismo. ................. 139

Figura 52. El Geoturismo y su relación con formas de turismo "natural" y "cultural". ........................... 144

Figura 53. Relaciones del Geoturismo y otras formas de turismo. ................................................... 144

Figura 54. El lugar del Geoturismo en el Turismo Sostenible .......................................................... 145

Figura 55. Relaciones entre procesos, formas y relieve. .................................................................... 162

Figura 56. Aspectos integrantes de la valoración didáctica en Geomorfología de LIGm....................... 165

Figura 57. Mapa del Parque Nacional de la Montaña de Covadonga. .................................................. 175

Figura 58. Mapa del PNPE, en rojo el área del Parque en 1918. ............................................................ 176

Figura 59. Imagen de Google Earth de los macizos de Picos de Europa. .............................................. 177

Figura 60. Perfil de los macizos de Picos de Europa.......................................................................... 177

Figura 61. Macizos del Parque Nacional de los Picos de Europa. ........................................................ 178

Figura 62. EI Naranjo de Bulnes es un punto de referencia del PNPE. ................................................ 179

Figura 63. Bloque tectónico tridimensional de la región de los Picos de Europa.................................. 180

Figura 64. Reconstrucción de los sistemas glaciares del Macizo Central durante la etapa de máxima expansión de los hielos. .................................................................................................................. 181

Figura 65. Efectos del modelado glaciar en la zona de los lagos de Covadonga................................... 182

Figura 66. Afluencia de visitantes a la Red de Parques Nacionales y al PNPE (2007- 2012).................. 185

Figura 67. Afluencia de visitantes a la Red de Parques Nacionales (España) en 2012. .......................... 185

Figura 68. Puntos de entrada de visitantes al PNPE. ............................................................................. 186

Figura 69. Entrada de visitantes al PNPE (2007-2012) según puntos de ingreso. ............................... 187

Figura 70. Entrada mensual de visitantes al PNPE (2007-2012)........................................................ 188

Figura 71. Centro de visitantes Pedro Pidal. ....................................................................................... 189

Figura 72. Centro de visitantes del Parque en Sotama. ................................................................. 189

Figura 73. Distribución de tipos de visitantes al PNPE. ........................................................................ 190

Figura 74. El refugio de Cabaña Verónica constituye un punto de referencia para montañeros y excursionistas del Parque............................................................................................................... 190

Figura 75. Metodología de análisis de los LIGm en Espacios Naturales Protegidos. ............................... 196

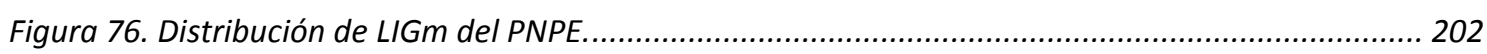

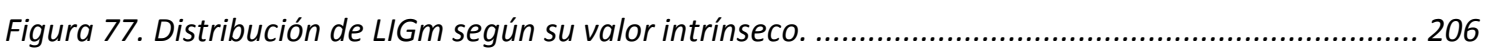

Figura 78. Distribución de LIGm según su valor añadido................................................................ 207

Figura 79. Distribución de LIGm según su valor en el criterio "Paisajística y estética"........................... 209 
Figura 80. Distribución de LIGm según su valor en el criterio "Asociación a elementos de valor patrimonial". 210

Figura 81. Distribución de LIGm según su valor en el criterio "Contenido cultural". .............................. 210

Figura 82. Distribución de LIGm según su valor en el criterio "Contenido histórico"............................. 211

Figura 83. Distribución de LIGm según su valor en el criterio "Recursos pedagógicos". ......................... 211

Figura 84. Distribución de LIGm según su valor en el criterio "Niveles pedagógicos". ............................ 212

Figura 85. Distribución de LIGm según su valor en el criterio "Valor científico"...................................... 212

Figura 86. Distribución de LIGm según su valor en el criterio "Representatividad científica"................ 213

Figura 87. Distribución de LIGm según su valor en el criterio "Contenidos turísticos reales".................. 213

Figura 88. Distribución de LIGm según su valor en el aspecto "Atractivo turístico (potencial)".............. 214

Figura 89. Distribución de LIGm según su valor de uso y gestión. ......................................................... 215

Figura 90. Distribución de LIGm según su valor en el aspecto "Accesibilidad"....................................... 217

Figura 91. Distribución de LIGm según su valor en el aspecto "Fragilidad"......................................... 218

Figura 92. Distribución de LIGm según su valor en el criterio "Vulnerabilidad". ................................... 218

Figura 93. Distribución de LIGm según su valor en el criterio "Intensidad de uso"............................... 219

Figura 94. Distribución de LIGm según su valor en el aspecto "Riesgo de degradación". ...................... 219

Figura 95. Distribución de LIGm según su valor en el criterio "Estado de conservación". ....................... 220

Figura 96. Distribución de LIGm según su valor en el criterio "Impactos".............................................. 220

Figura 97. Distribución de LIGm según su valor en el criterio "Condiciones de observación".................. 221

Figura 98. Distribución de LIGm según su valor en el criterio "Límites de cambios aceptables". ............ 221

Figura 99. Valoración de LIGm según aspectos seleccionados (Macizo Central)...................................226

Figura 100. Valoración de LIGm según aspectos seleccionados (Macizo Oriental). .............................. 226

Figura 101. Valoración de LIGm según aspectos seleccionados (Macizo Occidental). ........................... 227

Figura 102. Vista Panorámica del Complejo glaciar de Fuente Dé-Pido............................................... 229

Figura 103. Ubicación del Desfiladero o Garganta del Cares................................................................. 230

Figura 104. Vista general del tramo medio e inferior de la canal de Dobresengos. .............................. 231

Figura 105. Conos y taludes de la Vueltona (parte central de la imagen). ........................................... 232

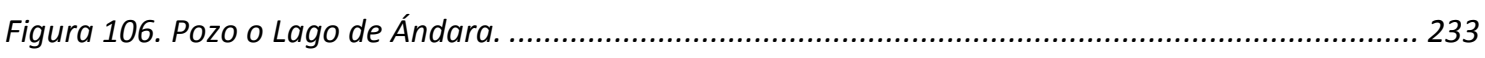

Figura 107. Vista del Polje de Comeya..................................................................................................... 236

Figura 108. Avalancha de rocas en los escarpes que limitan el lago de la Ercina por el este................ 237

Figura 109. Boceto de panel interpretativo sobre geomorfología kárstica. ........................................ 239

Figura 110. Borrador de panel interpretativo sobre Geomorfología kárstica. ..................................... 239

Figura 111. Panel interpretativo sobre geomorfología kárstica. ........................................................ 241

Figura 112. Boceto de panel interpretativo sobre geomorfología periglaciar....................................... 243

Figura 113. Borrador de panel interpretativo sobre Geomorfología periglaciar.................................. 243

Figura 114. Panel interpretativo sobre geomorfología periglaciar..................................................... 245

Figura 115. Boceto de panel interpretativo sobre Geomorfología glaciar. ........................................ 247

Figura 116. Borrador de panel interpretativo sobre Geomorfología glaciar. ...................................... 247

Figura 117. Panel interpretativo sobre Geomorfología glaciar. ...................................................... 249

Figura 118. Localización de LIGm del PNPE según tópicos geomorfológicos.......................................... 253

Figura 119. Folleto del PNPE con promoción de rutas guiadas............................................................ 254

Figura 120. Señalización y panel informativo sobre rutas de senderismo en el PNPE........................... 255 
La Interpretación del Patrimonio Geomorfológico en los Picos de Europa: una propuesta para su aprovechamiento didáctico y geoturístico 


\section{Capítulo 1 \\ Introducción General}

La investigación que se presenta como Tesis Doctoral, La Interpretación del Patrimonio Geomorfológico en los Picos de Europa: una propuesta para su aprovechamiento didáctico y geoturístico, está dirigida por el Dr. Enrique Serrano Cañadas y la Dra. Purificación Ruiz Flaño, y se encuentra vinculada al Departamento de Geografía de la Universidad de Valladolid a través del Programa de Doctorado Geografía y Ordenación del Territorio.

El Grupo de Investigación Reconocido PANGEA (Patrimonio Natural y Geografía Aplicada) ha constituido un importante marco de referencia para la presente investigación, que se adscribe a las siguientes líneas de trabajo:

- Patrimonio Natural y Geodiversidad en medios de montaña: geomorfología y cartografía en Espacios Naturales Protegidos.

- Evaluación y valoración de Lugares de Interés Natural (LIN) y Patrimonial. Metodologías para el inventario y valoración de elementos del patrimonio natural, en particular LIGm.

- Gestión y ordenación de espacios naturales protegidos y del Patrimonio Natural.

- Valoración y puesta en valor del Patrimonio Natural.

- Análisis y cartografía de la Geodiversidad como herramienta de gestión y ordenación.

Este trabajo de investigación se centra en el análisis de las relaciones $e$ interdependencias entre la Interpretación del Patrimonio como herramienta de comunicación y gestión de sitios patrimoniales, las formas sostenibles de turismo en espacios naturales y el patrimonio geomorfológico como recurso educativo y turístico, cuestiones que serán tratadas en los diferentes capítulos de la tesis doctoral.

\section{1) Interpretación del Patrimonio}

Actualmente es definida como un proceso creativo de comunicación estratégica que ayuda a conectar intelectual y emocionalmente al visitante con los significados del recurso patrimonial visitado, para que lo aprecie y disfrute (Morales, 2008). Nacida en parques naturales de Estados Unidos, hasta mediados de los años 80 del siglo pasado se llamó interpretación ambiental porque explicaba los fenómenos naturales que sucedían en su 
interior; luego se llamó Interpretación del Patrimonio para incluir a las producciones de la Humanidad, expresión que se consolida a partir de la celebración en 1985 del Primer Congreso Mundial de Interpretación del Patrimonio, en Banff, Canadá (Morales, 1998a, 2008; Guerra, 2006; Monteserín, 2008). La esencia de la interpretación estriba en el mensaje, en cómo se redacte o cómo se presente al público, aunque el medio de comunicación utilizado y el entorno también juegan un papel importante. El mensaje representa el nexo de unión entre el visitante y el recurso que está siendo objeto de interpretación.

Esta disciplina presenta claros vínculos con teorías de la comunicación, la educación, la psicología de la conducta y el turismo. Por ejemplo, su relación con el campo comunicacional se estableció al utilizar el modelo clásico de la comunicación, al existir un mensaje, un emisor y un receptor. Según este modelo, para asegurar que el mensaje sea bien recibido, se optimiza la comunicación interpretativa. La incorporación de la semiótica en el estudio de la comunicación implicó nuevas aportaciones para la práctica interpretativa. Este nuevo paradigma en la comunicación se preocupa principalmente del proceso de descodificación del receptor, en el que existe una diversidad de subcódigos (ideológico, estético, afectivo, etc.) que inciden en dicho proceso (Eco, 1977). Esta manera de concebir el acto comunicativo tiene especial incidencia en la Interpretación del Patrimonio, ya que presenta nuevos fundamentos teóricos para las prácticas interpretativas.

Esta concepción como un proceso de comunicación ha permitido que se aprovecharan los avances de la psicología cognitiva y del comportamiento para examinar las causas y los efectos que ocurrirían si la interpretación resultase exitosa (Ham, 2009b). Diversos trabajos relacionan las implicaciones del conocimiento como proceso cognitivo, la comprensión de la conducta individual y su influencia en el comportamiento de un grupo en la interpretación (Cacioppo y Petty 1983; Orams, 1995; Petty et al., 2009). Por ejemplo, cuando la interpretación provoca el pensamiento de una persona, se genera un conflicto cognitivo que, a su vez, produce nuevas creencias afectando a las ideas previas, ya sea para ser reforzadas o cambiadas.

La Interpretación inicialmente fue considerada una actividad educativa, pero tal calificativo se prestó a confusiones desde un comienzo, ya que en los países anglosajones lo educativo se relaciona con estudiantes. Más tarde, Tilden (considerado el padre de la Interpretación del Patrimonio) reconoció este hecho, comentando que si emprendiera una revisión de su libro Interpreting our Heritage definiría a la interpretación como una actividad recreativa, pues define mejor el contexto de la interpretación (Morales, 2008). Más allá de esto, diferentes trabajos evidencian las conexiones con procesos de enseñanza/aprendizaje en 
general o con la educación ambiental en particular (Knapp, 2005; Cable y Cadden, 2006; Bazán, 2013a).

Al concepto de Interpretación Patrimonial se vinculan otros términos como difusión, divulgación o didáctica del patrimonio. Cuenca (2002), por ejemplo, afirma que la difusión o divulgación se refiere a los procesos a través de los cuales se comunican y se ponen en conocimiento los elementos patrimoniales a un conjunto de personas. Para este mismo autor, se recurriría a la didáctica para fundamentar de manera teórico-práctica proyectos de difusión patrimonial. Tal socialización del patrimonio (divulgación, difusión, didáctica) pasa a denominarse interpretación cuando permite que el visitante conecte de manera intelectual y emocional con los significados inherentes al recurso patrimonial (Morales, 2008). Por su parte, Mateos (2008) considera que las técnicas interpretativas constituyen una de las alternativas que existen para la difusión cultural del Patrimonio, componiendo una situación intermedia entre la didáctica y la divulgación del Patrimonio.

Finalmente, para diversos autores (Benton, 2009; Ruiz, 2010; Mendoza-Ontiveros et al., 2011; Martín Hernanz, 2012) son evidentes las relaciones de la interpretación patrimonial con el turismo, ya que el turista enriquece su experiencia gracias a un buen conocimiento del lugar que visita, y el emisor, a través de una buena comunicación, mejora la calidad de su producto.

\section{2) Lugares de interés geomorfológico}

Existen varios conceptos del campo de las Ciencias de la Tierra que hacen referencia a la importancia geomorfológica de un lugar y al que puede vincularse con el cuidado y difusión del patrimonio. Uno de ellos es el de lugares de interés geomorfológico. Serrano y González Trueba (2005) reconocen como Lugares de Interés Geomorfológico (en adelante LIGm) a todos aquellos elementos o lugares geomorfológicos de interés, inventariables, caracterizables y valorables desde un punto de vista científico, cultural y de uso y gestión. Su valoración y evaluación requiere el conocimiento de sus valores intrínsecos (contenido científico), de su vulnerabilidad al cambio derivada de su funcionalidad, dinámica natural, usos e impactos sobre él, de sus valores añadidos (contenido cultural), de la relación con el territorio en el que está inserto, y de la importancia escalar, relativa y absoluta (González Trueba y Serrano, 2008). Por lo tanto son los atributos presentes en estas formas de modelado y relieve los que le dan valor y permiten que sea declarado de valor geomorfológico. Lacreu (2003) aborda el concepto de Recursos Geoambientales, el cual incluye y potencia el de Patrimonio Geomorfológico porque incorpora las relaciones entre la sociedad y los elementos constituyentes de dicho patrimonio, 
estableciendo con mayor énfasis el estudio acerca del espacio (superficie) ocupado por el hombre en sus diversas actividades, los procesos actuales naturales y/o antrópicos actuantes y los riesgos asociados.

Inicialmente el concepto de LIGm podía ser considerado inserto en otros términos (geositios, geotopos, lugares de interés geológico, puntos de interés geológico, entre otros). Sin embargo Panizza (2001) planteó la necesidad de diferenciarlos de aquéllos cuyo interés es puramente geológico. De este modo, los geomorfositios son, según este autor, una forma de relieve a la cual se le puede atribuir un valor de tipo científico, ecológico, cultural, estético y/o socioeconómico.

La protección del patrimonio en general, y del geomorfológico en particular, debe hacerse procurando su conservación, pero también buscando el desarrollo sostenible y su utilidad para la sociedad. En ese sentido la mayoría de los métodos de valoración de LIGm proponen tres grupos de usos para el patrimonio geológico o geomorfológico: científico, educativo y turístico. Para el inventario y valoración de LIGm de esta investigación, se utilizará la propuesta de Serrano y González Trueba (2005), conocido como el método de Valladolid (Reynard, 2009).

\section{3) Estado de la cuestión}

Para realizar un primer contacto con el estado de la cuestión en España, se consultó en la Base de datos de Tesis Doctorales (TESEO) del Ministerio de Educación y bibliotecas de las Universidades, con el fin de identificar los trabajos cuya temática principal de investigación fuera la Interpretación del Patrimonio presentados a la fecha de inicio de esta tesis (junio de 2011), y que aportaran información actualizada sobre esta temática (Tabla 1). Inicialmente esto resultó infructuoso, ya que las dos primeras tesis de Doctorado en España que tuvieron como tema principal a la Interpretación del Patrimonio se presentaron en noviembre y diciembre de ese año. Igualmente, se han identificado tesis doctorales (González Méndez, 1999; Cuenca, 2002; Monteserín, 2007) que presentan aportaciones sobre la Interpretación del Patrimonio, pero las mismas resultan breves apartados y aproximaciones a la temática, por lo que difieren respecto al planteamiento del presente estudio en cuanto a su alcance teórico o desarrollo metodológico. 
Tabla 1. Tesis doctorales realizadas en España sobre Interpretación del Patrimonio.

\begin{tabular}{|c|c|c|c|c|}
\hline Título & Autor/a & Universidad & Departamento & $\begin{array}{l}\text { Fecha de } \\
\text { lectura }\end{array}$ \\
\hline $\begin{array}{l}\text { La presentación e } \\
\text { interpretación del patrimonio } \\
\text { arqueológico in situ. Los } \\
\text { yacimientos arqueológicos } \\
\text { visibles en España. }\end{array}$ & $\begin{array}{l}\text { López- } \\
\text { Menchero } \\
\text { Bendicho, } \\
\text { Víctor Manuel }\end{array}$ & $\begin{array}{l}\text { Castilla-La } \\
\text { Mancha }\end{array}$ & Historia & $24 / 11 / 2011$ \\
\hline $\begin{array}{l}\text { Las técnicas interpretativas en } \\
\text { la enseñanza de la geología de } \\
\text { campo con énfasis ambiental. }\end{array}$ & $\begin{array}{l}\text { Pastor } \\
\text { Gascón, } \\
\text { Emerenciana }\end{array}$ & Illes Balears & $\begin{array}{l}\text { Pedagogía aplicada } \\
\text { y psicología de la } \\
\text { educación }\end{array}$ & $09 / 12 / 2011$ \\
\hline $\begin{array}{l}\text { Identidad en tránsito. La } \\
\text { interpretación cultural y la } \\
\text { puesta en valor del patrimonio } \\
\text { intangible. }\end{array}$ & $\begin{array}{l}\text { Portillo } \\
\text { Stephens, } \\
\text { Chantal Marie }\end{array}$ & $\begin{array}{l}\text { Las Palmas de } \\
\text { Gran Canaria }\end{array}$ & Filología Moderna & $28 / 04 / 2012$ \\
\hline $\begin{array}{l}\text { La Interpretación del } \\
\text { Patrimonio como herramienta } \\
\text { de sostenibilidad turística en } \\
\text { áreas rurales. }\end{array}$ & $\begin{array}{l}\text { Martín } \\
\text { Hernanz, Iris }\end{array}$ & $\begin{array}{l}\text { Autónoma de } \\
\text { Madrid }\end{array}$ & Geografía & $04 / 05 / 2012$ \\
\hline
\end{tabular}

En el momento de finalizar la presente investigación, se habían presentado en España cuatro tesis doctorales con la Interpretación del Patrimonio como línea principal de investigación. Dos de ellas abordaron esta temática desde una perspectiva asociada al Patrimonio Cultural intangible (Portillo Stephens, 2012) y arqueológico (López-Menchero Bendicho, 2011). Las otras dos investigaciones conectaron esta disciplina con el turismo sostenible de zonas rurales (Martín Hernanz, 2012) y el ámbito educativo (Pastor Gascón, 2011).

La causa de la escasez de tesis doctorales sobre esta temática puede asociarse a que se trata de una disciplina muy joven en el mundo académico hispanohablante. Dentro del material bibliográfico en castellano puede mencionarse:

Interpretación Ambiental. Una guía práctica para gente con grandes ideas y presupuestos pequeños (Ham, 1992). Presenta una variada colección de técnicas de comunicación de bajo costo y elevada utilidad para interpretadores y educadores ambientales. Un conjunto de estudios de casos que muestran cómo se han aplicado en diferentes lugares las técnicas presentadas en el libro, enriquecen unas sugerencias que resultan muy claras y prácticas.

Guía Práctica para la Interpretación del patrimonio. El arte de acercar el legado natural y cultural al público visitante (Morales, 1998a). Abarca cuestiones teóricas esenciales para el desarrollo de métodos para comunicar el patrimonio cultural y natural a personas en su tiempo libre y revisa aspectos profesionales de la disciplina interpretativa. 
La interpretación de nuestro patrimonio (Tilden, 2006). Esta traducción al castellano de la obra original del autor de 1957 por parte de la Asociación para la Interpretación del Patrimonio de España, constituye una guía básica en la capacitación y preparación en Interpretación del Patrimonio. "Interpreting Our Heritage" sentó las bases de esta actividad y brindó una aproximación tangible a la presentación del patrimonio.

Interpretación y Educación Ambiental en Áreas Naturales Protegidas (INRENA, 2006). Documento técnico del Instituto Nacional de Recursos Naturales de Perú para el desarrollo de la Educación Ambiental y de la Interpretación, especialmente enfocado a la actividad de guardaparques de las áreas naturales protegidas de aquel país sudamericano.

La Interpretación del Patrimonio en Argentina. Estrategias para conservar y comunicar nuestros bienes naturales y culturales (Fernández Balboa-Coord. -, 2007). Este libro, editado por la Administración de Parques Nacionales de Argentina, compendia conocimientos, experiencias y sugerencias para el desarrollo profesional de la Interpretación del Patrimonio en ese país, desde actividades museísticas hasta aquellas que se realizan en los Parques Nacionales.

Interpretación del Patrimonio. Diseño de programas de ámbito municipal (Guerra et al., 2008). Esta obra proporciona ideas básicas sobre las posibilidades de la Interpretación y orientaciones metodológicas para la planificación, implementación y evaluación de programas interpretativos que aporten solución al deterioro del patrimonio natural y cultural asociado al desarrollo turístico en el ámbito de los municipios.

Guías técnicas de proyectos de ecoturismo: Guía de Interpretación del Patrimonio Natural y Cultural (Lazo Cruz y Arróspide Tehuay, 2011). Además de una breve introducción al concepto de Interpretación del Patrimonio, esta guía del Ministerio de Comercio Exterior y Turismo de Perú presenta métodos y herramientas interpretativas para el fortalecimiento del ecoturismo en la Región San Martín (Perú) como un modelo de negocio sostenible.

La interpretación del patrimonio natural y cultural. Una visión intercultural y participativa (Moreira-Wachtel y Trellez Solis, 2013). Este manual repasa cuestiones teóricas y prácticas sobre la temática, poniendo énfasis en acciones realizadas en el ámbito de la interculturalidad y la inclusión social en los procesos y recursos de la educación, comunicación e interpretación ambiental, particularmente a través de talleres participativos.

Las obras de Ham (1992), Morales (1998a) y Tilden (2006) son consideradas las principales referencias teóricas y prácticas en castellano en materia de interpretación; mientras que las otras, más actuales, focalizan su presentación de la Interpretación en un aspecto concreto (áreas naturales protegidas, turismo sostenible de áreas municipales). 
En el ámbito internacional, algunas de las tesis sobre interpretación del Patrimonio analizaron los principios interpretativos en espacios naturales protegidos (Chen, 2003), presentando modelos de planificación para tales espacios (Cho, 2005), diseñando actividades turísticas (Saipradist, 2005; Moreira, 2008) o demostrando la efectividad de la interpretación del patrimonio para reducir el impacto de los visitantes (Littlefair, 2003).

En conclusión, nos encontramos ante una línea de investigación novedosa y escasamente desarrollada en España a nivel de tesis de doctorado, con los condicionantes que ello trae aparejado, como la falta de una sustentación teórica y práctica consolidada. Por ello la presente tesis doctoral pretende contribuir a reducir las carencias en el panorama investigador hispanohablante de esta disciplina.

Respecto a la investigación sobre los lugares de interés geomorfológico del Parque Nacional de los Picos de Europa, ésta es un tema abordado en dos tesis doctorales hasta la fecha (Tabla 2). El trabajo de González Trueba (2007) analiza 22 geositios del Macizo Central de los Picos de Europa a través de un método de valoración triple (valor intrínseco, añadido y de uso y gestión); mientras que la investigación de Fuertes Gutiérrez (2013) realiza una valoración de LIGm de la provincia de León (afectando una pequeña porción del Macizo Occidental) evaluando, por un lado, el valor intrínseco y la potencialidad de uso, y por el otro, el riesgo de degradación.

Tabla 2. Tesis doctorales realizadas en España sobre Patrimonio Geomorfológico del Parque Nacional de los Picos de Europa.

\begin{tabular}{|l|l|l|l|l|}
\hline \multicolumn{1}{|c|}{ Título } & \multicolumn{1}{|c|}{ Autor/a } & Universidad & Departamento & \multicolumn{1}{c|}{$\begin{array}{c}\text { Fecha de } \\
\text { lectura }\end{array}$} \\
\hline $\begin{array}{l}\text { El macizo central de los Picos } \\
\text { de Europa: geomorfología y sus } \\
\text { implicancias geoecológicas en } \\
\text { la alta montaña cantábrica. }\end{array}$ & $\begin{array}{l}\text { González } \\
\text { Trueba, Juan } \\
\text { José }\end{array}$ & Cantabria & $\begin{array}{l}\text { Geografía, } \\
\text { Urbanismo y } \\
\text { Ordenación del } \\
\text { Territorio }\end{array}$ & $12 / 01 / 2007$ \\
\hline $\begin{array}{l}\text { Patrimonio geológico y } \\
\text { ordenación del territorio. } \\
\text { Implicación en la gestión de } \\
\text { espacios naturales protegidos. }\end{array}$ & $\begin{array}{l}\text { Fuertes } \\
\text { Gutiérrez, Inés }\end{array}$ & León & $\begin{array}{l}\text { Biodiversidad y } \\
\text { gestión } \\
\text { ambiental }\end{array}$ & $17 / 05 / 2013$ \\
\hline \begin{tabular}{l} 
Fuente: elaboración propia. \\
\hline
\end{tabular} & & & \\
\hline
\end{tabular}

Existen inventarios parciales de LIGm de Picos de Europa, tanto del Macizo Central (Serrano y González Trueba, 2005; González Trueba 2007a) como del Oriental (González Trueba y Serrano, 2010a), o del Occidental (Fuertes y Fernández, 2010; Gómez Lende et al., 2011), en los que ya existen clasificaciones y valoraciones previas a distintas escalas y con diferentes objetivos. Sin embargo, en los dos últimos macizos, los trabajos se limitan al inventariado de elementos y someras clasificaciones, sin que exista una valoración de los LIGm que permita su 
estudio desde otras ópticas de interés, como la didáctica o el geoturismo. Estos inventarios y descripciones se han revisado e incorporado a esta valoración.

De acuerdo a lo anterior, se observa que esta línea de investigación no presenta muchos antecedentes a nivel de tesis doctorales, sumado a que los mismos hicieron la valoración parcial de los LIGm del Parque Nacional de los Picos de Europa, ya que uno de los trabajos evaluó el Macizo Central, mientras que el otro ejemplo mencionado registró los geositios de una porción del Macizo Occidental. En este trabajo se hará el inventario y la valoración de los LIGm de los tres macizos que integran el Parque Nacional y su posterior análisis para un aprovechamiento didáctico y geoturístico.

\section{4) Descripción del área de estudio}

La zona de estudio del trabajo coincide con el área del Parque Nacional de los Picos de Europa. Este espacio natural protegido fue declarado en 1995 y ocupa 64.660 has. en el Norte de la Península Ibérica, siendo la ampliación del Parque Natural de la Montaña de Covadonga, creado en 1918. Es el primer Parque Nacional español y el único gestionado por tres comunidades autónomas: Principado de Asturias, Cantabria y Castilla y León (Figura 1).

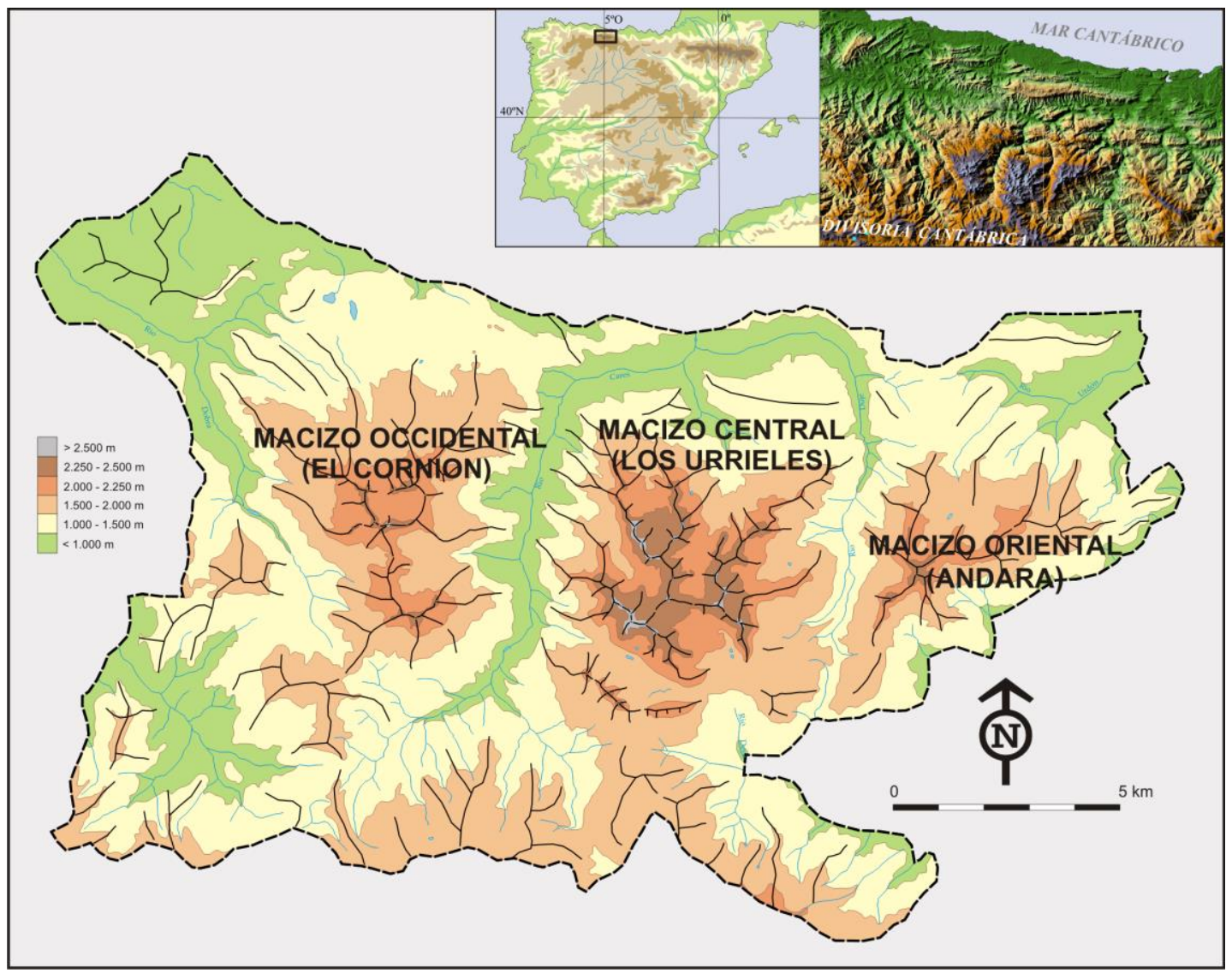

Figura 1. Mapa del Parque Nacional de los Picos de Europa.

Fuente: González Trueba, 2006. 
Las áreas protegidas constituyen de por sí espacios que resultan de gran atractivo para el público en general, más aún para aquellos que disponen de tiempo libre. Una de las funciones de estas áreas, además de conservar el patrimonio cultural y/o natural que le da existencia, es la de difundir, comunicar y dar a conocer tal patrimonio. En los últimos años las técnicas de Interpretación del Patrimonio se constituyeron en herramientas válidas y probadas para comunicar al público que visita un espacio patrimonial.

Los valores abióticos del Parque Nacional de los Picos de Europa incluyen formas de relieve derivadas de procesos glaciares cuaternarios actuando sobre un macizo montañoso calcáreo, así como los fenómenos de karstificación que han conformado un paisaje de excepcional variabilidad y valor estético, en el que destacan los profundos cañones excavados por los ríos y los impresionantes cantiles de roca caliza, en permanente proceso de alteración por la acción erosiva del agua y el hielo.

Comprender y reconocer distintos paisajes geomorfológicos es entender el valor científico de los relieves, su papel en la construcción histórica de un lugar (criterios culturales asociados) y las percepciones actuales de los residentes y visitantes de la zona. La Interpretación del Patrimonio (IP) constituye una herramienta efectiva y versátil por su aplicación para la socialización de los valores inherentes a bienes patrimoniales y la gestión de los espacios que los contienen. Por lo tanto, se presenta como una estrategia de desarrollo sostenible para áreas que poseen Patrimonio Natural o Cultural, y también como una forma práctica y atractiva de presentar contenidos curriculares. No sólo es importante dar a conocer el bien patrimonial sino que también interesa la manera en que se haga.

¿Cómo se pueden aplicar los principios interpretativos para un aprovechamiento didáctico y turístico de LIGm en el Parque Nacional de los Picos de Europa? (Figura 2). 


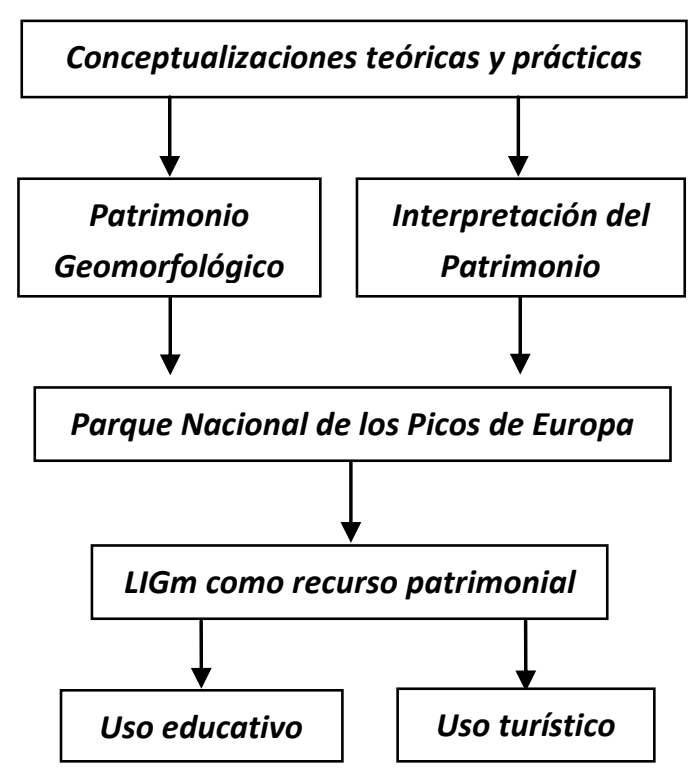

Figura 2. Diagrama descriptivo del abordaje de los objetivos del trabajo.

Fuente: elaboración propia

\section{5) Objetivos}

El presente trabajo posee dos objetivos principales: el análisis y relación entre técnicas interpretativas y actividades didácticas y geoturisticas, y la aplicación de principios y técnicas de Interpretación del Patrimonio, mediante el desarrollo de fichas de valoración didáctica de LIGm y de paneles interpretativos que permitan la Interpretación del Patrimonio Geomorfológico en el Parque Nacional de los Picos de Europa. Estos registros y paneles pueden ser utilizados como una herramienta didáctica para el desarrollo de contenidos curriculares y la elaboración de servicios turísticos.

El enfoque de este trabajo se realiza alrededor de tres ejes temáticos, los cuales engloban a los objetivos específicos:

1) Entender el concepto de Interpretación del Patrimonio en su totalidad, su aplicación en geoformas y su vinculación con la Educación y el Turismo.

2) Comprender la importancia de los Lugares de Interés Geomorfológico como elementos representativos de la formación y evolución de distintas formas del relieve y del paisaje de Áreas Naturales Protegidas y su utilidad para la educación y el turismo.

3) Producir mensajes interpretativos de LIGm en el Parque Nacional de los Picos de Europa para el aprovechamiento turístico y educativo.

Los objetivos específicos de estos tres ejes temáticos son: 


\section{a) Interpretación del Patrimonio (IP)}

Analizar la construcción histórica del concepto y de la práctica de IP. Identificar las distintas etapas de la evolución en la definición de IP. Comparar distintos modelos de planificación interpretativa.

Identificar las características que definen al mensaje interpretativo. Comparar y analizar textos de paneles interpretativos de Patrimonio Geomorfológico.

Establecer los puntos de contacto entre la IP con la Teoría de la comunicación, la Educación y el Turismo.

b) Lugares de Interés Geomorfológico (LIGm)

Analizar distintos métodos de valoración de LIGm.

Analizar el aprovechamiento didáctico de tales métodos. Identificar los LIGm del Parque Nacional Picos de Europa. Seleccionar los LIGm para aplicar principios interpretativos.

c) Parque Nacional Picos de Europa (PNPE)

Analizar el patrimonio geomorfológico del PNPE. Identificar el perfil de visitantes al PNPE.

Analizar los principales puntos de ingreso al PNPE.

Conocer la evolución del ingreso de turistas al Parque.

Elaborar mensajes interpretativos para los LIGm seleccionados.

\section{6) Metodología}

Esta investigación se basa en Interpretación del Patrimonio y el uso de LIGm en los ámbitos del turismo y de la educación en el Parque Nacional de los Picos de Europa. Por lo tanto, el análisis de la misma se abordará de manera teórica y práctica. Se indagará sobre la Interpretación del Patrimonio (origen del concepto y su práctica, principios interpretativos, elaboración del mensaje a ofrecer, planificación interpretativa, entre otros), especialmente su vinculación con la educación y el turismo, y se elaborarán paneles interpretativos, instrumentos para el análisis de sus mensajes y fichas didácticas de valoración geomorfológica, en general, y de contenidos relacionados con ambientes glaciares, periglaciares y kársticos, en particular.

El tipo de investigación es mayormente descriptivo, ya que da cuenta de los hechos históricos y el pensamiento teórico que se suceden desde mediados del siglo XX para conformar la disciplina de Interpretación del Patrimonio, junto a casos prácticos en los que se aplican los 
principios interpretativos. Por esto, la metodología empleada es cualitativa; se enfatiza el uso de técnicas de este tipo y su relación con modelos de otras disciplinas (comunicación, educación, turismo). Para el estudio del quehacer interpretativo se trabajó con fuentes bibliográficas de los principales autores en este ámbito (por ejemplo Ham, 1992; Morales, 1998a; Tilden, 2006; Guerra et al., 2008). Su análisis y contrastación se realizó desde enfoques de la comunicación (Shannon, 1948; Eco, 1977; Jakobson, 1985), de la psicología del comportamiento (Cacioppo y Petty, 1983; Ajzen, 1991), de teorías relacionadas con la enseñanza/aprendizaje, como herramienta para el aprovechamiento en el turismo (Orams 1995; Weiler, 1999; Tarlton y Ward, 2006; Ballantyne et al., 2007; Wearing et al., 2007) y el aporte de otros campos que tratan el tema.

Puntualizando las tareas desarrolladas para la elaboración del presente trabajo, las mismas pueden englobarse en los siguientes grupos:

a) Recopilación y tratamiento de bibliografía: se obtuvo información de distintas fuentes referida a la temática principal de la investigación, así como al área de estudio en particular (bibliográfica, cartográfica, fotográfica, estadística y documental). Para establecer el marco teórico se realizó una revisión bibliográfica sobre Interpretación del Patrimonio y Valoración del Patrimonio Geomorfológico en general y del PNPE en particular, a través de conceptos teóricos, metodológicos y estudios de casos sobre estos temas. También se investigó sobre formas de turismo sustentable, desarrolladas con preferencia en áreas naturales protegidas.

b) Trabajo de campo: visitas a la zona de estudio (Parque Nacional de los Picos de Europa), como así también a otros sitios para obtener ejemplos de presentaciones interpretativas (Parque Nacional Talampaya, Parque Provincial Ischigualasto, Monumento Natural Puente del Inca, Parque Recreativo, Autóctono y Cultural Los Terrones, todos ellos en Argentina; Colorado National Monument, en Estados Unidos; senderos guiados y autoguiados en Murcia, España).

c) Tareas de gabinete complementarias: en este caso, se consideran aquellas producciones prácticas surgidas del análisis de la información obtenida recogida en las etapas previas. Para algunos ejemplos, dada la escasez de datos para la temática y el área de estudio, como en otros en que había una diversidad de enfoques, fue necesario llevar a cabo varias técnicas para recabar y analizar la información. Dentro de las cuales pueden mencionarse:

- Análisis de Contenido de 33 definiciones de Interpretación de Patrimonio para conocer la evolución de esta disciplina a través de los años, identificando 
aspectos coincidentes y particulares en las mismas. El desarrollo, análisis y conclusiones de la utilización de la técnica de análisis de contenido se presentan en el Capítulo 2.

- Análisis comparativo del aprovechamiento didáctico de métodos de valoración de lugares de interés geológico y geomorfológico, estableciendo sus diferencias y similitudes y extrayendo conclusiones al respecto (Capítulo 4).

- Análisis de diseños curriculares de Educación Primaria, ESO y Bachillerato de Asturias, Cantabria y Castilla y León, de planes de estudio de carreras de universidades públicas de estas comunidades relacionadas con la geomorfología y de bibliografía especializada en geomorfología general, glaciar, periglaciar y kárstica. El objetivo de los mismos es la identificación de los contenidos comunes necesarios para el aprendizaje de saberes geológicos y geomorfológicos presentes en la bibliografía y en los planes de estudios para la elaboración posterior de fichas de valoración didáctica.

- Elaboración de una propuesta de valoración didáctica en geomorfología general, glaciar, periglaciar y kárstica (Capítulo 4) surgida del análisis de los diseños curriculares, planes de estudio y bibliografía sobre la temática. El objetivo es conseguir un método de registro y de valoración con mayor precisión para el uso didáctico.

- Elaboración de fichas para el análisis del mensaje de paneles interpretativos de áreas con patrimonio geomorfológico. Las mismas han permitido examinar la composición del mensaje de distintas señales interpretativas de sitios naturales protegidos de ambos lados del Atlántico, constituyéndose en herramientas para la mejora de la comunicación interpretativa (Capítulo 2).

- Valoración de LIGm del PNPE. El fundamento teórico y metodológico de la propuesta utilizada se desarrolla en el capítulo correspondiente (6). Se realiza el inventario y posterior evaluación de los geositios. Esta actividad permite comparar la importancia de cada sitio de acuerdo a una triple evaluación (valores intrínsecos, culturales y de uso y gestión).

- Análisis de la valoración de LIGm, en la misma se identifican los LIGm según la puntuación obtenida. El objetivo del mismo es identificar aquellos sitios que presenten elementos naturales y mejores condiciones de infraestructura para el aprovechamiento didáctico y turístico (Capítulo 6). 
- Análisis de datos del PNPE (puntos de acceso, visitantes, etc.). Con datos obtenidos a través del Consorcio Interautonómico Parque Nacional Picos de Europa, se identificaron los principales puntos de acceso al área, el perfil de turistas, la estacionalidad de las visitas, etc., para conocer entre otros aspectos, el tipo de público destinatario de la interpretación y los lugares posibles de la misma (Capítulo 5).

- Confección de paneles interpretativos sobre temas principales del patrimonio geomorfológico del PNPE. En el diseño de estas señales interpretativas se tuvieron en cuenta los atributos tangibles identificados en los LIGm seleccionados para el aprovechamiento didáctico y turístico y las recomendaciones de elaboración de mensajes interpretativos (extensión y calidad del texto, identificación de elementos tangibles e intangibles y conceptos universales asociados a los LIGm, etc.). En distintos momentos de su confección, el texto de los paneles confeccionados fue mejorado a través de la utilización de la ficha de análisis diseñada para esta investigación.

- Presentación de propuestas para el aprovechamiento didáctico y geoturístico de los LIGm del PNPE. Como conclusión de las actividades realizadas en las etapas previas, se presenta una propuesta de la utilización didáctica y geoturística de los paneles interpretativos y de los valores patrimoniales del Parque. 


\section{Capítulo 2}

\section{La Interpretación del Patrimonio}

Para conceptualizar el término Interpretación no pueden dejar de mencionarse las aportaciones realizadas por Tilden (2006, primera edición en castellano; 1957, ed. original), consideradas las bases teóricas y metodológicas de la interpretación patrimonial tal como se conoce a esta actividad en la actualidad. Para este autor estadounidense la interpretación es desvelar a los visitantes parte de la belleza, las maravillas, la inspiración y el significado espiritual que se ocultan detrás de lo que perciben con sus sentidos. En términos académicos la define como:

Una actividad educativa que pretende revelar significados e interrelaciones mediante el uso de objetos originales, experiencias de primera mano y medios ilustrativos, en lugar de simplemente transmitir la información de los hechos (Tilden, 2006, p. 35).

El empleo del adjetivo educativa se prestó a muchas confusiones desde un comienzo, ya que en los países anglosajones lo educativo se relaciona con estudiantes. Más tarde, el propio Tilden reconoció este hecho, comentando en una de sus últimas conferencias, en 1975, que si emprendiera una revisión de su libro definiría a la interpretación como una actividad recreativa, pues define mejor el contexto de la interpretación (Morales, 2008).

Algunos autores consideran que lo que hoy se define como Interpretación del Patrimonio tuvo sus orígenes a fines del siglo XIX con el surgimiento de los Parques Naturales de Estados Unidos (Morales, 1998a, 2008; Monteserín, 2007; Santamarina, 2008). Otros investigadores consideran un doble inicio en la historia de esta disciplina interpretativa: uno europeo (con el surgimiento de parques de la vida tradicional escandinavos), y otro estadounidense apoyado en ideas conservacionistas que dieron origen a los parques nacionales (Santamarina, 2008; Ruiz, 2010; Martín Hernanz, 2012).

John Muir pudo haber sido la primera persona que utilizara el término interpretación para describir en 1871 esta comprensión del patrimonio (Dong, 2009; Brochu y Merriman, 2012), mientras que profesionalmente la actividad interpretativa tuvo sus inicios en la década de 1950 en el Servicio de Parques Nacionales de los Estados Unidos (Guerra et al., 2008). 
Debido a su nacimiento en áreas naturales, hasta mediados de los años 80 del siglo pasado se llamó interpretación ambiental porque, surgida en tales espacios, explicaba los fenómenos naturales que sucedían en su interior. ${ }^{1}$ Como la interpretación es un conjunto de técnicas de comunicación que sirve para explicar un producto del hombre o uno de la naturaleza, el adjetivo ambiental quedó limitado, ya que existen profesionales que las aplican pero trabajan en otros contextos (sitios arqueológicos, museos, cascos urbanos o históricos). Así fue como, al buscar un término más general, se llegó al concepto de heritage, que incluye el natural heritage y el cultural heritage y que se traduce como patrimonio. Desde entonces tiene más amplitud hablar de interpretación del patrimonio que de interpretación ambiental, expresión que se consolida a partir de la celebración en 1985 del Primer Congreso Mundial de Interpretación del Patrimonio, en Banff, Canadá (Morales, 1998a, 2008; Guerra, 2006; Monteserín, 2007).

Los registros más antiguos que se conocen hasta la fecha sobre Interpretación y que constituyen valiosos antecedentes de la misma son Research and Education in the National Parks de Harold C. Bryant y Wallace W. Atwood Jr. (1932) y The History and Status of Interpretative Work en National Parks de Carl. P. Russell (1939). Puede que no utilizaran explícitamente el término interpretación para referirse a la manera en que una persona realiza su tarea en un área protegida para dar a conocer las principales características del mismo, pero es evidente que se referían a lo que actualmente se conoce como Interpretación del Patrimonio. Otros autores destacan la figura de Enos Mills quien trabajó desde finales de 1880 hasta la década de 1920 en lo que actualmente es el Parque Nacional Rocky Mountain (EE.UU.) y escribió Adventures of a Nature Guide and Essays in Interpretation publicado en 1920. Mills creó una serie de principios que pueden considerarse un fundamento filosófico de la interpretación. Entre sus notas se destaca: "Un guía de la naturaleza [es decir, un intérprete] es un naturalista que puede guiar a otros a los secretos de la naturaleza" (NPS, 2007; Beck y Cable, 2011; Brochu y Merriman, 2012).

Respecto a la práctica interpretativa en general, es destacable la siguiente afirmación:

De todas maneras, la interpretación es un acto de transferencia cultural que puede ser tan antiguo como la humanidad, ya que en muchas culturas podemos encontrar ejemplos de sus aplicaciones, aunque se le haya

\footnotetext{
${ }^{1}$ En algunos países no angloparlantes las actividades interpretativas fueron designadas con otros nombres hasta la década de 1980. En el caso de Francia, por ejemplo, se utilizaron los conceptos information, animation, vulgarisation, communication, éducation à l'environnement, pédagogie de l'environnement... (Guerra et al., 2008).
} 
definido y denominado sólo hace menos de cien años (Comisión

Centroamericana del Ambiente y Desarrollo, 2005, p.5).

Los objetivos de la Interpretación son variados, pueden incluir el desarrollo de las conexiones emocionales $e$ intelectuales entre los visitantes y los significados inherentes al recurso (Brochu y Merriman, 2012), favoreciendo su protección (Ham, 2009b; Veverka, 1994), o facilitando el aumento de comportamientos específicos (Cacioppo y Petty, 1983; Orams, 1995; Petty et al., 2009) y de una conciencia social (Atkinson y Mullins, 1998). En relación a esto, la Interpretación plantea tres grandes tipos de objetivos. Primero se encuentra aquello que se quiere dar a conocer al público (objetivos de conocimiento). A continuación, en un segundo nivel, más profundo, qué sentimientos deberían surgir en las personas a partir de ese conocimiento (objetivos emocionales) y culminando con nuevas reacciones o actitudes que incorpora el visitante después de los sentimientos creados por el nuevo conocimiento (objetivos actitudinales o de comportamiento). Tales objetivos contribuyen a orientar la planificación interpretativa, pudiéndose aplicar en cualquier escala de trabajo (Maragliano, 2010).

\section{1) La Interpretación en Iberoamérica}

En la mayoría de los países iberoamericanos, la Interpretación del Patrimonio tuvo un nacimiento vinculado al campo de la Educación Ambiental, en correspondencia con el surgimiento y desarrollo de esta disciplina en otras partes del mundo. Para Monteserín (2007) esta actividad llegó a España en el último tercio del siglo XX, proveniente de los EE.UU., siendo los parques nacionales quienes incorporan el término interpretación al final de la década de 1970, aunque sin desarrollarlo demasiado. En este período se destaca el primer esfuerzo de aplicar la metodología interpretativa en 1977, con su introducción en el Parque Nacional del Teide (Santamarina, 2008). Durante la década siguiente se llevan a cabo eventos nacionales de Educación Ambiental en los que comienzan a tratarse contenidos básicos relacionados con la Interpretación: en 1983, y organizado por la Dirección General de Medio Ambiente del M.O.P.U, se celebra en Madrid (Casa de Campo) el Primer Curso de Educación Ambiental; ese mismo año se presenta una comunicación sobre Interpretación en las Primeras Jornadas Nacionales de Educación Ambiental, celebradas en Sitges (Barcelona). Ligado a las II Jornadas Nacionales de Educación Ambiental (Valsaín, 1987), nace el Seminario Permanente de Educación Ambiental en Espacios Naturales Protegidos, que tratará del tema de la interpretación como herramienta de gestión (CENEAM, 2011). Entre 1987 y 1988 se publican varios artículos de interpretación en la revista "Educación Ambiental" de la Cooperativa Oikos, 
de Valladolid, y se difunden conceptos de interpretación en el boletín "La Ventana de Doñana", editado por los trabajadores del Parque Nacional de Doñana entre 1989 y 1992.

Durante la década de 1990 distintas actividades contribuyen a la conformación actual de esta disciplina en este país: en 1993 se da inicio al Aula de Verano de Interpretación y Educación Ambiental del Centro Nacional de Educación Ambiental en Valsaín (Segovia). En junio de 1994 se celebra en Pamplona el Seminario Internacional sobre Interpretación Ambiental y Turismo Rural, organizado por el Gobierno de Navarra y el CEFAT (Centro Europeo de Formación Ambiental y Turística). En 1995 se lleva a cabo en Barcelona el Cuarto Congreso Internacional sobre Interpretación del Patrimonio y se funda la Asociación para la Interpretación del Patrimonio (AIP). En 1998, durante el desarrollo de las III Jornadas Nacionales de Educación Ambiental (Pamplona), la Interpretación del Patrimonio cuenta con un grupo de trabajo propio y varias comunicaciones sobre la temática. Desde 1999 El Boletín de Interpretación de la AIP aporta textos de interés y formativos para su difusión y reflexión.

En los últimos años la AIP presenta diferentes textos que contribuyen a la consolidación de la actividad interpretativa en España, por ejemplo la edición en castellano de la principal obra de Tilden (Interpreting our heritage) en 2006, como así también otros textos traducidos (Bases de la Interpretación, 2007) o propios (Recomendaciones para las Buenas Prácticas en Interpretación del Patrimonio Natural y Cultural, 2006). En 2008 presenta Uso Público e Interpretación del patrimonio natural y cultural, que recoge ponencias de las Primeras Jornadas de Uso Público en Espacios Naturales Protegidos y Difusión del Patrimonio Cultural, desarrolladas en 2007.

Cruzando el Atlántico se observa que la actividad interpretativa estuvo ligada a la creación de los parques nacionales de principios y mediados del siglo XX bajo la figura del guardaparque o guía turístico. En el caso de Argentina, ésta acumuló experiencia a través del trabajo de especialistas en áreas protegidas, museos, centros culturales, parques temáticos, zoológicos, parques botánicos, guías de turismo, entre otros. Desde la década de 1970, la interpretación se practica y crece a partir de cursos de capacitación no formal, principalmente realizados por organizaciones no gubernamentales como Amigos de la Tierra, Fundación Vida Silvestre Argentina y algunas empresas turísticas de la Patagonia. A nivel gubernamental, la Administración de Parques Nacionales adopta durante muchos años las metodologías y los cursos del Cuerpo de Paz de los Estados Unidos (Fernández Balboa, 2007).

En el caso brasileño, el Ministerio de Ambiente destacó en 1994 la importancia de la Interpretación Medioambiental como un instrumento de la conciencia ambientalista en las Diretrizes para a Política Nacional de Ecoturismo. En 1995 Murta y Goodey publicaron A 
interpretação do patrimônio para o turismo sustentado - um guía, consiguiendo que algunos académicos brasileños se interesaran más por esta disciplina y se dispararan iniciativas interpretativas en diversas partes del Brasil (Farías, 2006). Desde comienzos del siglo XXI se puede identificar en este país un mínimo de tres tipos de grupos con relación a la práctica interpretativa. Uno de ellos aplica la técnica estadounidense a partir de los manuales y textos norteamericanos (principalmente en el Sur y Sureste del País, con relación al patrimonio natural); un segundo equipo de trabajo promueve la Interpretación del Patrimonio en directo, un tipo de interpretación vinculado a temas de mayor complejidad (por ejemplo, en una hacienda del estado de Río de Janeiro se interpreta el período colonial de la Historia de Brasil abordándose la problemática de la esclavitud); y finalmente un tercer grupo promueve que la interpretación abarque la inclusión social, sobre todo en áreas del interior de Brasil o de su costa, en su mayoría empobrecidos y con pocas perspectivas económicas, para que puedan tener oportunidades de trabajo y renta a partir de la presentación de su historia, de sus tradiciones y de su medio ambiente natural.

En Cuba la actividad interpretativa comenzó en la década de 1980 junto al diseño de un sendero interpretativo autoguiado para el Parque Nacional Desembarco del Gramma. Uno de los problemas para la implementación de la actividad interpretativa en la isla, como muchas otras cuestiones, es la falta de presupuesto para llevar adelante proyectos, pero estos son resueltos con creatividad y austeridad, reutilizando los materiales o manteniendo el diseño de los folletos (Juarrero de Varona y Martínez Montero, 2003).

En Costa Rica los primeros trabajos en interpretación datan de la década de 1970 por voluntarios del Cuerpo de Paz de EE.UU. en el Parque Nacional Volcán Poás, continuando en las décadas siguientes con el desarrollo de planes y actividades interpretativas en diversos ámbitos: Centro Agronómico Tropical de Investigación y Enseñanza -CATIE-, Zoológico Simón Bolívar, Escuela de Biología de la Universidad de Costa Rica, áreas silvestres protegidas y en museos del país (Morrison, 2010).

\section{2) Principios interpretativos}

Desde el origen de la Interpretación del Patrimonio pueden identificarse distintas aportaciones que ayudaron a su conformación como disciplina. En este sentido, además de las contribuciones de Muir y Mills, destaca la obra de Tilden (Interpreting our heritage, publicada en 1957), donde se presentan las primeras líneas a seguir por los intérpretes, y que aún hoy constituyen un recurso referencial en el campo profesional interpretativo. A continuación se 
hará una breve descripción de estos principios, los que luego ser retomados en un análisis de su vinculación con aspectos didácticos (Capítulo 3).

1) Cualquier interpretación que de alguna forma no relacione lo que se muestra o describe con algo que se halle en la personalidad o en la experiencia del visitante será estéril (Tilden, 2006).

El desafío de la interpretación es poner en común los intereses personales del visitante y los significados que posee el recurso patrimonial (Morales, 2008). El visitante relacionará la información que recibe del intérprete con algo que se vincule con su conocimiento y experiencias íntimos, ya que percibe lo que observa a través de sus ojos, no a través de los del intérprete; por lo que este último debe presentar una serie de datos seleccionados con la finalidad de provocar el pensamiento en los visitantes y que ellos mismos construyan su propia comprensión. Uno de los objetivos fundamentales de la Interpretación del Patrimonio es producir cambios conductuales y abrir nuevas relaciones entre el ser humano y su entorno. ¿En qué medida podremos alcanzar esto si nuestro interlocutor no nos comprende? (Fernández Balboa y Taubenschlag, 2007).

Tilden (2006) ilustra este principio con el contenido de un rótulo de un museo texano junto a un esqueleto de mamut: "los mamuts prehistóricos habitaban Texas hace sólo unos miles de años. Deambulaban por la llanura en grandes manadas (...) Lo más probable es que se alimentaran justo en el lugar donde usted se encuentra ahora." Con esta afirmación, estos animales no se presentan lejanos en el tiempo o en el espacio ya que posiblemente estuvieron "justo en el lugar donde usted se encuentra".

20) La información, tal cual, no es interpretación. La interpretación es revelación basada en información, aunque son cosas completamente diferentes. Sin embargo, toda interpretación incluye información (Tilden, 2006).

Este principio se relaciona con el anterior ya que propone que el intérprete en el momento de brindar información lo haga relacionándola con otros datos que pueden ser conocidos por el visitante. La información debe ser utilizada como base teórica, como el sustento que permitirá desarrollar la actividad interpretativa, pero nunca como eje de la misma. Tilden (2006) relata el caso de un periodista californiano que trabajaba en Nueva York en la cobertura periodística del terremoto de San Francisco de 1906. Este reportero no sólo aportó datos concretos de la catástrofe natural a su informe sino que añadió un agregado 
extra a sus notas, ya que como natural de esa ciudad describió el terremoto aportando referencias que revelaban el alma de la ciudad. Otro ejemplo que aporta Tilden (2006) lo constituye un artículo que Robert Griggs escribe para la National Geographic Society sobre la erupción en junio de 1912 del monte Katmai (Alaska), muy desconocido para la época. Griggs logró captar la atención del lector, en este caso, al hacerle imaginar lo que hubiera sucedido si esa erupción volcánica se hubiese producido en Nueva York: la misma ciudad se habría visto enterrada con 3 a 5 metros de cenizas o que el sonido de las explosiones se hubieran escuchado en Denver, Atlanta o San Louis...

En ambos casos no sólo hubo información de hechos, sino que se pudo realizar una interpretación de los mismos. En el primero de los ejemplos, el periodista relató un fenómeno geológico ocurrido en la ciudad de San Francisco por puño y letra de un sanfranciscano que aportó otra información a los datos objetivos del terremoto; en el segundo caso, Griggs traslada la erupción volcánica a la ciudad de Nueva York recurriendo para ello a la imaginación de los lectores.

Es una equivocación asociar la idea de que sólo entregando información a la audiencia la misma podrá apreciar y valorar los recursos interpretados (Ham, 2009a). Tal confusión queda demostrada al leer carteles informativos (en este caso, mal llamados interpretativos) o escuchar guías de áreas patrimoniales que, con el afán de trasmitir datos del recurso interpretado, logran que la audiencia pierda interés por el mismo al ofrecer sólo una mera descripción.

30) La interpretación es un arte, que combina otras muchas artes, sin importar que los materiales que se presentan sean científicos, históricos o arquitectónicos. Cualquier arte se puede enseñar en cierta forma (Tilden, 2006).

Especialmente en este principio hay que tener presente que el principal motivo de visita a áreas protegidas es conocer in situ alguna manifestación natural o cultural en el tiempo de ocio que disponen las personas. Por lo tanto no buscan ser instruidas académicamente sobre lo que están observando. Sin llegar a abusar del significado de la palabra entretenimiento, la mayoría de los destinatarios de la interpretación va en busca de eso y no sólo de instrucción.

Para lograr tal fin, es conveniente que el intérprete se sumerja en su propia apreciación artística, cuente una historia en lugar de recitar un inventario (Tilden, 2006). Conjuntamente con el dominio de saber contar una historia (lograr captar la atención y el interés de las personas), el intérprete debe ser competente en exponer sus ideas siendo necesario el 
conocimiento de principios de retórica. Pero se debe tener mucho cuidado en que la acción del intérprete no quite la atención que debe recaer sobre el bien patrimonial a interpretar. Cuando el intérprete deja de ser un nexo entre el visitante y el elemento del patrimonio para convertirse en el centro de atención, la interpretación ha fracasado en gran medida (Fernández Balboa y Taubenschlag, 2007).

Como corolario de este principio Tilden (2006) afirma que los nutrientes para una interpretación de calidad proceden del uso apropiado e ingenioso de los recursos idiomáticos.

4ㅇ) El objetivo principal de la interpretación no es la instrucción, sino la provocación (Tilden, 2006).

Con el término provocación el autor se refiere a que la interpretación despierte en el espectador un deseo de ampliar el horizonte de intereses y conocimientos. Como en el principio anterior, el buen intérprete debe captar el interés del visitante. Por ejemplo, reproduciendo una larguísima clasificación de términos científicos, se lograría el efecto contrario al deseado en Interpretación, que es atraer la atención de las personas para provocar sensaciones y emociones en ellas. Es más importante trasmitir pasión y la experiencia directa que contar todo lo que se sabe, ya que si se logra motivar al turista será él quien buscará información en otros sitios o simplemente regresará al lugar (Bertonattti, 2005). Este es un hecho que sirve para darnos cuenta de que el acercamiento de la gente hacia el área que visitó ha sido eficaz (Fernández Balboa y Taubenschlag, 2007).

50) La interpretación debe intentar presentar un todo en lugar de una parte, y debe estar dirigida al ser humano en su conjunto, no a un aspecto particular (Tilden, 2006).

Lo prioritario en la interpretación es ofrecer un todo en lugar de una parte, por más que esa porción pueda resultar interesante. Al analizar las características del área o elemento a interpretar, es conveniente encontrar un hilo conductor que guíe la visita. Para un visitante de cualquier sitio patrimonial es mejor que se le ofrezca un panorama general del atractivo principal que recibir un cúmulo de información que lo termine confundiendo. Esto se logra mediante la clarificación del mensaje central, lo que a su vez recupera lo que la psicología cognitiva y las ciencias de la comunicación conocen bien: la gente recuerda las ideas centrales, aún si olvida los detalles (Gándara, 2003). 
Para la formación del intérprete es importante brindar los aspectos más amplios del ambiente e interrelacionarlos, abarcando aspectos sociales y culturales además de los naturales. A esto se llama establecer relaciones (Tilden, 2006), o construir puentes. En lo posible hay que ir de lo general a lo particular, recordando que es más fácil entender un concepto cuando lo podemos ver dentro de un contexto más amplio. En cuanto a captar la atención y motivación de los visitantes, debemos tener en cuenta que las personas no son sólo su profesión o su actividad cotidiana. Los seres humanos reunimos una serie de intereses y experiencias que el intérprete puede aprovechar para enriquecer la presentación interpretativa, captando y manteniendo la atención de la audiencia.

60) La interpretación dirigida a los niños (digamos, hasta los doce años) no debe ser una dilución de la presentación a los adultos, sino que debe seguir un enfoque básicamente diferente. Para obtener el máximo provecho, necesitará un programa específico (Tilden, 2006).

En toda producción interpretativa es necesario adecuar los conceptos al nivel de desarrollo cognitivo de las personas. Por ejemplo, los términos más abstractos serán explicados de una forma que puedan ser comprendidos por niños, o bien aprovechar su interés por lo superlativo (si están en un museo recuerdan el huevo más grande, de avestruz, y el más pequeño, de colibrí...), interés que perdura con el correr del tiempo y a medida que dejan la niñez y son adolescentes y adultos. Recordemos que muchas veces las personas se acuerdan de la montaña más elevada del mundo, el río más largo, el país más poblado, etc.

Los niños tienen una visión totalmente diferente del mundo que los rodea. Es mucho más real e inmediata. Generando el clima apropiado, el intérprete puede provocar la curiosidad de un niño, su sorpresa y un sentido de exploración de lo que lo rodea, mucho más fácil que con los adultos. La interpretación para los niños debe tratar de engrandecer y guiar ese entusiasmo especial en vez de entorpecerlo, llenándola sólo de hechos. Otra característica distintiva de los infantes es que, además de "percibir" la realidad que pueden encontrar en un museo a través de la vista y del oído, lo hacen junto a los otros sentidos (por ejemplo, comprueban el qué se siente a través del tacto). La imaginación y la facilidad de preguntar sin colocarse filtros son otras de las características de las conductas de los niños que deben ser consideradas al formular un programa interpretativo. No basta con colocar diminutivos: pajarito, casita, o aflautar la voz para tratar a los más pequeños. 
Tomando como punto de partida los seis principios originales de Tilden (2006), Beck y Cable (1998) los reformulan y complementan con 9 principios más, para un total de 15 nuevos principios de la interpretación ${ }^{2}$ para el siglo XXI:

1) Para despertar el interés, los intérpretes deben conseguir que los contenidos de sus mensajes se relacionen con la vida de los visitantes.

2) El propósito de la interpretación va más allá de la entrega de información, consiste en revelar una verdad y un significado profundos.

3) Toda presentación interpretativa -al igual que una obra de arte- se debería diseñar como una historia que informe, entretenga e ilustre.

4) El propósito del mensaje interpretativo es inspirar y provocar a la gente para que amplíe sus horizontes.

5) La interpretación debería presentar un tema o un planteamiento completo, y debería ir dirigida al individuo como un todo.

6) La interpretación para niños, adolescentes y adultos -cuando éstos constituyen grupos homogéneos- debería aplicar enfoques diferentes.

7) Todo lugar tiene su historia. Los intérpretes pueden revivir el pasado para hacer que el presente sea más placentero y que el futuro adquiera un mayor significado.

8) Las nuevas tecnologías pueden revelar el mundo de maneras nuevas y apasionantes. Sin embargo, la incorporación de estas tecnologías a los programas interpretativos debe realizarse con cuidado y precaución.

9) Los intérpretes deben cuidar la cantidad y calidad de la información a presentar (en cuanto a su selección y precisión). Bien sintetizada y fundamentada en una buena investigación, la interpretación tendrá más poder que un gran discurso.

10) Antes de aplicar diseños en interpretación, el intérprete debe conocer técnicas básicas de comunicación. Una interpretación de calidad se fundamenta en las habilidades y los conocimientos del intérprete, atributos que se deben poder desarrollar de forma continua.

11) Los textos interpretativos deberían transmitir aquello que a los lectores les gustaría conocer, con la autoridad del conocimiento, y la humildad y responsabilidad que ello conlleva.

12) Un programa interpretativo debe ser capaz de conseguir apoyo -político, financiero, administrativo, voluntariado-, sea cual fuera la ayuda necesaria para que el programa prospere.

\footnotetext{
${ }^{2}$ Los primeros seis principios de Beck y Cable (1998) guardan estrecha relación con los principios de Tilden (1957).
} 
13) La interpretación debería estimular las capacidades de la gente e infundir un deseo de sentir la belleza de su alrededor, para elevar el espíritu y propiciar la conservación del rasgo que es interpretado.

14) Los intérpretes deben ser capaces de promover actividades interpretativas óptimas, a través de programas e infraestructuras bien concebidas, diseñadas de forma intencionada. 15) La pasión es el ingrediente indispensable para una interpretación poderosa y efectiva; pasión por el rasgo que es interpretado y por aquellos que vienen a inspirarse con él.

La Tabla 3 enumera los principios de la interpretación aportados por Tilden (2006) y Beck y Cable (1998), identificando en ellos distintos elementos tenidos en cuenta en la Interpretación del Patrimonio (objetivos, características del mensaje, medio interpretativo, visitante, intérprete y proceso de planificación).

Tabla 3. Correspondencia entre los principios enunciados por Tilden (2006) y Beck y Cable (1998) con elementos interpretativos.

\begin{tabular}{|l|l|}
\hline \multicolumn{1}{|c|}{ Elementos interpretativos } & \multicolumn{1}{c|}{ Principios } \\
\hline Objetivos de la Interpretación & $4,13$. \\
\hline Características del mensaje & $2,3,5,6,9,11$. \\
\hline Relacionados con el visitante & $1,4,5,6,13,15$. \\
\hline Relacionados con el intérprete & $7,10,14,15$. \\
\hline Medio interpretativo & 8. \\
\hline Planificación interpretativa & $9,12$. \\
\hline Fuente: elaboración propia. & \\
\hline
\end{tabular}

Las principales coincidencias entre estos autores tienen que ver con el tratamiento realizado del mensaje interpretativo (por ejemplo, ambos trabajos consideran que el mensaje debe ser relevante para el ego del visitante y ser algo más que mera información), pero también del intérprete y del visitante, es decir los integrantes del clásico modelo comunicacional. En este sentido, hay principios que explicitan la necesidad de vincular el mensaje con la experiencia de los visitantes (principios 5 y 6), o bien refieren a las cualidades del intérprete para trasmitir el mismo (principio 7). Otra cuestión a destacar en los principios analizados tiene que ver con conseguir objetivos de la interpretación: aumentar el interés de los visitantes y lograr la conservación del recurso interpretado (principios 4 y 13). Beck y Cable (1998) mencionan dos aspectos no considerados en los principios de Tilden (2006), como es el medio interpretativo (principio 8) y la planificación (principios 9 y 12). 
A manera de síntesis de tales principios, Beck y Cable (2011), en la tercera edición de su libro sobre los principios para el siglo XXI, presentan la metáfora de GIFT (regalo, presente) y la relacionan con los principios enunciados con anterioridad. También hacen referencia a que cada intérprete posee estos dones y los entrega a los demás en innumerables ocasiones (Tabla 4). A continuación se hará una breve mención de cada uno de esos regalos.

1. El Don del Despertar la Chispa: para despertar el interés, los y las intérpretes deben conseguir que los contenidos de sus mensajes se relacionen con la vida de los visitantes.

2. El Don de la Revelación: el propósito de la interpretación va más allá de la entrega de información, consiste en revelar una verdad y un significado profundos.

3. El Don de las Historias: toda presentación interpretativa -al igual que una obra de arte- se debería diseñar como una historia que informe, entretenga e ilustre.

4. El Don de la Motivación: el propósito del mensaje interpretativo es inspirar e impulsar a la gente a ampliar sus horizontes.

5. El Don de la Integralidad: la interpretación debería presentar un tema o un planteamiento completo, y debería ir dirigida al individuo como un todo.

Tabla 4. Correspondencia entre los principios enunciados por Beck y Cable (1998) y los GIFT mencionados por los mismos autores en 2011.

\begin{tabular}{|l|l|}
\hline \multicolumn{1}{|c|}{ Principio } & GIFT (Regalo, presente) \\
\hline Primer Principio & El regalo de una chispa \\
\hline Segundo Principio & El don de la revelación \\
\hline Tercer Principio & El Regalo de la historia \\
\hline Cuarto Principio & El don de la provocación \\
\hline Quinto Principio & El Regalo de la Totalidad \\
\hline Sexto Principio & El Regalo de los programas focalizados \\
\hline Principio Séptimo & El don de la Personalización del pasado \\
\hline Principio Octavo & El don de la iluminación a través de tecnología \\
\hline Principio Noveno & El don de la precisión \\
\hline Décimo Principio & El don de la profesionalidad \\
\hline Principio Undécimo & El don de la escritura interpretativa \\
\hline Principio Duodécimo & El regalo de una relación \\
\hline Principio Decimotercero & El don de la belleza \\
\hline Principio Decimocuarto & El don de la alegría \\
\hline Principio Decimoquinto & El Regalo de la Pasión \\
\hline Fuente: elaboración propia. & \\
\hline
\end{tabular}


6. El Don de los Programas Específicos: la interpretación para niños y niñas, adolescentes y personas de la tercera edad debería utilizar enfoques diferentes.

7. El Don de Personalizar el Pasado: todo lugar tiene su historia. Las y los intérpretes pueden revivir el pasado para hacer que el presente sea más placentero y que el futuro adquiera un mayor significado.

8. El Don de la lluminación a través de las Nuevas Tecnologías: las tecnologías pueden revelar el mundo de maneras nuevas y apasionantes. Sin embargo, la incorporación de estas tecnologías a los programas interpretativos debe realizarse con cuidado y precaución.

9. El Don de la Precisión: quienes se dedican a la interpretación deben cuidar la cantidad y calidad de la información a presentar (selección y precisión). Bien sintetizada y fundamentada en una buena investigación, la interpretación tendrá más poder que un gran discurso.

10. El Don del Profesionalismo: antes de aplicar diseños en interpretación, los y las intérpretes deben conocer las técnicas básicas de la comunicación. Una interpretación de calidad se fundamenta en las habilidades y en los conocimientos de quien la realiza, atributos que se deben poder desarrollar de forma continua.

11. El Don de la Escritura Interpretativa: Ios textos interpretativos deberían transmitir aquello que les gustaría conocer a las y los lectores, con la autoridad del conocimiento de quien escribe pero con la humildad y responsabilidad que ello conlleva.

12. El Don de las Relaciones: un plan o programa interpretativo debería ser capaz de conseguir apoyo -político, financiero, administrativo, de voluntariado-, para lograr ponerlo en marcha.

13. El Don de la Belleza: la interpretación debería estimular las capacidades de la gente e infundir un deseo de sentir la belleza de su alrededor, para elevar el espíritu y propiciar la conservación de aquello que es interpretado.

14. El Don del Disfrute: los y las intérpretes deben ser capaces de promover actividades interpretativas óptimas, a través de programas y servicios bien concebidos.

15. El Don de la Pasión: la pasión es el ingrediente indispensable para una interpretación poderosa y efectiva: pasión por el rasgo que es interpretado y por aquellos que vienen a inspirarse con él.

\section{3) Características y elementos de una Interpretación exitosa}

La esencia de la interpretación estriba en el mensaje, en cómo se redacta o cómo se presenta al público, aunque el medio de comunicación utilizado, el patrimonio y el entorno 
también juegan un papel importante. El mensaje representa el nexo de unión entre el visitante y el recurso que está siendo objeto de interpretación. Por lo tanto debe suscitar su atención y, estar relacionado con sus vidas y experiencias diarias (Veverka, 1994). El sentido del discurso es más que la suma de los significados de los signos que lo componen, el sentido es global. Es conveniente que el mensaje sea atractivo, breve, claro y directo (Morales, 2008). En el momento de elaborar un mensaje interpretativo es necesario considerar esto, sumado a otras recomendaciones para su elaboración, y que se resumen en la Tabla 5.

Tabla 5. Recomendaciones para elaborar mensajes interpretativos.

\begin{tabular}{|l|}
\multicolumn{1}{|c|}{ Principales recomendaciones } \\
\hline Suscitar la atención y curiosidad del público visitante. \\
\hline Aludir a algún aspecto de la personalidad del receptor. \\
\hline Estar relacionado con su vida y experiencia diarias. \\
\hline Hay que usar un lenguaje sencillo. \\
\hline Es conveniente que sea corto. \\
\hline El "tono" del mensaje debe ser ameno. \\
\hline Abordar la redacción del mensaje en primera persona. \\
\hline Usar verbos en voz activa. \\
\hline Utilizar metáforas, analogías y/o comparaciones. \\
\hline Usar el humor, pero con cuidado. \\
\hline Evitar los tecnicismos \\
\hline Es conveniente utilizar sólo una idea en cada frase. \\
\hline Lograr un mensaje unitario, apoyando la presentación integral del mensaje. \\
\hline $\begin{array}{l}\text { Referirnos a la totalidad del bien patrimonial interpretado, por ejemplo estableciendo } \\
\text { conexiones con la historia de una comunidad. }\end{array}$ \\
\hline Se deben evitar errores ortográficos o gramaticales para que el mensaje quede bien claro. \\
\hline $\begin{array}{l}\text { Utilizar preguntas sencillas (sin abusar de esta estrategia). Las respuestas las debe } \\
\text { proporcionar el visitante, o las debe encontrar sin dificultad. }\end{array}$ \\
\hline $\begin{array}{l}\text { En el mensaje, sea el comentario de un guía o el texto de un folleto, hay que incluir } \\
\text { invitaciones a hacer algo y a utilizar los sentidos. }\end{array}$ \\
\hline $\begin{array}{l}\text { La parte final del programa debe retomar el tema, esa frase que se ha reiterado y } \\
\text { desarrollado con ideas complementarias. Aquí se concluye. }\end{array}$ \\
\hline Fuente: elaboración propia en base a Veverka, 1994; Morales 1998a; Scottish Natural Heritage. \\
\hline
\end{tabular}

El Servicio de Parques Nacionales de Estados Unidos (NPS, 2000) propone una Planificación Integral de Interpretación donde se identifican aspectos a tener en cuenta en un mensaje interpretativo:

a) Elementos tangibles: el mensaje identifica con claridad las características del rasgo a interpretar (Ej.: un lugar junto a un arroyo donde el agua golpea a un acantilado rocoso y hace un giro).

b) Significados intangibles: ideas abstractas contenidas en el mensaje que surgen a partir de los atributos tangibles del recurso (Ej.: proceso de erosión). 
c) Conceptos universales: son ideas que representan conceptos más elevados, importantes y entendibles para una amplia mayoría de personas (Ej.: poder, energía).

¿Cómo se vinculan entre sí tales elementos?: ¿Qué es más fuerte, la roca o el agua? Las respuestas proporcionarán información sobre cómo el agua disuelve la roca y el sedimento esculpe el lecho del arroyo. Estos ejemplos servirían para explicar la formación de canales en el Parque Nacional de Picos de Europa u otras formaciones similares.

Larsen (2003) ejemplifica la conexión entre elementos tangibles, intangibles y conceptos universales:

El proceso geológico de exfoliación podría tener relevancia y significado para aquellos que están interesados en las Ciencias de la Tierra. La exfoliación explica algunos desprendimientos de rocas y por qué ciertos rasgos adquieren determinadas formas. Una explicación de este proceso proporciona una valiosa oportunidad para que el público establezca conexiones intelectuales a los significados de los recursos (...). Sin embargo, una descripción del proceso de tectónica de placas, la elevación de la tierra, el efecto de la erosión y el deshielo y la congelación del agua no puede relacionarse con la experiencia de muchos visitantes que deseen conectarse a ese recurso. Por lo tanto estas explicaciones dependen de la información y pueden ser abrumadoras.

Sin embargo, una explicación de la exfoliación puede ser poderosa si se combina con enlaces a conceptos universales como el cambio y el poder. La pared de granito que se eleva sobre el fondo del valle surgió a partir de cinco millas debajo de la superficie de casi 3.000 metros sobre el inmenso poder de más de 25 millones de años. Cuando el proceso de exfoliación rompe la roca, como ocurre con regularidad, la energía de 25 millones años se libera en cuestión de segundos. (...)

El tiempo, la energía, el cambio y la destrucción son conceptos universales. Su relación con el proceso de exfoliación hace una geología comprensible y recordable.

Aplicando las bases de la psicología cognitiva y para que los mensajes interpretativos sean captados por los visitantes, se considera que la interpretación tiene que ser (Ham, 2007):

1) Amena: agradable, atractiva, con poder para captar la atención. 
2) Relevante para el público: esta característica se vincula en dos aspectos con el primer principio interpretativo:

a) con mensajes comprensibles que evoquen significados claros, y

b) significativo para el ego del visitante, que lo involucre y tenga en cuenta sus intereses y experiencias personales. Así consigue mantener su atención.

3) Ordenada: en un guión o esquema conceptual lógico. La estructura de las ideas debe facilitar que el público siga el hilo sin perderse, ayudándole a organizar la información en su mente.

4) Temática: el mensaje interpretativo debe tener una idea o tema claro y definido. Este tema debe sintetizar la idea principal del mensaje que representará el sentido y la esencia de los valores del recurso. Y si el tema es potente, provocará pensamientos más profundos (Ham, 2007). La estructura de la idea a transmitir debe seguir el orden de oración, con sujeto, verbo y predicado (Morales, 1998b; 2008). Por ejemplo, así se prepara el tema:

a) ¿Qué queremos explicar? "Queremos explicar el relieve kárstico."

b) Más concretamente ¿qué del relieve kárstico? "Queremos explicar la relación de la roca caliza en la formación de este tipo de relieve."

c) Entonces, ¿qué queremos que la gente sepa? (o qué le diremos al visitante, en definitiva). Al visitante le diremos que "La disolución de la roca caliza origina estas formas de relieve".

Este tipo de frase representa el concepto de tema interpretativo, que luego se desarrolla con más explicaciones que giran en torno a él. Esta explicación la puede dar un guía lo preguntárselo al público) o bien puede aparecer como texto en los carteles de un itinerario o en una exhibición de un centro. Es conveniente que un producto interpretativo desarrolle no más de cinco puntos principales para así poder proporcionar oportunidades en las que se establezcan conexiones emocionales e intelectuales de la audiencia con los significados del recurso (Larsen, 2003). Sin el desarrollo coherente de una idea o ideas relevantes, los productos no son más que colecciones de información relacionadas u ordenadas al azar y no se produce la interpretación.

Una vez definido el tema interpretativo es necesario definir el mensaje y los canales de comunicación. Morales (2008) presenta un modelo para analizar los mensajes interpretativos escritos, con el fin de mejorar su redacción y hacerlos más efectivos (los tres primeros puntos son similares a lo propuesto por el NPS, 2000):

\section{1) Elementos y atributos tangibles. \\ 2) Elementos intangibles.}




\section{3) Conceptos universales.}

4) Conexión intelectual con el visitante: oportunidad que ofrece el mensaje para que el público comprenda conceptos e ideas nuevas.

5) Conexión emocional con el visitante: oportunidad que ofrece el mensaje para producir emociones en el público.

6) Estímulo al pensamiento: capacidad del mensaje para provocar en el visitante un pensamiento más profundo. Es la provocación lo que causa el pensamiento.

7) Actitud de custodia/respeto: actitud que podría generar el mensaje para que el público aprecie y contribuya a la salvaguarda del recurso.

8) Idea central: una oración-tema que otorgue cohesión a los distintos aspectos tratados en el mensaje -con sujeto, verbo y predicado-. Además, el propósito de comunicar el "tema" es estimular el pensamiento del visitante.

Para que una interpretación logre el objetivo deseado es necesaria la interacción de determinados elementos: conocimiento del recurso a interpretar, conocimiento del público destinatario, técnicas interpretativas y oportunidad interpretativa. Un intérprete posee un Conocimiento del Recurso (CR) y un Conocimiento de la Audiencia (CA) a los que aplicaría una Técnica Apropiada (TA) para generar una Oportunidad Interpretativa (OI). Así, cuanto mayor conocimiento del recurso y de la audiencia tenga el intérprete, y cuanto más apropiadas sean las técnicas para presentar ese conocimiento, habrá más probabilidades de brindar a los visitantes oportunidades de formar conexiones personales con el recurso (NPS, 2007). Existen muchas maneras de representar las relaciones entre estos elementos. Una de ellas, lo constituye un triángulo interpretativo en donde cada lado de este triángulo equilátero representa uno de los elementos descritos en el proceso interpretativo: Conocimiento del Recurso, Conocimiento de la Audiencia y Técnicas Apropiadas (Figura 3). La elección de esta figura geométrica no es azarosa ya que en ella está implícito el equilibrio que debe existir en

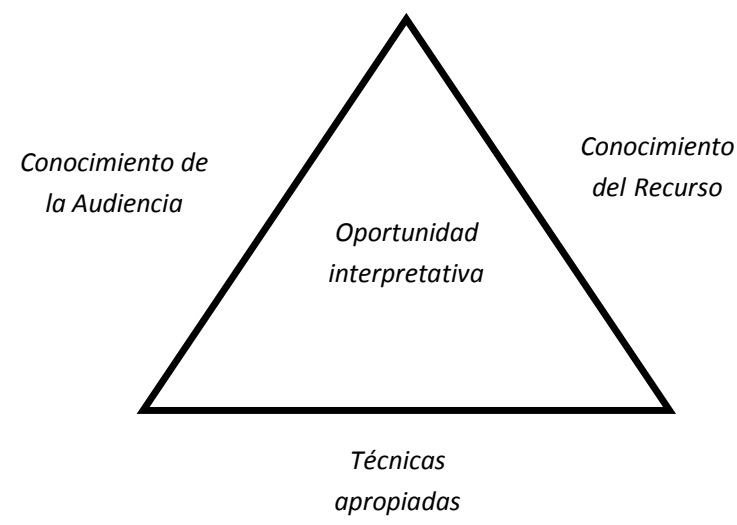

Figura 3. Triángulo interpretativo de NPS, 2007. Fuente: traducido de NPS, 2007. 
cada uno de los lados (representantes de los elementos mencionados con anterioridad) para desarrollar oportunidades interpretativas. Si un intérprete posee grandes conocimientos sobre el recurso interpretado pero no así de la audiencia, puede seleccionar técnicas interpretativas inapropiadas o ineficaces para ese auditorio. Larsen (2003) sugiere que los intérpretes hagan preguntas que permitan conocer los intereses o motivaciones de la audiencia; por ejemplo: ¿Qué te trajo aquí hoy?, ¿Qué esperabas encontrar?, ¿Qué esperas que tus hijos se "Ileven" con ellos luego de esta visita?, Si estuvieras en mi lugar, ¿qué le dirías a la gente?

Otra forma de visualizar esta relación es a través de una ecuación matemática, donde la combinación adecuada de los elementos da como resultado una oportunidad interpretativa: $(C R+C A) T A=0$ I. Pero para que esta ecuación represente una equitativa distribución de los pesos entre los elementos considerados, es recomendable citarla $\mathbf{C R}+\mathbf{C A}+\mathbf{T A}=\mathbf{O} \mathbf{I}$, ya que de la forma propuesta por el NPS (2007) induce pensar que las técnicas interpretativas prevalecen sobre el conocimiento del recurso y de la audiencia.

La tercera manera que utiliza el NPS (2007) para recordar los elementos que intervienen en la interpretación es la construcción de la sigla ART (arte en inglés), donde $\boldsymbol{A}$ representa el concepto AUDIENCIA; $R$, el RECURSO a interpretar y $T$, las TÉCNICAS ADECUADAS a emplear. La utilización de este término (arte) recuerda el tercer principio de Tilden (2006) y algunas definiciones sobre interpretación, la que es definida como una forma de ARTE que combina muchas otras ARTES.

\section{4) Investigación sobre Interpretación}

Desde sus inicios en la década de 1960, la investigación interpretativa ha luchado por encontrar su nicho entre otras ciencias sociales. Con el correr de los años, ha abordado cuestiones más sofisticadas que antes y en la actualidad toma prestado aportes de la teoría social y psicológica (incluyendo otras ramas de las ciencias sociales aplicadas, tales como el marketing, el comportamiento del consumidor y la educación). La producción de la investigación en interpretación requiere de la formación de investigadores que sepan cómo acceder, realizar, interpretar y aplicar la investigación (Ham, 2002). El enfoque práctico de la Interpretación del Patrimonio busca aplicar las teorías de la manera más eficiente y posible. En el campo de la gestión de los recursos y la conservación del patrimonio, la interpretación tradicionalmente ha hecho hincapié en la ejecución de los programas y el manejo de los sitios patrimoniales. 
Las distintas etapas de la evolución de la investigación en Interpretación del Patrimonio y sus principales áreas de estudio, aparecen resumidas en las Tablas 6 y 7, respectivamente.

Tabla 6. Evolución de la investigación sobre Interpretación del Patrimonio.

\begin{tabular}{|c|c|c|}
\hline Épocas & Etapa evolutiva & Características \\
\hline $\begin{array}{l}\text { Décadas } \\
1960-70\end{array}$ & $\begin{array}{c}\text { Años de } \\
\text { formación }\end{array}$ & $\begin{array}{l}\text { Al principio de esta etapa existía poca precisión para definir el objeto a } \\
\text { investigar en Interpretación. } \\
\text { En } 1973 \text { Field y Wagar publican el primer artículo que relaciona los } \\
\text { visitantes de un parque con variables dependientes como la diversión o } \\
\text { el disfrute. Esto es considerado el inicio de la investigación } \\
\text { metodológica en Interpretación. }\end{array}$ \\
\hline $\begin{array}{l}\text { Décadas } \\
1970-80\end{array}$ & $\begin{array}{l}\text { Búsqueda del } \\
\text { mejor medio }\end{array}$ & $\begin{array}{l}\text { Influenciados por modelos de comunicación (emisor, receptor, canal y } \\
\text { retroalimentación), los investigadores interpretativos se ocupan de } \\
\text { encontrar los mejores medios interpretativos para la comunicación con } \\
\text { los turistas. Se considera que el medio era el mensaje y que el medio } \\
\text { preferido de los visitantes es el más efectivo. Posteriormente, con } \\
\text { aportes de psicología de la comunicación, se concluye que las personas } \\
\text { prefieren distintos medios interpretativos, por lo que cada medio es el } \\
\text { mejor para alguien. } \\
\text { El principal logro teórico de esta etapa es la constatación empírica de } \\
\text { la existencia de muchos tipos de visitantes que pueden desear } \\
\text { diferentes clases de experiencias de recreación, por lo que el modelo } \\
\text { del mejor medio se sustituyó por uno diferente, basado en la idea de } \\
\text { que si se ofrece un abanico de medios interpretativos, los espectadores } \\
\text { recurrirán a lo que les conviene más, de acuerdo con el tipo de } \\
\text { experiencia recreativa que buscan. }\end{array}$ \\
\hline $\begin{array}{c}\text { Década } \\
1980\end{array}$ & $\begin{array}{l}\text { Búsqueda de } \\
\text { legitimidad }\end{array}$ & $\begin{array}{l}\text { El reconocimiento de la necesidad de la interpretación para lograr } \\
\text { legitimidad se originó de forma prominente en la década de } 1980 . \\
\text { Diversos autores consideraron oportuno demostrar la contribución de } \\
\text { la interpretación a la gestión de espacios naturales y fue en esa } \\
\text { ocasión cuando surgió un claro enfoque en la evaluación sistemática } \\
\text { de la investigación interpretativa. Coincidiendo con este nuevo interés } \\
\text { en la evaluación, llegó un tratamiento distinto de la interpretación, no } \\
\text { sólo como una herramienta divertida para revelar a los visitantes los } \\
\text { valores de lugares protegidos, sino más bien como una herramienta de } \\
\text { gestión de recursos. Tal énfasis ha continuado hasta la actualidad. }\end{array}$ \\
\hline $\begin{array}{c}\text { Década } \\
1990\end{array}$ & $\begin{array}{c}\text { Principios de la } \\
\text { madurez }\end{array}$ & $\begin{array}{l}\text { La tendencia más notable de esta etapa es la internacionalización de la } \\
\text { investigación interpretativa. Aparecen estudios de experiencias de } \\
\text { diferentes partes del mundo (en un principio la mayoría de la literatura } \\
\text { sobre el tema era originaria de Estados Unidos y Canadá). } \\
\text { Otra señal de madurez es la elaboración de una base teórica más } \\
\text { sofisticada. Metodológicamente, el viejo enfoque de análisis } \\
\text { univariado y bivariado incorpora diseños con múltiples variables. Existe } \\
\text { un uso más frecuente de los estudios de casos y otros diseños de } \\
\text { investigación cualitativa. Del mismo modo, la investigación } \\
\text { interpretativa de esta etapa toma aportes de la teoría social y la } \\
\text { psicología. } \\
\text { Otro aspecto relevante es que el sector turístico privado ha reconocido } \\
\text { que los programas interpretativos bien realizados generan beneficios } \\
\text { para su actividad. }\end{array}$ \\
\hline Siglo XXI & $\begin{array}{l}\text { Consolidación } \\
\text { como disciplina } \\
\text { y relación con } \\
\text { otras } \\
\text { actividades }\end{array}$ & $\begin{array}{l}\text { Fortalecimiento del desarrollo teórico y práctico de la Interpretación } \\
\text { como resultado de la continuidad en la investigación. En esta etapa se } \\
\text { prosiguen las investigaciones sobre los beneficios de la Interpretación } \\
\text { sobre las actividades turísticas y el modelo de planificación } \\
\text { interpretativa como propuesta de desarrollo local. }\end{array}$ \\
\hline
\end{tabular}


Tabla 7. Principales áreas de investigación en Interpretación del Patrimonio.

\begin{tabular}{|c|c|c|}
\hline Área de Investigación & Enfoques & Principales investigaciones \\
\hline $\begin{array}{l}\text { Mejora de la } \\
\text { experiencia y } \\
\text { satisfacción del turista }\end{array}$ & $\begin{array}{l}\text { Eficacia de las estrategias de } \\
\text { interpretación, sobre todo } \\
\text { aquellas relacionadas en } \\
\text { satisfacer las expectativas de } \\
\text { los visitantes. Un tema común } \\
\text { se refiere a si la alta } \\
\text { satisfacción necesariamente se } \\
\text { traduce en una experiencia } \\
\text { positiva de aprendizaje. }\end{array}$ & $\begin{array}{l}\text { Hughes, 1991; Moscardo y Pearce, 1997; } \\
\text { Weiler, 1999; Kuo, 2002; Moscardo, 2002; } \\
\text { Armstrong y Weiler, 2003; Chen, 2003; } \\
\text { Luck, 2003; Hwang et al., 2005; Tarlton y } \\
\text { Ward, 2006; Jensen, 2006; Morgan y } \\
\text { Dong, 2008; Macklin, Hvenegaard y } \\
\text { Johnson, 2010; Moreira, 2012; Stern et } \\
\text { al., 2013. }\end{array}$ \\
\hline $\begin{array}{l}\text { Fomento de actitudes } \\
\text { positivas hacia la } \\
\text { conservación de la } \\
\text { naturaleza }\end{array}$ & $\begin{array}{l}\text { Capacidad de los programas } \\
\text { interpretativos para influir en } \\
\text { las tendencias de } \\
\text { comportamiento existentes en } \\
\text { materia de conservación de la } \\
\text { naturaleza. Se presta atención a } \\
\text { las normas sociales respecto a } \\
\text { la interacción con el entorno y } \\
\text { la adecuación de estrategias } \\
\text { interpretativas para influir en } \\
\text { diferentes grupos sociales. }\end{array}$ & $\begin{array}{l}\text { Roggenbuck y Williams, 1991; Orams, } \\
\text { 1995; Moscardo et al, 1996; Cole et al, } \\
\text { 1997; Reiling et al., 1998; Stewart et al, } \\
\text { 1998; Howard, 1999/2000; Winter et al, } \\
\text { 2000;Beaumont, 2001; Parkin y Parkin, } \\
\text { 2001; Armstrong y Weiler, 2003; Lackey y } \\
\text { Ham, 2003; Littlefair, 2003; Luck, 2003; } \\
\text { Moscardo, 2003; Madin y Fenton, 2004; } \\
\text { Appleby, 2005; Parkin y Morris, 2005; } \\
\text { Woods y Moscardo, 2005; Wiles y Hall, } \\
\text { 2005; Ernst, 2005; }\end{array}$ \\
\hline $\begin{array}{l}\text { Conexión de los } \\
\text { resultados en } \\
\text { interpretación con los } \\
\text { objetivos estratégicos }\end{array}$ & $\begin{array}{l}\text { Manera en que la } \\
\text { interpretación (y la educación) } \\
\text { es definida y usada en la } \\
\text { planificación estratégica. Por lo } \\
\text { tanto se trabaja sobre el } \\
\text { desarrollo de los servicios } \\
\text { interpretativos y en relación con } \\
\text { los objetivos de gestión. }\end{array}$ & $\begin{array}{l}\text { Roggenbuck y Berrier, 1982; Bass et al., } \\
\text { 1989; Roggenbuck y Williams, 1991; } \\
\text { Orams, 1995; Ryan y Dewar, 1995; Cole et } \\
\text { al., 1997; Orams, 1997; Hefferman, 1998; } \\
\text { Reiling et al., 1998; Chen et al, 1999; } \\
\text { Evans, 1999; Moscardo 1999b; Winter et } \\
\text { al., 2000; Hendricks et al., 2001; } \\
\text { Papageorgiou, 2001; Kuo, 2002; Smith- } \\
\text { Jackson y Hall, 2002; Armstrong y Weiler, } \\
\text { 2003; Ballantyne and Hughs, 2003; } \\
\text { Mallick y Driessen, 2003; Madin y Fenton, } \\
\text { 2004; Moscardo, Woods y Pearce, 2004; } \\
\text { Pearce, 2004; Cho, 2005; Hughes y } \\
\text { Morrison-Saunders, 2005; Winters, 2009. }\end{array}$ \\
\hline $\begin{array}{l}\text { Disminución de los } \\
\text { impactos por parte de } \\
\text { los visitantes }\end{array}$ & $\begin{array}{l}\text { Respuestas cognitivas } \\
\text { (aprendizaje, procesamiento de } \\
\text { la información) y de conducta } \\
\text { (acciones o inacciones del } \\
\text { público objetivo). }\end{array}$ & $\begin{array}{l}\text { Stoep y Gramman, 1987; Parkin y Parkin, } \\
\text { 2001; Littlefair, 2003; Hockett y Hall, } \\
\text { 2007; Reigner y Lawson, } 2009 .\end{array}$ \\
\hline $\begin{array}{l}\text { Conexión de los } \\
\text { visitantes con los } \\
\text { recursos }\end{array}$ & $\begin{array}{l}\text { Estrategias para el desarrollo y } \\
\text { fortalecimiento del vínculo } \\
\text { recursos-visitante. }\end{array}$ & $\begin{array}{l}\text { Falk y Dierking, 1997; Wells, 2000; Knapp } \\
\text { y Yang, 2002; Anderson, 2003; Povey y } \\
\text { Rios,2003; Knapp y Benton, 2004; Jensen, } \\
\text { 2006; Morgan, } 2009 .\end{array}$ \\
\hline $\begin{array}{l}\text { Promoción de los } \\
\text { resultados del turismo }\end{array}$ & $\begin{array}{l}\text { Capacidad de los programas } \\
\text { interpretativos para mejorar la } \\
\text { oferta turística. }\end{array}$ & $\begin{array}{l}\text { Zeppel, 2002; Archer y Wearing, 2003; } \\
\text { Deutschlander y Miller, 2003; Strange y } \\
\text { Kempa, 2003; Tubb, 2003; Carr, 2004; } \\
\text { Ham y Weiler, 2007; Moreira, 2008; } \\
\text { Martín Hernanz, 2012. }\end{array}$ \\
\hline Otras investigaciones & $\begin{array}{l}\text { Diversos objetivos (por ejemplo, } \\
\text { factores que intervienen en una } \\
\text { Interpretación exitosa) }\end{array}$ & $\begin{array}{l}\text { Ham, 1986; Moscardo, 1995; Bolwell, } \\
\text { 1996; Ballantyne y Uzzell, 1999; Staiff et } \\
\text { al., 2002; Moscardo, 2003; Taylor y } \\
\text { Caldarelli, 2004; Stern y Powell, } 2013 .\end{array}$ \\
\hline
\end{tabular}




\section{5) El potencial interpretativo y su evaluación}

Un rasgo interpretativo (cualidad intrínseca) es todo objeto, proceso, fenómeno o concepto que merece ser interpretado o que tiene importancia interpretativa (Morales, 1992). El potencial interpretativo existe cuando una variedad de rasgos y ambientes importantes se encuentran a la vista. Estos rasgos pueden inspirar para darle nombre. Un rasgo interesante puede servir como señuelo para atraer a la gente a visitar el sitio, y por lo tanto, incrementar el número de personas al que se puede llegar. Ejemplos de rasgos interpretativos pueden ser caídas o nacimientos de agua, formaciones geológicas, afloramientos de fósiles, un punto de valor escénico o paisajístico, sucesos históricos, etc.

Para la interpretación de grandes áreas, es necesario organizar unos criterios de evaluación para el potencial interpretativo de los sitios, de forma que, posteriormente se pueden establecer prioridades de operación. En la Tabla 8 se presenta una matriz para la valoración del potencial interpretativo de los recursos a interpretar. Dentro de los criterios aplicables para la selección final de tales elementos está la singularidad, la disponibilidad de información, la facilidad de explicación, entre otros. Los criterios se valoran de acuerdo a una clasificación en bueno, regular o malo y su correspondiente intervalo de puntuación. Tras aplicar esta matriz se obtiene un valor numérico para cada punto: el índice del potencial interpretativo (IPI), que puede indicar la prioridad a la hora de elección de los sitios con potencial de uso para la interpretación.

Tabla 8. Matriz para la evaluación del potencial interpretativo.

\begin{tabular}{|l|c|c|c|}
\hline \multicolumn{1}{|c|}{ Criterios } & Bueno & Regular & Malo \\
\hline Singularidad & $12-9$ & $8-5$ & $4-1$ \\
\hline Atractivo & $12-9$ & $8-5$ & $4-1$ \\
\hline Resistencia al impacto & $12-9$ & $8-5$ & $4-1$ \\
\hline Acceso a una diversidad de público & $9-7$ & $6-4$ & $3-1$ \\
\hline Estacionalidad & $9-7$ & $6-4$ & $3-1$ \\
\hline Afluencia actual de público & $9-7$ & $6-4$ & $3-1$ \\
\hline Representatividad didáctica & $6-5$ & $4-3$ & $2-1$ \\
\hline Pertinencia de contenidos & $6-5$ & $4-3$ & $2-1$ \\
\hline Seguridad & $6-5$ & $4-3$ & $2-1$ \\
\hline Facilidad de infraestructura & $6-5$ & $4-3$ & $2-1$ \\
\hline Fuente: modificado de Morales, 1998a; Comisión Centroamericana de Ambiente y Desarrollo, 2005. \\
\hline
\end{tabular}


Este valor relativo puede orientar hacia qué dirección dirigir las acciones prioritarias de la Interpretación. Los criterios que aparecen en la Tabla 8 son definidos de la siguiente manera (Morales, 1998; Comisión Centroamericana de Ambiente y Desarrollo, 2005):

- Singularidad: frecuencia con que aparece ese rasgo o valor en el área o Parque. La singularidad indica su grado de rareza y el grado de importancia intrínseca de ese lugar (o rasgo) con respecto a toda el área. Normalmente, cuanto más único o relevante sea el sitio, mayor potencial interpretativo tendrá.

- Atractivo: capacidad del recurso o sitio en cuestión para despertar la curiosidad y el interés en el público. Cuanto más interesante sea un sitio a los ojos del visitante, mayor puntuación tendrá. Este valor es subjetivo.

- Resistencia al impacto: capacidad del recurso o sitio en cuestión para resistir la presión de visitas y el uso. Esta capacidad depende del sustrato, de las características ecológicas del lugar y de la fragilidad del recurso en cuestión.

- Acceso a una diversidad de público: posibilidad física que ofrece el lugar para que una amplia variedad de público lo visite. Ciertos lugares, por ejemplo, los muy abruptos, no permitirán el acceso a ancianos, niños y minusválidos físicos. El potencial interpretativo se vería afectado por esa disminución en la posibilidad de acceso directo.

- Estacionalidad: tiempo o período en que el rasgo puede permanecer asequible al visitante a lo largo del año. Esto puede ser debido a factores climáticos, biológicos o de conservación.

- Afluencia actual de público: cantidad de público que se estima que visita, se concentra o reúne en ese momento en el recurso en cuestión o en sus alrededores inmediatos, sea debido al rasgo interpretativo en sí o por otros motivos.

- Representatividad didáctica: facilidades que ofrece el lugar para ser explicado al visitante en términos comprensibles, gráficos y esquemáticos.

- Pertinencia de contenidos: que el lugar ofrezca la oportunidad de tratar temas o contenidos en concordancia con los temas generales del parque o área, y que los mismos puedan insertarse en un programa general.

- Seguridad: grado de seguridad que ofrece el rasgo y sus alrededores inmediatos para los visitantes.

- Facilidad de infraestructura: facilidades que ofrece el lugar de ser acondicionado para recibir visitas, considerando su estado actual de acceso, conservación e información. 


\section{6) Los cambios en la definición de Interpretación del} Patrimonio

Actualmente se concibe a la Interpretación del Patrimonio como un proceso creativo de comunicación estratégica que ayuda a conectar intelectual y emocionalmente al visitante con los significados del recurso patrimonial visitado, para que lo aprecie y disfrute (Morales, 2008), pero esta definición no es única ni acabada y ha sufrido modificaciones a través del tiempo. En esta parte del trabajo, se llevará a cabo un análisis de contenido de 33 definiciones de Interpretación del Patrimonio, lo que permitirá observar la evolución histórica del concepto y de la práctica interpretativa.

Toda definición describe y delimita un concepto, proporcionando información sobre el uso del término, a la vez de servir para normalizar el significado del mismo (Valero, 2008). Por su parte, el análisis de contenido constituye una ayuda metodológica en la realización de investigaciones cualitativas que pretende sustituir las interpretaciones subjetivas del estudio de documentos o de comunicaciones por unos procedimientos estandarizados que procuran objetivar y convertir en datos los contenidos de determinados documentos o comunicaciones para que puedan ser analizados y tratados de forma mecánica. Con esta técnica no es el estilo del texto lo que se pretende analizar, sino las ideas expresadas en él, siendo el significado de las palabras, temas o frases lo que intenta cuantificarse (López, 2002). La codificación de los datos se ha realizado utilizando técnicas de codificación abierta (Bardin, 2002):

- Exclusión mutua: cada elemento no puede estar afectado a más de una categoría.

- Homogeneidad: un mismo principio de clasificación debe dirigir su organización.

- Pertinencia: el sistema de categorías debe reflejar las intenciones de búsqueda, como así también, en este trabajo, los artículos y/o incisos que haya en cada categoría.

- Objetividad y fidelidad: si se someten a varios análisis un trozo del mismo material al que se aplique la misma planilla de categorías, deberán ser codificados de la misma manera. EI organizador del análisis debe definir claramente las variables que utilice, igual que debe precisar los índices que determinen la entrada de un elemento en una categoría.

- Productividad: un conjunto de categorías es productivo si proporciona resultados ricos: ricos en inferencias, ricos en hipótesis nuevas, ricos en datos fiables.

\subsection{1) Definiciones analizadas de Interpretación Ambiental y/o del Patrimonio}

1) Tilden (1957): la interpretación es una actividad educativa que pretende revelar significados e interrelaciones mediante el uso de objetos originales, experiencias de 
primera mano y medios ilustrativos, en lugar de simplemente transmitir la información de los hechos (Ed. en castellano, 2006, p. 35).

2) Countryside Commission (1970, Inglaterra): la interpretación es el proceso de desarrollar el interés, el disfrute y la comprensión del visitante por un área, mediante la explicación de sus características y sus interrelaciones (Boletín de Interpretación, 2001, 4, p. 8).

3) Aldridge (1973): la interpretación es el arte de explicar el lugar del hombre en su medio, con el fin de incrementar la conciencia del visitante acerca de la importancia de esa interacción, y despertar en él un deseo de contribuir a la conservación del ambiente (Morales, 1998a, p. 31).

4) Edwards (1976): la interpretación posee cuatro características que hacen de ella una disciplina especial: es comunicación atractiva, ofrece una información concisa, es entregada en presencia del objeto en cuestión y su objetivo es la revelación de un significado (Morales, 1998a, p. 31).

5) Interpretation Canada (1976): la interpretación del patrimonio es cualquier proceso de comunicación diseñado para revelar significados y relaciones de patrimonio cultural y natural de la población, a través de la participación de primera mano con un objeto, artefacto, paisaje o sitio. ${ }^{3}$

6) Peart (1977): la interpretación es un proceso de comunicación diseñado para revelar al público significados e interrelaciones de nuestro patrimonio natural y cultural, a través de su participación en experiencias de primera mano con un objeto, artefacto, paisaje o sitio (Morales, 1998a, p. 31).

7) Risk (1982): la interpretación es lo que la misma palabra quiere decir: la traducción del lenguaje técnico y a menudo complejo del ambiente, a una forma no técnica -sin por ello perder su significado y precisión-, con el fin de crear en el visitante una sensibilidad, conciencia, entendimiento, entusiasmo y compromiso hacia el recurso que es interpretado (Morales, 1998a, p. 31).

8) Sharpe (1988): la interpretación es un servicio para los visitantes de parques, bosques, refugios y áreas similares de recreación. A pesar de que los visitantes llegan a estas áreas para disfrutar del descanso e inspiración, también pueden desear aprender acerca de los recursos naturales y culturales del área. Estos recursos comprenden los procesos geológicos, animales, plantas, comunidades ecológicas, la historia y la

3 Texto original: Heritage interpretation is any communication process designed to reveal meanings and relationships of cultural and natural heritage to the public, through first-hand involvement with an object, artifact, landscape or site. 
prehistoria del hombre. La interpretación es la comunicación que conecta al visitante con estos recursos (Comisión Centroamericana de Ambiente y Desarrollo, 2005, p. 3).

9) Chaverri (1988): Ia Interpretación Ambiental es un medio de comunicación humana, y a la vez un arte que trata de traducir y explicar al hombre las características del ambiente". Teniéndose en cuenta que no solo trata las características naturales, sino también las de tipo histórico, arqueológico, cultural, entre otras. Por lo que es aplicable en otros ambientes no naturales, ejemplos: museos, ciudades históricas, etc. (Comisión Centroamericana de Ambiente y Desarrollo, 2005, p. 3).

10) Ham (1992): la Interpretación Ambiental involucra la traducción del lenguaje técnico de una ciencia natural o área relacionada en términos e ideas que las personas en general, que no son científicos, puedan entender fácilmente, e implica hacerlo de forma que sea entretenido e interesante para ellos.

11) Veverka (1994): resalta el hecho de que las comunicaciones interpretativas no consisten únicamente en presentar una serie coherente de datos, sino en desarrollar una estrategia de comunicación específica para traducir esa información para otras personas, convirtiéndose de esta forma el lenguaje técnico del especialista en el lenguaje corriente del visitante (Comisión Centroamericana de Ambiente y Desarrollo, 2005, p. 3).

12) Dean (1994): la interpretación es el acto o el proceso de explicar o clarificar, de traducir o presentar una comprensión personal del objeto (Proyecto Hicira, 2005, p. 16). ${ }^{4}$

13) Padró (1996, p. 9): la interpretación es un método para la presentación, comunicación y explotación del patrimonio, con el objetivo de aprehensión y utilización del mismo con finalidades culturales, educativas, sociales y turísticas.

14) Rideout-Civitarese et al (1997): Ia interpretación es una actividad de comunicación diseñada para mejorar la calidad de la experiencia recreativa del visitante, y para inspirar, de una forma agradable, un mayor aprecio por el recurso (Comisión Centroamericana de Ambiente y Desarrollo, 2005, p. 3).

15) ICOMOS-Carta Internacional sobre Turismo Cultural (1999, p. 3):

Principio 1.3: la interpretación y presentación de los programas debería proporcionar un alto nivel de conciencia pública y el soporte necesario para la supervivencia del patrimonio natural y cultural a largo plazo.

Principio 1.4: los programas de interpretación deberían proporcionar el significado de los sitios del patrimonio y de sus tradiciones y prácticas culturales así como ofrecer sus

\footnotetext{
${ }^{4}$ Proyecto Hicira (2005, p. 16)
} 
actividades dentro del marco tanto de la experiencia del pasado como de la actual diversidad cultural de la comunidad anfitriona y de su región, sin olvidar las minorías culturales o grupos lingüísticos. El visitante debería siempre estar informado acerca de la diversidad de los valores culturales que pueden adscribirse a los distintos bienes patrimoniales.

16) Cuenca (2002, p. 154): respecto a cómo desarrollar el proceso de interpretación, hemos de considerar que la forma más efectiva es mediante el contacto directo del visitante con el elemento patrimonial, mediante una comunicación atractiva, comprensible, participativa, interactiva, significativa y relevante que mantenga un guión lógico en torno a una idea central motivadora que articule todos los contenidos objeto de la interpretación.

17) Proyecto Hicira (2005, p.15): la interpretación es un método de trabajo que nos facilita la presentación y el uso social del patrimonio y sirve para ofrecer lecturas y opciones para un uso activo de éste, utilizando toda clase de recursos de presentación y animación. La interpretación parte de unos testimonios culturales y/o naturales, ya sean materiales o inmateriales, que se han desarrollado en un lugar concreto, e intenta conseguir la dinamización del patrimonio en su contexto original. Por ello, siempre se persigue la recuperación in situ y la mayor contextualización posible de los recursos patrimoniales, y se rechaza la idea del objeto como valor en sí mismo, al margen de su función y su entorno.

18) Comisión Centroamericana de Ambiente y Desarrollo (2005, prólogo): la interpretación ambiental es una actividad educativa ambiental que examina y revela de manera atractiva, las características de un área y sus relaciones biofísicas y culturales, a través de experiencias directas que generen en las personas disfrute, sensibilidad, conocimiento y compromiso con los valores interpretados. Es un instrumento que facilita la gestión de sitios con potenciales atractivos para ser visitados (espacios naturales protegidos, lugares arqueológicos, etc.) con el fin de conseguir apoyo del público en tareas de conservación. Busca comunicar los valores del patrimonio natural y cultural, prevenir los efectos negativos, aportar a los procesos de conservación que se estén desarrollando en el área.

19) Fernández y Fallas (2005, p. 1): la interpretación ambiental, lejos de comunicar información literal, lo que busca es transmitir ideas y relaciones a partir de un acercamiento directo entre la audiencia y los recursos que se interpretan. Para lograrlo se utilizan diferentes técnicas que ayudan a las personas a entender y apreciar lo que 
se observa. La meta es comunicar un mensaje. La interpretación ambiental traduce el lenguaje técnico de los profesionales en términos e ideas que las personas en general entienden fácilmente.

20) Morales (2008, p. 58): la interpretación del patrimonio es un proceso creativo de comunicación estratégica que ayuda a conectar intelectual y emocionalmente al visitante con los significados del recurso patrimonial visitado, para que lo aprecie y disfrute.

21) Santamarina (2008, p. 39): Ia interpretación puede ser entendida como "el arte de dotar de significado y sentido a un lugar" para su reconocimiento, uso y disfrute que permita su conservación como legado para generaciones futuras.

22) Serantes (2010): la interpretación del Patrimonio (IP) es una forma de comunicación estratégica, es decir, una forma planificada y consciente de dirigir mensajes a un determinado público del que se espera una respuesta. En este caso, se trata del "arte" y de la técnica de comunicar "in situ" los valores naturales, culturales y etnográficos a un público no especializado que visita el lugar en su tiempo libre.

23) Queensland National Parks and Wildlife Service (Australia): la interpretación es el proceso de estimular y alentar el aprecio en los visitantes por su patrimonio natural y cultural, además de comunicarles los ideales y las prácticas de conservación (Comisión Centroamericana de Ambiente y Desarrollo, 2005, p. 3).

24) División de Bosques y Parques de Massachusetts: la interpretación es una actividad educativa que revela a los visitantes los rasgos naturales y culturales, la gestión de los recursos los elementos recreativos de un bosque, un parque, etc., de una forma emocionante y provocativa, de modo que incremente el disfrute de ese público y su aprecio por el sitio (Boletín de Interpretación, 1999, 2, p. 12).

25) Countryside Commission for Scotland: la interpretación es el arte de explicar al público el carácter de un lugar, especialmente a los visitantes casuales, de forma que tomen conciencia del significado del sitio que visitan y desarrollen el deseo de conservarlo (Boletín de Interpretación, 2000, 3, p. 15).

26) Peak National Park Study Center (Gran Bretaña): Ia interpretación explica el lugar a sus visitantes no sólo en cuanto a unos hechos, sino para que la gente establezca conexiones personales con las ideas que se le presentan. El resultado final de la interpretación debe ser un estado de conciencia y un deseo de contribuir a la conservación del patrimonio. Sin embargo, la interpretación NO ES LO MISMO QUE el dar información, la educación ambiental, decidir qué es lo que la gente "debería" 
apreciar de un lugar, o la obtención de apoyo público para lograr los objetivos de gestión (Boletín de Interpretación, 2001, 5, p. 14).

27) MacFarlane: la interpretación es el proceso de comunicación que pretende que el visitante descubra el significado de cosas, lugares, personas y acontecimientos. Es más que información, es más que educación...implica ayudar a que la gente cambie la forma que tiene de verse a ella misma y al mundo, a través de una mayor comprensión de sí mismo y del mundo que lo rodea (INRENA, 2006, p. 38).

28) Merriman (EEUU): Ia interpretación es la disciplina dedicada al estudio y a la práctica de la comunicación con el público acerca de los recursos naturales y culturales (Boletín de Interpretación, 2002, 6, p. 17).

29) Asociación para la Interpretación del Patrimonio (AIP, España): la interpretación del patrimonio es el "arte" de revelar in situ el significado del legado natural y cultural al público que visita esos lugares en su tiempo libre.

30) Association Heritage Interpretation (AHI, Reino Unido): la interpretación es ante todo un proceso de comunicación que ayuda a dar sentido y entender más acerca de su sitio, colección o evento. ${ }^{5}$

31) Interpret Europa: la interpretación del patrimonio es un enfoque estructurado para la educación no formal que se ha especializado en la comunicación de ideas importantes acerca de un lugar para la gente en el ocio. Se establece un vínculo entre los visitantes y lo que puede descubrir en una reserva natural, sitio histórico o un museo. ${ }^{6}$

32) Interpretation Australia: la interpretación del patrimonio es un medio de comunicación de ideas y sentimientos que ayudan a la gente a entender más acerca de sí mismos y de su entorno. ${ }^{7}$

33) National Association por Interpretation (NAI, EE.UU.): la interpretación es un proceso de comunicación basado en misiones que forja conexiones emocionales e intelectuales entre los intereses de la audiencia y los significados inherentes al recurso. ${ }^{8}$

\footnotetext{
${ }^{5}$ Texto original: Interpretation is primarily a communication process that helps people make sense of, and understand more about, your site, collection or event.

${ }^{6}$ Texto original: Heritage interpretation is a structured approach to non-formal education that is specialized in communicating significant ideas about a place to people on leisure. It establishes a link between visitors and what they can discover at a nature reserve, a historic site or a museum.

7 Texto original: Heritage interpretation is a means of communicating ideas and feelings which help people understand more about themselves and their environment.

8 Texto original: Interpretation is a mission-based communication process that emotional and intellectual connections between the interests of the audience and the meanings inherent in the resource.
} 


\subsection{2) Resultados y conclusiones del análisis de las definiciones}

En conjunto se analizaron 33 definiciones de Interpretación del Patrimonio o Ambiental, todas ellas de distinta autoría. Para el manejo mecánico de datos se utilizó el programa informático Atlas.ti, obteniendo representaciones gráficas de la estructura conceptual de los datos. Este software sirvió como herramienta para almacenar y rastrear las agrupaciones de palabras y hacer el seguimiento de los significados que se le asignó a las distintas categorías de información. Con la utilización de Atlas.ti se identificaron aquellos fragmentos de texto relevantes para este trabajo, los que fueron codificados en función al tipo de referencia conceptual que describían, para luego crear relaciones entre ellos o entre sus códigos. En este trabajo se elaboraron los códigos a medida que aparecían los diferentes tipos de características en las definiciones. En la Figura 4 se puede observar que al fragmento de texto "ayuda a conectar intelectual" se le ha asignado el código OBJETIVO DE CONOCIMIENTO.

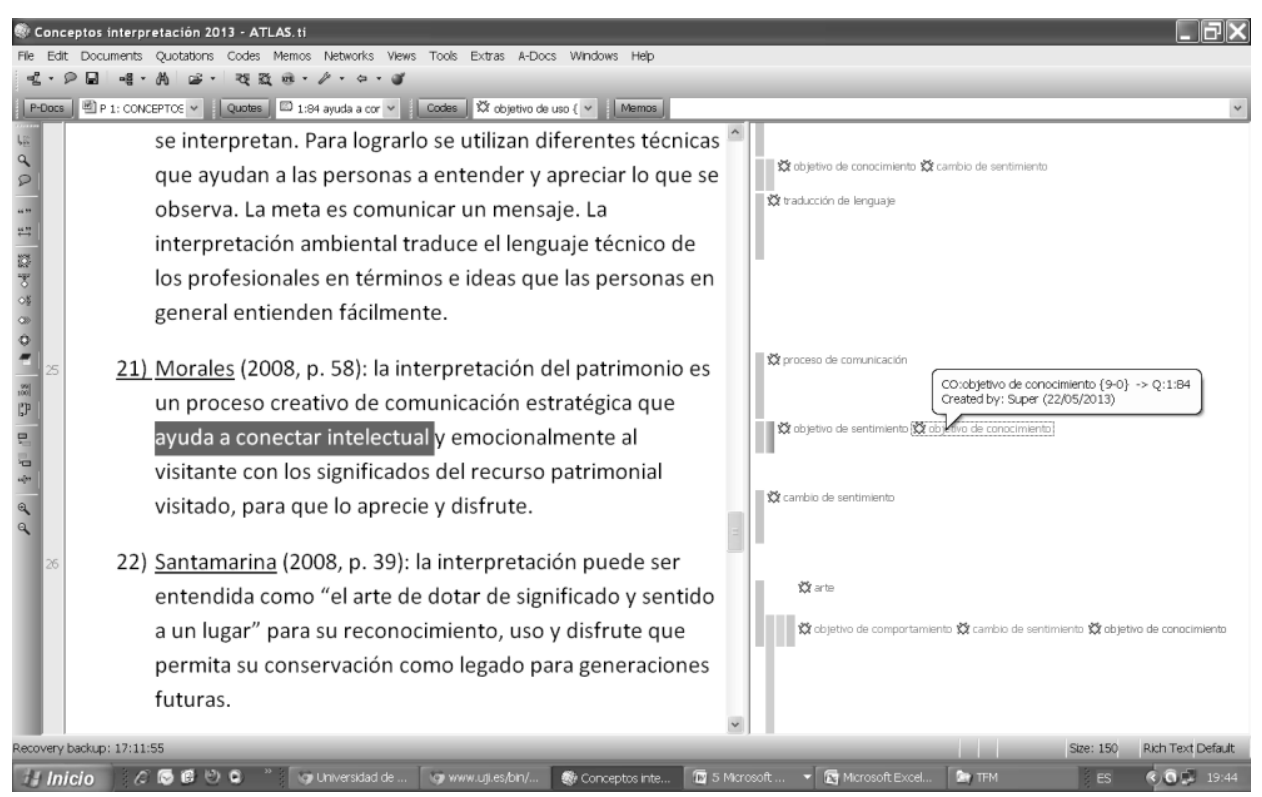

Figura 4. Texto codificado en ATLAS.ti.

Fuente: captura de pantalla.

La Tabla 9 muestra las características identificadas en el análisis de datos referentes a los grupos conceptuales. Los aspectos analizados son a) ¿Qué es la Interpretación?, b) Tipo de contacto con el patrimonio, c) Relación información e interpretación, d) Objetivos de la interpretación, y e) Otras características. La mayoría de las definiciones (21, que representan un 64 \% del total) relacionan la Interpretación con una sola idea (comunicación, traducción, arte, etc. $)^{9}$, mientras que otras (9 y 27\%, respectivamente) lo hacen con dos ${ }^{10}$, tres (Padró,

\footnotetext{
${ }^{9}$ Tilden, 1957; Countryside Commission (Inglaterra) 1970; Edwards, 1976; Interpretation Canada, 1976; Peart, 1977; Risk, 1982; Ham, 1992; Rideout-Civitarese et al, 1997; Cuenca, 2002; Fernández y Fallas, 2005; Morales, 2008;
} 
1996) o cuatro representaciones (Chaverri, 1988). Sólo una definición (ICOMOS-Carta Internacional sobre Turismo Cultural, 1999) describe las características de la interpretación, más no presenta un concepto de la misma, según norma ISO 704 (Alcina y Valero, 2008).

Tabla 9. Análisis de definiciones de Interpretación del Patrimonio y/o Ambiental.

\begin{tabular}{|c|c|c|c|}
\hline $\begin{array}{l}\text { Aspectos } \\
\text { analizados }\end{array}$ & Respuestas & Citas & Autores \\
\hline \multirow{10}{*}{$\begin{array}{l}\text { ¿Qué es la } \\
\text { interpretación? }\end{array}$} & Es comunicación & 17 & $\begin{array}{l}4,5,6,8,9,11,13,14,16 \\
20,22,23,27,30,31,32,33\end{array}$ \\
\hline & Es una traducción de lenguaje & 6 & $7,9,10,11,12,19$ \\
\hline & Es un arte & 6 & $3,9.21,22,25,29$ \\
\hline & Es explicación & 5 & $3,9,12,25,26$ \\
\hline & Es un instrumento de gestión o que la facilita & 4 & $13,17,18,24$ \\
\hline & Es una actividad educativa & 3 & $1,18,24$ \\
\hline & Es un proceso de estimular, desarrollar interés & 2 & 2,23 \\
\hline & Es un método de presentación o de trabajo & 2 & 13,17 \\
\hline & Es un servicio para los visitantes & 1 & 8 \\
\hline & $\begin{array}{l}\text { Es una disciplina dedicada al estudio y a la } \\
\text { práctica de la comunicación }\end{array}$ & 1 & 28 \\
\hline \multirow{2}{*}{$\begin{array}{l}\text { Tipo de contacto } \\
\text { con el } \\
\text { patrimonio }\end{array}$} & Contacto directo & 11 & $\begin{array}{l}1,3,4,5,6,16,17,1819, \\
22,29\end{array}$ \\
\hline & Contacto indirecto & 1 & 1 \\
\hline \multirow{2}{*}{$\begin{array}{c}\text { Relación } \\
\text { información e } \\
\text { interpretación }\end{array}$} & Es más que una mera información & 5 & $1,11,19,26,27$ \\
\hline & Es información & 1 & 4 \\
\hline \multirow{3}{*}{$\begin{array}{l}\text { Objetivos de la } \\
\text { interpretación }\end{array}$} & $\begin{array}{l}\text { De conocimiento (conexión intelectual, ayuda } \\
\text { a entender, conciencia, etc.) }\end{array}$ & 18 & $\begin{array}{l}\begin{array}{l}2,3,7,8,10,13,15,18,19, \\
20,21,23,25,26,27,30, \\
32,33 .\end{array}\end{array}$ \\
\hline & $\begin{array}{l}\text { Emocionales (conexión emocional, disfrute, } \\
\text { aprecio, etc.) }\end{array}$ & 12 & $\begin{array}{l}2,7,14,18,19,20,21,23, \\
24,26,32,33 .\end{array}$ \\
\hline & $\begin{array}{l}\text { De comportamiento (cuidado, conservación } \\
\text { del bien) }\end{array}$ & 6 & $3,7,18,21,25,26$ \\
\hline \multirow{4}{*}{$\begin{array}{c}\text { Otras } \\
\text { características }\end{array}$} & Referencia explícita al público visitante & 24 & $\begin{array}{l}\begin{array}{l}2,3,6,7,8,10,11,14,15, \\
16,18,19,20,22,23,24, \\
25,26,27,28,29,31,32, \\
33 .\end{array}\end{array}$ \\
\hline & La Interpretación revela significados & 8 & $1,4,5,6,18,24,27,29$ \\
\hline & $\begin{array}{l}\text { Posee finalidades prácticas (recreativas, } \\
\text { culturales, educativas, sociales, turisticas, } \\
\text { incremento del disfrute o preventivas de } \\
\text { efectos negativos) }\end{array}$ & 7 & $1,13,14,17,18,21,24$ \\
\hline & $\begin{array}{l}\text { La Interpretación se produce de forma } \\
\text { atractiva (emocionante, significativa, } \\
\text { provocativa) }\end{array}$ & 5 & $4,10,16,18,24$ \\
\hline
\end{tabular}

Santamarina, 2008; Serantes, 2010; Peak National Park Study Center (Gran Bretaña); MacFarlane; Merriman; Asociación para la Interpretación del Patrimonio (España); Association Heritage Interpretation (Reino Unido); Interpret Europe; Interpretation Australia; National Association for Interpretation (EE.UU.).

${ }^{10}$ Aldridge, 1973; Sharpe, 1988; Dean, 1994; Veverka, 1994; Proyecto Hicira, 2005; Comisión Centroamericana de Ambiente y Desarrollo, 2005; División de Bosques y Parques de Massachusetts; Countryside Commission for Scotland; Queensland National Parks and Wildlife Service (Australia). 
Como puede observarse, la mayoría de las definiciones hace referencia al destinatario de la Interpretación (público visitante), los objetivos que persigue esta práctica (se enuncian de manera explícita los de conocimiento sobre los emocionales o de comportamiento) y la manera en qué es considerada esta actividad (comunicación). Del total de respuestas dado (47) al primer aspecto por identificar (¿Qué es la interpretación?) se desprende que la misma es descrita (17 respuestas, 36 \% del total) como una forma de comunicación o la relacionan con ella (Figura 5), seguida por definiciones que la nombran como una traducción de lenguaje (6 y 13\% respectivamente), un arte (6y 13\%) o una explicación (5 y 11\%). Es Ilamativo que Tilden (1957), considerado el padre de esta actividad, inicialmente la haya catalogado como una actividad educativa para luego adjetivarla como recreativa pero sin definirla como una forma de comunicación. Continuando con el análisis de las definiciones, 11 de ellas (33\%) especifican que debe haber un contacto directo con el bien patrimonial interpretado. El único autor analizado que contempla un contacto indirecto (Tilden, 1957) también afirma que puede ser por contacto directo.

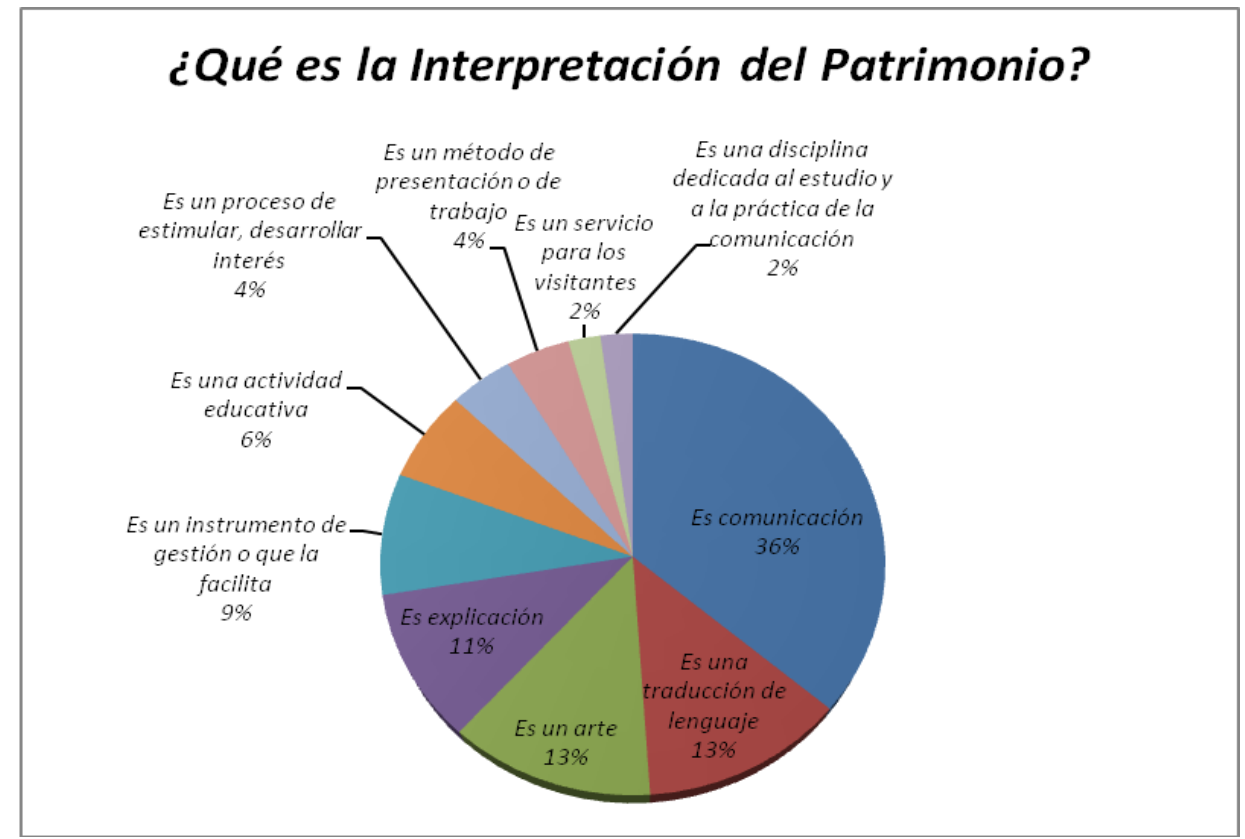

Figura 5. Análisis de definiciones. Respuestas a la pregunta ¿Qué es la Interpretación? Fuente: elaboración propia.

Uno de los aspectos que diferencia a la interpretación es el público destinatario de su práctica. Por definición, el destinatario de la misma es el público general que se encuentra en su tiempo libre (un visitante casual, heterogéneo en edades, procedencias e intereses, no cautivo y con un tiempo limitado) y cuya expectativa de provecho es meramente espiritual o 
estética. Es por ello que el $73 \%$ de las definiciones alude de manera explícita al público de destino en la Interpretación. ${ }^{11}$

Otra cualidad distintiva de la práctica interpretativa lo constituye la manera en que ésta se produce. A pesar de ello, cerca del $15 \%$ de las conceptualizaciones sobre Interpretación del Patrimonio afirma de manera clara que la misma se debe desarrollar de manera emocionante o relevante para el público (Edwards, 1976; Ham, 1992; Cuenca, 2002; Comisión Centroamericana de Ambiente y Desarrollo, 2005; División de Bosques y Parques de Massachusetts). Como en el caso anterior, si bien la mayoría de los autores analizados aclara en el desarrollo de su bibliografía que no toda información es interpretación, sólo 5 definiciones (15\%) lo dejan explicitado ${ }^{12}$, mientras que una definición (3\%) considera que la Interpretación ofrece información concisa (Edwards, 1976).

Considerando los objetivos propuestos por Veverka (1994), 6 citas (18\%) mencionan que la Interpretación debe producir un cambio de comportamiento (Aldridge, 1973; Risk, 1982; Comisión Centroamericana de Ambiente y Desarrollo, 2005; Santamarina, 2008; Countryside Commission for Scotland; Peak National Park Study Center), 18 responden a un objetivo de conocimiento $^{13}$ (54\%), mientras que 12 definen que la Interpretación provoca una modificación en los sentimientos del visitante ${ }^{14}$ (36 \%). Sólo 4 autores (Risk, 1982; Comisión Centroamericana de Ambiente y Desarrollo, 2005; Santamarina, 2008; Peak National Park Study Center) postulan de manera explícita estos tres objetivos en sus respectivas definiciones (12\%).

\footnotetext{
11 Countryside Commission (Inglaterra) 1970; Aldridge, 1973; Peart, 1977; Risk, 1982; Sharpe, 1988; Ham, 1992; Veverka, 1994; Rideout-Civitarese et al, 1997; ICOMOS, 1999; Cuenca, 2002; Comisión Centroamericana de Ambiente y Desarrollo, 2005; Fernández y Fallas, 2005; Morales, 2008; Serantes, 2010; Queensland National Parks and Wildlife Service (Australia); División de Bosques y Parques de Massachusetts; Countryside Commission for Scotland; Peak National Park Study Center (Gran Bretaña); MacFarlane; Merriman; Asociación para la Interpretación del Patrimonio (España); Interpret Europe; Interpretation Australia; National Association for Interpretation

12 Tilden, 1957; Veverka, 1994; Fernández y Falla, 2005; Peak National Park Study Center (Gran Bretaña); MacFarlane.

13 Countryside Commission, 1970; Aldridge, 1973; Risk, 1982; Sharpe, 1988; Ham, 1992; Padró, 1996; ICOMOS, 1999; Comisión Centroamericana de Ambiente y Desarrollo, 2005; Fernández y Falla, 2005; Morales, 2008; Santamarina, 2008; Queensland National Parks and Wildlife Service (Australia); Countryside Commission for Scotland; Peak National Park Study Center (Gran Bretaña); MacFarlane; Merriman, Interpretation Australia; National Association for Interpretation (EE.UU.).

14 Countryside Commission, 1970; Risk, 1982; Rideout-Civitarese et al, 1997; Comisión Centroamericana de Ambiente y Desarrollo, 2005; Fernández y Falla, 2005; Morales, 2008; Santamarina, 2008; Queensland National Parks and Wildlife Service (Australia); División de Bosques y Parques de Massachusetts; Peak National Park Study Center (Gran Bretaña); Interpretation Australia; National Association for Interpretation.
} 
Finalmente, 8 definiciones (24\%) mencionan que la Interpretación pretende revelar significados en las personas ${ }^{15}$ y 7 (21\%) sostienen que puede tener finalidades prácticas determinadas (recreación, turismo, educación, entre otras) ${ }^{16}$.

Se puede afirmar que el análisis de contenido se presenta como una técnica que permite su aplicación en diferentes campos como es el de la investigación social, y también como un procedimiento equilibrado, ya que se sitúa en un punto intermedio entre los métodos cualitativos y cuantitativos. Del análisis efectuado a las definiciones y recogido en la Tabla 9, se pueden extraer las siguientes conclusiones:

- A lo largo de los años la Interpretación del Patrimonio recogió en su definición los avances de otros campos. Por ejemplo, se observa que algunas definiciones estuvieron muy influenciadas por la visión de los padres fundadores de esta actividad (Mills, Muir, Tilden) ya que hacen referencia a la interpretación como una actividad educativa (Padró, 1996; Comisión Centroamericana de Ambiente y Desarrollo, 2005; División de Bosques y Parques de Massachusetts; Interpret Europa) o desarrollada en áreas naturales protegidas (Sharpe, 1988), culturales o mixtas (Chaverri, 1988; Proyecto Hicira, 2005; Merriman); mientras que otras incorporan las investigaciones en comunicación y psicología entendiendo a la interpretación como un proceso de comunicación (Interpretation Canada, 1976; Peart, 1977; Veverka, 1994; Serantes, 2010) que conecta emocional e intelectualmente al visitante con los significados de un recurso patrimonial (Countryside Commission, 1970; Risk, 1982; Morales, 2008) para su cuidado y disfrute (Aldridge, 1973, Rideout-Civitarese et al., 1997; Santamarina, 2008).

- La diversidad de definiciones identificadas en este estudio demuestra que el 64\% de los autores relacionan la Interpretación con una sola idea (comunicación, traducción, arte, etc.) mientras que otros lo hacen con dos (27\%), tres (3\%) o cuatro conceptos (3\%). EI $3 \%$ restante para completar el 100 \% lo aporta la descripción de ICOMOS-Carta Internacional sobre Turismo Cultural (1999), que no reúne los requisitos mínimos para ser considerada una definición terminológica (Valero, 2008) ya que no describe el concepto, enunciando sólo las características de la interpretación.

\footnotetext{
15 Tilden, 1957; Edwards, 1976; Interpretation Canada, 1976; Peart, 1977; Comisión Centroamericana de Ambiente y Desarrollo, 2005; División de Bosques y Parques de Massachusetts; MacFarlane; Asociación para la Interpretación del Patrimonio (España).

16 Tilden, 1957; Padró, 1996; Rideout-Civitarese et al, 1997; Proyecto Hicira, 2005; Comisión Centroamericana de Ambiente y Desarrollo, 2005; Santamarina, 2008; División de Bosques y Parques de Massachusetts.
} 
- Al conceptualizar la actividad interpretativa, la mayoría de las definiciones (52\%) consideran que es una forma de comunicación (17 autores), seguido por una traducción de lenguaje (18\% y 6 respectivamente).

- Sin embargo, en toda esta diversidad de definiciones aparecen puntos en común (los que dan respuesta a interrogantes básicos de los modelos comunicacional y de planificación de tareas: cómo, para qué, por qué, quién, dónde realizar la interpretación).

- Dónde: once definiciones (33\%) especifican que debe haber un contacto directo con el bien patrimonial interpretado (interpretación in situ).

- Cómo: 5 definiciones (15\%) mencionan de forma explícita que, para ser efectiva la comunicación deber ser atractiva o recreativa. Otras 8 conceptualizaciones (24\%) consideran que la Interpretación se produce a través de la revelación de significados, mientras que 5 (15\%) definiciones especifican que la interpretación es más que mera información.

- Por qué: cinco autores (15\%) mencionan en sus respectivas definiciones que la Interpretación logra los tres objetivos propuestos por Veverka (1994), 18 explicitan sólo un cambio de pensamiento, 6 citas mencionan un cambio de comportamiento y 5, una modificación en los sentimientos del visitante.

- Para qué: el 15 \% (cinco definiciones) consideran que la Interpretación posee varias finalidades.

Utilizando Wordle, aplicación online que permite crear nubes de palabras a partir de un texto dado a elección donde los vocablos más repetidos aparecen con mayor tamaño, se confeccionó una imagen con las definiciones analizadas. En la misma (Figura 6) se observa con precisión que los términos más usados en las conceptualizaciones son "comunicación" y "patrimonio", además de "interpretación".

Aunque las definiciones analizadas varían ampliamente, fueron identificados temas recurrentes a través de la aplicación del método de análisis de contenido, los cuales son elementos integrantes del marco conceptual de esta disciplina. Por lo tanto se puede afirmar que la Interpretación del Patrimonio (1) es un procedimiento comunicativo atractivo, relevante, organizado y temático de las características de un bien patrimonial (natural, cultural o mixto), (2) que permite que el visitante lo aprecie y disfrute (3) a través de vínculos intelectuales y emocionales con el mismo (4) y que promueva la generación de significados personales sobre el Patrimonio y (5) un deseo de conservación como legado para generaciones futuras. 


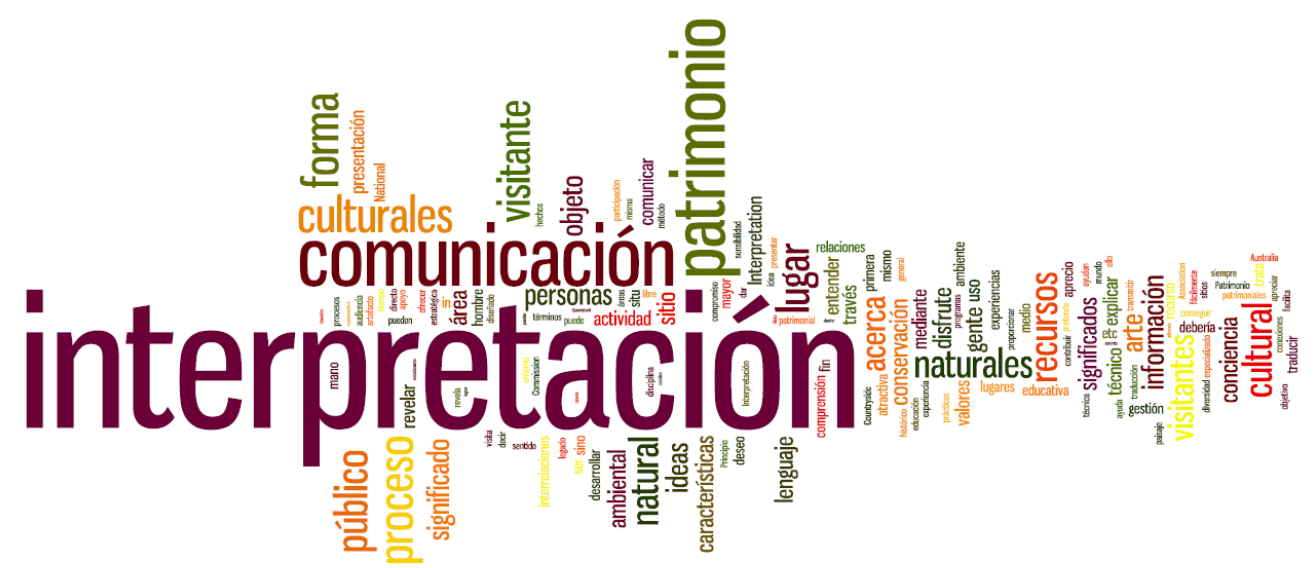

Figura 6. Nube de palabras creada con la aplicación en línea Wordle, surgida de las definiciones analizadas.

Fuente: elaboración propia.

\section{7) La importancia de la planificación en Interpretación. Modelos de planificación interpretativa}

Toda planificación es un proceso de toma de decisiones para alcanzar un futuro deseado, teniendo en cuenta la situación actual y los factores internos y externos que pueden influir en el logro de los objetivos mediante el uso eficiente de medios y recursos (Jiménez, 1982, Ander-Egg y Aguilar, 1996). En líneas generales, la planificación de tareas responde a las preguntas contenidas en la Tabla 10.

Tabla 10. Interrogantes que guían el proceso de la planificación de tareas.

\begin{tabular}{|c|c|c|}
\hline \multicolumn{2}{|c|}{ Preguntas } & Elementos del proyecto \\
\hline ¿Qué & se quiere hacer? & Naturaleza del proyecto \\
\hline ¿Por qué & se quiere hacer? & Origen y fundamentación \\
\hline ¿Para qué & se quiere hacer? & Objetivos, propósitos \\
\hline ¿Cuánto & se quiere hacer? & Metas \\
\hline ¿Dónde & se quiere hacer? & Localización física (ubicación en el espacio) \\
\hline ¿Cómo & se va hacer? & Actividades y tareas. Metodología \\
\hline ¿Cuándo & se va hacer? & Cronograma (ubicación en el espacio) \\
\hline ¿A quiénes & va dirigido? & Destinatarios o beneficiarios \\
\hline ¿Quiénes & lo van hacer? & Recursos humanos \\
\hline \multirow{2}{*}{ ¿Con qué } & se va hacer? & Recursos materiales \\
\hline & se va a costear? & Recursos financieros \\
\hline
\end{tabular}


Cada práctica interpretativa debería provenir de un plan de interpretación elaborado a tal fin para que el mensaje brindado sea óptimo. Por tal motivo, y para que la interpretación sea algo más que un simple entretenimiento intelectual, debe considerar tres premisas básicas (Miró, 1997):

- La relación entre patrimonio e identidad: de qué manera el patrimonio puede actuar o actúa como elemento generador de imagen y de identidad.

- La relación entre patrimonio y economía: cómo garantizamos la rentabilidad de las inversiones en patrimonio.

- La rentabilidad entre patrimonio y sociedad: en qué medida el desarrollo de una oferta patrimonial va a contribuir a mejorar la calidad de vida de la población.

La Planificación Interpretativa describe las experiencias deseadas (resultados) y recomienda las maneras de llevarlas a cabo. Al evitar la duplicación de esfuerzos redunda en una racionalización de recursos y en la efectividad en la entrega del mensaje al público. Es un proceso dinámico, continuo, que debe apoyar las operaciones diarias en el contexto de la realización de una visión de largo alcance para los visitantes y los recursos (Morales, 1998a; Jiménez Izarraraz, 2000).

A continuación, revisaremos brevemente algunos modelos teóricos de planificación interpretativa, para luego realizar comentarios sobre la evolución observada en la práctica de la planificación en Interpretación. Los modelos analizados son:

1) Modelo de Comunicación para la Planificación Interpretativa (Peart \& Woods, 1976) ${ }^{17}$;

2) Modelo de Interpretación (Cherem, 1977) ${ }^{17}$;

3) Planificación interpretativa por fases (Bradley, 1982) ${ }^{17}$;

4) Planificación de la Interpretación (Bringer, 1988)

5) Proceso de planificación interpretativa (Kuehn, 1993);

6) Metodología para la preparación de planes de interpretación ambiental en áreas protegidas (Servicio de Parques Nacionales de EE.UU, Moore, 1993);

7) Plan Maestro Interpretativo (Veverka, 1994);

8) Plan de Experiencia del Visitante y Protección de los Recursos (NPS, 2007);

9) Método para la planificación de una oferta patrimonial (Miró, 1997);

10) Modelo de interpretación centrado en la audiencia (Jacobson y Marynowski 1998);

11) Planificación interpretativa (Morales, 1998);

\footnotetext{
${ }^{17}$ Modelos citados en CHO, 2005.
} 
12) Modelo interpretativo de ANZECC Working Group (Ministerios de Medio Ambiente de Australia y Nueva Zelanda, 1999);

13) Pasos de un Programa Interpretativo (Domroese y Sterling, 1999);

14) Plan interpretativo (Servicio de Parques Nacionales de EE.UU., 2000);

15) Tesis interpretativa temática (Jiménez Izarraraz, 2001);

16) Modelo de los siete pasos de la comunicación ambiental (Castro, 2002);

17) Guía para la planificación y diseño de actividades y servicios de interpretación (Levy Hynes, 2002);

18) Modelo de Proceso Interpretativo (Servicio de Parques Nacionales de EE.UU., 2002) y (Larsen, 2003);

19) Plan de Gestión Patrimonial (Zamora Baño, 2002)

20) Modelo de planificación interpretativa (Cho, 2005);

21) Plan de interpretación (Proyecto Hicira, 2005);

22) Proceso de planificación interpretativa (Tourism Tasmania, 2005);

23) Plan interpretativo (Asociación para la Interpretación del Patrimonio, 2006);

24) Metodología interpretativa (INRENA, 2006);

25) Modelo de planificación interpretativa (Fratto, 2007);

26) Planeación interpretativa temática (Jiménez Izarraraz, 2007);

27) Proceso interpretativo (Morales, 2007);

28) Modelo-guía de la planificación de la Interpretación (Guerra et al, 2008);

29) Proceso de interpretación (Morales, 2008).

La propuesta de Peart y Woods (1976) se basa en el modelo clásico de la teoría de la comunicación de emisor-mensaje-receptor. En este modelo el emisor elige un mensaje a enviar, como así también el modo o medio en que lo hará (oral, escrito). Una vez codificado el mensaje se envía al receptor, quien una vez decodificado puede responder con otro mensaje (retroalimentación). Una modificación de este modelo instruye a los planificadores sobre lo que debe determinarse en el desarrollo de un programa o una serie de programas de interpretación (Figura 7).

- ¿POR QUÉ? - ¿Está dando el evento? ¿Cuáles son sus objetivos y limitaciones?

- ¿QUÉ? - ¿Parte de su mensaje total se va a seleccionar para interpretar?

- ¿QUÉ? - ¿Vas a hablar?

- ¿QUIÉN? - ¿Por lo general, quién asiste a estos sitios? ¿Quién es su público objetivo y cuáles son sus características? 
- ¿CÓMO? ¿CUÁNDO? ¿DÓNDE? -¿Vas a llevar a cabo el evento? ¿Qué enfoque se va a utilizar para transmitir el mensaje, teniendo en cuenta las características de su grupo objetivo?

- ¿CÓMO SE EVALUARÁ? - Cuando el evento se ha completado, ¿cómo vas a conseguir la retroalimentación? ¿Cómo se va a evaluar si sus objetivos se cumplieron y el mensaje se decodificó correctamente?

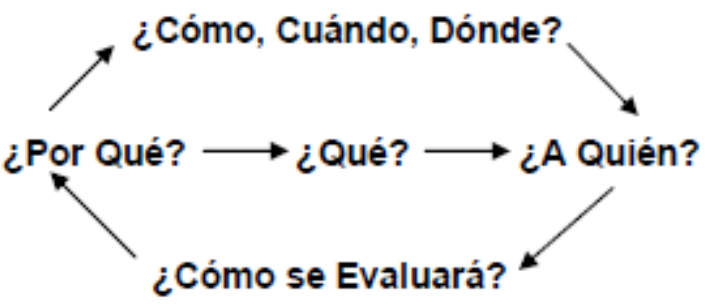

Figura 7. Modelo de Comunicación para el Proceso de Planificación Interpretativa de Peart y Woods.

Fuente: Morales, 2008.

El Modelo de Cherem (1977, en Cho, 2005) considera que los intérpretes tienen que trabajar dentro de las realidades y limitaciones de gestión propias de cada área protegida (presupuesto, recursos, tiempo, personal, planes de gestión de visitantes). Esta propuesta destaca que los comentarios de los visitantes permiten la evaluación y mejora de los objetivos, las técnicas y los enfoques (Figura 8). Como en otras propuestas interpretativas, es necesario identificar un sitio o tema a interpretar y las características demográficas de los visitantes (edad, procedencia, motivaciones, intereses, expectativas).

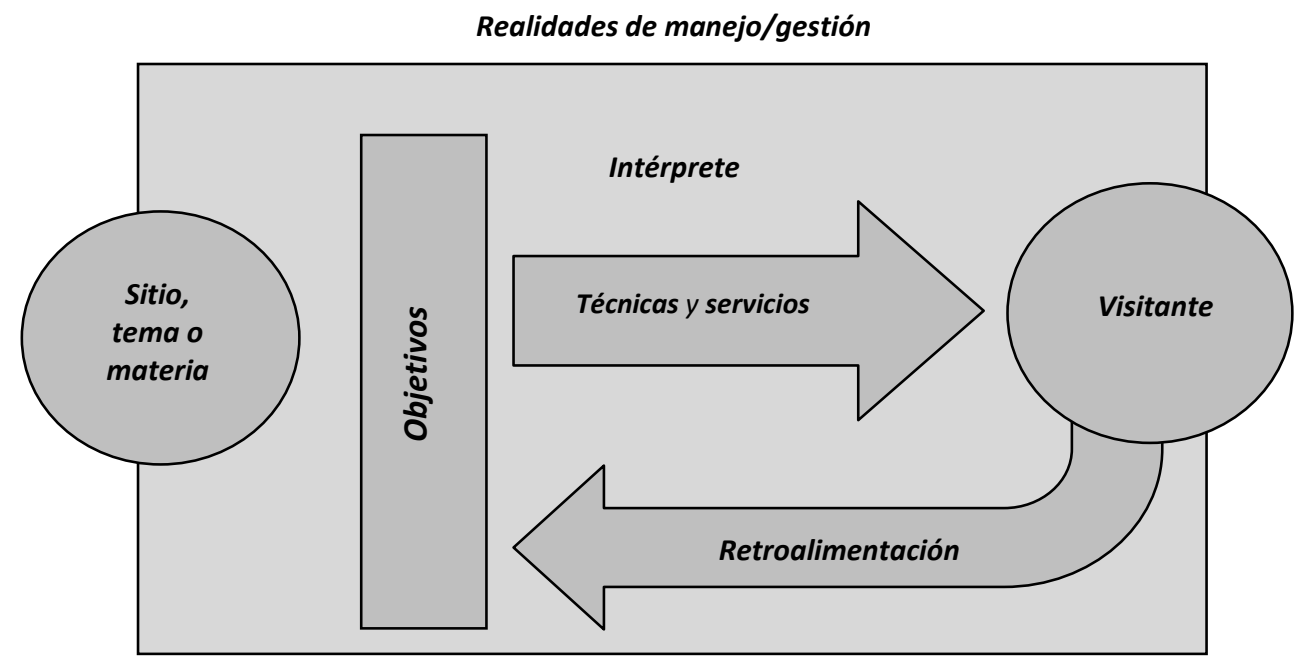

Figura 8. Modelo de Interpretación de Cherem.

Fuente: traducido de Cho, 2005. 
En su modelo, Bradley (1982, en Cho, 2005) propone una retroalimentación permanente de las fases que componen el proceso de planificación interpretativa (objetivos, inventario análisis, síntesis, etc.) lo que permitiría su revisión y modificación en cualquier momento del modelo propuesto (Figura 9).

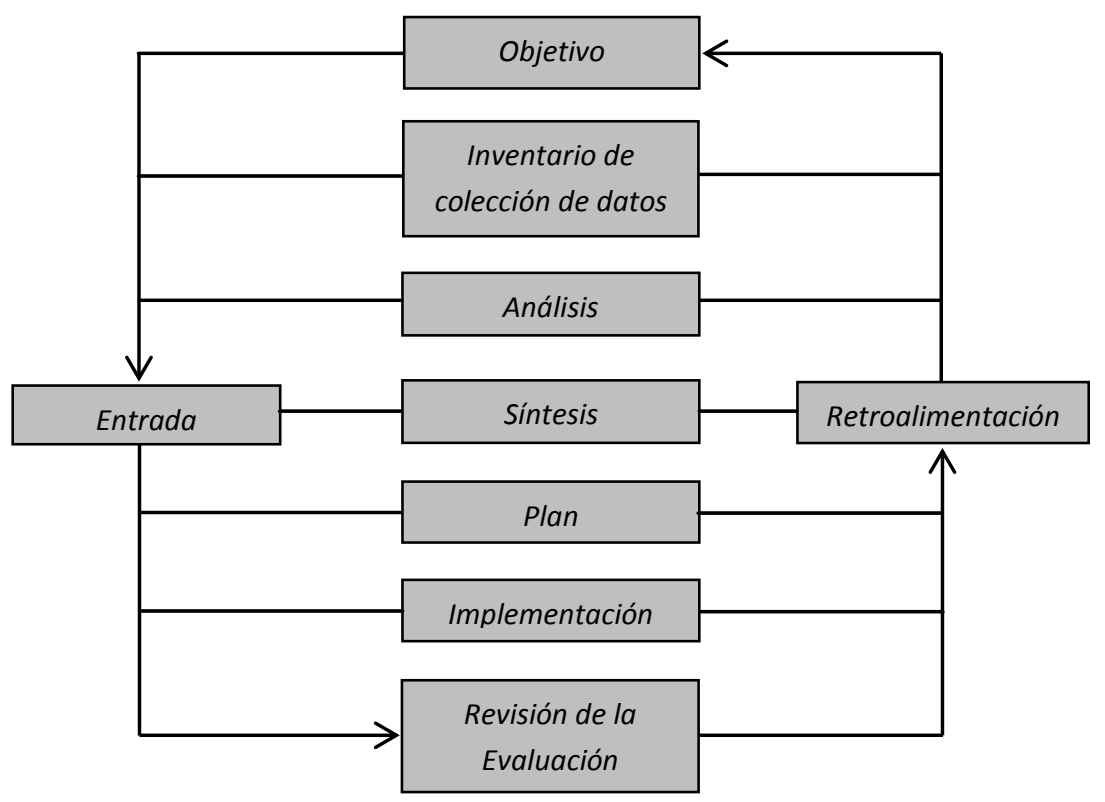

Figura 9. Fases de la planificación interpretativa de Bradley. Fuente: traducido de Cho, 2005.

En la propuesta de Bringer (1998), la planificación de la interpretación es considerada un procedimiento exhaustivo y metodológico, realizado en un momento dado, con el fin de definir las mejores opciones en materia de interpretación para un territorio particular. Este proceso se divide en las siguientes fases (Figura 10):

a) Inventario y análisis: con la finalidad de identificar el potencial interpretativo de los recursos, se realiza un inventario de los mismos, indicando su distribución espacial y su jerarquización por el potencial interpretativo. En esta fase también se consideran las características de los visitantes (edad, origen, actividad, etc.).

b) Definición de objetivos: es necesario identificar los objetivos generales, como así también otros más específicos (de gestión, económicos-financieros, etc.).

c) Definición de temas: puede ser un elemento natural, un personaje, un hecho histórico. El tema es lo que permite conectar al sujeto con una referencia más universal (ejemplo, la Supervivencia). Un buen tema no es una construcción lógica sencilla de obtener. 
d) Propuestas: en este punto se desarrolla una estrategia de interpretación, en la que se seleccionan los medios a utilizar así como el emplazamiento de los mismos.

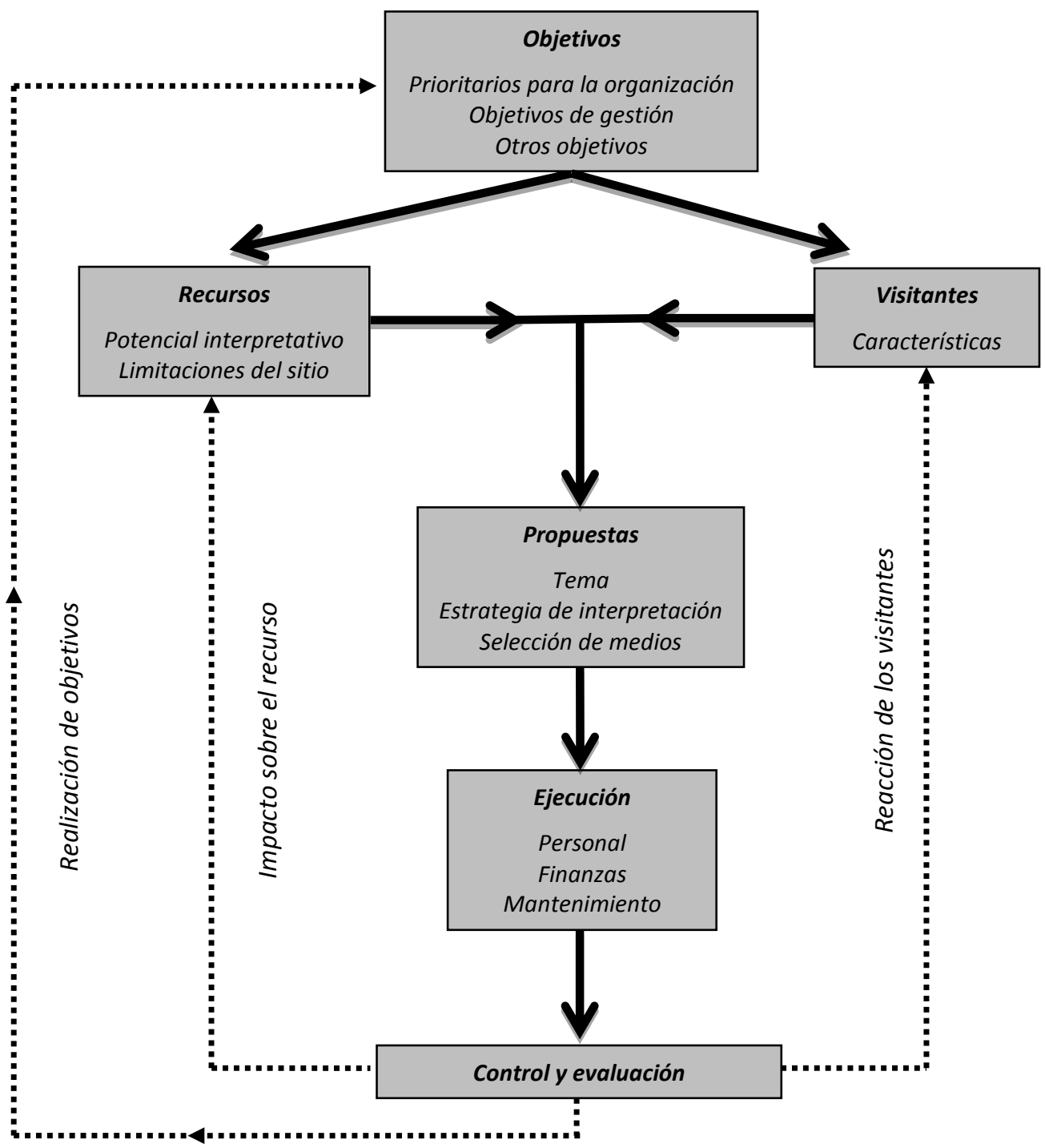

Figura 10. Diagrama de planificación interpretativa de Bringer.

Fuente: traducido de Bringer, 1988.

El proceso de planificación de Kuehn (1993) fue elaborado para la interpretación de senderos panorámicos, pero ha sido adaptado para interpretar otros temas y ámbitos. Este proceso de planificación incluye elementos similares a los modelos anteriores, tales como la definición de objetivos, la realización de un inventario ${ }^{18}$, el desarrollo de temas y subtemas, y la elección de los tipos de programas. Sin embargo, añade varios elementos nuevos: la formación de un comité del programa de líderes comunitarios, organismos patrocinadores, y los empleados del parque, que serán responsables de la planificación y desarrollo del programa en

\footnotetext{
${ }^{18}$ Kuehn (1993) introduce una adaptación su modelo, al proponer omitir el inventario si ya ha sido realizado (A).
} 
general, priorizando el inventario para ayudar a identificar los lugares de interés, los objetivos (B), los recursos que son importantes para el proyecto, y la promoción del programa a los grupos de visitantes. Se incluye la evaluación (C) para permitir la retroalimentación y para determinar si la interpretación está funcionando según lo previsto, dejando constancia de los cambios y mejoras necesarias (Figura 11).

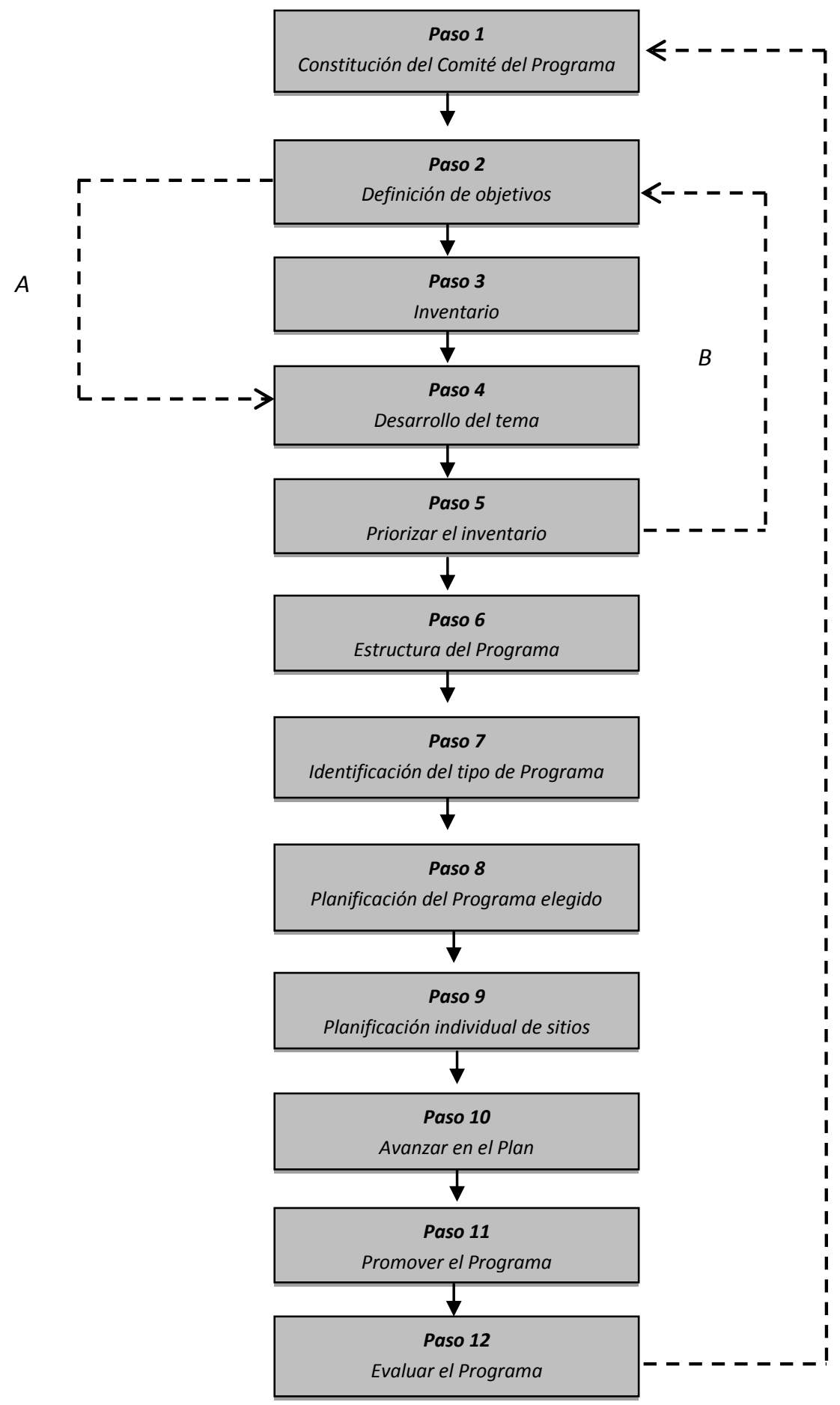

Figura 11. Diagrama de flujos del proceso de planificación interpretativa de Kuehn. Fuente: traducido de Kuehn, 1993. 
El Servicio de Parques Nacionales de los Estados Unidos (Moore, 1993) concentra en tres fases las actividades necesarias para diseñar un plan de interpretación (Figura 12):

- Fase 1: reunir toda la información disponible sobre el recurso a interpretar, para luego analizarla;

- Fase 2: realizar un estudio sobre los usuarios del área protegida, a fin de determinar el auditorio para los mensajes de la interpretación;

- Fase 3: seleccionar y desarrollar los métodos que mejor llevan el mensaje del recurso a los usuarios.

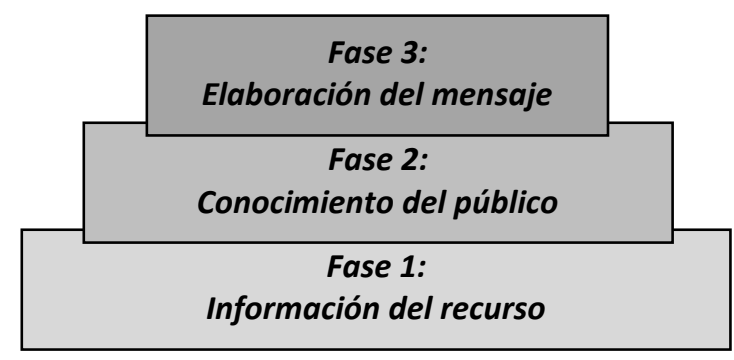

Figura 12. Fases del plan interpretativo de NPS, 1993. Fuente: elaboración propia.

Veverka (1994) presenta un Plan Maestro de Interpretación para la elaboración de un plan escrito, basando su trabajo en el modelo de planificación interpretativa de Peart y Woods (1976). Desarrolla seis elementos básicos del modelo de planificación interpretativa distribuidos en tres fases básicas, las que dan respuestas a algunas preguntas fundamentales que guían la formulación de proyectos (Ander-Egg y Aguilar, 1996; Figura 13 y Tabla 11): Por qué, Qué, Quién, Cómo, Cuándo y Dónde.

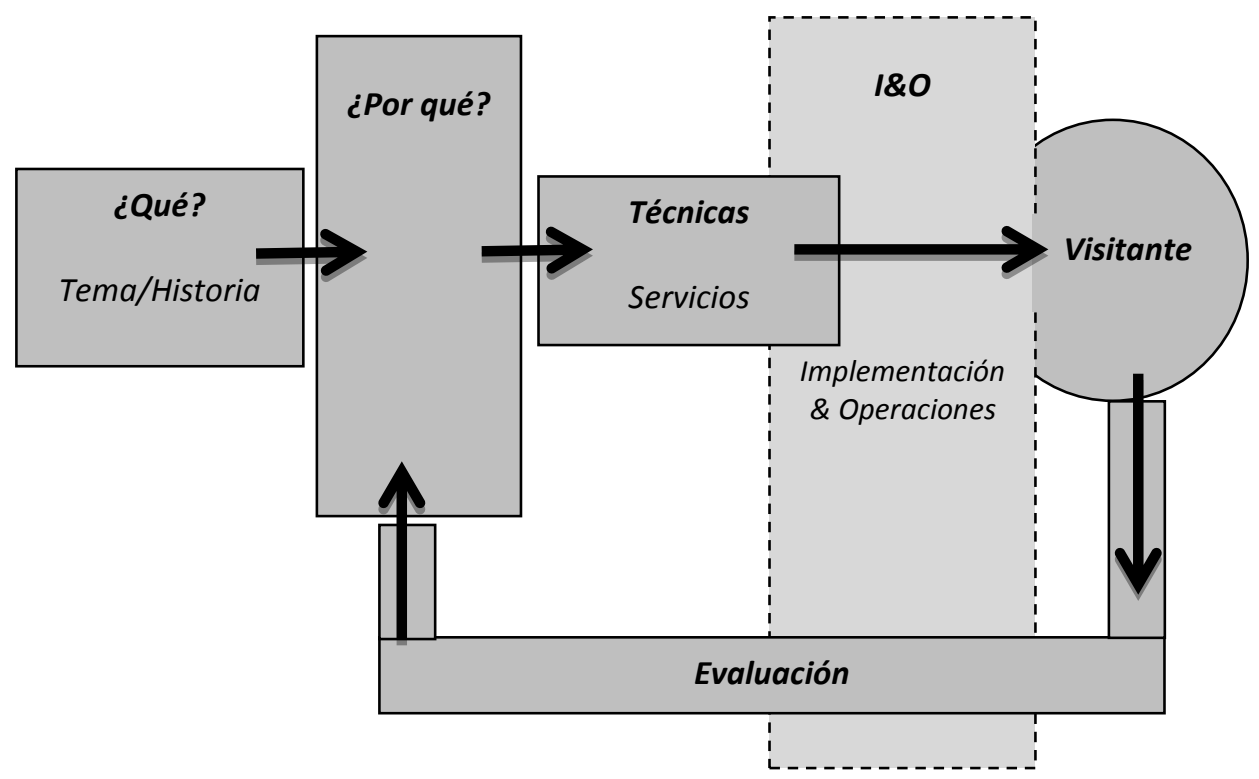

Figura 13. Plan Maestro de Interpretación de Veverka.

Fuente: traducido de Veverka, 1994. 
Tabla 11. Esquema General de un Plan Maestro Interpretativo Escrito (Veverka, 1994).

\begin{tabular}{|c|c|c|}
\hline Elemento & & Contenido del elemento \\
\hline Tabla de contenidos & Lista de las secciones del & lan con sus correspondientes números de páginas \\
\hline Introducción & Descripción general del pl & an de interpretación \\
\hline \multirow{11}{*}{ Fase I } & \multirow{3}{*}{ ¿Por qué? } & $\begin{array}{l}\text { A) Filosofía, políticas, metas y objetivos del } \\
\text { programa y del plan de interpretación }\end{array}$ \\
\hline & & B) Estructura administrativa (opcional) \\
\hline & & $\begin{array}{l}\text { C) Alcance de las actividades/ámbito de } \\
\text { aplicación del plan }\end{array}$ \\
\hline & \multirow[t]{3}{*}{ ¿Qué? } & $\begin{array}{l}\text { A) Realizar un inventario de todos los recursos: } \\
\text { 1. Ubicación del sitio; } \\
\text { 2. Descripción del sitio; } \\
\text { 3. Accesibilidad estacional; } \\
\text { 4. Importancia significativa; } \\
\text { 5. Fotos, mapas o dibujos (si correspondiera) }\end{array}$ \\
\hline & & B) Índice de mapas del sitio \\
\hline & & $\begin{array}{l}\text { C) Generar tema interpretativo principal y sub } \\
\text { temas }\end{array}$ \\
\hline & \multirow{5}{*}{ ¿Quién? } & $\begin{array}{l}\text { A) Determinar las características demográficas de } \\
\text { los visitantes }\end{array}$ \\
\hline & & B) Aislar grupos específicos del público objetivo \\
\hline & & $\begin{array}{l}\text { C) Considerar motivaciones, expectativas y } \\
\text { percepciones de los visitantes }\end{array}$ \\
\hline & & $\begin{array}{l}\text { D) Considerar el sistema de orientación de los } \\
\text { visitantes (previo a la visita, en el lugar, } \\
\text { después de la visita) }\end{array}$ \\
\hline & & $\begin{array}{l}\text { E) Considerar cualquier patrón de uso turístico } \\
\text { (fecha/duración de la visita, estación, etc.) }\end{array}$ \\
\hline Fase II & ¿Cómo/Cuándo/Dónde? & $\begin{array}{l}\text { Para cada recurso inventariado, considerar: } \\
\text { - } \quad \text { Tema interpretativo para cada sitio individual } \\
\text { - } \quad \text { Objetivos del sitio } \\
\text { - } \quad \text { Objetivos del programa interpretativo } \\
\text { - } \quad \text { Servicios interpretativos recomendados } \\
\text { - Justificación } \\
\text { - } \quad \text { Comentarios de la planificación general }\end{array}$ \\
\hline \multirow[b]{2}{*}{ Fase III } & $\begin{array}{l}\text { Implementación y } \\
\text { Operaciones (I\&O) }\end{array}$ & $\begin{array}{l}\text { Seleccionar estrategias, presupuestos, necesidades } \\
\text { del personal, etc. }\end{array}$ \\
\hline & $\begin{array}{l}\text { Entonces, ¿qué? } \\
\text { ¿Cómo se evaluará? }\end{array}$ & $\begin{array}{l}\text { Las estrategias de evaluación que podrían ser } \\
\text { utilizadas para ver si los objetivos interpretativos se } \\
\text { están cumpliendo }\end{array}$ \\
\hline \multirow{2}{*}{\multicolumn{2}{|c|}{ Bibliografía y anexos }} & A) Lista de materiales de referencia \\
\hline & & B) Adjuntar material adjunto \\
\hline
\end{tabular}

Miró (1997) establece conexiones entre el patrimonio y el uso social del mismo, al sostener que la interpretación aparece como respuesta a una demanda social de uso del patrimonio y a la necesidad de cada territorio de posicionarse frente a otros espacios. Por lo tanto, la interpretación se convierte en un instrumento de planificación dentro de estrategias 
de desarrollo territorial. En función de estas cuestiones básicas, realizar la interpretación de un territorio implica:

- Descubrir un concepto-paraguas (criterio clave de interpretación) para:

- singularizar y posicionar la imagen del territorio,

- desarrollar un hilo argumental que permita englobar la presentación del patrimonio bajo una unidad conceptual.

- Establecer un sistema de organización y presentación de los recursos patrimoniales que haga posible su accesibilidad, conservación y explotación.

- Definir una serie de programas y actividades dirigidas a las demandas específicas.

- Diseñar un programa de comunicación para dar a conocer los recursos al público.

En este sentido, una propuesta metodológica para la elaboración de un plan de interpretación podría ser la siguiente:

1. Conocer el pensamiento/mentalidad de la población del territorio sobre el que se quiere actuar: principales rasgos identitarios, rasgos culturales, etc.

2. Inventariar los recursos patrimoniales y analizarlos para evaluar su potencial tanto desde un punto de vista turístico, didáctico y científico.

3. Determinar la audiencia (real y potencial) y evaluar las dificultades y las oportunidades relacionadas con la motivación del visitante y la accesibilidad al lugar.

4. Evaluar los recursos humanos y financieros disponibles o potencialmente disponibles.

5. En base a las conclusiones de los puntos anteriores, deben fijarse los objetivos del plan de interpretación: económicos, sociales, conservación y puesta en valor, educativos, científicos, etc.

6. Determinar los temas para la interpretación: se trata de definir la especificidad y los contenidos de la oferta patrimonial. La interpretación debe proveer las claves para la lectura del territorio. Desde este punto de vista, la interpretación debe centrarse en la dimensión simbólica del patrimonio y en la emoción individual que se experimenta a través de su descubrimiento y su contemplación.

7. Definir los sistemas de presentación: esta elección se realiza en base a tres criterios: los tipos de "objetos patrimoniales", las características de la audiencia y las disponibilidades presupuestarias.

8. Determinar los tipos de servicios complementarios: Además de los sistemas de presentación, es necesario prever los aspectos que influyen en la calidad de la experiencia del visitante: recepción, aparcamientos, señalización, etc. 
9. Perfilar el presupuesto de implementación y el cálculo de los gastos corrientes: esto permitirá garantizar la viabilidad del proyecto y decidir sobre las posibles vías de financiación.

10. Determinar el sistema de gestión: pública directa, pública autónoma, mixta, delegada, privada, concesión, etc.

11. Trazar una estrategia de promoción y marketing: dar a conocer la existencia de la oferta para posicionarla y por la presencia en los medios a través de la generación de noticias (actividades dirigidas a públicos específicos, exposiciones temporales, actividades de animación, entre otros ejemplos).

Con el objetivo de gestionar la capacidad de carga de las áreas naturales, el Servicio de Parques Naturales de Estados Unidos (NPS, 1997) propone una metodología para su manejo, con la intención de incluir conocimiento, actitudes y sensaciones en las experiencias de los visitantes. Muchos de los elementos mencionados en esta guía, integran la planificación general de la gestión de áreas patrimoniales. Es importante recordar que esta metodología es retroalimentada con lo que sucede al aplicar cada uno dichos elementos.

1. Conformación del equipo interdisciplinario que trabajará en el proyecto: se necesita un equipo básico que debe incluir a las personas que pueden desarrollar el plan y los que van a ponerlo en práctica. Puede necesitarse una amplia variedad de consultores con diversos antecedentes y experiencia.

2. Desarrollo de una estrategia de participación pública. Tanto el personal de gestión del parque como el público externo a la misma deber ser considerados.

3. Declaración del propósito del Parque, su significado e importancia, y los temas interpretativos primarios. Estos enunciados constituyen la base de las estrategias de implementación del Plan de gestión de visitantes. Todos los elementos siguientes deben ser coherentes y de apoyo a ellos.

4. Análisis de los recursos del parque y de la actual gestión de visitantes. Este análisis debe documentarse a través de una combinación de textos, mapas y matrices.

5. Descripción del potencial de las experiencias de los visitantes y de los recursos (zonas potenciales). Las zonas potenciales son descritas por las condiciones de los recursos y las diferentes oportunidades de experiencias deseadas por los visitantes y que podrían proporcionarse en el parque. Estas zonas potenciales sólo son descritas con textos, pero se aplican a áreas geográficas específicas en el elemento 6. 
6. Localización del potencial de las zonas para usos específicos. En este elemento las zonas descritas en el elemento 5 son asignadas a posiciones específicas en un parque. El esquema de división por zonas no describe las condiciones existentes, sino que establece situaciones futuras. En el caso que se desea continuar con las actuales condiciones de gestión de visitantes, el equipo planificador deberá desarrollar planes de zonificación alternativas y evaluar sus impactos positivos y negativos.

7. Selección de indicadores y normas específicas. Desarrollo de un plan de monitoreo. Son identificados los indicadores (variables específicos que serán monitoreados) y los estándares (condiciones mínimas aceptables) para cada zona. Se desarrolla un plan de supervisión que determine las prioridades de gestión, los métodos de financiación y el análisis de las necesidades del personal.

8. Supervisión del recurso e indicadores. El personal del parque realiza un seguimiento periódico de las condiciones de los recursos en las diversas zonas.

9. Llevar a cabo medidas de gestión. Cuando la supervisión indica que las condiciones del recurso o de los visitantes están fuera del estándar o lo deterioran, es obligatorio tomar medidas de gestión.

Jacobson y Marynowski (1998) proponen un modelo de interpretación centrado en la audiencia (Figura 14), donde el público es el elemento central y las características de la audiencia (actitudes, intereses, conocimientos) determinan los servicios interpretativos. Este modelo se inicia con las metas y objetivos que dotan al proyecto de servicios de interpretación

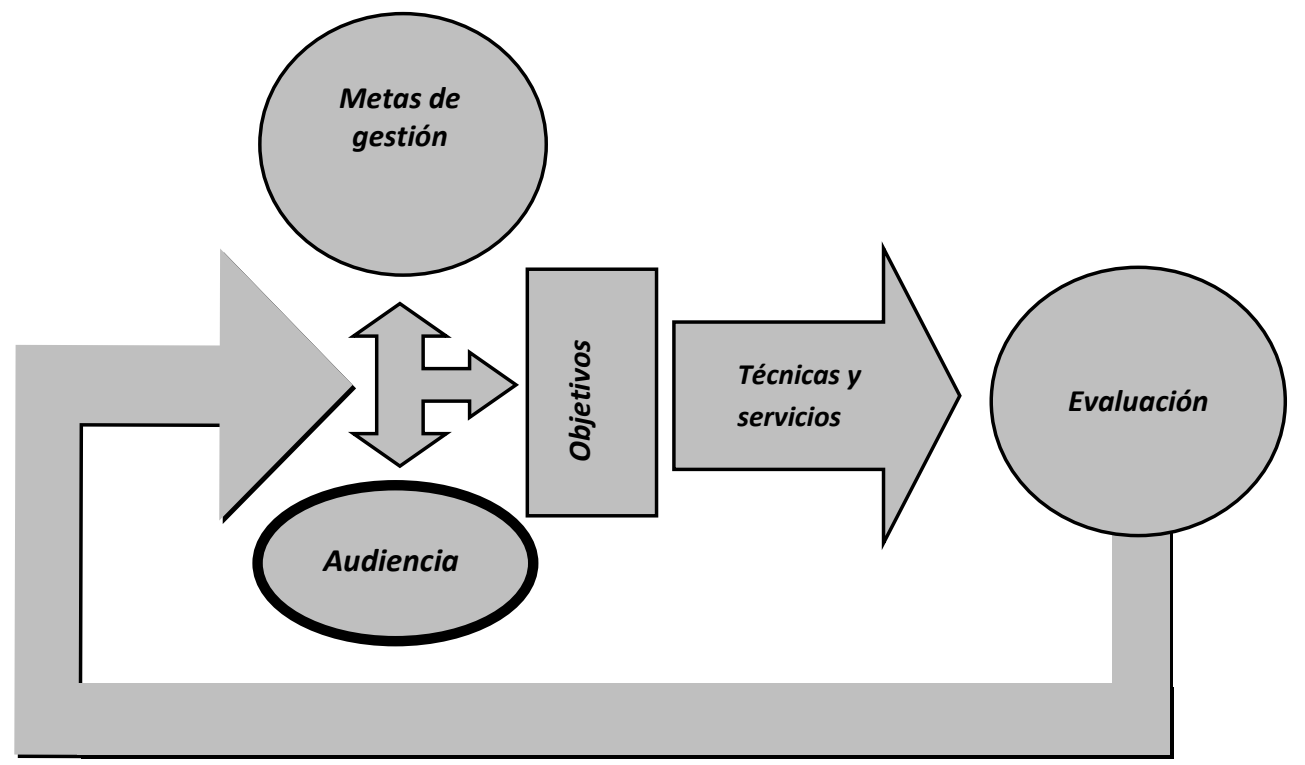

Figura 14. Modelo de Interpretación enfocado en la audiencia de Jacobson y Marynowski. Fuente: traducido de Jacobson y Marynowski, 1998. 
que satisfacen las necesidades actuales de los visitantes. En la evaluación de seguimiento se valora la eficacia proporcionando información para modificar y mejorar continuamente los programas considerados (retroalimentación).

Para Morales (1998a) todo plan de interpretación debe ser una referencia para la toma de decisiones, siendo un documento flexible, de consulta permanente y en continua revisión. Los principales pasos en la planificación interpretativa de este modelo son:

a) Situación de partida: incluye el reconocimiento del lugar que es propuesto para su interpretación, su uso actual, su accesibilidad, etc. También es necesario conocer la disponibilidad de recursos humanos y financieros.

b) Formulación de objetivos: incluyen los objetivos de planificación y los de interpretación. Los primeros describen qué se pretende lograr con la planificación, mientras que los segundos indican para qué se va a interpretar. Estos últimos se constituyen en insumos para la planificación posterior de programas y medios.

c) Inventario y recopilación de información: el tipo de información requerido dependerá de las características de lo que se va a interpretar (por ejemplo, elemento natural o cultural) e incluye también datos sobre los visitantes. En esta etapa surgirán los conceptos y tópicos, además de las oportunidades para la interpretación: rasgos con potencial interpretativo y la infraestructura factible de acondicionar.

d) Análisis: se estudia la información recabada (recurso, destinatarios y objetivos de la interpretación, tópicos, medios para su comunicación).

e) Síntesis: en este punto se toman decisiones con respecto al proceso analítico anterior, definiendo los puntos cruciales del futuro plan de interpretación: objetivos, tópicos, diseño de medios, entre otros.

f) Plan de interpretación: en forma de documento, recoge una descripción sintética de los elementos anteriormente analizados para ser sometidos a permanente revisión.

g) Ejecución: es la puesta en marcha del punto anterior. A veces sucede que se presentan cambios de última hora (siempre y cuando no modifiquen sustancialmente los objetivos y metas originales), que pueden ser incluidos dado que el plan es flexible.

h) Evaluación y sequimiento: se considera la efectividad de los medios y en la entrega del mensaje, la pertinencia de los contenidos, el estado presupuestario, etc.

El modelo de ANZECC Working Group (1999) coloca el énfasis en que la planificación interpretativa incluya la evaluación en dos maneras. Por un lado, debe ser una etapa separada 
que resuma la eficacia y el valor del proyecto, y por el otro, debe ser incorporada en el proceso de planificación como un ciclo de retroalimentación en cada etapa (Figura 15). Este modelo presenta un proceso de planificación interpretativa que:

- Describe los objetivos.

- Define los indicadores claves de rendimiento.

- Identifica los factores de éxito para la interpretación.

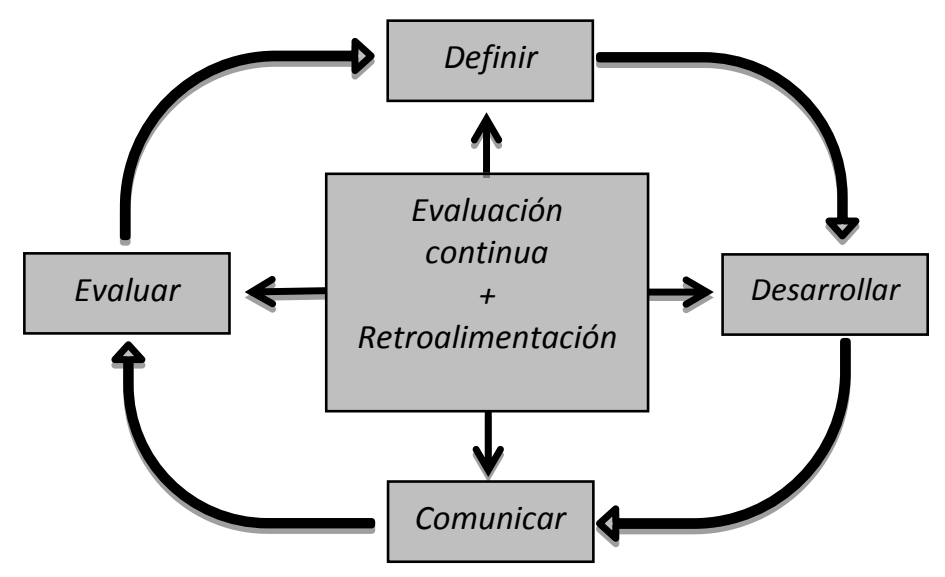

Figura 15. Proceso de Planificación en Interpretación de ANZECC. Fuente: traducido de ANZECC, 1999.

Domroese y Sterling (1999), a través de una propuesta para la Interpretación de la Biodiversidad, presentan el siguiente programa interpretativo:

a. Investigar el contexto del programa: además del ambiente natural se incluyen aspectos sociales y políticos. Lograr la participación de la comunidad es esencial, por lo tanto es conveniente investigar las aptitudes y recursos disponibles en los diferentes miembros de la comunidad.

b. Definir e investigar los temas a tratar: en esta etapa se identifican los problemas de biodiversidad que afectan la región donde se quiera realizar la interpretación.

c. Identificar la audiencia: cada tipo de público (edad, origen, ocupación) tiene un nivel diferente de interés y de comprensión de los aspectos que se quiere presentar.

d. Establecer las metas y los objetivos: una meta es una afirmación amplia que resume lo que se quiere hacer. Un objetivo es una afirmación que describe un aspecto de cómo la meta se logrará. Generalmente, varios objetivos son necesarios para lograr una meta. Los objetivos establecen qué, cuándo y cómo ésta se llevará a cabo. 
e. Definir el presupuesto: el presupuesto es un plan de distribución de recursos económicos en relación a las metas y objetivos propuestos. Para ello es necesario identificar lo que se tiene y lo que se necesita obtener para el desarrollo del programa.

f. Planificar una evaluación para el programa: la evaluación debe efectuarse a través de registros de la información obtenida; de esta manera, se pueden realizar ajustes en los programas interpretativos.

Después de haber diseñado un programa interpretativo, estas autoras dedican un procedimiento más acotado para la planificación de actividades relacionadas con el programa:

a. Seleccionar el tema: retomando los temas investigados en el punto b) del desarrollo del programa.

b. Elaborar un mensaje relacionado al tema: cada actividad debe tener un mensaje central, una idea o concepto que transmitir a la audiencia. El mensaje debe ser simple, específico y adecuado a la audiencia.

c. Seleccionar la audiencia meta: para que la gente responda al mensaje, el mismo debe ser relevante para el visitante. Por lo tanto, sería necesario que la selección de la audiencia sea un paso anterior a la elaboración del mensaje.

d. Llevar a cabo la actividad: el mensaje a transmitir será llevado a cabo a través de una actividad (en forma de una exhibición, un video, una charla, una visita guiada o un juego). Sin importar su tipología, toda actividad debe incluir una introducción, una presentación de la información y una conclusión.

El Servicio de Parques Nacionales de Estados Unidos (NPS, 2000) propuso un nuevo plan interpretativo, compuesto por tres grandes fases:

SECCIÓN I: Plan de Interpretación a Largo Plazo (PILP). En esta sección se describe la información que guiará el desarrollo del futuro programa interpretativo.

SECCIÓN II: Plan Anual de Aplicación (PAA). Se trata de un plan operativo de un año para el programa interpretativo. Es un trabajo modelo que describe cuáles son los servicios de interpretación que se ofrecerán al público durante un año. También incluye información sobre el presupuesto y la dotación de personal, acciones y desafíos, y una comparación del programa del año pasado con el de este año. Está basado en el Plan Interpretativo de Largo Plazo. Este plan debería ser breve. 
SECCIÓN III: Base de datos de Interpretación (BDI). Esta sección contiene las referencias a materiales que apoyan el programa de interpretación (por ejemplo, la lista de lecturas del parque, las propuestas de financiamiento, informes, etc.).

La base de datos de Interpretación es una compilación de los planes, documentos, y los inventarios que se reúnen para facilitar la planificación y ejecución de las actividades interpretativas. Esta base de datos debe incluir al menos los elementos mencionados en la Tabla 12.

Tabla 12. Plan interpretativo propuesto por el Servicio de Parques Nacionales (NPS, 2000).

\begin{tabular}{|c|c|c|}
\hline Secciones & Partes & Sub partes \\
\hline \multirow{16}{*}{$\begin{array}{c}\text { Plan de } \\
\text { Interpretación de } \\
\text { Largo Plazo (PILP) }\end{array}$} & \multirow{7}{*}{ Fundamentos } & Propósito y significado \\
\hline & & Temas \\
\hline & & Objetivos de gestión \\
\hline & & Experiencia deseada para el visitante \\
\hline & & Temas e influencias que afectan la interpretación \\
\hline & & Perfiles de los visitantes \\
\hline & & Condiciones actuales de interpretación \\
\hline & \multirow{8}{*}{$\begin{array}{c}\text { Futuro } \\
\text { Programa } \\
\text { Interpretativo }\end{array}$} & Servicios personales \\
\hline & & Servicios no personales \\
\hline & & Asociaciones \\
\hline & & Biblioteca y colecciones necesarias \\
\hline & & Necesidades de Investigación \\
\hline & & Necesidades del personal \\
\hline & & Los costos del Programa de interpretación \\
\hline & & Plan de Implementación \\
\hline & \multicolumn{2}{|c|}{\begin{tabular}{l|l} 
Anexos & \\
\end{tabular}} \\
\hline \multirow{6}{*}{$\begin{array}{c}\text { Plan Anual de } \\
\text { Aplicación (PAA) }\end{array}$} & \multicolumn{2}{|c|}{ Resumen del Plan Anual } \\
\hline & \multicolumn{2}{|c|}{ Análisis del programa actual } \\
\hline & \multicolumn{2}{|c|}{ Problemas de administración que enfrenta Interpretación } \\
\hline & \multicolumn{2}{|c|}{ Plan de Trabajo Anual } \\
\hline & \multicolumn{2}{|c|}{ Borradores de nuevos planes de servicios } \\
\hline & \multicolumn{2}{|c|}{ Estado de Situación del Plan de Implementación } \\
\hline & \multicolumn{2}{|c|}{ Plan Estratégico } \\
\hline & \multicolumn{2}{|c|}{ Historia Legislativa del Parque } \\
\hline & \multicolumn{2}{|c|}{ Inventario Anual de Medios } \\
\hline Base de datos de & \multicolumn{2}{|c|}{ Los datos de los visitantes de la encuesta } \\
\hline Interpretación & \multicolumn{2}{|c|}{ Informe Interpretativo } \\
\hline (BDI) & \multicolumn{2}{|c|}{ Informe Anual de voluntarios en los Parques } \\
\hline & \multicolumn{2}{|c|}{ Planes de Medios de Comunicación } \\
\hline & \multicolumn{2}{|c|}{ Lista de Lectura Básica del Parque } \\
\hline & \multicolumn{2}{|c|}{ Otros componentes de identificación potenciales } \\
\hline
\end{tabular}


La propuesta de Jiménez Izarraraz (2001) recoge los principios interpretativos para la práctica arqueológica, y propone los siguientes pasos para el enunciado de la $\mathrm{Tesis}^{19}$ :

1) Orientación general: esta etapa consiste en el esclarecimiento de los objetivos del mensaje, conocer a quién va dirigido el mismo y qué es lo que se comunicará.

a) Propósito del discurso

b) Identificación del receptor

c) Reconocimiento de la cultura a interpretar

2) Reconocimiento y síntesis de temáticas reiterativas: esta actividad permitirá identificar el Genius Loci, es decir, la parte distintiva y significativa que hace único al sitio o cultura que se está interpretando.

a) Elaboración de cuadro de apoyo

b) Extracción de términos y conceptos reiterativos

3) Elaboración de enunciados interpretativos-temáticos: éstos se pueden generar a partir de la información obtenida en el paso anterior, sintetizando las características significativas del bien patrimonial.

4) Creación de la Tesis y su desarrollo para públicos especializados: es importante que el intérprete visualice ideas de apoyo a la Tesis Central y el tipo de público destinatario de esta planificación temática.

a) ¿El público entiende nuestro enunciado?

b) Elaboración de subtesis

5) Adaptación a los medios de comunicación: los medios interpretativos pueden variar dependiendo tanto del tipo de información que se requiera como de las propuestas de actividades (lectura, escucha, teatro, juegos, etc.) que se planteen al público.

a) Características de los medios de comunicación

b) Desarrollo del discurso

Para la planificación de tareas, Castro (2002) hace foco en la comunicación ambiental y presenta un modelo procesual de siete pasos (Figura 16):

-Paso 1. Determinar unos objetivos coherentes y racionales: esto se hará considerando los recursos disponibles y la meta a alcanzar. Se formularán los objetivos de tal forma que sean medidos con facilidad.

${ }^{19}$ Gándara $(1999,2003)$ propone que la idea central de la interpretación temática de Ham (1992) se traduzca como "tesis", dado que no hace referencia a tema en el sentido de contenido (subject matter), sino de un enunciado que encapsule aquello que, como mínimo, nos interesa pueda llevarse consigo el visitante a un sitio patrimonial. 
- Paso 2. Realizar una evaluación previa de la intervención: valorar con detalle la situación que se quiere intervenir. También se pueden evaluar experiencias anteriores de la misma situación o similares.

- Paso 3. Conocer en profundidad la población objetivo: es de utilidad conocer la población de destino ya que de esa manera se podrá adecuar el mensaje a trasmitir.

- Paso 4. Diseñar mensajes con poder de cambio: no es suficiente brindar información, sino que también es importante la manera en que la misma llega a las personas

- Paso 5. Elegir cuidadosamente y combinar de forma adecuada los medios y soportes: estos se deben adaptar a las características de la población objetivo, como así también el mensaje debe ser congruente con el canal que lo trasmite.

- Paso 6. Planificar las rutinas de la campaña: es importante revisar la ejecución del programa, decidiendo las correcciones necesarias en su desarrollo.

- Paso 7. Evaluar el impacto del programa: se valorarán los resultados conseguidos (cambios en la población) con las acciones desarrolladas.

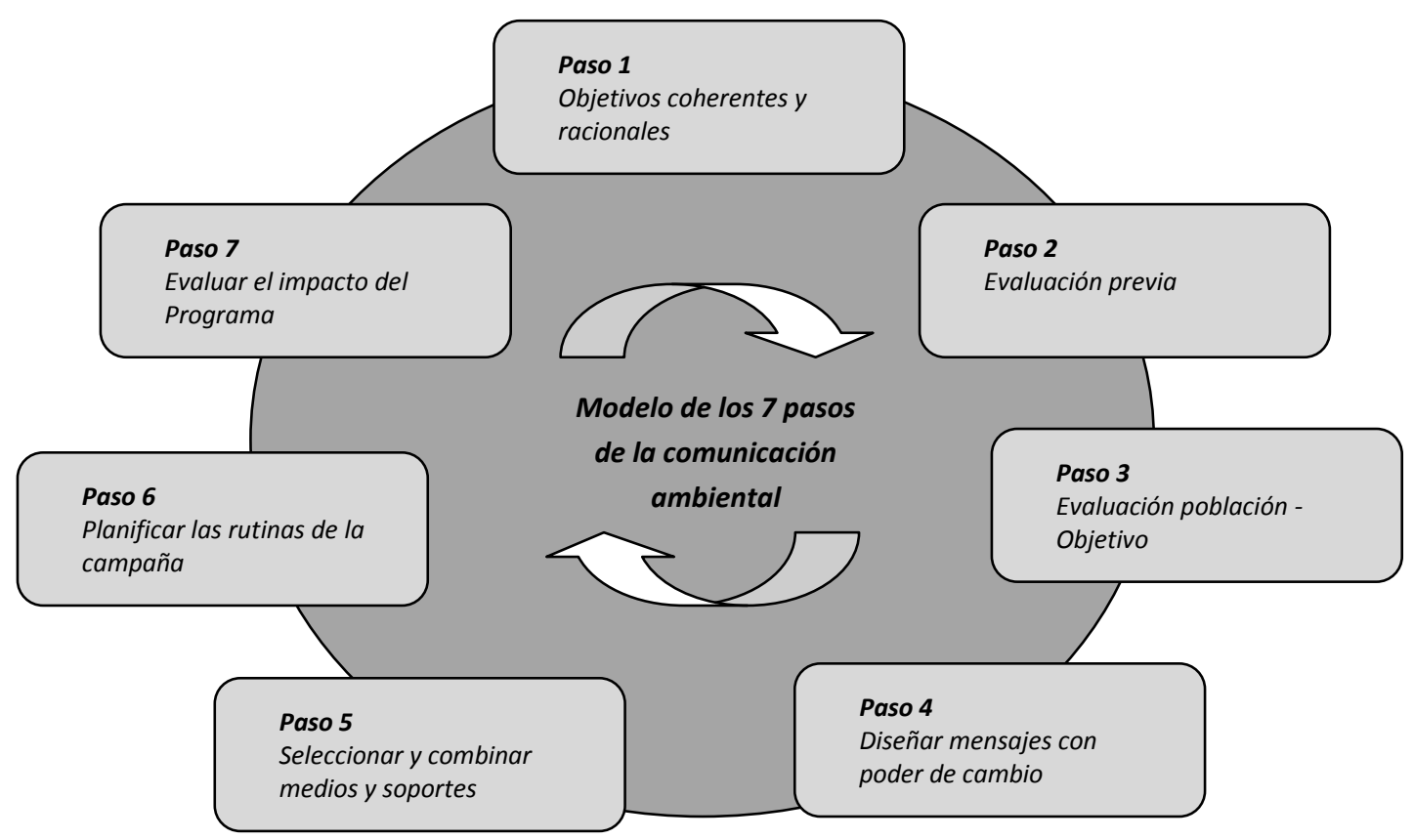

Figura 16. Modelo de los siete pasos de la comunicación ambiental de Castro (2002). Fuente: Castro, 2002. 
Levy Hynes (2002) propone una guía de planificación y diseño de actividades y servicios de interpretación que responde a preguntas (Tabla 13) similares a las necesarias para la planificación de tareas (Ander-Egg y Aguilar, 1996).

Tabla 13. Planificación y diseño de actividades interpretativas (Levy Hynes, 2002).

\begin{tabular}{|c|c|}
\hline Interrogantes & Descripción \\
\hline ¿Qué vamos a hacer? & Título, que en una frase describa lo que queremos hacer. \\
\hline ¿Por qué lo vamos a hacer? & $\begin{array}{l}\text { Fundamentación de la necesidad de hacer esta actividad de } \\
\text { interpretación. }\end{array}$ \\
\hline ¿Para quiénes lo vamos a hacer? & $\begin{array}{l}\text { Destinatarios: describir las características de los destinatarios } \\
\text { de esta actividad. }\end{array}$ \\
\hline ¿Para qué lo vamos a hacer? & $\begin{array}{l}\text { Objetivos específicos de experiencia:* } \\
\text { Objetivo de conocimiento } \\
¿ Q u e ́ \text { queremos que la gente recuerde? El mensaje } \\
\text { Objetivo de afectividad } \\
¿ Q u e ́ \text { queremos que la gente sienta? } \\
\text { Objetivo de actitudes y/o comportamientos } \\
¿ Q u e ́ \text { queremos que la gente haga? O no haga, porque el "no } \\
\text { hacer" también es un comportamiento. } \\
\text { (*) Se pueden aplicar a distintas escalas (para toda la actividad } \\
\text { interpretativa o para momentos específicos de estas } \\
\text { actividades). }\end{array}$ \\
\hline ¿Dónde lo vamos a hacer? & Lugar preciso donde se realice esta actividad. \\
\hline ¿Cómo lo vamos a hacer? & $\begin{array}{l}\text { Medios y técnicas de interpretación, describir cómo se llevará a } \\
\text { cabo la actividad interpretativa, desde el momento de } \\
\text { encuentro con los destinatarios hasta la despedida. } \\
\text { Número de personas mínimo y máximo para realizar esta } \\
\text { actividad. }\end{array}$ \\
\hline ¿Quiénes lo vamos a hacer? & $\begin{array}{l}\text { Recursos humanos, responsable/s y colaboradores: asesores e } \\
\text { informantes claves. }\end{array}$ \\
\hline ¿Con qué contamos para hacerlo? & $\begin{array}{l}\text { Recursos materiales, lista de insumos, cantidad necesaria, } \\
\text { equipamiento. Bibliografía. } \\
\text { Recursos financieros. }\end{array}$ \\
\hline ¿Cuándo lo vamos a hacer? & $\begin{array}{l}\text { Tiempo que dura la actividad. } \\
\text { Horarios del día o la noche en la que se puede realizar. } \\
\text { Estacionalidad: épocas del año en la que se puede realizar la } \\
\text { actividad. }\end{array}$ \\
\hline ¿Cuánto cuesta lo que vamos a hacer? & Presupuesto, precios de los insumos o materiales. \\
\hline ¿Cómo lo vamos a evaluar? & $\begin{array}{l}\text { Técnicas de evaluación y monitoreo de la actividad. } \\
\text { Se evalúa si se cumplieron los objetivos de la experiencia. } \\
\text { Momentos de evaluación. } \\
\text { Técnica de evaluación del guía. } \\
\text { Evaluación del impacto ambiental de la actividad. }\end{array}$ \\
\hline $\begin{array}{l}\text { ¿Qué grado de accesibilidad tiene esta } \\
\text { actividad? }\end{array}$ & $\begin{array}{l}\text { Fácil, relativamente fácil o difícil. } \\
\text { Describir las dificultades del terreno, por ejemplo si hay } \\
\text { peldaños, si es apto para menores de } 12 \text { años, o embarazadas. } \\
\text { Si es posible participar de la actividad para personas que } \\
\text { utilizan silla de ruedas o que tienen alguna dificultad motriz. } \\
\text { Si es necesaria ropa, calzado o equipo especial. } \\
\text { Si los destinatarios tienen que poseer destrezas especiales, } \\
\text { como saber montar a caballo, o si es necesario acampar. }\end{array}$ \\
\hline Observaciones & \\
\hline
\end{tabular}


Dos años después del plan interpretativo del Servicio de Parques Nacionales (NPS, 2000), este mismo organismo estadounidense rediseñó sus planes previos, presentando un nuevo modelo (NPS, 2002) que complementa la información a consignar y desarrollar respecto a los Planes Interpretativos anteriores. Esta propuesta fue retomada por Larsen (2003) y está compuesta por las siguientes etapas:

1. Selección de un lugar concreto, objeto, persona o acontecimiento que se desee interpretar: normalmente hay un recurso tangible que actúa como un ícono o un símbolo para un producto o servicio interpretativo y puede provocar que el público se preocupe por tal recurso, por ejemplo al utilizar un artefacto especifico para representar una cultura material en particular, también lo hará por las personas que lo crearon y utilizaron. Ese ícono es el motor que impulsa la presentación. Es un ancla que capta y revela ideas, valores, y procesos. El ícono es un punto de partida y referencia para la exploración de recursos tangibles asociados y de múltiples significados.

2. Identificación de los significados intangibles: ¿Qué se puede interpretar con este recurso tangible? ¿Qué procesos, ideas, relaciones, conceptos y valores podrían representarlo significativamente? Cuando un concepto tangible está ligado a significados más amplios $e$ intangibles, su valor se convierte en relevante para más personas. Cada recurso tangible tiene una increíble variedad de significados intangibles. Estos significados pueden ser obvios y populares u ocultos y controvertidos. Cuanto más conocimiento del recurso y de la audiencia tenga un intérprete, más significados pueden estar vinculados a lo tangible.

3. Identificación de los conceptos universales: éstos son significados intangibles relevantes para casi todo el mundo. Constituyen poderosos vehículos que llegan a muchas personas de manera significativa. Al igual que los significados intangibles, los conceptos universales se pueden vincular a un recurso tangible y despertar el deseo de entender $y$ apreciar los significados intangibles (significados que de otro modo podrían parecer poco interesantes).

4. Identificación de la audiencia: el éxito o fracaso en la interpretación tiene relación con el significado que el público asigna al recurso interpretado. Las audiencias de expertos requieren diferentes enfoques que el público en general o que los niños, personas mayores o visitantes internacionales, siendo necesario pensar en una combinación de estilos de públicos para la presentación del producto interpretado. Conocer el público visitante permitirá elaborar un mensaje relevante y significativo.

5. Escribir un tema vinculado a un concepto universal: anteriormente se aconsejó a los intérpretes y gestores de parques que el éxito o el fracaso de un producto interpretativo podía 
medirse fácilmente por la capacidad de la audiencia para exponer el tema. Esto llevó a elaborar productos donde el tema se reiteraba constantemente con la esperanza de que la audiencia fuera capaz de repetir el mensaje de manera mecánica, pero un tema bien elaborado no es un simple refrán. Un programa bien presentado y sobre la base de un tema interpretativo sólido, probablemente provocará conexiones en el público que el intérprete no anticipará.

6. Utilizar métodos de interpretación para establecer conexiones con los significados. llustrar el tema de interpretación: una vez elegidos y desarrollados los vínculos tangibles / intangibles que ilustran la idea y producen oportunidades para conectar la audiencia con los significados del recurso, es necesario seleccionar técnicas interpretativas para lograr tal conexión. Narraciones, explicaciones, citas, actividades, demostraciones, ejemplos, pruebas, preguntas y discusiones son sólo algunos de los métodos de uso de los intérpretes. Es importante que un producto interpretativo proporcione, al mismo tiempo, oportunidades para conexiones emocionales e intelectuales a los significados del recurso.

7. Utilice el tema elegido para organizar conexiones y desarrollar ideas coherentes: para que un producto interpretativo sea relevante y provocativo debe desarrollar de manera coherente una idea o las ideas a lo largo de su entrega. Una idea significativa captura, organiza y mantiene la atención de la audiencia, y proporciona oportunidades para que el público haga sus propias conexiones con los significados del recurso. Sin el desarrollo coherente de una idea o las ideas relevantes, los productos no son más que colecciones de información o arreglos al azar de los vínculos entre los significados intangibles, los conceptos universales y los recursos.

Partiendo de la identificación de la misión que guiará los pasos a seguir en la planificación, Zamora Baño (2002) presenta un Plan de Gestión Patrimonial ${ }^{20}$. Responder preguntas como ¿qué hacemos aquí, para qué estamos gestionando tal recurso?, ayudarán a ese propósito. Una vez definida la misión, es necesario especificar las metas a conseguir para cumplirla, y para ello se estructura de lo más general a lo particular y detallado, considerando como mínimo los siguientes puntos:

a) la situación de partida (indicando lo conseguido en los años anteriores),

b) la organización,

c) los objetivos a cumplir incluyendo los estándares de calidad aplicables,

d) las actividades a desarrollar para cumplir los objetivos,

e) los recursos a utilizar en esas actividades,

\footnotetext{
${ }^{20}$ Para el autor, un Plan de Gestión Patrimonial es un documento escrito que dota a la organización de tres cosas fundamentales: un "sentido de propósito" (¿para qué estamos aquí?), un "sentido de dirección" (¿hacia dónde nos dirigimos?) y un "sentido de consecución" (¿cómo cumplimos nuestra función?, es decir, qué tal lo hacemos).
} 

f) la forma de obtenerlos si no se cuenta ya con ellos,
g) el orden de prioridades,
h) los presupuestos,
i) los mecanismos de control y medidas correctoras.

Cho (2005) propone un modelo (Figura 17) en el que interactúan los deseos y necesidades de las partes interesadas (SWAN), los criterios de protección del recurso (RPC) y los criterios de Gestión del Parque (PMC), en el que existe una dependencia mutua de estos elementos dentro del proceso de planificación interpretativa. Este modelo de planificación supone un proceso en el cual los interesados puedan iniciar y mantener un intercambio de ideas con el manejo del parque. Según esta propuesta, los administradores y empleados del parque estarían mejor equipados para planificar si tienen datos SWAN adecuados, complementados con un conocimiento equivalente de RPC y PMC. Fomentar el flujo de información entre las partes interesadas, no sólo podría mejorar la calidad de la gestión en estos parques, sino que también podría contribuir a la sostenibilidad a largo plazo de los parques nacionales.

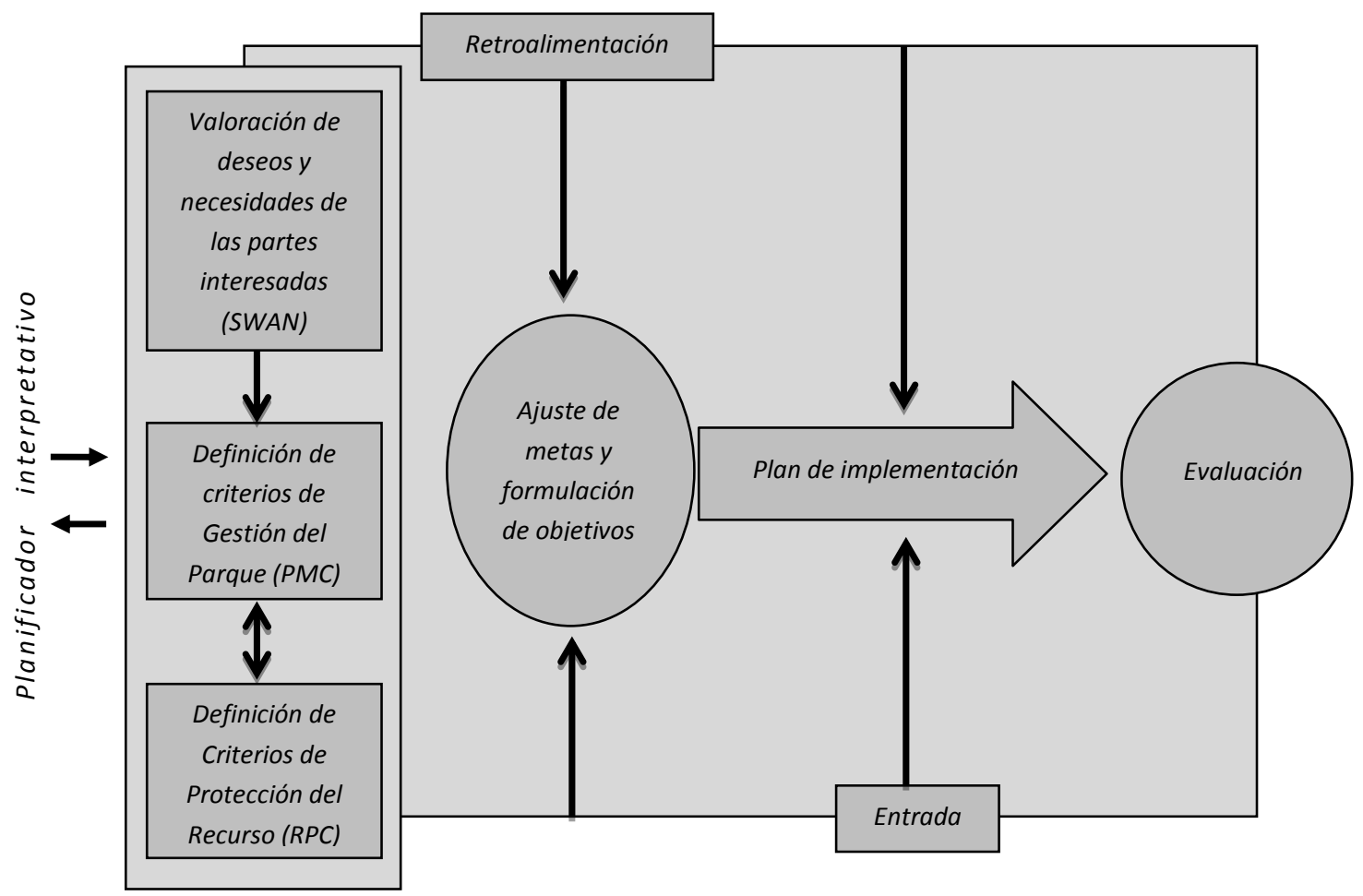

Figura 17. Planificación Interpretativa de Cho (2005).

Fuente: traducido de Cho, 2005. 
El proyecto HICIRA (2005), del que forman parte diferentes instituciones europeas relacionadas con la conservación y difusión del patrimonio, pretende facilitar el trabajo de los gestores públicos sobre la creación y gestión de centros de interpretación. Para ello realizó un análisis de las características y problemas existentes en estos centros, así como el establecimiento de criterios sobre las condiciones que deben considerarse para la creación de nuevos espacios de este tipo, definiendo las funciones mínimas y los servicios a ofrecer. Dentro de este proyecto, un plan de interpretación se constituye en un instrumento de gestión de tales centros, y abarcará desde el diagnóstico y análisis del recurso y del territorio en el que se inserta, hasta la definición de los elementos necesarios para la creación e institucionalización de un nuevo producto de turismo cultural. Para tal fin, se propone el siguiente esquema organizativo:

Análisis y diagnóstico. Se recaba información del contexto social, económico y cultural y el análisis de la demanda interna y externa. El análisis detallado de estos elementos permitirá identificar los principales aspectos positivos y negativos del territorio, así como las influencias externas que puedan afectar su desarrollo.

Conceptualización del proyecto. A partir del análisis anterior surgirán el proyecto y sus contenidos, fijándose sus metas y objetivos.

Desarrollo del proyecto. En esta etapa se concretan las líneas estratégicas y el diseño de los medios, equipamientos y programas (medidas de protección, conservación y difusión del patrimonio; propuestas de sostenibilidad económica; identificación del público destinatario del mensaje, etc.).

De manera sintética, Tourism Tasmania (2005) manifiesta que en el momento de planificar la actividad interpretativa se debe decidir:

- ¿Cuál es la audiencia de interpretación?

- ¿Qué temas o mensajes centrales recibirán?

- ¿Cómo serán transmitidos los mensajes?

Es por esto que, en respuesta a tales interrogantes, propone ocho pasos para la planificación interpretativa temática:

1) Preparación de un inventario interpretativo: esto incluye la clarificación de lo importante del lugar, lo que allí sucede y los rasgos observables más característicos. Es necesario describir el potencial interpretativo, poniendo énfasis en los aspectos que serían de interés para los visitantes. 
2) Selección de metas interpretativas: éstas deben estar relacionadas con la visión, misión y objetivos estratégicos de la organización, e indicar cuál es el objetivo del programa de interpretación. Algunos ejemplos de objetivos relevantes para el programa de interpretación pueden ser:

- Mejora de la experiencia de los visitantes.

- Mejora de las relaciones públicas, proyectando una imagen positiva.

- Protección del sitio y sus recursos.

- Protección a los visitantes de riesgos.

3) Identificación de audiencias: uno de los principios fundamentales de la Interpretación temática es definido por lo que el intérprete puede comunicar a una audiencia en un tiempo y espacio determinados. Conocer sus intereses es un buen indicio de una buena experiencia interpretativa.

4) Determinación de objetivos para el logro de las metas: aquí es donde se determina cómo se puede saber cuándo se ha tenido éxito. Los resultados indican aquello en que se necesita centrar para el monitoreo y la evaluación.

5) Desarrollo de temas: expresan la esencia del mensaje a transmitir; es conveniente la elaboración de temas potentes con elementos tangibles e intangibles. Las palabras elegidas para comunicar el tema a los visitantes dependen del tipo de público y de experiencia que buscan.

6) Elección de medios: la selección de los medios es vital para el éxito del programa interpretativo ya que son el canal que transmite los temas a la audiencia.

7) Implementación del Plan: se elaborará un plan de acción que describa cómo será la interpretación, documentando las etapas, las acciones requeridas y los plazos para alcanzarlos, los responsables para llevarlo a cabo, el presupuesto, los recursos que se requieren o están disponibles, entre otros aspectos.

8) Proceso de evaluación: la evaluación es importante porque permite conocer los progresos en el desarrollo del programa interpretativo. Debe ser continua y se puede realizar brindando cuestionarios a los visitantes u observando su conducta.

Como se dijo en la introducción de este apartado, toda práctica interpretativa debe provenir de un plan elaborado a tal fin, asegurándose que el mensaje brindado sea efectivo. Por tal motivo, es importante reparar en varias instancias durante su confección. En España, la Asociación para la Interpretación del Patrimonio (AIP, 2006) considera cinco momentos a tener en cuenta para la preparación de un plan interpretativo: 
A) Planificación: en esta etapa se definen las necesidades del programa, servicios y recursos disponibles, se especifican objetivos y se examinan diferentes alternativas a llevar a cabo, como así también el tipo de evaluación a implementar. En el proceso de planificación se debería dar respuesta a:

- ¿Por y para qué? (objetivos)

- ¿Dónde y qué? (análisis del recurso)

- ¿A quién? (análisis de los destinatarios)

- ¿Cómo, cuándo, dónde? (medios y programas)

- ¿Cómo y cuándo se evaluará? (determinación de indicadores y evaluación)

B) Diseño: se definen los objetivos generales y específicos, para la gestión, el servicio y sobre todo, los resultados esperados en el público visitante (propósitos de conocimientos, emocionales y de comportamientos). En este momento se ajustan los intereses institucionales (imagen, posibilidades técnicas, presupuesto) con la conveniencia técnica de aplicar tal o cual medio a una circunstancia interpretativa para un público determinado (Morales, 2001).

C) Fabricación/instalación: en este momento se considerarán los canales para la difusión del mensaje, tanto en lo referido al medio (relación con la vegetación, impacto visual, sonoro, etc.) como también al público visitante (accesibilidad, seguridad, ubicación, etc.). Es importante poner atención en los materiales que se utilicen para su elaboración, y que los mismos sean coherentes con el mensaje que se quiere difundir.

D) Intervención/desarrollo de los servicios interpretativos: se analizan los servicios interpretativos atendidos por personal (guías o intérpretes) y aquellos que no lo están (senderos autoguiados, señales, exhibiciones, etc.). Los medios interpretativos garantizan una buena calidad cuando su diseño y ejecución tienen en cuenta los principios esenciales de la interpretación, transmitiendo un mensaje claro y atractivo.

E) Evaluación: tiene como finalidad alcanzar la retroalimentación de la actuación interpretativa, analizando los objetivos planteados en un comienzo. Para tal fin, los objetivos deben estar enunciados de manera que puedan ser mensurados.

El Instituto Nacional de Recursos Naturales (INRENA, 2006), organismo dependiente del Ministerio de Agricultura de Perú, menciona las diferentes etapas al momento de planificar un proceso interpretativo de un área protegida:

a. Elegir o elaborar las metas provisionales del plan. 
b. Analizar y sintetizar los antecedentes e información básica, referidos a los recursos y características del área, el perfil de los visitantes y las fuentes de colaboración, existentes y potenciales.

c. Elaborar las metas definitivas del plan.

d. Elaborar y analizar las limitaciones y condiciones para el proceso de planificación.

e. Definir los criterios básicos para la interpretación para todo el plan, por ejemplo temas generales, normas de estilo y diseño, distribución en el espacio y el tiempo, entre otros.

f. Preparar los programas propuestos de interpretación describiendo en detalle cada componente y utilizando el siguiente concepto básico de desarrollo: nombre de componente o actividad (ej. Senderos Interpretativos); objetivo específico; temas; medios y actividades; infraestructura requerida; estilo y diseño; materiales.

g. Preparar el Plan Integral de Desarrollo que debe incluir un mapa de desarrollo integral, un programa de capacitación para la formación del personal necesario, un programa de colaboración y coordinación intra e interinstitucional y un cronograma de desarrollo.

h. Presentar, discutir, y revisar el plan con instituciones gubernamentales y no gubernamentales a nivel local, regional y nacional.

i. Publicar y distribuir el plan.

j. Ejecutar el plan.

k. Evaluar el plan sobre la marcha.

I. Revisar el plan y realizar los cambios necesarios.

Para Fratto (2007), si bien el proceso de planificación interpretativa debe estar coordinado por un "intérprete planificador", ello no significa que sea una tarea individual. Por eso resulta necesario disponer de un equipo interdisciplinario de planificación que aporte su especificidad de saberes (turismo, educación, investigación, etc.). Este autor considera que en el momento de plantear los objetivos que guiarán la planificación interpretativa, es importante conocer el plan de gestión del área protegida (en el caso que lo hubiere) para adecuar los objetivos específicos con los generales que dan lugar a la existencia de la zona en cuestión. Una vez superada esta fase es necesario realizar un inventario de los recursos a interpretar, de la audiencia (actual y/o potencial) y de los servicios interpretativos que pueden llevarse a cabo en 
la actualidad. Teniendo claro lo que queremos (objetivos) y lo que tenemos (inventario), la siguiente cuestión es ¿cómo lo hacemos? (determinación de medios). Para ello, propone completar una matriz en la cual se relacionen los objetivos con los medios disponibles (Tabla 14), indicando a través de qué medios se alcanzan los objetivos planteados.

Tabla 14. Detalle de una matriz elaborada para un campo de producción forestal en la Patagonia Argentina.

\begin{tabular}{|c|c|c|c|c|c|c|c|c|c|c|c|c|}
\hline \multirow[b]{3}{*}{ 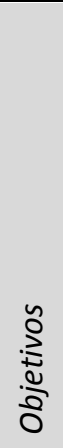 } & \multicolumn{6}{|c|}{ Actividades autoguiadas } & \multicolumn{4}{|c|}{ Actividades guiadas } & \multicolumn{2}{|c|}{$\begin{array}{l}\text { Disponibilidad } \\
\text { de información }\end{array}$} \\
\hline & \multicolumn{2}{|c|}{ Senderos } & \multicolumn{2}{|c|}{ Exhibiciones } & \multicolumn{2}{|c|}{ Gráfica } & \multirow[b]{2}{*}{$\begin{array}{l}\text { o } \\
\text { పे } \\
0 \\
\frac{0}{0} \\
\text { ஸे }\end{array}$} & \multirow[b]{2}{*}{ 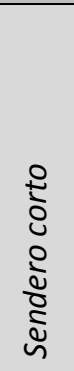 } & \multirow[b]{2}{*}{ 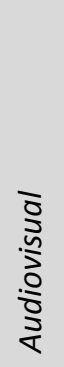 } & \multirow[b]{2}{*}{ 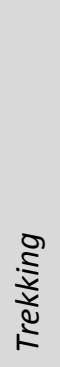 } & \multirow[b]{2}{*}{ 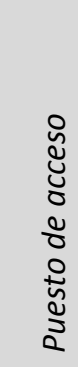 } & \multirow[b]{2}{*}{ 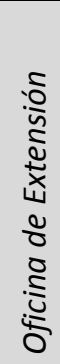 } \\
\hline & 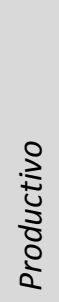 & 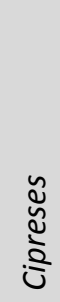 & 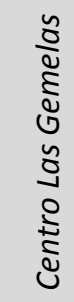 & 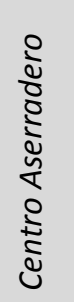 & 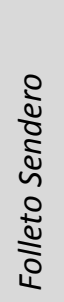 & 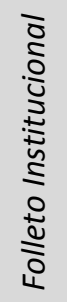 & & & & & & \\
\hline$A 1$ & $x$ & & & $x$ & & $x$ & & & $x$ & & $x$ & \\
\hline$A 2$ & & $x$ & & & $x$ & & & & & $x$ & & \\
\hline A3 & $x$ & & $x$ & & $x$ & & $x$ & & & & $x$ & \\
\hline$B 1$ & & & $x$ & & & & & & $x$ & & & \\
\hline
\end{tabular}

Tabla 15. Detalle de una matriz elaborada para inventariar tópicos.

\begin{tabular}{|l|c|c|c|c|c|c|c|c|}
\hline Recursos culturales & \multicolumn{3}{|c|}{ Centros, museos } & \multicolumn{2}{c|}{ Mirador } & \multicolumn{3}{c|}{ Senderos } \\
\hline Tópicos Sitios & Museo & Reserva & $\begin{array}{c}\text { Centro de } \\
\text { exposiciones }\end{array}$ & $\begin{array}{c}\text { Del } \\
\text { río }\end{array}$ & $\begin{array}{c}\text { Cerro } \\
\text { Colorado }\end{array}$ & $\begin{array}{c}\text { De la } \\
\text { rivera }\end{array}$ & $\begin{array}{c}\text { De } \\
\text { flora }\end{array}$ & Bosque \\
\hline Indígenas & $\boldsymbol{E}$ & $\boldsymbol{M}$ & & & $\boldsymbol{M}$ & $\boldsymbol{I}$ & & \\
\hline $\begin{array}{l}\text { Primeros poblados } \\
\text { blancos }\end{array}$ & $\boldsymbol{E}$ & $\boldsymbol{I}$ & $\boldsymbol{I}$ & $\boldsymbol{M}$ & & & & $\boldsymbol{M}$ \\
\hline Ferrocarril & $\boldsymbol{M}$ & & $\boldsymbol{E}$ & & & $\boldsymbol{I}$ & & \\
\hline Antigua iglesia & $\boldsymbol{I}$ & & & $\boldsymbol{E}$ & & & & \\
\hline Primeras casas & $\boldsymbol{I}$ & & $\boldsymbol{M}$ & & & $\boldsymbol{E}$ & & \\
\hline
\end{tabular}

Referencias: $\boldsymbol{M}$ (mención: si apenas se hace mención al recurso); I (información básica: si se describe el tópico sin desarrollarlo en profundidad); $\boldsymbol{E}$ (información específica: si el tópico se desarrolla en un espacio y/o medio específico).

Fuente: Fratto, 2007.

Para inventariar los tópicos elegidos (Tabla 15), se realizará un procedimiento similar al anteriormente expuesto. Se colocarán en las filas los tópicos y en las columnas, los sitios donde se hace mención de ellos. Como la forma en que se trata un mismo tópico variará según el sitio, se utilizará una simbología de referencia para indicar la manera en que se presenta. Por ejemplo, se propone identificar con una $\boldsymbol{M}$ (mención) si apenas se hace referencia al recurso $o$ si el mismo es abordado muy superficialmente; con una I (información básica), si se describe el tópico sin desarrollarlo en profundidad; y con una $E$ (información específica), si el tópico se desarrolla en un espacio y/o un medio específico (panel, diorama, exposición, etc.). Si el sitio a 
intervenir lo permite, es conveniente que los visitantes comiencen un recorrido desde los sitios M o I hacia los de mayor desarrollo del tema, para poder obtener mayor información si así lo quisieran.

Es sumamente importante que el diseño de los medios se realice en base a la disponibilidad de los recursos económicos y materiales de los que se dispone. Por tal motivo es necesario contar con alguna persona del lugar donde se trabaje y que tenga decisión en aspectos financieros y administrativos. Mientras se desarrolle el plan de trabajo propuesto por el equipo de planificación interpretativa, será importante la presencia del intérprete quien determinará si la ejecución de las obras se lleva a cabo según los principios interpretativos. En la instancia de evaluación del plan diseñado, se valorará si los medios cumplen los objetivos planteados inicialmente. Esta evaluación puede hacerse a través de encuestas a los destinatarios, entrevistas, o bien, colocando un buzón o libro de sugerencias para que los visitantes dejen su impresión sobre la actividad interpretativa recibida.

La propuesta de Jiménez Izarraraz (2007) integra los propósitos del Plan Estratégico del sitio o Plan General de Manejo como un componente elemental en la planeación de la Interpretación Temática. Nuevamente desde el campo de la arqueología, propone una divulgación planeada, con objetivos claros, con información de calidad y con atención a las necesidades, capacidades y expectativas del público no especializado, para lograr no sólo la transmisión de la información, sino el disfrute de los visitantes. De manera esquemática, este planeamiento está conformado por:

a) Directrices generales (Revisión del Plan General ó Plan Estratégico del sitio): su significado, misión, visión y metas del mismo.

b) Aspectos para preparar la divulgación (propósito de la divulgación, mensaje central: tesis y subtesis).

c) Estudios previos: visitantes actuales y potenciales, capacidad de carga, mapa de experiencias y servicios, áreas de oportunidad.

d) Producción / ejecución: selección de medios, producción (con adaptación del discurso a las especificidades de los medios de comunicación), creación de centros Interpretativos.

e) Monitoreo y evaluación: selección de indicadores, delimitación de estándares, formulación de estrategia de monitoreo. 
Morales (2007) considera que la planificación interpretativa persigue cuatro finalidades esenciales: comunicar el significado del lugar de forma interesante y efectiva, contribuir a la satisfacción de las necesidades del visitante, proteger el recurso (conservarlo para que pueda ser utilizado posteriormente) y mejorar la calidad de vida de los habitantes locales. Esta planificación la podemos llevar a cabo poniendo énfasis en los visitantes, en el recurso, en el desarrollo local, en varios aspectos o en la totalidad de ellos al mismo tiempo. Para tal fin es necesario seguir una serie de pasos a para la elaboración del plan interpretativo, los cuales pueden ser cumplidos de manera simultánea (Tabla 16).

Tabla 16. Etapas de un plan interpretativo (Morales, 2007).

\begin{tabular}{|c|c|}
\hline Etapa & Detalle \\
\hline Situación Inicial & Reconocimiento del lugar a interpretar \\
\hline $\begin{array}{l}\text { Formulación de los objetivos de } \\
\text { la planificación }\end{array}$ & Se determina lo que se quiere conseguir con la planificación \\
\hline Recopilación de la información & Datos útiles para la interpretación a realizar \\
\hline Análisis & $\begin{array}{l}\text { - Recurso: potencial interpretativo } \\
\text { - Destinatarios: características } \\
\text { - Objetivos de la interpretación: ¿qué mensajes trasmitir? ¿a } \\
\text { través de qué medios? } \\
\text { - Contenidos: tema de los mensajes a trasmitir } \\
\text { - Medios: canal para la trasmisión del mensaje }\end{array}$ \\
\hline Síntesis & Toma de decisiones. Selección de actividades y mensajes \\
\hline Plan de interpretación & $\begin{array}{l}\text { Esquema que guiará la planificación de los servicios } \\
\text { interpretativos: } \\
\text { - El equipo técnico (breve descripción) } \\
\text { - Introducción (o antecedentes) } \\
\text { - El recurso } \\
\text { - Los destinatarios } \\
\text { - Objetivos de la interpretación } \\
\text { - El mensaje } \\
\text { - Los servicios interpretativos } \\
\text { - Seguimiento y evaluación } \\
\text { - Necesidades de investigación complementaria } \\
\text { - Recomendaciones para la ejecución de los servicios } \\
\text { - Referencias y anexos }\end{array}$ \\
\hline Ejecución & $\begin{array}{l}\text { Propuesta técnica para la interpretación de los mensajes (p.e. } \\
\text { canal más viable) }\end{array}$ \\
\hline Evaluación y seguimiento & $\begin{array}{l}\text { Evaluación de las actividades según los objetivos propuestos. } \\
\text { Retroalimentación de la información }\end{array}$ \\
\hline \multicolumn{2}{|c|}{ Fuente: elaboración propia en base a Morales, 2007.} \\
\hline
\end{tabular}


Morales (2008) complementa su propuesta de 2007, describiendo el proceso de interpretación de la siguiente manera:

a) Se parte del reconocimiento de una necesidad; hay que conservar el patrimonio para conseguir el aprecio y una actitud de custodia por parte del público visitante.

b) Se analiza toda la información posible relacionada con el recurso patrimonial, incluso las que tienen más potencial interpretativo y las que tienen menos.

c) Es importante analizar y determinar el tipo de público que visita o podría llegar a visitar el lugar.

d) Se elabora de forma creativa un mensaje atractivo, breve, claro y directo (ABCD).

e) Se seleccionan el medio y las técnicas de interpretación adecuadas.

f) Es importante lograr que el público contacte con el mensaje diseñado: que lean un texto de una exposición, que escuchen a un guía, etc.

g) El proceso finaliza con una idea clara en la mente de los visitantes: un significado que les estimule a una determinada actitud.

Para finalizar esta presentación de modelos de planificación interpretativa, Guerra et al. (2008) consideran que para planificar un programa interpretativo es necesario dar respuesta a cuestiones referidas al conocimiento del elemento a interpretar, a los grupos de personas que se quiere incidir, a los mensajes y medios interpretativos y las personas que llevarán a cabo esta interpretación. La Tabla 17 presenta un resumen a tales cuestiones.

Tabla 17. Planificación de un programa interpretativo (Guerra et al., 2008).

\begin{tabular}{|l|l|}
\hline \multicolumn{1}{|c|}{ Interrogantes } & \multicolumn{1}{|c|}{ Descripción } \\
\hline $\begin{array}{l}\text { ¿Qué pretendemos conseguir mediante el } \\
\text { programa? }\end{array}$ & Finalidades y objetivos \\
\hline $\begin{array}{l}\text { ¿Cuáles son las características socioeconómicas } \\
\text { del municipio? }\end{array}$ & Análisis socioeconómico del municipio \\
\hline ¿Qué sabemos sobre los visitantes? & Análisis de los visitantes \\
\hline $\begin{array}{l}\text { ¿Qué elementos patrimoniales constituirán los } \\
\text { ejes del programa? }\end{array}$ & Determinación del potencial interpretativo \\
\hline ¿Qué mensajes y qué temas? & $\begin{array}{l}\text { Determinación de los temas de } \\
\text { Interpretación }\end{array}$ \\
\hline ¿Con qué equipamientos y medios? & $\begin{array}{l}\text { Incorporación en el programa de } \\
\text { equipamientos ya existentes y creación de } \\
\text { nuevos }\end{array}$ \\
\hline Fuente: elaboración propia en base a Guerra et al., 2008. \\
\hline
\end{tabular}




\subsection{1) Consideraciones al análisis de los modelos de planificación}

De la revisión de los modelos de planificación interpretativa, se observa que los mismos presentan diferencias en su diseño y que las mismas responden a la evolución de la investigación, el pensamiento y la práctica de esta disciplina. De igual modo, respetan las fases generales para la planificación de tareas y proyectos (Ander-Egg y Aguilar, 1996; Project Management Institute, 2004):

- Diagnóstico: conocimiento de la zona a trabajar y de los recursos disponibles.

- Planificación y diseño: toma de decisiones para alcanzar los objetivos propuestos.

- Desarrollo: poner en práctica la planificación llevada con anterioridad.

- Evaluación/Autoevaluación: valorar lo planeado y lo ejecutado, así como sus resultados, en relación con los objetivos planteados

Frente a varias denominaciones similares (programa, proyecto) y a la finalidad perseguida por la Interpretación, la palabra planificación es la que refleja con más precisión la intención de alcanzar unos objetivos previamente estipulados. Respecto a los vocablos mencionados con anterioridad, el término programa hace alusión a un documento vinculante, un plan puede ser implementado a través de varios programas (Bringer, 1988), y un proyecto, es un grupo de actividades con vistas a alcanzar un objetivo específico en un tiempo dado (Comisión Europea, 2001).

Sin la intención de comparar exhaustivamente todas las propuestas expuestas, se reconocen en las mismas aspectos que las diferencian y las asemejan entre sí. Dentro de las primeras, podemos señalar que todos los modelos consideran necesario planificar la Interpretación a ofrecer $y$, además, recogen importantes aportaciones teóricas $y$ metodológicas de disciplinas como la comunicación y la psicología. Esto último también forma parte de su diferenciación mutua. Por ejemplo, en algunas de ellas se hace hincapié en las oportunidades de experiencias para la audiencia (NPS, 1997; Jacobson y Marynowski, 1998); en otras, sobre el mensaje a enviar (Peart y Woods, 1975; Veverka, 1995), o en la relación de la interpretación con el uso social del patrimonio (Miró, 1997). Otros modelos se desarrollan especificando su objeto de interpretación en la arqueología (Jiménez Izarraraz, 2000 y 2007), en la biodiversidad (Domroese y Sterling, 1999) o el medio ambiente (Castro, 2002), mientras que algunos se centran en las estrategias de evaluación de los programas interpretativos (ANZECC, 1999).

Una de las características que dota de singularidad a la práctica interpretativa es la elaboración del mensaje que servirá de conexión con la audiencia. A pesar de ello, no todos los 
modelos analizados realizan una mención explícita de tal peculiaridad de la planificación. Las investigaciones realizadas en el campo de la psicología conductual, la educación y/o la comunicación sólo fueron recogidas en algunos de los modelos presentados en los últimos años como es la identificación de conceptos universales y significados tangibles e intangibles en los recursos patrimoniales (NPS, 2002; Larsen, 2003; Morales, 2008).

Como se dijo anteriormente, la Planificación Interpretativa describe las experiencias deseadas (resultados) y recomienda las maneras de llevarlas a cabo. Por tanto, debe ser cuidadosamente elaborada a estos efectos, teniendo en cuenta los servicios ofrecidos en otros espacios protegidos y considerando una distribución equilibrada de los programas en el área en cuestión. De esta manera se la considera como previsión de las intenciones y como plan de intervención, entendida como un marco flexible para la orientación de la práctica interpretativa, que permita introducir modificaciones y adaptaciones, tanto en la planificación a más largo plazo como en la aplicación puntual, según el conocimiento que se va adquiriendo a través de las manifestaciones de los visitantes y su evaluación continuada.

\section{8) Técnicas y medios en Interpretación}

El término técnica interpretativa se refiere a un tipo de lenguaje (estilo) o la aplicación de una idea para mejorar la efectividad en la captación del mensaje interpretativo, desarrollando un vínculo entre un recurso tangible y sus significados intangibles. Estos enlaces se convierten en oportunidades de conexión con los significados, con el fin de presentar el recurso de forma convincente y atractiva. Esto se consigue a través de técnicas interpretativas específicas, tales como: citas de textos importantes, cuentos o refranes; desarrollo de actividades prácticas; empleo del humor, la ironía y la imaginación; uso de personificaciones, demostraciones, comparaciones y analogías; estrategia de preguntas y respuestas, debates; uso de los sentidos, etc. La selección de estas técnicas debe estar siempre basada en los objetivos específicos del programa y en el conocimiento de las fortalezas y debilidades de cada técnica. Las técnicas deben ser apropiadas para la audiencia, el recurso y el intérprete. Hay varios factores acerca de la audiencia que se deben tener en cuenta a la hora de seleccionar técnicas. Edad, lengua materna, aspectos de accesibilidad y composición social del grupo (edades, géneros, intereses, nivel educativo, etc.) son algunas de las primeras cuestiones a considerar. Así como las técnicas deben ser apropiadas para la audiencia, también deben serlo para el recurso y el intérprete. La protección de los recursos es siempre primordial. Cualquier 
técnica que degrade un recurso debe evitarse. Respecto al intérprete, si no se siente cómodo con el uso de una técnica, o no la ha practicado lo suficiente, no es apropiado usarla.

El medio interpretativo hace referencia al vehículo o soporte a través del cual se entrega el mensaje a los visitantes (Guerra et al., 2008). Diversos trabajos (Morales, 1998a; Fernández y Fallas, 2005; SPN, 2007; Guerra et al., 2008) diferencian dos grandes grupos a través de los cuales se puede producir la tarea interpretativa. Uno de ellos se conoce como personal o guiada, mientras que la otra es la impersonal, autoguiada o autónoma. Ejemplos de la interpretación guiada por personas lo representan contactos informales, charlas, paseos, recorridos guiados y demostraciones; brindan la oportunidad de que los visitantes interactúen con un intérprete en persona y suelen ser menos económicos que la interpretación a través de servicios impersonales, ya que requieren de una persona capacitada y disponible para quienes desean hacer el recorrido. La segunda alternativa está representada por carteles, folletos, periódicos, audio guías, mesas interpretativas, programas audiovisuales y paneles de exhibición; presenta la ventaja de que es más económica y está a disposición del público en todo momento. La decisión de cuáles son los medios más adecuados para llevar a cabo la Interpretación de un lugar es responsabilidad de los profesionales de cada sitio. La Tabla 18 presenta características e investigaciones asociadas a algunos medios interpretativos.

Tabla 18. Características e investigaciones sobre medios interpretativos.

\begin{tabular}{|c|c|c|}
\hline $\begin{array}{l}\text { Medio / } \\
\text { Técnica }\end{array}$ & Detalle & $\begin{array}{c}\text { Referencias Académicas } \\
\text { Seleccionadas }\end{array}$ \\
\hline $\begin{array}{l}\text { Centro de } \\
\text { visitantes }\end{array}$ & $\begin{array}{l}\text { Los Centros de información de visitantes suelen } \\
\text { actuar como el punto de partida para las } \\
\text { personas que deseen explorar el parque. Reciben } \\
\text { información sobre el mismo y las actividades que } \\
\text { pueden participar. No todas las áreas naturales } \\
\text { protegidas tienen estos centros. }\end{array}$ & $\begin{array}{l}\text { Prince, 1982; Moscardo y Pearce, } \\
\text { 1997; Orams, 1997; Hefferman, } \\
\text { 1998; Stewart et al., 1998; Evans, } \\
\text { 1999; Howard, 1999/2000; Burke, } \\
\text { 2002; Bushell and Kennedy, 2002; } \\
\text { Fallon y Kriwoken, 2003; Staiff, } \\
\text { Tubb, 2003; Pearce, 2004; Hughes } \\
\text { and Morrison-Saunders, 2005. }\end{array}$ \\
\hline $\begin{array}{l}\text { Caminatas / } \\
\text { Recorridos } \\
\text { guiados }\end{array}$ & $\begin{array}{l}\text { Las visitas guiadas a las áreas protegidas suelen } \\
\text { ser ofrecidas con el objetivo de educar a los } \\
\text { visitantes sobre sus recursos patrimoniales. Las } \\
\text { empresas independientes de turismo basado en } \\
\text { la naturaleza también son importantes. Algunas } \\
\text { excursiones tienen un enfoque educativo / } \\
\text { interpretativo específico, otras simplemente } \\
\text { visitan lugares de interés. }\end{array}$ & $\begin{array}{l}\text { Roggenbuck y Berrier, 1982; } \\
\text { Stoep y Gramann, 1987; Hughes, } \\
\text { 1991; Ryan y Dewar, 1995; Chen } \\
\text { et al., 1999; Moscardo y Pearce, } \\
\text { 1997; Orams, 1997; Beaumont, } \\
\text { 2001; Howard, 1999/2000; } \\
\text { Hendricks et al, 2001; Armstrong } \\
\text { y Weiler, 2003; Black y Weiler, } \\
\text { 2003; Luck, 2003; Madin y } \\
\text { Fenton, 2004. }\end{array}$ \\
\hline $\begin{array}{l}\text { Señalización } \\
\text { / Tablones } \\
\text { de anuncios }\end{array}$ & $\begin{array}{l}\text { La señalización es una de las maneras más } \\
\text { rentables de publicidad de la gestión de las áreas } \\
\text { protegidas. A menudo se limita a la provisión de } \\
\text { información sobre el viaje, por ejemplo, sobre la }\end{array}$ & $\begin{array}{l}\text { Cole et al, 1997; Winter et al, } \\
\text { 2000; Beaumont, 2001; Smith- } \\
\text { Jackson y Hall, 2002; Ballantyne y } \\
\text { Hughes, 2003; Mallick y Driessen, }\end{array}$ \\
\hline
\end{tabular}




\begin{tabular}{|c|c|c|}
\hline & $\begin{array}{l}\text { fácil circulación de los visitantes en el parque. En } \\
\text { otros casos, se centra en la interpretación o en la } \\
\text { seguridad de los turistas. }\end{array}$ & $\begin{array}{l}\text { 2003; Hughes y Morrison- } \\
\text { Saunders, 2005; Jensen, 2006; } \\
\text { Hall et al., 2010. }\end{array}$ \\
\hline Folletos & $\begin{array}{l}\text { Estos materiales son producidos por los } \\
\text { organismos de gestión de los parques y pueden } \\
\text { centrarse en la educación de los visitantes en } \\
\text { cuanto a sus impactos sobre el medio ambiente e } \\
\text { informar sobre las actividades que se llevan a } \\
\text { cabo en el parque. La capacidad de los folletos } \\
\text { para ser traducidos a otros idiomas los hace un } \\
\text { instrumento útil para educar a visitantes } \\
\text { internacionales. }\end{array}$ & $\begin{array}{l}\text { Roggenbuck y Berrier, 1982; Bass } \\
\text { et al., 1989; Young y Witter, 1994; } \\
\text { Lawton y Page, 1997; Moscardo y } \\
\text { Pearce, 1997; Moscardo, 1999a; } \\
\text { Winter et al., 2000; Parkin y } \\
\text { Parkin, 2001; Beaumont, 2001; }\end{array}$ \\
\hline $\begin{array}{l}\text { Media } \\
\text { (Televisión, } \\
\text { videos, } \\
\text { radio, } \\
\text { libros) }\end{array}$ & $\begin{array}{l}\text { A menudo son vistos como complementos a la } \\
\text { educación de turistas en los centros de visitantes. } \\
\text { El uso de ayudas visuales y de audio puede } \\
\text { ayudar en dar a conocer a los visitantes las } \\
\text { características del entorno natural antes de la } \\
\text { entrada en el parque. }\end{array}$ & $\begin{array}{l}\text { Moscardo y Pearce, 1997; Stewart } \\
\text { el al, 1998; Smith-Jackson y Hall, } \\
2002 .\end{array}$ \\
\hline
\end{tabular}

\subsection{1) Dos ejemplos de medios interpretativos: senderos y paneles}

En el contexto de los espacios naturales protegidos, la Interpretación del Patrimonio se posiciona como un instrumento de gestión que hace énfasis en la comunicación de los valores del patrimonio natural y cultural, la prevención de los efectos negativos que puedan generar los programas de visitas y recorridos en tales espacios, y en el aporte de productos de turismo alternativo como opciones sustentables de uso del territorio. Muchas veces, un simple paseo puede convertirse en una verdadera expedición de búsqueda y exploración cuando se realiza por senderos interpretativos bien diseñados.

Los recorridos, rutas o senderos interpretativos son servicios que se brindan por caminos previamente definidos y acordados, e implican un contacto directo del público con el recurso $o$ el lugar que se desea conocer y en torno al cual se quiere dar un mensaje. Cada sendero tiene un objetivo específico (reducir el impacto antrópico en la zona del recorrido, favorecer la conservación del sitio patrimonial, despertar sensaciones y percepciones en los visitantes, etc.), que se sustenta en el desarrollo de las actividades, centrando la atención en un aspecto que el visitante pueda interiorizar y que a la vez sirva de hilo conductor de los contenidos del mensaje. Por lo general están orientados a la divulgación y recreación.

En un sendero interpretativo, el visitante depende de las señales del mismo para guiarse sin peligro y poder regresar al punto de partida. Por ello, se recomienda que estas rutas tengan una longitud menor de $1600 \mathrm{~m}$, siendo los $800 \mathrm{~m}$ la longitud más acertada, ya que el visitante promedio podrá ir y venir en no más de media hora. Se recomienda que el recorrido en un sendero no requiera más de 45 minutos. En la relación al número de estaciones o paradas ideal 
para un sendero no existe un acuerdo entre los autores (Ham, 1992). No obstante, se recomienda no sobrepasarse las 15 paradas. Además, la mayoría de ellas, deberían estar localizadas en la primera mitad del sendero, y la primera parada debe ser visible desde el rótulo introductorio.

La percepción de que los senderos son tan sólo caminos acondicionados con letreros y miradores puede ocasionar un impacto negativo en el sitio en que se instalen. Estos itinerarios deben diseñarse y ser empleados de manera que no generen intensidades de uso que puedan afectar severamente o de manera irreversible a los recursos naturales. Para su construcción se requiere realizar valoraciones previas de las zonas por donde pasará, con la finalidad de evitar alteraciones al medio natural (por ejemplo, destrucción de vegetación endémica, erosión o compactación del suelo, perturbación de áreas de anidamiento de aves, etc.). Los buenos senderos interpretativos permiten acceder a las zonas de mayor belleza escénica y consideran medidas de diseño para regular la capacidad de carga. Los senderos buscan llevar a los visitantes a lugares de especial valor paisajístico, previamente identificados en un inventario de elementos singulares o atractivos, conectando los puntos seleccionados en su trazado. Por ello, es importante considerar algunas cuestiones al planificar el diseño de un sendero (MoreiraWachtel y Trellez Solis, 2013):

a) Establecer objetivos interpretativos y de gestión.

b) Conocer al destinatario (tipo de visitantes, intensidad y variaciones de la demanda).

c) Decidir si el sendero será temporal o permanente.

d) Planificar la ruta a seguir (distancia y tipo del recorrido, paradas y rasgos significativos o interesantes, etc.).

Respecto al trazado de los senderos (Figura 18), el más común es el que presenta un esquema circular (comienzo y final en un mismo punto). Suelen ser recorridos en un solo sentido y esto representa una ventaja para los visitantes que pueden visitar las paradas interpretativas sin tropezar con otras personas. Existen también los senderos en forma de ocho; estos tienen como ventaja que la gente puede regresar una vez que terminen de recorrer el primer círculo, aún sin haber completado el recorrido o continuar hacia el segundo, si así lo desean. Una variante a esta propuesta es el diseño de senderos multicircuitos: de un sendero principal, se desprenden otros senderos, con diferentes niveles de dificultad, distancia, duración y atractivos, lo que permite diversificar el área de uso público. De acuerdo con Ham (1992), el diseño menos común es el lineal, en ellos la gente va y regresa por el mismo sendero y se crea un patrón de tráfico de doble vía. Este tipo de sendero no es usualmente utilizado, pero algunas 
veces son necesarios para evitar obstáculos físicos como rocas, bordes de colinas o cuerpos de aguas, que impiden realizar otro tipo de diseño.

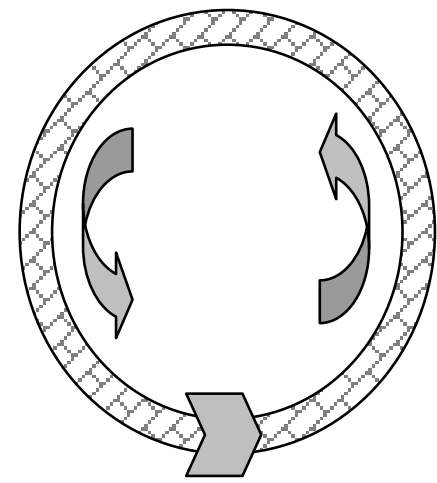

Circular

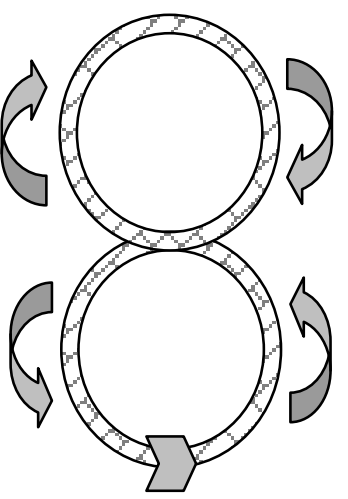

Ocho

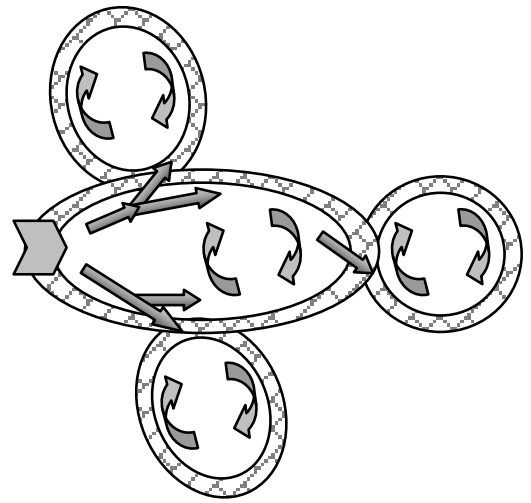

Multicircuito

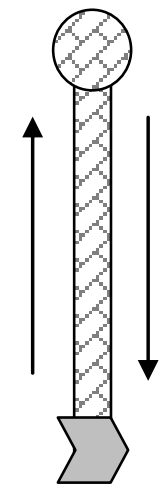

Lineal

Figura 18. Trazado de recorridos interpretativos.

Fuente: elaboración propia

A continuación (Tabla 19) se exponen las características, beneficios y desventajas del uso de los senderos interpretativos.

Tabla 19. Tipos de senderos interpretativos.

\begin{tabular}{|c|c|c|c|}
\hline Tipo de Sendero & Descripción & Ventajas & Limitaciones \\
\hline Autoguiado & $\begin{array}{l}\text { Es una actividad en una } \\
\text { ruta especifica en la que el } \\
\text { público es autónomo para } \\
\text { la interpretación de los } \\
\text { rasgos, mediante la } \\
\text { utilización de diversos } \\
\text { medios. La dirección puede } \\
\text { ser indicada por medio de } \\
\text { instrucciones en un folleto } \\
\text { o marcas en la ruta: } \\
\text { flechas, estacas o signos } \\
\text { en el suelo (Figura 19) }\end{array}$ & $\begin{array}{l}\text { - Son usados al propio ritmo } \\
\text { del visitante. } \\
\text { - Organizan el uso del } \\
\text { espacio. } \\
\text { - Pueden estimular el uso } \\
\text { de los sentidos. } \\
\text { - Implican una } \\
\text { participación, aptos para } \\
\text { familias y otros tipos de } \\
\text { grupos. }\end{array}$ & $\begin{array}{l}\text { - Son impersonales, } \\
\text { no responden a } \\
\text { dudas. } \\
\text { - Son susceptibles al } \\
\text { vandalismo. } \\
\text { - Pueden ser difíciles } \\
\text { de mantener y } \\
\text { controlar. }\end{array}$ \\
\hline $\begin{array}{l}\text { Paseos guiados; } \\
\text { Itinerarios } \\
\text { interpretativos }\end{array}$ & $\begin{array}{l}\text { Es una ruta que realiza un } \\
\text { grupo de personas, nunca } \\
\text { más de veinte, junto a un } \\
\text { guía o un intérprete, quien } \\
\text { explica los rasgos más } \\
\text { sobresalientes, al tiempo } \\
\text { que estimula al grupo a } \\
\text { participar activamente y } \\
\text { usar sus sentidos. Los } \\
\text { contenidos y el estilo de la } \\
\text { presentación pueden } \\
\text { variar dependiendo del } \\
\text { guía y del grupo. }\end{array}$ & $\begin{array}{l}\text { - Hay contacto personal con } \\
\text { un intérprete. } \\
\text { - Hay una experiencia de } \\
\text { primera mano con el } \\
\text { recurso y es posible usar } \\
\text { los sentidos. } \\
\text { - Se pueden responder } \\
\text { preguntas. } \\
\text { - Se adaptan al nivel de la } \\
\text { concurrencia. } \\
\text { - Permiten un control } \\
\text { directo del uso del recurso } \\
\text { con el público. }\end{array}$ & $\begin{array}{l}\text { - La efectividad } \\
\text { dependerá de la } \\
\text { capacidad del guía. } \\
\text { - El visitante no } \\
\text { puede ir a su } \\
\text { propio ritmo. } \\
\text { - Restringido a no } \\
\text { más de } 20 \\
\text { personas por guía } \\
\text { para que sea } \\
\text { efectivo. } \\
\text { - Algunos senderos } \\
\text { requieren medidas } \\
\text { especiales de } \\
\text { seguridad (Figura } \\
\text { 20). }\end{array}$ \\
\hline
\end{tabular}




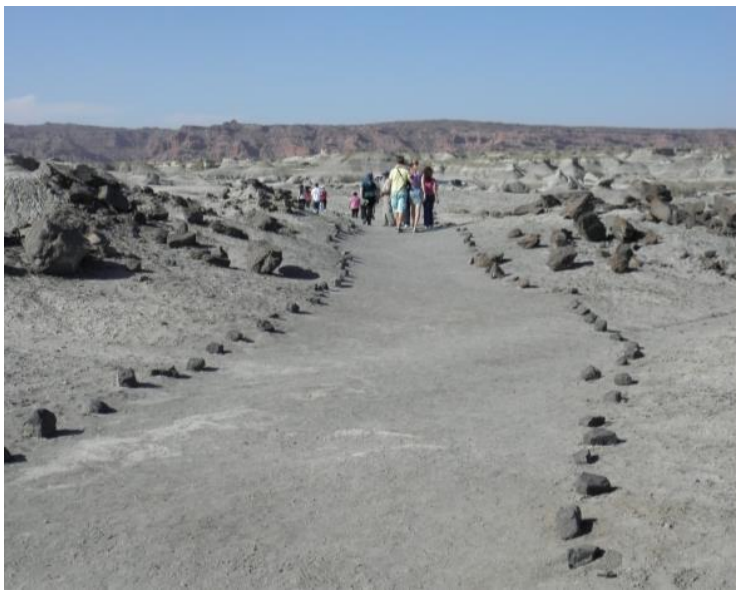

Figura 19. Itinerario demarcado por rocas en el Parque Provincial Ischigualasto (Argentina).

Fuente: Héctor Bazán.

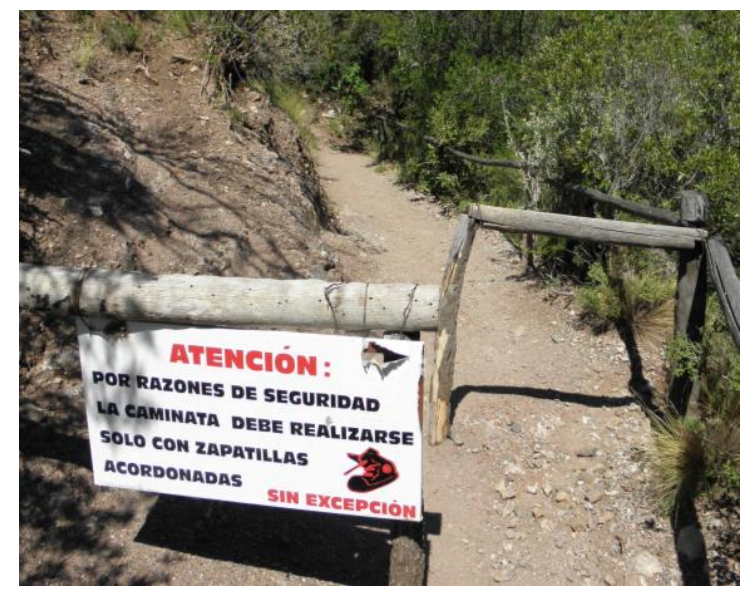

Figura 20. Medidas de seguridad para el uso de sendero en el Parque Los Terrones (Argentina). Fuente: Héctor Bazán.

Por su parte, los carteles intepretativos son las señales más utilizadas en los senderos autoguiados, en exposiciones al borde del camino, en los puntos de interés o en los centros de información de los visitantes. Cumplen la función de explicar a los visitantes los valores de un lugar concreto. Hay una gran diferencia entre la señalización informativa y señalización interpretativa. La señalización informativa ofrece datos, tales como nombres, fechas y cifras. La señalización interpretativa convierte esa información en un tema o experiencia que captura los intereses de los visitantes, provocando su curiosidad. La sola presencia de estos paneles, añade un sentido de permanencia y trascendencia a un sitio que ningún otro medio ofrece: aquí algo pasó o algo es importante en este lugar. Constituyen un ejemplo de medios interpretativos no personales, siendo algunas de sus ventajas que pueden ser utilizados por un gran número de personas y son fáciles de comprender cuando está bien confeccionado su mensaje. Sin embargo su uso presenta algunas limitaciones: los paneles pueden atraer una atención no deseable a

Figura 21. Panel con mensaje difícil de leer debido a condiciones climáticas (Murcia, España). Fuente: Héctor Bazán.

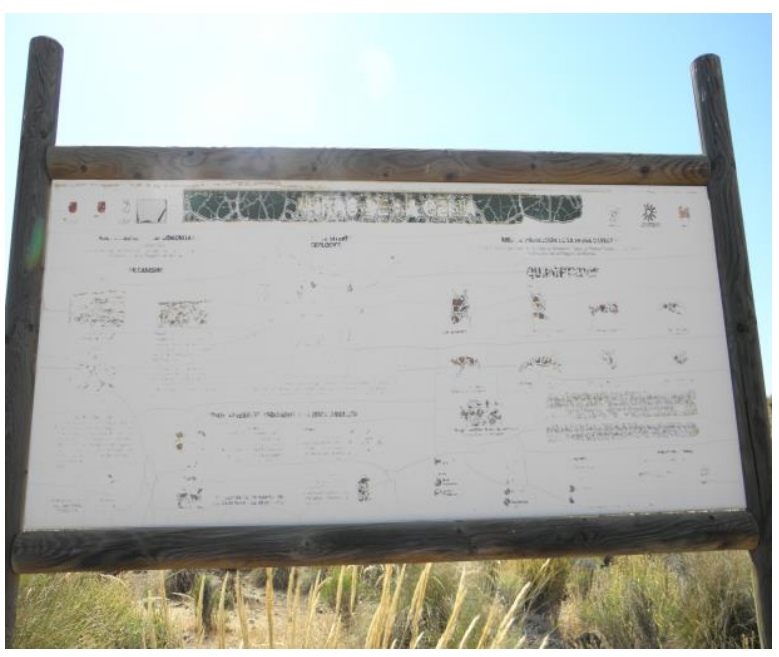


sitios frágiles, no responden a preguntas y están expuestos al deterioro por condiciones ambientales y el vandalismo (Figura 21). Otros beneficios e inconvenientes que presenta la utilización de paneles interpretativos se recogen en la Tabla 20.

Tabla 20. Principales ventajas y desventajas en el uso de paneles interpretativos.

\begin{tabular}{|c|c|}
\hline Ventajas & Desventajas \\
\hline $\begin{array}{l}\text { - Pueden proporcionar información cuando el } \\
\text { - Personal está ocupado con otros visitantes. } \\
\text { visitantes. } \\
\text { - Pueden utilizarse para dar respuestas a preguntas } \\
\text { - Precuentes. } \\
\text { - Pueden utilizarse en casi cualquier entorno. } \\
\text { - Pueden ser colocados fuera del Centro de } \\
\text { - Son relativamente económicos (en comparación } \\
\text { con otros medios de interpretación). }\end{array}$ & $\begin{array}{l}\text { - No se pueden cambiar fácilmente. } \\
\text { - No responden a preguntas específicas } \\
\text { de los visitantes. } \\
\text { - Deben ser precisos y concisos, por } \\
\text { tanto, pueden no ser adecuado para } \\
\text { mensajes complejos. } \\
\text { - Es necesario que reciban } \\
\text { mantenimiento regular. } \\
\text { Están expuestos al vandalismo y a las } \\
\text { condiciones climáticas. }\end{array}$ \\
\hline
\end{tabular}

Los carteles de más éxito, los más leídos, son aquellos que están escritos y diseñados para atraer el interés del visitante, responder a sus preguntas y estimular su pensamiento. Por lo tanto se debe tener cuidado en su elaboración e instalación (es importante que los paneles estén integrados en el paisaje y que posean, preferentemente, formas rectangulares y horizontales), para crear una interpretación efectiva y alcanzar los objetivos deseados. Además, el material para ser utilizado en su montaje debe considerar la relación entre la durabilidad, el coste y la estética. Al elaborar letreros interpretativos el mensaje debe cumplir con ciertas funciones: llamar la atención del visitante, mantener su interés, asegurar la comprensión de lo que se desea comunicar, y, en algunas circunstancias, causar alguna acción específica en el comportamiento del visitante (Moore (1993). No sólo el mensaje de los paneles es importante para lograr la interpretación deseada, también lo es su diseño. Por ejemplo, el color de fondo del panel (o las fuentes que utiliza, el tipo de ilustraciones, etc.) puede influir en la percepción del público al mismo nivel que las palabras usadas para transmitir el mensaje (Jensen, 2006; Hall et al., 2010).

Respecto al mensaje presente en estos paneles, el mismo puede dividirse de la siguiente forma: un título que logre la atención del visitante para que siga leyendo, seguido de un párrafo corto e interesante; también se puede agregar un párrafo interior que desarrolle la comprensión de un tema y puede terminar el mensaje. Si no, se puede agregar un párrafo de clausura aclarando la acción que se desea que tome el visitante. Por ejemplo, si el mensaje tiene que ver con el cuidado del medio ambiente, se pide que no camine en ciertas áreas o que no arroje basura. Los carteles llaman la atención de los turistas para que éste se acerque a 
leerlo. Pero si no se consigue mantener el interés, el esfuerzo de su confección habrá sido en vano. Por ejemplo, la mayor parte de visitantes al Parque Nacional Iguazú (Brasil) no leen los paneles interpretativos, pero los que así lo hacen aprecian su contenido. Dentro de las causas de la falta de lectura se encuentran que el panel no posee una buena ubicación, no son del interés del visitante, su diseño no es atractivo, las letras son muy pequeñas o los textos son muy extensos. Más allá de este porcentaje, casi todos los encuestados consideran importante a este tipo de medio interpretativo y entienden mejor la geología del parque después de la lectura de los paneles (Moreira, 2012). Por lo tanto, además de considerar la ubicación y los materiales de los paneles, se recomienda seguir algunas sugerencias para elaborar el mensaje que ofrecen los mismos (Ham, 1992; Morales, 1998a, 1998b; Domroese y Sterling, 1999; Carcavilla et al., 2007; Guerra et al., 2008):

- Cada panel contará con un título-tema atractivo y no un título-tópico, en forma de frase completa, de manera que el lector pueda apreciar la existencia de una idea clave.

- Los textos deben ser generalmente cortos, con 10 a 15 palabras por oración. En total, se recomienda no superar las 70 palabras en paradas de itinerarios o miradores y 90 en paneles de exhibición. Sobre este punto, Masters y Carter (1999) proponen textos no mayores a 100 palabras, Lancaster County Planning Commission (2007) y Carcavilla et al. (2007) restringen el texto a 150 palabras por panel y el sitio web de Scottish Natural Heritage sugiere que el texto no debe superar las 200 palabras.

- Después del título, se suele dividir el texto en un párrafo de atracción (planteando algunos interrogantes que animen a realizar la visita), otro principal y uno de clausura (que recoja algunas conclusiones y que presente preguntas abiertas). El texto presentará ideas sencillas, claras, breves y se adecuará al público con un nivel medio de conocimientos, organizadas en torno a cinco o menos ideas principales.

- Invitar a los visitantes a participar con el uso de sus sentidos: "Busque las... "; "Puede encontrar la ... "; "Siga adelante y toque el .... "; " Escuche el .... ", etc. (Figuras 22y 23).

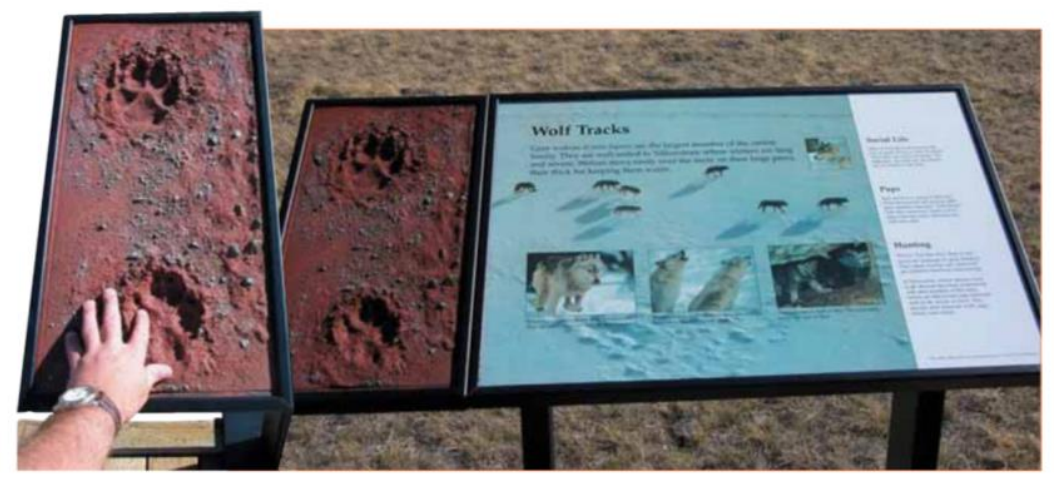

Figura 22. Panel interpretativo sobre un sendero del Parque Nacional de Yellowstone (EE.UU.) que provoca el uso del tacto. Fuente: Colquhoun, 2005. 


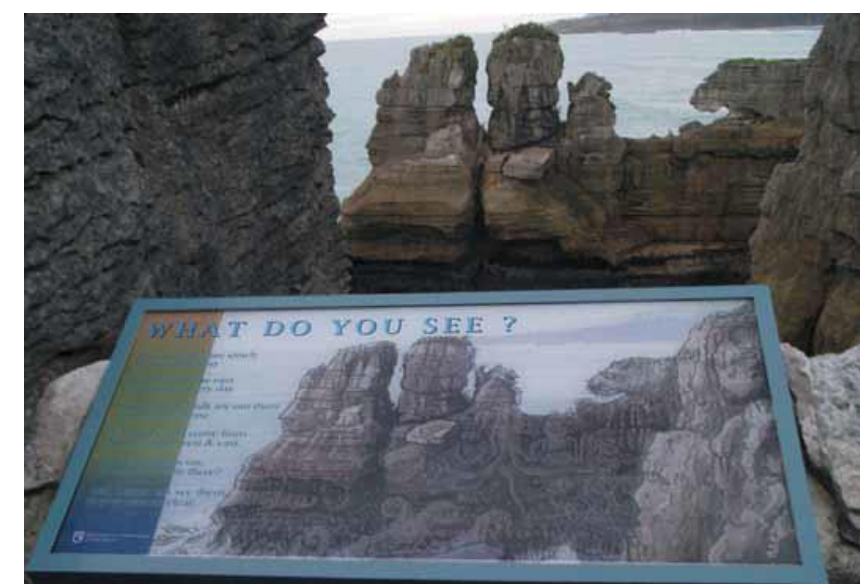

Figura 23. Panel que invita a descubrir "rostros en las rocas" en el Parque Nacional Paparoa (Nueva Zelanda). Fuente: Colquhoun, 2005.

- Se hará referencia al visitante, utilizando fórmulas de relevancia al ego y, en algunos textos, harán referencia explícita a la población infantil.

- Eliminar las conjugaciones pasivas, sustituyéndolas por verbos activos. Por ejemplo: La lluvia desnuda los suelos desprotegidos de nuestra tierra, y no Los suelos desprotegidos están siendo desnudados de nuestra tierra por la lluvia.

- Elegir una o, como máximo, dos fuentes de texto y hasta tres tamaños de letra.

- Partir de lo simple para llegar a lo complejo, utilizando ejemplos, metáforas y analogías, lenguaje familiar, huyendo de tecnicismos. En el caso de utilizar algún concepto específico, cuyo significado puede ignorar habitualmente el visitante, incluir una breve explicación entre paréntesis.

- Los gráficos, dibujos, esquemas y fotografías son apoyos visuales al texto y nunca repetirán sus contenidos. Es importante organizarlos alrededor del mensaje.

Morales (2008), siguiendo recomendaciones de la NPS (2002), presenta un modelo para analizar los mensajes interpretativos escritos, con el fin de mejorar su redacción y hacerlos más efectivos:

1) Elementos y atributos tangibles: el mensaje identifica con claridad los aspectos y características físicas del elemento a interpretar.

2) Elementos intangibles: ideas abstractas contenidas en el mensaje que surgen a partir de los atributos tangibles del recurso.

3) Conceptos universales: el mensaje conlleva ideas intangibles con un nivel de relevancia superior para los visitantes. Surgen del punto 2, y son las ideas que 
representan conceptos más elevados, importantes para una amplia mayoría de visitantes.

4) Conexión intelectual con el visitante: oportunidad que ofrece el mensaje para que el público comprenda conceptos e ideas nuevas.

5) Conexión emocional con el visitante: oportunidad que ofrece el mensaje para producir emociones en el público.

6) Estímulo al pensamiento: capacidad del mensaje para provocar en el visitante un pensamiento más profundo. Es la provocación lo que causa el pensamiento.

7) Actitud de custodia/respeto: actitud que podría generar el mensaje para que el público aprecie y contribuya a la salvaguarda del recurso.

8) Idea central: una oración-tema que dé cohesión a los distintos aspectos tratados en el mensaje -con sujeto, verbo y predicado-. Además, el propósito de comunicar el tema es estimular el pensamiento del visitante.

Resumiendo, debemos de tener en cuenta estas premisas para la elaboración del mensaje interpretativo:

- Hay que atraer a un público que está en su tiempo de ocio y que no es cautivo.

- Hay que brindar una información fácil de comprender (interpretar, traducir de un lenguaje a otro) evitando tecnicismos.

- Hay que contar algo interesante para las personas, que se conecte con sus pensamientos, intereses o motivaciones. Esto se podrá conseguir con mayor facilidad si se utilizan metáforas, analogías y comparaciones.

- Tiene que girar en torno a un tema central y tener un buen guión.

- Hay que utilizar oraciones y párrafos cortos y sólo una idea en cada frase.

- Es conveniente narrar el mensaje en primera persona.

- Usar verbos en voz activa en lugar de voz pasiva.

- Evitar errores ortográficos y gramaticales.

- Debe contener elementos y atributos tangibles como elementos o conceptos intangibles.

- Utilizar conceptos universales.

- Hay que considerar que el mensaje puede infundir una actitud de custodia/respeto.

Teniendo en cuenta las recomendaciones anteriores, y con el fin de analizar la calidad y utilidad de los paneles interpretativos que habitualmente se utilizan en sitios patrimoniales, hemos elaborado una matriz para el análisis de aspectos puntuales del mensaje de los textos 
presentes en paneles interpretativos (Tabla 21) la cual fue aplicada en ejemplos de diversas áreas protegidas de interés geomorfológico:

- Centro de visitantes de Sotama (Picos de Europa, España).

- Centro de Interpretación de Parque Provincial Ischigualasto (Argentina).

- Sendero autoguiado en Colorado National Monument (Estados Unidos).

- Monumento Natural Puente del Inca (Argentina).

- Sendero autoguiado en Murcia (España).

- Centro de visitantes Pedro Pidal (Picos de Europa, España).

Tabla 21. Matriz para el análisis de paneles interpretativos.

\begin{tabular}{|c|c|c|c|}
\hline \multicolumn{4}{|l|}{ Título } \\
\hline \multicolumn{4}{|l|}{ Subtítulo } \\
\hline \multicolumn{4}{|l|}{ Texto } \\
\hline & & Si & No \\
\hline \multirow{12}{*}{ 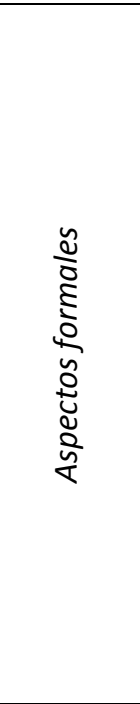 } & $\begin{array}{l}\text { ¿En la lectura del título y/o subtítulo se puede apreciar la } \\
\text { existencia de una idea clave? }\end{array}$ & & \\
\hline & Extensión del título y/o subtítulo & \multirow{4}{*}{$\begin{array}{l}\text { Indicar la } \\
\text { cantidad }\end{array}$} & \\
\hline & $\begin{array}{l}\text { Extensión del texto (se recomienda } 70 \text { palabras en miradores y } \\
\text { paradas de itinerario y } 90 \text { en paneles de exhibición) }\end{array}$ & & \\
\hline & Tipos de fuentes de textos (se recomienda el uso de hasta 2) & & \\
\hline & Tamaño de letra (se recomienda el uso de hasta 3) & & \\
\hline & $\begin{array}{l}\text { El mensaje posee una idea central clara, presentada en forma de } \\
\text { oración, con sujeto, verbo y predicado }\end{array}$ & & \\
\hline & El mensaje es atractivo, breve, claro y directo & & \\
\hline & Se presenta el todo y no las partes aisladas & & \\
\hline & ¿Está narrado en primera persona? & & \\
\hline & En el caso de utilizar tecnicismos, ¿'los mismos están explicados? & & \\
\hline & ¿Se utilizan metáforas, analogías o comparaciones? & & \\
\hline & $\begin{array}{l}\text { ¿Las imágenes utilizadas son apoyos visuales del texto o } \\
\text { redundantes? }\end{array}$ & & \\
\hline \multirow{8}{*}{ 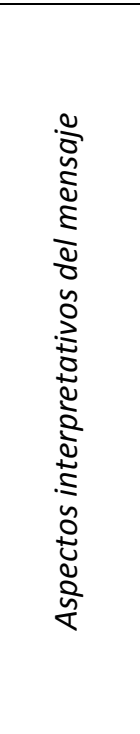 } & $\begin{array}{l}\text { Elementos y atributos tangibles ( el mensaje identifica con } \\
\text { claridad los aspectos y características físicas del rasgo) }\end{array}$ & & \\
\hline & $\begin{array}{l}\text { Elementos intangibles ( ideas abstractas contenidas en el } \\
\text { mensaje que surgen a partir de los atributos tangibles) }\end{array}$ & & \\
\hline & $\begin{array}{l}\text { Conceptos universales (ideas intangibles con un nivel de } \\
\text { relevancia superior para los visitantes. Surgen del punto anterior) }\end{array}$ & & \\
\hline & $\begin{array}{l}\text { Conexión intelectual con el visitante (oportunidad que ofrece el } \\
\text { mensaje para que el público comprenda conceptos e ideas) }\end{array}$ & & \\
\hline & $\begin{array}{l}\text { Conexión emocional con el visitante (oportunidad que ofrece el } \\
\text { mensaje para producir emociones en el público) }\end{array}$ & & \\
\hline & $\begin{array}{l}\text { Estímulo al pensamiento (capacidad del mensaje para provocar } \\
\text { en el visitante un pensamiento más profundo) }\end{array}$ & & \\
\hline & $\begin{array}{l}\text { Actitud de custodia/respeto (actitud que podría generar el } \\
\text { mensaje para que el público aprecie y contribuya a la } \\
\text { salvaguarda del recurso) }\end{array}$ & & \\
\hline & $\begin{array}{l}\text { Idea central (una oración-tema que dé cohesión a los distintos } \\
\text { aspectos tratados) }\end{array}$ & & \\
\hline
\end{tabular}




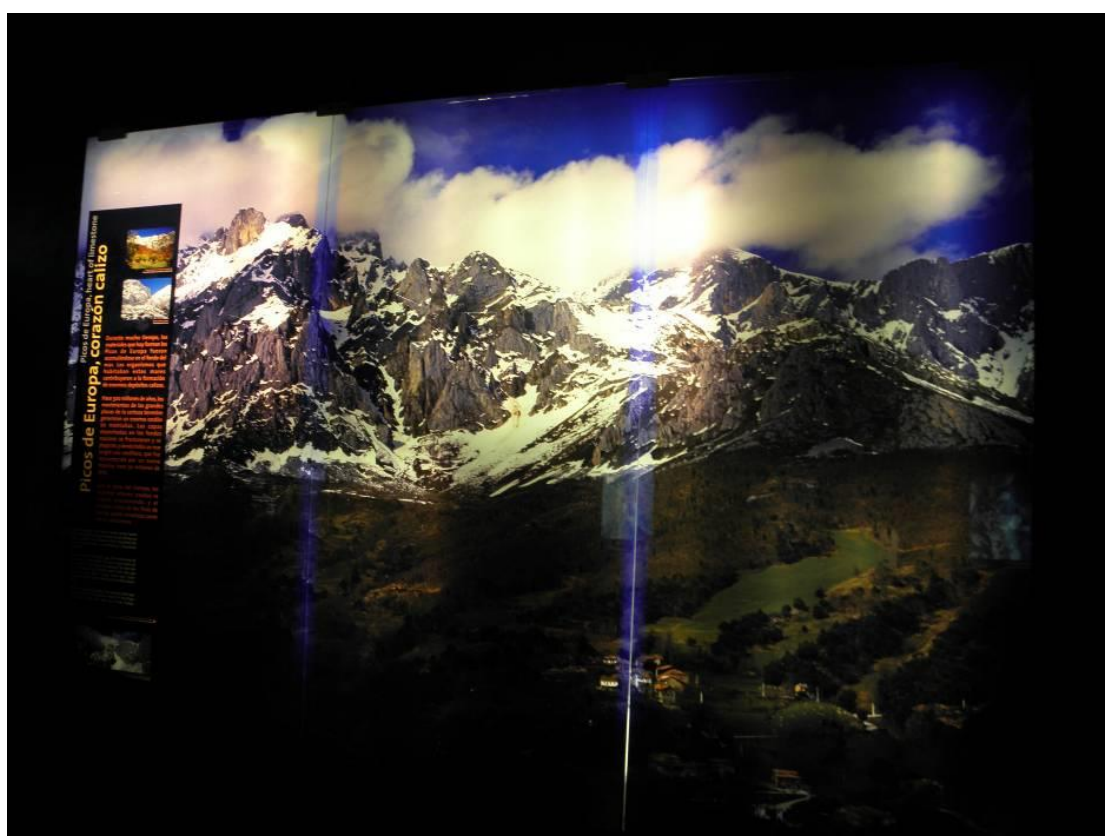

Figura 24. Panel interpretativo del Centro de Interpretación de Sotama (Parque Nacional de los Picos de Europa, España). Fuente: Héctor Bazán.

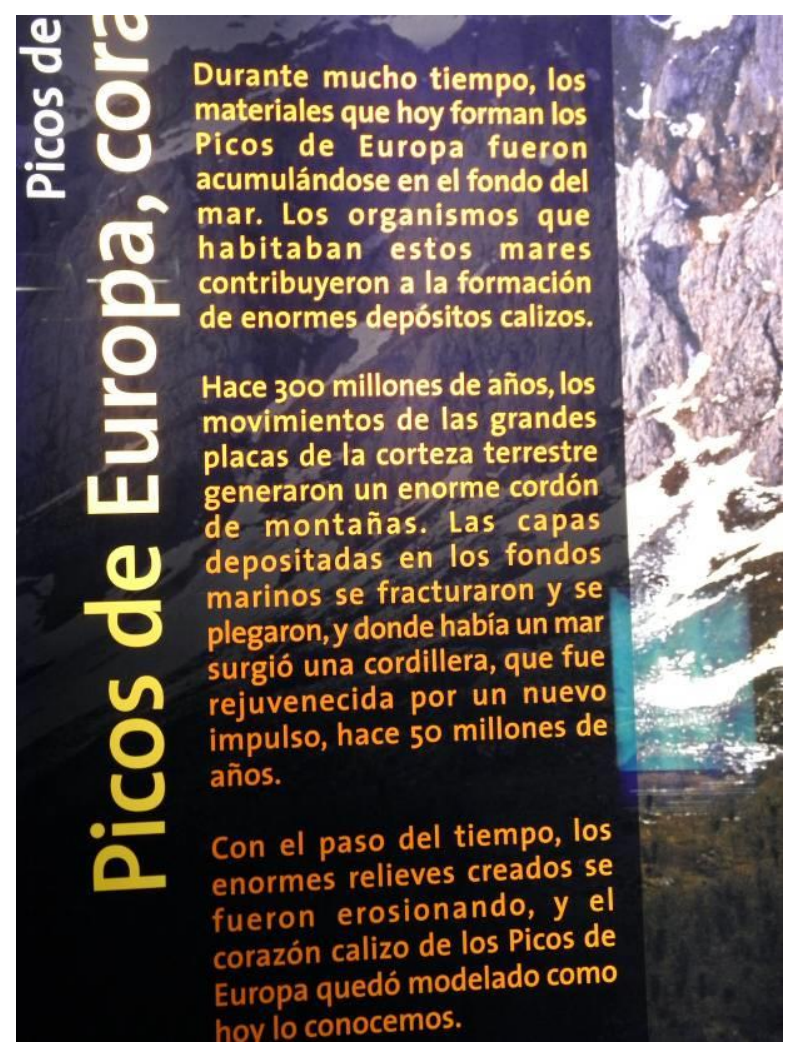

Figura 25. Detalle de figura 24. 
Tabla 22. Análisis de panel interpretativo del Centro de Interpretación de Sotama (Parque Nacional de los Picos de Europa, España).

\begin{tabular}{|c|c|c|c|c|}
\hline Título & \multicolumn{4}{|l|}{ Picos de Europa, corazón calizo } \\
\hline Subtítulo & \multicolumn{4}{|c|}{ No posee } \\
\hline Texto & \multicolumn{4}{|c|}{$\begin{array}{l}\text { Durante mucho tiempo, los materiales que hoy forman los Picos de Europa fueron } \\
\text { acumulándose en el fondo del mar. Los organismos que habitaban estos mares } \\
\text { contribuyeron a la formación de enormes depósitos calizos. } \\
\text { Hace } 300 \text { millones de años, los movimientos de las grandes placas de la corteza terrestre } \\
\text { generaron un enorme cordón de montañas. Las capas depositadas en los fondos marinos se } \\
\text { fracturaron y se plegaron, y donde había un mar surgió una cordillera, que fue rejuvenecida } \\
\text { por un nuevo impulso, hace } 50 \text { millones de años. } \\
\text { Con el paso del tiempo, los enormes relieves creados se fueron erosionando, y el corazón } \\
\text { calizo de Picos de Europa quedó modelado como hoy lo conocemos. }\end{array}$} \\
\hline \multirow{13}{*}{ 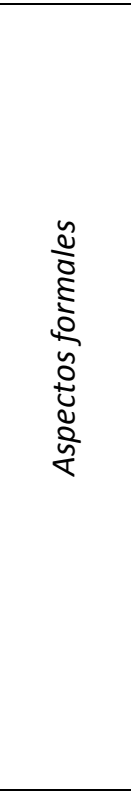 } & & & Si & No \\
\hline & $\begin{array}{l}\text { ¿En la lectura del título y/o subtítulo se puede aprecic } \\
\text { existencia de una idea clave? }\end{array}$ & & $x$ & \\
\hline & Extensión del título y/o subtítulo & & \multirow{4}{*}{$\begin{array}{l}\text { Indicar la } \\
\text { cantidad }\end{array}$} & 5 \\
\hline & \multicolumn{2}{|l|}{$\begin{array}{l}\text { Extensión del texto (se recomienda } 70 \text { palabras en miradores y } \\
\text { paradas de itinerario y } 90 \text { en paneles de exhibición) }\end{array}$} & & 112 \\
\hline & \multicolumn{2}{|l|}{ Tipos de fuentes de textos (se recomienda el uso de hasta 2) } & & 1 \\
\hline & \multicolumn{2}{|l|}{ Tamaño de letra (se recomienda el uso de hasta 3) } & & 2 \\
\hline & \multicolumn{2}{|l|}{$\begin{array}{l}\text { El mensaje posee una idea central clara, presentada en forma de } \\
\text { oración, con sujeto, verbo y predicado }\end{array}$} & \multicolumn{2}{|l|}{ Si } \\
\hline & \multicolumn{2}{|l|}{ El mensaje es atractivo, breve, claro y directo } & $\begin{array}{l}\text { Breve y } \\
\text { atractivo }\end{array}$ & aro. Poco \\
\hline & \multicolumn{2}{|l|}{ Se presenta el todo y no las partes aisladas } & Si & \\
\hline & \multicolumn{2}{|l|}{ ¿Está narrado en primera persona? } & No & \\
\hline & \multicolumn{2}{|l|}{ En el caso de utilizar tecnicismos, ¿'los mismos están explicados? } & \multicolumn{2}{|c|}{ No se utilizan } \\
\hline & \multicolumn{2}{|l|}{ ¿Se utilizan metáforas, analogías o comparaciones? } & \multicolumn{2}{|c|}{ No } \\
\hline & \multicolumn{2}{|l|}{$\begin{array}{l}\text { ¿Las imágenes utilizadas son apoyos visuales del texto o } \\
\text { redundantes? }\end{array}$} & \multicolumn{2}{|c|}{$\begin{array}{l}\text { Las imágenes no } \\
\text { acompañan al texto. }\end{array}$} \\
\hline \multirow{8}{*}{ 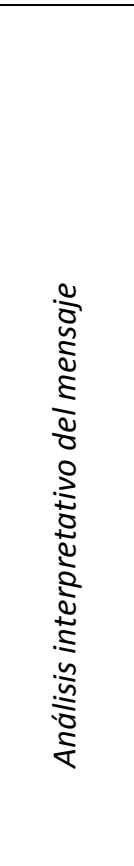 } & $\begin{array}{l}\text { Elementos y atributos tangibles ( el mensaje identifica con } \\
\text { claridad los aspectos y características físicas del rasgo) }\end{array}$ & \multicolumn{3}{|c|}{$\begin{array}{l}\text { Rocas, mar, montañas, } \\
\text { "habitantes del mar" }\end{array}$} \\
\hline & $\begin{array}{l}\text { Elementos intangibles (ideas abstractas contenidas en el } \\
\text { mensaje que surgen a partir de los atributos tangibles ) }\end{array}$ & \multicolumn{3}{|c|}{ Proceso orogénico, erosión } \\
\hline & $\begin{array}{l}\text { Conceptos universales (ideas intangibles con un nivel de } \\
\text { relevancia superior para los visitantes. Surgen del punto } \\
\text { anterior) }\end{array}$ & \multicolumn{3}{|c|}{ Plegamiento } \\
\hline & $\begin{array}{l}\text { Conexión intelectual con el visitante (oportunidad que } \\
\text { ofrece el mensaje para que el público comprenda conceptos } \\
\text { e ideas) }\end{array}$ & \multicolumn{3}{|l|}{ Si } \\
\hline & $\begin{array}{l}\text { Conexión emocional con el visitante (oportunidad que } \\
\text { ofrece el mensaje para producir emociones en el público) }\end{array}$ & \multicolumn{3}{|l|}{ No } \\
\hline & $\begin{array}{l}\text { Estímulo al pensamiento (capacidad del mensaje para } \\
\text { provocar en el visitante un pensamiento más profundo) }\end{array}$ & \multicolumn{3}{|l|}{ Si } \\
\hline & $\begin{array}{l}\text { Actitud de custodia/respeto ( actitud que podría generar el } \\
\text { mensaje para que el público aprecie y contribuya a la } \\
\text { salvaguarda del recurso) }\end{array}$ & \multicolumn{3}{|c|}{ No } \\
\hline & $\begin{array}{l}\text { Idea central (una oración-tema que dé cohesión a los } \\
\text { distintos aspectos tratados) }\end{array}$ & \multicolumn{3}{|c|}{$\begin{array}{l}\text { Gran parte de Picos de } \\
\text { Europa está formado de } \\
\text { calizas (presente en el título) }\end{array}$} \\
\hline
\end{tabular}




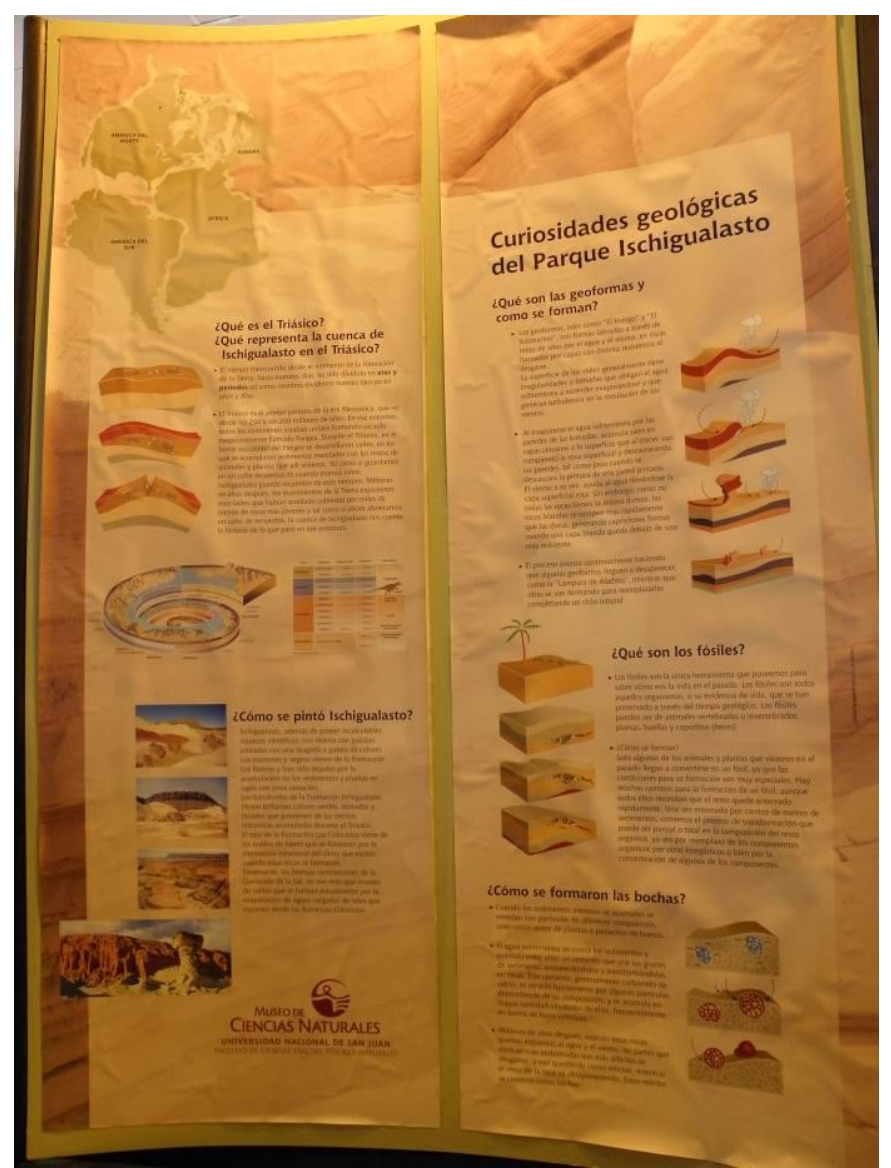

Figura 26. Panel interpretativo en el Centro de Visitantes (Parque Provincial Ischigualasto, Argentina).

Fuente: Héctor Bazán.

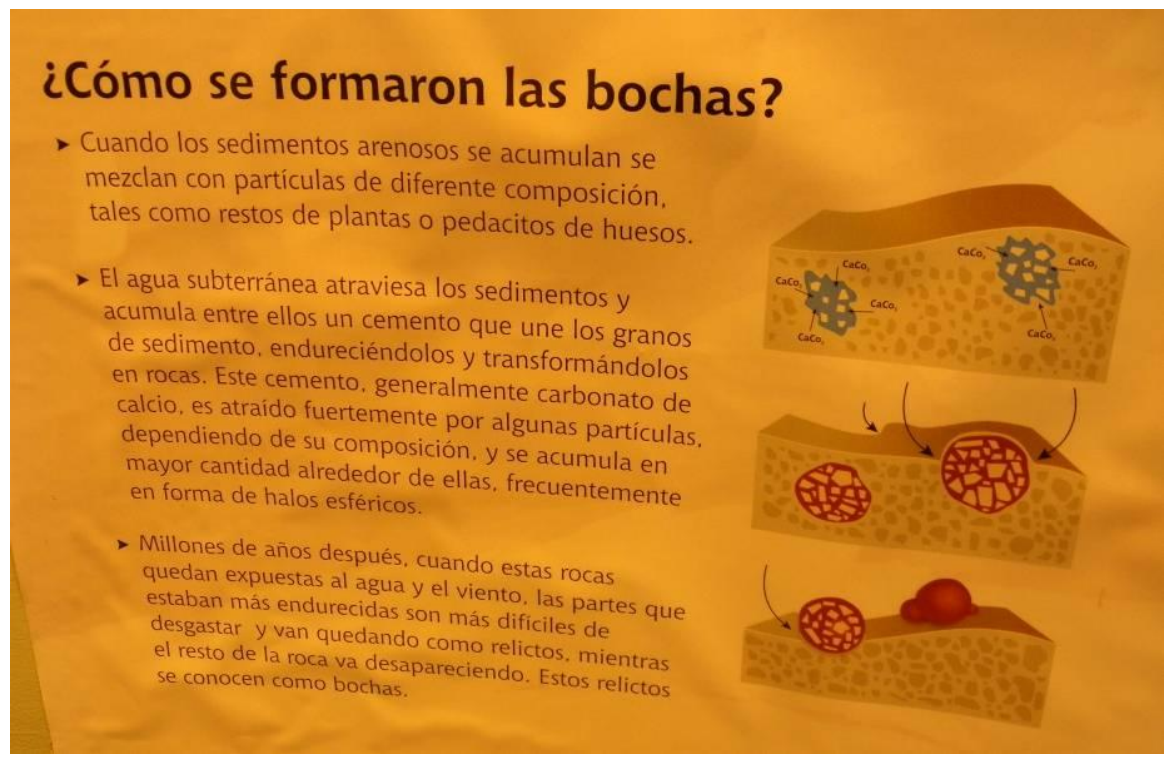

Figura 27. Detalle de figura 26. 
Tabla 23. Análisis de panel interpretativo en Parque Provincial Ischigualasto (Argentina).

\begin{tabular}{|c|c|c|c|c|}
\hline Título & \multicolumn{4}{|l|}{ Curiosidades geológicas del Parque Ischigualasto. } \\
\hline Subtítulo & \multicolumn{4}{|c|}{ ¿Cómo se formaron las bochas? } \\
\hline \multirow[t]{2}{*}{ Texto } & \multicolumn{4}{|c|}{$\begin{array}{l}\text { Cuando los sedimentos se acumulan se mezclan con partículas de diferente composición, tales } \\
\text { como restos de plantas o pedacitos de huesos. } \\
\text { El agua subterránea traviesa los sedimentos y acumula entre ellos un cemento que une los } \\
\text { granos de sedimento, endureciéndolos y transformándolos en rocas. Este cemento, } \\
\text { generalmente carbonato de calcio, es atraído por algunas partículas, dependiendo de su } \\
\text { composición, y se acumula en mayor cantidad alrededor de ellas, frecuentemente en forma de } \\
\text { halos esféricos. } \\
\text { Millones de años después, cuando estas rocas quedan expuestas al agua y viento, las partes } \\
\text { que estaban más endurecidas son más difíciles de desgastar y van quedando como relictos, } \\
\text { mientras el resto de la roca va desapareciendo. Estos relictos se conocen como bochas. }\end{array}$} \\
\hline & & & Si & No \\
\hline \multirow{12}{*}{ 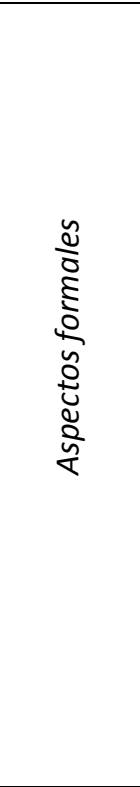 } & $\begin{array}{l}\text { ¿En la lectura del título y/o subtítulo se puede apreciar } \\
\text { existencia de una idea clave? }\end{array}$ & & $x$ & \\
\hline & Extensión del título y/o subtítulo & \multirow{4}{*}{\multicolumn{2}{|c|}{$\begin{array}{l}\text { Indicar la } \\
\text { cantidad }\end{array}$}} & 10 \\
\hline & $\begin{array}{l}\text { Extensión del texto (se recomienda } 70 \text { palabras en miradore } \\
\text { y paradas de itinerario y } 90 \text { en paneles de exhibición) }\end{array}$ & & & 117 \\
\hline & Tipos de fuentes de textos (se recomienda el uso de hasta 2) & & & 1 \\
\hline & Tamaño de letra (se recomienda el uso de hasta 3) & & & 2 \\
\hline & \multicolumn{2}{|l|}{$\begin{array}{l}\text { El mensaje posee una idea central clara, presentada en forma } \\
\text { de oración, con sujeto, verbo y predicado }\end{array}$} & \multicolumn{2}{|l|}{ Si } \\
\hline & \multicolumn{2}{|l|}{ El mensaje es atractivo, breve, claro y directo } & \multicolumn{2}{|c|}{$\begin{array}{l}\text { Regular en todos los } \\
\text { aspectos. }\end{array}$} \\
\hline & \multicolumn{2}{|l|}{ Se presenta el todo y no las partes aisladas } & \multicolumn{2}{|c|}{ Si } \\
\hline & \multicolumn{2}{|l|}{ ¿Está narrado en primera persona? } & \multicolumn{2}{|l|}{ No } \\
\hline & \multicolumn{2}{|l|}{$\begin{array}{l}\text { En el caso de utilizar tecnicismos, ¿ilos mismos están } \\
\text { explicados? }\end{array}$} & \multicolumn{2}{|c|}{ No se explican (p.e. relictos) } \\
\hline & \multicolumn{2}{|l|}{ ¿Se utilizan metáforas, analogías o comparaciones? } & \multicolumn{2}{|l|}{ No } \\
\hline & \multicolumn{2}{|l|}{$\begin{array}{l}\text { ¿Las imágenes utilizadas son apoyos visuales del texto o } \\
\text { redundantes? }\end{array}$} & \multicolumn{2}{|c|}{ Apoyan el texto } \\
\hline \multirow{8}{*}{ 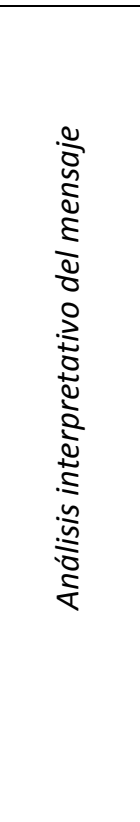 } & $\begin{array}{l}\text { Elementos y atributos tangibles ( el mensaje identifica con } \\
\text { claridad los aspectos y características físicas del rasgo) }\end{array}$ & \multicolumn{3}{|c|}{ Rocas, minerales, agua, viento. } \\
\hline & $\begin{array}{l}\text { Elementos intangibles ( ideas abstractas contenidas en el } \\
\text { mensaje que surgen a partir de los atributos tangibles) }\end{array}$ & \multicolumn{3}{|c|}{$\begin{array}{l}\text { Procesos geológicos y } \\
\text { geomorfológicos. Meteorización }\end{array}$} \\
\hline & $\begin{array}{l}\text { Conceptos universales (ideas intangibles con un nivel de } \\
\text { relevancia superior para los visitantes. Surgen del punto } \\
\text { anterior) }\end{array}$ & \multicolumn{3}{|c|}{ Cambio en la materia. } \\
\hline & $\begin{array}{l}\text { Conexión intelectual con el visitante (oportunidad que } \\
\text { ofrece el mensaje para que el público comprenda } \\
\text { conceptos e ideas) }\end{array}$ & \multicolumn{3}{|l|}{ Si. } \\
\hline & $\begin{array}{l}\text { Conexión emocional con el visitante (oportunidad que } \\
\text { ofrece el mensaje para producir emociones en el público) }\end{array}$ & \multicolumn{3}{|c|}{ No. } \\
\hline & $\begin{array}{l}\text { Estímulo al pensamiento (capacidad del mensaje para } \\
\text { provocar en el visitante un pensamiento más profundo) }\end{array}$ & \multicolumn{3}{|l|}{ Si. } \\
\hline & $\begin{array}{l}\text { Actitud de custodia/respeto (actitud que podría generar } \\
\text { el mensaje para que el público aprecie y contribuya a la } \\
\text { salvaguarda del recurso) }\end{array}$ & \multicolumn{3}{|c|}{$\begin{array}{l}\text { Sí, en la medida que se otorgue } \\
\text { valor a las geoformas. }\end{array}$} \\
\hline & $\begin{array}{l}\text { Idea central (una oración-tema que dé cohesión a los } \\
\text { distintos aspectos tratados) }\end{array}$ & \multicolumn{3}{|c|}{$\begin{array}{l}\text { La naturaleza crea formas de } \\
\text { paisajes }\end{array}$} \\
\hline
\end{tabular}


La Interpretación del Patrimonio Geomorfológico en los Picos de Europa: una propuesta para su aprovechamiento didáctico y geoturístico

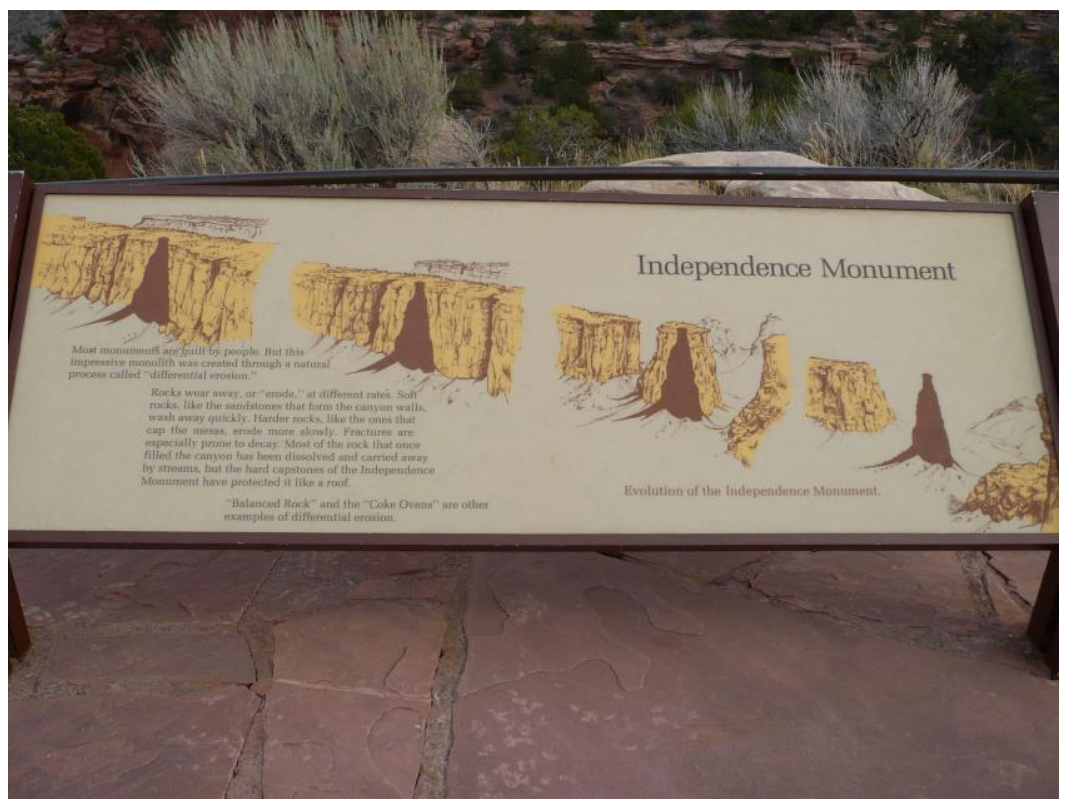

Figura 28. Panel interpretativo en Colorado National Monument (Estados Unidos).

Fuente: Héctor Bazán.

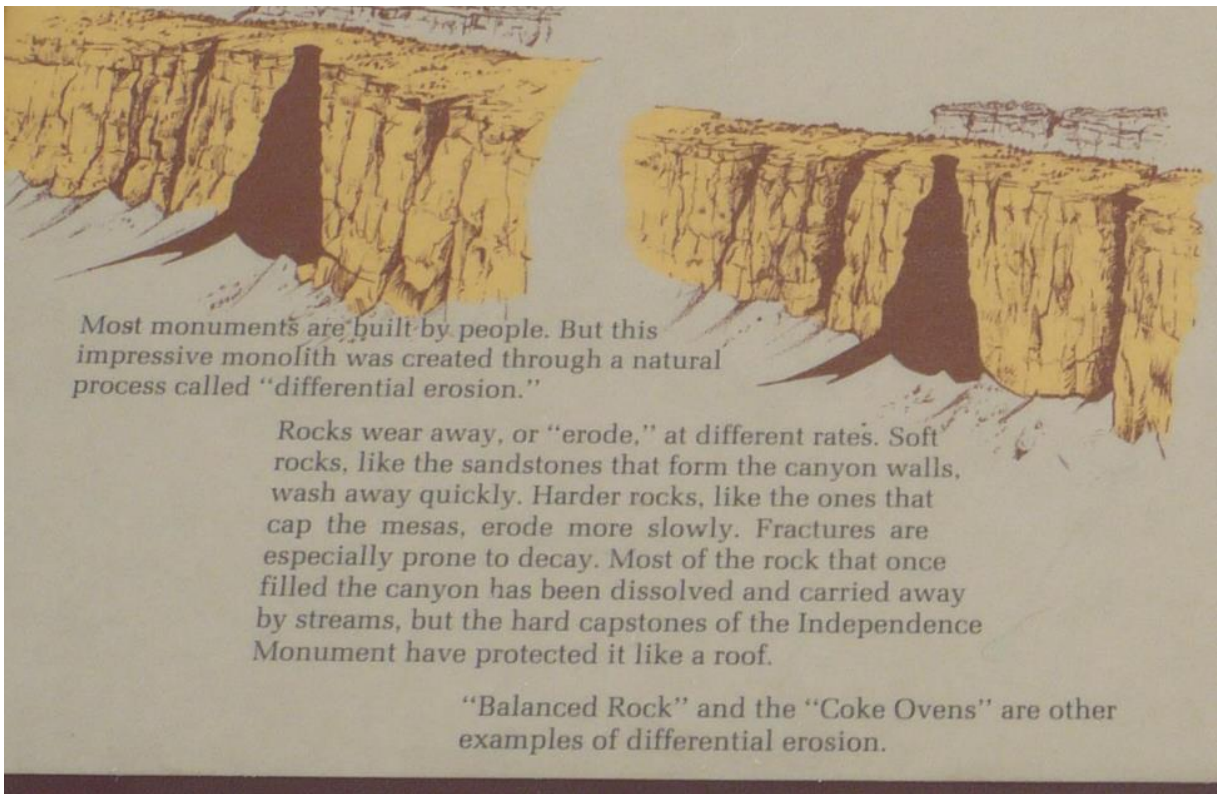

Figura 29. Detalle de figura 28. 
Tabla 24. Análisis de panel interpretativo en Colorado National Monument (Estados Unidos).

\begin{tabular}{|c|c|c|c|c|}
\hline Título & \multicolumn{4}{|l|}{ Independence Monument } \\
\hline Subtítulo & \multicolumn{4}{|c|}{ Evolution of the Independence Monument } \\
\hline \multirow[t]{2}{*}{ Texto } & \multicolumn{4}{|c|}{$\begin{array}{l}\text { Most monuments are built by people. But this impressive monolith was created through a } \\
\text { natural process called "differential erosion". } \\
\text { Rocks wear away, or "erode", at different rates. Soft rocks, like the sandstones that form the } \\
\text { canyon walls, wash away quickly. Harder rocks, like the ones that cap the mesas, erode more } \\
\text { slowly. Fractures are especially prone to decay. Most of the rock that once filled the canyon } \\
\text { has been dissolved and carried away by streams, but the hard capstones of the Independence } \\
\text { Monument have protected it like a roof. } \\
\text { "Balance Rock" and the "Coke Ovens" are other examples of differential erosion. } \\
\text { Traducción: La mayoría de los monumentos están construidos por la gente. Pero este } \\
\text { impresionante monolito fue creado a través de un proceso natural llamado "erosión } \\
\text { diferencial". } \\
\text { Las rocas se desgastan, o "recortan", a diferentes velocidades. Rocas blandas, como las } \\
\text { areniscas que forman las paredes del cañón, son arrastrados rápidamente. Las rocas más } \\
\text { duras, como las que cubren las mesas, erosionan más lentamente. Las fracturas son } \\
\text { especialmente propensas a caer. La mayor parte de la roca que una vez llenó el cañón ha sido } \\
\text { disuelta y arrastrada por las corrientes, pero las losas duras del Monumento a la } \\
\text { Independencia lo han protegido como un techo. } \\
\text { "La Roca del Equilibrio"y los "Hornos de Coque" son otros ejemplos de la erosión diferencial. }\end{array}$} \\
\hline & & & & No \\
\hline \multirow{12}{*}{ 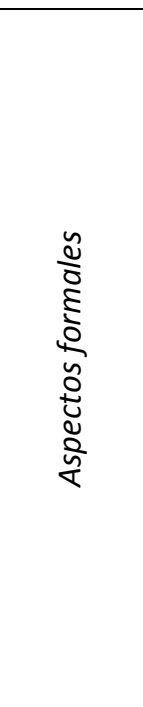 } & \multicolumn{2}{|c|}{$\begin{array}{l}\text { ¿En la lectura del título y/o subtítulo se puede apreciar la } \\
\text { existencia de una idea clave? }\end{array}$} & $x$ & \\
\hline & \multicolumn{2}{|c|}{ Extensión del título y/o subtítulo } & \multirow{4}{*}{$\begin{array}{l}\text { Indicar la } \\
\text { cantidad }\end{array}$} & 7 \\
\hline & \multicolumn{2}{|c|}{$\begin{array}{l}\text { Extensión del texto (se recomienda } 70 \text { palabras en miradores y } \\
\text { paradas de itinerario y } 90 \text { en paneles de exhibición) }\end{array}$} & & 101 \\
\hline & \multicolumn{2}{|c|}{ Tipos de fuentes de textos (se recomienda el uso de hasta 2) } & & 1 \\
\hline & \multicolumn{2}{|c|}{ Tamaño de letra (se recomienda el uso de hasta 3) } & & 3 \\
\hline & \multicolumn{2}{|c|}{$\begin{array}{l}\text { El mensaje posee una idea central clara, presentada en forma de } \\
\text { oración, con sujeto, verbo y predicado }\end{array}$} & \multicolumn{2}{|l|}{ Si } \\
\hline & \multicolumn{2}{|c|}{ El mensaje es atractivo, breve, claro y directo } & \multicolumn{2}{|c|}{ Si, en todos los aspectos. } \\
\hline & \multicolumn{2}{|c|}{ Se presenta el todo y no las partes aisladas } & \multicolumn{2}{|c|}{ Si } \\
\hline & \multicolumn{2}{|c|}{ ¿Está narrado en primera persona? } & \multicolumn{2}{|l|}{ No } \\
\hline & \multicolumn{2}{|c|}{ En el caso de utilizar tecnicismos, ¿̇los mismos están explicados? } & \multicolumn{2}{|l|}{ Si } \\
\hline & \multicolumn{2}{|c|}{ ¿Se utilizan metáforas, analogías o comparaciones? } & \multicolumn{2}{|l|}{ Sí } \\
\hline & \multicolumn{2}{|c|}{$\begin{array}{l}\text { ¿Las imágenes utilizadas son apoyos visuales del texto o } \\
\text { redundantes? }\end{array}$} & \multicolumn{2}{|c|}{ Apoyan el texto } \\
\hline \multirow{8}{*}{ 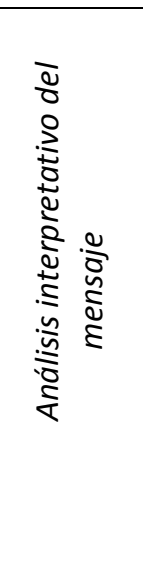 } & \multicolumn{4}{|c|}{$\begin{array}{l}\text { Elementos y atributos } \\
\text { tangibles }\end{array}$} \\
\hline & Elementos intangibles & \multicolumn{3}{|c|}{ Procesos geológicos y geomorfológicos. Erosión diferencial } \\
\hline & Conceptos universales & \multicolumn{3}{|c|}{ Cambio en la materia, poder } \\
\hline & $\begin{array}{l}\text { Conexión intelectual } \\
\text { con el visitante }\end{array}$ & \multicolumn{3}{|l|}{ Si. } \\
\hline & $\begin{array}{l}\text { Conexión emocional } \\
\text { con el visitante }\end{array}$ & \multicolumn{3}{|l|}{ No. } \\
\hline & $\begin{array}{l}\text { Estímulo al } \\
\text { pensamiento }\end{array}$ & Si. & & \\
\hline & $\begin{array}{l}\text { Actitud de } \\
\text { custodia/respeto }\end{array}$ & Sí, en la medida que se otorgue valor a I & s geoformas & \\
\hline & Idea central & La "erosión diferencial" creó el Indepeno & ence Monum & \\
\hline
\end{tabular}


La Interpretación del Patrimonio Geomorfológico en los Picos de Europa: una propuesta para su aprovechamiento didáctico y geoturístico

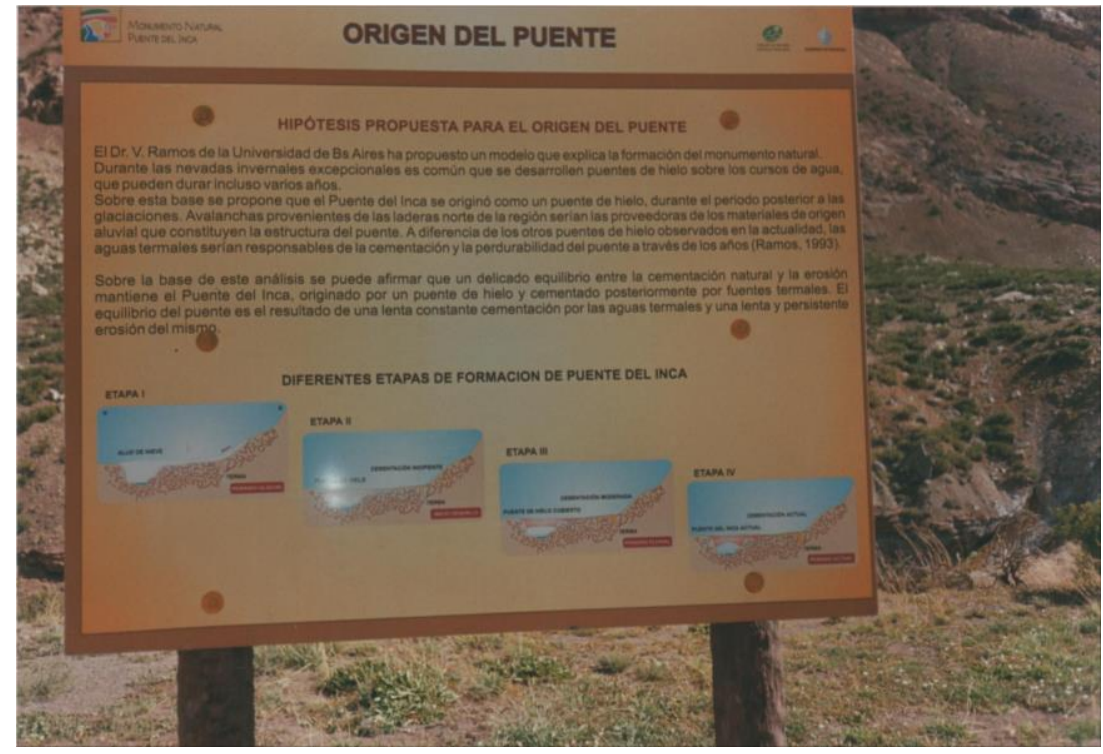

Figura 30. Panel informativo en Monumento Natural Puente del Inca (Argentina).

Fuente: Héctor Bazán.

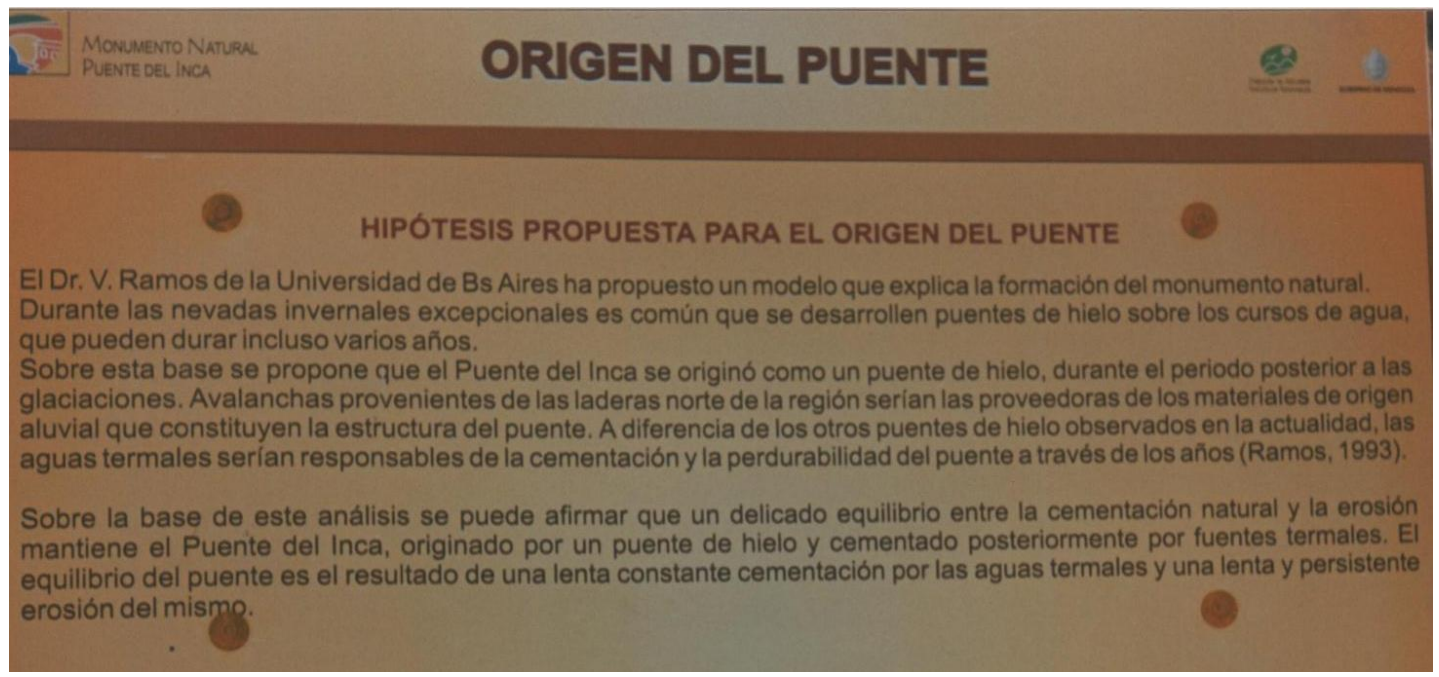

Figura 31. Detalle de figura 30. 
Tabla 25. Análisis de Panel informativo en Monumento Natural Puente del Inca (Argentina).

\begin{tabular}{|c|c|c|c|c|}
\hline Título & \multicolumn{4}{|l|}{ Origen del puente } \\
\hline Subtítulo & \multicolumn{4}{|c|}{ Hipótesis propuesta para el origen del puente } \\
\hline \multirow[t]{2}{*}{ Texto } & \multicolumn{4}{|c|}{$\begin{array}{l}\text { El Dr. V. Ramos de la Universidad de Buenos Aires ha propuesto un modelo que explica la } \\
\text { formación del monumento natural. Durante las nevadas invernales excepcionales es común } \\
\text { que se desarrollen puentes de hielo sobre los cursos de agua que pueden durar incluso varios } \\
\text { años. } \\
\text { Sobre esta teoría se propone que el Puente del Inca se originó como un puente, durante el } \\
\text { período posterior a las glaciaciones. Avalanchas provenientes de las laderas norte de la región } \\
\text { serian las proveedoras de los materiales de origen aluvial que constituyen la estructura del } \\
\text { puente. A diferencia de los otros puentes de hielo observados en la actualidad, las aguas } \\
\text { termales serían responsables de la cementación y la perdurabilidad del puente a través de los } \\
\text { años (Ramos, 1993). } \\
\text { Sobre la base de este análisis se puede afirmar que un delicado equilibrio entre la cementación } \\
\text { natural y la erosión mantiene el Puente del Inca, originado por un puente de hielo y cementado } \\
\text { posteriormente por fuentes termales. El equilibrio del puente es el resultado de una lenta } \\
\text { cementación por las aguas termales y una lenta y persistente erosión del mismo. }\end{array}$} \\
\hline & & & Si & No \\
\hline \multirow{12}{*}{ 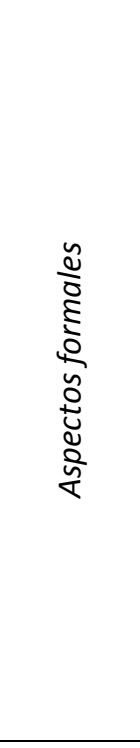 } & $\begin{array}{l}\text { ¿En la lectura del título y/o subtítulo se puede apreciar } \\
\text { existencia de una idea clave? }\end{array}$ & & $x$ & \\
\hline & Extensión del título y/o subtítulo & & \multirow{4}{*}{$\begin{array}{l}\text { Indicar la } \\
\text { cantidad }\end{array}$} & 10 \\
\hline & $\begin{array}{l}\text { Extensión del texto (se recomienda } 70 \text { palabras en miradores } \\
\text { paradas de itinerario y } 90 \text { en paneles de exhibición) }\end{array}$ & & & 183 \\
\hline & \multicolumn{2}{|l|}{ Tipos de fuentes de textos (se recomienda el uso de hasta 2) } & & 1 \\
\hline & \multicolumn{2}{|l|}{ Tamaño de letra (se recomienda el uso de hasta 3) } & & 3 \\
\hline & \multicolumn{2}{|l|}{$\begin{array}{l}\text { El mensaje posee una idea central clara, presentada en forma de } \\
\text { oración, con sujeto, verbo y predicado }\end{array}$} & \multicolumn{2}{|l|}{ Sí } \\
\hline & \multicolumn{2}{|l|}{ El mensaje es atractivo, breve, claro y directo } & \multicolumn{2}{|c|}{$\begin{array}{l}\text { Regular en todos los } \\
\text { aspectos. }\end{array}$} \\
\hline & \multicolumn{2}{|l|}{ Se presenta el todo y no las partes aisladas } & \multicolumn{2}{|c|}{ Sí } \\
\hline & \multicolumn{2}{|l|}{ ¿Está narrado en primera persona? } & \multicolumn{2}{|l|}{ No } \\
\hline & \multicolumn{2}{|l|}{ En el caso de utilizar tecnicismos, ¿los mismos están explicados? } & \multicolumn{2}{|c|}{ No (p.e. cementación) } \\
\hline & \multicolumn{2}{|l|}{ ¿Se utilizan metáforas, analogías o comparaciones? } & \multicolumn{2}{|c|}{ No } \\
\hline & \multicolumn{2}{|l|}{$\begin{array}{l}\text { ¿Las imágenes utilizadas son apoyos visuales del texto o } \\
\text { redundantes? }\end{array}$} & \multicolumn{2}{|c|}{ Apoyan el texto } \\
\hline \multirow{8}{*}{ 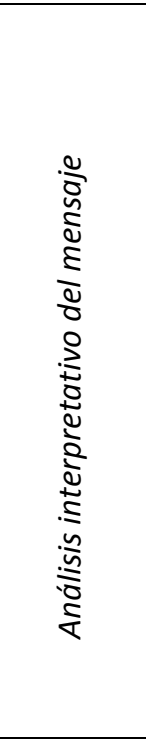 } & $\begin{array}{l}\text { Elementos y atributos tangibles (el mensaje identifica con } \\
\text { claridad los aspectos y características físicas del rasgo) }\end{array}$ & \multicolumn{3}{|c|}{$\begin{array}{l}\text { Nieve, hielo, aguas termales, } \\
\text { avalanchas }\end{array}$} \\
\hline & $\begin{array}{l}\text { Elementos intangibles (ideas abstractas contenidas en el } \\
\text { mensaje que surgen a partir de los atributos tangibles) }\end{array}$ & \multicolumn{3}{|c|}{ Erosión, cementación } \\
\hline & $\begin{array}{l}\text { Conceptos universales (ideas intangibles con un nivel de } \\
\text { relevancia superior para los visitantes. Surgen del punto } \\
\text { anterior) }\end{array}$ & \multicolumn{3}{|c|}{ Equilibrio } \\
\hline & $\begin{array}{l}\text { Conexión intelectual con el visitante (oportunidad que ofrece } \\
\text { el mensaje para que el público comprenda conceptos e ideas) }\end{array}$ & \multicolumn{3}{|l|}{ Si } \\
\hline & $\begin{array}{l}\text { Conexión emocional con el visitante (oportunidad que ofrece } \\
\text { el mensaje para producir emociones en el público) }\end{array}$ & \multicolumn{3}{|c|}{ No } \\
\hline & $\begin{array}{l}\text { Estímulo al pensamiento (capacidad del mensaje para } \\
\text { provocar en el visitante un pensamiento más profundo) }\end{array}$ & \multicolumn{3}{|l|}{ Si } \\
\hline & $\begin{array}{l}\text { Actitud de custodia/respeto ( actitud que podría generar el } \\
\text { mensaje para que el público aprecie y contribuya a la } \\
\text { salvaguarda del recurso) }\end{array}$ & No & & \\
\hline & \begin{tabular}{l|l} 
Idea central & El origen del Puente del Inca \\
\end{tabular} & & & \\
\hline
\end{tabular}




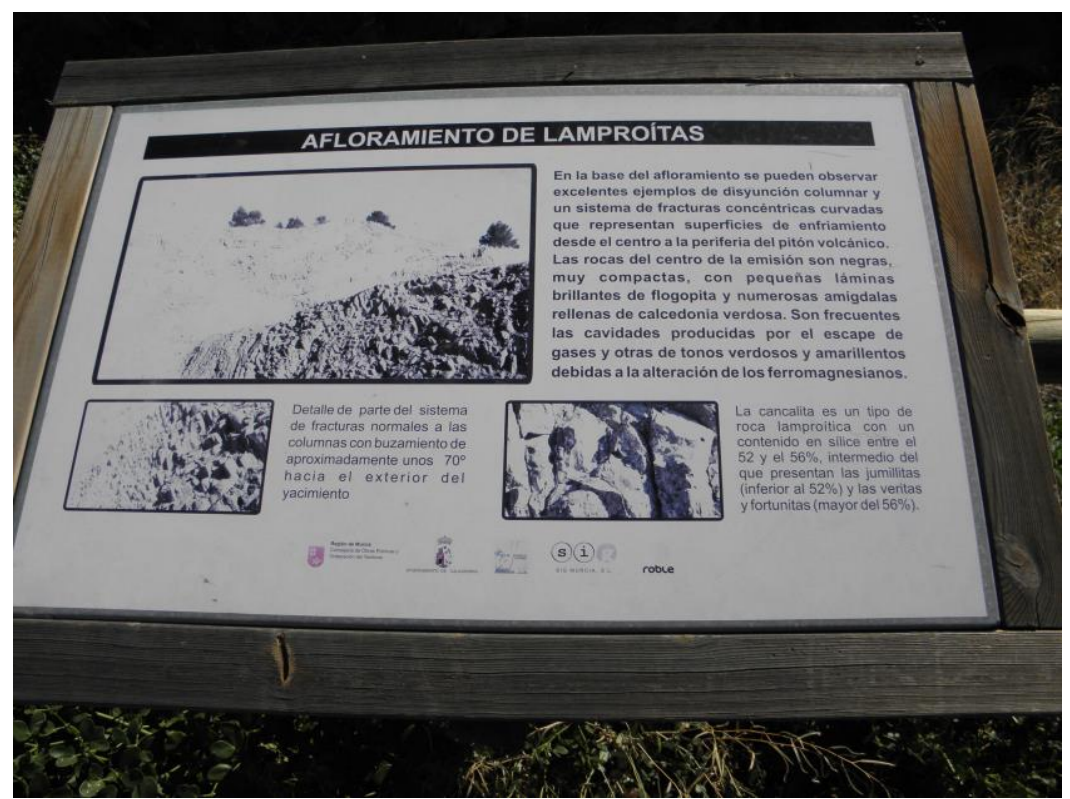

Figura 32. Panel informativo en sendero autoguiado de Murcia (España). Fuente: Héctor Bazán.

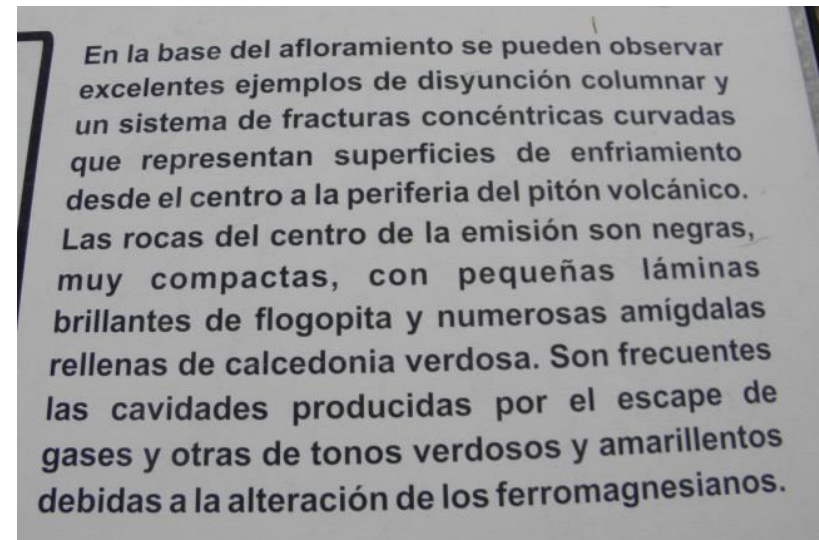

Figura 33. Detalle de figura 32.

Detalle de parte del sistema de fracturas normales a las columnas con buzamiento de aproximadamente unos $70^{\circ}$ hacia el exterior del yacimiento

Figura 34. Detalle de figura 32.
La cancalita es un tipo de roca lamproítica con un contenido en silice entre el 52 y el $56 \%$, intermedio del que presentan las jumillitas (inferior al $52 \%$ ) y las veritas y fortunitas (mayor del $56 \%$ ).

Figura 35. Detalle de figura 32. 
Tabla 26. Análisis de panel informativo en sendero autoguiado de Murcia (España).

\begin{tabular}{|c|c|c|c|}
\hline Título & \multicolumn{3}{|l|}{ Afloramiento de lamproíta } \\
\hline Subtítulo & \multicolumn{3}{|l|}{--- } \\
\hline Texto & \multicolumn{3}{|c|}{$\begin{array}{l}\text { En la base del afloramiento se pueden observar excelentes ejemplos de disyunción columnar y un } \\
\text { sistema de fracturas concéntricas curvadas que representan superficies de enfriamiento desde el } \\
\text { centro a la periferia del pitón volcánico. Las rocas del centro de la emisión son negras, muy } \\
\text { compactas, con pequeñas láminas brillantes de flogopita y numerosas amígdalas rellenas de } \\
\text { calcedonia verdosa. Son frecuentes las cavidades producidas por el escape de gases y otras de } \\
\text { tonos verdosos y amarillentos debidas a la alteración de ferromagnesianos. } \\
\text { Detalle de parte del sistema de fracturas normales a las columnas con buzamiento de } \\
\text { aproximadamente unos } 70 \text { o hacia el exterior del yacimiento. } \\
\text { La cancalita es un tipo de roca lamproítica con un contenido en sílice entre el } 52 \text { y el 56\%, } \\
\text { intermedio del que presentan las jumullitas (inferior al 52\%) y las veritas y fortunitas (mayor del } \\
56 \% \text {. }\end{array}$} \\
\hline & & Si & No \\
\hline \multirow{12}{*}{ 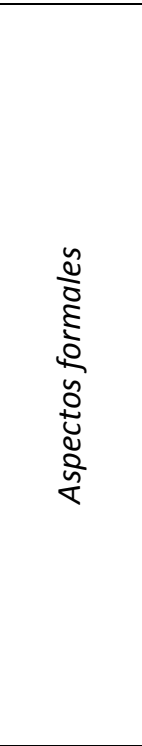 } & $\begin{array}{l}\text { ¿En la lectura del título y/o subtítulo se puede apreciar la } \\
\text { existencia de una idea clave? }\end{array}$ & $x$ & \\
\hline & Extensión del título y/o subtítulo & \multirow{4}{*}{$\begin{array}{l}\text { Indicar la } \\
\text { cantidad }\end{array}$} & 3 \\
\hline & $\begin{array}{l}\text { Extensión del texto (se recomienda } 70 \text { palabras en miradores } \\
\text { y paradas de itinerario y } 90 \text { en paneles de exhibición) }\end{array}$ & & 139 \\
\hline & Tipos de fuentes de textos (se recomienda el uso de hasta 2) & & 1 \\
\hline & Tamaño de letra (se recomienda el uso de hasta 3) & & 3 \\
\hline & $\begin{array}{l}\text { El mensaje posee una idea central clara, presentada en forma } \\
\text { de oración, con sujeto, verbo y predicado }\end{array}$ & \multicolumn{2}{|c|}{$\begin{array}{l}\text { Posee idea central, pero no su } \\
\text { enunciado no es sencillo. }\end{array}$} \\
\hline & El mensaje es atractivo, breve, claro y directo & \multicolumn{2}{|c|}{ No } \\
\hline & Se presenta el todo y no las partes aisladas & \multicolumn{2}{|l|}{ Si } \\
\hline & ¿Está narrado en primera persona? & \multicolumn{2}{|l|}{ No } \\
\hline & $\begin{array}{l}\text { En el caso de utilizar tecnicismos, ¿ilos mismos están } \\
\text { explicados? }\end{array}$ & \multicolumn{2}{|c|}{$\begin{array}{l}\text { No se explican (p.e. disyunción } \\
\text { columnar }\end{array}$} \\
\hline & ¿Se utilizan metáforas, analogías o comparaciones? & \multicolumn{2}{|c|}{ No } \\
\hline & $\begin{array}{l}\text { ¿Las imágenes utilizadas son apoyos visuales del texto o } \\
\text { redundantes? }\end{array}$ & \multicolumn{2}{|c|}{ Apoyan el texto } \\
\hline \multirow{8}{*}{ 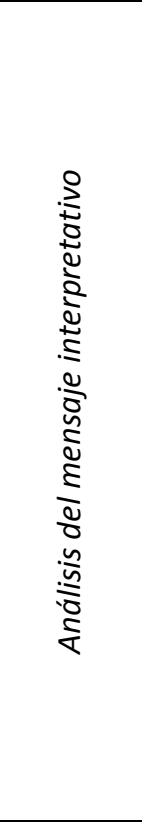 } & $\begin{array}{l}\text { Elementos y atributos tangibles ( el mensaje identifica con } \\
\text { claridad los aspectos y características físicas del rasgo) }\end{array}$ & \multicolumn{2}{|c|}{ Rocas, minerales, cavidades } \\
\hline & $\begin{array}{l}\text { Elementos intangibles ( ideas abstractas contenidas en el } \\
\text { mensaje que surgen a partir de los atributos tangibles) }\end{array}$ & \multicolumn{2}{|c|}{$\begin{array}{l}\text { Procesos geológicos. Alteración } \\
\text { por minerales. Escapes de } \\
\text { gases. }\end{array}$} \\
\hline & $\begin{array}{l}\text { Conceptos universales (ideas intangibles con un nivel de } \\
\text { relevancia superior para los visitantes. Surgen del punto } \\
\text { anterior) }\end{array}$ & \multicolumn{2}{|c|}{$\begin{array}{l}\text { Variedad en los procesos de } \\
\text { formación de rocas. }\end{array}$} \\
\hline & $\begin{array}{l}\text { Conexión intelectual con el visitante (oportunidad que ofrece } \\
\text { el mensaje para que el público comprenda conceptos e ideas) }\end{array}$ & \multicolumn{2}{|l|}{ Escaso. } \\
\hline & $\begin{array}{l}\text { Conexión emocional con el visitante (oportunidad que ofrece } \\
\text { el mensaje para producir emociones en el público) }\end{array}$ & \multicolumn{2}{|l|}{ No. } \\
\hline & $\begin{array}{l}\text { Estímulo al pensamiento (capacidad del mensaje para } \\
\text { provocar en el visitante un pensamiento más profundo) }\end{array}$ & \multicolumn{2}{|l|}{ Si. } \\
\hline & $\begin{array}{l}\text { Actitud de custodia/respeto ( actitud que podría generar el } \\
\text { mensaje para que el público aprecie y contribuya a la } \\
\text { salvaguarda del recurso) }\end{array}$ & \multicolumn{2}{|l|}{ No } \\
\hline & $\begin{array}{l}\text { Idea central (una oración-tema que dé cohesión a los distintos } \\
\text { aspectos tratados) }\end{array}$ & \multicolumn{2}{|l|}{ No posee. } \\
\hline
\end{tabular}


La Interpretación del Patrimonio Geomorfológico en los Picos de Europa: una propuesta para su aprovechamiento didáctico y geoturístico

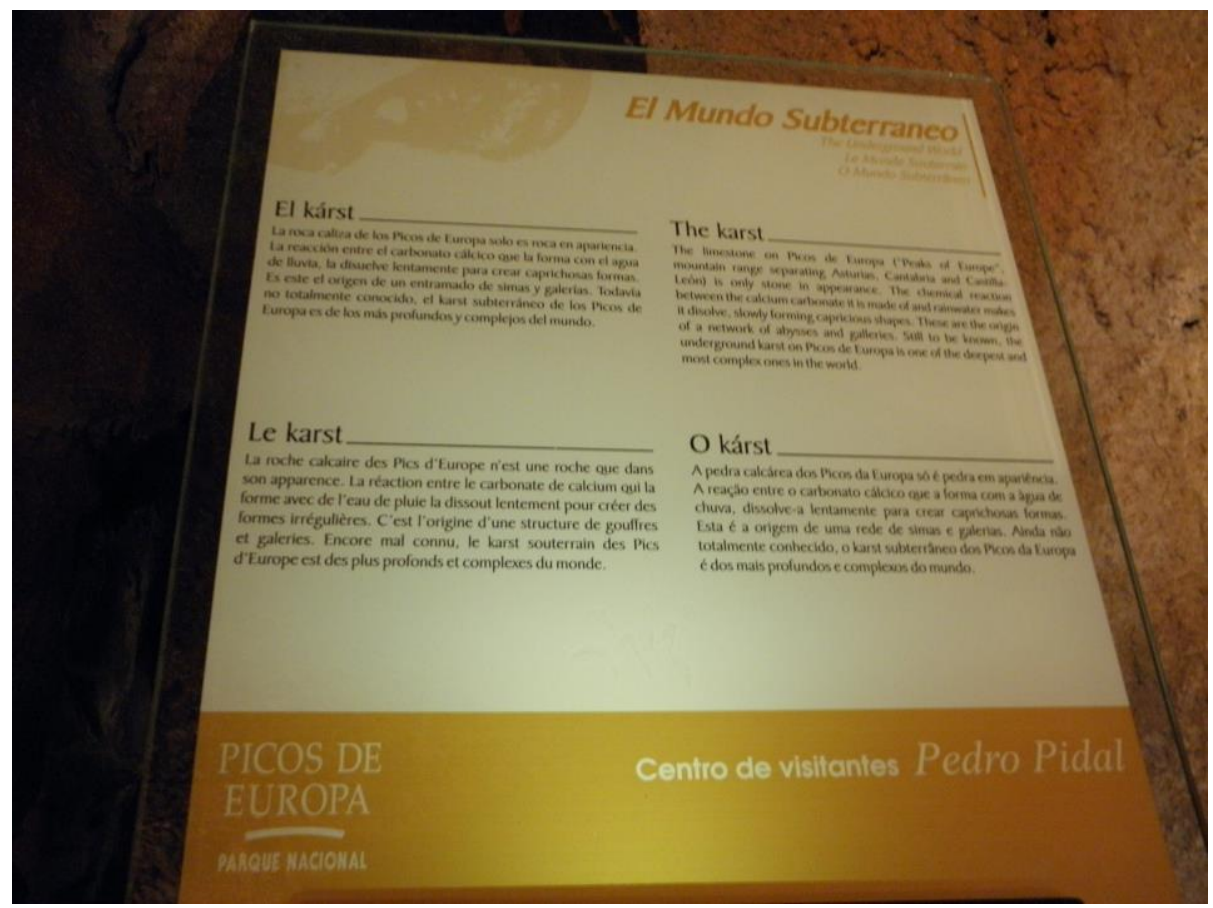

Figura 36. Panel interpretativo en el Centro de visitantes Pedro Pidal (Parque Nacional de los Picos de Europa, España).

Fuente: Héctor Bazán.

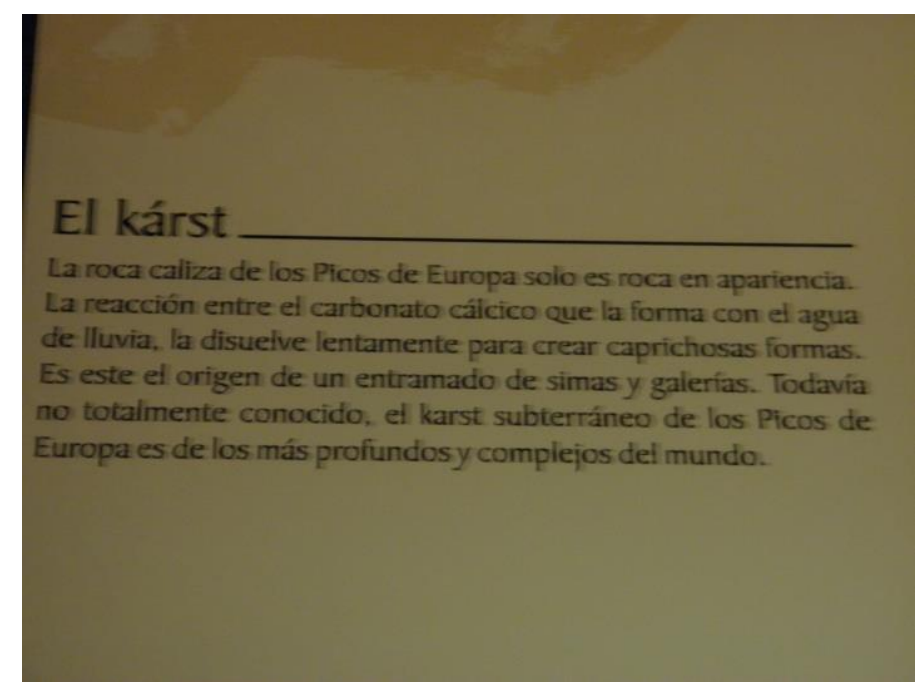

Figura 37. Detalle de figura 36. 
Tabla 27. Análisis de panel interpretativo en el Centro de visitantes Pedro Pidal (Parque Nacional de los Picos de Europa, España).

\begin{tabular}{|c|c|c|c|}
\hline Título & \multicolumn{3}{|l|}{ El mundo subterráneo } \\
\hline Subtítulo & \multicolumn{3}{|l|}{ El karst } \\
\hline Texto & \multicolumn{3}{|c|}{$\begin{array}{l}\text { La roca caliza de los Picos de Europa solo es roca en apariencia. La reacción entre el carbonato } \\
\text { cálcico que la forma con el agua de lluvia, la disuelve lentamente para crear caprichosas } \\
\text { formas. Es este el origen de un entramado de simas y galerías. Todavía no totalmente } \\
\text { conocido, el karst subterráneo de los Picos de Europa es de los más profundos y complejos del } \\
\text { mundo. }\end{array}$} \\
\hline & & Si & No \\
\hline \multirow{12}{*}{ 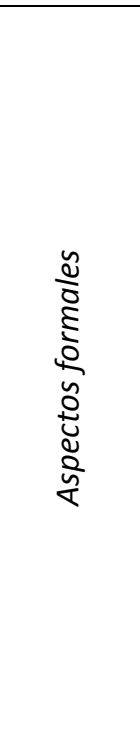 } & $\begin{array}{l}\text { ¿En la lectura del título y/o subtítulo se puede apreciar la } \\
\text { existencia de una idea clave? }\end{array}$ & $x$ & \\
\hline & Extensión del título y/o subtítulo & \multirow{4}{*}{$\begin{array}{l}\text { Indicar la } \\
\text { cantidad }\end{array}$} & 5 \\
\hline & $\begin{array}{l}\text { Extensión del texto (se recomienda } 70 \text { palabras en miradores } \\
\text { y paradas de itinerario y } 90 \text { en paneles de exhibición) }\end{array}$ & & 66 \\
\hline & Tipos de fuentes de textos (se recomienda el uso de hasta 2) & & 2 \\
\hline & Tamaño de letra (se recomienda el uso de hasta 3) & & 2 \\
\hline & $\begin{array}{l}\text { El mensaje posee una idea central clara, presentada en forma } \\
\text { de oración, con sujeto, verbo y predicado }\end{array}$ & \multicolumn{2}{|l|}{ Si } \\
\hline & El mensaje es atractivo, breve, claro y directo & \multicolumn{2}{|l|}{ Si } \\
\hline & Se presenta el todo y no las partes aisladas & \multicolumn{2}{|l|}{ Si } \\
\hline & ¿Está narrado en primera persona? & \multicolumn{2}{|l|}{ No } \\
\hline & $\begin{array}{l}\text { En el caso de utilizar tecnicismos, ¿ilos mismos están } \\
\text { explicados? }\end{array}$ & \multicolumn{2}{|c|}{ Sin tecnicismos } \\
\hline & ¿Se utilizan metáforas, analogías o comparaciones? & \multicolumn{2}{|l|}{ No } \\
\hline & $\begin{array}{l}\text { ¿Las imágenes utilizadas son apoyos visuales del texto o } \\
\text { redundantes? }\end{array}$ & \multicolumn{2}{|c|}{ Sin imágenes } \\
\hline \multirow{8}{*}{ 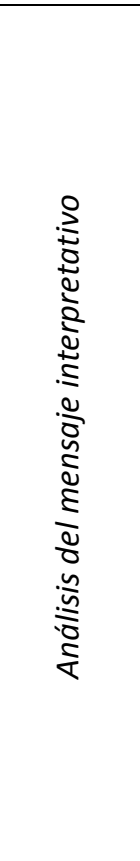 } & $\begin{array}{l}\text { Elementos y atributos tangibles ( el mensaje identifica con } \\
\text { claridad los aspectos y características físicas del rasgo) }\end{array}$ & \multicolumn{2}{|c|}{$\begin{array}{l}\text { Rocas, agua de lluvia, simas, } \\
\text { galerías. }\end{array}$} \\
\hline & $\begin{array}{l}\text { Elementos intangibles (ideas abstractas contenidas en el } \\
\text { mensaje que surgen a partir de los atributos tangibles) }\end{array}$ & \multicolumn{2}{|c|}{$\begin{array}{l}\text { Reacción entre el carbonato } \\
\text { cálcico de las rocas calizas y } \\
\text { el agua de lluvia }\end{array}$} \\
\hline & $\begin{array}{l}\text { Conceptos universales (ideas intangibles con un nivel de } \\
\text { relevancia superior para los visitantes. Surgen del punto } \\
\text { anterior) }\end{array}$ & \multicolumn{2}{|c|}{ Poder } \\
\hline & $\begin{array}{l}\text { Conexión intelectual con el visitante (oportunidad que ofrece } \\
\text { el mensaje para que el público comprenda conceptos e ideas) }\end{array}$ & \multicolumn{2}{|l|}{ Si } \\
\hline & $\begin{array}{l}\text { Conexión emocional con el visitante (oportunidad que ofrece } \\
\text { el mensaje para producir emociones en el público) }\end{array}$ & \multicolumn{2}{|l|}{ Si } \\
\hline & $\begin{array}{l}\text { Estímulo al pensamiento (capacidad del mensaje para } \\
\text { provocar en el visitante un pensamiento más profundo) }\end{array}$ & \multicolumn{2}{|l|}{ Si } \\
\hline & $\begin{array}{l}\text { Actitud de custodia/respeto (actitud que podría generar el } \\
\text { mensaje para que el público aprecie y contribuya a la } \\
\text { salvaguarda del recurso) }\end{array}$ & \multicolumn{2}{|l|}{ No } \\
\hline & $\begin{array}{l}\text { Idea central (una oración-tema que dé cohesión a los distintos } \\
\text { aspectos tratados) }\end{array}$ & \multicolumn{2}{|c|}{$\begin{array}{l}\text { La acción del agua de lluvia } \\
\text { en la roca caliza crea formas } \\
\text { caprichosas. }\end{array}$} \\
\hline
\end{tabular}


A modo de conclusión, se puede afirmar que todos los mensajes de los paneles analizados brindan información, pero no todos son interpretativos ya que algunos de ellos no posibilitan una conexión emocional ni estimulan el pensamiento del visitante, como veremos a continuación. Recordemos que la Interpretación del Patrimonio persigue objetivos de conocimiento, emocionales y de comportamiento. Además el cuarto principio interpretativo es elocuente respecto a este punto: el objetivo principal de la interpretación no es la instrucción, sino la provocación.

Es conveniente que los paneles estén elaborados de manera conjunta con especialistas de la disciplina científica respectiva (en los casos analizados, la geología o geomorfología), de Interpretación del Patrimonio y de comunicación visual. Independientemente de la motivación que llevó al visitante a visitar un área protegida, los paneles están siempre disponibles y son un tipo de interpretación potencialmente eficaz y popular. Pero no es suficiente con trasmitir una idea central en el título del panel para que considerar interpretativo al resto del mismo: en todos los paneles se pudo apreciar la existencia de una idea clave, pero no todos presentaron un mensaje atractivo, breve, claro y directo. En este punto, algunos de los textos analizados superaban la extensión recomendada de los mismos (70 palabras en miradores y paradas de itinerarios y 90 en paneles de exhibición): en el panel del Puente del Inca (Argentina) se contaron 183 palabras, mientras que en el panel del sendero autoguiado de Murcia (España) se registraron 139. Respecto a la claridad en el mensaje, algunos ejemplos presentaron tecnicismos sin su explicación correspondiente (por ejemplo: Ischigualasto, Puente del Inca, Murcia).

El empleo de principios interpretativos en la elaboración del mensaje a transmitir (sean estos orales o escritos) y en el caso específico de paneles interpretativos posibilita que un mayor número de personas se relacionen con los bienes patrimoniales de una manera integral (conocer, sentir, actuar), permitiendo una protección de los mismos ya que, según Tilden (2006) a través de la interpretación, la comprensión; a través de la comprensión, el reconocimiento y, a través de la apreciación, la protección. ¿De qué manera podrá conseguirse este principio con textos como el sendero autoguiado de Murcia (Figuras 32 a 35) si el mismo presenta demasiados tecnicismos sin explicación posterior, ni logra la conexión emocional con los visitantes al utilizar expresiones como "La cancalita es un tipo de roca lamproítica con un contenido en sílice entre el 52 y el 56\%, intermedio del que presentan las jumullitas (inferior al 52\%) y las veritas y fortunitas (mayor del 56\%)"? En otros de los ejemplos analizados se observa una buena utilización de la conexión entre elementos intangibles y atributos o elementos tangibles de los bienes interpretados (Colorado National Monument), mientras que 
en otros casos (Sotama, Ischigualasto, Puente del Inca, Murcia) tal vínculo es presentado de una manera más cercana a la transmisión de información que a la interpretación.

Como suministro de información, los paneles interpretativos pueden ser mejor utilizados por los turistas y también ayudan a guías turísticos y docentes. Para esto, se sugiere que se toman las siguientes acciones:

1. La reformulación de los textos de los paneles, dejando de lado los tecnicismos, respetando las recomendaciones enunciadas para la elaboración de los mensajes en paneles interpretativos.

2. Llevar a cabo sesiones de capacitación con maestros y guías en las regiones en las que se encuentran los paneles para comprender los aspectos relacionados con el patrimonio geomorfológico de esas zonas y valorar su importancia para el uso en actividades educativas y/o turísticas. 


\section{Capítulo 3}

\section{Relaciones de la Interpretación del Patrimonio con otras disciplinas}

A lo largo de su evolución como disciplina, la Interpretación del Patrimonio se ha visto influenciada por distintas ramas de conocimiento y, a su vez, ha influido en otras actividades. Desde sus orígenes se relacionó con la educación e incluso en la actualidad algunos autores destacan el poder de la interpretación para la consecución de objetivos de educación ambiental y patrimonial en áreas protegidas (Cuenca, 2002; Santamarina, 2002; Moreira-Wachtel y Trellez Solis, 2013). Por su parte, los progresos en investigaciones sobre comunicación y psicología han sido incorporados por distintos autores en la planificación y elaboración de productos y servicios turísticos, para influir en el público y conseguir determinados objetivos. En el presente capítulo, se abordarán las principales conexiones de la Interpretación del Patrimonio con otras actividades relevantes para esta investigación.

\section{1) Vinculación con teorías de comunicación}

Al girar en torno a la transmisión de mensajes (ya sean verbales, no verbales o icónicos), la Interpretación puede ser considerada un proceso comunicativo, con unos mensajes especificos entre quien desea interpretar y el usuario o visitante (emisor y receptor, respectivamente). El estudio de la comunicación es bastante complejo, lo que hace necesaria la creación de reglas para entenderla y poder analizar sus efectos. Todos los modelos de comunicación universalmente aceptados cuentan con cuatro elementos comunes: el emisor, el receptor, el mensaje y el canal (Figura 38).

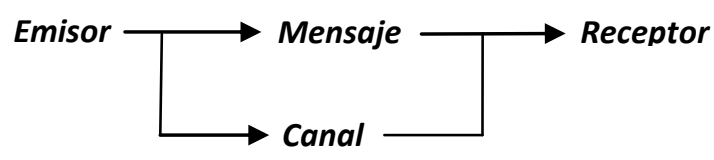

Figura 38. Modelo general de comunicación.

Fuente: elaboración propia. 
El proceso de comunicación se realiza en el momento en que se transmite un mensaje que va del emisor a un receptor por medio de un canal que pueda ser utilizado por ambas partes. Para que se realice una comunicación correcta es necesario que el emisor y el receptor compartan un mismo código e identificar el contexto en que se produce la comunicación (Jakobson, 1985). Los CÓDIGOS funcionan como un lenguaje paralelo al cual se acude en caso de duda sobre la emisión o recepción del mensaje. EI CONTEXTO está conformado por todos los elementos externos que, directamente o de manera imperceptible, influyen en la comunicación (características de un lugar, si uno de los interlocutores tiene hambre, se siente mal, etc.). Por lo que se tendría que ampliar al anterior esquema para incluir un código y un contexto (Figura 39).

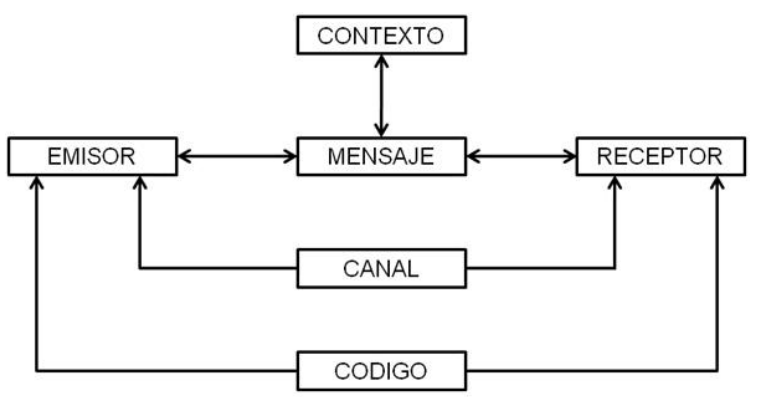

Figura 39. Modelo de comunicación de Jakobson. Fuente: Jakobson, 1985.

Dentro de las Ciencias de la Información, Shannon (1948) relaciona las leyes matemáticas que rigen la transmisión y el procesamiento de la información, ocupándose de la medición y representación de la misma, así como también de la capacidad de los sistemas de comunicación para transmitir y procesar la información (Figura 40). En este modelo, la fuente de información es de donde proviene el mensaje, el transmisor es el recurso técnico que lo transmite, el canal es el medio que lo transporta, el receptor es el recurso técnico que lo recibe y lo decodifica, el destino es el componente final del proceso de comunicación y la fuente de ruido es la suma de distracciones o distorsiones que pueden influir en el mensaje.

Lo importante en este modelo es que la señal se decodifique de forma adecuada para que el mensaje codificado por el emisor sea el mismo al recibido por el destinatario. Aplicando este modelo al campo de la Interpretación del Patrimonio, el intérprete es la fuente o emisor (es quien decide llevar a cabo el programa interpretativo), el mensaje es lo que queremos trasmitir y el visitante del área patrimonial es el destinatario del mismo o receptor. Optimizar la comunicación interpretativa y asegurar que el mensaje sea bien recibido implicaría disminuir los ruidos en la misma (por ejemplo, poco conocimiento de la audiencia o de técnicas interpretativas por parte del intérprete o un panel deteriorado) y presentando un mensaje 
atractivo (Figura 41). Por este motivo, la Interpretación del Patrimonio es una buena herramienta para la gestión de espacios naturales protegidos y, en concreto, en la planificación del uso público (Spangle y Puney, 1974).

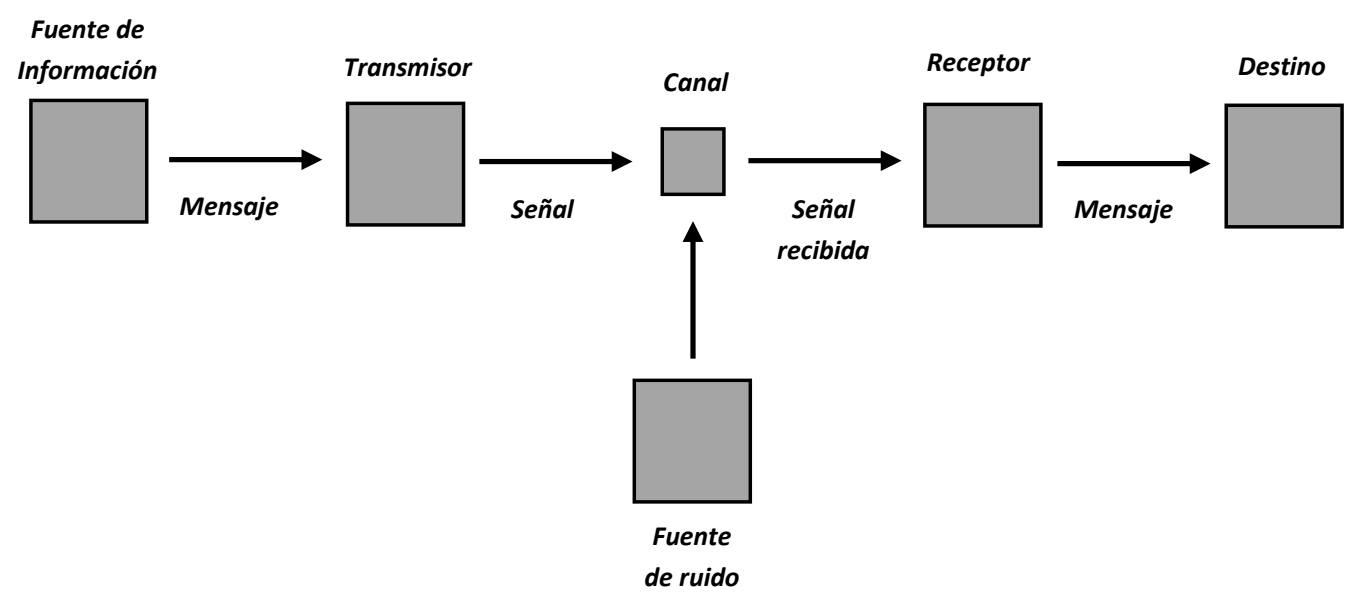

Figura 40. Modelo de comunicación de Shannon.

Fuente: traducido de Shannon, 1948.

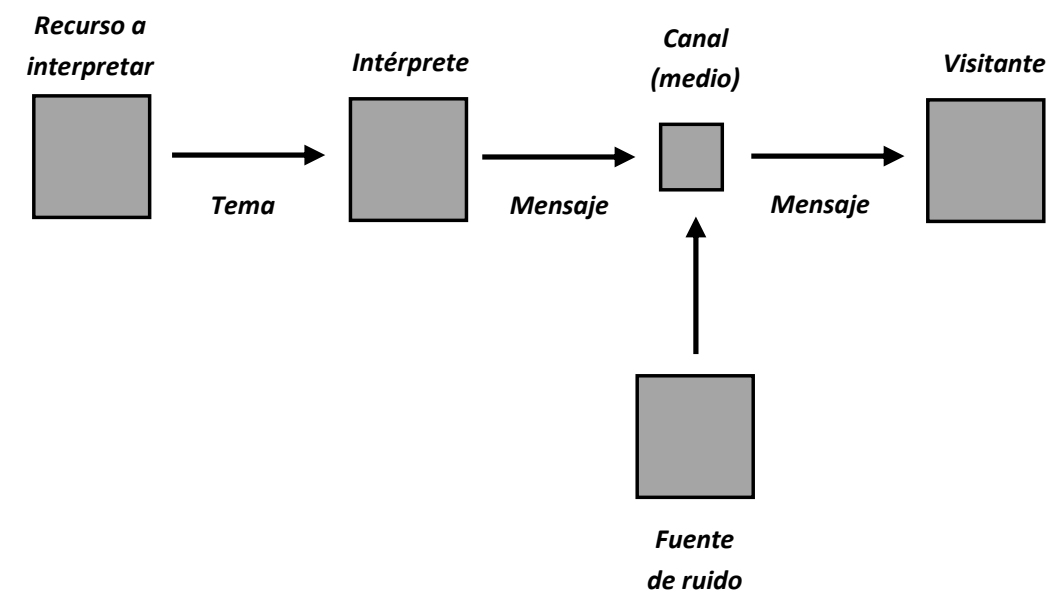

Figura 41. Modelo de comunicación en Interpretación del Patrimonio. Fuente: elaboración propia, en base a Shannon, 1948.

En la década de los años setenta del siglo XX, la semiótica se convirtió en una disciplina importante en el estudio de la comunicación. En este período surgen modelos explicativos que superan al de Shannon (1948) y que explican con mayor precisión el proceso de comunicación. Por ejemplo, el modelo semiótico propuesto por Eco (1977) gira en torno al concepto de código y a la decodificación del destinatario. Este modelo parte de la premisa de que en todo proceso de comunicación requiere una respuesta INTERPRETATIVA del destinatario. Por ejemplo en un 
proceso entre una máquina u otra, la señal no tiene capacidad "significante" ninguna. En este caso no hay comunicación, aun cuando se pueda decir efectivamente que hay paso de información. El proceso de comunicación se verifica sólo cuando existe un código. Un código es un SISTEMA DE SIGNIFICACIÓN que reúne entidades presentes y entidades ausentes. Siempre que una cosa MATERIALMENTE presente a la percepción del destinatario REPRESENTA otra cosa a partir de reglas subyacentes, hay significación. Para Eco (1977) existe una multiplicidad de códigos, una variedad de contextos y circunstancias que hacen que un mismo mensaje pueda codificarse desde puntos de vista diferentes y por referencia a sistemas de convenciones distintos (Figura 42).

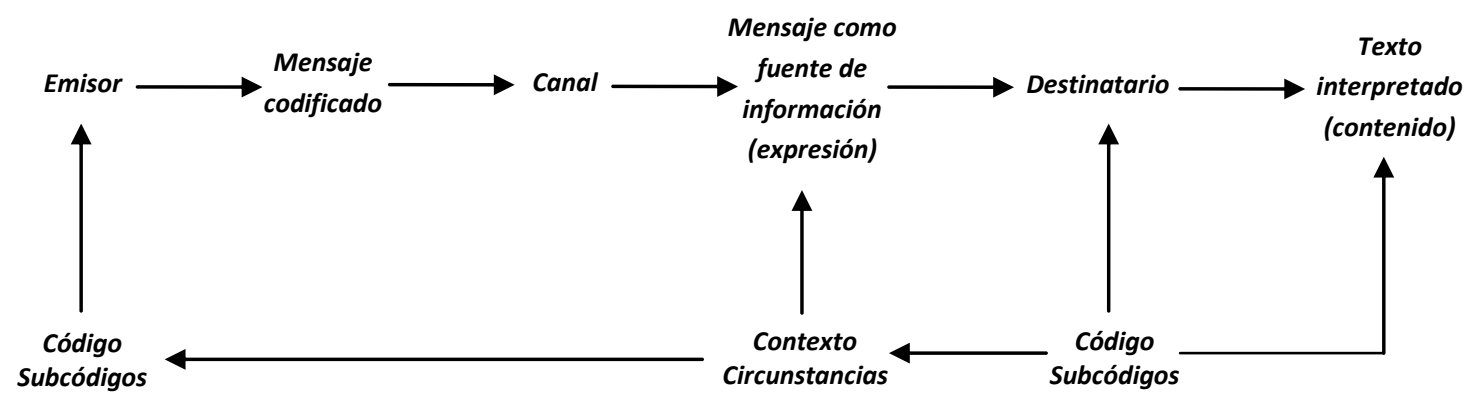

Figura 42. Modelo de comunicación de Eco.

Fuente: Eco, 1977.

Esta diversidad de subcódigos (ideológico, estético, afectivo, etc.) incide en los procesos de codificación y decodificación, aportando una nueva información más allá de la simple indicación del mensaje, como también lo hacen los elementos contextuales y circunstanciales. El contexto hace referencia a los elementos del entorno en que se produce el mensaje. Según el contexto del mensaje, manteniéndose la expresión, puede cambiar su significado (por ejemplo, el color de los carteles de autopista en varios países, azul en España, verde en Argentina, puede intervenir para modificar el sentido adoptado, y alguien creerá que sigue en una autopista cuando se encuentra en una carretera nacional o provincial). Por el contrario la circunstancia hace referencia a las relaciones que se establecen entre el emisor y el destinatario.

Un elemento muy importante de este modelo es diferenciar el mensaje como fuente de la información (expresión) y el texto interpretado como el contenido del mensaje, después que el destinatario lo ha interpretado de acuerdo al contexto y de sus códigos y subcódigos (Rodrigo, 2005). Este cambio en el modelo es muy relevante porque plantea que el receptor lleva a cabo una lectura personal del mensaje, pudiendo distorsionar las intenciones del emisor. Es decir, más allá de la intencionalidad comunicativa del emisor, tenemos las emociones no programadas por éste, pero que se producen en el receptor. Esto pone de manifiesto que, en la 
comunicación, no siempre es evidente comprender el mensaje y/o compartir el contenido del mensaje. Para el campo interpretativo son significativas las aportaciones realizadas por Eco (1977), ya que fundamentan de manera teórica determinadas prácticas interpretativas. La interpretación sucede en el interior de la persona, es lo que intelectual y emocionalmente logra conectarse con el bien patrimonial. En este proceso intervienen factores cognitivos y afectivos que, al igual en el modelo de Eco (1977), condicionan la decodificación del mensaje interpretativo. Por lo tanto es necesario conocer el destinatario de nuestra presentación, evitando posibles dificultades en la decodificación del mensaje para que este último ofrezca oportunidades interpretativas en el interior de las personas de nuestra audiencia.

\section{2) Vinculación con estudios cognitivos y conductuales}

Al considerar la Interpretación como un proceso de comunicación, estamos en condiciones de aprovechar los avances de la psicología cognitiva y del comportamiento para examinar las causas y los efectos que ocurrirían si la interpretación está bien realizada (Ham, 2009b). Comprender la relación entre el conocimiento, la actitud y el comportamiento es fundamental para entender cómo la Interpretación puede influir en la conducta. La Tabla 28 resume las principales teorías de cambio en el comportamiento que se han desarrollado hasta el momento.

Tabla 28. Teorías de cambio conductual relacionadas con la Interpretación.

\begin{tabular}{|c|c|c|}
\hline Teoría o modelo & Autores & Conceptos claves \\
\hline $\begin{array}{l}\text { Modelo de la } \\
\text { Persuasión }\end{array}$ & $\begin{array}{l}\text { Manfredo y Bright, } \\
1991\end{array}$ & $\begin{array}{l}\text { El comportamiento por la acción del mensaje se } \\
\text { mide por el número de pensamientos generados, } \\
\text { adquisición de nuevas creencias y cambios en las } \\
\text { creencias antiguas. }\end{array}$ \\
\hline $\begin{array}{l}\text { Modelo de } \\
\text { probabilidad de } \\
\text { elaboración }\end{array}$ & $\begin{array}{l}\text { Petty y Cacioppo, } 1981 \\
\text { Petty y Cacioppo, } 1986 \\
\text { Petty et al., } 1992\end{array}$ & $\begin{array}{l}\text { La motivación y la capacidad de procesar } \\
\text { argumentos determinan si la persuasión es vía ruta } \\
\text { central o periférica. La ruta central implica una alta } \\
\text { elaboración del mensaje, mientras que la ruta } \\
\text { periférica influye a través de señales tangenciales } \\
\text { al mensaje. }\end{array}$ \\
\hline $\begin{array}{l}\text { Teoría de } \\
\text { Comportamiento } \\
\text { Planificado y Teoría } \\
\text { de Acción Razonada }\end{array}$ & $\begin{array}{l}\text { Ajzen, } 1991 \\
\text { Ajzen y Fishbein, } 1980 \\
\text { Fishbein, } 1967 \\
\text { Fishbein y Ajzen, } 1975\end{array}$ & $\begin{array}{l}\text { El comportamiento humano, o al menos la } \\
\text { intención de conducta, es coherente con las } \\
\text { creencias. La intención del comportamiento se ve } \\
\text { afectada por la actitud hacia la conducta } \\
\text { (creencias sobre la conducta y evaluación de esas } \\
\text { creencias), la norma subjetiva (creencias y } \\
\text { motivaciones normativas para cumplir con esas } \\
\text { creencias), y el control del comportamiento } \\
\text { percibido (creencias de control). }\end{array}$ \\
\hline $\begin{array}{l}\text { Teoría Centrada en la } \\
\text { Norma }\end{array}$ & $\begin{array}{l}\text { Cialdina et al., } 1990 \\
\text { Festinger, } 1957\end{array}$ & $\begin{array}{l}\text { La gente se comporta de acuerdo a como ellos } \\
\text { piensan que deben comportarse, en base a las }\end{array}$ \\
\hline
\end{tabular}




\begin{tabular}{|l|l|l|}
\hline & Reno et al., 1993 & $\begin{array}{l}\text { normas sociales. Las normas son descriptivas (lo } \\
\text { que pensamos que la mayoría de la gente hace) o } \\
\text { por coacción social (lo que creemos que es } \\
\text { socialmente aceptable). }\end{array}$ \\
\hline Atención plena & $\begin{array}{l}\text { Langer, 1989a } \\
\text { Langer, 1989b } \\
\text { Moscardo, 1996 }\end{array}$ & $\begin{array}{l}\text { En cualquier situación una persona puede estar } \\
\text { atenta o distraída. La atención plena está } \\
\text { influenciada por el establecimiento de factores } \\
\text { (como demostraciones, señales, mapas y paseos) y } \\
\text { por el visitante (como la familiaridad con el sitio, } \\
\text { motivaciones y compañeros). }\end{array}$ \\
$\begin{array}{l}\text { Modelo o } \\
\text { Comportamiento } \\
\begin{array}{l}\text { Ambiental } \\
\text { Responsable }\end{array}\end{array}$ & Hines et al., 1986/87 \\
$\begin{array}{l}\text { La intención de actuar está influenciada por las } \\
\text { habilidades de acción, el conocimiento de las } \\
\text { estrategias de acción, el conocimiento de los } \\
\text { problemas y factores de personalidad (incluyendo } \\
\text { las actitudes, el lugar de control y la } \\
\text { responsabilidad personal). }\end{array}$ \\
$\begin{array}{l}\text { Marco conceptual de } \\
\text { la conducta ambiental } \\
\text { responsable }\end{array}$ & Cottrel y Graefe, 1997 & $\begin{array}{l}\text { El comportamiento es influenciado por variables } \\
\text { sociodemográficas, la experiencia, el medio } \\
\text { ambiente en general, el tema específico y los } \\
\text { factores de situación. }\end{array}$ \\
\hline \begin{tabular}{l} 
Fuente: traducido de Littlefair, 2003. \\
\hline
\end{tabular}
\end{tabular}

Los dos principales fundamentos teóricos que han guiado las investigaciones en el campo interpretativo son el Modelo de Probabilidad de Elaboración (en adelante, MPE) y la Teoría del Comportamiento Planificado (en adelante, TCP). Según el MPE (Figura 43), el cambio de actitudes que genera un determinado mensaje en las personas se puede producir a través de dos rutas de procesamiento cognitivo distintas: la ruta central y la ruta periférica. Los mensajes que son procesados mediante la primera reciben mayor interés por nuestra parte y son examinados de manera racional y profunda en función de la calidad de sus argumentos. Los cambios de actitud resultante del procesamiento a través de esta ruta son relativamente duraderos, resistentes a mensajes contrarios y predictores de nuestras conductas. Por el contrario, con el procesamiento por ruta periférica dedicamos mucha menos atención al mensaje y lo evaluamos en función de elementos totalmente periféricos (la cantidad de los argumentos, el atractivo de la fuente, la música, etc.) que tienen poca relación con la calidad de los argumentos. Los cambios de actitud que se producen a través de esta vía tienden a ser menos duraderos, fáciles de modificar con mensajes contrarios y malos predictores de la conducta (Cacioppo y Petty, 1983; Petty et al., 2009). Mientras que la TCP (Figura 44) ayuda a entender cómo podemos cambiar el comportamiento de la gente sosteniendo que la conducta humana es voluntaria y está determinada por la intención conductual, la cual a su vez se construye a partir de tres procesos principales: actitudes sociales, norma subjetiva y control conductual percibido (Ajzen, 1991). 


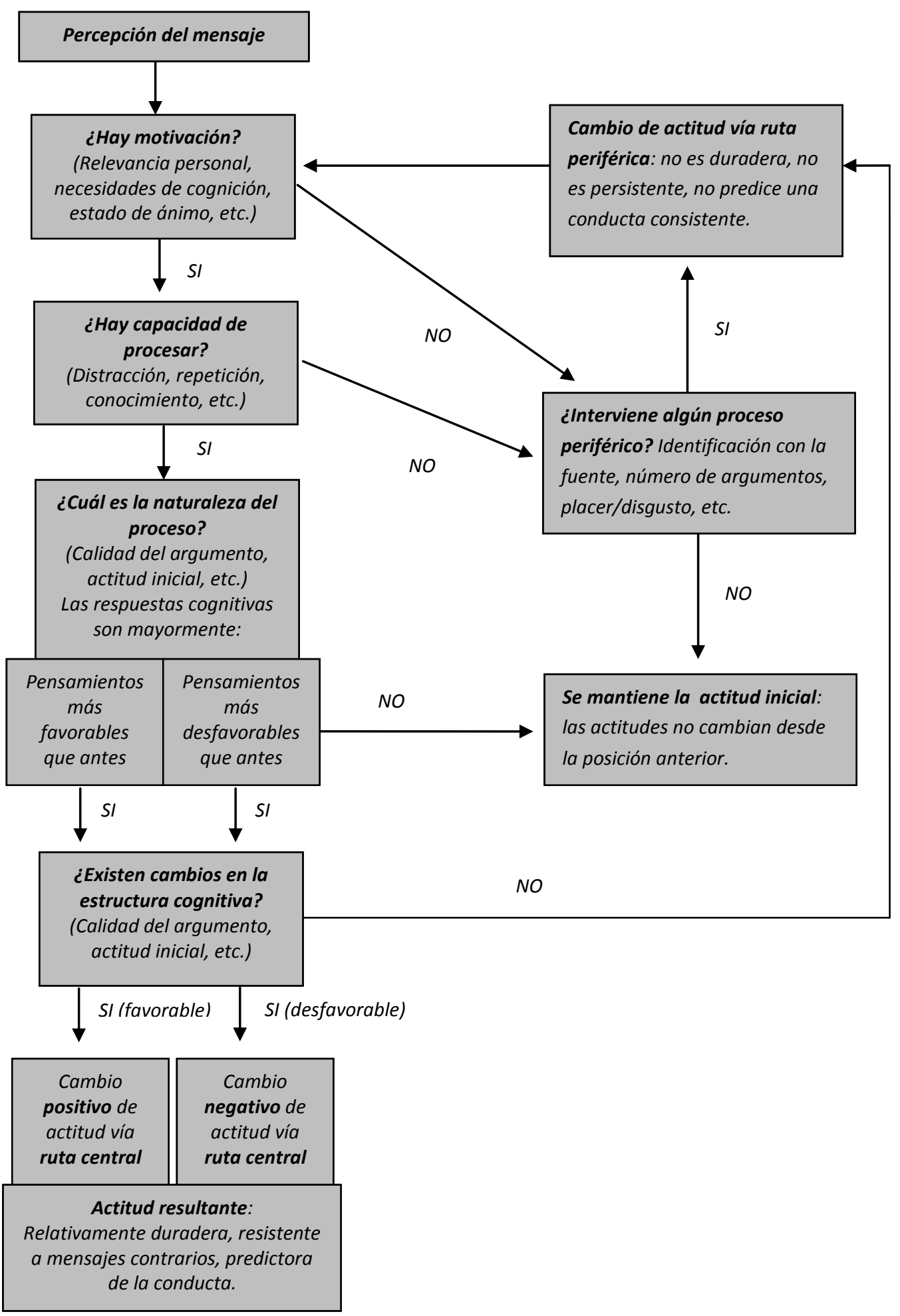

Figura 43. Modelo de Probabilidad de Elaboración.

Fuente: traducido de Cacioppo y Petty, 1983; Petty et al., 2009. 


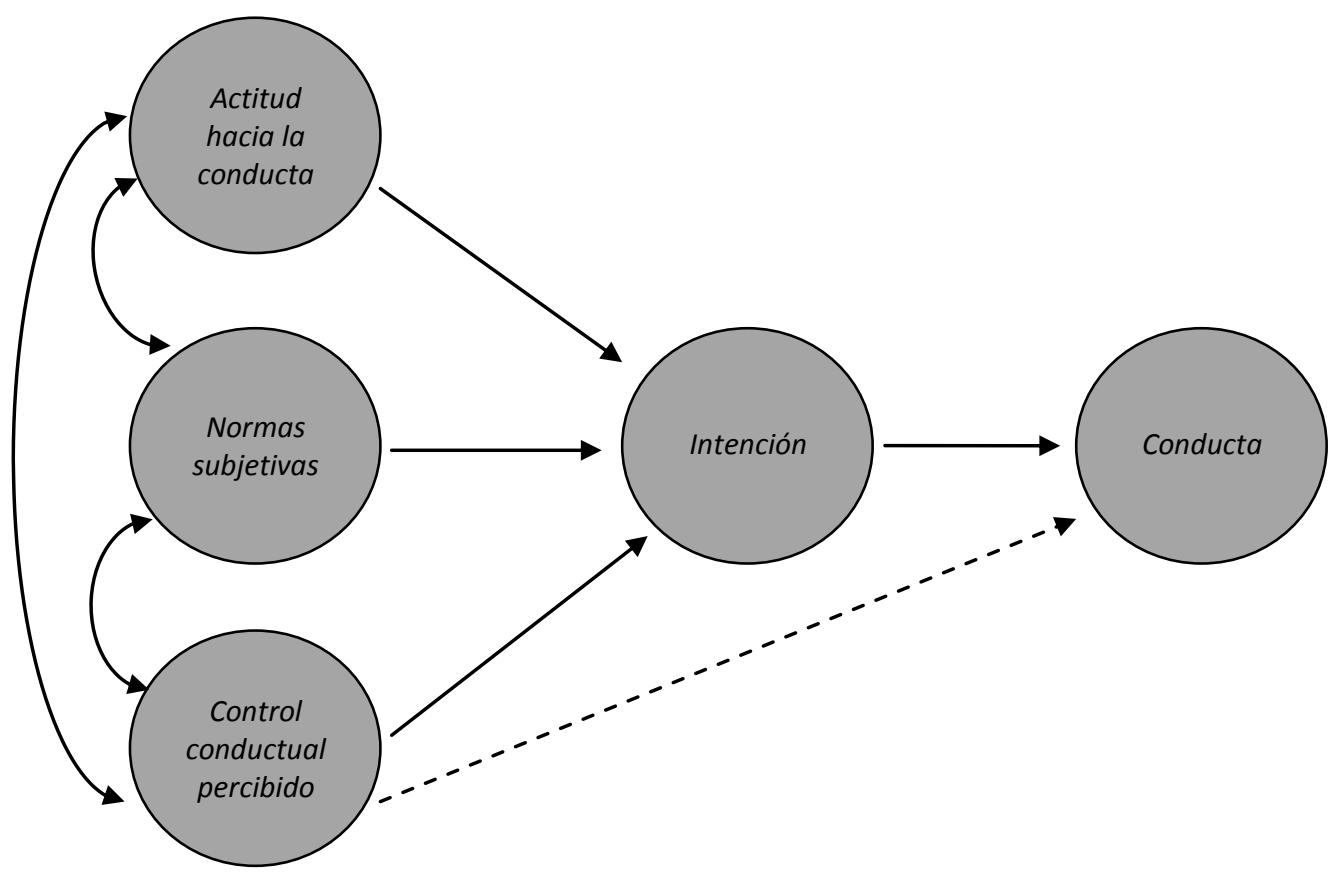

Figura 44. Diagrama de la Teoría del Comportamiento Planificado. Fuente: traducido de Ajzen, 1991.

La investigación sobre el MPE ha demostrado que cuanta mayor relevancia personal posea una presentación interpretativa, existe una mayor probabilidad de que las personas asistan y tomen contacto con el mensaje de la misma (Cacioppo y Petty, 1983; Petty et al., 2009). Es decir, mensajes relevantes provocan al pensamiento, que a su vez conduce a la formación de significados subjetivos. Cuando la interpretación provoca el pensamiento de una persona, se genera una especie de conversación en el interior de su mente que, a su vez, produce nuevos saberes afectando a las ideas previas, ya sea para ser reforzadas o cambiadas. La comprensión, las asociaciones, las elaboraciones e inferencias son más importantes que la memoria textual de los argumentos (Cacioppo y Petty, 1983). Como en el caso de los mapas cognitivos $^{21}$, es importante estimular determinados procesos cognitivos para facilitar la transferencia de información en la programación interpretativa (Hammit, 1981, 1984; Knopf, 1981). ¿Pero cómo podría la comprensión conducir a la apreciación? Estudios de TCP demuestran que los preconceptos de las personas sobre algo dan lugar a su actitud sobre ello (Ajzen, 1991). Mientras que una creencia describe que es, una actitud describe la valoración que una persona realiza sobre una cosa, si está bien o mal, correcto o incorrecto, positivo o negativo. Según la TCP, para influir en un comportamiento sería eficaz empezar por influir en

\footnotetext{
${ }^{21}$ La Teoría del Mapa Cognitivo sugiere que las personas reciben información de un entorno, codificándola en unidades simplificadas y la almacenan mentalmente en relación a otra información (Morales, 1998a).
} 
los preconceptos que la gente posee acerca de tal comportamiento (Figura 45). Por lo tanto, la interpretación que provoca la formación de conceptos positivos sobre los resultados de un determinado comportamiento dará lugar a una actitud positiva acerca de ese comportamiento. Cuando esto ocurre, la probabilidad de que un visitante se acople al comportamiento deseado por la planificación interpretativa (si se presenta la oportunidad) es significativamente mayor. Diseñar mensajes que impacten en una o más de estas creencias a su vez puede influir en el comportamiento consecuente (Ham, 2009b; Hughes et al., 2009).

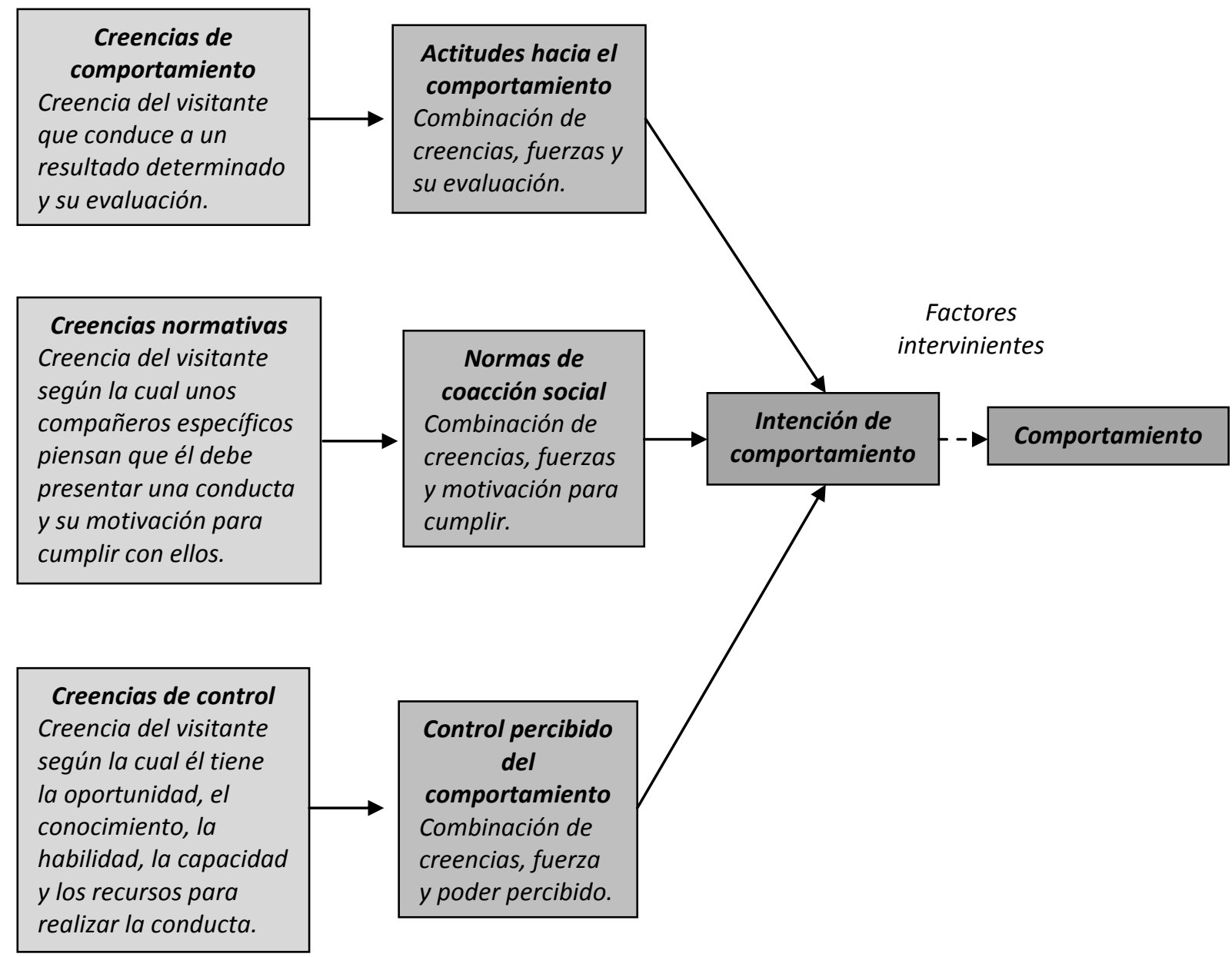

Figura 45. Relación de los tres tipos de creencias, su interrelación y su comportamiento posterior, según la Teoría del Comportamiento Planificado.

Fuente: traducido de Hughes et al., 2009.

La comprensión de la conducta individual y la influencia en el comportamiento del grupo es especialmente importante para el personal responsable de la interpretación, por lo que sería conveniente la aplicación de conceptos sociológicos en Interpretación (Field y Wagar, 1984). Por ello, encontramos cinco premisas para lograr una interpretación efectiva:

- existe una diversidad de visitantes;

- Ios visitantes esperan un ambiente relajado y agradable; 
- Ia información interpretativa debe ser provechosa para el visitante así como despertar y mantener su atención;

- la información interpretativa debe entenderse;

- la eficacia de la interpretación debe ser continuamente evaluada.

Finalmente, para lograr una mayor conexión entre los visitantes de un parque con la naturaleza del mismo es importante considerar el orden en que es visitado y el tipo de programas de interpretación, ya que ambos factores influyen en la claridad percibida por los visitantes (Knopf, 1981). Respecto a la relación programas interpretativos-naturaleza, los visitantes que participan en actividades de interpretación tienen una mayor conexión con el entorno natural que los visitantes que participaron en actividades recreativas sin interpretación. Este resultado apoya la idea de que la participación de personas en actividades recreativas basadas en la naturaleza y ofrecidos a través de la interpretación puede aumentar la relación de una persona con el medio natural (Burbach et al., 2012).

\section{3) Vinculación con la educación}

Algunos trabajos consideran que existe una estrecha relación entre la Interpretación del Patrimonio y la Educación en general (Bazán, 2013a) o con la Educación Ambiental en particular (Wadszinski y Knapp, 1995; Knapp, 2005; Moreira, 2012). De igual manera, existen autores que vinculan el concepto de Interpretación del Patrimonio con términos y prácticas afines (difusión, divulgación, didáctica del patrimonio). La Real Academia Española define difundir como propagar o divulgar conocimientos, noticias, actitudes, costumbres, modas. Cuenca (2002), por ejemplo, afirma que la difusión o divulgación se refiere a los procesos a través de los cuales se comunican y se ponen en conocimiento los elementos patrimoniales a un conjunto de personas. Según esta postura se recurriría a la didáctica para fundamentar de manera teórico-práctica proyectos de difusión patrimonial. Sin embargo, la didáctica del patrimonio se ha visto reducida casi exclusivamente a una enseñanza formal, frecuentemente centrada en la visita a elementos patrimoniales como complemento de los contenidos trabajados en el aula (Cuenca, 2002). Martín (2007) conceptualiza este mismo término como aquella actividad que convierte en producto patrimonial al objeto, siendo una gestión cultural entre dicho patrimonio y la sociedad. Otros autores consideran que tal socialización del patrimonio (divulgación, difusión, didáctica) pasa a denominarse interpretación cuando permite que el visitante conecte de manera intelectual y emocional con los significados 
inherentes al recurso patrimonial (Morales, 2008), siendo una situación intermedia entre la didáctica y la divulgación del Patrimonio (Mateos, 2008).

Los bienes patrimoniales pierden sentido como tales cuando permanecen en un círculo cerrado de especialistas en la investigación científica (Querol y Martínez, 1996, en Cuenca 2002). La Interpretación del Patrimonio es un factor esencial en los procesos de difusión del mismo. Por eso es necesario potenciar el vínculo entre investigación y difusión, para que esta última haga rentable al patrimonio desde la perspectiva de su función social (Miró, 1997). A través de la interpretación patrimonial se logra que la sociedad tome conciencia que el patrimonio puede perderse (concepto de fragilidad), que es de la sociedad (concepto de pertenencia) y que debe ser una herencia para las generaciones futuras (concepto de perdurabilidad) (Martín (2007).

Considerando las conexiones entre la Interpretación y la educación ambiental ${ }^{22}$, algunas posturas consideran difícil la separación entre ellas, debiéndose reconocer a esta última como una extensión de la primera (Sharpe, 1982, en Cable y Cadden, 2006). Otros han invertido el orden de esta declaración y han visto la interpretación como una extensión de la educación ambiental, o bien consideran que esta última debe utilizar la metodología y los instrumentos de la interpretación para ser efectiva (Netto, 2004), o bien las ven como actividades completamente separadas e identificables (Cable y Cadden, 2006). De manera más categórica, Morales (en Bao, 2009) menciona que la interpretación es un tipo de didáctica que se aplica a unos destinatarios y en unas circunstancias muy concretas con el objetivo de transmitir unas ideas para que estas puedan afectar de alguna forma las actitudes de la gente, generando en el público una actitud positiva o de respeto.

Dentro de la educación formal, el aprovechamiento didáctico de un elemento o sitio patrimonial seguramente variará si el mismo se realiza como una manera de introducción de un contenido curricular, como desarrollo del mismo, como un refuerzo de lo aprendido en el aula o como una instancia de evaluación del aprendizaje de tal contenido. En tales casos, es la intencionalidad docente la que adecuará las actividades a realizar con el sitio o elemento patrimonial y de acuerdo a los objetivos que se propongan anticipadamente.

Más allá de distintas posturas sobre el tema, pueden identificarse similitudes y diferencias entre la Interpretación del Patrimonio, la didáctica patrimonial y la educación ambiental, al utilizar criterios tales como el lugar de desarrollo (parques temáticos, museos,

\footnotetext{
${ }^{22}$ La EA se puede desarrollar desde ámbitos diferentes y distintas estrategias. A groso modo se puede definir a la EA formal aquella que se lleva a cabo a través de los diseños curriculares de diferentes niveles de escolaridad, mientras que la EA no formal es aquella que no se realiza en el ámbito de instituciones escolares y planes de estudios reconocidos oficialmente (Novo, 1998).
} 
centros escolares), el tipo de público (personas en tiempo de ocio frente a personas requeridas para estar presente), las finalidades (recreación, desarrollo de contenidos curriculares), el plazo de los objetivos (corto o largo), el objeto de conocimiento (definidos por un diseño curricular o por un plan de interpretación), el tiempo de intervención (corto, contactos de una sola vez frente a múltiples o largas sesiones) y la evaluación (enfocada a la regulación del proceso de enseñanza/aprendizaje, evaluación informal y formal). Es importante tener en cuenta que tales diferencias se encuentran relacionadas entre sí, por ejemplo el lugar de desarrollo requiere un tipo de público, que a su vez influye en el tiempo disponible para la comunicación y con el propósito de la misma (Cable y Cadden, 2006). Al mismo tiempo, estas disciplinas presentan semejanzas: resultan globalizadoras y son interdisciplinarias, multidisciplinarias y transdisciplinarias en sus objetivos de conocimiento. No basta con enseñar desde la naturaleza o el patrimonio, utilizándolos como un recurso educativo; hay que educar para la conservación de los mismos, hay que presentar y aprender nuevas conductas hacia el entorno, no sólo conocerlo. Se trata de un nuevo vínculo del ser humano con su entorno, se pasa así de objetivos psicológicos y didácticos a criterios relacionados con la valoración y la conservación. Estas similitudes y diferencias aparecen recopiladas en la Tabla 29. 
Tabla 29. Diferencias y similitudes entre Didáctica del Patrimonio, Educación Ambiental e Interpretación del Patrimonio.

\begin{tabular}{|c|c|c|c|}
\hline & Didáctica del Patrimonio & $\begin{array}{l}\text { Educación } \\
\text { Ambiental }\end{array}$ & Interpretación del Patrimonio \\
\hline $\begin{array}{l}\text { Público } \\
\text { destinatario }\end{array}$ & \multicolumn{2}{|c|}{ - Estudiantes. Audiencia cautiva (en su mayoría) } & $\begin{array}{l}\text { - Visitantes al sitio patrimonial, } \\
\text { en su mayoría audiencia no } \\
\text { cautiva (ocio) }\end{array}$ \\
\hline $\begin{array}{l}\text { Características } \\
\text { de la } \\
\text { audiencia }\end{array}$ & \multicolumn{2}{|c|}{$\begin{array}{l}\text { - Preponderancia de grupos homogéneos (edad, } \\
\text { conocimientos, experiencias) }\end{array}$} & $\begin{array}{l}\text { - Predominio de grupos } \\
\text { heterogéneos (edad, } \\
\text { conocimientos, experiencias) }\end{array}$ \\
\hline Finalidades & $\begin{array}{l}\text { - Construcción de } \\
\text { conocimiento } \\
\text { - Formación del pensamiento } \\
\text { estético, histórico -artístico, } \\
\text { científico y etnológico } \\
\text { - Construcción del significado } \\
\text { de patrimonio } \\
\text { - Disfrute razonado }\end{array}$ & $\begin{array}{l}\text { - Construcción de } \\
\text { conocimiento } \\
\text { - Formación y } \\
\text { fortalecimiento del } \\
\text { pensamiento } \\
\text { ambiental } \\
\text { - Disfrute razonado }\end{array}$ & $\begin{array}{l}\text { - Conexión emocional e } \\
\text { intelectual con el patrimonio } \\
\text { - Adquisición de conocimientos } \\
\text { - Valorización del significado } \\
\text { de patrimonio } \\
\text { - Disfrute extemporáneo }\end{array}$ \\
\hline Objetivos & \multicolumn{2}{|c|}{$\begin{array}{l}\text { - Precisa definición de los objetivos, mayormente } \\
\text { prescritos por un currículo escolar } \\
\text { - Formativos } \\
\text { - Largo plazo }\end{array}$} & $\begin{array}{l}\text { - Definidos en lo que queremos } \\
\text { que el visitante conozca, sienta } \\
\text { o haga } \\
\text { - Recreativos } \\
\text { - Corto plazo }\end{array}$ \\
\hline $\begin{array}{l}\text { Lugar de } \\
\text { desarrollo }\end{array}$ & $\begin{array}{l}\text { - Variados: museos, centros } \\
\text { escolares, parques } \\
\text { arqueológicos, etc. }\end{array}$ & $\begin{array}{l}\text { - Variados: parques } \\
\text { naturales, aulas } \\
\text { ambientales, etc. }\end{array}$ & $\begin{array}{l}\text { - In situ, ante el recurso o en el } \\
\text { sitio que será interpretado }\end{array}$ \\
\hline $\begin{array}{l}\text { Planificación } \\
\text { de la actividad }\end{array}$ & \multicolumn{2}{|l|}{ - Programación didáctica } & - Planificación interpretativa \\
\hline Instrumentos & - Materiales estructurados & $\begin{array}{l}\text { - Materiales } \\
\text { estructurados } \\
\text { - Contacto con la } \\
\text { naturaleza }\end{array}$ & $\begin{array}{l}\text { - Mensaje interpretativo (oral, } \\
\text { escrito, representaciones } \\
\text { teatrales, etc.) }\end{array}$ \\
\hline $\begin{array}{l}\text { Tipos de } \\
\text { operaciones }\end{array}$ & \multicolumn{2}{|c|}{ - Actividades cognitivas y de operatividad } & $\begin{array}{l}\text { - En relación con los objetivos: } \\
\text { de escucha, de lectura, motoras }\end{array}$ \\
\hline $\begin{array}{l}\text { Resultados } \\
\text { esperados }\end{array}$ & \multicolumn{2}{|c|}{$\begin{array}{l}\text { - Conocimientos sistémicos, modelos de procesos de } \\
\text { construcción del conocimiento y competencias } \\
\text { transferibles }\end{array}$} & $\begin{array}{l}\text { - Conocimientos relacionados } \\
\text { con el recurso interpretado } \\
\text { - Aproximación integral al } \\
\text { mismo }\end{array}$ \\
\hline $\begin{array}{l}\text { Procesos } \\
\text { evaluativos }\end{array}$ & \multicolumn{2}{|c|}{$\begin{array}{l}\text { - Múltiples e importantes con la finalidad de la } \\
\text { regulación del proceso de enseñanza y aprendizaje }\end{array}$} & $\begin{array}{l}\text { - Múltiples, previstos para la } \\
\text { mejora de la comunicación } \\
\text { interpretativa } \\
\text { - Retroevaluación }\end{array}$ \\
\hline $\begin{array}{l}\text { Organización } \\
\text { temporal }\end{array}$ & \multicolumn{2}{|c|}{$\begin{array}{l}\text { - Tiempo largo, estructurado en secuencias de } \\
\text { actividades diversas }\end{array}$} & - Tiempo limitado a la visita \\
\hline $\begin{array}{l}\text { Relación con } \\
\text { la escuela }\end{array}$ & \multicolumn{2}{|l|}{ - Estructurado } & - Ocasional \\
\hline
\end{tabular}


Aunque luego la definió como una actividad recreativa, originalmente Tilden (2006) relacionó a la Interpretación con las actividades educativas (Capítulo 2). Como se verá a continuación, existe un solapamiento entre las técnicas interpretativas y el proceso de enseñanza/aprendizaje. Por ello y para estructurar tal proximidad, hemos vinculado teorías de aprendizaje y/o propuestas de enseñanza con los principios interpretativos enunciados por Tilden (1957) y los primeros seis "Principios para el siglo XXI" propuestos por Beck y Cable (1998).

\subsection{1) Intervenir desde lo que el otro conoce}

Tabla 30. Primer Principio Interpretativo y su relación con la educación.

\begin{tabular}{|c|c|c|}
\hline Tilden (1957) & Beck y Cable (1998) & Educación \\
\hline $\begin{array}{l}\text { Cualquier interpretación que de } \\
\text { alguna forma no relacione lo que } \\
\text { se muestra o describe con algo } \\
\text { que se halle en la personalidad o } \\
\text { en la experiencia del visitante, } \\
\text { será estéril. }\end{array}$ & $\begin{array}{l}\text { Para despertar el interés, los } \\
\text { intérpretes deben conseguir } \\
\text { que los contenidos de sus } \\
\text { mensajes se relacionen con } \\
\text { la vida de los visitantes. }\end{array}$ & 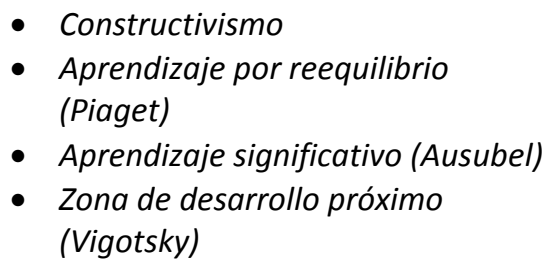 \\
\hline
\end{tabular}

En su conexión con la educación, estos principios se relacionan con las teorías constructivistas (Tabla 30). El Constructivismo asume que nuestra estructura cognitiva está configurada por una red de esquemas de conocimiento, siendo estos esquemas las representaciones que una persona posee sobre algún objeto de conocimiento, en un momento dado de su existencia. A lo largo de la vida, estos esquemas se revisan, se modifican, se vuelven más complejos y adaptados a la realidad, más ricos en relaciones. La naturaleza de los esquemas de conocimiento de un alumno depende de su nivel de desarrollo y de los conocimientos previos que ha podido ir construyendo; la situación de enseñanza/aprendizaje puede ser conceptualizada como un proceso de contraste, de revisión y de construcción de esquemas de conocimiento sobre los contenidos escolares (Zabala, 1995). Dentro de los autores constructivistas que apoyan sus teorías en lo que el alumno sabe, podemos mencionar:

- Jean Piaget (1896-1980). Para este psicólogo suizo el aprendizaje se explica por tres mecanismos: la asimilación, la acomodación y el equilibrio. A través de la asimilación el alumno toma alguna experiencia o información y la introduce en la estructura existente de su conocimiento. La acomodación sucede cuando el alumno cambia los esquemas existentes para responder a una situación nueva de aprendizaje, llegando de este modo a un nuevo equilibrio que seguirá avanzando paulatinamente por nuevos desequilibrios 
(Fernández, 2009). Por lo tanto, para Piaget aprender es otorgar significados a los objetos, resignificando lo previo.

- David Ausubel (1918-2008). Este pedagogo estadounidense postuló el concepto de aprendizaje significativo, según el cual los nuevos conocimientos se incorporan en la estructura cognitiva del alumno, relacionándolos con los anteriormente adquiridos. El aprendizaje significativo supone que los esquemas de conocimiento que ya tiene el individuo se revisan, se modifican y se enriquecen al establecer nuevas conexiones y relaciones entre ellos. De igual manera, resulta necesario que el alumnado se interese por aprender lo que se le esté enseñando (Fernández, 2009).

- Lev Vigotsky (1896-1934). Según este psicólogo ruso, las interacciones sociales con compañeros y adultos constituyen el medio principal del desarrollo intelectual del niño. Toda persona nace con habilidades mentales elementales (percepción, atención, memoria, etc.) las cuales se transforman en funciones mentales superiores mediante esa interacción social. Vigotsky creía que era importante trabajar con la zona de desarrollo próximo para lograr el máximo aprendizaje. La zona de desarrollo próximo contiene cosas que el niño no es capaz de hacer solo en ese momento, pero que se encuentra próximo a lograr. El escalonamiento involucra incentivos y asistencia en la forma de consejos y sugerencias para ayudar al niño a entender un nuevo concepto (Mendiburu, 2001).

En Interpretación del Patrimonio el visitante relacionará la información que recibe del intérprete con algo que se vincule con su conocimiento y experiencias íntimos, ya que percibe lo que observa a través de sus ojos, y no a través de los del intérprete; este último presentará una serie de datos seleccionados con la finalidad de provocar el pensamiento en los visitantes y que ellos mismos construyan su propia comprensión (Ham, 2009a). Por lo tanto, el desafío de la Interpretación del Patrimonio es poner en común los intereses personales del visitante y los significados que posee el recurso patrimonial (Morales, 2008).

En el campo educativo, cuanto más consciente es un profesor de las experiencias pasadas, deseos, intereses y esperanzas de los estudiantes, mejor entenderá qué estrategias dirigir y utilizar para la formación de hábitos de reflexión (Dewey, 1916, en Cable y Cadden, 2006). El docente debe conocer su grupo de estudiantes para generar estrategias significativas de aprendizaje. De igual manera el intérprete debe conocer la audiencia y así elaborar el mensaje interpretativo, generando oportunidades interpretativas. A partir de los conocimientos previos se debe elaborar la estrategia didáctica que permita alcanzar el cambio conceptual, es decir, el proceso y el mecanismo de una posible modificación de las ideas previas de los 
alumnos en dirección al concepto a enseñar (Castorina, 2006). Al respecto, las posibilidades de ocurrencia del cambio conceptual están estrechamente vinculadas a las características del conocimiento previo (Carretero, 2006).

\subsection{2) El mensaje es más que mera información}

Tabla 31. Segundo Principio Interpretativo y su relación con la educación.

\begin{tabular}{|l|l|l|}
\hline \multicolumn{1}{|c|}{ Tilden (1957) } & \multicolumn{1}{|c|}{ Beck y Cable (1998) } & \multicolumn{1}{c|}{ Educación } \\
\hline La información, tal cual, no es & El propósito de la & - Constructivismo \\
interpretación. La interpretación es & interpretación va más allá & - Aprendizaje por \\
revelación basada en información, & de la entrega de & reequilibrio (Piaget) \\
aunque son cosas completamente & información, consiste en & Aprendizaje significativo \\
diferentes. Sin embargo, toda & revelar una verdad y un & (Ausubel) \\
interpretación incluye información & significado profundos. & \\
\hline Fuente: elaboración propia.
\end{tabular}

El 2o principio interpretativo (Tabla 31) se corresponde con el anterior al proponer que el intérprete brinde información relacionándola con datos que pueden ser conocidos por el visitante. Como se afirmó anteriormente, para que una comunicación interpretativa tenga éxito tiene que ser amena para la audiencia y relevante con lo que ya conoce y le importa, organizada para que sea fácil de procesar, y debe incidir en algún punto atrayente (comunicar un tema potente), es decir el modelo TORA (Ham, 2007). La aplicación de tal método (Figura 46) parte de la presentación de un tema relevante (a), hecha de manera amena y ordenada (b),

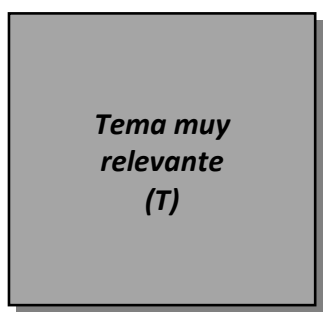

(a)

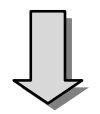

Presentado de forma que la audiencia esté interesada $y$ motivada para prestar atención (ORA)

(b) Lo que hace el
intérprete

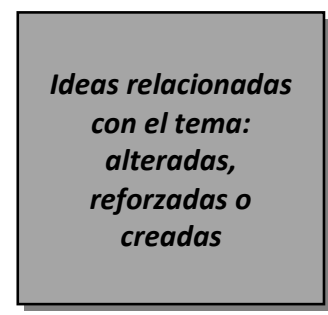

(d)
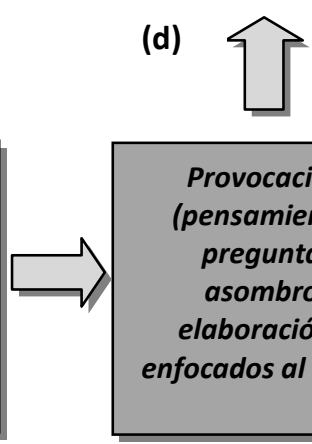
(c)

Provocación (pensamiento, pregunta, asombro, elaboración... enfocados al tema)

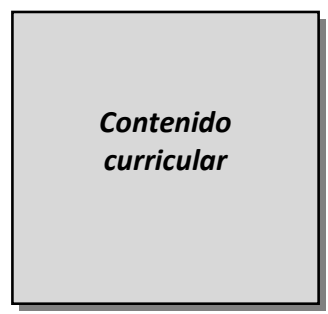

(e)

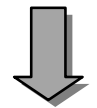

que hace la audiencia

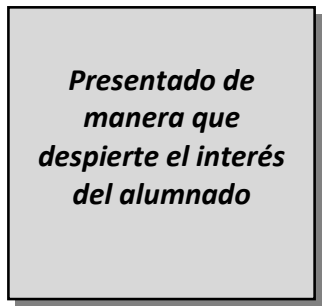

(f)

Figura 46. Proceso de comunicación en el Método TORA $^{\text {TM }}$.

Fuente: modificado de Ham, 2007.

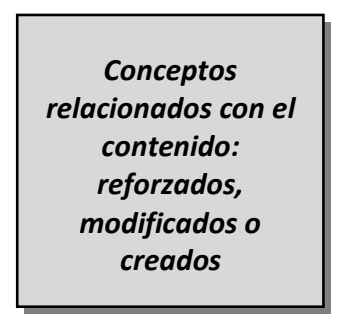

(h)

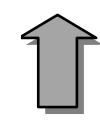

(g)

Figura 47. Proceso de comunicación en el acto didáctico.

Fuente: elaboración propia. 
permitiendo que el visitante establezca significados con lo que se está presentando (c), los cuales pueden ser un refuerzo, un cambio o la creación de nuevas ideas (d). En Educación sucede un proceso similar (Figura 47) donde el docente presenta un contenido a enseñar ${ }^{23}$ (e), el cual es conveniente que sea presentado (f) como en (b), permitiendo que el alumnado vincule el concepto presentado con sus ideas previas (g), lo que resultará en una reafirmación de lo que sabe, una modificación o la generación de un concepto nuevo (h).

En educación no alcanza con sólo transmitir datos (aunque pareciera que algunos docentes se olvidaran de esta premisa). La génesis del aprendizaje significativo propuesto por Ausubel se encuentra en la psicología genética de Piaget (Boggino, 2005). Al respecto se sugieren estrategias didácticas adecuadas para elaborar el mensaje a transmitir durante el acto pedagógico y el logro de objetivos docentes (Gallego y Salvador, 2002; Mejía, 2008):

- Neutralizar la pérdida informativa de los mensajes. Para conseguir este objetivo, se procura que los mensajes sean sencillos, que se relacionen con ideas familiares y con temas generales, y que se impregnen de connotaciones personales.

- Reforzar la comprensibilidad de los mensajes. Por ello, se procura que el mensaje se presente breve y ordenado, y que se utilicen diversos códigos: verbal (palabras), práxico (gestos, movimientos, etc.) e icónico (imágenes, objetos reales, etc.).

- Centrar y mantener la atención, utilizando el humor como estímulo para despertar la atención y haciendo uso de las referencias personales del grupo clase.

- Presentar la información de forma que favorezca el aprendizaje y el conocimiento significativo (informaciones organizadas, mensajes breves, etc.).

- Guiar el razonamiento utilizando preguntas.

- Tener en cuenta el nivel de desarrollo del alumnado.

\subsection{3) Diversidad de aprendizajes, diversidad de enseñanzas}

Tabla 32. Tercer Principio Interpretativo y su relación con la educación.

\begin{tabular}{|c|c|c|}
\hline Tilden (1957) & Beck y Cable (1998) & Educación \\
\hline $\begin{array}{l}\text { La interpretación es un arte, que } \\
\text { combina otras muchas artes, sin } \\
\text { importar que los materiales que se } \\
\text { presentan sean científicos, históricos o } \\
\text { arquitectónicos. Cualquier arte se puede } \\
\text { enseñar en cierta forma. }\end{array}$ & $\begin{array}{l}\text { Toda presentación } \\
\text { interpretativa -al igual que } \\
\text { una obra de arte-se debería } \\
\text { diseñar como una historia que } \\
\text { informe, entretenga e ilustre. }\end{array}$ & $\begin{array}{l}\text { - Constructivismo } \\
\text { - Teoría de las } \\
\text { Inteligencias Múltiples } \\
\text { (Gardner) }\end{array}$ \\
\hline
\end{tabular}

\footnotetext{
${ }^{23}$ El cual proviene de un diseño curricular jurisdiccional, del que forman parte saberes considerados socialmente valiosos, relevantes y significativos.
} 
Desde que en 1983 Gardner postulara su Teoría de Inteligencias Múltiples (Gardner, 1987), es más evidente comprender que todas las personas aprenden de distintas formas. Según esta teoría, los seres humanos somos capaces de conocer el mundo de ocho modos diferentes (lingüistica y lógico-matemática, espacial, musical, cinético-corporal, intrapersonal, interpersonal y naturalista), todas las personas tienen en mayor o menor grado tales inteligencias y las mismas funcionan juntas de modo complejo. Por lo tanto, todos los individuos aprenden, representan y utilizan el saber de muchos y diferentes modos. Los docentes son conscientes de que no deben utilizar una única estrategia didáctica para que su intervención logre el objetivo formulado en un principio; muchas veces se requiere hacer uso de una combinación de ellas. La educación marca la más perfecta e íntima unión de ciencia y arte concebible en la experiencia humana (Cable y Cadden, 2006).

La habilidad de saber contar una historia (lograr captar la atención y el interés de las personas) es esencial para los intérpretes y los docentes (Tabla 32). Los nutrientes para una interpretación de calidad proceden del uso apropiado e ingenioso de los recursos idiomáticos (Tilden, 2006). En la planificación y práctica docente es conveniente establecer la vinculación del contenido enseñado con el resto de la unidad o del programa y facilitando un organizador previo, es decir, presentar un breve resumen de los nuevos contenidos al alumnado antes de su desarrollo didáctico que cumpla la función de marco de referencia para vincular los conceptos y relaciones que posteriormente se explicarán.

\subsection{4) Sin atraer la atención es difícil establecer conexiones}

Tabla 33. Cuarto Principio Interpretativo y su relación con la educación.

\begin{tabular}{|l|l|l|}
\hline \multicolumn{1}{|c|}{ Tilden (1957) } & \multicolumn{1}{|c|}{ Beck y Cable (1998) } & \multicolumn{1}{c|}{ Educación } \\
\hline $\begin{array}{l}\text { El objetivo principal de la } \\
\text { interpretación no es la } \\
\text { instrucción, sino la provocación. }\end{array}$ & $\begin{array}{l}\text { El propósito del mensaje } \\
\text { interpretativo es inspirar y } \\
\text { provocar a la gente para que } \\
\text { amplíe sus horizontes. }\end{array}$ & $\begin{array}{l}\text { Constructivismo } \\
\text { - Aprendizaje significativo } \\
\text { (Ausubel) }\end{array}$ \\
\hline Fuente: elaboración propia.
\end{tabular}

El término provocación (Tabla 33) se refiere a que la interpretación, además de obtener una comprensión de las verdades que se ocultan detrás de cualquier hecho, despierte en el espectador un deseo de ampliar intereses y conocimientos, provocándolos en lo profundo de su pensamiento (Tilden, 2006). Cuando pensamos profundamente en una cosa, hacemos nuestros propios significados sobre ella, y estos significados constituyen nuestra comprensión de esa cosa. Por eso, el intérprete debe presentar unos datos seleccionados con el propósito de provocar el pensamiento en los visitantes, y que ellos mismos elaboren sus propios 
conocimientos. De esta comprensión puede surgir y desarrollarse el aprecio y el amor por el recurso interpretado (Ham, 2009a). Tal como un intérprete aburriría con una extensa tipificación de tecnicismos, el docente conseguirá iguales resultados en su clase; un estudiante motivado buscará ampliar la información aprendida en el aula. Es necesario recordar que despertar y mantener la atención del alumnado es vital en el proceso de enseñanza y aprendizaje.

Como se dijo anteriormente, una de las condiciones para que se genere el aprendizaje significativo es que el alumnado se interese por aprender lo que se le esté mostrando (Fernández, 2009). Por lo tanto, es necesario que el profesor conozca cómo estimular a los alumnos a conectarse con el aprendizaje y cómo mantenerlos implicados en el aprendizaje de cuestiones que, en algunos casos, no son de su agrado e interés (Moral y Pérez, 2009). Esto lo logrará con el conocimiento de los elementos del triángulo didáctico (Figura 48): cómo aprende el alumnado, de la asignatura que imparte y de la enseñanza (estrategias didácticas). Coincidentemente el Servicio de Parques Nacionales de Estados Unidos (NPS, 2007) afirma que para que una interpretación resulte efectiva (Capítulo 2) el intérprete debe tener conocimiento del recurso a interpretar (CR), de la audiencia (CA) y de técnicas adecuadas (TA) para así poder ofrecer oportunidades interpretativas (OI): cuanto mayor sea el conocimiento del recurso y de la audiencia por parte del intérprete, y cuanto más apropiadas sean las técnicas para presentar ese conocimiento, habrá más probabilidades de brindar a los visitantes una oportunidad para que formen sus propias conexiones personales con el recurso.

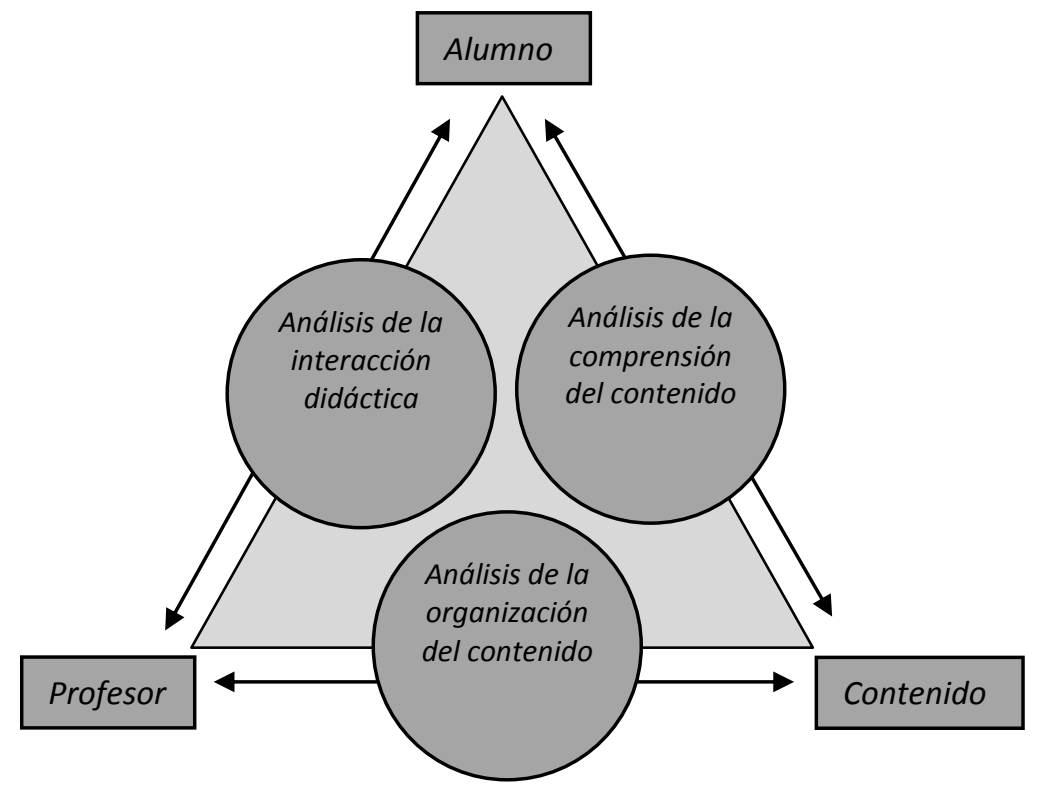

Figura 48. Relaciones entre los componentes del triángulo didáctico.

Fuente: elaboración propia. 


\subsection{5) El todo es mejor que las partes}

Tabla 34. Quinto Principio Interpretativo y su relación con la educación.

\begin{tabular}{|l|l|l|}
\hline \multicolumn{1}{|c|}{ Tilden (1957) } & \multicolumn{1}{|c|}{ Beck y Cable (1998) } & \multicolumn{1}{c|}{ Educación } \\
\hline $\begin{array}{l}\text { La interpretación debe intentar } \\
\text { presentar un todo en lugar de una } \\
\text { parte, y debe estar dirigida al ser } \\
\text { humano en su conjunto, no a un } \\
\text { aspecto particular. }\end{array}$ & $\begin{array}{l}\text { La interpretación debería } \\
\text { presentar un tema o un } \\
\text { planteamiento completo, y } \\
\text { debería ir dirigida al } \\
\text { individuo como un todo. }\end{array}$ & $\begin{array}{l}\text { Constructivismo } \\
\text { - Aprendizaje significativo } \\
\text { (Ausubel) }\end{array}$ \\
& & $\begin{array}{l}\text { Métodos globalizadores } \\
\text { (Decroly, Kilpatrick) } \\
\text { Fuente: elaboración propia. }\end{array}$ \\
\hline
\end{tabular}

Estos principios interpretativos recuerdan métodos globalizadores de enseñanza, donde los contenidos de aprendizaje y su organización en unidades didácticas sólo son relevantes en función de su capacidad para comprender una realidad que siempre se manifiesta globalmente (Tabla 34). Esta concepción fundamentalmente psicológica de la percepción humana y de la necesidad de suscitar el interés de los alumnos es el primer desencadenante de los métodos globalizadores (Zabala, 1995). Ejemplo de ellos son:

- Los centros de interés de Decroly (1871-1932). Este método se sustenta, entre otros puntos, en partir de un programa motivador con ideas ejes para el alumno y siguiendo el proceso de observación, asociación y expresión, integra diferentes áreas del conocimiento (Zabala, 1995; Fernández, 2009). Este modelo considera que el niño posee una percepción confusa e indiferenciada de la totalidad de las cosas y no de las partes. Pero para que la función de la globalización se ponga en marcha hace falta un móvil: el interés del niño. Pero el niño sólo sentirá ganas de conocer la nueva realidad si se siente atraído por ella (Fernández, 2009).

- El método de proyectos de Kilpatrick, que consiste, básicamente, en la elaboración y producción de algún objeto o montaje (una máquina, un audiovisual, un terrario, un huerto escolar, un periódico, etc.). El punto de partida del método de proyectos es el interés y el esfuerzo. El docente tendrá que aprovechar las energías individuales, naturalmente dispersas, canalizarlas e integrarlas hacia un objetivo concreto (Zabala, 1995).

En este principio, Beck y Cable (1998) consideran que la interpretación debe ir dirigida al individuo como un todo y por lo tanto se entrelaza con la teoría de Gardner (1987), al considerar que es necesario abordar la enseñanza de una manera integral que incluya las diferentes inteligencias que poseen las personas y no hacer hincapié en las culturalmente más 
desarrolladas (lingüística y lógico-matemática) en detrimento de las restantes (espacial, musical, cinético-corporal, intrapersonal, interpersonal y naturalista).

Lo prioritario en la Interpretación del Patrimonio, es ofrecer un todo en lugar de una parte, por más que esa porción pueda resultar interesante. Esto se conseguirá analizando las características del área a interpretar y buscando un hilo conductor que guíe la visita (Tilden, 2006) o si no se puede confundir al visitante con el cúmulo de información. En este sentido Veverka (1994) afirma que es necesario esforzarse para lograr un mensaje unitario - utilizar los colores adecuados, el estilo del diseño, la música etc. (puesta en escena)- para apoyar la presentación integral del mensaje y que debemos referirnos a la totalidad; ilustrar el modo en que esta interpretación forma parte de un todo mayor.

\subsection{6) Adecuar el mensaje a la edad del grupo}

Tabla 35. Sexto Principio Interpretativo y su relación con la educación.

\begin{tabular}{|c|c|c|}
\hline Tilden (1957) & Beck y Cable (1998) & Educación \\
\hline $\begin{array}{l}\text { La interpretación dirigida a los niños (digamos, } \\
\text { hasta los doce años) no debe ser una dilución } \\
\text { de la presentación a los adultos, sino que debe } \\
\text { seguir un enfoque básicamente diferente. Para } \\
\text { obtener el máximo provecho, necesitará un } \\
\text { programa específico. }\end{array}$ & $\begin{array}{l}\text { La interpretación para niños, } \\
\text { adolescentes y adultos - } \\
\text { cuando éstos constituyen } \\
\text { grupos homogéneos- } \\
\text { debería aplicar enfoques } \\
\text { diferentes. }\end{array}$ & 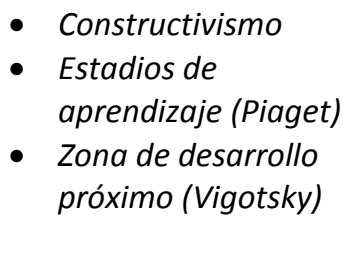 \\
\hline
\end{tabular}

En Interpretación es recomendable adecuar los conceptos al nivel de desarrollo cognitivo de las personas (Tabla 35). Piaget marca ese desarrollo cognitivo en una serie de etapas y subetapas por las cuales atraviesan los niños hasta llegar a la adolescencia: la primera es la sensorio motriz (0-2 años, la inteligencia es práctica y se relaciona con la resolución de problemas a nivel de acción); la segunda es la etapa preoperatoria (2-7 años, el niño adquiere capacidad para manejar el mundo de manera lógica o mediante representaciones como el juego simbólico o imágenes mentales); la tercera es el estadio de las operaciones concretas (712 años, el niño empieza a utilizar operaciones mentales y la lógica para reflexionar sobre los hechos y objetos de su ambiente), y la última, la etapa de las operaciones formales o abstractas (a partir de la adolescencia, aparece la lógica formal y la capacidad de verificar hipótesis de manera exhaustiva y sistemática); teniendo cada una de ellas una edad predefinida y características propias. Para Vigotsky, el desarrollo cognitivo depende en gran medida de las relaciones con las personas que están presentes en el mundo del niño y las herramientas (lenguaje, números, sistemas de normas sociales, etc.) que la cultura le otorga para apoyar el pensamiento. Los niños adquieren conocimientos, ideas, actitudes y valores a 
partir del trato con los demás. Las herramientas reales y simbólicas desempeñan funciones muy importantes en el desarrollo cognitivo (Mendiburu, 2001). Por lo que para Piaget la potencialidad cognitiva del sujeto depende de la etapa del desarrollo en que la se encuentre, para Vigotsky depende de la calidad de la interacción social y de la zona de desarrollo próximo.

Para planificar la Interpretación según grupos etarios es necesario considerar que los niños tienen rangos de atención diferentes según su edad, así como intereses y curiosidades que el intérprete tiene que potenciar, mientras las personas de la tercera edad pueden constituir un público particularmente interesado en aprender y profundizar debido a la experiencia que han acumulado. Claramente, interpretar para grupos de edades heterogéneas es un reto especial. Por ejemplo, los términos más abstractos serán explicados de una forma que puedan ser comprendidos por niños. En estos casos es conveniente utilizar analogías y comparaciones en la elaboración de mensajes interpretativos, como así también intercalar preguntas para que la audiencia responda (Ham, 1992; Carcavilla et al., 2007). Tales estrategias discursivas son recomendadas para el fortalecimiento del aprendizaje significativo ya que las analogías potencian el enlace entre conocimientos previos y la información que se ha de aprender (mejorar las conexiones externas), mientras que las preguntas intercaladas en un mensaje oral o escrito orientan y mantienen la atención (Díaz y Hernández, 1999). A su vez, en muchas situaciones las ilustraciones permiten explicar de manera comprensiva procesos o conceptos complejos para la mayoría de las personas, sobre todo para el público infantil. La Tabla 36 muestra las etapas del desarrollo infantil con ejemplos de propuestas de interpretación según las mismas.

Tabla 36. La Interpretación y el desarrollo infantil.

\begin{tabular}{|c|l|l|}
\hline Edad & \multicolumn{1}{|c|}{ Etapa de desarrollo y capacidades } & \multicolumn{1}{c|}{ Tipo de Interpretación a que apelar } \\
\hline $\begin{array}{c}\mathbf{0 - 2} \\
\text { años }\end{array}$ & $\begin{array}{l}\text { Desarrolla patrones de pensamiento, } \\
\text { principalmente con los sentidos y el movimiento. }\end{array}$ & $\begin{array}{l}\text { Actividades de repetición, estímulos de } \\
\text { color, sonido, tacto. }\end{array}$ \\
\hline $\begin{array}{c}\text { 2-7 } \\
\text { años }\end{array}$ & $\begin{array}{l}\text { El desarrollo del lenguaje se centra en un aspecto } \\
\text { a la vez. }\end{array}$ & $\begin{array}{l}\text { Juegos, experiencias repetidas, identificar } \\
\text { y emparejar cosas, experimentar cosas } \\
\text { reales, desarrollo de la comprensión } \\
\text { simple. }\end{array}$ \\
\hline $\begin{array}{c}\text { 7-11 } \\
\text { años }\end{array}$ & $\begin{array}{l}\text { Desarrollo de una mayor profundidad de } \\
\text { significados. Mayor capacidad de atención. } \\
\text { Creación de propios significados de las } \\
\text { experiencias. }\end{array}$ & $\begin{array}{l}\text { Actividades relacionadas con la } \\
\text { exploración. } \\
\text { Facilidad a participar en actividades. } \\
\text { Experiencias que aprovechen el } \\
\text { desarrollo de la coordinación motora } \\
\text { fina. }\end{array}$ \\
\hline $\begin{array}{c}\text { Mayor } \\
\text { a 11 } \\
\text { años }\end{array}$ & $\begin{array}{l}\text { Capacidad de formular hipótesis y comprender } \\
\text { conceptos abstractos. } \\
\text { Resolución de problemas más complejos. } \\
\text { Posibilidad de distracción y aburrimiento con } \\
\text { facilidad. }\end{array}$ & $\begin{array}{l}\text { Las actividades participativas son las } \\
\text { mejores } \\
\text { Descubrimiento y exploración; desafíos, } \\
\text { competencias. }\end{array}$ \\
\hline Fuente: modificado de Colquhoun, 2005.
\end{tabular}


Como se describió en el Capítulo 2, Tilden (2006) considera importante trabajar el interés por lo superlativo por parte de los niños. Recordemos que muchas veces las personas se acuerdan de la montaña más elevada del mundo, el río más largo, el país más poblado, etc. En estos ejemplos es necesario aclarar que, si bien muchas personas pueden recordar el río más largo o la montaña más elevada, la Geografía escolar no puede quedar reducida a la enumeración de tales datos; una sugerencia didáctica válida, es que el docente utilice tal información como disparador para desarrollar la unidad didáctica.

\section{4) Vinculación con actividades turísticas.}

En las últimas décadas el turismo se ha transformado en una de las actividades económicas más productivas a nivel internacional. Sin embargo, también ha evidenciado que, sin una adecuada planificación, sus beneficios socioeconómicos son reducidos e incluso causan grandes problemas a las regiones y a sus pobladores. Esto explica el surgimiento de variantes en conceptos y prácticas turísticas que promueven la conservación del lugar, el bienestar de los residentes y la calidad de la experiencia para los visitantes, como el turismo sostenible, el geoturismo y el ecoturismo. La evolución de estos conceptos (Tabla 37) está emparejada con el desarrollo de la relación entre el turismo y el ambiente.

Tabla 37. Evolución de la relación entre el turismo y el ambiente.

\begin{tabular}{|c|c|c|c|c|c|c|c|}
\hline Década & 1950 & 1960 & 1970 & 1980 & 1990 & 2000 & 2010 \\
\hline Relación & Coexistencia & Conflicto & Simbiosis & Integración & Sostenibilidad & Especialización & Madurez \\
\hline Aspectos & & $\begin{array}{c}\text { Conciencia } \\
\text { ambiental; } \\
\text { turismo de } \\
\text { masas. }\end{array}$ & $\begin{array}{c}\text { Turismo como } \\
\text { herramienta } \\
\text { para la } \\
\text { conservación. }\end{array}$ & $\begin{array}{c}\text { Ecodesarrollo } \\
\text { Fuente: traducido de Dowling, 2013. }\end{array}$ & $\begin{array}{c}\text { Desarrollo } \\
\text { sostenible }\end{array}$ & $\begin{array}{c}\text { Turismo de vida } \\
\text { salvaje; } \\
\text { Geoturismo. }\end{array}$ & $\begin{array}{c}\text { Turismo } \\
\text { responsable }\end{array}$ \\
\hline
\end{tabular}

En una presentación conjunta (OMT-PNUMA, 2005), la Organización Mundial del Turismo y el Programa de las Naciones Unidas para el Medio Ambiente definen al Turismo Sostenible como el turismo que tiene en cuenta las repercusiones actuales y futuras, económicas, sociales y medioambientales para satisfacer las necesidades de los visitantes, de la industria, del entorno y de las comunidades anfitrionas, debiendo:

1) Dar un uso óptimo a los recursos ambientales, manteniendo los procesos ecológicos esenciales y ayudando a conservar los recursos naturales y la diversidad biológica. 
2) Respetar la autenticidad sociocultural de las comunidades anfitrionas, conservar sus activos culturales y arquitectónicos y sus valores tradicionales, y contribuir al entendimiento y la tolerancia intercultural.

3) Asegurar unas actividades económicas viables a largo plazo, que reporten a todos los agentes unos beneficios socio-económicos bien distribuidos.

El logro de un turismo sostenible es un proceso continuo y requiere un seguimiento constante de sus incidencias para introducir las medidas preventivas o correctivas que resulten necesarias. El turismo sostenible debe reportar también un alto grado de satisfacción a los turistas y representar para ellos una experiencia significativa, que fomente en ellos una conciencia de los problemas de la sostenibilidad y prácticas turísticas sostenibles. La definición aportada por la OMT recupera extractos de la conceptualización de Desarrollo Sostenible (Figura 49) presentes en el informe de 1987 de la Comisión Mundial sobre el Medio Ambiente y el Desarrollo (CMMAD, también conocido como el Informe Brundtland): el desarrollo sostenible es aquel que satisface las necesidades de la generación actual sin comprometer la capacidad de las generaciones futuras para satisfacer sus propias necesidades. La existencia de otras palabras, que a menudo se consideran como relacionadas con el turismo sostenible (Figura 50), es una complicación añadida ya que ninguna de ellas es sinónimo de él (Swarbrooke, 1998).

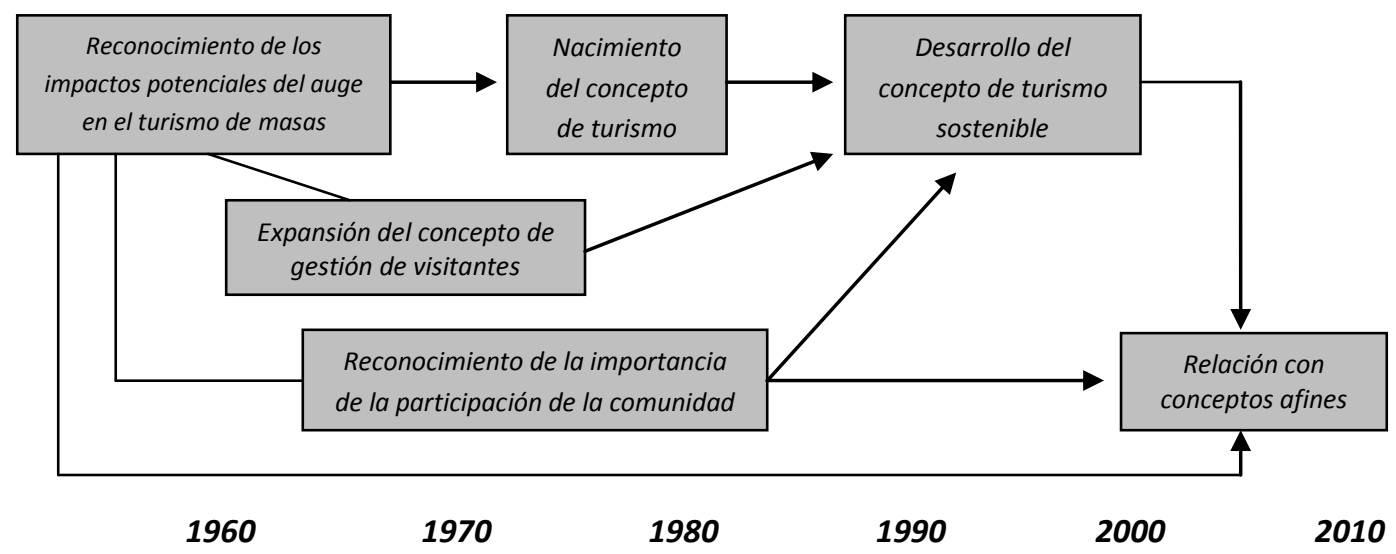

Figura 49. Evolución del concepto de Turismo Sostenible.

Fuente: modificado de Swarbrooke, 1998; Ruhanen-Hunter, 2006.

La gestión del turismo sostenible sólo puede ser exitosa si las interrelaciones entre las tres dimensiones que lo constituyen son plenamente reconocidas (Swarbrooke, 1998):

- el entorno, tanto el natural como el construido por el hombre,

- la vida económica de las comunidades y las empresas,

- el aspecto social del turismo, en términos del impacto en la cultura local como en los turistas, y la forma en que son tratados los empleados en el turismo. 


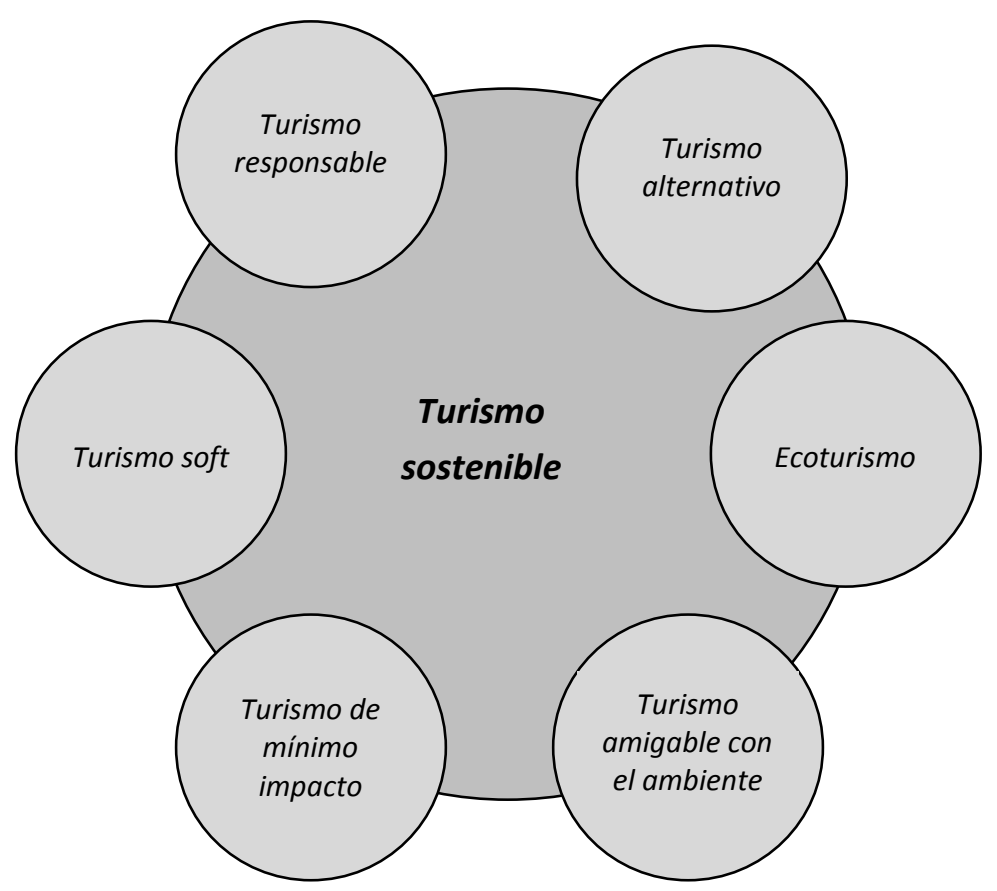

Figura 50. Relación del turismo sostenible con términos similares. Fuente: traducido de Swarbrooke, 1998.

Por su parte, el término ecoturismo surgió a finales de la década de 1980 como resultado directo del reconocimiento y la reacción a las prácticas sostenibles y prácticas ecológicas globales del mundo, por lo que mucha gente ve el ecoturismo y el turismo sostenible en estrecha relación. Si bien el origen del término en sí mismo es objeto de debate, la literatura académica señala a Ceballos-Lascurain como la persona responsable de acuñar el término en 1983 al definir el ecoturismo como un turismo responsable con el medio ambiente, con el fin de disfrutar y apreciar la naturaleza (y cualquier manifestación cultural tanto en el pasado y presente), y que promueve la conservación, tiene bajo impacto del visitante, y prevé una participación socioeconómica de las poblaciones locales. (Ceballos-Lascurain, 1996; Swarbrooke, 1998; Fennell, 2002). Dentro del mercado turístico el ecoturismo (Figura 51) se

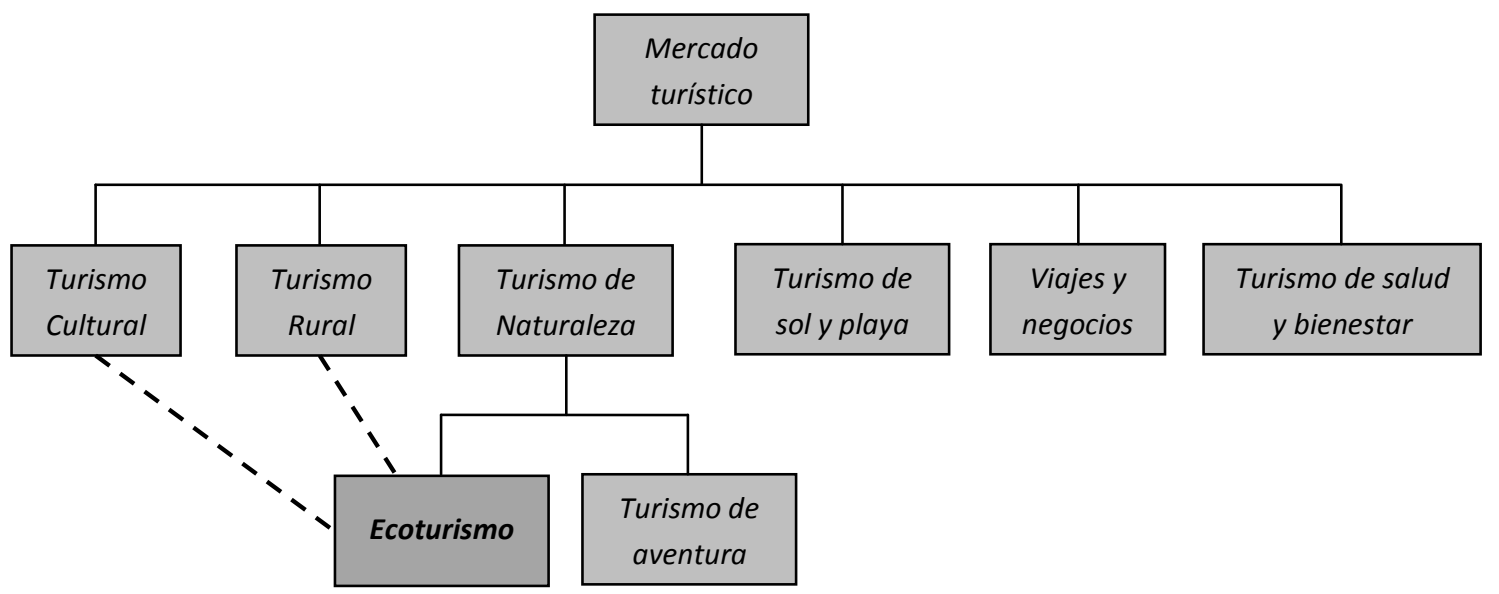

Figura 51. Modalidades del mercado turístico según la Organización Mundial del Turismo. Fuente: traducido de Wood, 2002. 
inscribe como un subcomponente del turismo de la naturaleza (al igual que el turismo de aventura) teniendo estrechos vínculos con el turismo rural y cultural (Wood, 2002).

Una amplia variedad de términos (Tabla 38) han sido adoptados por diferentes autores para promover conceptos afines al ecoturismo. La mayor parte de los mismos permanecen bastante vagos e indefinidos. Estos términos comparten algunos conceptos generales (en particular, ya que son una alternativa al turismo de masas), pero no son sinónimos. Algunos entraron en boga durante un corto período, pero ya no parecen estar en uso. Otros son comunes en el uso actual, pero tienen un significado diferente del término mismo de ecoturismo (Diamantis, 1999; Buckley, 2009).

Tabla 38. Términos relacionados al Ecoturismo.

\begin{tabular}{|c|c|}
\hline Términos & Significado \\
\hline $\begin{array}{l}\text { Geoturismo } \\
\text { (versión } \\
\text { geográfica) }\end{array}$ & $\begin{array}{l}\text { El geoturismo es un turismo que sustenta o enriquece el carácter geográfico de un } \\
\text { lugar y su ambiente, el patrimonio, la estética, la cultura y el bienestar de sus } \\
\text { habitantes. Uso propuesto por la National Geographic Society y que está } \\
\text { estrechamente relacionado con el ecoturismo. }\end{array}$ \\
\hline $\begin{array}{l}\text { Geoturismo } \\
\text { (versión } \\
\text { geológica) }\end{array}$ & $\begin{array}{l}\text { Turismo donde la atracción principal es una característica geológica, incluyendo un } \\
\text { paisaje espectacular. }\end{array}$ \\
\hline $\begin{array}{l}\text { Turismo } \\
\text { alternativo }\end{array}$ & $\begin{array}{l}\text { Término utilizado en la literatura académica de turismo para establecer una } \\
\text { distinción del turismo convencional o de masas; por lo tanto, significa cualquier } \\
\text { tipo de turismo con un pequeño mercado específico, o cualquier producto que } \\
\text { normalmente no puede ser reservado a través de un agente de viajes } \\
\text { convencional. }\end{array}$ \\
\hline $\begin{array}{l}\text { Turismo de } \\
\text { naturaleza }\end{array}$ & $\begin{array}{l}\text { El turismo de naturaleza integra el patrimonio natural con el turista. El primero } \\
\text { incluye la fauna y el hábitat (con sus características geológicas y paisajes), que } \\
\text { permiten la práctica deportiva de naturaleza y el conocimiento en parques y zonas } \\
\text { protegidas. Y el segundo se define por las motivaciones: bienestar físico, estímulo } \\
\text { intelectual, disfrute de la naturaleza, contacto con escenarios personalizados e } \\
\text { intimos. }\end{array}$ \\
\hline $\begin{array}{l}\text { Turismo } \\
\text { endémico }\end{array}$ & $\begin{array}{l}\text { Término poco utilizado y derivado de la biología y destinada a indicar cualquier } \\
\text { tipo de producto turístico donde la principal atracción ocurre sólo en un área en } \\
\text { particular. }\end{array}$ \\
\hline $\begin{array}{l}\text { Turismo } \\
\text { responsable }\end{array}$ & $\begin{array}{l}\text { Término poco utilizado, probablemente derivado por analogía con el cuidado } \\
\text { responsable. Iniciativa de la industria química y que se centra en aspectos sociales. }\end{array}$ \\
\hline Turismo soft & $\begin{array}{l}\text { Es un tipo de turismo compatible con un medio ambiente intacto que no pone en } \\
\text { peligro la identidad cultural de la región de acogida. Favorece un turismo para, por } \\
\text { y con los nativos (desarrollo turístico cauteloso y controlado por los residentes, } \\
\text { basado en las estructuras locales existentes y en recursos locales que puedan ser } \\
\text { regenerados). Este tipo de desarrollo turístico está estrechamente relacionado con } \\
\text { sectores productivos como la agricultura y el comercio local. }\end{array}$ \\
\hline $\begin{array}{l}\text { Turismo } \\
\text { sostenible }\end{array}$ & $\begin{array}{l}\text { Indica el tipo de turismo que cumple con los principios de desarrollo sostenible. Se } \\
\text { refiere en términos generales a la gestión ambiental en la industria del turismo de } \\
\text { masas y que no se limita al ecoturismo. Concepto adoptado por la OMT. }\end{array}$ \\
\hline Turismo verde & $\begin{array}{l}\text { En principio, término esencialmente utilizado como sinónimo de ecoturismo, pero } \\
\text { nunca muy bien definido. }\end{array}$ \\
\hline
\end{tabular}


La Declaración de Quebec sobre el Ecoturismo (2002) reconoce que esta modalidad turística abraza los principios del turismo sostenible en relación con los impactos económicos, sociales y medioambientales del turismo, al mismo tiempo de adherir a los siguientes principios específicos y que lo diferencian del más amplio concepto de turismo sostenible: contribuir a la conservación del patrimonio natural y cultural, incluir a las comunidades locales en su planificación, desarrollo y explotación (contribuyendo a su bienestar), interpretar el patrimonio natural y cultural del destino para los visitantes (siendo pertinente a viajeros independientes, así como a los circuitos organizados para grupos reducidos) e incrementar la sensibilización de los viajeros respecto a la conservación del patrimonio natural y cultural.

Tras una revisión de la literatura sobre el tema (Ceballos-Lascurain, 1996; Swarbrooke, 1998; Diamantis, 1999; Fennell, 2002; Edwards et al., 2003; Ham, 2003; Donohoe y Needham, 2006; Weaver y Lawton, 2007; Buckley, 2009; Gale y Hill, 2009; Dowling, 2013), se identifican tres aspectos principales relativos al mismo. En primer lugar, el ecoturismo se ha transformado en la última década debido a la aparición de nuevos segmentos de interés en esta actividad (como la observación de ballenas y el turismo antártico) y a procesos de difuminación de las fronteras entre el ecoturismo y otras formas de turismo; esto último puede ocasionar problemas de comercialización y superposición en el desarrollo de productos turísticos. En segundo lugar, hay un esfuerzo para comprender los impactos del ecoturismo en aspectos ecológicos, económicos y éticos, por ejemplo llevando a cabo investigaciones sobre el ecoturismo y el turismo de masas, con el fin de identificar las medidas preventivas necesarias para evitar que el ecoturismo se convierta en un fenómeno de ecoturismo de masas (Diamantis, 1999). En tercer lugar, la literatura refleja y revela una profunda brecha Norte-Sur dentro del propio sector, ya que existen estudios de casos de modelos ecoturísticos basados en la comunidad dominados por ejemplos de países menos desarrollados, mientras que los estudios de caso de mercados y de la industria turística provienen en su mayoría de países más desarrollados, al igual que la autoría de la mayor parte de la literatura sobre ecoturismo (Weaver y Lawton, 2007). En cuanto a la delimitación del su campo de acción, estos mismos autores observan que las definiciones disponibles sobre ecoturismo cohesionan en torno a tres criterios: (1) es una fuerza positiva para la conservación (con énfasis en la protección y la perpetuación de los paisajes y características que atraen a los turistas, (2) beneficia de manera económica a las comunidades de acogida y (3) promueve la conciencia ambiental, tanto entre los turistas como en las comunidades locales (Edwards et al., 2003). Otros criterios son: (1) basado en la naturaleza, (2) la preservación/conservación; (3) educación, (4) sostenibilidad, (5) la distribución de los beneficios, y (6) desarrollo de una ética/responsabilidad/conciencia 
(Donohoe y Needham, 2006). Esta recurrencia de ideas se presenta como un marco conceptual para el desarrollo de las políticas sobre el tema y definen de manera ideológica al ecoturismo (Ham, 2003).

El Ecoturismo se concentra en los ambientes naturales que están menos modificados por causa antrópica, lo que provoca que en muchos de estos destinos esta modalidad turística sea la única forma visible de actividad económica. El desarrollo del ecoturismo puede proporcionar una herramienta útil dentro de un abanico de estrategias más amplias hacia un turismo más sostenible. En esto se encuentra el primer reto para el ecoturismo: seguir siendo una forma atractiva de turismo encarnado por principios educativos y de sostenibilidad (Diamantis, 1999).

Finalmente, en el caso del Geoturismo, el uso más antiguo del término se registra como abreviatura del concepto turismo geológico (Buckley, 2003), pero al realizar la lectura de la Tabla 39, se advierte que no existe un acuerdo sobre la definición de Geoturismo y que la misma tiene a la Geología y a la Geografía como principales marcos teóricos. Algunos autores (Hose, 1995; Słomka y Kicińska -Swiderska, 2004; Dowling y Newsome, 2006; Ruchkys, 2007; Carcavilla et al., 2011) consideran el término geoturismo colocando su énfasis en los elementos geológicos, mientras que otros lo relacionan con aspectos geográficos (National Geographic Society, 1997; Stokes et al., 2003), bien como un segmento del ecoturismo (Fennell, 2003), del turismo sostenible (Drew, 2003; Dowling y Newsome, 2006) o una combinación de ambos (Buckley, 2003).

Tabla 39. Definiciones de Geoturismo.

\begin{tabular}{|l|l|}
\hline \multicolumn{1}{|c|}{ Autores/año } & \multicolumn{1}{c|}{ Definición } \\
\hline Hose, 1995 & $\begin{array}{l}\text { Provisión de los servicios de interpretación e instalaciones, con el fin de } \\
\text { permitir a los turistas adquirir el conocimiento y la comprensión de sitios } \\
\text { geológicos y geomorfológicos. }\end{array}$ \\
\hline $\begin{array}{l}\text { National Geographic } \\
\text { Society, 1997 }\end{array}$ & $\begin{array}{l}\text { El geoturismo es un turismo que sustenta o enriquece el carácter geográfico de } \\
\text { un lugar y su ambiente, el patrimonio, la estética, la cultura y el bienestar de } \\
\text { sus habitantes. }\end{array}$ \\
\hline Buckley, 2003 & $\begin{array}{l}\text { Geoturismo no es una definición nueva, sino simplemente una forma de } \\
\text { combinar el concepto de sostenibilidad con el desarrollo de conceptos de } \\
\text { segmentación del mercado turístico. }\end{array}$ \\
\hline Fennell, 2003 & $\begin{array}{l}\text { Geoturismo puede constituir un segmento del ecoturismo. Es una forma } \\
\text { sostenible de turismo basado en los recursos naturales que se centra } \\
\text { principalmente en experimentar y aprender sobre la naturaleza. Es gestionado } \\
\text { éticamente para ser de bajo impacto, no consumista y localmente orientado } \\
\text { (control, beneficios y escala). Por lo general ocurre en áreas naturales, y debe } \\
\text { contribuir a la conservación o preservación de dichas áreas }\end{array}$ \\
\hline Reynard, 2003 & $\begin{array}{l}\text { Conjunto de prácticas, infraestructura y productos, encaminado a aunar las } \\
\text { Ciencias de la Tierra con el turismo. }\end{array}$ \\
\hline Stokes et al., 2003. & $\begin{array}{l}\text { El geoturismo es un nicho de mercado emergente en el turismo sostenible y se } \\
\text { centra en mantenery mejorar el carácter geográfico de un lugar. }\end{array}$ \\
\hline $\begin{array}{l}\text { Stomka y y kicińska rama del turismo cognitivo y / o turismo de aventura basado en visitas } \\
\text { Swiderska, 2004 }\end{array}$ & $\begin{array}{l}\text { Es una rementos geológicos (Lugares de Interés Geológico) y el reconocimiento de } \\
\text { a elementom }\end{array}$ \\
\hline
\end{tabular}




\begin{tabular}{|c|c|}
\hline & $\begin{array}{l}\text { procesos geológicos integrados con experiencias estéticas obtenidas por el } \\
\text { contacto con el Geositio. }\end{array}$ \\
\hline Pralong, 2006 & $\begin{array}{l}\text { El geoturismo es una especie de turismo que explota, de un modo didáctico y } \\
\text { entretenido, espacios naturales y paisajes que contienen interesantes rasgos } \\
\text { para las ciencias de la tierra. }\end{array}$ \\
\hline Frey et al., 2006. & $\begin{array}{l}\text { El geoturismo es un nuevo sector profesional y empresarial. Las principales } \\
\text { tareas del geoturismo son la transferencia y difusión de conocimientos e ideas } \\
\text { geo- científicos para el público en general. }\end{array}$ \\
\hline $\begin{array}{l}\text { Dowling y Newsome, } \\
2006 .\end{array}$ & $\begin{array}{l}\text { El geoturismo es el turismo sostenible con un enfoque principal en } \\
\text { experimentar las caracteristicas geológicas de la Tierra de una manera que } \\
\text { fomenta la comprensión ambiental y cultural, la valoración y la conservación. } \\
\text { Es beneficiosa a nivel local. }\end{array}$ \\
\hline Ruchkys, 2007. & $\begin{array}{l}\text { El geoturismo es un segmento de la actividad turística que tiene al patrimonio } \\
\text { geológico como principal atractivo y busca la protección por medio de la } \\
\text { conservación de sus recursos y de la sensibilización del turista, utilizando la } \\
\text { interpretación para volver este patrimonio accesible al público lego y promover } \\
\text { la divulgación y desarrollo de las Ciencias de la Tierra. }\end{array}$ \\
\hline James y Hose, 2008 & $\begin{array}{l}\text { Geoturismo comprende formas y procesos de los elementos geológicos, en } \\
\text { combinación con los componentes del turismo, tales como atracciones, } \\
\text { alojamiento, excursiones, actividades, interpretación, planificación y gestión. }\end{array}$ \\
\hline Voth, 2008. & $\begin{array}{l}\text { El término geoturismo no puede ser reducido a un turismo geológico. Se trata } \\
\text { de un concepto más amplio, orientado en un marketing y uso turístico del } \\
\text { potencial paisajistico y de las peculiaridades regionales relacionadas con la } \\
\text { historia de la Tierra. }\end{array}$ \\
\hline Sadry, 2009. & $\begin{array}{l}\text { El geoturismo es un tipo de turismo basado en el conocimiento, conservación e } \\
\text { interpretación de los atributos abióticos de la naturaleza y su integración } \\
\text { interdisciplinar en la industria del turismo, buscando acercar los lugares de } \\
\text { interés geológico al público general además de mostrar aspectos culturales } \\
\text { con ellos relacionados. }\end{array}$ \\
\hline $\begin{array}{l}\text { Newsome y Dowling, } \\
2010 .\end{array}$ & $\begin{array}{l}\text { El geoturismo es una forma de turismo de un área natural que se centra } \\
\text { específicamente en la geología y el paisaje. Promueve el turismo en sitios } \\
\text { geológicos y la conservación de la geodiversidad y la comprensión de las } \\
\text { ciencias de la tierra a través de la apreciación y el aprendizaje. Esto se } \\
\text { consigue a través de visitas a los sitios geológicos, el uso de geo-senderos, } \\
\text { miradores, visitas guiadas, geoactividades y el apoyo a centros de visitantes en } \\
\text { los Geositios. }\end{array}$ \\
\hline Carcavilla et al., 2011. & $\begin{array}{l}\text { El geoturismo se basa en la utilización del patrimonio geológico como recurso } \\
\text { por su interés científico, naturalístico, cultural, recreativo y didáctico. La } \\
\text { existencia de elementos geológicos patrimoniales en una región puede } \\
\text { constituir un recurso que favorezca el desarrollo social, económico e incluso } \\
\text { cultural de la sociedad. }\end{array}$ \\
\hline $\begin{array}{l}\text { Declaración de Arouca, } \\
2011\end{array}$ & $\begin{array}{l}\text { Es un turismo que sustenta y mejora la identidad de un territorio, considerando } \\
\text { su geología, medio ambiente, cultura, valores estéticos, patrimonio y bienestar } \\
\text { de sus residentes. El turismo geológico se asume como uno de los diversos } \\
\text { componentes del geoturismo. }\end{array}$ \\
\hline Hose, 2012 & $\begin{array}{l}\text { Es la prestación de servicios de interpretación para sitios geológicos, } \\
\text { geomorfológicos y la topografía que abarcan sus artefactos asociados in situ y } \\
\text { ex situ, para su conservación generando reconocimiento, aprendizaje e } \\
\text { investigación, por y para las generaciones actuales y futuras. }\end{array}$ \\
\hline Newsome et al., 2012. & $\begin{array}{l}\text { Geoturismo se refiere a menudo como una forma de turismo basado en la } \\
\text { naturaleza, que se centra principalmente en el geosistema (Newsome y } \\
\text { Dowling, 2010; Gray, 2011). Al hacerlo, se promueve y desarrolla el turismo a } \\
\text { los sitios de interés geológico. }\end{array}$ \\
\hline \multicolumn{2}{|c|}{$\begin{array}{l}\text { Fuente: elaboración propia en base a NGS, 1997; Pralong, 2004; Voth, 2008; Allan, 2011; Carcavilla et al., 2011; } \\
\text { Farsani, 2012; Hose, } 2012 .\end{array}$} \\
\hline
\end{tabular}


Pralong (2006) considera al Geoturismo como parte del turismo de naturaleza, debido a su esencia y dado que su componente práctica requiere un marco natural (aunque presente actividades en lugares cerrados como centros de interpretación) y del turismo cultural, cuya motivación principal es la búsqueda de conocimiento y emociones a través del descubrimiento del patrimonio y su territorio (Figura 52). Mientras que para Dowling (2010), se trata de un enlace con el ecoturismo, el turismo cultural y el turismo de aventura, pero no es sinónimo de cualquiera de estas formas de turismo (Figura 53).

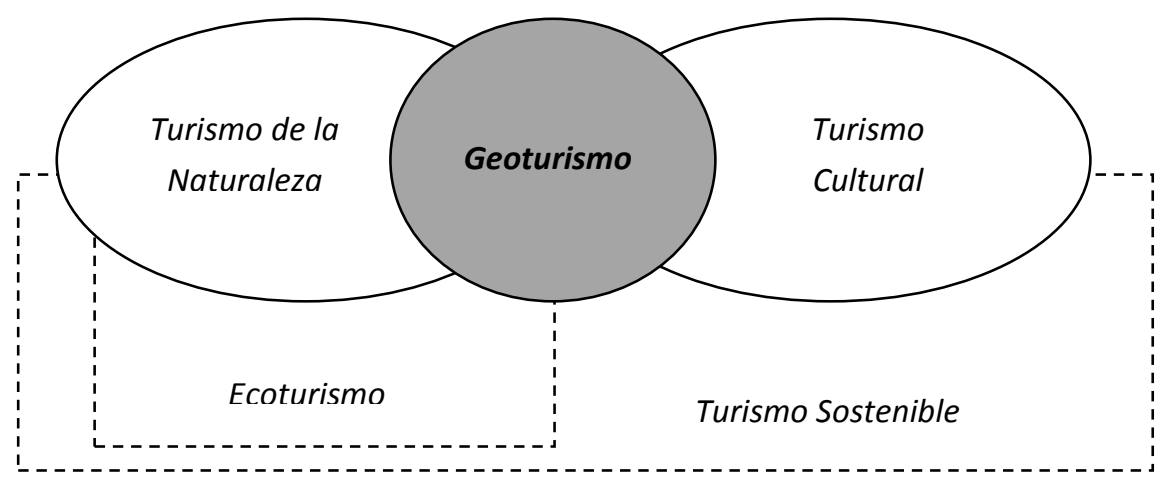

Figura 52. El Geoturismo y su relación con formas de turismo "natural" y "cultural". Las proporciones del solapamiento de los diferentes elementos tienen sólo una justificación gráfica y no traducen la importancia efectiva de las interacciones Fuente: traducido de Pralong, 2006.
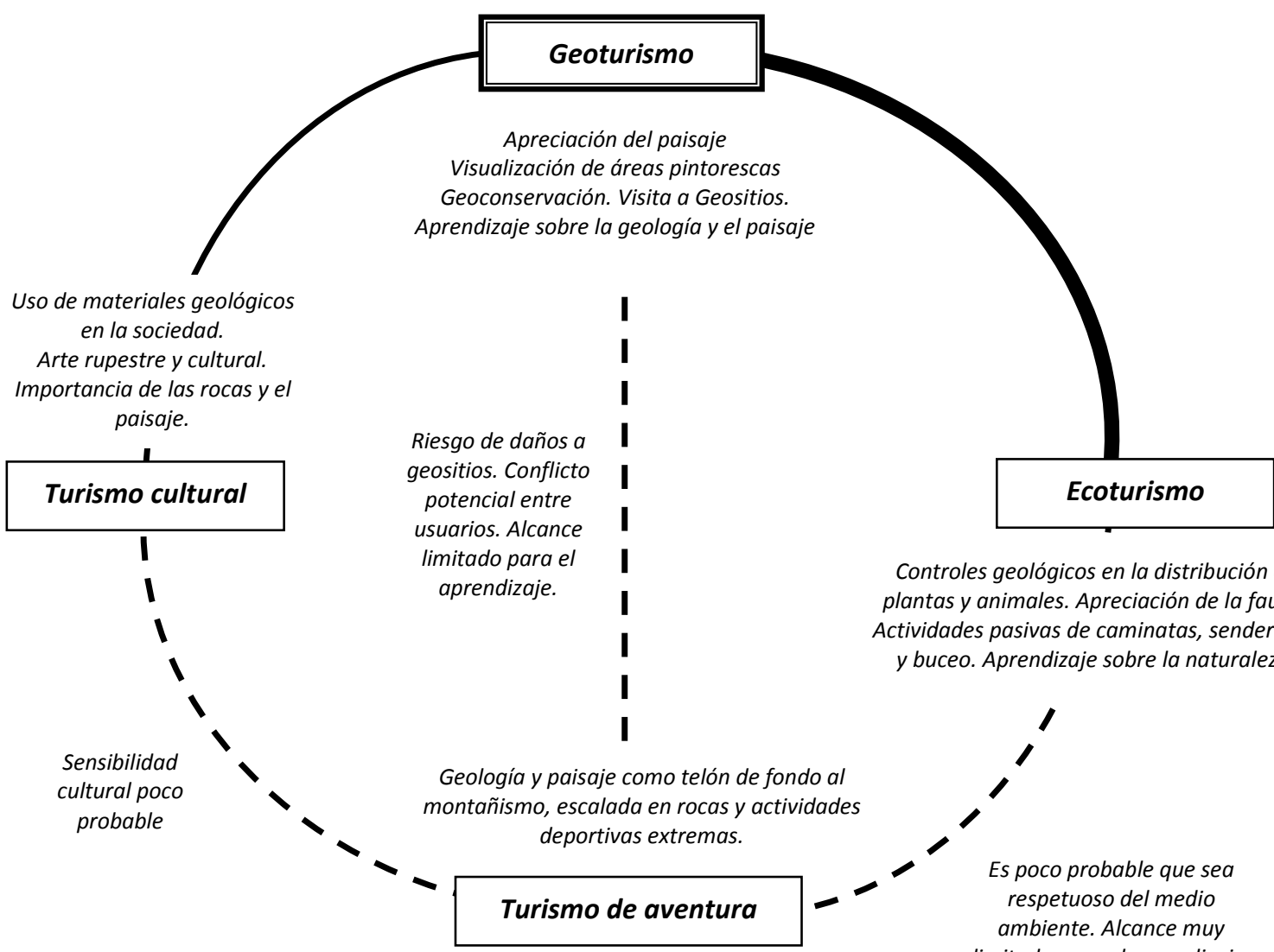

Controles geológicos en la distribución de plantas y animales. Apreciación de la fauna. Actividades pasivas de caminatas, senderismo y buceo. Aprendizaje sobre la naturaleza.

Figura 53. Relaciones del Geoturismo y otras formas de turismo.

Las líneas continuas y de puntos representan las interconexiones. La conexión entre el ecoturismo y geoturismo se representa como una relación particularmente fuerte. 
Realizando una revisión de las definiciones sobre Geoturismo, se observa que las enunciadas por Hose (1995, 2012), Buckley (2003), Pralong (2006), Voth (2008) se mezclan con otras formas de turismo profundizando el alcance del geoturismo como fenómeno multidimensional. La definición de la National Geographic Society (NGS, 1997), por su parte, anima a encontrar aquello que distingue y diferencia a un sitio: sentido de lugar, para enfatizar el carácter distintivo de su entorno local y beneficiar a los visitantes y residentes por igual, a través de un enfoque holístico que proporciona un efecto sinérgico no disponible en otras formas de turismo. Si bien la principal diferencia en las definiciones de esta actividad es determinar los fenómenos (geográficos o geológicos) con los que planificar el servicio turístico, los principales defensores de estos puntos de vista (National Geographic Society, 1997; Dowling, 2010, respectivamente) presentan puntos en común: es una actividad sostenible (económicamente viable y compatible con la integridad del lugar), que mejora y fomenta la conservación de los recursos y con beneficios en la comunidad (económicos, sociales) y en los visitantes (satisfacción turística). Por lo tanto, en lugar de debatir las diferencias sobre los fenómenos geológicos o geográficos que atiende esta actividad, lo mejor es ver el geoturismo como una forma holística de turismo sostenible (Boley, 2009) que incorpora temas de distintos tipos de segmentos de turismo sostenible, como el turismo rural integrado, el turismo del patrimonio cultural, el turismo basado en la comunidad y el ecoturismo (Figura 54).

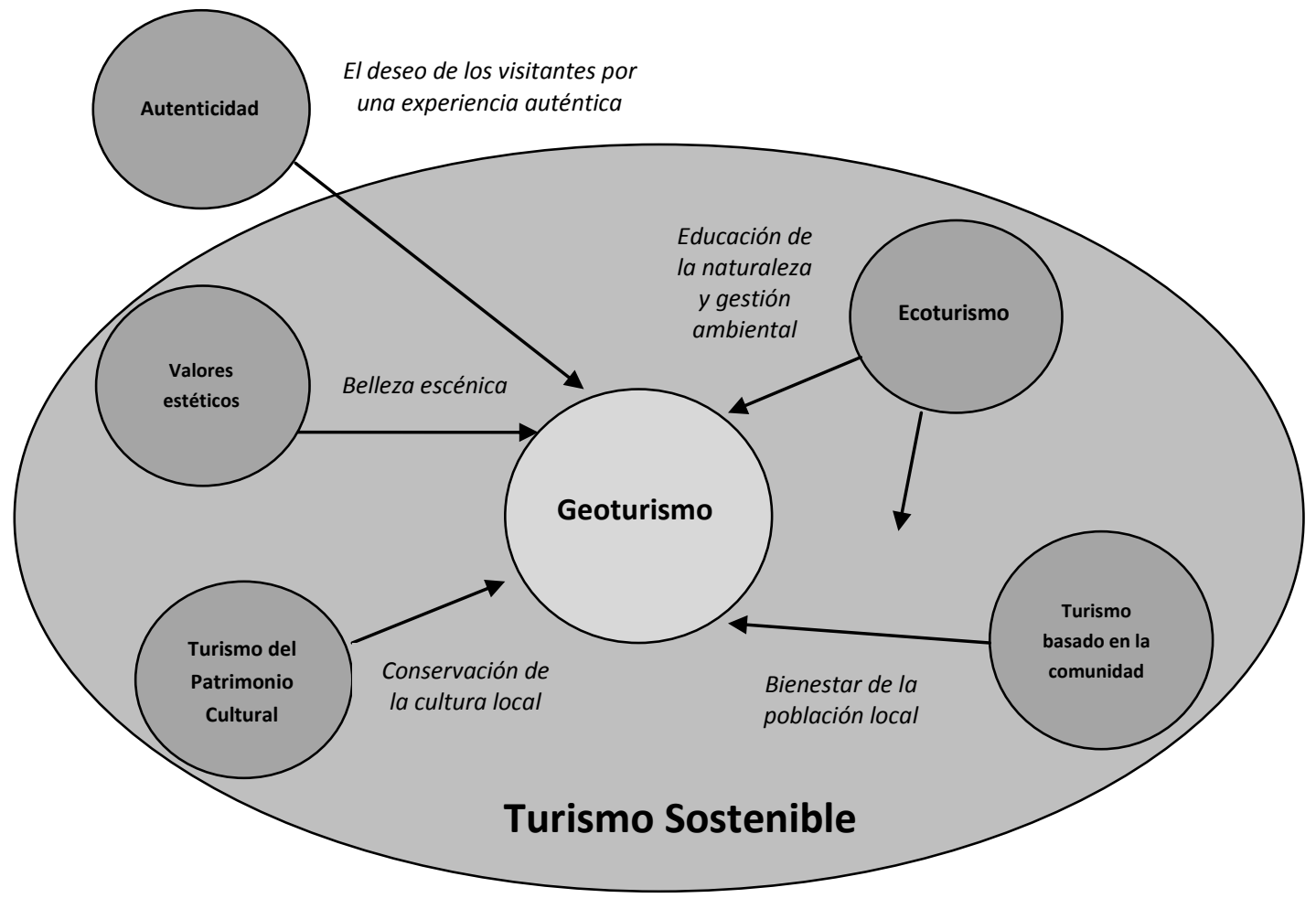

Figura 54. El lugar del Geoturismo en el Turismo Sostenible.

Fuente: traducido de Boley, 2009. 
Más allá de tratarse de una actividad de geoturismo, ecoturismo o de turismo sostenible, las buenas relaciones con la Interpretación del Patrimonio son evidentes ya que el turista enriquece su experiencia merced a un buen conocimiento del lugar que visita, y el emisor, con una buena comunicación, mejora la calidad de su producto (Ruiz, 2010), además de contribuir a evitar el deterioro del patrimonio, controlar el impacto de los visitantes de zonas y elementos patrimoniales (Ham y Krumpe, 1996) y colaborar a atemperar los sentimientos de la población local contra los turistas (Guerra et al., 2008).

Un producto interpretativo bien diseñado y presentado puede aumentar el conocimiento de la zona, fomentando actitudes de apoyo para la gestión de los recursos (Powell y Ham, 2008). Esto corrobora que si se ofrece a las personas un estímulo agradable, muy pertinente y de fácil acceso, todas van a ser atraídas a él (Ham, 2003). Estas mismas tres cualidades son utilizadas por los turistas para describir una experiencia satisfactoria en una visita guiada. EI conocimiento de las prácticas ambientales y experiencias satisfactorias en centros de turismo puede reforzar las actitudes ambientales favorables de los visitantes, lo que aumentaría su interés en nuevas experiencias de este tipo, logrando su objetivo educativo a través de estos efectos acumulativos (Lee y Moscardo, 2005). A su vez, la implementación de programas interpretativos influye en la autopercepción de conocimientos ambientales (Madin y Fenton, 2004) y en la necesidad de una alta calidad de geo-interpretación de los recursos naturales (Newsome et al., 2012) en visitantes a áreas protegidas pudiendo cambiar la comprensión del tema y cuestiones claves del mismo.

\section{5) Consideraciones finales}

De acuerdo a los temas analizados se puede considerar a la Interpretación del Patrimonio como una estrategia de intervención importante para llegar a públicos determinados con mensajes potencialmente influyentes, donde las teorías cognitivas y de la conducta proporcionan una guía útil para la toma de decisiones, no sólo en el desarrollo de los temas y enfoques de comunicación, sino también para evaluar la efectividad de la misma.

Dentro del ámbito educativo, durante muchos años se consideró a la Interpretación del Patrimonio como un aspecto de la Educación Ambiental, pero no es conveniente tratarla como tal, ya que presenta características que la dotan de una singularidad y es utilizada para alcanzar objetivos educativos más generales o de otros campos científicos. Un factor de unidad pueden ser los propósitos que persiguen, ya que la interpretación y la educación ambiental se apoyen en principios casi idénticos y a veces superpuestos (Cable y Cadden, 2006). Como se desarrolló en este capítulo, existen trabajos que vinculan a la Interpretación del Patrimonio con 
teorías cognitivas y de comportamiento. Por ejemplo, cuando la interpretación provoca el pensamiento de una persona, se genera un conflicto cognitivo que, a su vez, produce nuevas creencias reforzando o modificando las ideas previas. Según estudios sobre la teoría del comportamiento planificado (TCP), para influir en un comportamiento sería efectivo influir en las creencias que la gente posee acerca de tal comportamiento. Por lo tanto, la interpretación que provoca la formación de creencias positivas sobre los resultados de un determinado comportamiento dará lugar a una actitud positiva acerca de ese comportamiento. Cuando esto ocurre, la probabilidad de que un visitante se acople en el comportamiento deseado (si se presenta la oportunidad) es significativamente mayor (Ham, 2009b).

Respecto a la educación en general, son evidentes las coincidencias entre los principios interpretativos (Tilden, 2006; Cable y Beck, 1998) y teorías de aprendizaje y sugerencias didácticas. Tanto el docente como el intérprete necesitan conocer a quien va dirigido su mensaje (1 principio), reconociendo que existen diversas formas de construir el conocimiento en el interior de las personas (3o principio), las cuales pueden variar según la edad de las mismas (6 principio), siendo necesario atraer la atención del otro para que éste se interese en lo que está mirando o escuchando (4o principio), ofreciendo una comunicación de carácter globalizada (5o principio) y que la misma no sea sólo mera información (2o principio).

En el ámbito del turismo, la interpretación desempeña un papel significativo para ayudar a controlar su impacto sobre el medio y los recursos patrimoniales, potenciando los aspectos positivos y contribuyendo a limar los negativos (siempre y cuando esté bien planificada). En este sentido, los tres tipos de actividades turísticas mencionadas (geoturismo, ecoturismo y turismo sostenible) proponen que las comunidades, a través de criterios de sostentabilidad, redescubran y realcen su patrimonio cultural y natural, comprometiéndose con la transmisión al visitante de la conservación del entorno y de la cultura local.

De manera general se puede afirmar que la Interpretación del Patrimonio es una herramienta versátil para ser aprovechada tanto en la educación como en el turismo, ya que permite potenciar el mensaje a transmitir, al poner en práctica los descubrimientos de la psicología del comportamiento y estimular un uso turístico responsable de áreas protegidas, contribuyendo al fortalecimiento de una conciencia de preservación del entorno. 
La Interpretación del Patrimonio Geomorfológico en los Picos de Europa: una propuesta para su aprovechamiento didáctico y geoturístico 


\section{Capítulo 4}

\section{Lugares de Interés Geomorfológico (LIGm) y su aprovechamiento didáctico}

Para la aplicación práctica de los contenidos teóricos de Interpretación del Patrimonio desarrollados en los capítulos anteriores, se trabajará con los Lugares de Interés Geomorfológico (LIGm) del Parque Nacional de los Picos de Europa. En esta parte de la investigación, se hará una aproximación al desarrollo teórico y práctico de la valoración de LIGm, como así también se analizará la valoración didáctica que los métodos de valoración realizan de tales elementos geomorfológicos.

Existen sitios que por su importancia natural y/o cultural deben ser conservados y dados a conocer para el disfrute de las personas. Algunos de ellos hacen referencia a un aspecto de la naturaleza (eventos físicos, historia geológica, majestuosidad paisajística, procesos ecológicos, diversidad biótica), de la creación humana (cascos históricos de ciudades, testimonio de civilizaciones antiguas, edificios o conjuntos arquitectónicos relevantes) o presentan elementos de ambos.

Dentro de los elementos integrantes del Patrimonio Natural a conservar, existen clasificaciones que hacen referencia a la importancia geomorfológica de un territorio. Inicialmente este concepto podía ser considerado inserto en otros términos (geositios, geotopos, lugares de interés geológico, puntos de interés geológico, entre otros). Sin embargo, Panizza (2001) planteó la necesidad de diferenciarlos de aquellos cuyo interés es puramente geológico. Para este autor los geomorfositios son una forma de relieve a la cual se le puede atribuir un valor de tipo científico, ecológico, cultural, estético y/o socioeconómico. La mayoría de los paisajes geomorfológicos tienen más de un valor, que varían con las áreas y las culturas, y también evolucionan en el tiempo. En todo proceso de análisis, protección y optimización de geomorfositios ha de tenerse en cuenta este componente objetivo y subjetivo (Reynard, 2005). Serrano y González Trueba (2005) definen como Lugares de Interés Geomorfológico (LIGm) a todos aquellos elementos o lugares geomorfológicos de interés, inventariables, caracterizables y valorables desde tres puntos de vista: valor científico o intrínseco, valor cultural o añadido y valor de uso y gestión. 
Esta investigación se realiza sobre aspectos geomorfológicos, ya que éstos son visibles, se presentan en superficie y tienen importantes connotaciones espaciales en la conformación del paisaje, los usos humanos y los riesgos naturales, con un componente geográfico no que carecen los elementos puramente geológicos.

\section{1) Lugares de Interés Geomorfológico}

Los Lugares de Interés Geomorfológico (LIGm) pueden tener dimensiones y características variables, desde un elemento puntual como un bloque errático, hasta un lugar como un circo glaciar o una garganta fluvial, y pueden albergar varios elementos destacados y con notable entidad paisajística (González Trueba, 2006). Las primeras referencias al tema aparecieron durante la década de 1960 en el Reino Unido, pero hasta la década de 1980 no hay investigaciones para mejorar el conocimiento de los geomorfositios. La mayoría de los trabajos publicados provienen del Reino Unido, Italia, Suiza y Alemania (Pereira et al., 2007).

La valoración y evaluación de LIGm requiere el conocimiento de sus valores intrínsecos (contenido científico), de su vulnerabilidad al cambio derivada de su funcionalidad, dinámica natural, usos e impactos sobre él, de sus valores añadidos (contenido cultural), de la relación con el territorio en el que está inserto, y de la importancia escalar, relativa y absoluta (González Trueba y Serrano, 2008). Por lo tanto son los atributos presentes en estas formas geomorfológicas los que le dan valor y permiten que el relieve sea declarado de valor geomorfológico. En posteriores revisiones conceptuales, Reynard y Panizza (2007) consideran que los geomorfositios son formas de relieve que poseen un valor histórico, cultural, estético y/o socio económico, con un punto de vista evidentemente geográfico, debido a la percepción humana de los factores geológicos, geomorfológicos, históricos y sociales (Pralong, 2005).

Otro concepto que equivale a los presentados por Panizza (2001), Pralong (2005), Reynard (2005), Panizza y Reynard (2007) y González Trueba y Serrano $(2005,2008)$ es el de patrimonio geomorfológico. Este término refiere al conjunto de formas de relieve, suelos y depósitos correlativos que por sus características genéticas y de conservación, por su rareza u originalidad, por su grado de vulnerabilidad o por la forma en que se combinan espacialmente, evidencian un claro valor científico y son merecedoras de preservación (Ramos Pereira, 1995). A tales formas de relieve se les puede atribuir valor científico, estético, histórico, tangible, intangible (cultural), social o económico, en función de las percepciones de las personas o las necesidades de un determinado estudio (Hribar, 2010, en Erhartič y Zorn, 2012). La Tabla 40 recoge las principales definiciones de LIGm y términos relacionados a este concepto. 
Tabla 40. Definiciones de LIGm y términos similares.

\begin{tabular}{|c|c|c|}
\hline Términos & Autores y referencia & Definición. Valores y criterios de evaluación. \\
\hline $\begin{array}{l}\text { Bienes } \\
\text { geomorfológicos }\end{array}$ & $\begin{array}{l}\text { Panizza y Piacente, } \\
1993 ; \\
\text { Quaranta, } 1993\end{array}$ & $\begin{array}{l}\text { La evaluación puede ser de dos tipos: estética (intuitiva y por } \\
\text { tanto subjetiva) y científica (cuantitativa y objetiva) (Panizza } \\
\text { y Piacente, 1993). }\end{array}$ \\
\hline $\begin{array}{l}\text { Bienes } \\
\text { geomorfológicos }\end{array}$ & Carton et al., 1994 & $\begin{array}{l}\text { Los bienes geomorfológicos son evaluados a través de cuatro } \\
\text { tipos de atributos fundamentales: científicos, estéticos, } \\
\text { culturales y escénicos. En el caso del valor científico se } \\
\text { consideran cinco aspectos básicos: a) representatividad de } \\
\text { evolución geomorfológica, b) representatividad didáctica, c) } \\
\text { registro paleogeomorfológico, 4) rareza natural, d) función } \\
\text { ecológica, como soporte de un ecosistema. }\end{array}$ \\
\hline $\begin{array}{l}\text { Sitios } \\
\text { geomorfológicos }\end{array}$ & Hooke, 1994 & $\begin{array}{l}\text { Los sitios geomorfológicos se pueden evaluar a través de tres } \\
\text { aspectos fundamentales: 1) por la calidad para la } \\
\text { observación de procesos, 2) por su valor escénico y 3) por su } \\
\text { valor ecológico. }\end{array}$ \\
\hline $\begin{array}{l}\text { Geotopos } \\
\text { geomorfológicos }\end{array}$ & $\begin{array}{l}\text { Grandgirard, 1995, } \\
\text { 1997, } 1999\end{array}$ & $\begin{array}{l}\text { Se considerarían todos aquellos elementos con un valor } \\
\text { geomorfológico reconocido. Los geotopos deben ser } \\
\text { catalogados en un inventario que contenga todos aquellos } \\
\text { elementos y lugares representativos de la diversidad de } \\
\text { relieves del área estudiada (Grandgirard, 1995). }\end{array}$ \\
\hline Geotopos & $\begin{array}{l}\text { Strasser et al., } 1995 \\
\text { Grandgirard, } 1997, \\
\text { 1999; } \\
\text { Lugon y Reynard, } \\
2003,2004\end{array}$ & $\begin{array}{l}\text { Geotopos serían todos aquellos elementos geológicos y } \\
\text { geomorfológicos que presentan un valor científico de interés } \\
\text { para la comprensión de la Tierra, de los territorios y del } \\
\text { Clima. Los geotopos permiten comprender la evolución } \\
\text { espacio temporal de una región, la significación de los } \\
\text { procesos superficiales y la importancia de las rocas, en tanto } \\
\text { que elementos edificadores de paisajes (Strasser et al., 1995). }\end{array}$ \\
\hline $\begin{array}{l}\text { Sitios de Interés } \\
\text { Geomorfológico }\end{array}$ & Rivas et al., 1997 & $\begin{array}{l}\text { Estos sitios son definidos en base a su interés científico, } \\
\text { educativo y recreacional. }\end{array}$ \\
\hline Geomorfositios & $\begin{array}{l}\text { Panizza, } 2001 \\
\text { Reynard, } 2004\end{array}$ & $\begin{array}{l}\text { Un geomorfositio es una forma de relieve a la cual se le } \\
\text { puede atribuir un valor. El valor puede ser de tipo científico, } \\
\text { ecológico, cultural, estético y/socioeconómico. }\end{array}$ \\
\hline Geositio & Brilha, 2005 & $\begin{array}{l}\text { Un Geositio corresponde a un sitio donde se puede presentar } \\
\text { uno o más elementos de geodiversidad, geográficamente } \\
\text { bien delimitado y que presenta un valor singular desde un } \\
\text { punto de vista científico, pedagógico, cultural, turístico u } \\
\text { otro. }\end{array}$ \\
\hline $\begin{array}{l}\text { Lugares de Interés } \\
\text { Geomorfológico } \\
\text { (LIGm) }\end{array}$ & $\begin{array}{l}\text { Serrano y González } \\
\text { Trueba, } 2005 \\
\text { González Trueba, } \\
2007 a\end{array}$ & $\begin{array}{l}\text { Se refiere a todos aquellos elementos o lugares } \\
\text { geomorfológicos de interés, inventariables, caracterizables y } \\
\text { valorables desde tres puntos de vista: } \\
\text { 19) valor científico o intrínseco } \\
\text { 29) valor cultural o añadido } \\
\text { 3) valor de uso y gestión. }\end{array}$ \\
\hline Geositio & Jorajuria, 2007 & $\begin{array}{l}\text { Lugar donde se concentran diversas características } \\
\text { geomorfológicas y geológicas sobresalientes que le confieren } \\
\text { un carácter distintivo a los paisajes. Generalmente, estos } \\
\text { lugares contienen una belleza paisajística excepcional, o bien, } \\
\text { han adquirido un valor científico, cultural, histórico, estético } \\
\text { y/o socioeconómico debido a la percepción y/o explotación } \\
\text { humana. }\end{array}$ \\
\hline
\end{tabular}




\section{2) Evaluación de LIGm y de su aprovechamiento didáctico}

La selección de los lugares dignos de protección o promoción es una de las tareas más importantes de los investigadores en estudios de patrimonio geológico. Debido a que el valor del lugar de interés se realiza en función de características generales e intrínsecas del sitio, se precisa que tal proceso se lleve a cabo con la máxima objetividad posible. Por lo tanto se recurre a la utilización de criterios definidos que pueden ser objeto de evaluación externa y que sean replicables, pero también se basa en la opinión del experto que hace la evaluación (Bruschi y Cendrero, 2005).

La elaboración de inventarios o catálogos es un primer paso imprescindible para una estrategia de protección del patrimonio. Los inventarios deberían reunir la información necesaria para la catalogación, valoración, protección y, por supuesto, la gestión y puesta en valor de los elementos seleccionados, así como para la elaboración de documentos para cada exigencia, desde la gestión hasta la divulgación, tanto didáctica como lúdico-recreativa (García Cortés et al., 2000). El fin último del proceso de identificación, clasificación y evolución del patrimonio natural es su protección y puesta en valor. Es por tanto conveniente proponer estrategias y acciones encaminadas a la gestión y uso de los elementos de dicho patrimonio en el marco de la geoconservación. La protección del patrimonio, en general y, del geomorfológico, en particular, debe hacerse procurando su conservación, pero también buscando el desarrollo sostenible y su utilidad para la sociedad. En ese sentido la mayoría de los métodos de valoración proponen tres grupos de usos para el patrimonio geológico o geomorfológico:
a) usos científicos,
b) usos educativos,
c) usos turísticos.

El procedimiento de evaluación del patrimonio geomorfológico no es un objetivo en sí mismo, sino el medio de cumplir con otro objetivo: la protección del patrimonio, su promoción turística o programas educativos dirigidos a desarrollar el conocimiento sobre el elemento $o$ lugar (Reynard, 2009).

Para comenzar el análisis de la valoración del uso educativo de los LIGm, nos encontramos con una de las acepciones que la RAE propone del término didáctico: aquello que es adecuado para enseñar o instruir. Con esta definición, cualquier elemento puede ser considerado didáctico. Pero un rasgo geomorfológico no posee en sí mismo un valor didáctico, sino que es la intencionalidad docente la que lo transforma en un recurso educativo. Tal 
intención surge del conocimiento del contenido curricular que un determinado elemento puede ayudar a desarrollar, de técnicas didácticas, del aprendizaje del alumnado, etc. Shulman (1987) denomina este tipo de conocimiento como conocimiento didáctico del contenido y representa:

la mezcla entre el contenido y la didáctica por la que se llega a una comprensión de cómo determinados temas y problemas se organizan, se representan y se adaptan a los diversos intereses de los alumnos, y se exponen para la enseñanza.

La utilización de elementos naturales para la enseñanza de conceptos es una actividad conocida e implementada por los docentes. Las excursiones y salidas de campo, como las guías en base a estas últimas, son buenos ejemplos de prácticas pedagógicas que permiten comprender e interpretar de manera activa procesos y fenómenos naturales, y a través del contacto con referentes patrimoniales se puede potenciar el conocimiento reflexivo de la realidad (Estepa et al., 2007).

Continuando con este análisis de la valoración del uso educativo de LIGm, la Tabla 41 resume los métodos analizados. 
Tabla 41. Comparación de la valoración didáctica presente en métodos de valoración de lugares de interés geológico y/o geomorfológico.

\begin{tabular}{|c|c|c|c|c|}
\hline $\begin{array}{c}\text { Autor/es } \\
\text { (año) }\end{array}$ & Indicador & Definición & Categorización & Observaciones \\
\hline $\begin{array}{l}\text { Junta de } \\
\text { Andalucía } \\
\text { (2004) }\end{array}$ & Potencialidad didáctica & No presenta & \multicolumn{2}{|c|}{$\begin{array}{l}\text { 5: Ejemplifica claramente contenidos curriculares válidos para cualquier nivel } \\
\text { del sistema educativo. Apto además para la explicación de procesos de } \\
\text { interés medioambiental entre grupos o sectores sociales no integrados } \\
\text { específicamente en el sistema educativo. } \\
\text { 4: Ejemplifica claramente contenidos curriculares válidos para cualquier nivel } \\
\text { del sistema educativo } \\
\text { 3: Ejemplifica claramente contenidos curriculares válidos para los niveles } \\
\text { educativos de la ESO, Bachiller y ciclos universitarios } \\
\text { 2: Ejemplifica claramente contenidos curriculares válidos para los niveles } \\
\text { educativos de Bachiller y ciclos universitarios } \\
\text { 1: Ejemplifica claramente contenidos curriculares válidos sólo para los } \\
\text { niveles educativos de ciclos universitarios }\end{array}$} \\
\hline \multirow[b]{2}{*}{$\begin{array}{l}\text { Bruschi y } \\
\text { Cendrero } \\
\text { (2005) }\end{array}$} & $\begin{array}{l}\text { Utilidad como ejemplo de } \\
\text { modelo de proceso }\end{array}$ & No presenta & \multicolumn{2}{|c|}{$\begin{array}{l}\text { 4= Presente, proceso activo claramente visible / interpretable } \\
2=\text { Procesos actuales de erosión / deposición no claramente definidos } \\
0=\text { Fósiles y / o depósitos de difícil interpretación de procesos anteriores. }\end{array}$} \\
\hline & $\begin{array}{l}\text { Diversidad de elementos } \\
\text { (geomorfológico, } \\
\text { estratigráfico, } \\
\text { paleontológico, etc.) }\end{array}$ & No presenta & \multicolumn{2}{|c|}{$\begin{array}{l}4=5 \text { o más elementos } \\
3=4 \text { elementos } \\
2=3 \text { elementos } \\
1=2 \text { elementos } \\
0=\text { sólo } 1 \text { elemento }\end{array}$} \\
\hline $\begin{array}{l}\text { Coratza y } \\
\text { Giusti } \\
\text { (2005) }\end{array}$ & Valor Educativo & No presenta & $\begin{array}{l}0,00=\text { valor educativo nulo } \\
0,25=\text { bajo } \\
0,50=\text { medio } \\
0,75=\text { alto } \\
1,00=\text { muy alto }\end{array}$ & $\begin{array}{l}\text { El valor educativo se determina } \\
\text { considerando: } \\
\text { - la representatividad de una determinada } \\
\text { forma o procedimiento; } \\
\text { - si un Geomorfositio es citado en los libros } \\
\text { de texto como bien de importancia; } \\
\text { - si un Geomorfositio se inserta en algún } \\
\text { itinerario turístico / educativo y cuál es el } \\
\text { nivel educativo de este tipo de itinerario; } \\
\text { - si se conoce fuera del mundo científico; } \\
\text { - un Geomorfositio se considera que tiene }\end{array}$ \\
\hline
\end{tabular}




\begin{tabular}{|c|c|c|c|c|}
\hline & & & & $\begin{array}{l}\text { un valor educativo, incluso si no hay } \\
\text { material educativo que se haya creado a } \\
\text { partir de él. }\end{array}$ \\
\hline \multirow[b]{2}{*}{$\begin{array}{c}\text { Pralong } \\
\text { (2005) }\end{array}$} & Representatividad & $\begin{array}{l}\text { Depende de las características didácticas } \\
\text { del sitio para los no iniciados en la } \\
\text { geomorfología. La "legibilidad" del objeto } \\
\text { o sitio se debe a su valor educativo } \\
\text { intrínseco, su configuración general } \\
\text { (geometría, dimensiones, límites } \\
\text { constitución, edad, los antecedentes, la } \\
\text { geodiversidad). }\end{array}$ & \multicolumn{2}{|l|}{$\begin{array}{l}0=\text { nula } \\
0,25=\text { baja } \\
0,50=\text { moderada } \\
0,75=\text { alta } \\
1,00=\text { muy alta }\end{array}$} \\
\hline & Valor paleogeográfico & $\begin{array}{l}\text { Permite la reconstrucción de la evolución } \\
\text { geo (morfo) lógica del territorio. El hecho } \\
\text { de que el sitio es un lugar para estudiar los } \\
\text { avances en la geo (morfo) logía o } \\
\text { importancia para la historia de la ciencia } \\
\text { de la Tierra aumenta el valor. El número de } \\
\text { publicaciones científicas (o proyectos) debe } \\
\text { reflejar este interés en la teoría } \\
\text { paleogeográfica. }\end{array}$ & \multicolumn{2}{|l|}{$\begin{array}{l}0=\text { nula } \\
0,25=\text { baja } \\
0,50=\text { moderada } \\
0,75=\text { alta } \\
1,00=\text { muy alta }\end{array}$} \\
\hline $\begin{array}{l}\text { Serrano y } \\
\text { González } \\
\text { Trueba } \\
\text { (2005) }\end{array}$ & Valor didáctico & No presenta & $\begin{array}{l}\text { Lo dividen en dos partes: } \\
\text { - Recursos pedagógicos: } \\
\text { (máximo 5). } \\
\text { - Niveles pedagógicos: } \\
\text { (máximo 5) }\end{array}$ & $\begin{array}{l}\text { - Recursos pedagógicos: Enumerar los } \\
\text { contenidos pedagógicos y docentes } \\
\text { presentes en el LIGm, concediendo un valor } \\
1 \text { a cada uno de los presentes. } \\
\text { - Niveles pedagógicos: Enumerar y valorar } \\
\text { el nivel pedagógico del LIGm (Primario, } \\
\text { Secundario, Superior, Adultos, } \\
\text { Investigación). }\end{array}$ \\
\hline $\begin{array}{c}\text { Reynard } \\
\text { (2006) }\end{array}$ & Valor educativo & $\begin{array}{l}\text { Se evalúa la importancia del sitio para la } \\
\text { educación y la formación. Sitios legibles en } \\
\text { el paisaje, así como sitios que permiten la } \\
\text { observación de los procesos activos pueden } \\
\text { obtener una puntuación más alta. La } \\
\text { presencia de paneles educativos no es un } \\
\text { elemento de evaluación. }\end{array}$ & \multicolumn{2}{|l|}{$\begin{array}{l}0=\text { nula } \\
0,25=\text { baja } \\
0,50=\text { moderada } \\
0,75=\text { alta } \\
1,00=\text { muy alta }\end{array}$} \\
\hline
\end{tabular}




\begin{tabular}{|c|c|c|c|}
\hline & Representatividad & $\begin{array}{l}\text { Los geomorfositios seleccionados deben } \\
\text { ser representativos de la geomorfología del } \\
\text { área de estudio. Deben cubrir los } \\
\text { principales procesos, pasados o actuales de } \\
\text { la región. }\end{array}$ & $\begin{array}{l}0=\text { nula } \\
0,25=\text { baja } \\
0,50=\text { moderada } \\
0,75=\text { alta } \\
1,00=\text { muy alta }\end{array}$ \\
\hline & Valor paleogeográfico & $\begin{array}{l}\text { Este criterio evalúa la importancia del sitio } \\
\text { para la reconstrucción de la historia del } \\
\text { clima y la Tierra (por ejemplo, referencia a } \\
\text { una etapa glaciar). }\end{array}$ & $\begin{array}{l}0=\text { nula } \\
0,25=\text { baja } \\
0,50=\text { moderada } \\
0,75=\text { alta } \\
1,00=\text { muy alta }\end{array}$ \\
\hline & Importancia geohistórica & $\begin{array}{l}\text { Se evalúa la importancia del geomorfositio } \\
\text { en las Ciencias de la Tierra. Un sitio que } \\
\text { permite el desarrollo de una teoría o } \\
\text { demostrar un proceso obtendrá una } \\
\text { puntuación más alta. }\end{array}$ & $\begin{array}{l}0=\text { nula } \\
0,25=\text { baja } \\
0,50=\text { moderada } \\
0,75=\text { alta } \\
1,00=\text { muy alta }\end{array}$ \\
\hline \multirow{3}{*}{$\begin{array}{l}\text { Pereira et } \\
\text { al (2007a) } \\
y(2007 b)\end{array}$} & $\begin{array}{l}\text { Representatividad de los } \\
\text { procesos geomorfológicos } \\
\text { e interés pedagógico }\end{array}$ & No presenta & $\begin{array}{l}0=\text { Baja representatividad y sin interés pedagógico } \\
0,33=\text { Con alguna representatividad pero con bajo interés pedagógico } \\
0,67=\text { Buen ejemplo de procesos pero difícil para explicar a no expertos } \\
1=\text { Buen ejemplo de procesos y/o buen recurso pedagógico }\end{array}$ \\
\hline & $\begin{array}{l}\text { Diversidad de geoformas y } \\
\text { su importancia }\end{array}$ & No presenta & $\begin{array}{l}0=\text { Solamente un elemento / tema con interés geomorfológico } \\
0,33=\text { Dos elementos / temas con interés geomorfológico } \\
0,67=\text { Tres elementos / asuntos con interés geomorfológico } \\
1,00=\text { Más de tres elementos / aspectos con interés geomorfológico }\end{array}$ \\
\hline & $\begin{array}{l}\text { Otras características } \\
\text { geológicas con valor } \\
\text { patrimonial }\end{array}$ & No presenta & $\begin{array}{l}0=\text { No hay otros elementos geológicos destacados } \\
0,17=\text { Hay elementos geológicos, geomorfológicos, sin asociación a los } \\
\text { elementos } \\
0,33=\text { Hay elementos geológicos, geomorfológicos, con asociación a los } \\
\text { elementos } \\
0,50=\text { aparición de otro }(s) \text { elementos de interés geológico }\end{array}$ \\
\hline $\begin{array}{l}\text { Reynard et } \\
\text { al (2007) }\end{array}$ & Representatividad & $\begin{array}{l}\text { Se refiere a la ejemplaridad del sitio. } \\
\text { Se usa con respecto a un espacio de } \\
\text { referencia (por ejemplo, región, municipio, } \\
\text { país). Todos los sitios seleccionados deben } \\
\text { cubrir los principales procesos, activos o } \\
\text { pasados, en el área de estudio. }\end{array}$ & $\begin{array}{l}0=\text { ninguno } \\
0,25=\text { pequeña } \\
0,5=\text { mediana } \\
0,75=\text { alto } \\
1=\text { muy alto. }\end{array}$ \\
\hline
\end{tabular}




\begin{tabular}{|c|c|c|c|c|}
\hline & Valor paleogeográfico & $\begin{array}{l}\text { Importancia del lugar para la historia del } \\
\text { clima o del planeta (por ejemplo, sitio de } \\
\text { referencia para una etapa glacial). }\end{array}$ & \multicolumn{2}{|c|}{$\begin{array}{l}0=\text { ninguno } \\
0,25=\text { pequeña } \\
0,5=\text { mediana } \\
0,75=\text { alto } \\
1=\text { muy alto. }\end{array}$} \\
\hline \multirow[b]{2}{*}{$\begin{array}{l}\text { Zouros } \\
\text { (2007) }\end{array}$} & Representatividad & $\begin{array}{l}\text { Depende del grado en el que el sitio es } \\
\text { típico de cierto proceso geomorfológico. }\end{array}$ & \multicolumn{2}{|c|}{ Valoración numérica del 0 al 10} \\
\hline & Ejemplaridad & $\begin{array}{l}\text { Depende de la utilidad del sitio para } \\
\text { ayudar al público en general a comprender } \\
\text { una estructura geomorfológica o proceso. }\end{array}$ & \multicolumn{2}{|c|}{ Valoración numérica del 0 al 10} \\
\hline $\begin{array}{l}\text { García- } \\
\text { Cortés y } \\
\text { Carcavilla } \\
\text { (2009) }\end{array}$ & $\begin{array}{l}\text { Contenido didáctico/uso } \\
\text { didáctico }\end{array}$ & $\begin{array}{l}\text { Indica si el rasgo se presta con mayor o } \\
\text { menor facilidad a la docencia o ya se utiliza } \\
\text { para este fin. }\end{array}$ & \multicolumn{2}{|c|}{$\begin{array}{l}\text { 1= Ilustra contenidos curriculares universitarios } \\
2=\text { Ilustra contenidos curriculares de cualquier nivel del sistema educativo } \\
\text { 4= Está siendo utilizado habitualmente en actividades didácticas de } \\
\text { cualquier nivel del sistema educativo }\end{array}$} \\
\hline $\begin{array}{l}\text { Carton et } \\
\text { al (2012) }\end{array}$ & Ejemplo didáctico & $\begin{array}{l}\text { Depende de la presencia o ausencia de } \\
\text { procesos activos claramente visibles e } \\
\text { interpretables por la claridad de } \\
\text { interpretación del sitio geológico y su } \\
\text { similitud con respecto a los modelos } \\
\text { teóricos de interpretación. El valor } \\
\text { aumenta si una forma específica se cita } \\
\text { como un ejemplo en los textos para la } \\
\text { enseñanza. }\end{array}$ & $\begin{array}{l}0=\text { baja } \\
2=\text { media } \\
4=\text { alta }\end{array}$ & $\begin{array}{l}\text { El aumento de la enseñanza aumenta el } \\
\text { valor científico. }\end{array}$ \\
\hline $\begin{array}{l}\text { Henao y } \\
\text { Osorio } \\
\text { (2012) }\end{array}$ & Potencial Educativo & No presenta & \multicolumn{2}{|l|}{$\begin{array}{l}\text { Alto } \\
\text { Medio } \\
\text { Bajo }\end{array}$} \\
\hline $\begin{array}{l}\text { Ibáñez et } \\
\text { al (2012) }\end{array}$ & Didáctico & No presenta & \multicolumn{2}{|c|}{ Marca con una cruz si existe utilización didáctica del geositio } \\
\hline $\begin{array}{l}\text { ISPRA } \\
(2012)\end{array}$ & Didáctico & No presenta & $\begin{array}{l}\text { Primario } \\
\text { Secundario }\end{array}$ & $\begin{array}{l}\text { No especifica si corresponde a un nivel de } \\
\text { escolaridad o al valor didáctico del lugar de } \\
\text { interés. }\end{array}$ \\
\hline $\begin{array}{l}\text { Mardones } \\
\text { (2012) }\end{array}$ & Valor didáctico & $\begin{array}{l}\text { Utilidad como modelo para ilustrar } \\
\text { procesos geológicos. }\end{array}$ & \multicolumn{2}{|l|}{$\begin{array}{l}0=\text { Nulo } \\
1=\text { Bajo } \\
2=\text { Medio }\end{array}$} \\
\hline
\end{tabular}

Héctor Bazán 


\begin{tabular}{|c|c|c|c|}
\hline & & & $\begin{array}{l}3=\text { Elevado } \\
4=\text { Muy Elevado }\end{array}$ \\
\hline \multirow{2}{*}{$\begin{array}{c}\text { Medina } \\
\text { (2012) }\end{array}$} & $\begin{array}{l}\text { Posibilidad de realizar } \\
\text { actividades didácticas } \\
\text { (constituye uno de los } \\
\text { parámetros de valoración } \\
\text { dentro del valor } \\
\text { Científico/Educativo) }\end{array}$ & $\begin{array}{l}\text { Informa si el geositio cumple con las } \\
\text { condiciones para realizar actividades } \\
\text { didácticas teniendo en cuenta el nivel de } \\
\text { conocimiento }\end{array}$ & $\begin{array}{l}\text { 3= Cumple con las condiciones para realizar actividades didácticas a grupos } \\
\text { de cualquier nivel de conocimiento. } \\
\text { 2= Cumple con las condiciones para realizar actividades didácticas a grupos } \\
\text { de nivel de conocimiento medio, que recibieron en algún momento una } \\
\text { formación básica sobre las Ciencias de la Tierra. } \\
\text { 1= Cumple con las condiciones para realizar actividades didácticas a grupos } \\
\text { que posean un conocimiento técnico específico. }\end{array}$ \\
\hline & $\begin{array}{l}\text { Utilidad como modelo } \\
\text { para } \\
\text { ilustrar procesos } \\
\text { geológicos } \\
\text { (constituye uno de los } \\
\text { parámetros de valoración } \\
\text { dentro del valor } \\
\text { Científico/Educativo) }\end{array}$ & $\begin{array}{l}\text { Es la posibilidad del geositio de poder } \\
\text { representar fielmente un determinado } \\
\text { proceso geológico. }\end{array}$ & $\begin{array}{l}3 \text { - Muy útil, el geositio representa fielmente los procesos geológicos } \\
\text { pertinentes. } \\
2 \text { - Medianamente útil, el geositio presenta limitaciones en su fiel } \\
\text { interpretación de los procesos geológicos pertinentes. } \\
1 \text { - Poco útil, en el geositio hay ausencia de elementos importantes para la } \\
\text { fiel interpretación de los procesos geológicos pertinentes. }\end{array}$ \\
\hline
\end{tabular}


De la lectura de la Tabla 41, puede deducirse que todos los métodos de valoración de lugares de interés analizados dedican una mención al aprovechamiento didáctico/pedagógico de tales sitios, pero no todos presentan una definición de esa valoración educativa. Entre los que sí ofrecen una conceptualización se registra una disparidad de criterios para considerar la utilidad didáctica de los lugares de interés. Por ejemplo, Mardones (2012) define el valor didáctico de un LIGm como la utilidad como modelo para ilustrar procesos geológicos, pero no especifica cuáles procesos geológicos pueden explicarse, ni la intensidad de los mismos. GarcíaCortés y Carcavilla (2009) consideran que el LIGm posee un contenido didáctico/uso didáctico si el rasgo se presta con mayor o menor facilidad a la docencia o ya se utiliza para este fin, valorando si el mismo ilustra contenidos curriculares universitarios, de cualquier nivel del sistema educativo o si se utiliza en actividades didácticas, pero sin aclarar cuántos o qué contenidos pueden desarrollarse con la interpretación de un LIGm; tratamiento similar lo ofrecen los métodos de la Junta de Andalucía (2004) y el de Medina (2012). Los trabajos de Pereira et al (2007a y 2007b) proponen una relación subjetiva del interés pedagógico de LIGm sin determinar de forma específica la representatividad de los procesos geomorfológicos y su interés como recurso didáctico (su categorización se extiende desde sitios con una baja representatividad y sin interés pedagógico, hasta lugares que son buen ejemplo de procesos y/o buen recurso pedagógico). El modelo de lbáñez et al (2012) sólo propone marcar con una cruz la presencia de utilidad didáctica de un sitio de interés geomorfológico. Varios métodos de valoración utilizan el criterio de representatividad como elemento que explique modelos, teorías y/o procesos geológicos (Bruschi y Cendrero, 2005; Pereira et al., 2007a y 2007b; Carton et al., 2012). La propuesta de Serrano y González Trueba (2005) resulta un poco más amplia que las anteriores, ya que combina contenidos docentes y niveles de escolaridad, pero aún así no precisa su especificidad didáctica. En contraposición a los ejemplos mencionados, existen métodos que carecen de criterios para definir el valor didáctico de un sitio puesto que no presentan conceptualizaciones u orientaciones a considerar en sus escalas de valoración, y esto dificulta su utilización en otros espacios o una evaluación externa.

Como se dijo anteriormente, algunos métodos utilizan como criterio para valorar la utilidad didáctica de un lugar de interés si el mismo permite el desarrollo de contenidos curriculares. Siguiendo sólo este criterio, la totalidad de los LIGm tendrían utilidad didáctica ya que con ellos se podría ejemplificar conceptos simples como roca, minerales, pasando por unos más elaborados como erosión o meteorización diferenciada, hasta llegar a algunos más específicos como cabalgamiento o polje. Según este razonamiento, la mayoría de los sitios 
inventariados servirían para ejemplificar los conceptos más sencillos, pero no todos serían de utilidad de los ejemplos restantes.

Continuando con esta lógica, si la intención pedagógica es observar tipos de rocas metamórficas, no servirá un sitio donde sólo haya ígneas o sedimentarias, pero el mismo sitio será de utilidad si el objetivo es enseñar el concepto ROCA. De igual manera, si la finalidad pedagógica es observar una morrena glaciar, poco importa si la misma existe en cantidad en una zona o es el único ejemplo a cientos de kilómetros a la redonda. En cambio si el objetivo es observar la presencia actual o pasada de glaciares en una zona y si sólo se posee una morrena (por ejemplo), la misma es de vital importancia para explicar tal formación. Como se observa, es la intención docente lo que transforma cualquier elemento en un material didáctico. Valorar la función didáctica de LIGm es una tarea compleja y se relacionará con el nivel que se le atribuya al aspecto didáctico: se estará más próximo a la divulgación (y por tanto al uso turístico) o más próximo de la docencia a nivel universitario, y por tanto del uso científico (García Cortés, 1996).

Para Viñals et al (2011) el valor pedagógico de un lugar no sólo depende de las posibilidades del medio sino también de la existencia de equipamientos (aulas de naturaleza, centros de interpretación, granjas-escuela, senderos interpretativos, etc.), la calidad de los materiales educativos y el equipo de guías-intérpretes y monitores. Tal consideración entra en conflicto con los métodos analizados ya que los mismos no mencionan la presencia de infraestructura de ese tipo como elemento de valor de la utilidad didáctica de lugares de interés. De manera explícita Reynard (2006) afirma que la existencia de paneles educativos no es un elemento de evaluación para valorar la utilidad didáctica de sitios de interés.

Un comienzo para precisar el aprovechamiento didáctico de lugares de interés es especificando de qué forma tal elemento es útil para la enseñanza o qué contenidos escolares y en qué niveles educativos. Por lo tanto será necesario conocer los contenidos curriculares en los distintos niveles de enseñanza sobre un tema en particular (en este caso, sobre geología y/o geomorfología), como también analizar material bibliográfico al respecto para luego elaborar fichas que recaben información y que pueda ser utilizada en la toma de decisiones del proceso de enseñanza/aprendizaje.

En conclusión al análisis de la valoración didáctica en los métodos considerados, y aunque presente diferentes denominaciones (valor educativo, valor didáctico, potencialidad didáctica, potencial educativo, utilidad como modelo explicativo, importancia geohistórica, representatividad, etc.), la importancia didáctica de los lugares de interés geomorfológico es una característica considerada en la totalidad de los métodos de valoración analizados, pero 
no todos ofrecen una conceptualización de esa valoración educativa, ni presentan criterios y/o escalas similares. Esto último dificulta que los métodos sean replicados o que haya una evaluación externa de LIGm previamente valorados.

Respecto a los criterios para evaluar el aprovechamiento didáctico de lugares de interés, algunos de los indicadores encontrados en las propuestas analizadas son:

- la presencia de procesos y/o elementos geomorfológicos (ej. Bruschi y Cendrero, 2005; Reynard, 2006; Mardones, 2012; Medina, 2012);

- contenidos curriculares (ej. Junta de Andalucía, 2004; Serrano y González Trueba, 2005);

- niveles de enseñanza (ej. Serrano y González Trueba 2005; García Cortes y Carcavilla, 2009);

- el sitio sea útil como ejemplo de modelos o teorías (ej. Reynard, 2006; Cartón et al., 2012);

- el lugar permite la reconstrucción de la evolución del planeta (ej. Pralong, 2005);

- el lugar permite realizar actividades didácticas (ej. Medina, 2012);

- el valor didáctico aumenta si el sitio se encuentra presente en libros de enseñanza (ej. Coratza y Giusti, 2005; Cartón et al., 2012).

Más allá de la presencia de una valoración didáctica en los métodos analizados, la misma resulta confusa y poco precisa para el uso docente, ya que no se especifica de qué manera el lugar de interés es útil para la enseñanza o qué contenidos escolares se pueden desarrollar con el mismo. Por ello, uno de los aportes que proponemos en la presente investigación, es la elaboración de fichas metodológicas que permitan realizar esta valoración con mayor precisión sobre el aprovechamiento didáctico de los LIGm. Nuestra propuesta, que se desarrolla a continuación, nace de la deficiencia detectada en los métodos de valoración analizados, pero considera también los contenidos curriculares y la bibliografía específica sobre geomorfología.

\section{3) Elaboración de fichas para la valoración didáctica de LIGm}

Distintos autores mencionan los elementos necesarios para la comprensión de la geomorfología de un lugar. De Miró y Domingo (1995) consideran que para conocer las características geomorfológicas de una región es necesario observar los procesos morfogenéticos ( $p$. e. propiedades de las rocas en relación a su modelado), los condicionantes 
litoestructurales del relieve (p. e. tipo de pliegues), sus condicionamientos climáticos (p. e. dominios morfoclimáticos) y los antrópicos. Por su parte, Gallegos (2002) sostiene que para realizar un estudio algo detallado del modelado terrestre y de su génesis, es necesario tener un mínimo conocimiento de la acción de los agentes geológicos externos sobre una litología concreta que presenta ya una estructura dada. Para Pralong (2003), todo relieve es el resultado de la combinación de tres historias indisociables: la historia de las rocas, la historia de las deformaciones tectónicas y, la historia de las formas de modelado, heredadas unas, aún funcionales en la actualidad otras. Reynard (2004b) sostiene que las formas de relieve son el resultado de la combinación de procesos dinámicos en el espacio y el tiempo, y de intensidad variable. Estos procesos son provocados por agentes naturales endógenos (petrogénesis, placas tectónicas), exógenos (gravedad, agentes climáticos, químicos, etc.) y de génesis antrópica (Figura 55). Finalmente, Martínez-Zavala et al (2005) afirman que las formas del terreno son el resultado de los procesos de modelado que actúan sobre la superficie y que el mismo es función de los distintos agentes geomorfológicos que tienen lugar en la génesis del paisaje. El clima, la geología, la vegetación o el suelo son algunos de estos factores.

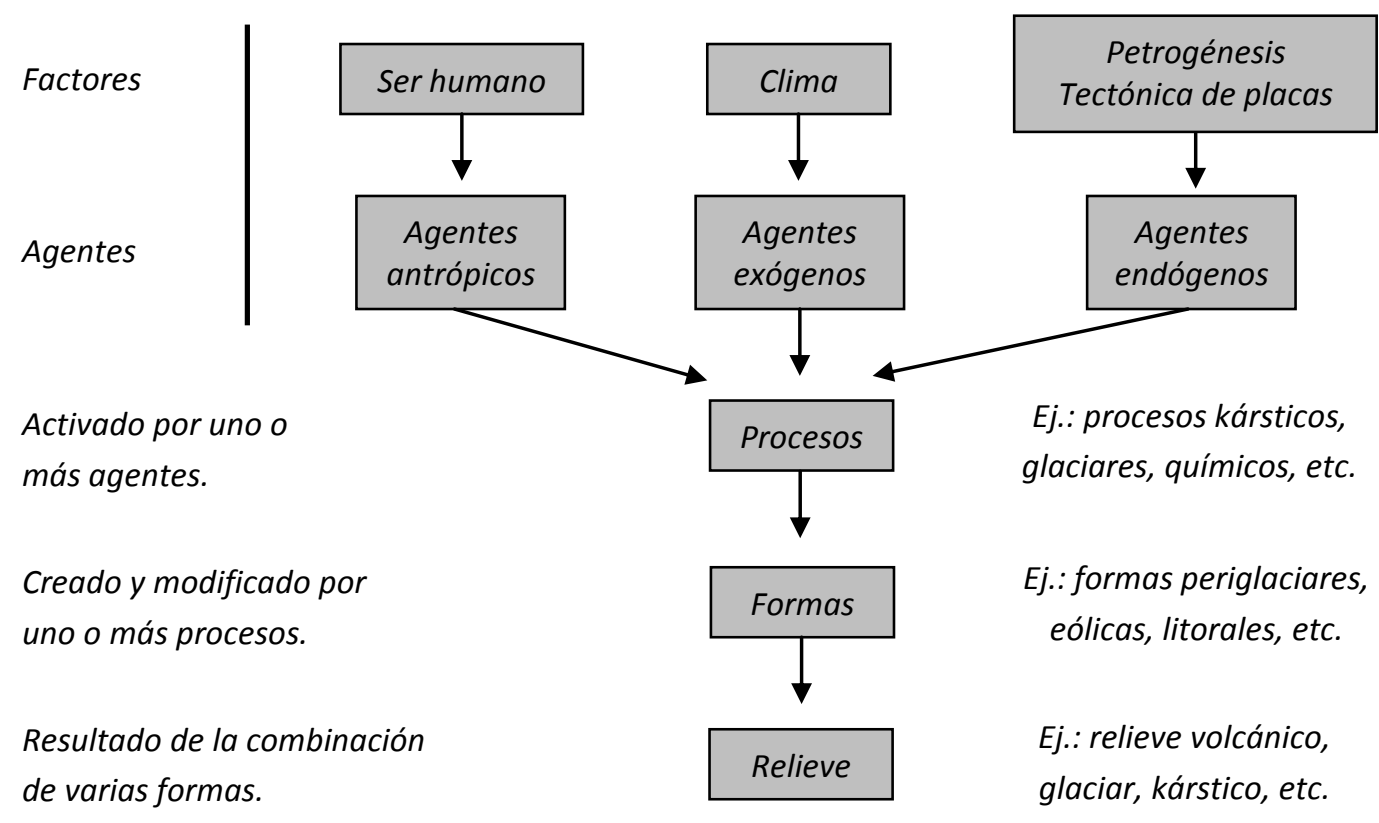

Figura 55. Relaciones entre procesos, formas y relieve. Fuente: traducido de Reynard, 2004b.

Por lo que respecta al otro aspecto considerado en esta propuesta, los contenidos curriculares, se consideraron sólo los contenidos geológicos necesarios para el aprendizaje de contenidos geomorfológicos presentes en los diseños curriculares (Tabla 42) de Educación Primaria, Educación Secundaria Obligatoria y Bachillerato de las Comunidades Autónomas que 
forman parte del Parque Nacional de los Picos de Europa (Asturias, Cantabria y Castilla y León) (Anexos 1, 2, 3). Es oportuno aclarar que el análisis consistirá en identificar los contenidos prescritos por los documentos oficiales y no en aspectos relacionados con la práctica educativa, como por ejemplo si el desarrollo de los mismos permite alcanzar los objetivos de nivel o su distribución didáctica anual.

Tabla 42. Instrumentos legales con los currículos oficiales de las Comunidades Autónomas seleccionadas.

\begin{tabular}{|l|c|c|c|}
\hline \multicolumn{1}{|c|}{ Nivel de escolaridad } & Asturias & Cantabria & Castilla y León \\
\hline Primaria & Decreto 56/2007 & Decreto 56/2007 & Decreto 40/2007 \\
\hline $\begin{array}{l}\text { ESO (Educación } \\
\text { Secundaria Obligatoria) }\end{array}$ & Decreto 74/2007 & Decreto 57/2007 & Decreto 52/2007 \\
\hline Bachillerato & Decreto 75/2008 & Decreto 74/2008 & Decreto 48/2008 \\
\hline Fuente: elaboración propia. & \multicolumn{3}{|l}{} \\
\hline
\end{tabular}

De la lectura de estos documentos se pudo deducir que, a pesar de presentar pequeñas variaciones en su redacción, existe una similitud de contenidos, fruto de la adaptación a La Ley Orgánica de Educación 2/2006 (LOE). En Educación Primaria, los contenidos relacionados con la Geología están dentro de una materia generalista denominada Conocimiento del Medio, con escaso contenido geológico (Calonge y Juan, 2009). Tales contenidos tienen el objetivo de identificar los principales elementos del entorno natural de las comunidades respectivas, analizando su organización y sus características; introduciendo al alumnado en el conocimiento de las rocas y minerales, desde una simple observación en los dos primeros años hasta lograr su identificación y clasificación en el resto de la trayectoria de este nivel escolar.

Los contenidos geológicos en los dos primeros cursos de la Educación Secundaria Obligatoria (ESO) están incluidos en la asignatura Ciencias de la Naturaleza, junto a otros de Física, Química y Biología, y en la materia Ciencias Sociales, Historia y Geografía (esta última sólo en el primer curso). Tal selección supone una complejización de saberes adquiridos en el nivel de Escolaridad anterior: identificación, origen y clasificación de tipos de roca, observación y descripción de los minerales más frecuentes, configuración del relieve, entre otros. En los dos últimos años de esta etapa, la materia Biología y Geología está separada de las otras dos ciencias, siendo una asignatura opcional en el último curso. En tercero de la ESO los contenidos geológicos están relacionados con transformaciones geológicas debidas a la energía externa del planeta (por ejemplo, el ciclo litológico y su imbricación en el ciclo geológico, meteorización, entre otros). En el cuarto curso los contenidos pretenden explicar los factores externos del modelado del relieve, la historia de la Tierra (tiempo geológico), la Teoría de la Tectónica de Placas, la formación de cordilleras, entre otros. 
Para finalizar, los dos cursos que conforman el Bachillerato desarrollan contenidos geológicos clásicos: origen y estructura de la Tierra, dinámica terrestre (procesos internos y externos), minerales y rocas, etc., repartidos entre las siguientes asignaturas:

- $\quad$ Ciencias para el mundo contemporáneo (materia común a todas las modalidades del primer curso),

- Biología y Geología (sólo en la modalidad Ciencias y Tecnología del primer curso)

- $\quad$ Ciencias de la Tierra y medioambientales (sólo en la Modalidad Ciencias y Tecnología del segundo curso)

- Geología (sólo como materia optativa de la modalidad Ciencias y Tecnología del segundo curso en Cantabria y Castilla León)

Existen muchas propuestas metodológicas de cómo recoger, almacenar, ordenar y clasificar la información asociada a los recursos naturales y culturales. Los inventarios deben ser, en definitiva, documentos que recojan información como mínimo sobre la localización del recurso, tipología y caracterización del mismo, valoración de su estado de conservación, riesgos y amenazas de que es objeto, y además toda la documentación gráfica y cartográfica necesaria. Los estudios metodológicos de valoración didáctica de LIGm son muy escasos. Para el presente trabajo, se ha partido de la utilización de criterios geológicos y climáticos, junto con otros del ámbito educativo. El establecimiento de la metodología propuesta para el análisis de valores didácticos en geomorfología de LIGm en Espacios Naturales Protegidos se basa en dos categorías diferenciadas que permiten la orientación de los distintos aspectos que las componen (Figura 56). Como queda expresado en esta figura, el círculo representa la primera categoría, que sugiere el relevamiento de la existencia y de la calidad de elementos geológicos y climáticos (por ejemplo la acción del viento y de la temperatura sobre el relieve) que permitirán el desarrollo de contenidos geomorfológicos. La segunda categoría, representada mediante una flecha, hace referencia a factores que condicionan el aprendizaje con los geositios (accesibilidad, fragilidad, intensidad de uso), contextualizándolo (niveles pedagógicos) y relacionándolo con otras áreas de conocimiento y recursos existentes sobre el mismo (por ejemplo guías didácticas, centros de interpretación, etc.). 


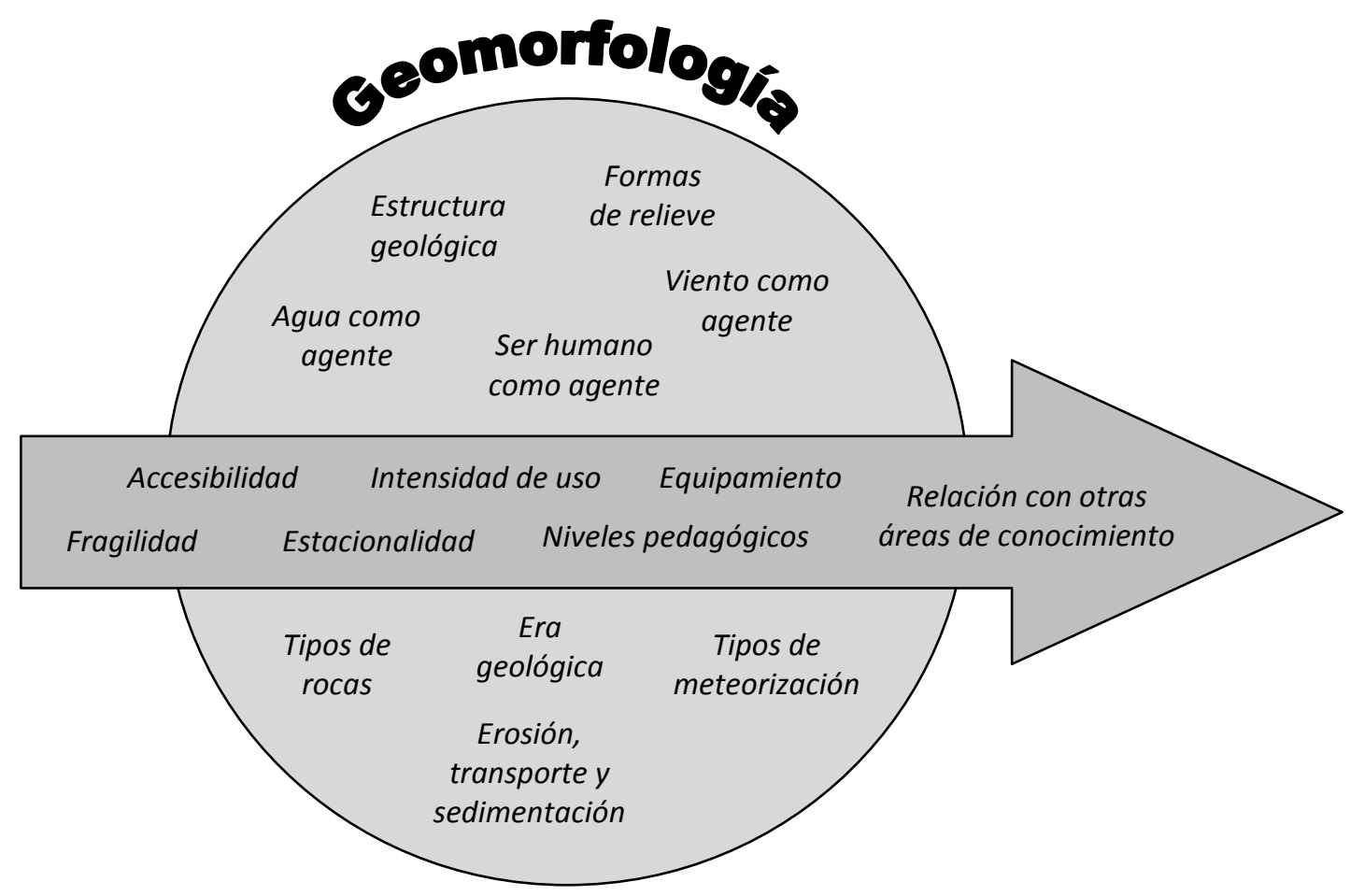

Figura 56. Aspectos integrantes de la valoración didáctica en Geomorfología de LIGm.

Fuente: elaboración propia.

Tras analizar distintos ejemplos de valoraciones de sitios con interés geomorfológico y considerando los contenidos requeridos para el aprendizaje del modelado terrestre planteados por De Miró y Domingo (1995), Gallegos (2002), Pralong (2003), Reynard (2004b), MartínezZavala et al (2005) y los contenidos curriculares necesarios para trabajar temas sobre geomorfología (Anexos 1, 2, 3), se propone el siguiente modelo de evaluación didáctica en geomorfología para LIGm (Tabla 43).

Tabla 43. Ficha de valoración didáctica en Geomorfología de LIGm.

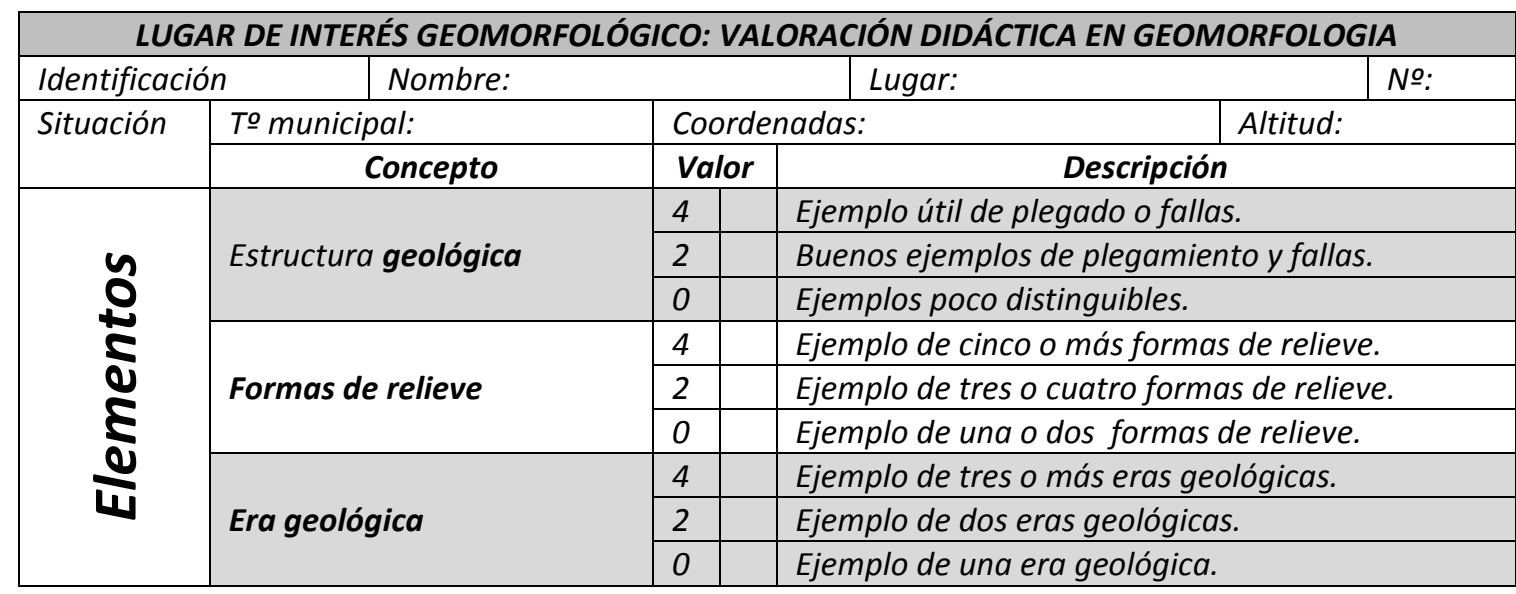




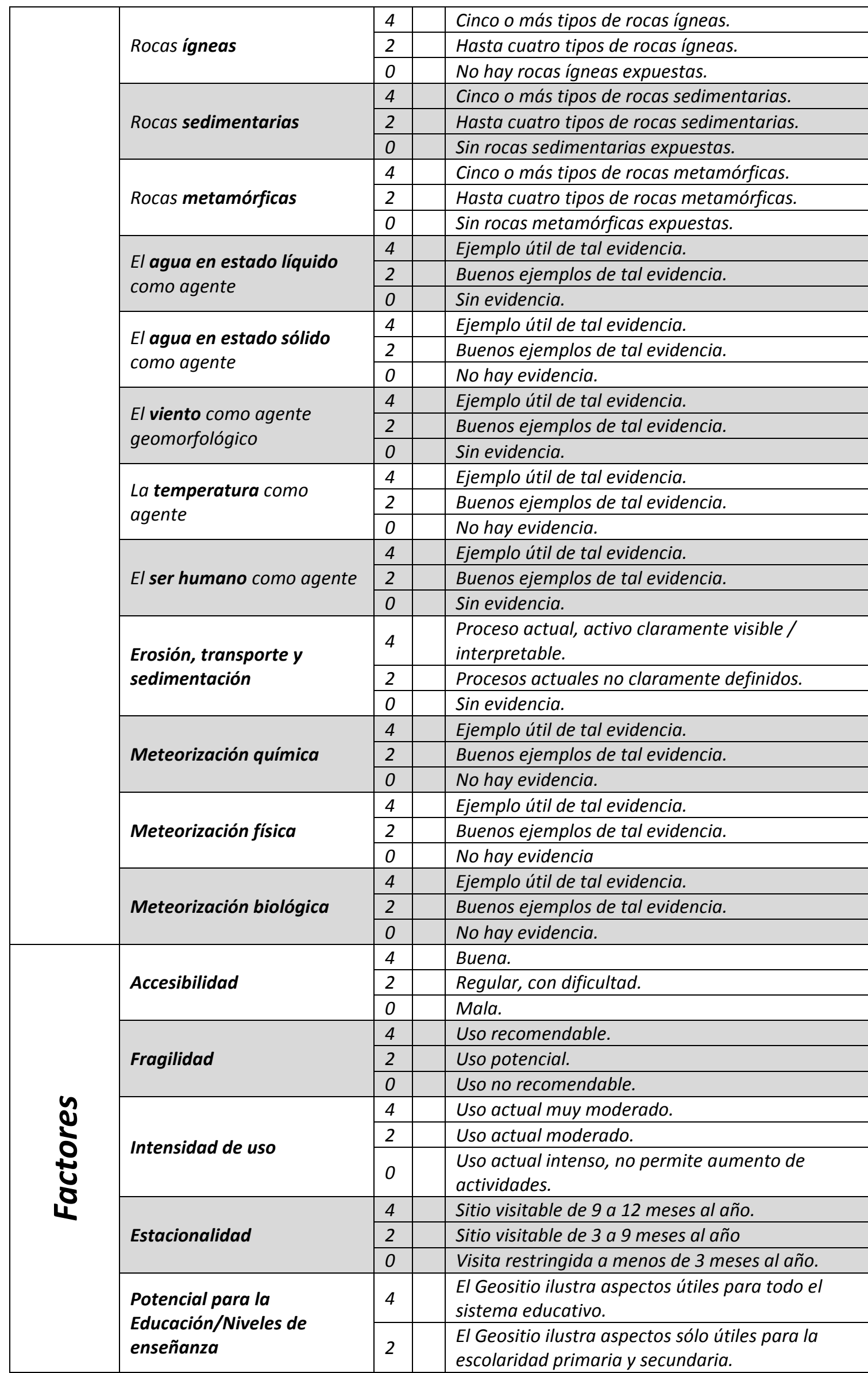


La Interpretación del Patrimonio Geomorfológico en los Picos de Europa: una propuesta para su aprovechamiento didáctico y geoturístico

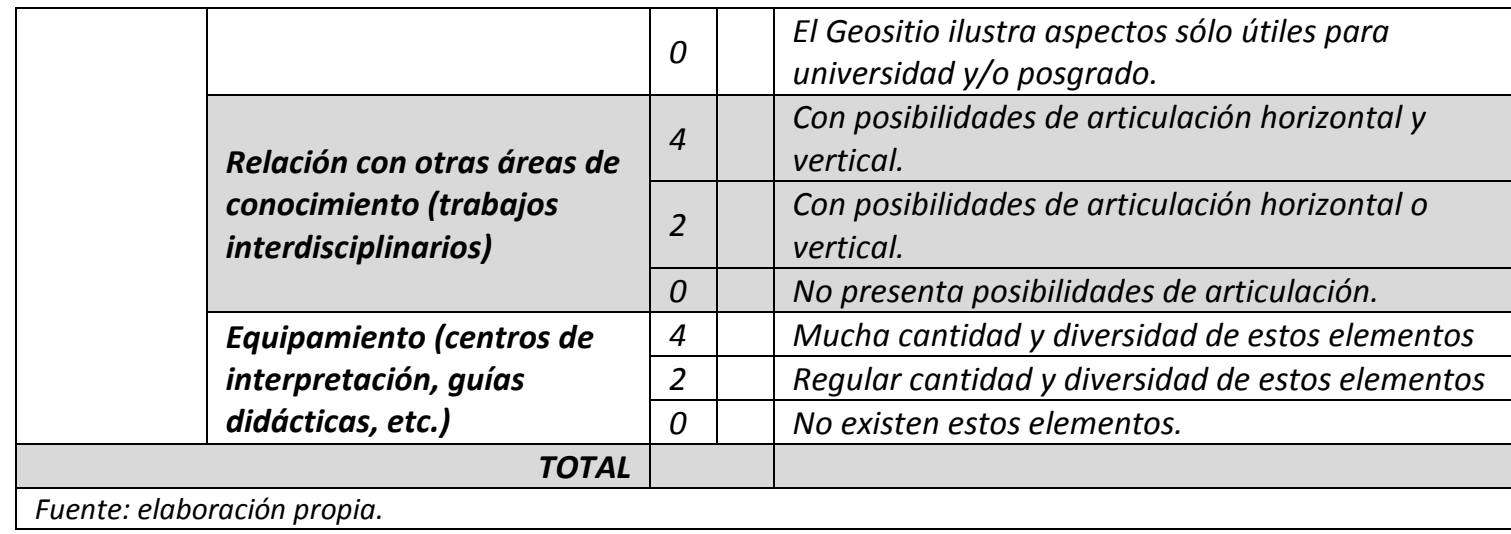

Por lo que respecta a la evaluación didáctica de los elementos geomorfológicos de los LIGm, los valores quedan recogidos en la Tabla 43 y derivan de distintas valoraciones y contenidos curriculares. Para esta ficha de valoración, es importante tanto su puntuación final como los valores parciales de los elementos y factores considerados (Tabla 44) ya que los mismos ayudarán a decidir la intervención docente (introducción, desarrollo o cierre de una unidad didáctica, diferentes grados de profundidad de acuerdo a las características de los estudiantes, etc.). El resultado de la valoración permitirá comparar la importancia de cada aspecto para el aprovechamiento específico en didáctica del LIGm. En todos los criterios se aplican tres valoraciones:

- Valor 4: presenta buenos y variados ejemplos para el atributo a considerar. Su uso es recomendado.

- Valor 2: presenta ejemplos regulares, parciales o no claramente definidos del aspecto considerado. Se recomienda su uso con moderación.

- Valor 0: no hay evidencias del rasgo valorado. Su uso no es recomendado.

Tabla 44. Criterios de valoración de factores condicionantes del aprendizaje de contenidos geomorfológicos en LIGm.

\begin{tabular}{|c|c|c|}
\hline Valoración & Definición & Puntuación \\
\hline Accesibilidad & $\begin{array}{l}\text { Capacidad de acceso al } \\
\text { LIGm para su utilización }\end{array}$ & $\begin{array}{l}\text { 4. Buena accesibilidad } \\
\text { 2. Accesibilidad con dificultades } \\
\text { 0. Mala accesibilidad }\end{array}$ \\
\hline Fragilidad & $\begin{array}{l}\text { Exposición a cambios en las } \\
\text { características intrínsecas } \\
\text { del LIGm }\end{array}$ & $\begin{array}{l}\text { 4. Su uso es recomendado. } \\
\text { 2. Se recomienda su uso con moderación. } \\
\text { 0. Su uso no es recomendable. }\end{array}$ \\
\hline Intensidad de uso & Uso actual del LIGm & $\begin{array}{l}\text { 4. Frecuentación y uso muy moderado. } \\
\text { 2. Frecuentación y uso moderado. } \\
\text { 0. Alta concurrencia, no permite el aumento de } \\
\text { actividades. }\end{array}$ \\
\hline Estacionalidad & $\begin{array}{l}\text { Posibilidad de observary } \\
\text { visitar el LIGm de acuerdo a } \\
\text { los meses del año. }\end{array}$ & $\begin{array}{l}\text { 4. Sitio visitable de } 9 \text { a } 12 \text { meses al año. } \\
\text { 2. Sitio visitable de } 3 \text { a } 9 \text { meses al año } \\
\text { o. Visita restringida a menos de } 3 \text { meses al año. }\end{array}$ \\
\hline
\end{tabular}




\begin{tabular}{|c|c|c|}
\hline $\begin{array}{l}\text { Potencial para la } \\
\text { Educación/Niveles } \\
\text { de enseñanza }\end{array}$ & $\begin{array}{l}\text { Posibilidad del LIGm de } \\
\text { representar procesos } \\
\text { geomorfológicos }\end{array}$ & $\begin{array}{l}\text { 4. El Geositio ilustra aspectos útiles para todo el } \\
\text { sistema educativo. } \\
\text { 2. El Geositio ilustra aspectos sólo útiles para la } \\
\text { escolaridad primaria y secundaria. } \\
\text { 0. El Geositio ilustra aspectos sólo útiles para } \\
\text { universidad y/o posgrado. }\end{array}$ \\
\hline $\begin{array}{l}\text { Relación con otras } \\
\text { áreas de } \\
\text { conocimiento } \\
\text { (trabajos } \\
\text { interdisciplinarios) }\end{array}$ & $\begin{array}{l}\text { Posibilidad de trabajo con } \\
\text { otras espacios curriculares }\end{array}$ & $\begin{array}{l}\text { 4. Presenta posibilidades de articulación curricular } \\
\text { horizontal y vertical. } \\
\text { 2. Presenta posibilidades de articulación curricular } \\
\text { horizontal o vertical. } \\
\text { 0. No presenta posibilidades de articulación } \\
\text { curricular horizontal y vertical. }\end{array}$ \\
\hline $\begin{array}{l}\text { Equipamiento } \\
\text { (centros de } \\
\text { interpretación, } \\
\text { guías didácticas, } \\
\text { etc.) }\end{array}$ & $\begin{array}{l}\text { Elementos que } \\
\text { complementen el uso } \\
\text { didáctico del LIGm. }\end{array}$ & $\begin{array}{l}\text { 4. Mucha cantidad y diversidad de estos elementos. } \\
\text { Actualizados y en buenas condiciones. } \\
\text { 2. Regular cantidad y diversidad de estos elementos. } \\
\text { Necesitan actualización o mantenimiento. } \\
0 . \text { No existen estos elementos. }\end{array}$ \\
\hline
\end{tabular}

Considerando lo expuesto hasta el momento, podemos considerar que los macizos de los Picos de Europa presentan escenarios adecuados para el desarrollo de contenidos específicos relacionados con la dinámica y la morfología glaciar, periglaciar y kárstica. Por este motivo, según los contenidos de los planes de estudios de carreras de grado de Universidades Públicas de las Comunidades Autónomas que forman parte del Parque Nacional de los Picos de Europa (Asturias, Cantabria y Castilla y León) relacionadas con la geomorfología (Tabla 45 y Anexo 4, $5,6)$ y aquellos desarrollados por autores especialistas en la temática (Tabla 46 y Anexo 7, 8, 9), proponemos modelos específicos de valoración didáctica en geomorfología glaciar (Tabla 47), geomorfología periglaciar (Tabla 48) y geomorfología exokárstica (Tabla 49) en zonas de montañas.

Tabla 45. Lista de planes de estudio consultados de las carreras de grado de Universidades Públicas de Asturias, Cantabria y Castilla y León.

\begin{tabular}{|c|c|}
\hline Universidad & Carrera \\
\hline \multirow{2}{*}{ Universidad de Oviedo } & Grado en Geografía y Ordenación del Territorio \\
\cline { 2 - 2 } Universidad de Cantabria & Grado en Geología \\
\hline \multirow{2}{*}{ Universidad de Salamanca } & Grado en Geografía y Ordenación del Territorio \\
\cline { 2 - 2 } & Grado en Geología \\
\cline { 2 - 2 } & Grado en Geografía \\
\hline Universidad de León & Grado en Geografía y Ordenación Geón de lón del Territorio \\
\cline { 2 - 2 } & Grado en Ingeniería Minera \\
\hline Universidad de Valladolid & Grado en Geografía y Ordenación del Territorio \\
\hline Fuente: elaboración propia. & \\
\hline
\end{tabular}


Tabla 46. Lista de la bibliografía consultada para el diseño de fichas de valoración.

\begin{tabular}{|c|c|c|}
\hline Geomorfología glaciar & Geomorfología periglaciar & Geomorfología exokárstica \\
\hline Gutiérrez (2001, 2008) & Gutiérrez (2001, 2008) & Serrano (1998) \\
\hline de Pedraza (1996) & de Pedraza (1996) & Derruau (1991) \\
\hline Derruau (1991) & Derruau (1991) & Sandoval (1991) \\
\hline Sandoval (1991) & Washburn (1973) & \multirow{2}{*}{ Tricart y Cailleux (1967) } \\
\hline Tricart (1963) & Tricart (1963) \\
\cline { 1 - 2 } Fuente: elaboración propia.
\end{tabular}

Estos modelos de valoración tienen como objetivo utilizar una serie de criterios para evaluar el aprovechamiento didáctico de los valores geomorfológicos de un LIGm y facilitar la toma de decisiones en cuanto a la planificación didáctica de los contenidos geomorfológicos a desarrollar. Estos criterios guardan relación con la metodología de análisis descrita para la Tabla 43: una categoría realiza el registro de la existencia y calidad de elementos geomorfológicos necesarios para el desarrollo de contenidos específicos de geomorfología glaciar, periglaciar y exokárstica, mientras que la clasificación restante considera los factores que influyen en el aprendizaje in situ de esos contenidos (Tabla 44).

Tabla 47. Ficha de valoración didáctica de geomorfología glaciar de montaña.

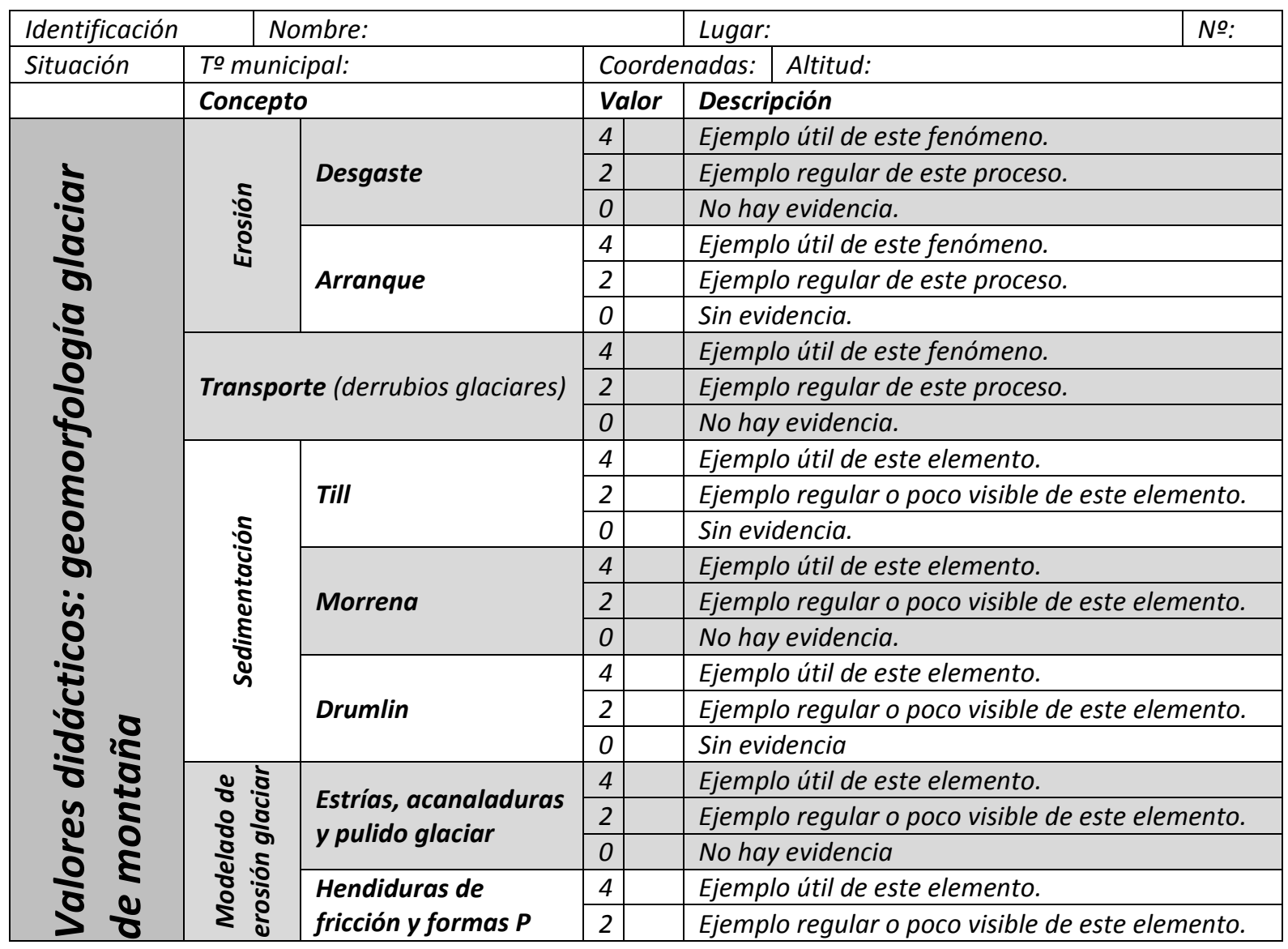




\begin{tabular}{|c|c|c|c|}
\hline & & 0 & No hay evidencia \\
\hline & \multirow{3}{*}{ Valle en forma de $U$} & 4 & Ejemplo útil de este elemento. \\
\hline & & 2 & Ejemplo regular o poco visible de este elemento. \\
\hline & & 0 & Sin evidencia \\
\hline & \multirow{3}{*}{$\begin{array}{l}\text { Espolones truncados } \\
\text { o alineados }\end{array}$} & 4 & Ejemplo útil de este elemento. \\
\hline & & 2 & Ejemplo regular o poco visible de este elemento. \\
\hline & & 0 & No hay evidencia \\
\hline & \multirow{3}{*}{$\begin{array}{l}\text { Aristas y picos } \\
\text { piramidales (Horn) }\end{array}$} & 4 & Ejemplo útil de este elemento. \\
\hline & & 2 & Ejemplo regular o poco visible de este elemento. \\
\hline & & 0 & Sin evidencia \\
\hline & \multirow{3}{*}{ Rocas aborregadas } & 4 & Ejemplo útil de este elemento. \\
\hline & & 2 & Ejemplo regular o poco visible de este elemento. \\
\hline & & 0 & No hay evidencia \\
\hline & \multirow{3}{*}{ Nunatak } & 4 & Ejemplo útil de este elemento. \\
\hline & & 2 & Ejemplo regular o poco visible de este elemento. \\
\hline & & 0 & Sin evidencia \\
\hline \multirow{18}{*}{ 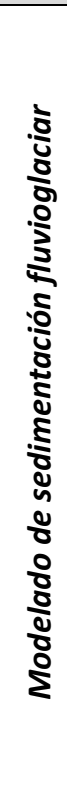 } & \multirow{3}{*}{ Esker } & 4 & Ejemplo útil de este elemento. \\
\hline & & 2 & Ejemplo regular o poco visible de este elemento. \\
\hline & & 0 & No hay evidencia \\
\hline & \multirow{3}{*}{ Kame } & 4 & Ejemplo útil de este elemento. \\
\hline & & 2 & Ejemplo regular o poco visible de este elemento. \\
\hline & & 0 & No hay evidencia \\
\hline & \multirow{3}{*}{ Outwash o sandur } & 4 & Ejemplo útil de este elemento. \\
\hline & & 2 & Ejemplo regular o poco visible de este elemento. \\
\hline & & 0 & No hay evidencia \\
\hline & \multirow{3}{*}{$\begin{array}{l}\text { Llanura de origen } \\
\text { glaciolacustre }\end{array}$} & 4 & Ejemplo útil de este elemento. \\
\hline & & 2 & Ejemplo regular o poco visible de este elemento. \\
\hline & & 0 & No hay evidencia \\
\hline & \multirow{3}{*}{ Varva } & 4 & Ejemplo útil de este elemento. \\
\hline & & 2 & Ejemplo regular o poco visible de este elemento. \\
\hline & & 0 & No hay evidencia \\
\hline & \multirow{3}{*}{ Kettle } & 4 & Ejemplo útil de este elemento. \\
\hline & & 2 & Ejemplo regular o poco visible de este elemento. \\
\hline & & 0 & No hay evidencia \\
\hline \multirow{16}{*}{ 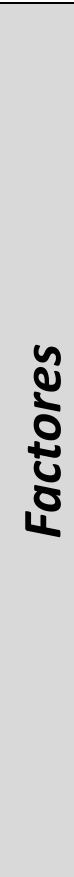 } & \multirow{3}{*}{ Accesibilidad } & 4 & Buena. \\
\hline & & 2 & Regular, con dificultad. \\
\hline & & 0 & Mala. \\
\hline & \multirow{3}{*}{ Fragilidad } & 4 & Uso recomendable. \\
\hline & & 2 & Uso potencial. \\
\hline & & 0 & Uso no recomendable. \\
\hline & \multirow{3}{*}{ Intensidad de uso } & 4 & Uso actual muy moderado. \\
\hline & & 2 & Uso actual moderado. \\
\hline & & 0 & $\begin{array}{l}\text { Uso actual intenso, no permite aumento de } \\
\text { actividades. }\end{array}$ \\
\hline & \multirow{3}{*}{ Estacionalidad } & 4 & Sitio visitable de 9 a 12 meses al año. \\
\hline & & 2 & Sitio visitable de 3 a 9 meses al año \\
\hline & & 0 & Visita restringida a menos de 3 meses al año. \\
\hline & \multirow{3}{*}{$\begin{array}{l}\text { Potencial para la } \\
\text { Educación/ } \\
\text { Niveles de enseñanza }\end{array}$} & 4 & $\begin{array}{l}\text { El Geositio ilustra aspectos útiles para todo el } \\
\text { sistema educativo. }\end{array}$ \\
\hline & & 2 & $\begin{array}{l}\text { El Geositio ilustra aspectos sólo útiles para la } \\
\text { escolaridad primaria y secundaria. }\end{array}$ \\
\hline & & 0 & $\begin{array}{l}\text { El Geositio ilustra aspectos sólo útiles para } \\
\text { universidad y/o posgrado. }\end{array}$ \\
\hline & Relación con otras & 4 & Con posibilidades de articulación horizontal y \\
\hline
\end{tabular}


La Interpretación del Patrimonio Geomorfológico en los Picos de Europa: una propuesta para su aprovechamiento didáctico y geoturístico

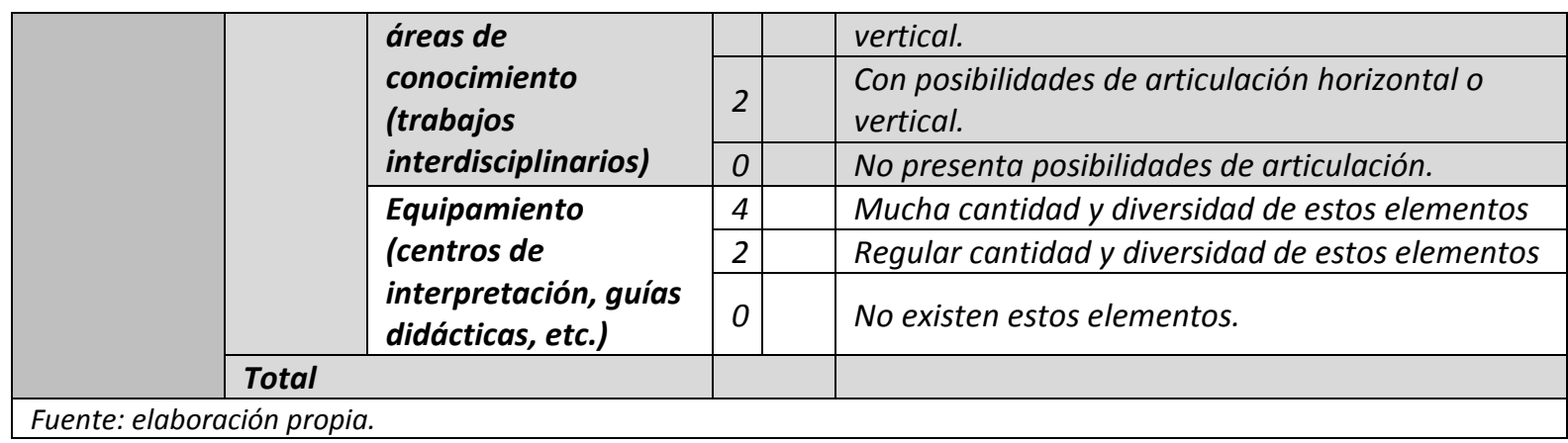

Tabla 48. Ficha valoración didáctica en geomorfología periglaciar en zona de montaña.

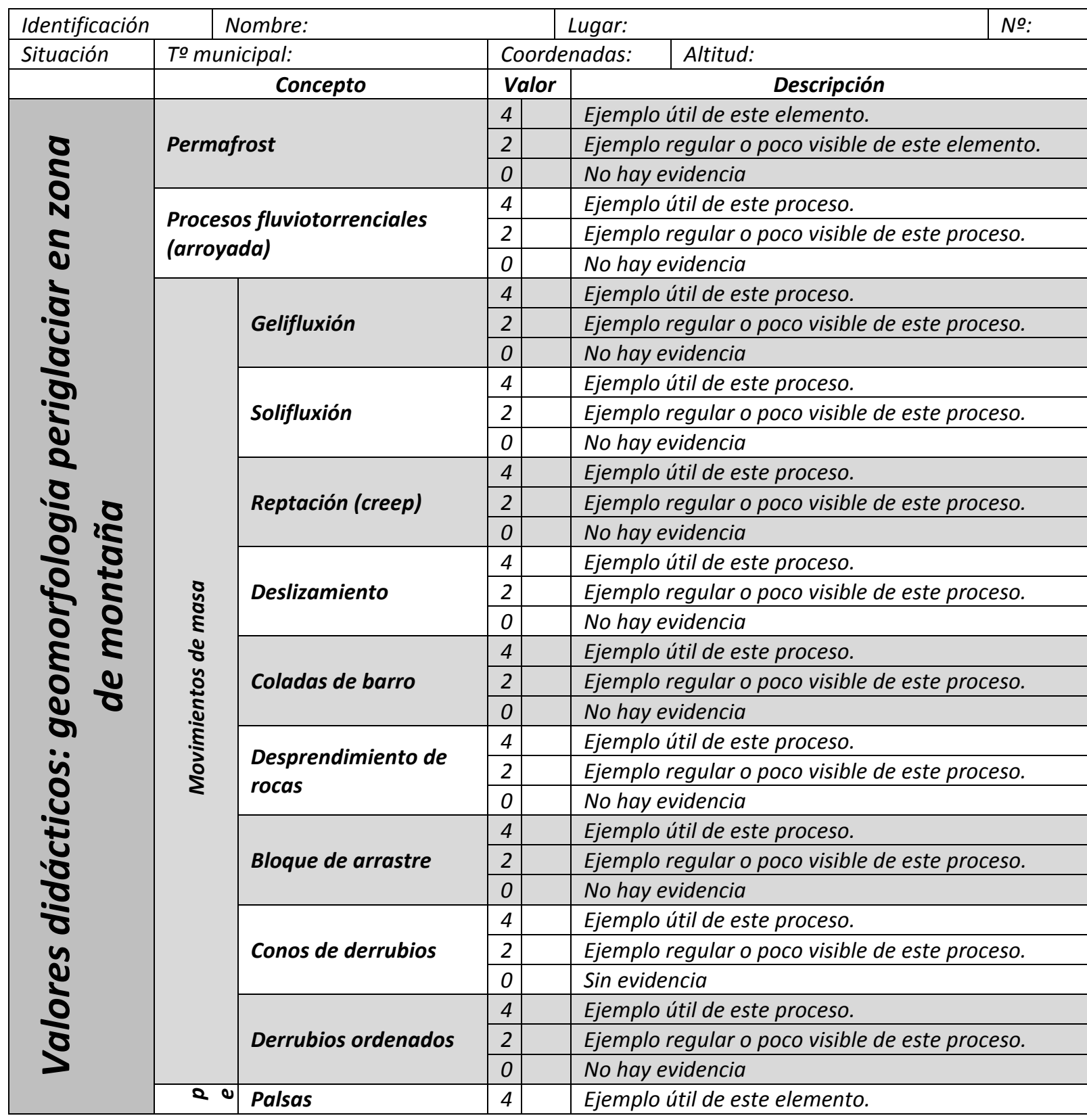




\begin{tabular}{|c|c|c|c|}
\hline & & 2 & Ejemplo regular o poco visible de este elemento. \\
\hline & & 0 & Sin evidencia \\
\hline & \multirow{3}{*}{ Pingos } & 4 & Ejemplo útil de este elemento. \\
\hline & & 2 & Ejemplo regular o poco visible de este elemento. \\
\hline & & 0 & No hay evidencia \\
\hline & \multirow{3}{*}{$\begin{array}{l}\text { Suelos ordenados } \\
\text { (bandas, círculos, } \\
\text { polígonos, redes) }\end{array}$} & 4 & Ejemplo útil de este elemento. \\
\hline & & 2 & Ejemplo regular o poco visible de este elemento. \\
\hline & & 0 & Sin evidencia \\
\hline & \multirow{3}{*}{ Césped almohadillado } & 4 & Ejemplo útil de este elemento. \\
\hline & & 2 & Ejemplo regular o poco visible de este elemento. \\
\hline & & 0 & No hay evidencia \\
\hline & \multirow{3}{*}{ Escalones } & 4 & Ejemplo útil de este elemento. \\
\hline & & 2 & Ejemplo regular o poco visible de este elemento. \\
\hline & & 0 & No hay evidencia \\
\hline & \multirow{3}{*}{ Guirnaldas de piedra } & 4 & Ejemplo útil de este elemento. \\
\hline & & 2 & Ejemplo regular o poco visible de este elemento. \\
\hline & & 0 & No hay evidencia \\
\hline \multirow{12}{*}{ 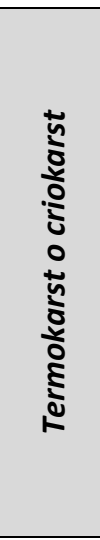 } & \multirow{3}{*}{ Lagos de deshielo } & 4 & Ejemplo útil de este elemento. \\
\hline & & 2 & Ejemplo regular o poco visible de este elemento. \\
\hline & & 0 & No hay evidencia \\
\hline & \multirow{3}{*}{ Lagos orientados } & 4 & Ejemplo útil de este elemento. \\
\hline & & 2 & Ejemplo regular o poco visible de este elemento. \\
\hline & & 0 & No hay evidencia \\
\hline & \multirow{3}{*}{ Pingos colapsados } & 4 & Ejemplo útil de este elemento. \\
\hline & & 2 & Ejemplo regular o poco visible de este elemento. \\
\hline & & 0 & No hay evidencia \\
\hline & \multirow{3}{*}{$\begin{array}{l}\text { Desplomes por } \\
\text { deshielo }\end{array}$} & 4 & Ejemplo útil de este elemento. \\
\hline & & 2 & Ejemplo regular o poco visible de este elemento. \\
\hline & & 0 & No hay evidencia \\
\hline \multirow{6}{*}{ 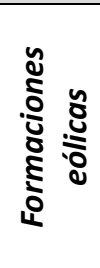 } & \multirow{3}{*}{ Loess } & 4 & Ejemplo útil de este elemento. \\
\hline & & 2 & Ejemplo regular o poco visible de este elemento. \\
\hline & & 0 & No hay evidencia \\
\hline & \multirow{3}{*}{ Duna } & 4 & Ejemplo útil de este elemento. \\
\hline & & 2 & Ejemplo regular o poco visible de este elemento. \\
\hline & & 0 & No hay evidencia \\
\hline \multirow{9}{*}{ 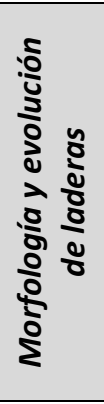 } & \multirow{3}{*}{ Laderas de gelifluxión } & 4 & Ejemplo útil de este elemento. \\
\hline & & 2 & Ejemplo regular o poco visible de este elemento. \\
\hline & & 0 & No hay evidencia \\
\hline & \multirow{3}{*}{$\begin{array}{l}\text { Taludes y conos de } \\
\text { derrubios }\end{array}$} & 4 & Ejemplo útil de este elemento. \\
\hline & & 2 & Ejemplo regular o poco visible de este elemento. \\
\hline & & 0 & No hay evidencia \\
\hline & \multirow{3}{*}{ Glaciares rocosos } & 4 & Ejemplo útil de este elemento. \\
\hline & & 2 & Ejemplo regular o poco visible de este elemento. \\
\hline & & 0 & No hay evidencia \\
\hline \multirow{9}{*}{ 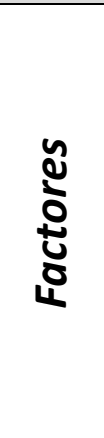 } & \multirow{3}{*}{ Accesibilidad } & 4 & Buena. \\
\hline & & 2 & Regular, con dificultad. \\
\hline & & 0 & Mala. \\
\hline & \multirow{3}{*}{ Fragilidad } & 4 & Uso recomendable. \\
\hline & & 2 & Uso potencial. \\
\hline & & 0 & Uso no recomendable. \\
\hline & \multirow{3}{*}{ Intensidad de uso } & 4 & Uso actual muy moderado. \\
\hline & & 2 & Uso actual moderado. \\
\hline & & 0 & $\begin{array}{l}\text { Uso actual intenso, no permite aumento de } \\
\text { actividades. }\end{array}$ \\
\hline
\end{tabular}


La Interpretación del Patrimonio Geomorfológico en los Picos de Europa: una propuesta para su aprovechamiento didáctico y geoturístico

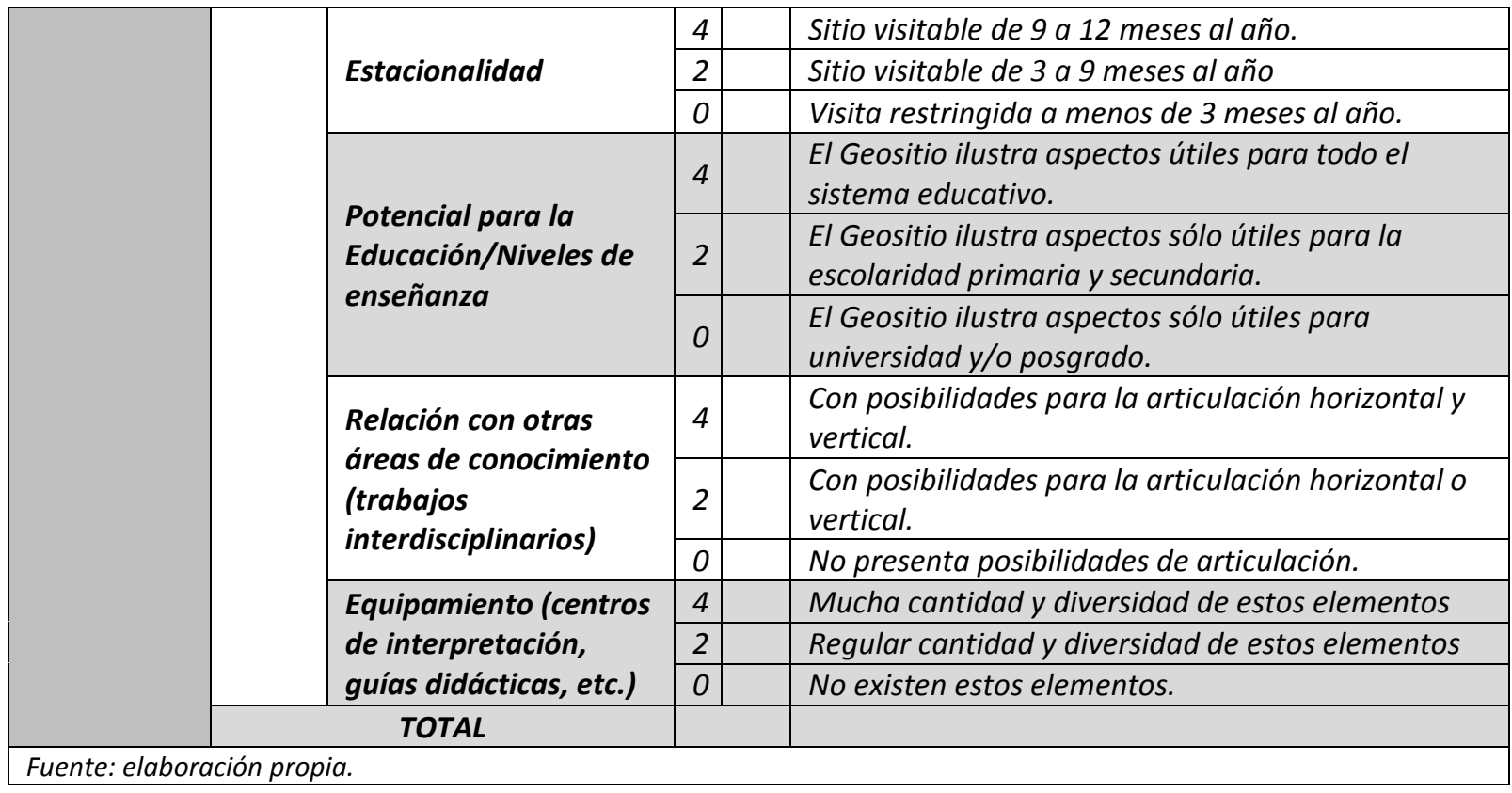

Tabla 49. Ficha de valoración didáctica en geomorfología exokárstica.

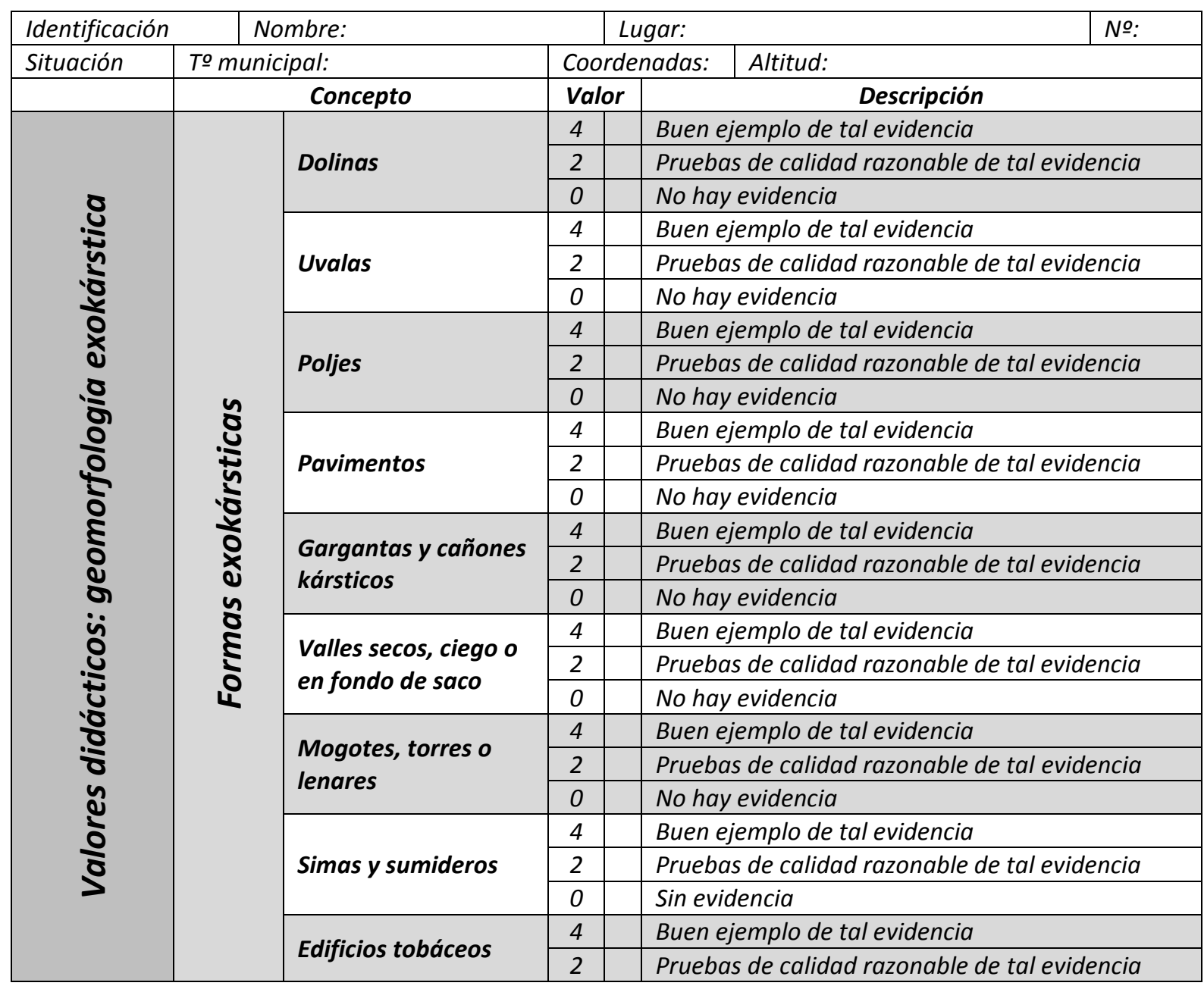


La Interpretación del Patrimonio Geomorfológico en los Picos de Europa: una propuesta para su aprovechamiento didáctico y geoturístico

\begin{tabular}{|c|c|c|}
\hline & 0 & No hay evidencia \\
\hline \multirow{3}{*}{$\begin{array}{l}\text { Cubetas de } \\
\text { descalcificación }\end{array}$} & 4 & Buen ejemplo de tal evidencia \\
\hline & 2 & Pruebas de calidad razonable de tal evidencia \\
\hline & 0 & Sin evidencia \\
\hline \multirow{3}{*}{ Ponor } & 4 & Buen ejemplo de tal evidencia \\
\hline & 2 & Pruebas de calidad razonable de tal evidencia \\
\hline & 0 & No hay evidencia \\
\hline \multirow{3}{*}{ Puentes naturales } & 4 & Buen ejemplo de tal evidencia \\
\hline & 2 & Pruebas de calidad razonable de tal evidencia \\
\hline & 0 & Sin evidencia \\
\hline \multirow{3}{*}{ Lapiaces } & 4 & Buen ejemplo de tal evidencia \\
\hline & 2 & Pruebas de calidad razonable de tal evidencia \\
\hline & 0 & Sin evidencia \\
\hline \multirow{3}{*}{ Accesibilidad } & 4 & Buena. \\
\hline & 2 & Regular, con dificultad. \\
\hline & 0 & Mala. \\
\hline \multirow{3}{*}{ Fragilidad } & 4 & Uso recomendable. \\
\hline & 2 & Uso potencial. \\
\hline & 0 & Uso no recomendable. \\
\hline \multirow{3}{*}{ Intensidad de uso } & 4 & Uso actual muy moderado. \\
\hline & 2 & Uso actual moderado. \\
\hline & 0 & $\begin{array}{l}\text { Uso actual intenso, no permite aumento de } \\
\text { actividades. }\end{array}$ \\
\hline \multirow{3}{*}{ Estacionalidad } & 4 & Sitio visitable de 9 a 12 meses al año. \\
\hline & 2 & Sitio visitable de 3 a 9 meses al año \\
\hline & 0 & Visita restringida a menos de 3 meses al año. \\
\hline \multirow{3}{*}{$\begin{array}{l}\text { Potencial para la } \\
\text { Educación/ } \\
\text { Niveles de enseñanza }\end{array}$} & 4 & $\begin{array}{l}\text { El Geositio ilustra aspectos útiles para todo el } \\
\text { sistema educativo. }\end{array}$ \\
\hline & 2 & $\begin{array}{l}\text { El Geositio ilustra aspectos sólo útiles para la } \\
\text { escolaridad primaria y secundaria. }\end{array}$ \\
\hline & 0 & $\begin{array}{l}\text { El Geositio ilustra aspectos sólo útiles para } \\
\text { universidad y/o posgrado. }\end{array}$ \\
\hline \multirow{3}{*}{$\begin{array}{l}\text { Relación con otras } \\
\text { áreas de } \\
\text { conocimiento } \\
\text { (trabajos } \\
\text { interdisciplinarios) }\end{array}$} & 4 & $\begin{array}{l}\text { Con posibilidades para la articulación horizontal y } \\
\text { vertical. }\end{array}$ \\
\hline & 2 & $\begin{array}{l}\text { Con posibilidades para la articulación horizontal o } \\
\text { vertical. }\end{array}$ \\
\hline & 0 & No presenta posibilidades de articulación. \\
\hline \multirow{3}{*}{$\begin{array}{l}\text { Equipamiento } \\
\text { (centros de } \\
\text { interpretación, guías } \\
\text { didácticas, etc.) }\end{array}$} & 4 & Mucha cantidad y diversidad de estos elementos \\
\hline & 2 & Regular cantidad y diversidad de estos elementos \\
\hline & 0 & No existen estos elementos. \\
\hline TOTAL & & \\
\hline
\end{tabular}




\section{Capítulo 5}

\section{Parque Nacional de los Picos de Europa}

El Parque Nacional de los Picos de Europa se encuentra situado en la Cordillera Cantábrica, al norte de España. Forma un frente montañoso entre las Comunidades Autónomas de Castilla y León, Cantabria y el Principado de Asturias, siendo la ampliación del primer parque nacional español, el Parque Nacional de la Montaña de Covadonga. Fue creado por Ley de 22 de julio de 1918, estableciéndose sus límites por disposición del Real Decreto de 17 de agosto del mismo año (Figura 57). Con una superficie original de 16.925 hectáreas del Macizo Occidental, esta declaración como Parque Nacional quería aunar una serie de eventos históricos (duodécimo centenario de la batalla de Covadonga), naturales (conservación de la naturaleza en el Macizo del Cornión), religiosos (Real Sitio de la Montaña de Covadonga) y folklóricos (actividades cotidianas de la comunidad).

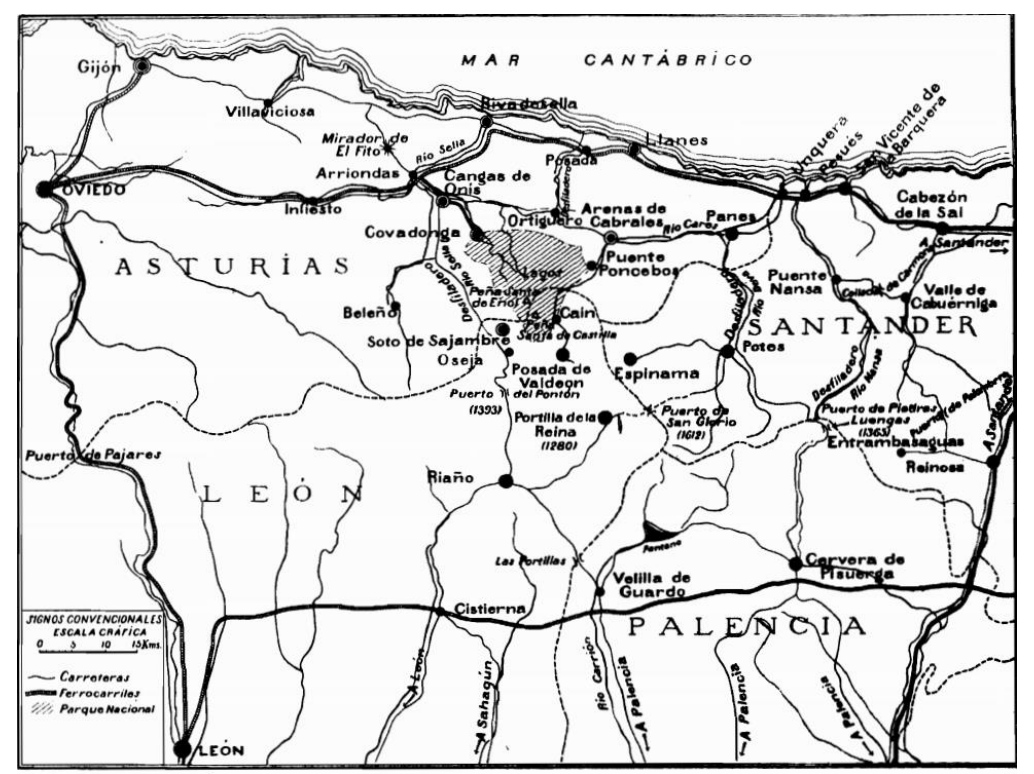

Figura 57. Mapa del Parque Nacional de la Montaña de Covadonga. Fuente: Delgado et al, 1932.

Por disposición de la Ley 16/1995 de 30 de mayo amplía su extensión a las 64.660 hectáreas que en la actualidad posee el Parque, abarcando también los macizos Oriental y Central y recibiendo el nombre de Parque Nacional de los Picos de Europa. El macizo de los 
Picos de Europa cubre un área aproximada de $500 \mathrm{~km}^{2}$, con 15 a $20 \mathrm{~km}$ de extensión de Norte a Sur y $35 \mathrm{~km}$ de Este a Oeste.

Uno de los objetivos de la creación del Parque Nacional fue la protección de la integridad de los ecosistemas incluidos dentro de sus límites, así como de los elementos físicos y biológicos que lo caracterizan (Figura 58). El alcance de dichos objetivos se apoya en la planificación previa, y ésta se concreta en el Plan Rector de Uso y Gestión (PRUG), elaborado conforme con el Plan Director de Parques Nacionales. En el caso del Parque Nacional de los Picos de Europa, el Real Decreto 384/2002, de 26 de abril, aprueba su PRUG. En él constan sus principales finalidades:

a) Mantener, y restaurar en la medida de lo posible, los valores naturales y culturales del parque.

b) Compatibilizar las actividades tradicionales de los residentes locales con la conservación.

c) Establecer un diversificado sistema de uso público adecuado a la capacidad de carga de las diferentes zonas del parque y siempre compatible con su conservación.

d) Determinar las carencias de conocimiento e investigación, y desarrollar las consideradas prioritarias.

e) Ordenar el uso de las infraestructuras existentes en el interior del parque, integrando su funcionamiento con el cumplimiento de los objetivos del mismo.

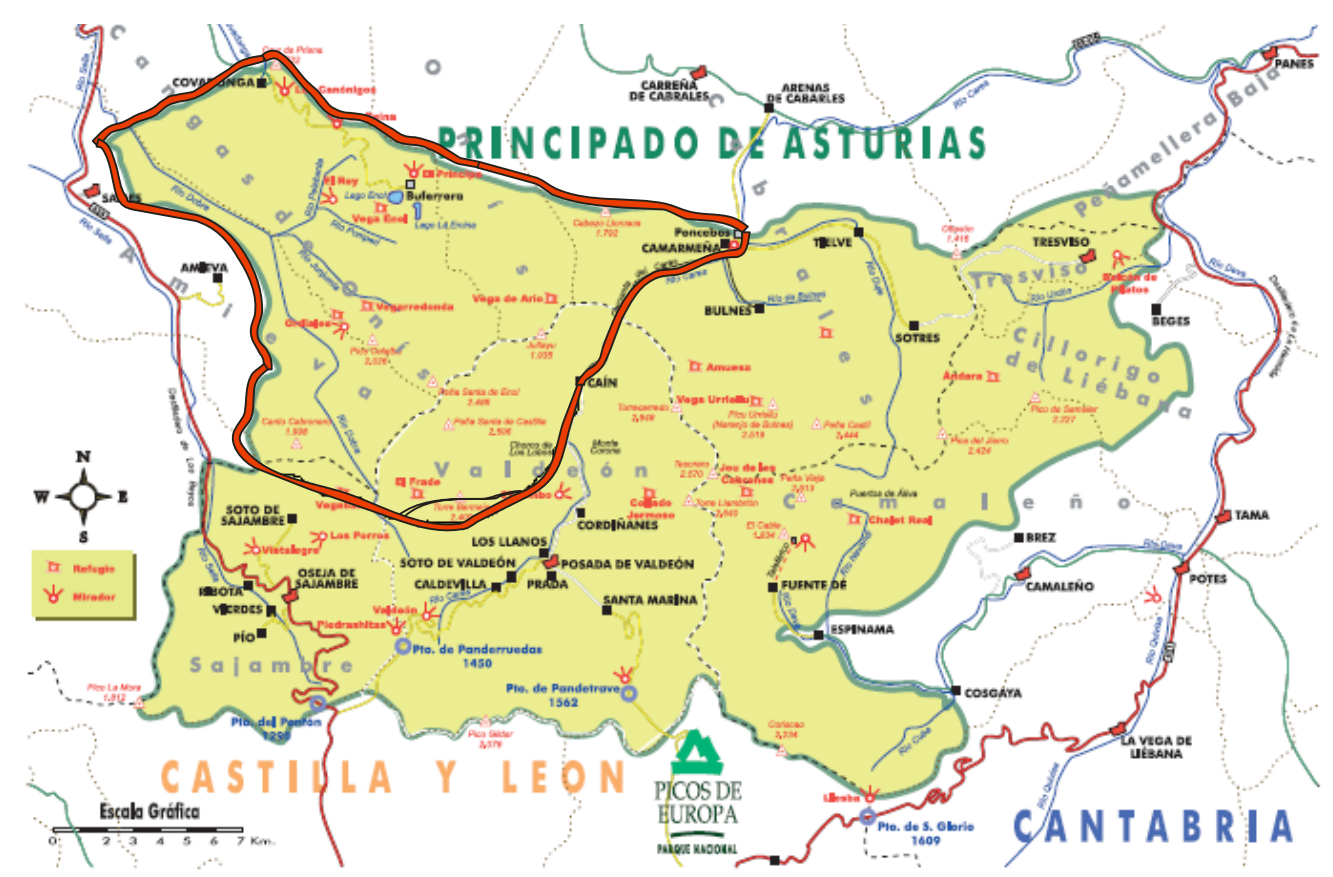

Figura 58. Mapa del PNPE, en rojo el área del Parque en 1918.

Fuente: modificado de Menéndez, 2002. 
Considerando los valores abióticos del Parque, son de importancia las formaciones geomorfológicas derivadas del glaciarismo cuaternario, así como los fenómenos de karstificación que han conformado un excepcional paisaje, en el que destacan los profundos cañones excavados por los ríos y el karst (Figuras 59y 60) y los impresionantes cantiles de roca caliza, en permanente proceso de alteración por la acción erosiva del agua en estado líquido y sólido.

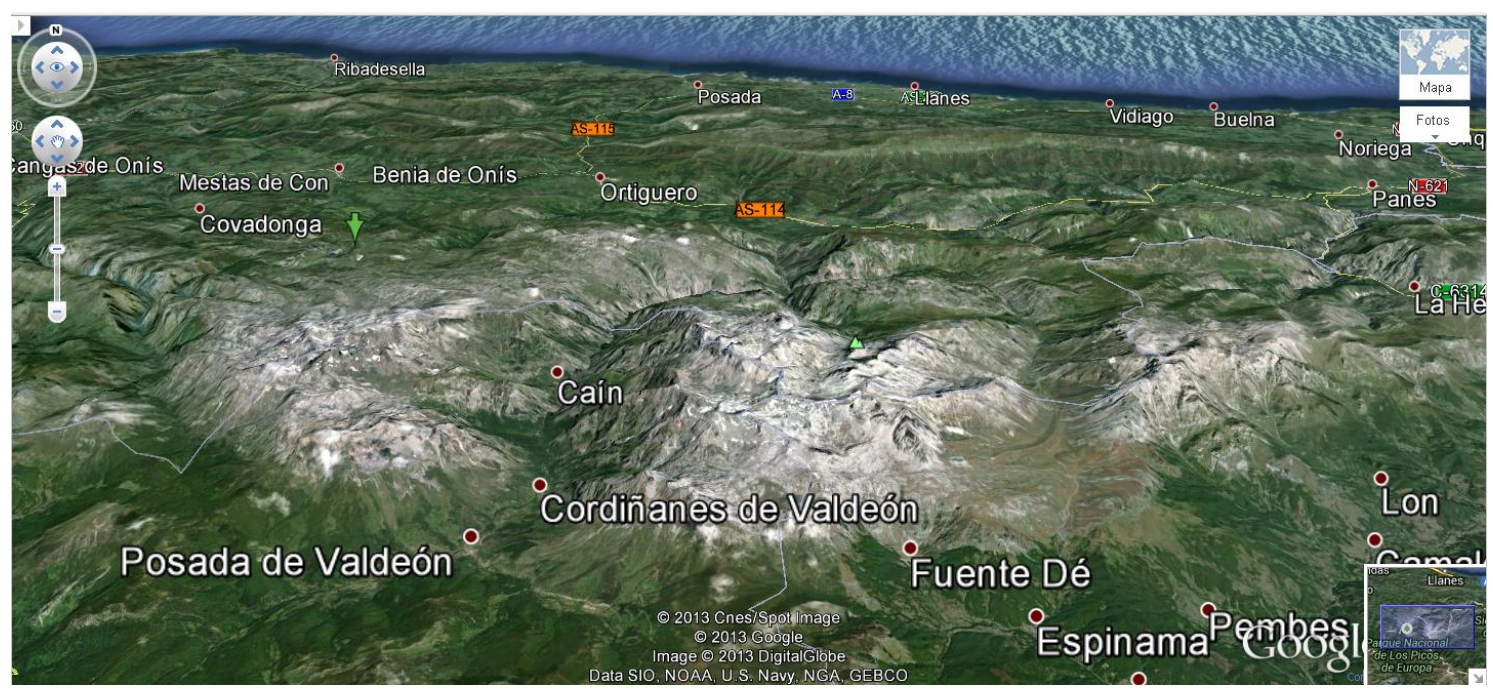

Figura 59. Imagen de Google Earth de los macizos de Picos de Europa.

Fuente: Google Earth (captura de pantalla).

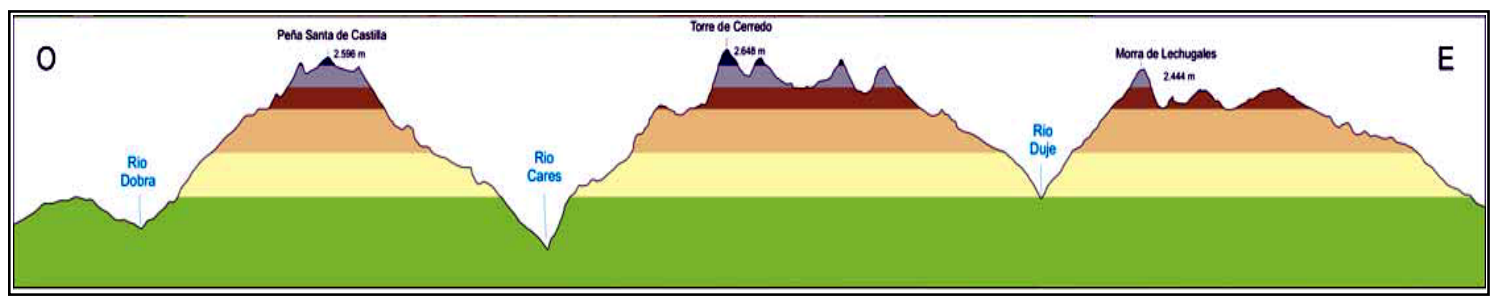

Figura 60. Perfil de los macizos de Picos de Europa.

Fuente: González Trueba, 2006.

\section{1) Medio físico}

El Parque Nacional de los Picos de Europa incluye al macizo de Picos de Europa así como también otros sectores geológicos de la Cordillera Cantábrica. Este cordón montañoso está cerca del mar Cantábrico (entre 15 y $20 \mathrm{~km}$ de distancia) y se caracteriza por poseer un paisaje modelado por la glaciación cuaternaria, abundancia de calizas y por lo abrupto de sus paredes. A todo ello se suma una activa dinámica de laderas, debido a las fuertes pendientes y desniveles existentes, y una morfodinámica asociada al frío y la nieve, activa especialmente en la parte superior de la montaña. Estas particularidades abióticas determinan sus componentes 
bióticos y antrópicos. Respecto a los primeros, presenta una flora y fauna de los biomas atlántico, mediterráneo y de alta montaña, mientras que la ocupación humana se ha desarrollado en comunidades muy aisladas unas de otras debido al difícil acceso a los valles.

Dentro de los Picos de Europa se distinguen tres macizos (Figura 61) limitados por sendos ríos que discurren a través de angostos cañones:

- Macizo Occidental o del Cornión: es el más extenso de los tres macizos y está limitado por los ríos Sella y Dobra al W y por el Cares al E. La parte sur se encuentra sobre los valles de Sajambre y Valdeón, mientras que por el $N$ llegan hasta los ríos Güeña y Castaño. Su cumbre más elevada es la Peña Santa de Castilla (2.596 msnm).

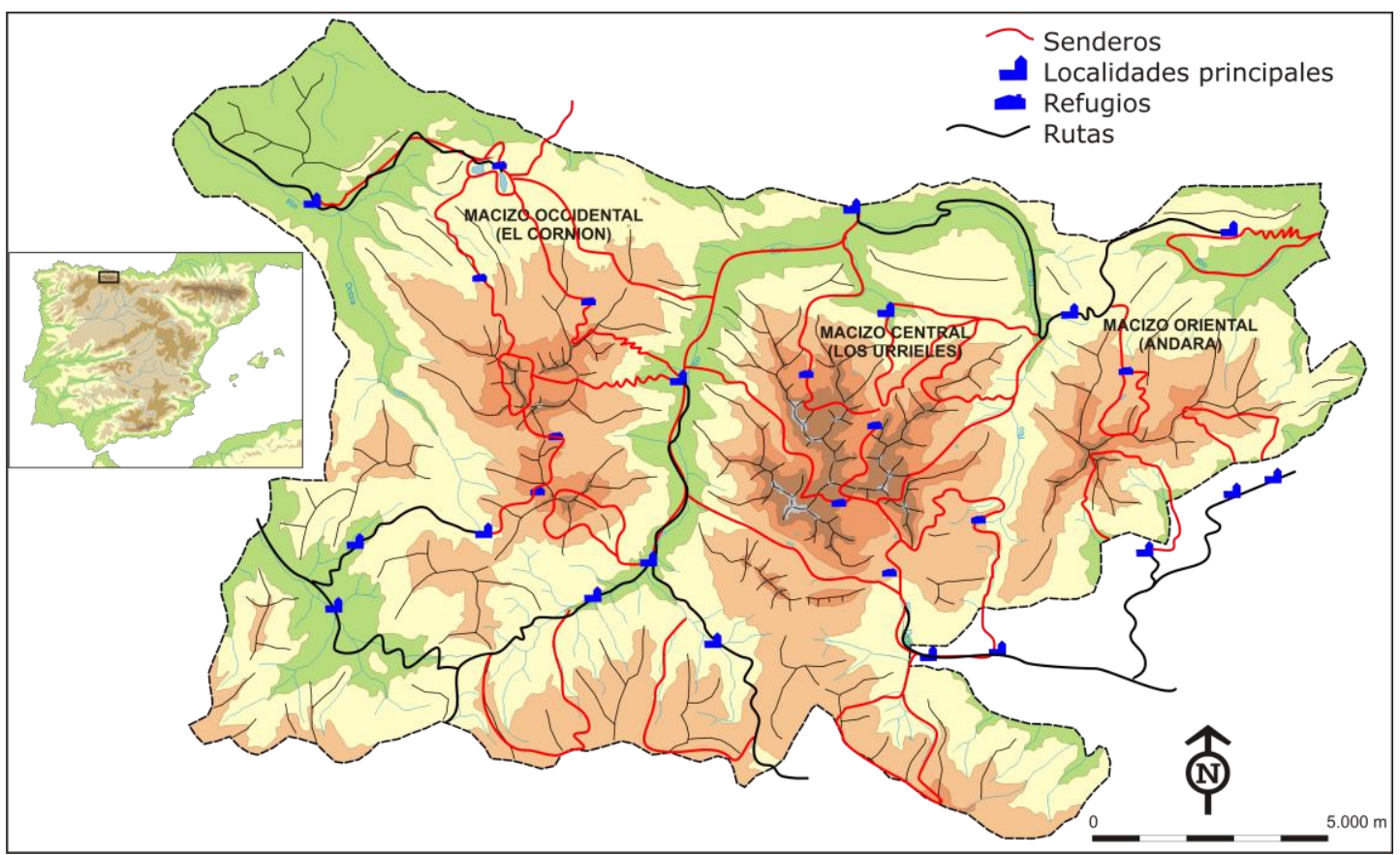

Figura 61. Macizos del Parque Nacional de los Picos de Europa.

Fuente: Serrano y González Trueba, 2011.

- Macizo Central o de Los Urrielles: los flancos E y $N$ de este macizo limitan con el río Duje, que a su vez le separa del macizo oriental en su primer tramo y de la sierra de Portudera en el segundo. Por el $\mathrm{O}$ y en parte por el $\mathrm{N}$, tiene al río Cares como frontera con el macizo occidental. La vertiente S limita con las estribaciones de la Cordillera Cantábrica por los valles de Fuente Dé, Valdeón y el puerto de Remoña. Es el que presenta las mayores altitudes de los Picos de Europa, contando con 14 cimas que superan los 2600 m, con la Torre de Cerredo de 2646 m (González Trueba, 2006) como pico culminante de todo el macizo central y de los Picos de Europa, junto a otras 
cumbres de importancia destacable tales como Peña Vieja o el conocido Naranjo de Bulnes (Figura 62).

- Macizo Oriental o de Ándara: entre los ríos Duje al Este y Deva al Oeste; es el menos extenso de los tres y el que presenta las menores alturas (Morra de Lechugales, $2444 \mathrm{~m}$ ). Su principal eje se extiende de SW a NE. Presenta una superficie aproximada de $96 \mathrm{~km}^{2}$ (13 km en sentido $\mathrm{N}-\mathrm{S}$ y $14 \mathrm{~km}$ de $\left.\mathrm{W}-\mathrm{E}\right)$.

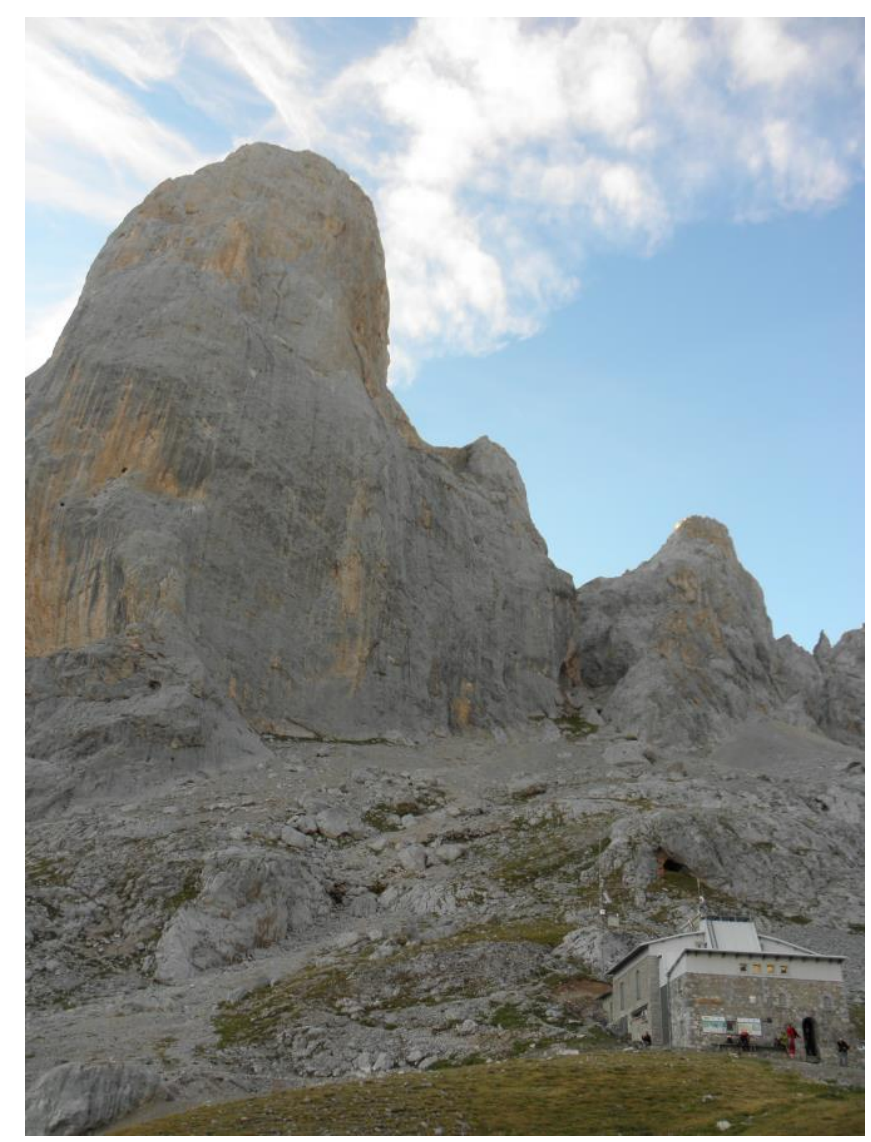

Figura 62. El Naranjo de Bulnes es un punto de referencia del PNPE.

Fuente: Héctor Bazán.

Estas elevaciones convierten a Picos de Europa en una barrera no solo fisiográfica sino también climática, concentrando una parte importante de las precipitaciones en sus vertientes $N$ y NW, ya que de esta última dirección procede la mayor parte de las borrascas. Esta misma característica, junto a la mayor insolación de la vertiente sur, influyó en la extensión y distribución general de los glaciares. Por otro lado, la litología también incidió en el desarrollo y conservación del relieve glaciar, que resulta fácilmente reconocible en las áreas siliciclásticas, especialmente en las zonas con sustrato cuarcítico (Menéndez, 2002). 
Tectónicamente estos macizos se sitúan en la denominada Zona Cantábrica: las unidades del Ponga (Valle de Sajambre) y Pisuerga-Carrión (valles de Liébana y Valdeón) (Figura 63). La Unidad Geológica de los Picos de Europa se caracteriza por un predominio de los materiales calizos; la Región del Ponga presenta un porcentaje similar de materiales siliciclásticos (areniscas, pizarras y conglomerados) y de calizas, mientras que en la Región del PisuergaCarrión son mayoría los materiales siliciclásticos. En el periodo Carbonífero se inicia la sedimentación de carbonatos sobre la plataforma marina, llegando a acumularse hasta 1.000 metros de sedimentos calcáreos que, hoy en día y tras los posteriores periodos orogénicos, forman el macizo calcáreo de Picos.

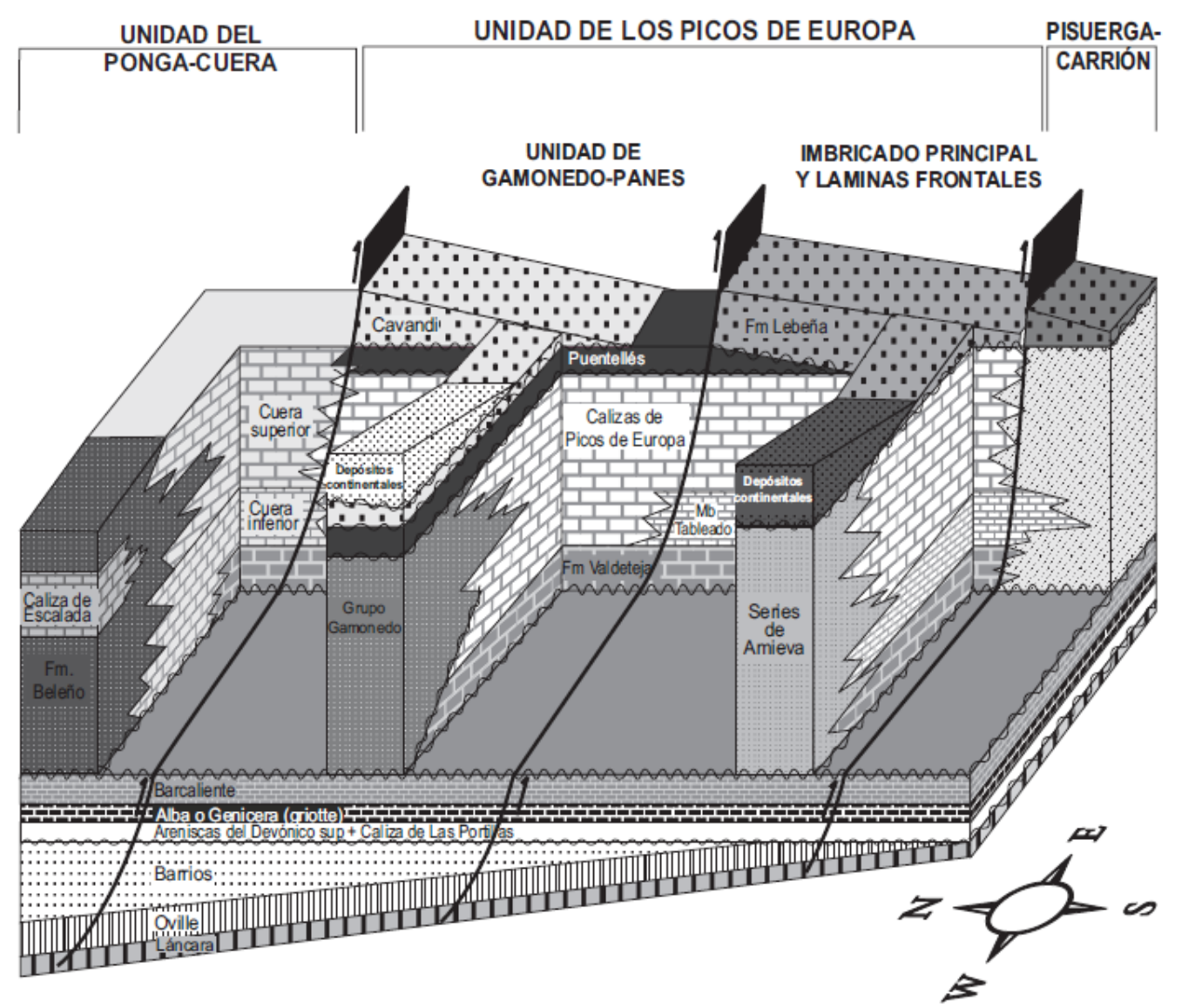

Figura 63. Bloque tectónico tridimensional de la región de los Picos de Europa. Fuente: Marquínez y Adrados, 2000.

El levantamiento tectónico del conjunto de los Picos de Europa, la configuración morfoestructural resultante, y la erosión diferencial respecto de los valles periféricos, son las responsables del volumen y la altitud del macizo, permitiendo el desarrollo de glaciares (Figura 64) durante las fases más frías (González Trueba, 2006). Así, el paisaje de la parte superior del macizo se caracteriza por formas resultantes de la erosión glaciar o glaciokárstica (circos 
glaciares, depresiones glaciokársticas, umbrales rocosos, etc.), mientras que la zona inferior de la montaña presenta ejemplos de acumulación glaciar (artesas, morrenas). Los principales relieves glaciares de los Picos de Europa son depresiones glaciokársticas, pero también existen depresiones glaciares cortas y fuertemente inclinadas. Las diferencias de altura impidieron un desarrollo longitudinal de los glaciares, aunque, en algunos sitios, sus frentes llegaron a altitudes muy bajas (450 m en Dobresengros, 600 m. en Bulnes, y 800 m en Liébana) (González Trueba, 2007; Serrano et al., 2013).

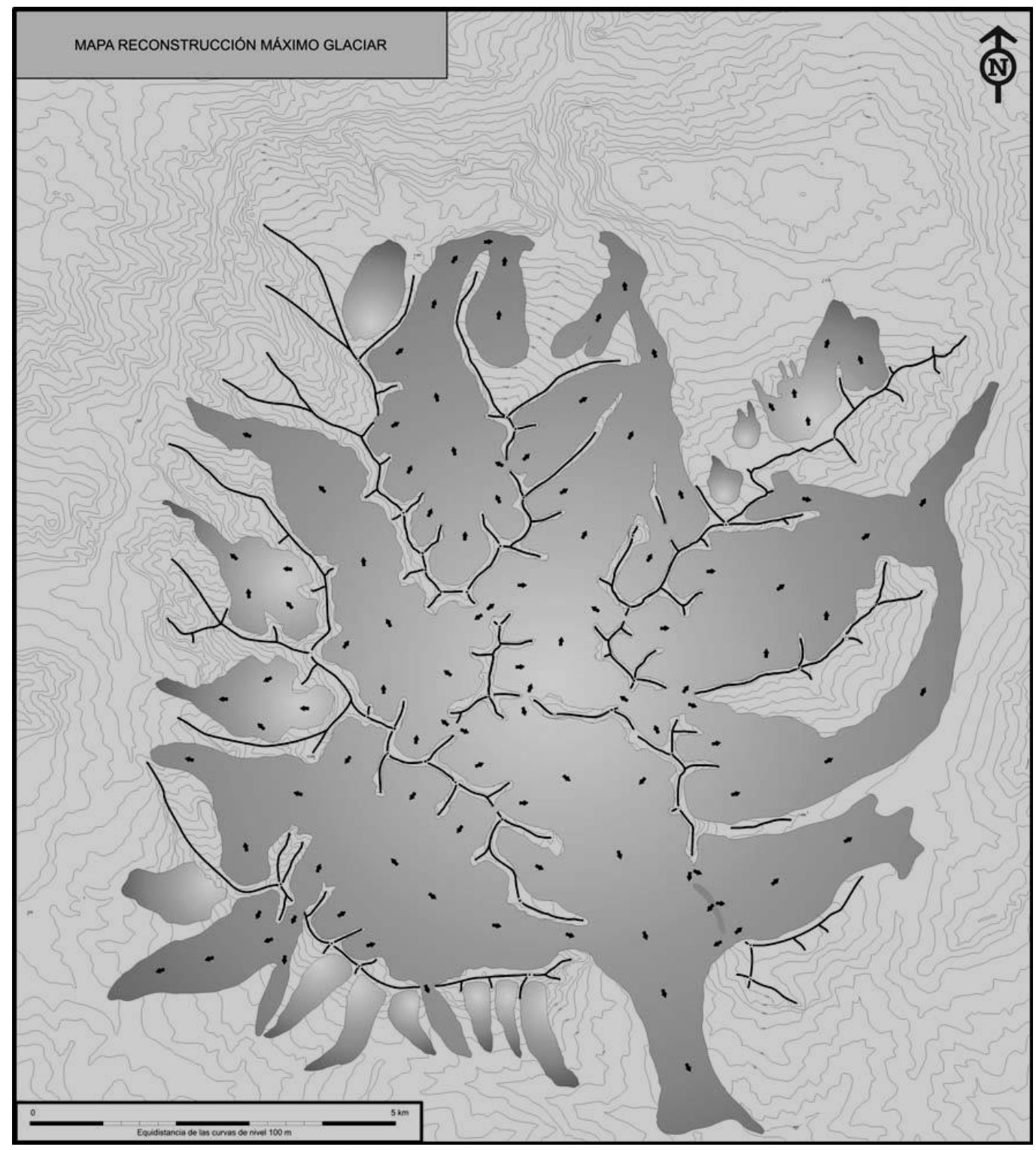

Figura 64. Reconstrucción de los sistemas glaciares del Macizo Central durante la etapa de máxima expansión de los hielos.

Fuente: González Trueba, 2006. 
Respecto al tipo de suelos, los calizos son los que adquieren una mayor magnitud en el Parque Nacional. En segundo lugar, aparecen suelos silíceos de pizarras y areniscas en las zonas bajas del Parque, pues allí se acumulan partículas procedentes de las zonas más altas y son particularmente frecuentes en sus zonas sur y sudoriental.

A pesar de que esta zona posee una historia geológica ligada a las orogenias hercínica y alpina, el glaciarismo cuaternario es el responsable del modelado de los Picos de Europa, que se extendió desde el Pleistoceno Superior hasta primeras décadas del S.XX, momento en el que desaparecieron los últimos glaciares del macizo. Estos procesos estuvieron dominados por fases interglaciares templadas y lluviosas y períodos más fríos en los que se desarrollaron los sistemas glaciares más importantes de la Cordillera Cantábrica, de intensa actividad erosiva. Las formas glaciares heredadas han permitido reconstruir una superficie total glaciada de algo más de 6.800 has. (González Trueba, 2006). Actualmente, la actividad glaciar en los Picos de Europa es meramente testimonial, conservándose algunos heleros por encima de los 2.000 metros (cuerpos de hielo estratificado relicto), en algún caso bajo la protección de un espeso manto de derrubios.

En la región de los Lagos de Covadonga (Asturias) se encuentra un conjunto morrénico frontal, destacando la morrena de Entrelagos (Figura 65) que separa los lagos de Enol y la Ercina. También se encuentran morrenas importantes en Belbín, las Vegas de Llós y Arestas y la zona de Caín en el Macizo del Cornión, en Amuesa y Áliva (Llomba del Toro) en el Macizo Central, o en La Llama en el Macizo de Ándara.

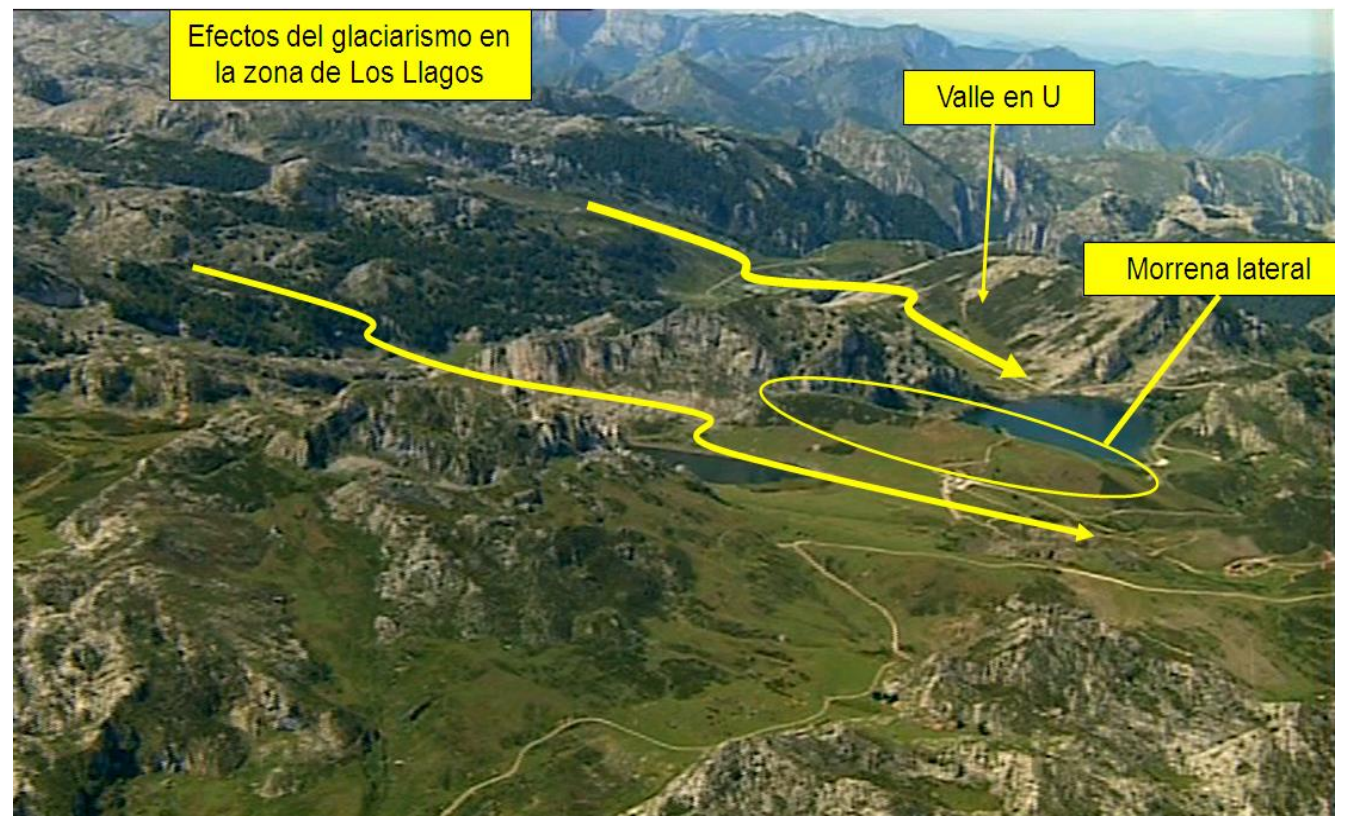

Figura 65. Efectos del modelado glaciar en la zona de los lagos de Covadonga.

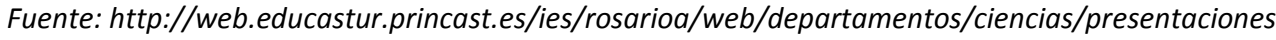


Topográficamente, los Picos de Europa se destacan sobre otras zonas de la misma Cordillera Cantábrica debido a que los materiales calizos que conforman sus moles rocosas son especialmente resistentes a la erosión mecánica. De todos modos, estos procesos han modificado el paisaje, pudiéndose apreciar múltiples testimonios. Uno de estos procesos mecánicos de erosión es el desprendimiento de clastos por gelifracción (rotura por el aumento de volumen del agua de las grietas al helarse). En Picos de Europa han sido comunes los desprendimientos de grandes volúmenes de rocas formando avalanchas.

Los grandes jous producidos por la sobre excavación y la disolución kárstica glaciar funcionaron durante las últimas glaciaciones como desagües de las aguas de fusión subglacial, de forma que durante las etapas más frías también existió un endokarst muy activo, cuyas surgencias son comunes en el contacto entre las calizas y las rocas siliciclásticas.

La organización y dinámica de las formas periglaciares son el resultado de una combinación de factores (altitud, topografía, características del suelo como la permeabilidad, la disponibilidad de agua en superficie y su régimen térmico, o la duración y distribución de la cubierta nival), lo que origina diversas formas de paisaje periglaciar en el que se puede diferenciar dos grandes pisos:

- Periglaciar superior o crionival (por encima de $2.200 \mathrm{~m}$ ): el descenso de la temperatura favorece el desarrollo de procesos criogénicos como crioturbación y gelifluxión y sus formas asociadas, aunque sin unas condiciones térmicas suficientemente rigurosas para el desarrollo de permafrost.

- Periglaciar inferior o nivoperiglaciar (entre 1.800 y 2.200 m): dominan los procesos de nivación, solifluxión y aquellos asociados a los ciclos de hielo/deshielo. Sobre los afloramientos de roca caliza, predomina la gelifracción y los procesos nivokársticos.

El agua es otro factor erosivo por excelencia en Picos de Europa, ya sea por el efecto de la escorrentía posterior a la fusión de la nieve, los episodios torrenciales potenciados por las fuertes pendientes o los fenómenos kársticos. La karstificación generó numerosas formas de modelado, tanto exokársticas como endokársticas. La intensa karstificación da lugar en la parte exterior a algunas formas muy características, como los jous, grandes depresiones glaciokársticas cerradas (hasta $1 \mathrm{~km}$ de diámetro y $100 \mathrm{~m}$ de profundidad) que aparecen jalonadas de dolinas; los valles secos, donde el río abandona durante trechos la superficie; los valles ciegos, como el de Orandi, donde el valle termina bruscamente al hacerse el río subterráneo; los cañones (río Dobra, río Urdón) y desfiladeros u hoces como los del Cares, de la Hermida (río Deva) o el de los Beyos (río Sella); y algunos poljes (depresiones kársticas cerradas que 
presentan varias surgencias y sumideros, inundadas estacionalmente y que aparecen rellenas de sedimentos). Entre los poljes destaca el de la Vega de Comeya, inundado periódicamente en tiempos pasados, que aparece relleno por más de $60 \mathrm{~m}$ de sedimentos cuaternarios. Por encima de los $2.000 \mathrm{~m}$ son frecuentes las dolinas y simas-nevero que aparecen cubiertas o taponadas de nieve todo el año. Otra de las formas características del exokarst son los campos de lapiaz, muy desarrollados y profundos.

Los conductos subterráneos (endokarst) son muy importantes en los Picos de Europa, existiendo sobre todo grandes conductos verticales o simas, que enlazan cortos tramos de desarrollo horizontal. Esto viene favorecido por la disposición subvertical que presentan tanto la estratificación como las grandes fallas y cabalgamientos.

Respecto a los procesos nivales, las condiciones climáticas derivadas de su localización en fachada oceánica, sobretodo su régimen térmico y pluviométrico, lo convierten en un macizo de alta montaña atlántica (hiperhúmedo), caracterizado por las frecuentes e intensas precipitaciones en forma de nieve. Este hecho favorece la existencia de procesos nivales generalizados en las porciones altas del macizo, que en ocasiones alcanzan también cotas muy bajas, debido a los fuertes desniveles existentes (González Trueba y Serrano, 2010b). La duración de la cubierta nival, 6 meses aproximadamente en torno a 1500 m y 8/9 meses por encima de los $2000 \mathrm{~m}$, condiciona la mayoría de los procesos geomorfológicos de la alta montaña, controla el régimen térmico e hídrico del suelo, y es un eficaz agente de modelado. Los procesos nivales más eficaces son los aludes, la erosión directa del sustrato por la acción térmica y química de las aguas de fusión, el deslizamiento y movimiento de derrubios sobre la superficie de los neveros y la alteración mecánica de la formación superficial infrayacente. Todos ellos generan formas características del modelado de la alta montaña de los Picos de Europa (González Trueba, 2006, 2007; González Trueba y Serrano, 2010b).

\section{2) Picos de Europa como punto de atracción de visitantes}

El Parque de los Picos de Europa es un importante destino turístico dentro de la Red de Parques Nacionales de España, atracción fundamentada en sus singulares valores naturales, especialmente paisajísticos. A pesar del decrecimiento en el número de visitantes registrado en la última década (más de 2.200.000 de visitantes en 2004, 1.719.000 en 2006 y poco más de 1.560.000 en 2012), el PNPE es el segundo parque nacional con más visitantes en España (Figura 66), detrás del Parque Nacional del Teide, recibiendo a un 16,87\% del total de visitantes de la Red de Parques Nacionales en 2011 y un 16, 40\% en 2012 (MAGRAMA, 2011, 
2012). Ese último año la afluencia de visitantes al PNPE fue la menor de los años considerados para el presente trabajo (2007-2012), pero la evolución de la afluencia de visitantes al PNPE (2007-2011) ha sido menos fluctuante que en el total de la Red de Parques Nacionales (Figura 67). Las causas de este descenso pueden encontrarse en la disminución de la capacidad adquisitiva de la población. El 90\% de los visitantes son de origen nacional.

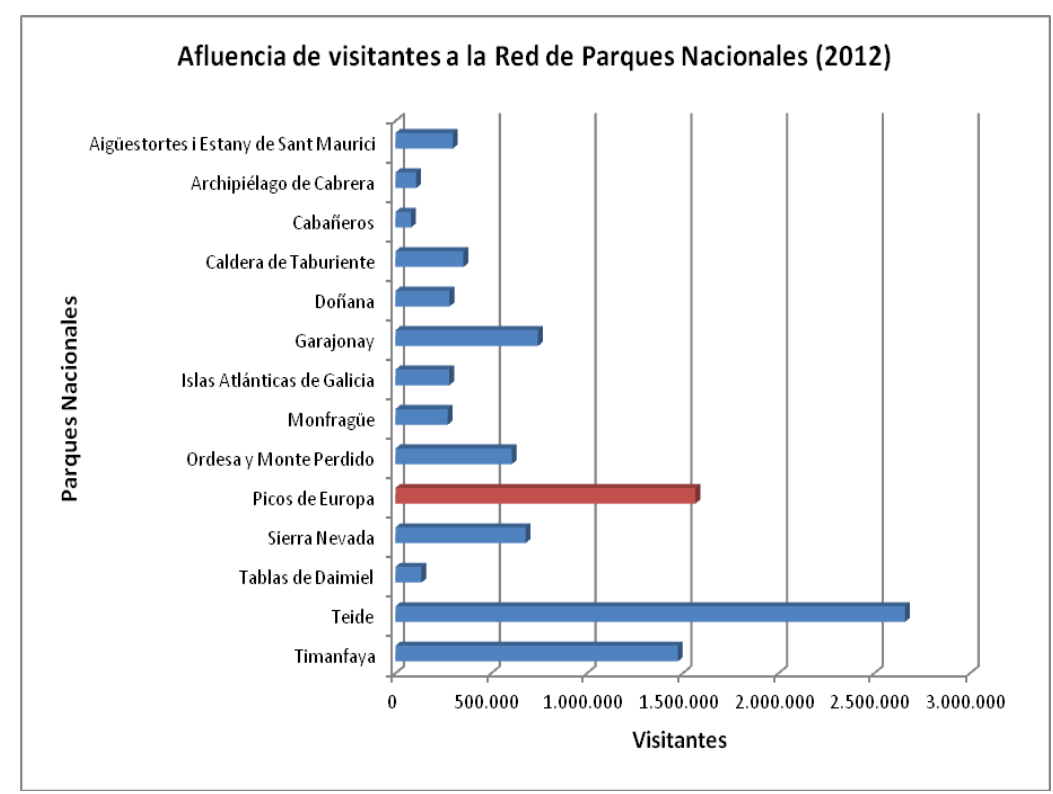

Figura 66. Afluencia de visitantes a la Red de Parques Nacionales y al PNPE (2007- 2012).

Fuente: elaboración propia.

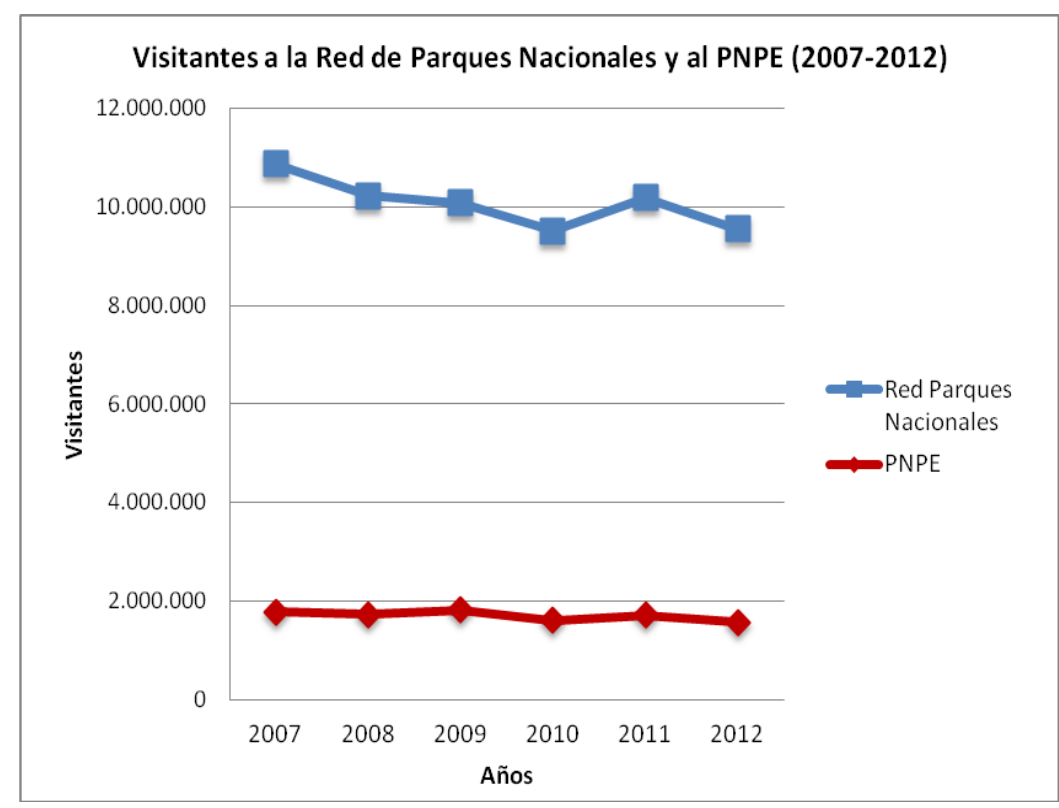

Figura 67. Afluencia de visitantes a la Red de Parques Nacionales (España) en 2012.

Fuente: elaboración propia. 
Considerando los puntos de entrada de visitantes al Parque (Figura 68) en el período 2007-2012, el ingreso estuvo concentrado en la zona de los Lagos de Covadonga y Fuente Dé (ambos sitios superan el $75 \%$ del total de ingresos al PNPE), mientras que los accesos de Cabrales y Valdeón registraron cerca de 17\% y 7\%, respectivamente (Tabla 50 y Figura 69). Más allá de estos porcentajes, hay que considerar las dificultades de acceso a estos dos últimos lugares (Macizo Central y desfiladero del Cares).

Tabla 50. Entrada de visitantes al PNPE (2007-2012) según puntos de ingreso.

\begin{tabular}{|c|c|c|c|c|c|}
\hline Año & Lagos & Valdeón & Fuente Dé & Cabrales & Total \\
\hline $\mathbf{2 0 0 7}$ & 724.564 & 130.846 & 653.793 & 265.752 & 1.774 .955 \\
\hline $\mathbf{2 0 0 8}$ & 689.351 & 108.200 & 660.622 & 260.593 & 1.718 .766 \\
\hline $\mathbf{2 0 0 9}$ & 717.477 & 112.294 & 676.535 & 312.369 & 1.818 .675 \\
\hline $\mathbf{2 0 1 0}$ & 626.456 & 118.855 & 564.133 & 300.901 & 1.610 .345 \\
\hline $\mathbf{2 0 1 1}$ & 640.318 & 137.052 & 618.788 & 321.572 & 1.717 .730 \\
\hline $\mathbf{2 0 1 2}$ & 607.489 & 112.853 & 574.341 & 271.443 & 1.566 .126 \\
\hline Porcentaje & $\mathbf{3 8 , 7 9}$ & $\mathbf{7 , 2 1}$ & $\mathbf{3 6 , 6 7}$ & $\mathbf{1 7 , 3 3}$ & $\mathbf{1 0 0 , 0 0}$ \\
\hline Fuente: elaboración propia. & & & \\
\hline
\end{tabular}

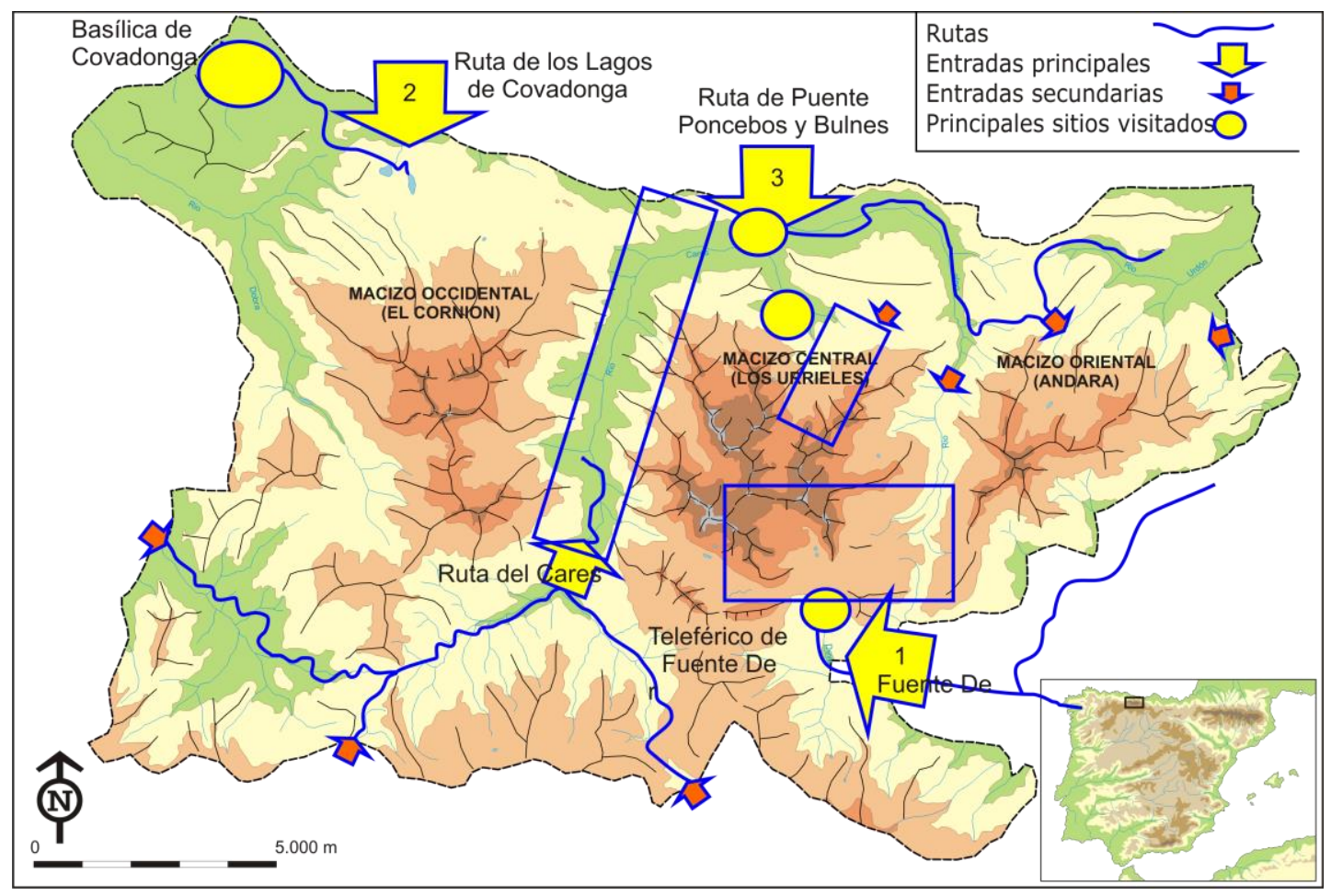

Figura 68. Puntos de entrada de visitantes al PNPE.

Fuente: modificado de Serrano y González Trueba, 2011. 


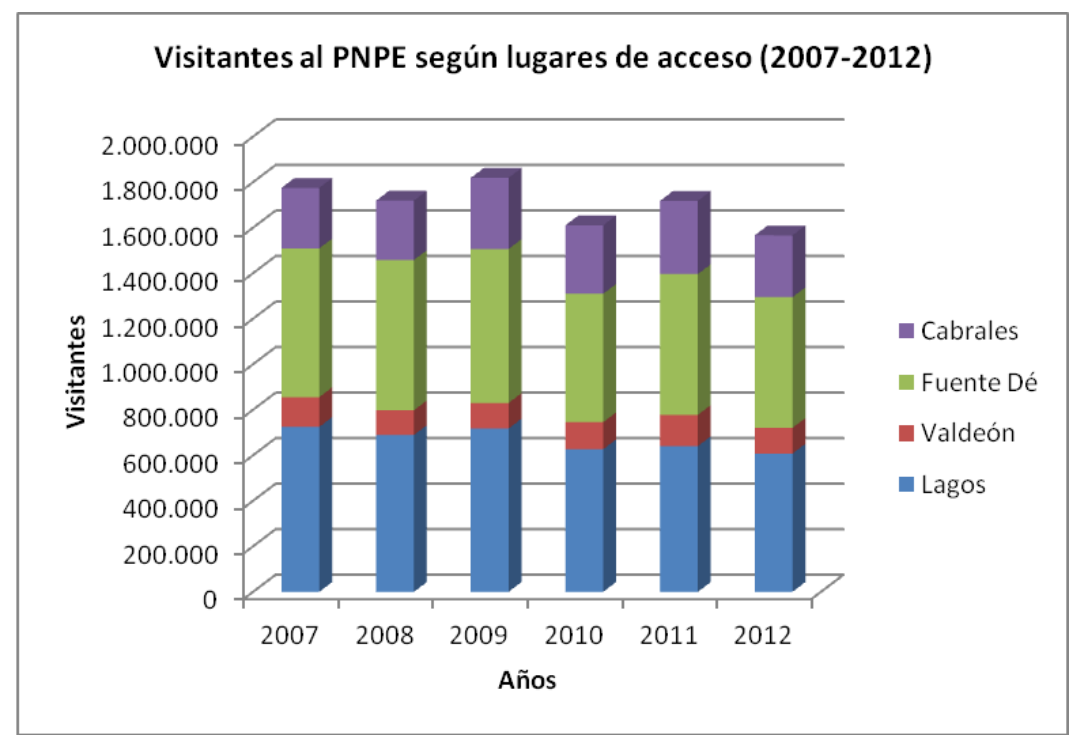

Figura 69. Entrada de visitantes al PNPE (2007-2012) según puntos de ingreso.

Fuente: elaboración propia.

Teniendo en cuenta la estacionalidad de las visitas (Tabla 51 y Figura 70), se observa que más del 50\% de las mismas se realizan en los meses de verano, sobresaliendo el mes de agosto con casi un cuarto de las visitas anuales, mientras que los meses de invierno registran menos del $10 \%$ de los visitantes al PNPE. Esta marcada estacionalidad del flujo de visitantes influye en el uso público de las instalaciones, siendo conveniente una dispersión más uniforme de la misma durante el año para que haya una disminución de la presión sobre los ámbitos más frágiles del Parque y también por cuestiones de seguridad de los visitantes.

Tabla 51. Entrada mensual de visitantes al PNPE (2007-2012) según puntos de ingreso.

\begin{tabular}{|c|c|c|c|c|c|c|}
\hline Mes & Lagos & Valdeón & Fuente Dé & Cabrales & Total & Porcentaje \\
\hline Enero & 80.543 & 13.691 & 94.578 & 17.582 & 206.394 & 2,02 \\
\hline Febrero & 91.670 & 19.336 & 111.440 & 23.822 & 246.268 & 2,41 \\
\hline Marzo & 216.601 & 38.917 & 218.741 & 51.340 & 525.599 & 5,15 \\
\hline Abril & 331.221 & 74.605 & 303.118 & 146.462 & 855.406 & 8,38 \\
\hline Mayo & 284.063 & 44.340 & 244.547 & 77.920 & 650.870 & 6,38 \\
\hline Junio & 348.743 & 54.739 & 326.961 & 94.803 & 825.246 & 8,09 \\
\hline Julio & 641.132 & 106.448 & 531.457 & 341.900 & 1.620 .937 & 15,88 \\
\hline Agosto & 816.163 & 168.023 & 842.054 & 575.397 & 2.401 .637 & 23,53 \\
\hline Septiembre & 530.596 & 85.040 & 430.355 & 232.896 & 1.278 .887 & 12,53 \\
\hline Octubre & 356.499 & 59.580 & 320.692 & 86.287 & 823.058 & 8,06 \\
\hline Noviembre & 166.722 & 32.328 & 168.949 & 31.429 & 399.428 & 3,91 \\
\hline Diciembre & 141.702 & 23.053 & 155.320 & 52.792 & 372.867 & 3,65 \\
\hline TOTAL & 4.005 .655 & 720.100 & 3.748.212 & 1.732 .630 & 10.206 .597 & 100,00 \\
\hline
\end{tabular}




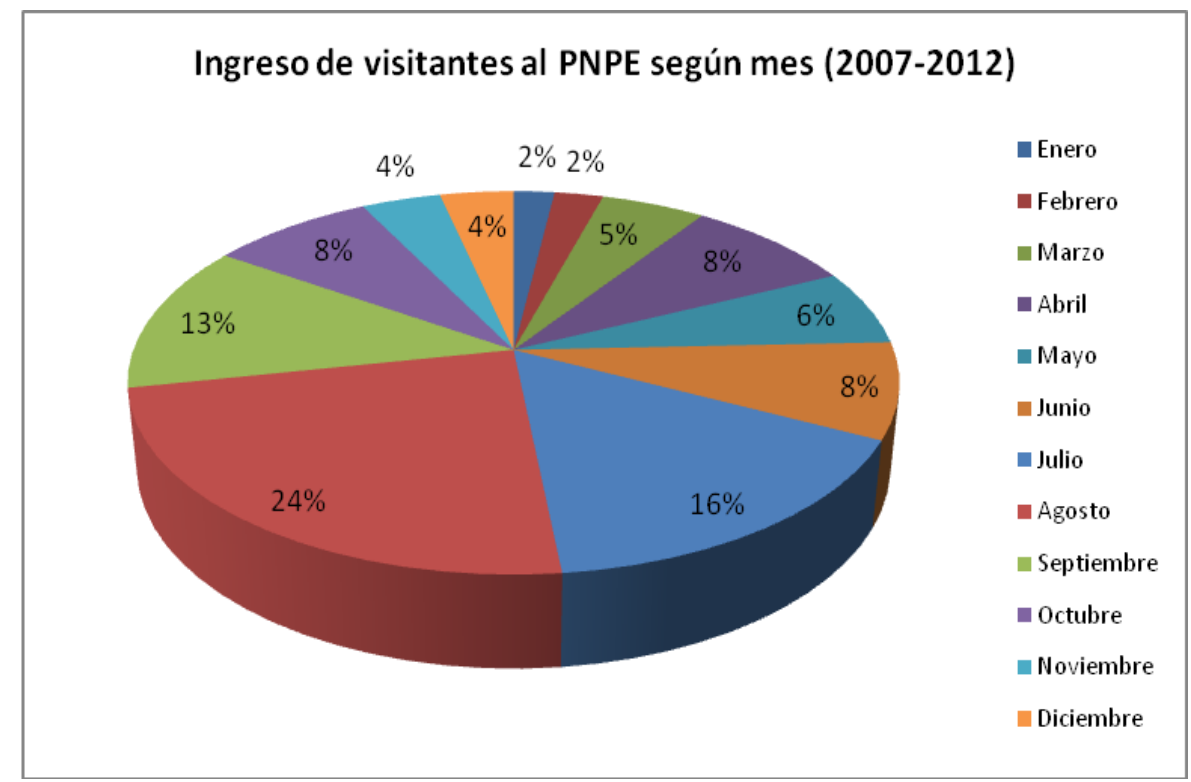

Figura 70. Entrada mensual de visitantes al PNPE (2007-2012).

Fuente: elaboración propia.

Las Memorias Anuales del PNPE del período 2008-2012 indican que se facilitó información al 23\% de las visitas al área conservada (con valores extremos cercanos al $19 \%$ y $27 \%)$. Este promedio es superior a la totalidad de visitantes de algunos parques nacionales, lo que pone de manifiesto la importancia de los centros de información para un mejor conocimiento y aprovechamiento del parque, conformando así importantes focos de divulgación del patrimonio resguardado (Tabla 52).

Es de destacar que los centros con atención personalizada que reúnen los mayores porcentajes (25,83\% y 20,24\%) se encuentran muy cerca entre sí (Caseta de Buferrera y Centro de Visitantes Pedro Pidal, Figura 71, respectivamente) y a una relativa corta distancia del acceso de Lagos de Covadonga. Este dato indica que cerca de un $27 \%$ de los visitantes que ingresan por esta entrada reciben atención personalizada, pudiéndose alcanzar algunos de los objetivos de la declaración del Parque Nacional (contribuir a la protección, recuperación, fomento y difusión de los valores culturales y antropológicos que conforman la historia de este espacio natural y facilitar el conocimiento y disfrute de sus principales valores asegurando, siempre en forma compatible con su conservación, tanto la actividad investigadora y educativa como el simple acceso de los visitantes, apartados b y c respectivamente del artículo 1.1 de la Ley 16/1995). En estos centros con atención personalizada los turistas pueden tomar folletos y mapas con la información del Parque Nacional, visitar exposiciones sobre sus elementos patrimoniales o realizar visitas guiadas por la zona, por lo que resultan sitios privilegiados para el desarrollo de actividades interpretativas y como recursos educativos o turísticos (Figura 72). 
La Interpretación del Patrimonio Geomorfológico en los Picos de Europa: una propuesta para su aprovechamiento didáctico y geoturístico

Tabla 52. Visitantes al PNPE con atención personalizada (VAP) 2008-2012.

\begin{tabular}{|c|c|c|c|c|c|c|c|}
\hline CC.AA. & Lugar & 2008 & 2009 & 2010 & 2011 & 2012 & $\%$ \\
\hline \multirow{7}{*}{ Asturias } & $\begin{array}{l}\text { Oficina de Cangas } \\
\text { de Onís }\end{array}$ & 9.797 & 13.050 & 13.791 & 14.442 & 10.480 & 3,18 \\
\hline & $\begin{array}{l}\text { Centro de Visitantes } \\
\text { Pedro Pidal }\end{array}$ & 76.310 & 81.855 & 82.137 & 82.053 & 69.734 & 20,24 \\
\hline & Caseta de Buferrera & 59.805 & 99.531 & 123.501 & 127.460 & 89.975 & 25,83 \\
\hline & $\begin{array}{l}\text { Caseta de Poncebos } \\
\text { (Ruta Cares) }\end{array}$ & 30.496 & 40.524 & 31.651 & 30.041 & 32.240 & 8,52 \\
\hline & $\begin{array}{l}\text { Caseta de Poncebos } \\
\text { (Funicular) }\end{array}$ & 34.851 & 41.095 & 34.200 & 31.592 & 36.612 & 9,21 \\
\hline & Caseta de de Panes & 6.274 & 7.479 & 6.107 & 4.858 & 3.466 & 1,46 \\
\hline & Caseta de Amieva & 3.169 & 4.357 & 2.825 & 3.752 & 3.812 & 0,92 \\
\hline \multirow{3}{*}{ Cantabria } & $\begin{array}{l}\text { Centro de Visitantes } \\
\text { de Sotama }\end{array}$ & 58.807 & 62.095 & 65.997 & 62.676 & 55.950 & 15,77 \\
\hline & $\begin{array}{l}\text { Caseta de la } \\
\text { Hermida }^{1}\end{array}$ & 0 & 3.959 & 5.904 & 6.954 & 6.544 & 1,21 \\
\hline & Caseta de Fuente De & 29.631 & 43.795 & 38.853 & 28.666 & 34.283 & 9,05 \\
\hline \multirow{4}{*}{$\begin{array}{l}\text { Castilla y } \\
\text { León }\end{array}$} & $\begin{array}{l}\text { Oficina de Posada } \\
\text { de Valdeón }\end{array}$ & 6.733 & 7.772 & 6.929 & 5.832 & 4.702 & 1,65 \\
\hline & $\begin{array}{l}\text { Caseta de Teja } \\
\text { Oscura }^{2}\end{array}$ & 4.344 & 8.619 & 0 & 0 & 0 & 1,32 \\
\hline & $\begin{array}{l}\text { Caseta del Chorco } \\
\text { de los Lobos }\end{array}$ & 0 & 0 & 9.478 & 9.098 & 6.960 & 0,67 \\
\hline & $\begin{array}{l}\text { Caseta de Oseja de } \\
\text { Sajambre }\end{array}$ & 4.070 & 4.562 & 4.285 & 3.806 & 2.398 & 0,99 \\
\hline \multicolumn{2}{|l|}{ Total VAP } & 324.287 & 418.693 & 425.658 & 411.230 & 357.156 & \\
\hline \multicolumn{2}{|c|}{ Total visitantes PNPE } & 1.718 .766 & 1.818 .675 & 1.610 .345 & 1.717 .730 & 1.566 .126 & \\
\hline \multicolumn{2}{|c|}{$\begin{array}{l}\text { Porcentaje de VAP sobre total } \\
\text { de visitantes }\end{array}$} & 18,87 & 23,02 & 26,43 & 23,94 & 22,81 & \\
\hline \multicolumn{8}{|c|}{$\begin{array}{l}{ }^{1} \text { En } 2009 \text { se incorpora el punto de información de La Hermida, ya en su ubicación definitiva desde verano de } 2010 \text { en una } \\
\text { nueva caseta. } \\
{ }^{2} \text { En } 2010 \text { se trasladó la caseta de Teja Oscura, en Valdeón, al nuevo aparcamiento del Chorco de los Lobos. }\end{array}$} \\
\hline
\end{tabular}

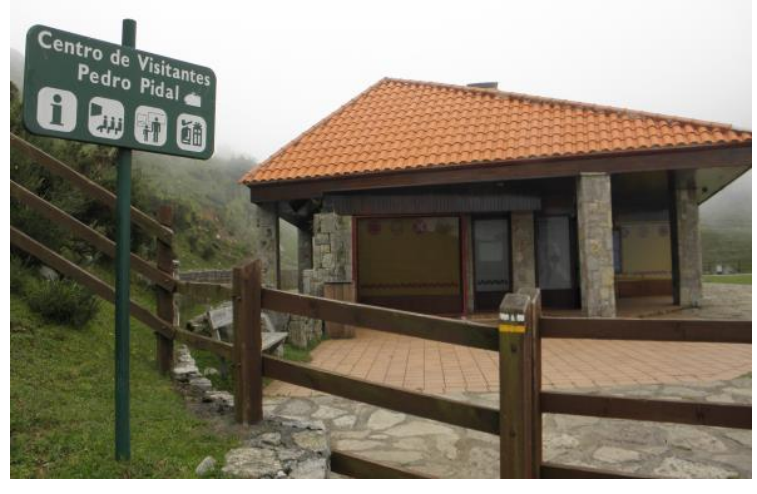

Figura 71. Centro de visitantes Pedro Pidal. Fuente: Héctor Bazán.

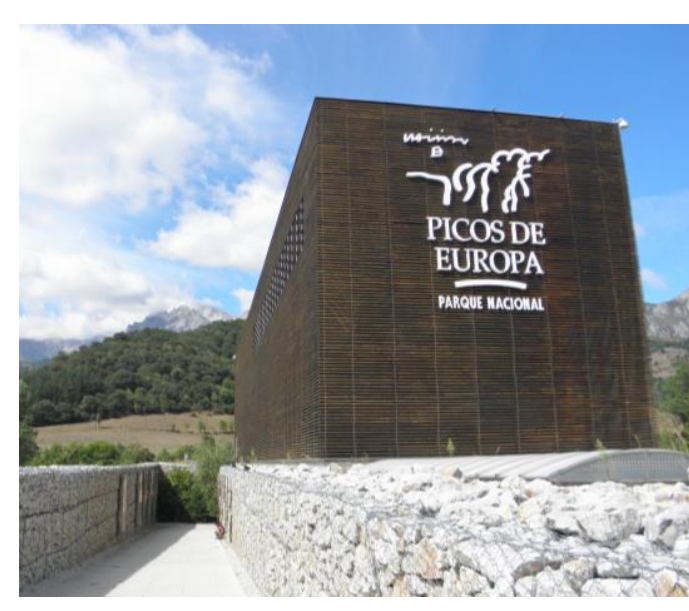

Figura 72. Centro de visitantes del Parque en Sotama.

Fuente: Héctor Bazán. 
Respecto a la tipología de visitantes, Serrano y González Trueba (2011) refieren que estos se distribuyen (Figura 73 ) entre turistas de ocio (67\%), estudiantes (16\%), turistas activos (10\%), excursionistas (5\%) y montañeros (2\%). Conocer el tipo de público que visita el Parque Nacional permitirá desarrollar mejores estrategias interpretativas, desde aquellas con información general para todos los grupos o bien realizar productos especialmente dirigidos a una audiencia en concreto. Por ejemplo, se podría disponer de folletos en los centros de atención personalizada con distintas informaciones para que el turista tome aquélla que sea de su interés o diseñar distintos itinerarios por senderos de acuerdo al tipo de visitante.

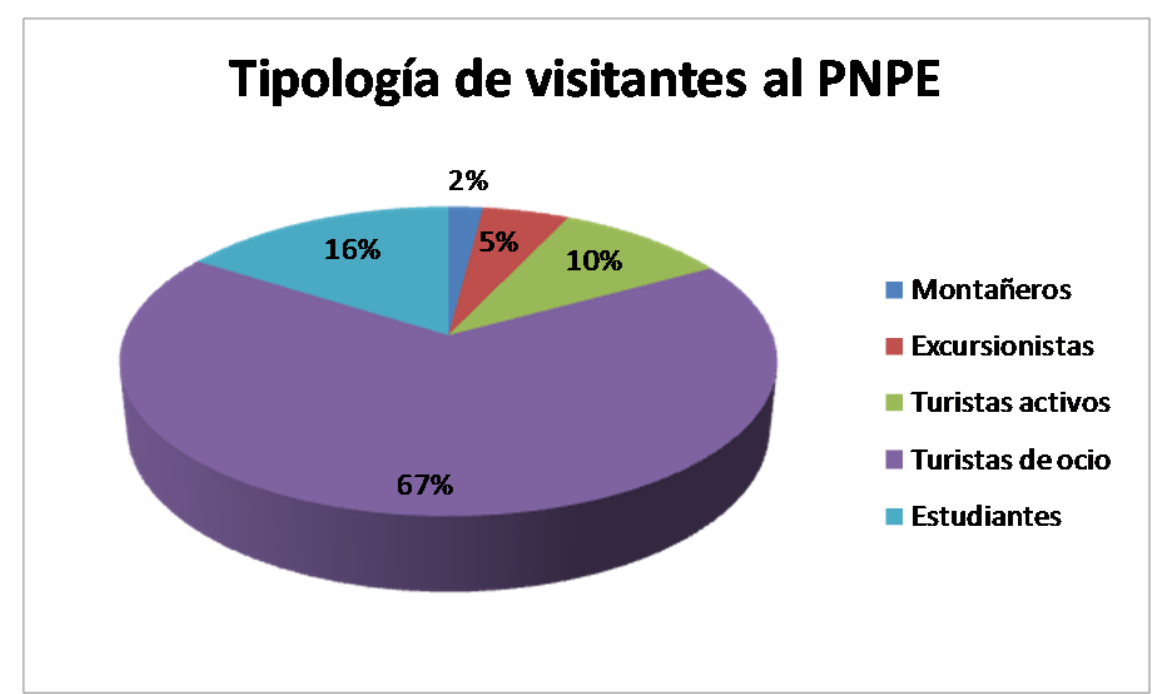

Figura 73. Distribución de tipos de visitantes al PNPE. Fuente: elaboración propia.

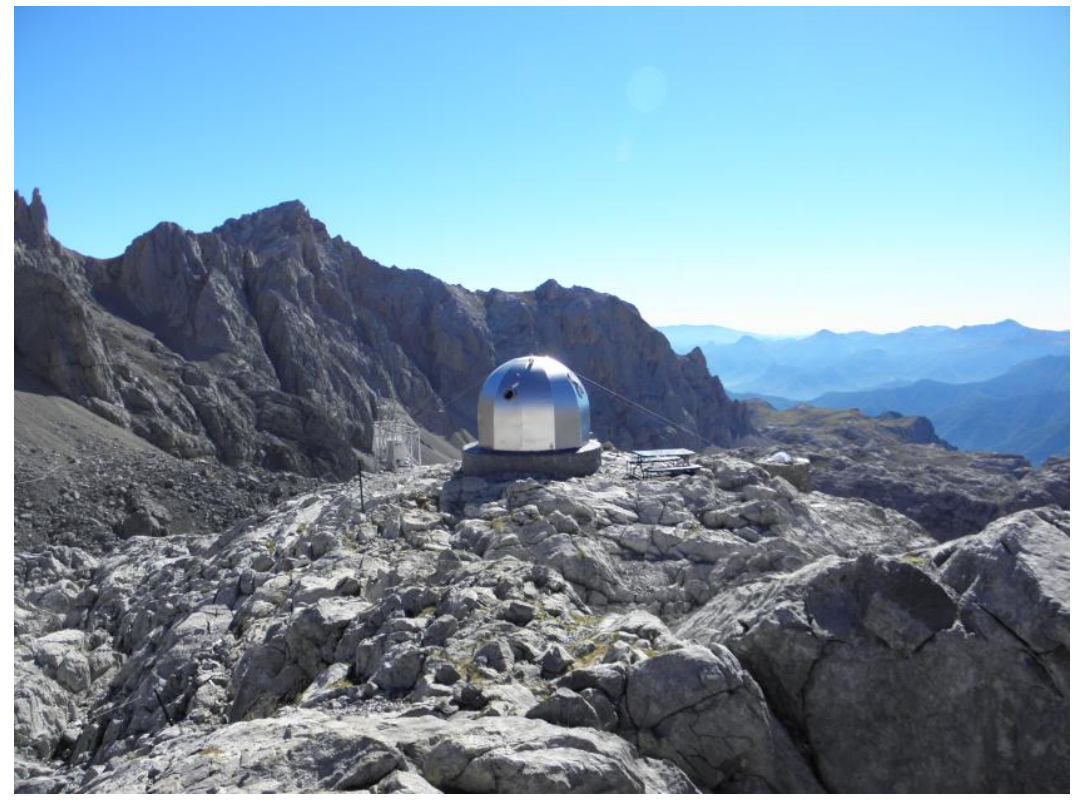

Figura 74. El refugio de Cabaña Verónica constituye un punto de referencia para montañeros y excursionistas del Parque.

Fuente: Héctor Bazán. 
- $\quad$ Turistas de ocio: buscan de esparcimiento y recreación en un ambiente natural. Su estancia puede ser por un corto tiempo y muchas veces sólo frecuentan los lugares donde se encuentran los principales productos y servicios turísticos.

- Estudiantes: los viajes educativos presentan una larga tradición en las prácticas educativas, desde los estudios primarios hasta la Universidad. Este grupo de visitantes vienen acompañados de monitores y/o profesores a estudiar la diversidad biótica y abiótica presentes en el Parque.

- Turistas activos: sus principales actividades están relacionadas con los valores culturales e históricos, pero son sensibles al paisaje y la naturaleza del entorno de Picos.

- Excursionistas y montañeros: son dos grupos relativamente pequeños, pero suelen estar interesados en actividades de geoturismo (valores patrimoniales naturales $y$ culturales) (Figura 74).

En líneas generales se puede apreciar que el PNPE dispone de un gran potencial para el desarrollo de actividades interpretativas (unos valores patrimoniales que conservar y una cantidad importante de visitantes llegados a través de una no menos importante red de infraestructuras) que pueden ser utilizadas para el uso turístico y educativo. Estos productos desarrollados siguiendo los principios interpretativos, podrían integrarse a la oferta de actividades existentes de divulgación y recreación, diversificando, de esta manera, el uso público de las mismas. 
La Interpretación del Patrimonio Geomorfológico en los Picos de Europa: una propuesta para su aprovechamiento didáctico y geoturístico 


\section{Capítulo 6}

\section{Inventario y valoración de LIGm en el PNPE}

Los elementos geomorfológicos constituyen un valor intrínseco en la naturaleza que nada o muy poco se ha tenido en cuenta para su protección o valoración. Al margen de los valores reales que les confieren sus características intrínsecas, estos elementos han adquirido un valor paisajístico a partir de su monumentalidad o apariencia. En este trabajo se trata, pues, de considerar los elementos geomorfológicos tanto para su conservación como su aprovechamiento didáctico y turístico en la gestión de espacios protegidos.

Desde los años 90, la evaluación de elementos y lugares geomorfológicos se planteó desde posiciones culturales (Panizza, 1992; Panizza y Piacente, 1993), relacionadas con factores antrópicos entre los que destacan las vinculaciones paisajísticas, y en las que la dinámica y la estructura morfológica es una parte esencial. También se han realizado estudios orientados exclusivamente a los elementos geomorfológicos (Thentorey y Gerber, 1993), pero los vinculados al Patrimonio Geológico y para escalas internacionales y nacionales (Geosites Projects; Johansson et al., 1977; Elízaga y Palacio, 1996; Cendrero, 1996; 2000; Barettino et al., 2000) son dominantes. A escala regional estos son menos representativos (Marchetti, 1999; Giusti y González, 2002; Tena, 2003), así como evaluaciones del impacto ambiental sobre elementos geomorfológicos con evaluaciones cuantitativas (Panizza, 1993; Cavallini y Marchetti, 1995; Rivas et al., 1997; Cendrero et al., 1999; Coratza y Giusti, 2003). Se han realizado diferentes metodologías que atienden a estos principios (Reynard, 2009), que responden a los principios básicos y permiten la valoración de LIGm.

La evaluación de los lugares de interés geomorfológico no puede ser mediante parámetros estadísticos o formulaciones matemáticas, pues, como ya ha expresado algún autor, nos enfrentamos a valores intangibles. Sin embargo, la necesidad de evaluar y valorar los distintos Lugar de Interés Geomorfológico (LIGm), junto a su inclusión en los elementos valorables en unidades ambientales, paisajísticas o territoriales, hace necesario disponer de un método, lo más objetivo posible, que permita su evaluación y valoración con un carácter comparado. Conocer sus valores intrínsecos cualitativos y cuantitativos, los elementos sensibles a cambios naturales o humanos, su valoración, su relación con el territorio y su importancia 
relativa entre otros elementos, constituye una necesidad en la gestión, conservación y puesta en valor de estos elementos naturales.

La metodología utilizada se basa en la valoración objetiva de los distintos componentes que aportan valores intrínsecos. Además, se han de considerar aspectos externos y valores culturales (históricos, paisajísticos, pedagógicos, turísticos, etc.) añadidos a su consideración meramente natural, que son los valores extrínsecos y de uso y gestión. Los primeros permiten una aproximación objetiva a los valores del LIGm y la forma o el sistema de formas que contiene, a partir de los cuales consideramos los aspectos extrínsecos y los de uso y gestión. Si los primeros son meramente científicos, los segundos constituyen formas de evaluación subjetivas que implican valoraciones matizadas por los valores culturales y personales del investigador, por lo que unos y otros no podrán considerarse en un solo parámetro. El resultado de la valoración será triple, exponiéndose los valores conjuntamente. Para ello se considera que un cálculo triple, en el que se diferencia la ausencia o presencia de elementos objetivos (naturales o no naturales) nos puede aproximar a la valoración del elemento.

\section{1) El método de valoración de LIGm utilizado en el Parque Nacional de los Picos de Europa}

A escala local, el relieve y sus elementos más importantes deben estar asociados a la comarca y su paisaje. El primer paso de la metodología propuesta es el conocimiento geomorfológico de la zona de estudio, esto es, del Parque Nacional de los Picos de Europa.

\subsection{1) Inventario}

El inventario tiene como objetivo realizar un primer listado de los elementos geomorfológicos significativos existentes en el parque, para después realizar una selección y valoración del conjunto, considerando los mayores valores, o bien mediante una selección previa. Esta labor debe realizarse mediante el conocimiento de la geomorfología del parque a una escala adecuada (1/25.000, 1/50.000). Una vez inventariados los elementos significativos, y conocidas sus relaciones con el entorno geomorfológico, se realizará la valoración de cada Lugar de Interés Geomorfológico (LIGm).

La metodología de inventario aplicada al Parque Nacional de los Picos de Europa se basa en la cartografía geomorfológica del parque (González Trueba, 2007; González Trueba y Serrano, 2010a, 2011) como documento básico para el relevamiento, análisis y estudio de los 
diferentes elementos significativos. Es ésta, pues, la herramienta básica de inventariado y localización de todas las formas y procesos presentes en la zona de estudio y sus relaciones espaciales. Su existencia es trascendental para iniciar el inventario de formas y lugares de interés, pues permite seleccionar elementos singulares o representativos para ser sometidos a una valoración lo más objetiva posible. Los mapas geomorfológicos del Parque a escala 1/25.000 publicados por el Parque Nacional (González Trueba, 2007; González Trueba y Serrano, 2010a, 2011) son la base para la realización de esta etapa. La metodología se basa en los sistemas cartográficos francés y del IGUL para la selección de capas, colores y símbolos, representando principalmente las formas (símbolos, tramas) y la morfogénesis (colores), al tiempo que se representan otros niveles de lectura propios de la cartografía (planimetría, altimetría, elementos humanos, etc.). La escala (1/25.000) y la representación morfogenética de formas $y$ asociaciones de formas permiten un buen conocimiento del emplazamiento $y$ características de los LIGm seleccionados para su valoración. La información cronológica y de valores añadidos o de uso se realiza mediante el trabajo de campo.

Existen inventarios parciales de LIGm de Picos de Europa, tanto del Macizo Central (Serrano y González Trueba, 2005; González Trueba 2007a, 2007b), como del Oriental (González Trueba y Serrano, 2010a) o del Occidental (Fuertes y Fernández, 2010; Gómez Lende et al., 2011), en los que ya existen clasificaciones y valoraciones previas a distintas escalas y con diferentes objetivos. Sin embargo, en los dos últimos macizos los trabajos se limitan al inventariado de elementos y someras clasificaciones. Estos inventarios y descripciones se han revisado e incorporado a esta valoración.

\subsection{2) Valoración de los LIGm}

Una vez inventariados los LIGm, se evalúa su valor desde distintas consideraciones útiles para su conocimiento científico, conservacionista o de gestión. Hay que tener en cuenta que esta es una labor aplicada de la investigación, cuya finalidad es la transferencia de conocimiento a técnicos y gestores de territorios protegidos. Un segundo paso será su transferencia a técnicos (Espacios Naturales Protegidos, del territorio, ambientalistas), al público en general (excursionistas, montañeros, geoturistas, turistas), a divulgadores (periodistas, guías, monitores de interpretación) o pedagógicos (educadores ambientales o sociales, profesores, maestros) que realizarán un uso práctico del mismo. Si los valores ambientales o culturales son significativos, se deberán realizar valoraciones ambientales (Rivas et al., 1997; Cendrero et al., 1999; Coratza y Giusti, 2003), y si son educativas, culturales o históricas, análisis y valoraciones que resalten estos aspectos para su puesta en valor y 
adecuada utilización desde la perspectiva conservacionista y educativa. Para este paso se necesitan planteamientos y metodologías focalizadas en la divulgación, interpretación o didáctica que partirán del conjunto de valores previamente definidos en la valoración de los LIGm.

El establecimiento de la metodología de análisis de LIGm en Espacios Naturales Protegidos (Figura 75) se basa en obtener una máxima objetividad en el análisis de los elementos geomorfológicos desde una perspectiva científica, y la inclusión de valores añadidos y de uso y gestión, sujetos a una mayor subjetividad (social, histórica, personal). Como señala Cendrero (1986), los valores son intangibles, de modo que su evaluación no puede ser meramente estadística. Sin embargo, se hace necesario disponer de un método lo más objetivo posible para evaluar y valorar con un carácter comparado (Cendrero, 1998; Serrano y González Trueba, 2005; Reynard, 2009).

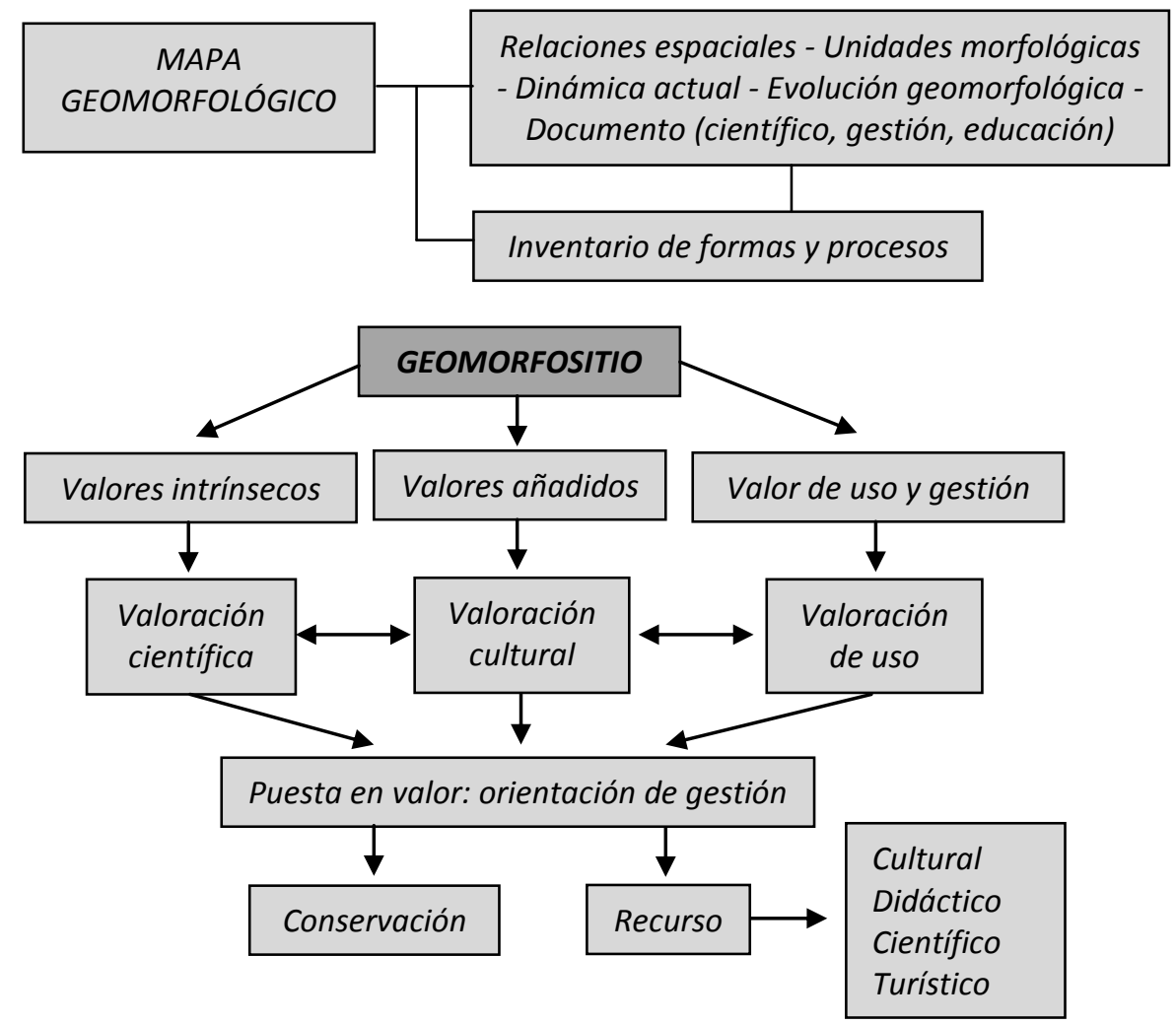

Figura 75. Metodología de análisis de los LIGm en Espacios Naturales Protegidos. Fuente: Serrano y González Trueba, 2005.

Para completar la información del inventario, se realiza una ficha de cada LIGm que permita disponer de la información más relevante de modo sintético para conocer y pasar a valorar los aspectos geomorfológicos del lugar o elemento seleccionado. La ficha se complementa con fotos del lugar, una cartografía geomorfológica del LIGm (Tabla 53), como 
herramienta básica para la posterior realización de mapas derivados de diverso tipo (interpretativos, geoturísticos, de localización, etc.), e imágenes (fotos y dibujos interpretados).

Tabla 53. Ficha de descripción de LIGm.

\begin{tabular}{|c|c|c|c|c|}
\hline \multicolumn{5}{|c|}{ LUGAR DE INTERÉS GEOMORFOLÓGICO: DESCRIPCIÓN } \\
\hline Identificación & Nombre: & & & No: \\
\hline Situación & To municipal: & Coordenadas: & Altitud: & \\
\hline \multirow{8}{*}{ Geomorfología } & TIPO & & & \\
\hline & Génesis & & & \\
\hline & $\begin{array}{l}\text { Morfología: descripción, } \\
\text { morfoestructuras, erosión }\end{array}$ & & & \\
\hline & Dinámica & & & \\
\hline & Cronología & & & \\
\hline & Interés principal & & & \\
\hline & Interés secundario & & & \\
\hline & Atribución del LIG & & & \\
\hline \multirow{9}{*}{ Usos } & Contenido cultural & & & \\
\hline & Accesibilidad & & & \\
\hline & Grado de interés & & & \\
\hline & Estado de conservación & & & \\
\hline & Usos actuales & & & \\
\hline & Comunicaciones & & & \\
\hline & Infraestructuras & & & \\
\hline & Impactos & & & \\
\hline & Situación legal & & & \\
\hline Bibliografía & & & & \\
\hline
\end{tabular}

La valoración aplicada en este trabajo se basa en tres criterios diferenciados que permiten la orientación de los distintos aspectos. El valor intrínseco, el propio del elemento desde una perspectiva naturalística y científica; su valor añadido, externo a su consideración geomorfológica (ambiental y cultural -históricos, paisajísticos, interpretativos, pedagógicos, turísticos). Por último se evaluarán los valores de uso y gestión, que señalan la capacidad de puesta en valor del LIGm. En este trabajo, pues, se adopta la metodología basada en una triple valoración (Serrano y González Trueba, 2005, 2008):

a) Científica o intrínseca: es la puramente geomorfológica, que permite una aproximación más objetiva. Se analizan las formas o sistemas de formas que lo componen y se evalúa mediante la enumeración de elementos que intervienen en el sistema morfogenético, analizando los aspectos fundamentales del mismo (Tabla 54). Para la obtención de un parámetro significativo el valor se representa entre 0 y 10 (Tabla 55). 
Tabla 54. Criterios de la valoración intrínseca.

\begin{tabular}{|c|c|c|c|}
\hline \multicolumn{2}{|r|}{ Valoración } & Puntuación & Definición \\
\hline \multicolumn{2}{|l|}{ Génesis } & máximo 5 & Procesos que han intervenido en su formación \\
\hline \multirow{3}{*}{ Morfología } & Morfoestructuras & máximo 5 & \multirow{3}{*}{$\begin{array}{l}\text { No de formas individualizadas que componen el } \\
\text { LIGm }\end{array}$} \\
\hline & Formas de erosión & máximo 5 & \\
\hline & Formas de acumulación & máximo 5 & \\
\hline \multirow{2}{*}{ Dinámica } & Heredados & máximo 5 & \multirow{2}{*}{$\begin{array}{l}\text { Elementos heredados y funcionales testigos de } \\
\text { procesos del pasado o funcionales. }\end{array}$} \\
\hline & Proceso actual & máximo 5 & \\
\hline \multicolumn{2}{|l|}{ Cronología } & máximo 5 & Periodos o fases genéticas representadas \\
\hline \multicolumn{2}{|l|}{ Litología } & máximo 5 & Materiales representados \\
\hline \multirow{2}{*}{ Estructura } & Geológicas & máximo 5 & \multirow{2}{*}{ № de estructuras visibles representadas } \\
\hline & Sedimentarias & máximo 5 & \\
\hline
\end{tabular}

Tabla 55. Puntuación total de la valoración intrínseca.

\begin{tabular}{|c|c|c|c|c|}
\hline \multicolumn{5}{|c|}{ Valoración intrínseca } \\
\hline Muy alta & Alta & Media & Baja & Muy baja \\
\hline$>8-10$ & $>6-8$ & $>4-6$ & $>2-4$ & $0-2$ \\
\hline Fuente: Serrano y González Trueba, 2005. \\
\hline
\end{tabular}

b) Cultural, o de valores añadidos: se basa en la consideración de los elementos culturales y ambientales que condicionan y enriquecen los valores intrínsecos (Tabla 56). El valor máximo es 70, pero se expresará, para su comparación con los valores intrínsecos, entre 0 y 10 (Tabla 57). En este caso se establece una valoración genérica; sin embargo algunos de los aspectos considerados pueden cobrar especial importancia, por lo que se hace necesario el desarrollo de una metodología particular para conocer su valor específico. Entre esos destacan las valoraciones en didáctica y geoturismo, cuya utilidad se hace patente en la gestión y usos de los espacios protegidos.

Tabla 56. Criterios de la valoración cultural o añadida.

\begin{tabular}{|c|c|c|c|}
\hline \multicolumn{2}{|c|}{ Valoración } & Puntuación & Definición \\
\hline \multicolumn{2}{|c|}{ Paisajística y estética } & Máximo 10 & $\begin{array}{l}\text { Consideración escalar paisajística y estética. No } \\
\text { existe (0), Componente muy local y puntual (2), } \\
\text { Componente a escala media (valle, municipio) } \\
\text { (4), Componente comarcal (6), Componente } \\
\text { esencial del paisaje en amplios panoramas } \\
\text { (regional) (8), Elemento protegido o gestionado } \\
\text { por sus contenidos paisajísticos (10). }\end{array}$ \\
\hline \multirow{3}{*}{$\begin{array}{l}\text { Elementos } \\
\text { culturales }\end{array}$} & $\begin{array}{l}\text { Asociación a } \\
\text { elementos de valor } \\
\text { patrimonial }\end{array}$ & Máximo 10 & $\begin{array}{l}\text { Elementos patrimoniales (monumentos, } \\
\text { yacimientos, poblaciones, construcciones } \\
\text { populares, elementos etnológicos, etc.) que } \\
\text { están representados. }\end{array}$ \\
\hline & $\begin{array}{l}\text { Contendido } \\
\text { cultural }\end{array}$ & Máximo 10 & $\begin{array}{l}\text { Aspectos culturales (mitos, leyendas, literatura, } \\
\text { pintura, etc.). }\end{array}$ \\
\hline & $\begin{array}{l}\text { Contenido } \\
\text { histórico }\end{array}$ & Máximo 10 & Fases históricas de uso u ocupación. \\
\hline
\end{tabular}


La Interpretación del Patrimonio Geomorfológico en los Picos de Europa: una propuesta para su aprovechamiento didáctico y geoturístico

\begin{tabular}{|c|c|c|c|}
\hline \multirow{2}{*}{ Didáctica } & $\begin{array}{l}\text { Recursos } \\
\text { pedagógicos }\end{array}$ & Máximo 5 & Contenidos pedagógicos y docentes. \\
\hline & $\begin{array}{l}\text { Niveles } \\
\text { pedagógicos }\end{array}$ & Máximo 5 & $\begin{array}{l}\text { Primario, Secundario, Superior, Adultos, } \\
\text { Investigación. }\end{array}$ \\
\hline \multirow[b]{2}{*}{ Cientifica } & Valor Científico & Máximo 5 & Áreas científicas con valor significativo. \\
\hline & $\begin{array}{l}\text { Representatividad } \\
\text { científica }\end{array}$ & Máximo 5 & $\begin{array}{l}\text { Local (1), comarcal (2), regional (3), nacional (4), } \\
\text { internacional (5). }\end{array}$ \\
\hline \multirow[t]{2}{*}{ Turística } & $\begin{array}{l}\text { Contenidos } \\
\text { turísticos reales } \\
\text { (reales) }\end{array}$ & Máximo 5 & $\begin{array}{l}\text { Histórico artístico; Activo (excursionista, otros); } \\
\text { paisajístico; esparcimiento-relax; otros. }\end{array}$ \\
\hline & $\begin{array}{l}\text { Atracción turística } \\
\text { (potencial) }\end{array}$ & Máximo 5 & $\begin{array}{l}\text { Capacidad de atracción turística: local, comarcal, } \\
\text { regional, nacional, internacional. }\end{array}$ \\
\hline
\end{tabular}

Tabla 57. Puntuación total de la valoración cultural o añadida.

\begin{tabular}{|c|c|c|c|c|}
\hline \multicolumn{5}{|c|}{ Valores añadidos } \\
\hline Muy altos & Altos & Medios & Bajos & Muy bajos \\
\hline$>8-10$ & $>6-8$ & $>4-6$ & $>2-4$ & $0-2$ \\
\hline
\end{tabular}

c) De uso y gestión: se evalúan los componentes territoriales y el potencial de uso de los LIGm (Tablas 58 y 59). La capacidad de uso y gestión se valora a partir del conocimiento detallado de los valores intrínsecos y añadidos, junto al trabajo de campo (situación, cartografía geomorfológica e imágenes). Se aplican tres valoraciones:

- Alta, valor 2, potencial de uso garantizando su conservación.

- Media, valor 1, potencial de uso con gestión adecuada.

- Baja, valor 0, imposibilidad de uso sin gestión adecuada y posible deterioro grave.

Tabla 58. Criterios de valoración de uso y gestión.

\begin{tabular}{|c|c|c|}
\hline Valoración & Puntuación & Definición \\
\hline Accesibilidad & $\begin{array}{l}\text { ALTA: 2. Buena accesibilidad } \\
\text { MEDIA: } 1 \text {, con dificultades } \\
\text { BAJA: valor } 0 \text {, mala accesibilidad }\end{array}$ & $\begin{array}{l}\text { Utilidad por lo accesible del } \\
\text { geomorfositio para su uso y } \\
\text { gestión. }\end{array}$ \\
\hline Fragilidad & $\begin{array}{l}\text { ALTA: 0. Uso no recomendable. } \\
\text { MEDIA: 1. Uso potencial. } \\
\text { BAJA: 2. Alto valor de uso. }\end{array}$ & $\begin{array}{l}\text { Grado de fragilidad del LIG por sus } \\
\text { características intrínsecas. }\end{array}$ \\
\hline Vulnerabilidad & $\begin{array}{l}\text { ALTA: 0. Elementos capaces de transformar la } \\
\text { estructura o dinámica del Geomorfositio } \\
\text { MEDIA: 1. Transformación en bajo grado. } \\
\text { BAJA: 2. No hay vulnerabilidad. }\end{array}$ & $\begin{array}{l}\text { Elementos del entorno del LIG que } \\
\text { hacen posibles cambios } \\
\text { irreversibles en sus valores } \\
\text { intrínsecos y extrínsecos. } \\
\end{array}$ \\
\hline $\begin{array}{l}\text { Intensidad de } \\
\text { uso }\end{array}$ & $\begin{array}{l}\text { ALTA: 0. Alta frecuentación, no permite el } \\
\text { incremento de actividades } \\
\text { MEDIA: 1. Frecuentación y uso moderado } \\
\text { BAJA: 2. Frecuentación y uso muy moderado. }\end{array}$ & Uso actual del Geomorfositio. \\
\hline $\begin{array}{l}\text { Riesgo de } \\
\text { degradación }\end{array}$ & $\begin{array}{l}\text { ALTO: } 0 . \\
\text { MEDIO: } 1 \\
\text { BAJO: } 2\end{array}$ & $\begin{array}{l}\text { Posibilidad de deterioro del } \\
\text { geomorfositio con su uso hasta } \\
\text { perder valores intrínsecos y } \\
\text { añadidos. }\end{array}$ \\
\hline
\end{tabular}




\begin{tabular}{|c|c|c|}
\hline $\begin{array}{l}\text { Estado de } \\
\text { conservación }\end{array}$ & $\begin{array}{l}\text { ALTO: 2. Permite su uso. } \\
\text { MEDIO: } 1 \text {, Uso restringido. } \\
\text { BAJO: } 0 \text {. No favorece su uso. }\end{array}$ & \\
\hline Impactos & $\begin{array}{l}\text { ALTOS: } 0 . \text { Desaconsejan su uso, con } \\
\text { orientaciones de restauración. } \\
\text { MEDIOS: 1. Permiten usos pero aconsejan } \\
\text { restauración o eliminación de impactos. } \\
\text { BAJOS: 2. No hay impactos intensos }\end{array}$ & $\begin{array}{l}\text { Elementos humanos que afectan } \\
\text { al Geomorfositio en modo directo } \\
\text { (carreteras, canteras, obras, etc.). }\end{array}$ \\
\hline $\begin{array}{l}\text { Condiciones de } \\
\text { observación }\end{array}$ & $\begin{array}{l}\text { ALTAS: } 2 . \\
\text { MEDIAS: } 1 . \\
\text { BAJA: } 0 .\end{array}$ & $\begin{array}{l}\text { Existencia o no de de condiciones } \\
\text { de observación (paisaje, } \\
\text { localización, accesibilidad, etc.) } \\
\text { para el uso de LIG. }\end{array}$ \\
\hline $\begin{array}{l}\text { Límites de } \\
\text { cambio } \\
\text { aceptables }\end{array}$ & $\begin{array}{l}\text { ALTO: 0. Baja fragilidad y débil intensidad de } \\
\text { uso, los cambios no implican pérdida de valores. } \\
\text { MEDIO: 1. Fragilidad y usos actuales permiten } \\
\text { cambios moderados sin pérdida de valores. } \\
\text { BAJO: 2. Elevada fragilidad o intensidad de usos, } \\
\text { el cambio implica pérdida de valores. }\end{array}$ & $\begin{array}{l}\text { Potencial de cambios que el } \\
\text { geomorfositio puede asumir sin } \\
\text { perder sus valores intrínsecos y } \\
\text { añadidos. Esta en relación con la } \\
\text { fragilidad y la intensidad de uso. }\end{array}$ \\
\hline
\end{tabular}

Tabla 59. Puntuación total de la valoración intrínseca.

\begin{tabular}{|c|c|c|}
\hline \multicolumn{3}{|c|}{ Valoración de uso y gestión: potencial } \\
\hline Alto & Medio & Bajo \\
\hline$>6-10$ & $>3-6$ & $0-3$ \\
\hline Fuente: modificado de Serrano y González Trueba, 2005. \\
\hline
\end{tabular}

Los valores culturales y los de uso y gestión son más subjetivos, por lo que se evalúan por separado. Para las tres partes se han seleccionado los aspectos a valorar y se recurre en las dos primeras (intrínsecos y añadidos) al sistema binario: los valores existentes 1, los inexistentes 0 , sin ponderación subjetiva de unos sobre otros. La ponderación ya existe mediante la selección previa de parámetros y la información disponible y conocida de cada LIGm. En la tercera se establece una escala de valores semicuantitativa. El resultado de la valoración será triple, mediante una valoración alfanumérica que refleja los tres elementos evaluados, y permitirá comparar la importancia de cada aspecto en la valoración y gestión del LIG. La obtención de un parámetro unitario no parece de utilidad, dado que los tres aspectos no se pueden sintetizar en un solo valor. Además, la ventaja de la valoración para gestores, educadores o técnicos se centra en la diferenciación de aspectos, y no en su unicidad. De este modo, el gestor puede tener una visión de los valores intrínsecos, añadidos y de uso y gestión de todos los LIG del espacio natural protegido y su distribución espacial. La puntuación de 0 a 10 de los valores culturales y de uso y gestión permite una comparación inmediata sobre el valor dominante (natural o añadido), y por tanto, en el contexto en el que inscribe su gestión, uso y conservación. 


\section{2) Análisis de los LIGm de los Picos de Europa}

En trabajos recientes se hace hincapié en la utilidad de los LIGm como recursos de diversa indole, elementos sobresalientes y que requieren un conocimiento y gestión adecuados en el contexto del parque. Hay diferentes trabajos científicos (Serrano y González Trueba, 2005; González Trueba 2007a, 2007b; González Trueba y Serrano, 2010a; Fuertes y Fernández, 2010; Gómez Lende et al., 2011) y de divulgación (Menéndez, 2002; García Canseco, 2003; Adrados et al., 2011) que han realizado inventarios o muestran los elementos más significativos del Parque desde una perspectiva geomorfológica. A partir de los mismos y de los trabajos de campo realizados para las investigaciones básicas efectuadas en el marco del Parque Nacional en varios proyectos se han realizado inventarios de LIGm para su valoración. Los proyectos concretos son: "Geoindicadores de alta montaña y cambio global: análisis y control de indicadores geomorfológicos en el Parque Nacional de los Picos de Europa", "Criosfera y cambio global en espacios naturales protegidos: control de procesos geomorfológicos asociados a la nieve y el hielo como geoindicadores de cambio ambiental en el Parque Nacional Picos de Europa" del OAPN (Ministerio de Medio Ambiente, Rural y Marino) y "La criosfera como geoindicadora ambiental y del cambio climático: procesos de ladera asociados al hielo y la nieve en las montañas del norte peninsular (Pirineos-Cantábrica)", del Programa Nacional de Investigación Fundamental del Ministerio de Ciencia e Innovación, todos ellos centrados prioritariamente en el estudio de los aspectos geomorfológicos. A partir de estos trabajos se han inventariado 51 Lugares de Interés Geomorfológico (Figura 76 y Tablas 60 y 61). Para el Macizo Central ya existía un valoración de los LIGm con la misma metodología (Serrano y González Trueba, 2005; González Trueba y Serrano, 2008) que se incorporan directamente, añadiéndose en este trabajo las fichas informativas de síntesis. Los 29 LIGm restantes (Macizos Ándara y Cornión) se han realizado para este trabajo, como base para su posterior evaluación educativa y geoturística. En una primera lectura se observa una mayoría de Lugares Representativos (26 LIGm), seguida de 9 Lugares Singulares e igual cantidad de Elementos Representativos y Singulares (8 LIGm en cada uno $)^{24}$.

\footnotetext{
${ }^{24}$ Un lugar o elemento representativo es cuando una forma o sistema de formas es muy común y caracteriza una región (por ejemplo unas formas glaciares o kársticas en Picos, los jous glaciokársticos....); y un lugar o elemento singular, es cuando su valor deriva de la originalidad de esta forma o sistema de formas en un área o región, es decir está poco representado. Ejemplos de ellos serían un helero en Picos de Europa o la presencia de estrías.
} 


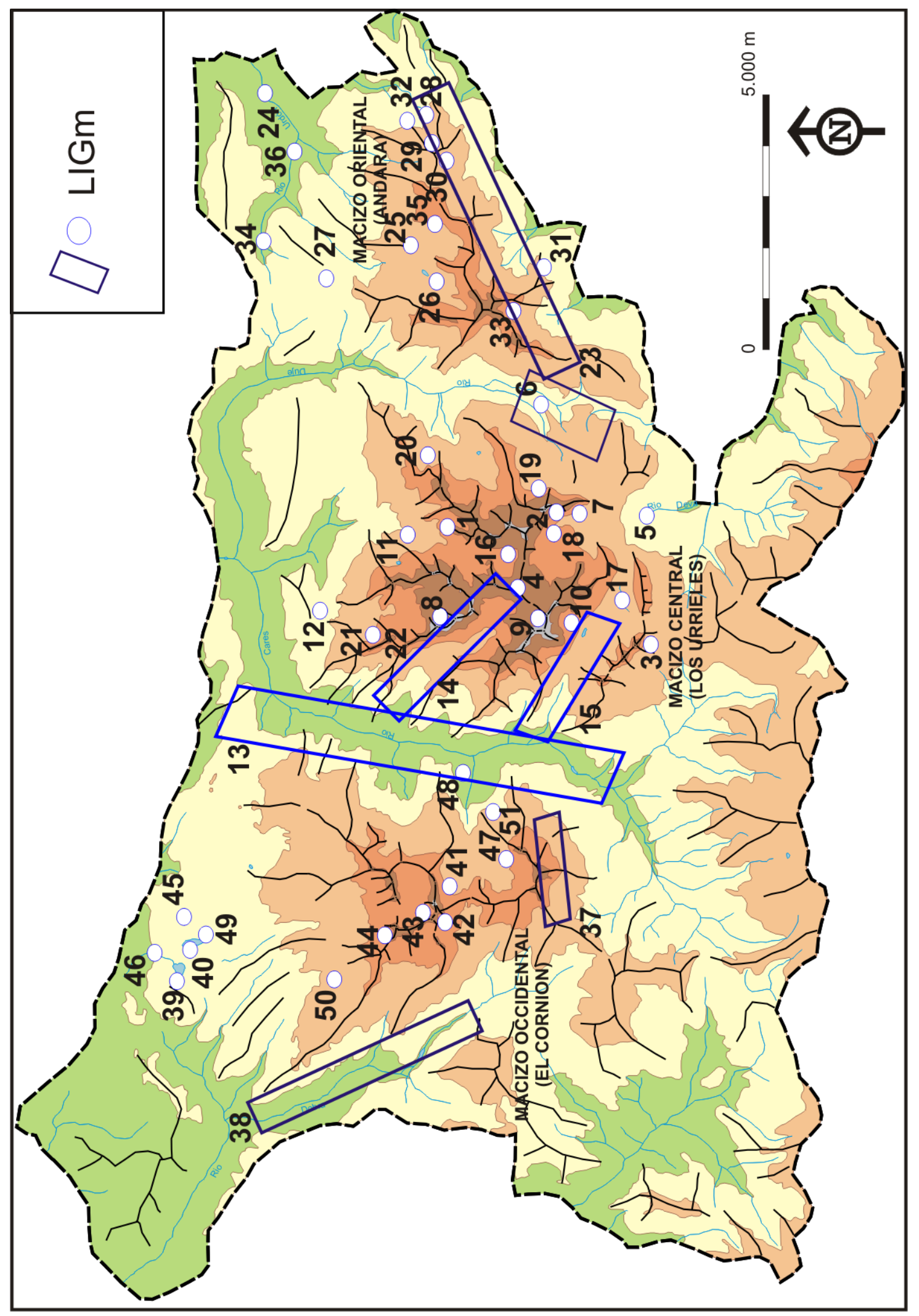

Figura 76. Distribución de LIGm del PNPE.

Fuente: elaboración propia. 
Tabla 60. LIGm de los tres macizos del Parque Nacional de los Picos de Europa.

\begin{tabular}{|c|c|c|c|}
\hline Macizo & № & NOMBRE & TIPO* \\
\hline \multirow{22}{*}{ Urrielles } & 1 & Monolito glaciokárstico del Naranjo de Bulnes & Elemento representativo \\
\hline & 2 & Morfoestructura cabalgante del pico Peña Vieja & Elemento representativo \\
\hline & 3 & Frente cabalgante de Traviesas de Salinas & Lugar representativo \\
\hline & 4 & Horn del pico Tesorero & Elemento representativo \\
\hline & 5 & Complejo glaciar Fuente Dé - Pido & Lugar representativo \\
\hline & 6 & Circos y morrenas de Áliva & Lugar representativo \\
\hline & 7 & Complejo glaciar de Lloroza & Lugar singular \\
\hline & 8 & Complejo glaciar de Jou Negro & Lugar singular \\
\hline & 9 & Complejo glaciar de Trasllambrión & Lugar singular \\
\hline & 10 & Complejo glaciar Torre Blanca-Hoyo de los Llagos & Lugar representativo \\
\hline & 11 & Artesa glaciar de Balcosín & Lugar representativo \\
\hline & 12 & Complejo glaciar y canales de Amuesa & Lugar representativo \\
\hline & 13 & Garganta fluviokárstica del Cares & Lugar representativo \\
\hline & 14 & Canal de Dobresengos & Lugar representativo \\
\hline & 15 & Canal de Asotín & Lugar representativo \\
\hline & 16 & Depresión glaciokárstica de los Boches & Lugar representativo \\
\hline & 17 & Polje de la Vega de Liordes & Elemento singular \\
\hline & 18 & Taludes y conos de derrubios de La Vueltona & Lugar representativo \\
\hline & 19 & Gonfolitas del Duje & Elemento singular \\
\hline & 20 & Cueva helada de Peña Castil & Elemento singular \\
\hline & 21 & Torca del Cerro (-1.589) & Lugar representativo \\
\hline & 22 & Sistema endokárstico del Trave (-1.441) & Lugar representativo \\
\hline \multirow{14}{*}{ Ándara } & 23 & Frente cabalgante de Ándara & Lugar representativo \\
\hline & 24 & Garganta de Urdón & Lugar representativo \\
\hline & 25 & Nunatak de Macondiú & Lugar singular \\
\hline & 26 & Artesa y lago de Ándara & Lugar representativo \\
\hline & 27 & Complejo morrénico de Escarandi & Lugar singular \\
\hline & 28 & Morrenas de El Torno & Lugar representativo \\
\hline & 29 & Canal del valle y complejo de La Aurora & Lugar representativo \\
\hline & 30 & Canchorral de Hormas & Elemento singular \\
\hline & 31 & Peñas de Brez & Lugar singular \\
\hline & 32 & Brañas de Corvera & Lugar representativo \\
\hline & 33 & Canal de Las Arredondas & Lugar representativo \\
\hline & 34 & Depresión del Sobra & Lugar singular \\
\hline & 35 & Torca S56 & Elemento representativo \\
\hline & 36 & Cueva del nacimiento & Elemento singular \\
\hline \multirow{15}{*}{ Cornión } & 37 & Frente cabalgante de Pembuches & Lugar representativo \\
\hline & 38 & Desfiladero de los Beyos & Lugar representativo \\
\hline & 39 & Lago y Vega de Enol & Lugar representativo \\
\hline & 40 & Complejo morrénico de la Ercina & Lugar representativo \\
\hline & 41 & Morrenas de Llós & Elemento representativo \\
\hline & 42 & Complejo morrénico del Callejón de las Horcadas & Lugar singular \\
\hline & 43 & Helero de La Forcadona & Elemento singular \\
\hline & 44 & Cemba Vieya & Lugar singular \\
\hline & 45 & Depresión de Belbín-La Llomba & Lugar representativo \\
\hline & 46 & Polje de Comeya & Lugar representativo \\
\hline & 47 & Sistema del Xitu & Elemento representativo \\
\hline & 48 & Sistema Jultayu-Xitu & Elemento representativo \\
\hline & 49 & Desprendimientos de La Veguina-Llucia & Elemento representativo \\
\hline & 50 & Gueyos de Junjumia & Elemento singular \\
\hline & 51 & Fuentes de la Farfada & Elemento singular \\
\hline
\end{tabular}


Tabla 61. Resumen de las valoraciones de los LIGm de los tres macizos del PNPE.

\begin{tabular}{|c|c|c|c|c|c|}
\hline $\begin{array}{c}\text { No } \\
\text { LIGm }\end{array}$ & Nombre & $\begin{array}{c}\text { Valor } \\
\text { intrínseco }\end{array}$ & $\begin{array}{c}\text { Valor } \\
\text { añadido }\end{array}$ & $\begin{array}{l}\text { Valor uso } \\
\text { y gestión }\end{array}$ & \\
\hline 1 & Monolito glaciokárstico del Naranjo de Bulnes & 5,2 & 8,1 & 4,4 & \\
\hline 2 & Morfoestructura cabalgante del pico Peña Vieja & 5,3 & 3,5 & 7,7 & \\
\hline 3 & Frente cabalgante de Traviesas de Salinas & 4,8 & 2,2 & 8,3 & \\
\hline 4 & Horn del pico Tesorero & 4 & 3,7 & 8,3 & \\
\hline 5 & Complejo glaciar Fuente Dé - Pido & 6,5 & 6,5 & 6,5 & \\
\hline 6 & Circos y morrenas de Áliva & 7,2 & 5,7 & 7 & \\
\hline 7 & Complejo glaciar de Lloroza & 6,4 & 2,7 & 5,5 & \\
\hline 8 & Complejo glaciar de Jou Negro & 6 & 4,1 & 5 & \\
\hline 9 & Complejo glaciar de Trasllambrión & 6,4 & 4,3 & 6,1 & \\
\hline 10 & Complejo glaciar Torre Blanca-Hoyo de los Llagos & 4,8 & 3,7 & 6,6 & \\
\hline 11 & Artesa glaciar de Balcosín & 4,4 & 3 & 7,3 & \\
\hline 12 & Complejo glaciar y canales de Amuesa & 4,4 & 3,2 & 7,7 & \\
\hline 13 & Garganta fluviokárstica del Cares & 5,6 & 7,1 & 2,8 & \\
\hline 14 & Canal de Dobresengos & 5 & 3,9 & 8,3 & \\
\hline 15 & Canal de Asotín & 5,2 & 4,1 & 8,3 & \\
\hline 16 & Depresión glaciokárstica de los Boches & 5,4 & 3,7 & 5 & \\
\hline 17 & Polje de la Vega de Liordes & 5,2 & 1,8 & 8,8 & \\
\hline 18 & Taludes y conos de derrubios de La Vueltona & 4,2 & 3,6 & 3,3 & \\
\hline 19 & Gonfolitas del Duje & 3,8 & 1,7 & 7,7 & \\
\hline 20 & Cueva helada de Peña Castil & 3,4 & 2 & 4,4 & \\
\hline 21 & Torca del Cerro (-1.589) & 3 & 1,7 & 5 & \\
\hline 22 & Sistema endokárstico del Trave (-1.441) & 3 & 1,7 & 5 & \\
\hline 23 & Frente cabalgante de Ándara & 2,4 & 2,2 & 2,8 & \\
\hline 24 & Garganta de Urdón & 5,6 & 7 & 7,7 & \\
\hline 25 & Nunatak de Macondiú & 2,4 & 4,3 & 8,8 & \\
\hline 26 & Artesa y lago de Ándara & 6,2 & 7 & 7,7 & \\
\hline 27 & Complejo morrénico de Escarandi & 3,8 & 3,3 & 7,2 & \\
\hline 28 & Morrenas de El Torno & 4,2 & 2,3 & 9,4 & \\
\hline 29 & Canal del valle y complejo de La Aurora & 5,2 & 2,1 & 8,8 & \\
\hline 30 & Canchorral de Hormas & 6,6 & 2,3 & 6,6 & \\
\hline 31 & Peñas de Brez & 4,4 & 3,3 & 8,3 & \\
\hline 32 & Brañas de Corvera & 6 & 3 & 9,4 & \\
\hline 33 & Canal de Las Arredondas & 5,8 & 3,6 & 9,4 & \\
\hline 34 & Depresión del Sobra & 4,8 & 3 & 8,8 & \\
\hline 35 & Torca S56 & 3 & 2,1 & 5 & \\
\hline 36 & Cueva del Nacimiento & 3 & 2,1 & 5 & \\
\hline 37 & Frente cabalgante de Pembuches & 2,4 & 2,2 & 8,8 & \\
\hline 38 & Desfiladero de los Beyos & 5,6 & 7 & 7,7 & Escala Valor \\
\hline 39 & Lago y Vega de Enol & 5,6 & 5,2 & 5,5 & Uso y gestión \\
\hline 40 & Complejo morrénico de la Ercina & 5,8 & 5,2 & 3,8 & $>6-10$ \\
\hline 41 & Morrenas de Llós & 4,8 & 2,5 & 7,2 & $>3-6$ \\
\hline 42 & Complejo morrénico del Callejón de las Horcadas & 4,8 & 2,4 & 7,2 & $0-3$ \\
\hline 43 & Helero de La Forcadona & 3 & 1,7 & 7,7 & Escala \\
\hline 44 & Cemba Vieya & 2,8 & 2,1 & 8 & Valores \\
\hline 45 & Depresión de Belbín-La Llomba & 5,6 & 4,5 & 7,7 & Intrínseco y \\
\hline 46 & Polje de Comeya & 5,6 & 4 & 7,7 & Añadido \\
\hline 47 & Sistema del Xitu & 3,2 & 1,4 & 3,3 & $>8-10$ \\
\hline 48 & Sistema Jultayu-Xitu & 3,2 & 1,4 & 3,3 & $>6-8$ \\
\hline 49 & Desprendimientos de La Veguina-Llucia & 3 & 2,8 & 9,4 & $>4-6$ \\
\hline 50 & Gueyos de Junjumia & 1,4 & 1,9 & 5 & $>2-4$ \\
\hline 51 & Fuentes de la Farfada & 2,4 & 1,4 & 4,4 & $0-2$ \\
\hline
\end{tabular}


La Interpretación del Patrimonio Geomorfológico en los Picos de Europa: una propuesta para su aprovechamiento didáctico y geoturístico

Tabla 62. Valoraciones en orden descendente de los LIGm de los tres macizos del PNPE.

\begin{tabular}{|c|c|c|c|c|c|c|c|}
\hline $\begin{array}{l}\text { No } \\
\text { orden }\end{array}$ & LIGm & $\begin{array}{c}\text { Valor } \\
\text { intrínseco }\end{array}$ & LIGm & $\begin{array}{c}\text { Valor } \\
\text { añadido }\end{array}$ & LIGm & $\begin{array}{c}\text { Valor de uso y } \\
\text { gestión }\end{array}$ & \\
\hline 1 & 6 & 7,2 & 1 & 8,1 & 33 & 9,4 & \\
\hline 2 & 30 & 6,6 & 13 & 7,1 & 32 & 9,4 & \\
\hline 3 & 5 & 6,5 & 26 & 7 & 49 & 9,4 & \\
\hline 4 & 9 & 6,4 & 24 & 7 & 28 & 9,4 & \\
\hline 5 & 7 & 6,4 & 38 & 7 & 25 & 8,8 & \\
\hline 6 & 26 & 6,2 & 5 & 6,5 & 34 & 8,8 & \\
\hline 7 & 32 & 6 & 6 & 5,7 & 37 & 8,8 & \\
\hline 8 & 8 & 6 & 40 & 5,2 & 29 & 8,8 & \\
\hline 9 & 33 & 5,8 & 39 & 5,2 & 17 & 8,8 & \\
\hline 10 & 40 & 5,8 & 45 & 4,5 & 15 & 8,3 & \\
\hline 11 & 24 & 5,6 & 9 & 4,3 & 14 & 8,3 & \\
\hline 12 & 38 & 5,6 & 25 & 4,3 & 4 & 8,3 & \\
\hline 13 & 45 & 5,6 & 8 & 4,1 & 31 & 8,3 & \\
\hline 14 & 46 & 5,6 & 15 & 4,1 & 3 & 8,3 & \\
\hline 15 & 39 & 5,6 & 46 & 4 & 44 & 8 & \\
\hline 16 & 13 & 5,6 & 14 & 3,9 & 26 & 7,7 & \\
\hline 17 & 16 & 5,4 & 16 & 3,7 & 24 & 7,7 & \\
\hline 18 & 2 & 5,3 & 10 & 3,7 & 38 & 7,7 & \\
\hline 19 & 17 & 5,2 & 4 & 3,7 & 45 & 7,7 & \\
\hline 20 & 29 & 5,2 & 33 & 3,6 & 46 & 7,7 & \\
\hline 21 & 15 & 5,2 & 18 & 3,6 & 2 & 7,7 & \\
\hline 22 & 1 & 5,2 & 2 & 3,5 & 12 & 7,7 & \\
\hline 23 & 14 & 5 & 31 & 3,3 & 19 & 7,7 & \\
\hline 24 & 34 & 4,8 & 27 & 3,3 & 43 & 7,7 & \\
\hline 25 & 3 & 4,8 & 12 & 3,2 & 11 & 7,3 & \\
\hline 26 & 41 & 4,8 & 32 & 3 & 27 & 7,2 & \\
\hline 27 & 42 & 4,8 & 34 & 3 & 41 & 7,2 & \\
\hline 28 & 10 & 4,8 & 11 & 3 & 42 & 7,2 & \\
\hline 29 & 31 & 4,4 & 49 & 2,8 & 6 & 7 & \\
\hline 30 & 12 & 4,4 & 7 & 2,7 & 10 & 6,6 & \\
\hline 31 & 11 & 4,4 & 41 & 2,5 & 30 & 6,6 & \\
\hline 32 & 28 & 4,2 & 42 & 2,4 & 5 & 6,5 & \\
\hline 33 & 18 & 4,2 & 30 & 2,3 & 9 & 6,1 & \\
\hline 34 & 4 & 4 & 28 & 2,3 & 39 & 5,5 & \\
\hline 35 & 19 & 3,8 & 3 & 2,2 & 7 & 5,5 & \\
\hline 36 & 27 & 3,8 & 37 & 2,2 & 8 & 5 & \\
\hline 37 & 20 & 3,4 & 23 & 2,2 & 16 & 5 & \\
\hline 38 & 47 & 3,2 & 29 & 2,1 & 35 & 5 & \\
\hline 39 & 48 & 3,2 & 35 & 2,1 & 36 & 5 & \\
\hline 40 & 49 & 3 & 36 & 2,1 & 50 & 5 & \multirow{2}{*}{$\begin{array}{l}\text { Escala cromática } \\
\text { Valor Uso y Gestión }\end{array}$} \\
\hline 41 & 43 & 3 & 44 & 2,1 & 21 & 5 & \\
\hline 42 & 21 & 3 & 20 & 2 & 22 & 5 & $>6-10$ (Alto) \\
\hline 43 & 22 & 3 & 50 & 1,9 & 1 & 4,4 & $>3-6$ (Medio) \\
\hline 44 & 35 & 3 & 17 & 1,8 & 20 & 4,4 & $0-3$ (Bajo) \\
\hline 45 & 36 & 3 & 19 & 1,7 & 51 & 4,4 & \multirow{2}{*}{$\begin{array}{c}\text { Escala cromática } \\
\text { Valores Intrínseco y } \\
\text { Añadido }\end{array}$} \\
\hline 46 & 44 & 2,8 & 43 & 1,7 & 40 & 3,8 & \\
\hline 47 & 25 & 2,4 & 21 & 1,7 & 18 & 3,3 & > 8-10 (Muy alto) \\
\hline 48 & 37 & 2,4 & 22 & 1,7 & 47 & 3,3 & $>6-8$ (Alto) \\
\hline 49 & 51 & 2,4 & 47 & 1,4 & 48 & 3,3 & $>4-6$ (Medio) \\
\hline 50 & 23 & 2,4 & 48 & 1,4 & 13 & 2,8 & $>2-4$ (Bajo) \\
\hline 51 & 50 & 1,4 & 51 & 1,4 & 23 & 2,8 & 0-2 (Muy bajo) \\
\hline
\end{tabular}


La evaluación efectuada sobre cada uno de los Lugares de Interés Geomorfológico arroja resultados variables en función de los valores considerados. Respecto de los Valores Intrínsecos (Tablas 62 y 63; Figura 77), se observa que existe una marcada concentración de valoraciones en la parte superior de la escala (valores medios y altos), poniendo en evidencia el carácter patrimonial del área de estudio y, desde un punto de vista geomorfológico, la importancia de su conservación y divulgación. Por las características de algunos de ellos (cercanía, accesibilidad), debe regularse su intensidad de uso y frecuentación actual, como es el caso del Complejo Glaciar Fuente Dé-Pido, el Lago y Vega de Enol, el Complejo morrénico de la Ercina y el Polje de Comeya. Es conveniente controlar el número de visitantes diarios, adecuando el uso a la capacidad de acogida del medio; una de las alternativas para ello es promover las visitas a otros puntos del PNPE o limitar el período de permanencia en los mismos. En otros casos, fue su mala accesibilidad (Complejos glaciares de Jou Negro y Trasllambrión) lo que ha favorecido su estado de conservación. En general, en estos casos debe primar una labor de conservación y preservación del LIGm.

Tabla 63. Identificación de LIGm según su valor intrínseco.

\begin{tabular}{|l|c|c|l|}
\hline \multicolumn{1}{|c|}{ Valoración } & Cantidad de LIGm & $\%$ & \multicolumn{1}{|c|}{ Identificación de LIGm } \\
\hline Muy alta (8-10) & 0 & 0 & Ninguno \\
\hline Alta (6-8) & 6 & 12 & $5,6,7,9,26,30$. \\
\hline Media (4-6) & 27 & 53 & $\begin{array}{l}1,2,3,8,10,11,12,13,14,15,16,17,18,24, \\
28,29,31,32,33,34,38,39,40,41,42,45,46 .\end{array}$ \\
\hline Baja (2-4) & 17 & 33 & $\begin{array}{l}4,19,20,21,22,23,25,27,35,36,37,43,44, \\
47,48,49,51 .\end{array}$ \\
\hline Muy baja (0-2) & 1 & 2 & 50. \\
\hline Total LIGm & 51 & 100 \\
\hline Fuente: elaboración propia. &
\end{tabular}

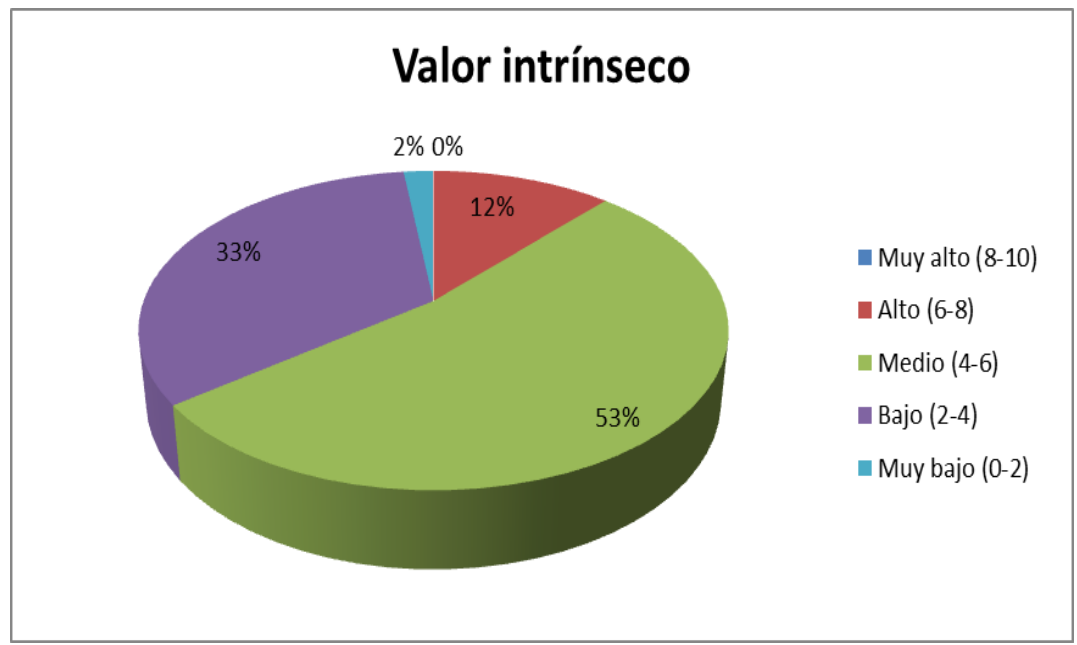

Figura 77. Distribución de LIGm según su valor intrínseco. Fuente: elaboración propia. 
La puntuación de los valores añadidos proporciona una consideración general de elementos culturales y ambientales que condicionan y enriquecen los valores intrínsecos. EI Naranjo de Bulnes vuelve a presentar una calificación elevada, siendo el único LIGm de valores muy altos dentro de esta valoración. Al ser uno de los puntos de atracción de visitantes en el PNPE es conveniente una gestión en los flujos e intensidad de los mismos, para así evitar una pérdida irreversible de valores en este elemento representativo. A nivel general, el $73 \%$ de los LIGm posee valor bajo o muy bajo (Figura 78) por lo que 37 sitios aparecen con puntuaciones inferiores a 4 (Tabla 64). Muchos de estos LIGm son representativos de procesos endokársticos, además de constituir algunas de las cavidades más profundas del mundo. Ese es el caso de las Torcas del Cerro y S56, el Sistema endokárstico del Trave y los Sistemas del Xitu y Jultayu Xitu. Su desconocimiento y su dificultad de acceso para el público en general favorecieron su conservación. La divulgación de los mismos y el fomento de su estudio y exploración son las vías de actuación de una política de gestión correcta.

Tabla 64. Identificación de LIGm según su valor añadido.

\begin{tabular}{|l|c|c|l|}
\hline \multicolumn{5}{|c|}{ VALOR AÑAIDO } \\
\hline \multicolumn{1}{|c|}{ Valoración } & Cantidad de LIGm & $\%$ & \multicolumn{1}{c|}{ Identificación de LIGm } \\
\hline Muy alta (8-10) & 1 & 2 & 1. \\
\hline Alta (6-8) & 5 & 10 & $5,13,24,26,38$. \\
\hline Media (4-6) & 8 & 16 & $6,8,9,15,25,39,40,45$. \\
\hline Baja (2-4) & 27 & 53 & $\begin{array}{l}2,3,4,7,10,11,12,14,16,18,23,27,28,29, \\
30,31,32,33,34,35,36,37,41,42,44,46,49 .\end{array}$ \\
\hline Muy baja (0-2) & 10 & 20 & $17,19,20,21,22,43,47,48,50,51$. \\
\hline Total LIGm & 51 & 100 \\
\hline Fuente: elaboración personal.
\end{tabular}

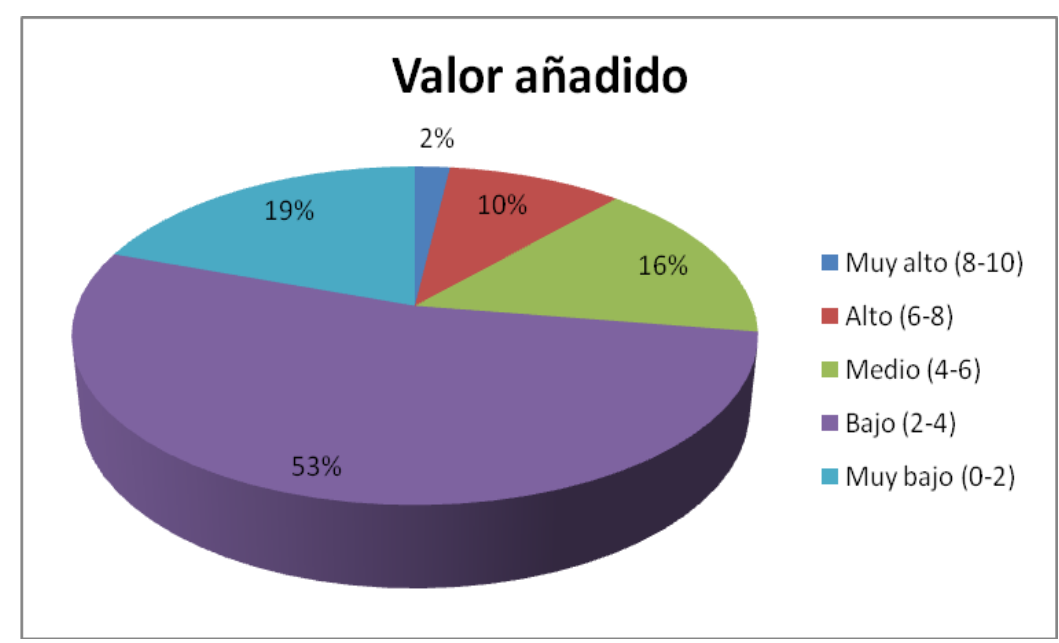

Figura 78. Distribución de LIGm según su valor añadido. Fuente: elaboración propia. 
Tabla 65. Valoración de los aspectos del valor añadido según LIGm.

\begin{tabular}{|c|c|c|c|c|c|c|c|c|c|c|c|}
\hline \multirow{3}{*}{ LIGm } & \multirow{3}{*}{$\begin{array}{c}\text { PyE } \\
*\end{array}$} & \multirow{2}{*}{\multicolumn{3}{|c|}{ Elementos culturales }} & \multicolumn{4}{|c|}{ Elementos didácticos y científicos } & \multirow{2}{*}{\multicolumn{2}{|c|}{$\begin{array}{l}\text { Valoración } \\
\text { turística }\end{array}$}} & \multirow{3}{*}{$\begin{array}{c}\text { Total } \\
\text { Valor } \\
\text { Añadido }\end{array}$} \\
\hline & & & & & \multicolumn{2}{|c|}{ Valor didáctico } & \multicolumn{2}{|c|}{$\begin{array}{c}\text { Valor } \\
\text { científico }\end{array}$} & & & \\
\hline & & $\begin{array}{c}\text { AEVP } \\
* *\end{array}$ & $\begin{array}{l}\text { Cont. } \\
\text { cult. }\end{array}$ & $\begin{array}{l}\text { Cont. } \\
\text { hist. }\end{array}$ & $\begin{array}{c}\text { Rec. } \\
\text { Pedag. }\end{array}$ & $\begin{array}{l}\text { Niv. } \\
\text { Pedag. }\end{array}$ & Áreas & Repr. & $\begin{array}{c}\text { Cont. } \\
\text { turístico }\end{array}$ & $\begin{array}{l}\text { Atract. } \\
\text { turístico }\end{array}$ & \\
\hline 1 & 8 & 2 & 10 & 10 & 5 & 4 & 3 & 5 & 5 & 5 & 8,1 \\
\hline 2 & 8 & 1 & 2 & 1 & 3 & 2 & 2 & 3 & 1 & 2 & 3,5 \\
\hline 3 & 6 & 0 & 0 & 0 & 2 & 2 & 2 & 2 & 1 & 1 & 2,2 \\
\hline 4 & 4 & 0 & 3 & 1 & 5 & 4 & 1 & 3 & 2 & 3 & 3,7 \\
\hline 5 & 10 & 4 & 1 & 2 & 5 & 4 & 5 & 5 & 5 & 5 & 6,5 \\
\hline 6 & 6 & 3 & 3 & 2 & 5 & 4 & 5 & 3 & 4 & 5 & 5,7 \\
\hline 7 & 2 & 0 & 0 & 0 & 5 & 5 & 4 & 3 & 1 & 2 & 2,7 \\
\hline 8 & 2 & 0 & 4 & 0 & 5 & 5 & 5 & 4 & 2 & 2 & 4,1 \\
\hline 9 & 4 & 0 & 4 & 0 & 5 & 5 & 2 & 4 & 2 & 4 & 4,3 \\
\hline 10 & 4 & 0 & 2 & 0 & 5 & 5 & 2 & 3 & 2 & 3 & 3,7 \\
\hline 11 & 4 & 0 & 0 & 0 & 5 & 4 & 1 & 2 & 2 & 3 & 3 \\
\hline 12 & 4 & 1 & 2 & 3 & 2 & 3 & 4 & 2 & 0 & 2 & 3,2 \\
\hline 13 & 8 & 10 & 3 & 4 & 5 & 4 & 1 & 5 & 5 & 4 & 7,1 \\
\hline 14 & 4 & 1 & 0 & 1 & 5 & 4 & 3 & 4 & 2 & 3 & 3,9 \\
\hline 15 & 4 & 2 & 0 & 1 & 5 & 4 & 3 & 4 & 2 & 4 & 4,1 \\
\hline 16 & 2 & 0 & 2 & 0 & 5 & 5 & 3 & 4 & 2 & 3 & 3,7 \\
\hline 17 & 2 & 1 & 0 & 1 & 2 & 2 & 3 & 1 & 1 & 0 & 1,8 \\
\hline 18 & 2 & 1 & 4 & 0 & 5 & 5 & 1 & 4 & 2 & 1 & 3,6 \\
\hline 19 & 2 & 1 & 0 & 0 & 3 & 2 & 1 & 3 & 0 & 0 & 1,7 \\
\hline 20 & 0 & 0 & 1 & 1 & 2 & 1 & 2 & 3 & 1 & 3 & 2 \\
\hline 21 & 0 & 0 & 1 & 1 & 1 & 2 & 2 & 4 & 0 & 1 & 1,7 \\
\hline 22 & 0 & 0 & 1 & 1 & 2 & 1 & 2 & 1 & 0 & 1 & 1,7 \\
\hline 23 & 8 & 0 & 0 & 0 & 2 & 3 & 2 & 3 & 1 & 1 & 2,2 \\
\hline 24 & 8 & 6 & 3 & 4 & 4 & 3 & 4 & 3 & 4 & 4 & 7 \\
\hline 25 & 6 & 1 & 1 & 2 & 3 & 3 & 3 & 2 & 2 & 2 & 4,3 \\
\hline 26 & 8 & 4 & 4 & 3 & 4 & 4 & 5 & 4 & 4 & 3 & 7 \\
\hline 27 & 4 & 1 & 2 & 1 & 2 & 3 & 2 & 3 & 1 & 1 & 3,3 \\
\hline 28 & 2 & 1 & 1 & 0 & 2 & 3 & 3 & 2 & 0 & 0 & 2,3 \\
\hline 29 & 4 & 1 & 1 & 0 & 3 & 3 & 3 & 1 & 1 & 0 & 2,1 \\
\hline 30 & 4 & 0 & 0 & 0 & 3 & 2 & 1 & 4 & 0 & 0 & 2,3 \\
\hline 31 & 4 & 2 & 0 & 1 & 4 & 4 & 3 & 3 & 0 & 0 & 3,3 \\
\hline 32 & 4 & 1 & 1 & 0 & 2 & 3 & 3 & 2 & 1 & 1 & 3 \\
\hline 33 & 6 & 1 & 1 & 1 & 2 & 2 & 2 & 3 & 2 & 2 & 3,6 \\
\hline 34 & 6 & 2 & 1 & 0 & 2 & 2 & 3 & 1 & 1 & 0 & 3 \\
\hline 35 & 0 & 0 & 1 & 1 & 2 & 1 & 3 & 4 & 0 & 1 & 2,1 \\
\hline 36 & 0 & 0 & 1 & 1 & 2 & 1 & 3 & 4 & 0 & 1 & 2,1 \\
\hline 37 & 8 & 0 & 0 & 0 & 2 & 2 & 2 & 3 & 1 & 1 & 2,2 \\
\hline 38 & 8 & 6 & 3 & 4 & 4 & 3 & 2 & 4 & 4 & 4 & 7 \\
\hline 39 & 6 & 2 & 2 & 1 & 4 & 5 & 4 & 4 & 4 & 5 & 5,2 \\
\hline 40 & 8 & 2 & 2 & 3 & 4 & 5 & 4 & 4 & 4 & 5 & 5,2 \\
\hline 41 & 8 & 1 & 1 & 0 & 3 & 2 & 2 & 2 & 1 & 2 & 2,5 \\
\hline 42 & 6 & 1 & 0 & 0 & 2 & 1 & 3 & 2 & 1 & 1 & 2,4 \\
\hline 43 & 4 & 0 & 0 & 1 & 1 & 2 & 2 & 4 & 0 & 0 & 1,7 \\
\hline 44 & 8 & 0 & 0 & 1 & 2 & 2 & 3 & 2 & 0 & 0 & 2,1 \\
\hline 45 & 6 & 1 & 1 & 2 & 4 & 4 & 5 & 3 & 3 & 3 & 4,5 \\
\hline 46 & 6 & 3 & 3 & 2 & 2 & 1 & 3 & 2 & 3 & 3 & 4 \\
\hline 47 & 0 & 0 & 0 & 1 & 1 & 0 & 4 & 4 & 0 & 0 & 1,4 \\
\hline
\end{tabular}




\begin{tabular}{l|c|c|c|c|c|c|c|c|c|c|c|c|}
\hline 48 & 0 & 0 & 0 & 1 & 1 & 0 & 4 & 4 & 0 & 0 & 1,4 \\
\hline 49 & 4 & 1 & 1 & 0 & 3 & 4 & 3 & 2 & 1 & 0 & 2,8 \\
\hline 50 & 2 & 1 & 1 & 0 & 2 & 3 & 2 & 1 & 1 & 0 & 1,9 \\
\hline 51 & 0 & 0 & 0 & 0 & 2 & 2 & 3 & 1 & 1 & 1 & 1,4 \\
\hline
\end{tabular}

Por tratarse de una valoración genérica, a continuación se detendrá el análisis en las variables que la componen para conocer en detalle tal evaluación e identificar aquellos aspectos que puedan cobrar especial importancia para su aprovechamiento posterior (Tabla 65).

Paisajística y estética: criterio basado en parámetros de tipo estético, emotivo y perceptual. Así, se valora la belleza, originalidad, el simbolismo y las emociones que el LIGm puede provocar en las personas. El análisis del atractivo paisajístico permite discernir cómo impactará en la experiencia del visitante la relevancia de los elementos que conforman el paisaje observado. Del total de 51 LIGm valorados sólo uno obtuvo la máxima puntuación en este aspecto (Complejo glaciar Fuente Dé - Pido). El 27 \% de los geositios de la zona de trabajo presenta un componente a escala media (valle, municipio) (Figura 79).

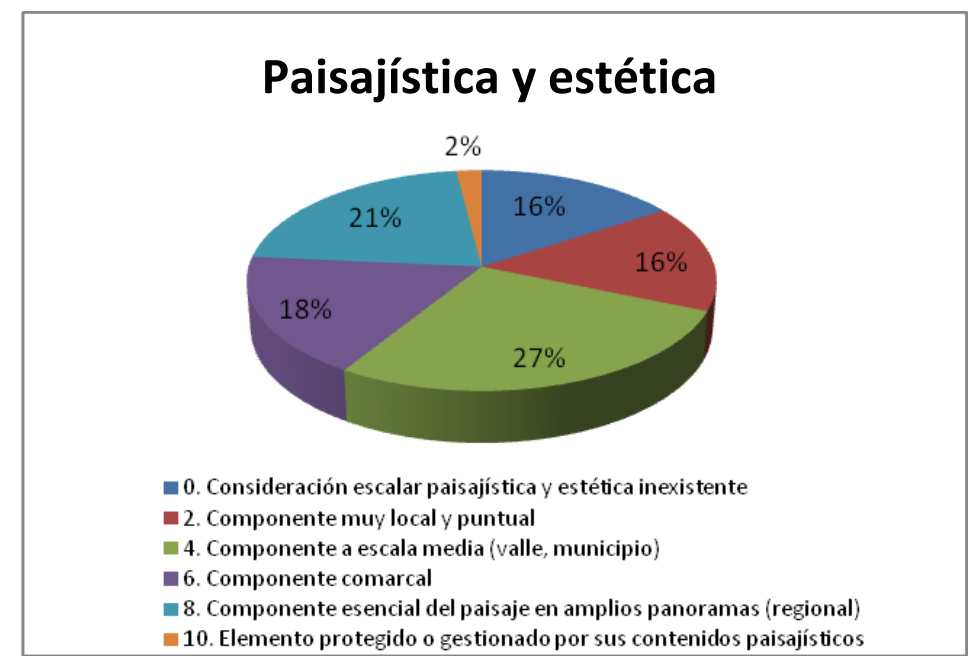

Figura 79. Distribución de LIGm según su valor en el criterio "Paisajística y estética".

Fuente: elaboración propia.

Asociación a elementos de valor patrimonial: para el mejor aprovechamiento de los recursos disponibles es importante registrar distintos elementos patrimoniales que permitan el trabajo mancomunado por su conservación, como fuente de recursos económicos y paisajísticos. De esta manera se promovería su integración a la oferta turística con 
modalidades de bajo impacto. Las máximas puntuaciones las obtuvieron tres Lugares Representativos: la Garganta fluviokárstica del Cares (10), la Garganta de Urdón (6) y el Desfiladero de los Beyos (6). A nivel general, el 41 \% de los LIGm no presenta una fuerte vinculación a elementos patrimoniales (monumentos, yacimientos, poblaciones, construcciones populares, elementos etnológicos, etc.) (Figura 80).

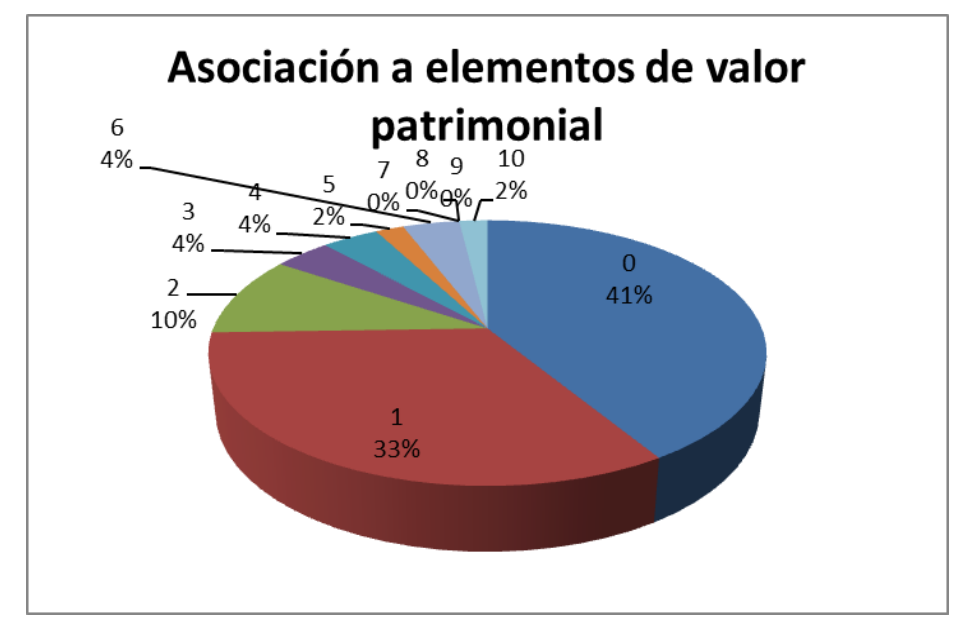

Figura 80. Distribución de LIGm según su valor en el criterio "Asociación a elementos de valor patrimonial". Fuente: elaboración propia.

Contenido cultural: este criterio hace referencia a la presencia en el imaginario colectivo y en producciones culturales de los distintos sitios valorados. En esta categoría el monolito glaciokárstico del Naranjo de Bulnes presenta la puntuación máxima debido a su presencia en obras literarias y su conocimiento popular. Las tres puntuaciones más bajas reúnen al $78 \%$ de los LIGm inventariados y evaluados (Figura 81).

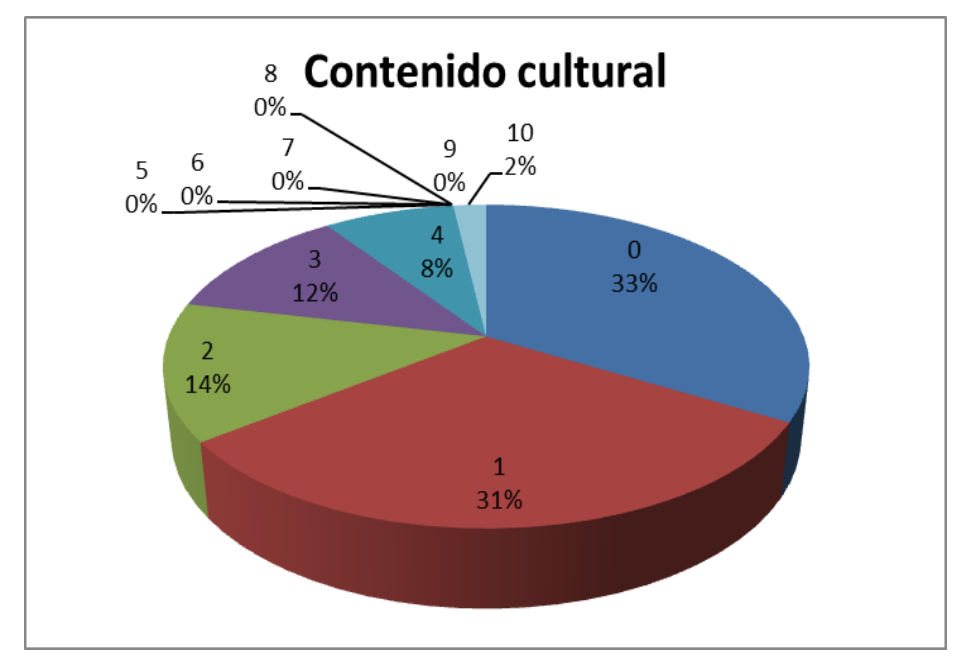

Figura 81. Distribución de LIGm según su valor en el criterio "Contenido cultural".

Fuente: elaboración propia. 
Contenido histórico: junto a los dos criterios anteriores, el contenido histórico integra el relevamiento de elementos culturales asociados a los LIGm. En este caso se hace mención a las fases históricas de uso u ocupación de los mismos. También en este criterio el Naranjo de Bulnes presenta la máxima puntuación (10), seguido por la Garganta del Cares, el Desfiladero de los Beyos y la Garganta de Urdón, todos con una valoración de 4. Las dos valores más bajos reúnen el $76 \%$ de los LIGm de la zona de estudio (Figura 82).

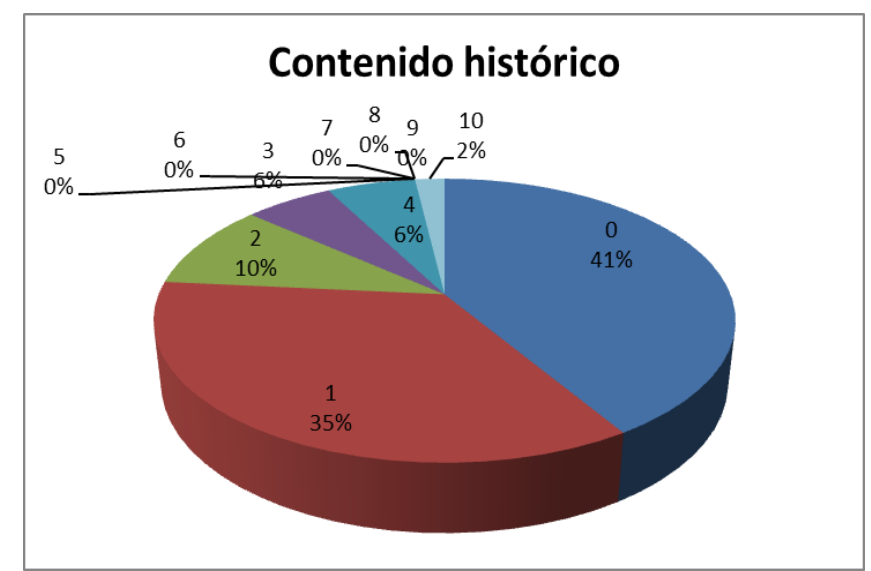

Figura 82. Distribución de LIGm según su valor en el criterio "Contenido histórico".

Fuente: elaboración propia.

Recuros pedagógicos: la posibilidad de utilizar los LIGm como material didáctico para el desarrollo de contenidos escolares es importante tanto para la transmisión de dichos conocimientos, como para el fortalecimiento de la importancia de la conservación de los espacios naturales. Al obtener alguna de las dos máximas punutaciones, 21 LIGm son considerados como una buena herramienta para el desarrollo de contenidos pedagógicos y docentes (Figura 83), dentro de los que se destacan los relacionados con la geodiversidad y la biodiversidad.

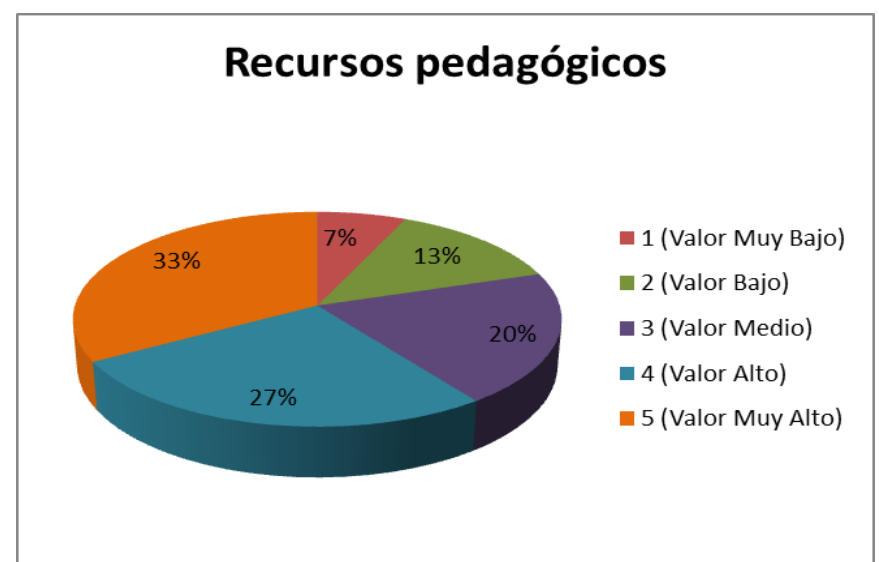

Figura 83. Distribución de LIGm según su valor en el criterio "Recursos pedagógicos".

Fuente: elaboración propia. 
Niveles pedagógicos: relacionado con el criterio anterior, este aspecto contextualiza el contenido a desarrollar con el aprovechamiento didáctico del LIGm a niveles de enseñanza. En la zona de estudio el $37 \%$ de los LIGm permite el desarrollo de los planes de estudio de alguno de los niveles de la escolaridad obligatoria en España. Debido a la excepcionalidad y exclusividad geomorfológica presente en el PNPE, el $59 \%$ de sus geositios permite una enseñanza de nivel superior o de investigación (Figura 84).

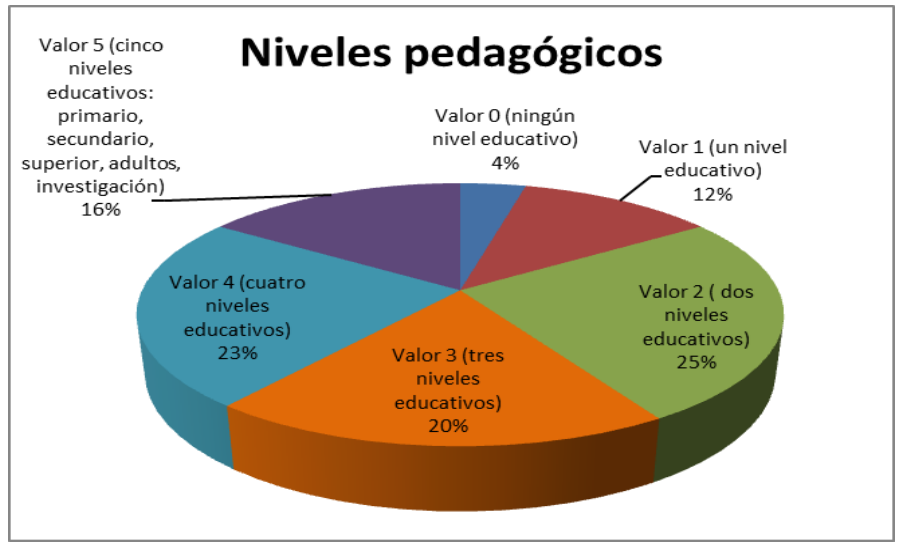

Figura 84. Distribución de LIGm según su valor en el criterio "Niveles pedagógicos".

Fuente: elaboración propia.

Valor científico: el análisis y valoración de los LIGm del PNPE determinó que el 59 \% de los mismos posee una relación significativa con, por lo menos, tres áreas científicas (Figura 85). Esto representa un alto valor científico de los sitios valorados, cada uno de los cuales, con contenidos y significados específicos, permitiendo una intervención multidisciplinar en el área de trabajo. En este criterio se destacan los complejos glaciares de Fuente Dé-Pido y del Jou Negro, la depresión de Belbín-La Llomba, el lago de Ándara y las morrenas de Áliva.

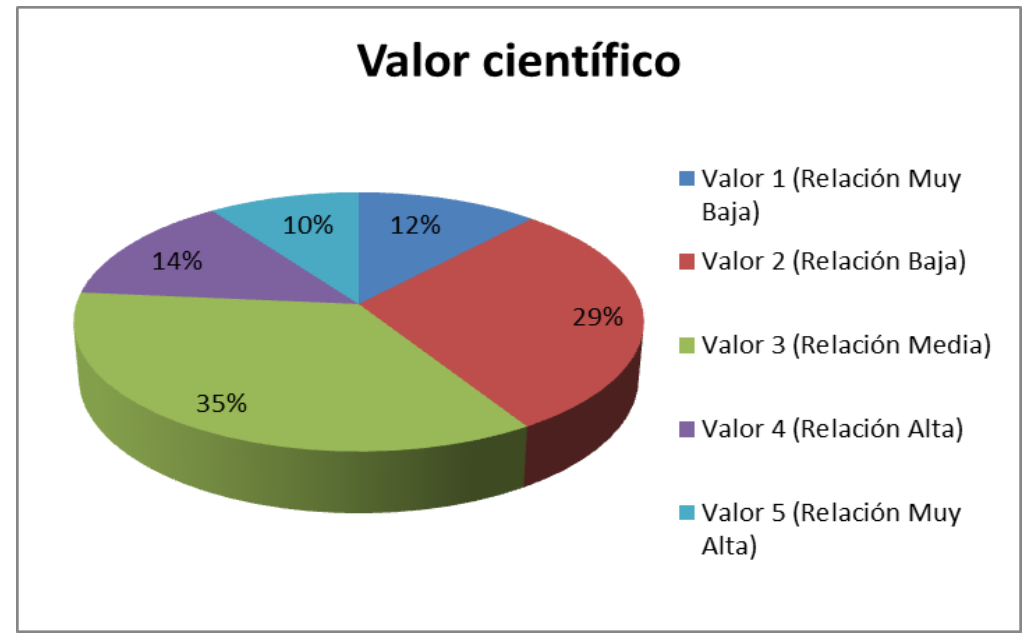

Figura 85. Distribución de LIGm según su valor en el criterio "Valor científico".

Fuente: elaboración propia. 
Representatividad científica: algunos de los sitios valorados presentan una importancia científica a escala nacional e internacional, en muchos casos con una singularidad y excepcionalidad que los individualiza más allá de las fronteras del parque, como por ejemplo poseer algunas de las cuevas más profundas del planeta o ser centro de atracción de montañistas. Otra vez el Naranjo de Bulnes, la Garganta del Cares y el Complejo glaciar Fuente Dé - Pido constituyen los máximos exponentes de los LIGm inventariados y valorados del PNPE. El 49 \% de los geositios tiene una representatividad científica a nivel regional o nacional (Figura 86) lo que permite llevar a cabo actividades turísticas y de investigación.

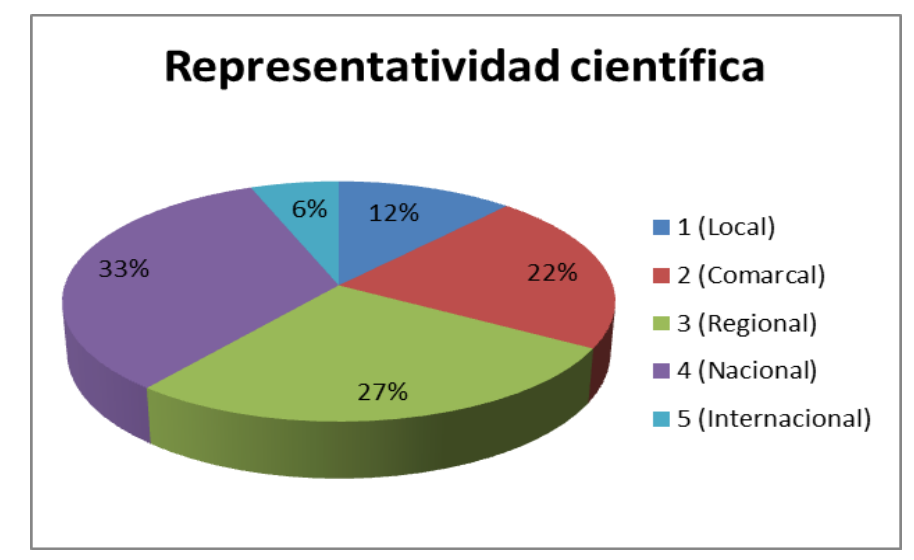

Figura 86. Distribución de LIGm según su valor en el criterio "Representatividad científica" Fuente: elaboración propia.

Contenidos turísticos reales: el $22 \%$ de los LIGm presenta una buena oferta turística relacionada con valores históricos, artísticos, excursionistas o de esparcimiento, al encontrarse en algunos de las tres valoraciones más elevados de la escala considerada. Nuevamente el Naranjo de Bulnes, la Garganta del Cares y el Complejo glaciar Fuente Dé - Pido aparecen como los geositios con mayor valoración (Figura 87).

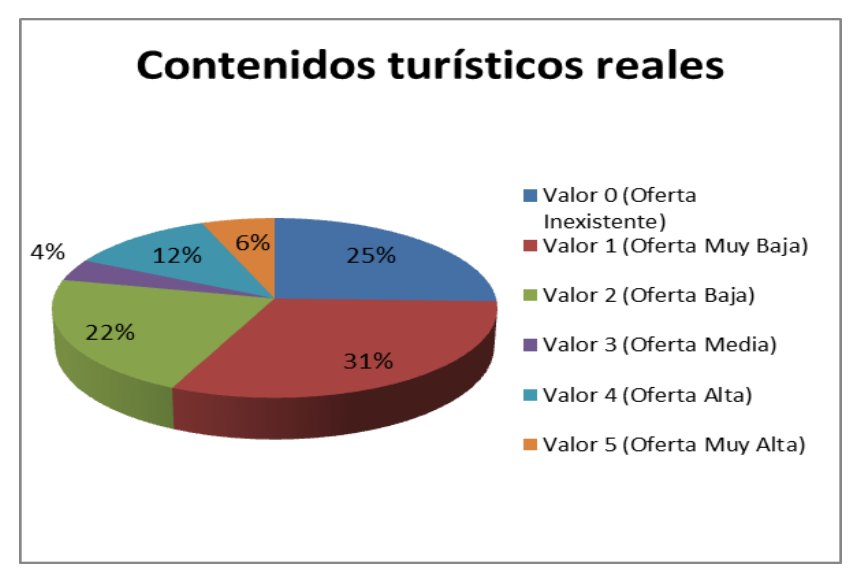

Figura 87. Distribución de LIGm según su valor en el criterio "Contenidos turísticos reales".

Fuente: elaboración propia. 
Atractivo turístico (potencial): este aspecto evalúa la capacidad de atracción turística a distintas escalas (local, comarcal, regional, nacional o internacional). El $20 \%$ de los LIGm posee un potencial turístico en los ámbitos nacional e internacional (Figura 88), destacándose el Monolito glaciokárstico del Naranjo de Bulnes, el Complejo glaciar Fuente Dé - Pido, los circos y morrenas de Áliva, el Desfiladero de los Beyos, el Lago y Vega de Enol, el Complejo morrénico de la Ercina, la Garganta de Urdón, el Complejo glaciar de Trasllambrión, la Garganta del Cares y la Canal de Asotín. Ello puede ser favorecido por el alto valor paisajístico con el que cuentan algunos sitios y por la aptitud para la práctica turística y recreativa de los sectores de los lagos.

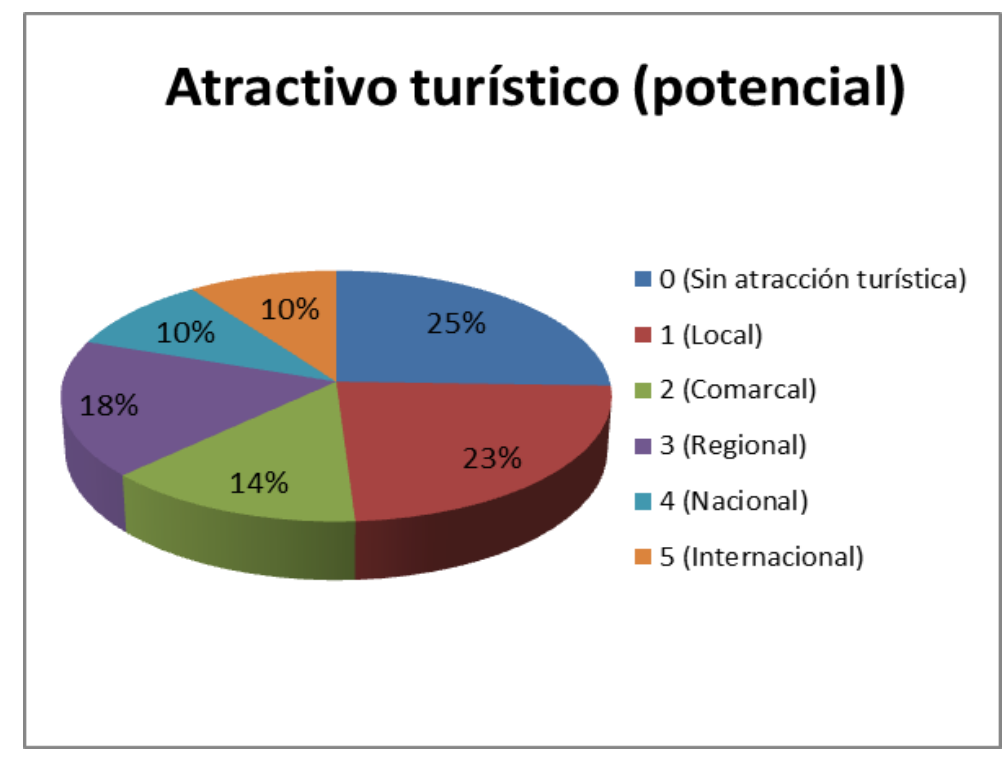

Figura 88. Distribución de LIGm según su valor en el aspecto "Atractivo turístico (potencial)".

Fuente: elaboración propia.

A través de la evaluación de los componentes territoriales y el potencial de uso se obtiene el valor de uso y gestión de los LIGm. En este aspecto, el 57 \% de los geositios del área de estudio muestran valores altos (Figura 89 y Tabla 66), pero es necesario acalarar que su orientación de uso no tiene que ser entendida sólo para el uso turístico, sino que el divulgativo y educativo pueden ser caminos relacionados y alternativos en algunos casos. Atendiendo a la geoconservación de los recursos y a la implementación de prácticas turísticas sostenibles, es necesario prestar atención a los impactos existentes, concentrados en torno a los destinos turísticos e itinerarios más frecuentados. La regulación del tráfico rodado y la intensidad de uso y frecuentación de algunos sectores por los visitantes debe ser atendida en la gestión del Parque Nacional, siempre a favor de la conservación y preservación de los valores naturales de los Picos de Europa. A continuación se analizará cada uno de los aspectos considerados en la valoración de uso y gestión (Tabla 67). 
La Interpretación del Patrimonio Geomorfológico en los Picos de Europa: una propuesta para su aprovechamiento didáctico y geoturístico

Tabla 66. Identificación de LIGm según su valor de uso y gestión.

\begin{tabular}{|l|c|c|l|}
\hline \multicolumn{4}{|c|}{ VALOR DE USO Y GESTIÓN } \\
\hline \multicolumn{1}{|c|}{ Valoración } & Cantidad de LIGm & $\%$ & \multicolumn{1}{c|}{ Identificación de LIGm } \\
\hline Alto (6-9) & 33 & 65 & $\begin{array}{l}2,3,4,5,6,9,10,11,12,14,15,17,19,24,25,26,29,30,31,32,33,34,37,38,41,42,43,44, \\
45,46,49 .\end{array}$ \\
\hline Medio (3-6) & 16 & 31 & $\begin{array}{l}1,7,8,16,18,20,21,22,35,36,39,40,47,48,50, \\
51 .\end{array}$ \\
\hline Bajo (0-3) & 2 & 4 & $13,23$. \\
\hline Total LIGm & 51 & 100 \\
\hline Fuente: elaboración propia.
\end{tabular}

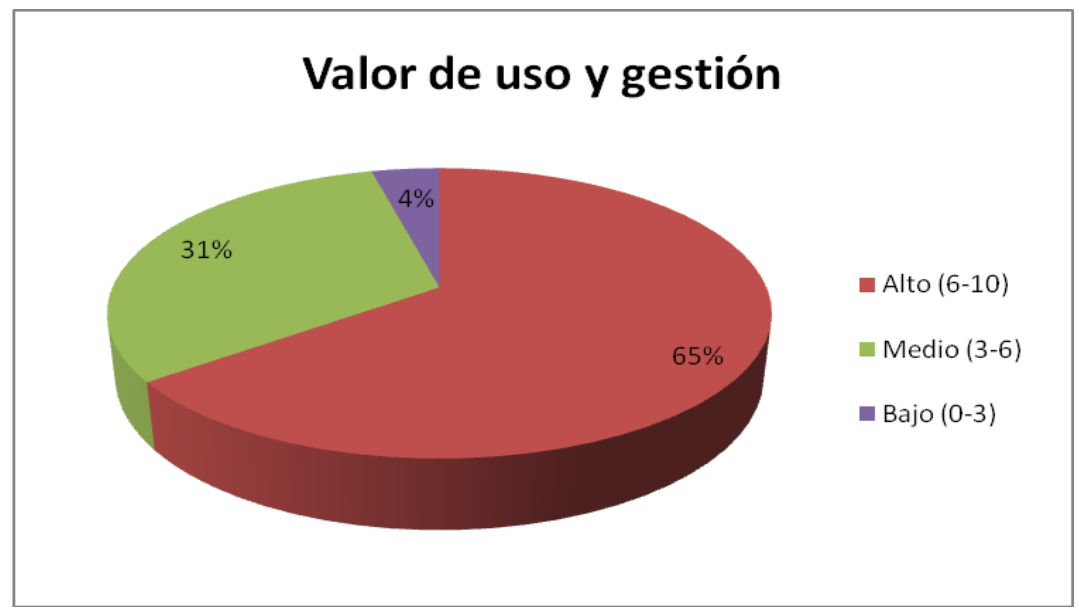

Figura 89. Distribución de LIGm según su valor de uso y gestión. Fuente: elaboración propia.

Tabla 67. Valoración de los aspectos del valor añadido según LIGm.

\begin{tabular}{|c|c|c|c|c|c|c|c|c|c|c|}
\hline LIGm & 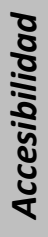 & 웅 & 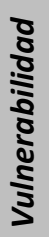 & 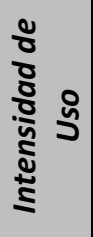 & 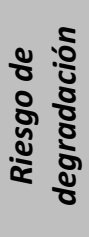 & 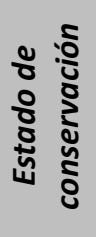 & 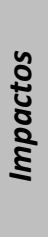 & 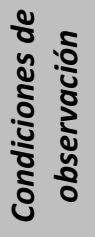 & 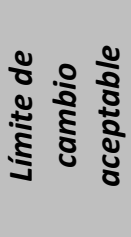 & $\begin{array}{c}\text { Total } \\
\text { Valor } \\
\text { uso y } \\
\text { gestión }\end{array}$ \\
\hline 1 & 0 & 1 & 2 & 1 & 0 & 1 & 1 & 2 & 0 & 4,4 \\
\hline 2 & 1 & 2 & 0 & 1 & 2 & 2 & 2 & 2 & 2 & 7,7 \\
\hline 3 & 0 & 2 & 2 & 2 & 2 & 2 & 2 & 1 & 2 & 8,3 \\
\hline 4 & 0 & 2 & 2 & 2 & 2 & 2 & 2 & 2 & 1 & 8,3 \\
\hline 5 & 2 & 2 & 1 & 0 & 2 & 2 & 1 & 1 & 1 & 6,5 \\
\hline 6 & 2 & 2 & 1 & 0 & 1 & 2 & 2 & 2 & 1 & 7 \\
\hline 7 & 2 & 1 & 1 & 1 & 0 & 1 & 1 & 2 & 1 & 5,5 \\
\hline 8 & 0 & 0 & 2 & 2 & 0 & 2 & 2 & 0 & 1 & 5 \\
\hline 9 & 0 & 0 & 2 & 2 & 0 & 2 & 2 & 2 & 1 & 6,1 \\
\hline 10 & 0 & 2 & 2 & 2 & 0 & 2 & 2 & 1 & 1 & 6,6 \\
\hline
\end{tabular}




\begin{tabular}{|c|c|c|c|c|c|c|c|c|c|c|}
\hline 11 & 1 & 2 & 2 & 2 & 1 & 2 & 2 & 1 & 2 & $\mathbf{7 , 3}$ \\
\hline 12 & 0 & 2 & 2 & 2 & 2 & 2 & 2 & 1 & 1 & $\mathbf{7 , 7}$ \\
\hline 13 & 2 & 1 & 0 & 0 & 0 & 1 & 0 & 1 & 0 & $\mathbf{2 , 8}$ \\
\hline 14 & 2 & 2 & 2 & 2 & 1 & 2 & 2 & 1 & 1 & $\mathbf{8 , 3}$ \\
\hline 15 & 2 & 2 & 2 & 1 & 1 & 2 & 2 & 2 & 1 & $\mathbf{8 , 3}$ \\
\hline 16 & 0 & 2 & 2 & 1 & 1 & 1 & 1 & 0 & 1 & $\mathbf{5}$ \\
\hline 17 & 0 & 2 & 2 & 2 & 2 & 2 & 2 & 2 & 2 & $\mathbf{8 , 8}$ \\
\hline 18 & 2 & 1 & 0 & 0 & 0 & 1 & 0 & 2 & 0 & $\mathbf{3 , 3}$ \\
\hline 19 & 2 & 1 & 1 & 2 & 2 & 2 & 1 & 2 & 1 & $\mathbf{7 , 7}$ \\
\hline 20 & 0 & 0 & 2 & 2 & 0 & 2 & 2 & 0 & 0 & $\mathbf{4 , 4}$ \\
\hline 21 & 0 & 1 & 2 & 2 & 0 & 2 & 2 & 0 & 0 & $\mathbf{5}$ \\
\hline 22 & 0 & 1 & 2 & 2 & 0 & 2 & 2 & 0 & 0 & $\mathbf{5}$ \\
\hline 23 & 0 & 2 & 2 & 2 & 2 & 2 & 2 & 2 & 2 & $\mathbf{2 , 8}$ \\
\hline 24 & 0 & 2 & 2 & 1 & 2 & 2 & 1 & 2 & 2 & $\mathbf{7 , 7}$ \\
\hline 25 & 1 & 2 & 2 & 2 & 2 & 2 & 1 & 2 & 2 & $\mathbf{8 , 8}$ \\
\hline 26 & 1 & 2 & 2 & 2 & 2 & 1 & 0 & 2 & 2 & $\mathbf{7 , 7}$ \\
\hline 27 & 2 & 2 & 1 & 1 & 1 & 1 & 1 & 2 & 1 & $\mathbf{7 , 2}$ \\
\hline 28 & 1 & 2 & 2 & 2 & 2 & 2 & 2 & 2 & 2 & $\mathbf{9 , 4}$ \\
\hline 29 & 1 & 2 & 2 & 2 & 2 & 2 & 2 & 1 & 2 & $\mathbf{8 , 8}$ \\
\hline 30 & 0 & 0 & 0 & 0 & 2 & 2 & 2 & 0 & 2 & $\mathbf{6 , 6}$ \\
\hline 31 & 2 & 2 & 2 & 1 & 2 & 2 & 2 & 2 & 0 & $\mathbf{8 , 3}$ \\
\hline 32 & 1 & 2 & 2 & 2 & 2 & 2 & 2 & 2 & 2 & $\mathbf{9 , 4}$ \\
\hline 33 & 1 & 2 & 2 & 2 & 2 & 2 & 2 & 2 & 2 & $\mathbf{9 , 4}$ \\
\hline 34 & 2 & 2 & 1 & 1 & 2 & 2 & 2 & 2 & 1 & $\mathbf{8 , 8}$ \\
\hline 35 & 0 & 1 & 2 & 2 & 0 & 2 & 2 & 0 & 0 & $\mathbf{5}$ \\
\hline 36 & 0 & 1 & 2 & 2 & 0 & 2 & 2 & 0 & 0 & $\mathbf{5}$ \\
\hline 37 & 0 & 2 & 2 & 2 & 2 & 2 & 2 & 2 & 2 & $\mathbf{8 , 8}$ \\
\hline 38 & 0 & 2 & 2 & 1 & 2 & 2 & 1 & 2 & 2 & $\mathbf{7 , 7}$ \\
\hline 39 & 2 & 1 & 1 & 0 & 1 & 1 & 1 & 2 & 1 & $\mathbf{5 , 5}$ \\
\hline 40 & 2 & 1 & 0 & 0 & 0 & 1 & 1 & 2 & 0 & $\mathbf{3 , 8}$ \\
\hline 41 & 0 & 2 & 2 & 1 & 2 & 2 & 2 & 0 & 2 & $\mathbf{7 , 2}$ \\
\hline 42 & 0 & 2 & 2 & 1 & 2 & 2 & 2 & 0 & 2 & $\mathbf{7 , 2}$ \\
\hline 43 & 0 & 2 & 2 & 2 & 2 & 2 & 2 & 0 & 2 & $\mathbf{7 , 7}$ \\
\hline 44 & 0 & 2 & 2 & 2 & 2 & 2 & 2 & 1 & 2 & $\mathbf{8}$ \\
\hline 45 & 1 & 2 & 2 & 1 & 1 & 2 & 1 & 2 & 2 & $\mathbf{7 , 7}$ \\
\hline 46 & 2 & 1 & 1 & 2 & 2 & 2 & 1 & 2 & 1 & $\mathbf{7 , 7}$ \\
\hline 47 & 0 & 0 & 0 & 2 & 0 & 2 & 2 & 0 & 0 & $\mathbf{3 , 3}$ \\
\hline 48 & 0 & 0 & 0 & 2 & 0 & 2 & 2 & 0 & 0 & $\mathbf{3 , 3}$ \\
\hline 49 & 2 & 2 & 2 & 2 & 2 & 2 & 2 & 1 & 2 & $\mathbf{9 , 4}$ \\
\hline 50 & 1 & 0 & 0 & 2 & 0 & 2 & 2 & 2 & 1 & $\mathbf{5}$ \\
\hline 51 & 0 & 0 & 0 & 2 & 2 & 2 & 2 & 0 & 0 & $\mathbf{4 , 4}$ \\
\hline Fuente: elaboración propia. & & & & & & & \\
\hline
\end{tabular}


Accesibilidad: sobre este criterio es necesario considerar las dificultades de tipo natural como pendientes fuertes, intransitabilidad debido a la vegetación densa o a la presencia de lodos o terrenos encharcados, como también la existencia de carreteras, caminos, equipamientos y servicios recreativos, señalización, transportes, etc. Este criterio determina el número de visitantes que accederán a los LIGm. En el caso del PNPE, el 51 \% de los LIGm valorados posee una mala accesibilidad, algunas veces por tratarse de sistemas de cavernas, $u$ otras por estar localizados en la parte superior de los macizos (Figura 90). Esta causa puede haber favorecido su conservación; en estos LIGm debe primar un trabajo de conservación y preservación, de forma que la estrategia de potenciación del recurso debe ser más sutil y sensible.

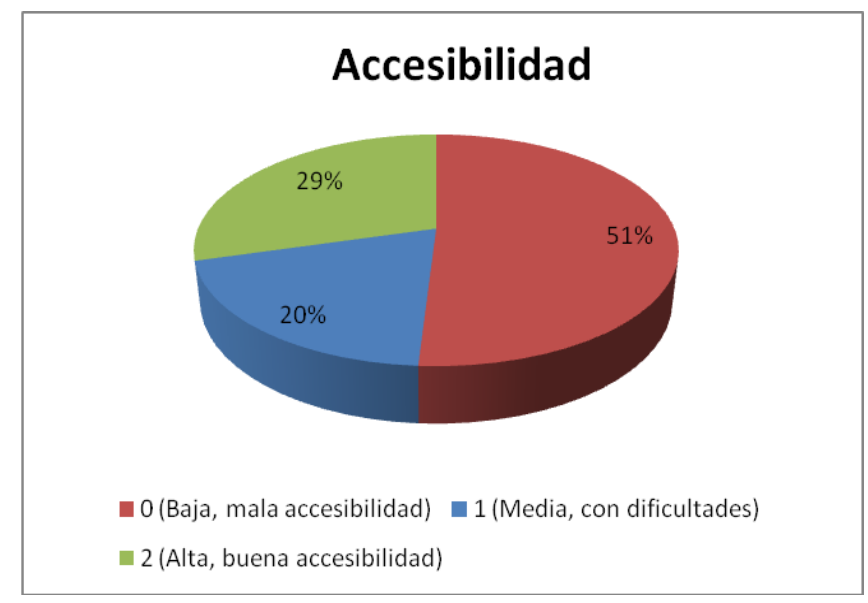

Figura 90. Distribución de LIGm según su valor en el aspecto "Accesibilidad".

Fuente: elaboración propia.

Fragilidad: la valoración de la fragilidad es importante para conocer las oportunidades para el uso público de los LIGm. De esta forma, se establece una relación inversamente proporcional entre fragilidad y desarrollo de actividades recreativas y divulgativas: a mayor fragilidad menos posibilidades de utilizar los recursos. En la zona de estudio, el $61 \%$ de los geositios presentan buenas condiciones intrínsecas para el uso actual o potencial que se realice de ellos (Figura 91). Sin embargo, debido a sus características, no es recomendable la utilización como recurso turístico de masas en el 16 \% de los LIGm, ya que el mismo supondría una pérdida irreversible de los valores geomorfológicos, como por ejemplo en el Complejo glaciar de Trasllambrión o los Gueyos de Junjumia. 


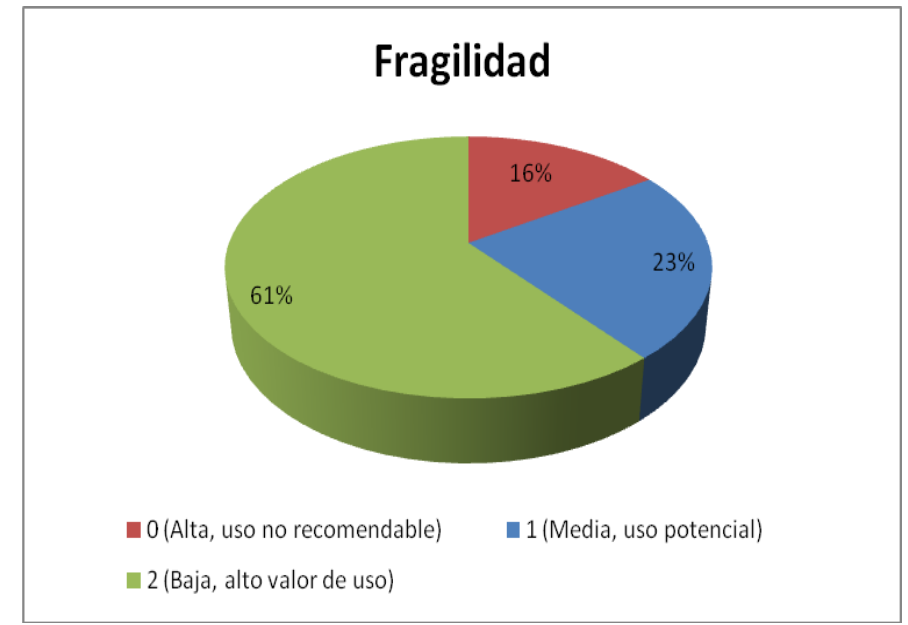

Figura 91. Distribución de LIGm según su valor en el aspecto "Fragilidad".

Fuente: elaboración propia.

Vulnerabilidad: el criterio de fragilidad se encuentra muy ligado al de vulnerabilidad, la que se puede definir como falta de capacidad para soportar determinados impactos causados por agentes ajenos a su propia dinámica natural, especialmente de origen humano. Dos terceras partes (67\%) de los LIGm no presentan riesgos de transformación en su estructura o dinámica (Figura 92), lo que permite una utilización racional de los mismos sin deterioro de sus cualidades intrínsecas, como ocurre en las Canales de Asotín y Dobresengos.

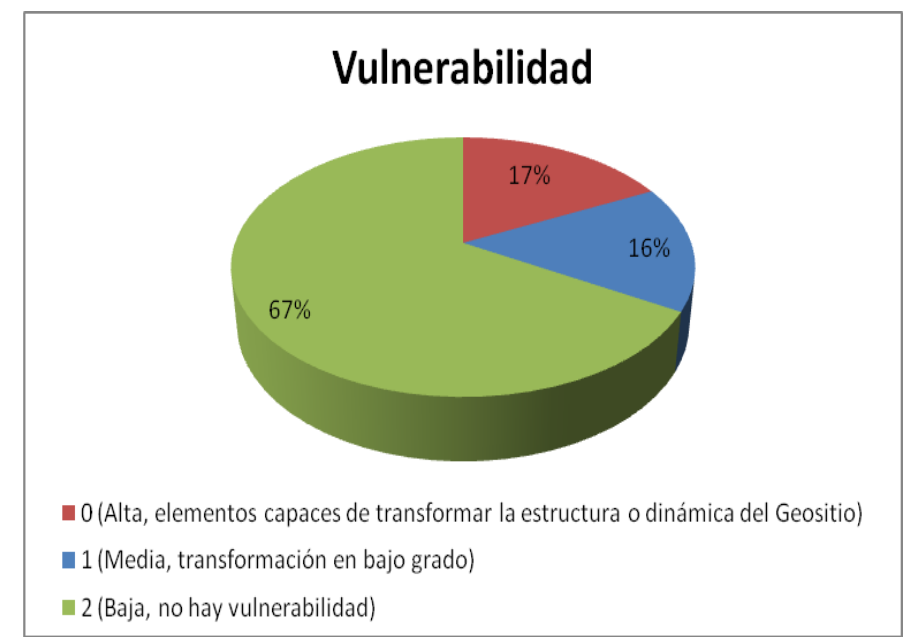

Figura 92. Distribución de LIGm según su valor en el criterio "Vulnerabilidad".

Fuente: elaboración propia.

Intensidad de uso: otro criterio fundamental de la valoración del uso y gestión de los LIGm es su intensidad de uso, ya que determina el nivel óptimo de utilización del recurso bajo 
condiciones de impacto mínimo. Está relacionada con la disponibilidad del recurso en el tiempo y en el espacio, las oportunidades para la visita, la frecuentación y la estacionalidad de las mismas, etc. Considerando el uso actual de los geomorfositios valorados, el $61 \%$ de ellos permite un aumento en el uso y frecuentación (Figura 93), como en los casos de la Vega del Polje de Liordes o en las Peñas de Brez.

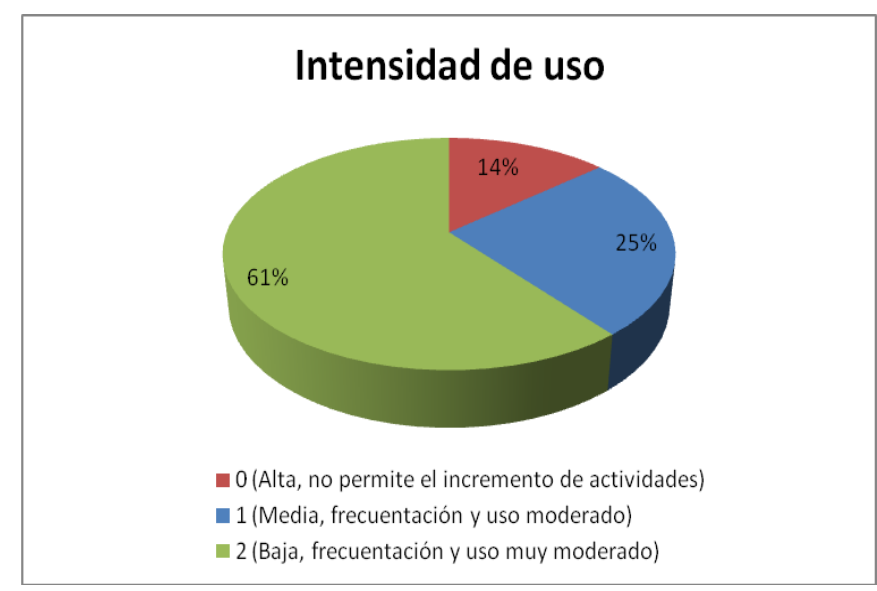

Figura 93. Distribución de LIGm según su valor en el criterio "Intensidad de uso".

Fuente: elaboración propia.

Riesgo de degradación: criterio relacionado con la fragilidad y la vulnerabilidad de los geomorfositios. Resulta un indicador de la resistencia que los LIGm van a presentar frente a los posibles impactos que puedan derivarse de la presencia de los visitantes. El 53 \% de los LIGm valorados permiten un uso moderado sin posibilidad de pérdida de sus valores intrínsecos o añadidos (Figura 94). Ejemplos de ello son el complejo glaciar Fuente Dé-Pido, las Gonfolitas del Duje o la Depresión del Sobra.

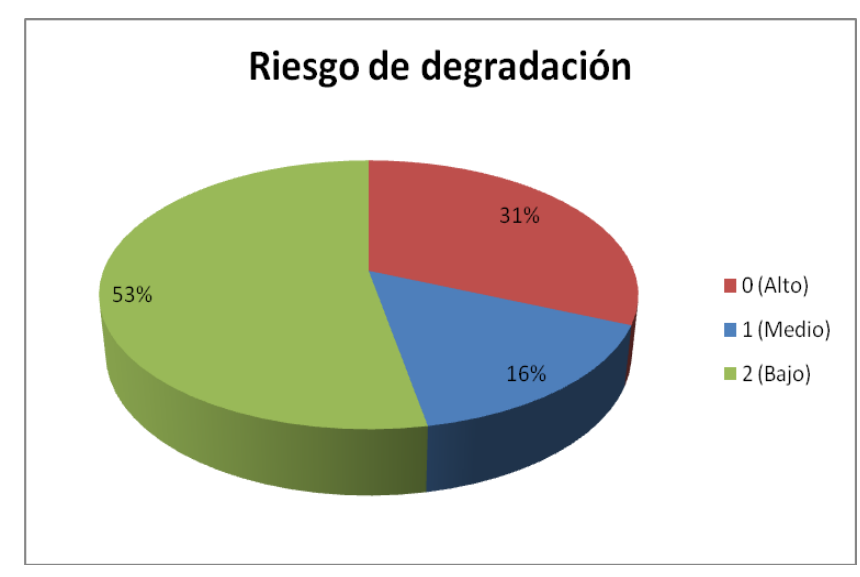

Figura 94. Distribución de LIGm según su valor en el aspecto "Riesgo de degradación".

Fuente: elaboración propia. 
Estado de conservación: otro aspecto a considerar para el uso y gestión de los LIGm lo constituye su estado de conservación. Elementos destruidos o degradados de forma irreversible son difíciles de utilizar para la divulgación o el turismo. A este respecto hay que añadir que los recursos colindantes al LIGm deberán presentar un buen estado de conservación, pues constituyen el fondo escénico del mismo. El $82 \%$ de los LIGm presentan un grado de conservación alto para poder ser utilizado en tales actividades (Figura 95).

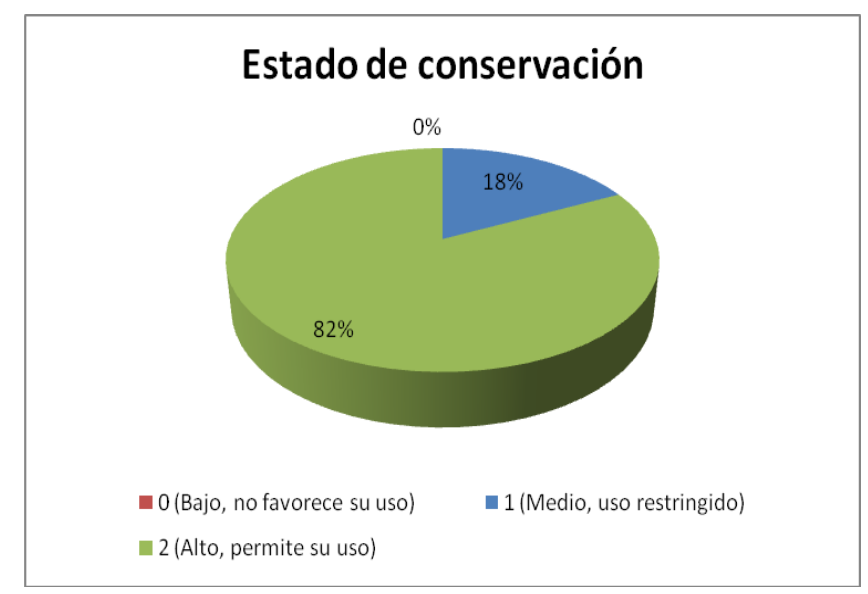

Figura 95. Distribución de LIGm según su valor en el criterio "Estado de conservación".

Fuente: elaboración propia.

Impactos: aquellos sitios que presenten un alto valor en los impactos pueden controlar su utilización, limitando el número de visitantes o la duración de la estancia en el mismo y fomentando el uso de otras áreas. En el PNPE el $69 \%$ de sus geositios no presentan impactos intensos, aunque en tres de los 51 LIGm valorados se desaconseja su uso (la Garganta del Cares, el lago de Ándara y los taludes y conos de derrubios de La Vueltona) debido a la acción antrópica que los afecta de manera directa (Figura 96).

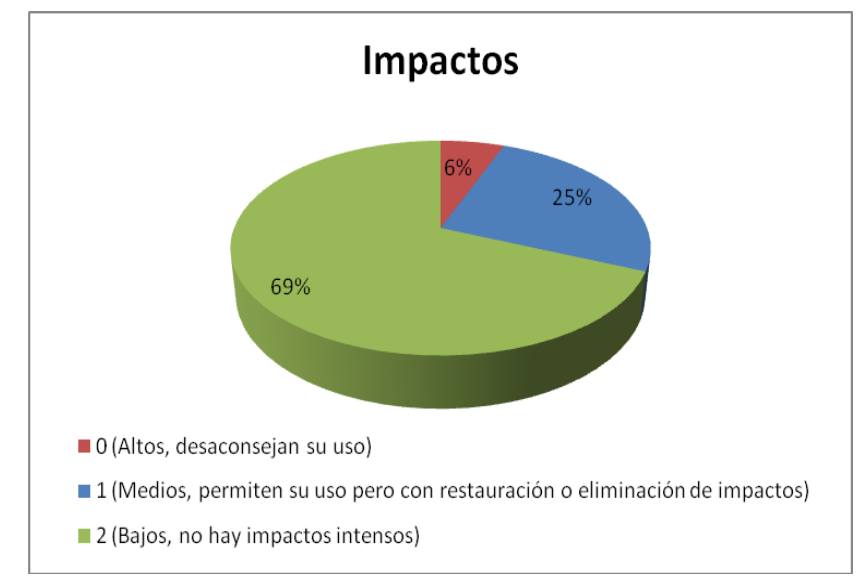

Figura 96. Distribución de LIGm según su valor en el criterio "Impactos".

Fuente: elaboración propia. 
Condiciones de observación: este criterio es elaborado por la interacción de variables (paisaje, acceso al sitio, localización, contaminación visual, estacionalidad, etc.). A partir de los resultados de este análisis es factible dilucidar la aptitud e idoneidad que tienen los recursos como atractivos para el público o para acoger determinadas actividades. El clima es determinante en algunas actividades de aire libre ya que condicionará el periodo de disfrute del recurso. También lo son las condiciones de acceso a los mismos al limitar su utilización (por ejemplo, las Torcas del Cerro o la S56 y el sistema endokárstico del Trave). El 53 \% de los LIGm valorados presentan altas condiciones de observación (Figura 97).

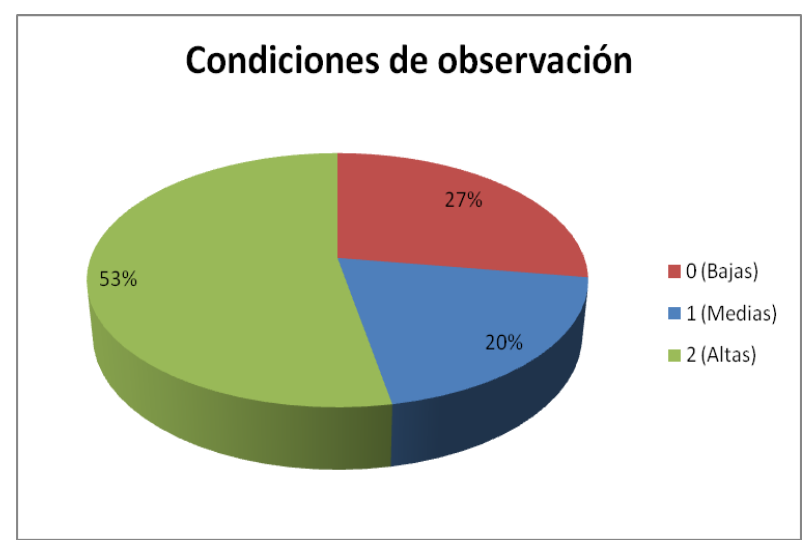

Figura 97. Distribución de LIGm según su valor en el criterio "Condiciones de observación". Fuente: elaboración propia.

Límites de cambio aceptables: un 59 \% de los geomorfositios del PNPE permiten cambios (algunos sólo moderados) en su dinámica o estructura, ya que no implicarían una pérdida en sus valores intrínsecos o culturales (Figura 98). En el extremo opuesto, el helero de la Forcadona o la cueva helada de Peña Castil son ejemplos de LIGm que perderían sus valores científicos o añadidos de producirse cambios en los mismos.

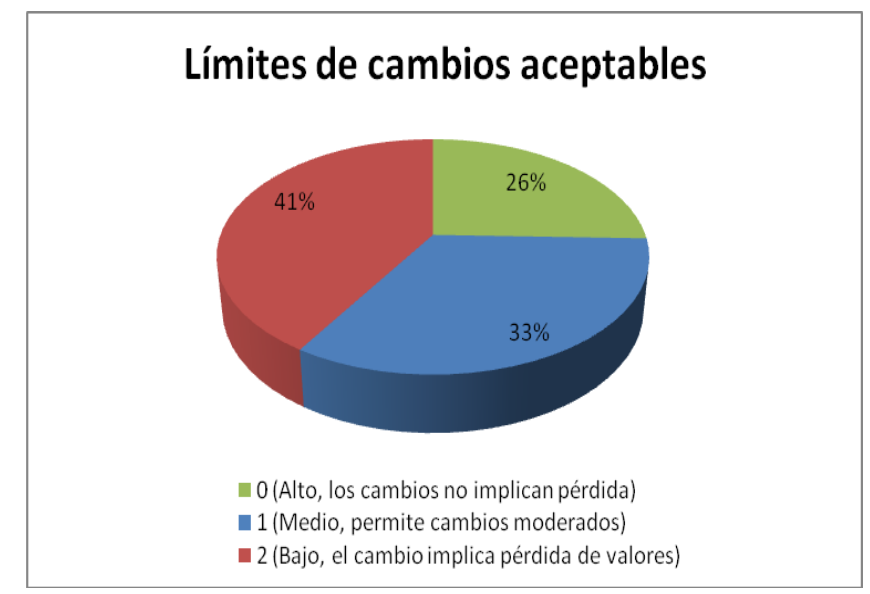

Figura 98. Distribución de LIGm según su valor en el criterio "Límites de cambios aceptables".

Fuente: elaboración propia. 
Para finalizar este análisis de las valoraciones obtenidas por los LIGm del PNPE, si tenemos en cuenta la interrelación entre los tres parámetros de valoración (Tabla 68), es posible observar que sólo dos geositios presentan una puntuación alta en cada una de las categorías contempladas. Estos son el Complejo Glaciar Fuente Dé-Pido y la Artesa y lago de Ándara. Para el primero de los casos sería conveniente regular su intensidad de uso actual (por ejemplo controlar el número de visitantes diarios), a fin de no modificar las características patrimoniales que lo caracterizan. El segundo representa un ejemplo de impactos antrópicos sobre el medio: la actividad minera fue la causante de filtraciones en el lecho del lago, lo que produjo su desaparición en el siglo XX. Su accesibilidad media ha permitido que no se agudicen los mismos. En el extremo opuesto de las valoraciones el frente cabalgante de Ándara (LIGm 23) presenta bajas puntuaciones en los tres aspectos considerados.

Tabla 68. Identificación de LIGm según interrelación de valoraciones.

\begin{tabular}{|c|c|c|c|}
\hline $\begin{array}{c}\text { Tipo de } \\
\text { Valoración }\end{array}$ & $\begin{array}{c}\text { Cantidad de } \\
\text { valores }\end{array}$ & $\begin{array}{l}\text { Cantidad } \\
\text { de LIGm }\end{array}$ & Identificación de LIGm \\
\hline \multirow{3}{*}{ Alta } & 3 & 2 & $\begin{array}{l}5 \text { (Complejo Glaciar Fuente Dé-Pido) y } 26 \text { (Artesa } \\
\text { y lago de Ándara) }\end{array}$ \\
\hline & $\begin{array}{l}2 \text { (Intrínseco y } \\
\text { Uso y Gestión) }\end{array}$ & 3 & $\begin{array}{l}6 \text { (Circos y morrenas de Áliva), } 9 \text { (Complejo } \\
\text { Glaciar de Trasllambrión) y } 30 \text { (Canchorral de } \\
\text { Hormas) }\end{array}$ \\
\hline & $\begin{array}{l}2 \text { (Añadido y } \\
\text { Uso y Gestión) }\end{array}$ & 2 & $\begin{array}{l}24 \text { (Garganta de Urdón) y } 38 \text { (Desfiladero de } \\
\text { Beyos) }\end{array}$ \\
\hline \multirow{3}{*}{ Media } & 3 & 3 & $\begin{array}{l}8 \text { (Complejo Glaciar de Jou Negro), } 39 \text { (Lago y } \\
\text { Vega de Enol) y } 40 \text { (Complejo morrénico de la } \\
\text { Ercina) }\end{array}$ \\
\hline & $\begin{array}{l}2 \text { (Intrínseco y } \\
\text { Añadido) }\end{array}$ & 1 & 1 (Monolito glaciokárstico del Naranjo de Bulnes) \\
\hline & $\begin{array}{l}2 \text { (Intrínseco y } \\
\text { Uso y Gestión) }\end{array}$ & 2 & $\begin{array}{l}15 \text { (Canal de Asotín) y } 45 \text { (Depresión de Belbín-La } \\
\text { Llomba). }\end{array}$ \\
\hline \multirow[b]{2}{*}{ Baja } & 3 & 1 & 23 (Frente cabalgante de Ándara) \\
\hline & $\begin{array}{l}2 \text { (Intrínseco y } \\
\text { Añadido) }\end{array}$ & 6 & $\begin{array}{l}25 \text { (Nunatak de Macondiú), } 35 \text { (Torca S56), } 36 \\
\text { (Cueva del Nacimiento), } 37 \text { (Frente cabalgante } \\
\text { de Pembuches), } 44 \text { (Cemba Vieya) y } 49 \\
\text { (Desprendimiento de La Veguina-Llucia). }\end{array}$ \\
\hline
\end{tabular}

Los LIGm 6 (Circos y morrenas de Áliva), 9 (Complejo Glaciar de Trasllambrión), 24 (Garganta de Urdón), 30 (Canchorral de Hormas) y 38 (Desfiladero de Beyos) presentan buen estado de conservación y un alto potencial de uso y gestión junto a un alto valor intrínseco o añadido, según el caso. En este sentido la actuación futura en estos sitios requeriría la 
elaboración de un estudio previo de sostenibilidad en relación a la actividad y el tipo e intensidad del uso que se les quisiera otorgar.

La accesibilidad de algunos sitios ha resultado determinante en la baja en la valoración global de los mismos, como es el caso del Naranjo de Bulnes que registra valores intrínsecos y añadidos medios, pero la dificultad relativa de acceso reduce la mayoría de sus visitantes a un público de montañeros. De igual manera, la facilidad para llegar a los LIGm 39 (Lago y Vega de Enol) y 40 (Complejo morrénico de la Ercina) permite la presencia de una mayor variedad de tipos de visitantes (turismo de masas, educativo), debiendo ser cuidadosamente gestionados para evitar una pérdida en los valores patrimoniales de tales sitios. En ese caso, las medidas a adoptar deberían estar enfocadas sobre ese criterio en particular, a fin de mitigar los efectos sobre los componentes estructurales y/o funcionales que tengan relación con él. De igual manera, se debe hacer una evaluación global del LIGm, la que deberá ser el producto de un análisis integrado y una reflexión sobre los pros y contras de los resultados alcanzados. En ello radica la importancia de la triple valoración del método utilizado para este trabajo. 
La Interpretación del Patrimonio Geomorfológico en los Picos de Europa: una propuesta para su aprovechamiento didáctico y geoturístico 


\section{Capítulo 7}

\section{Aprovechamiento didáctico de LIGm seleccionados}

Como síntesis de los capítulos anteriores, en este apartado se elaborará una propuesta interpretativa para los LIGm del Parque Nacional de los Picos de Europa seleccionados según su aprovechamiento didáctico y turístico. Teniendo en cuenta los momentos de la planificación interpretativa se desarrollaron los siguientes pasos:

- Diagnóstico de la situación

- Recopilación de información y trabajo de campo

- Análisis de los datos obtenidos

- Síntesis de las alternativas posibles

- Elaboración del tema interpretativo, tópicos y mensajes

Primeramente, para identificar los LIGm de la zona de estudio, se trabajó con la metodología propuesta por Serrano y González Trueba (2005) la cual permite una evaluación triple del Patrimonio Geomorfológico, considerando su valor científico, valor cultural y su valor de uso y gestión. Como se observó en el Capítulo 6, se identificaron 51 LIGm en el Parque Nacional de los Picos de Europa. A continuación, se realizará la selección de los geositios para su uso didáctico y turístico.

\section{1) Selección de LIGm para su aprovechamiento didáctico y turístico}

Del total de LIGm inventariados y valorados, se seleccionaron aquellos que poseyeran valoraciones positivas relacionadas con la accesibilidad, la fragilidad, el potencial turístico y constituyeran sitios aptos para el desarrollo de contenidos curriculares relacionados con la geomorfología. Teniendo en cuenta el recurso patrimonial y los tipos objetivos de visitantes al mismo (estudiantes y turistas), existen dos aspectos considerados que presentan una condición indispensable para la realización de cualquier actividad turística o educativa. Ellos son la accesibilidad y la fragilidad, ya que, por un lado, no todos los LIGm valorados poseen una óptima o buena posibilidad de acceso para grupos de estudiantes o turistas, mientras que por 
otro, no es conveniente atraer la atención de personas en algunos sitios que presenten una elevada posibilidad de cambio o pérdida de sus valores patrimoniales.

Las Figuras 99, 100 y 101 sintetizan el proceso de selección de los LIGm del Parque Nacional de los Picos de Europa para su aprovechamiento didáctico y turístico.

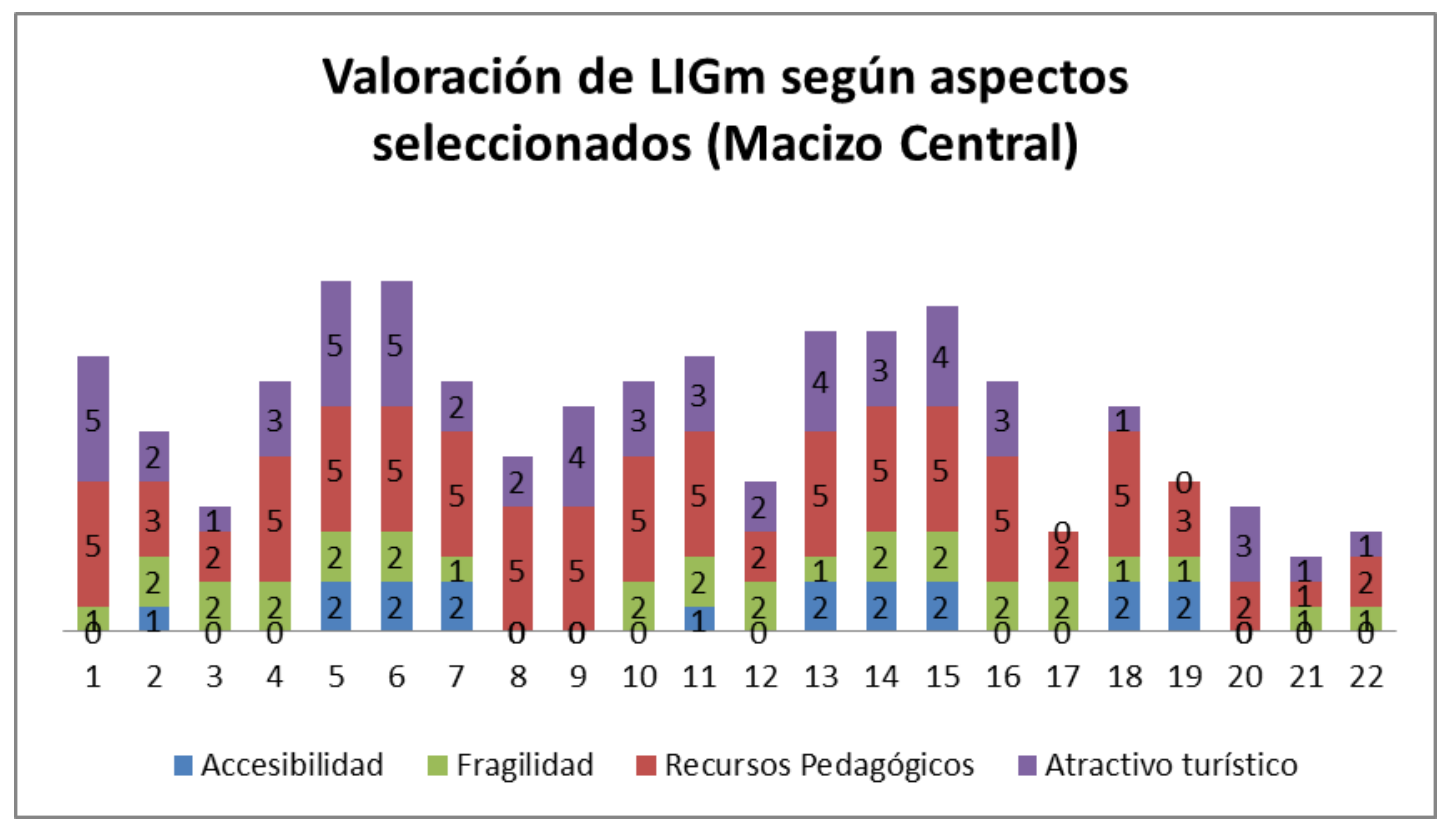

Figura 99. Valoración de LIGm según aspectos seleccionados (Macizo Central).

Fuente: elaboración propia.

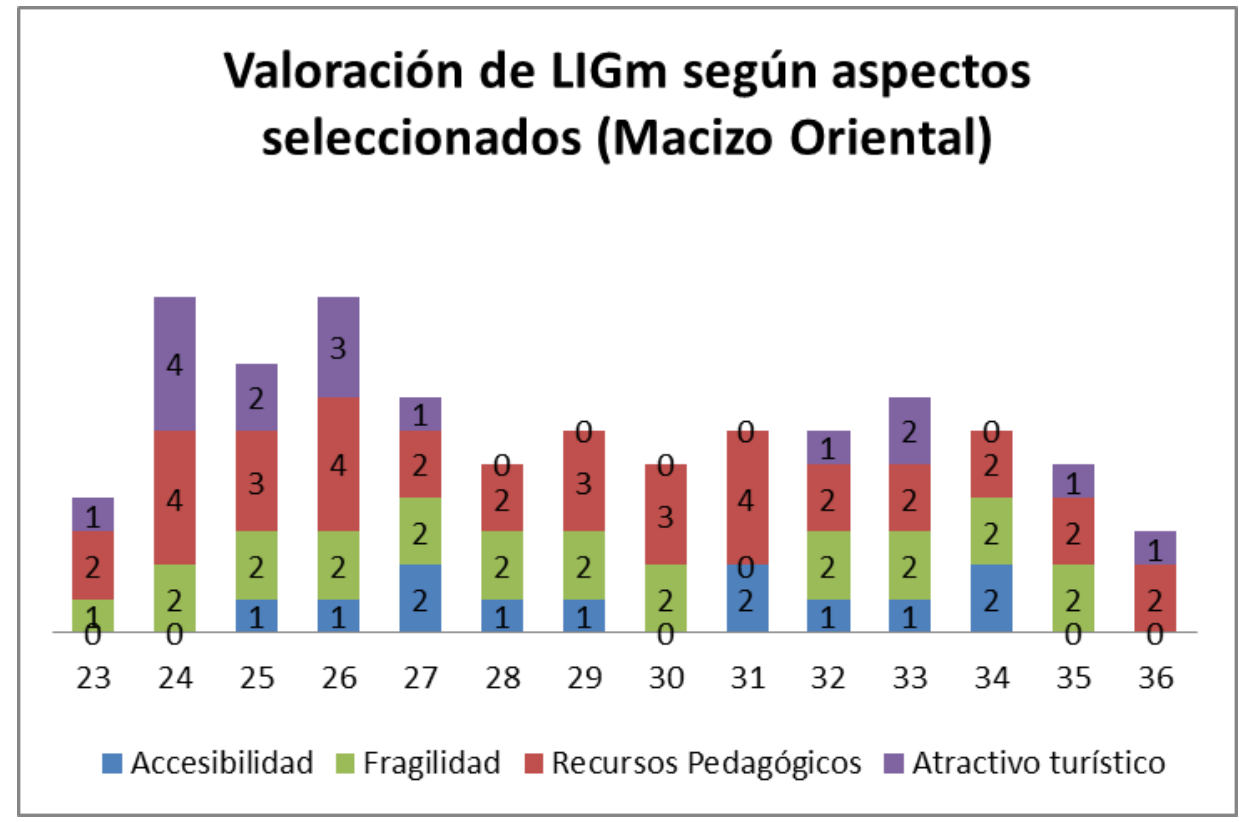

Figura 100. Valoración de LIGm según aspectos seleccionados (Macizo Oriental). Fuente: elaboración propia. 


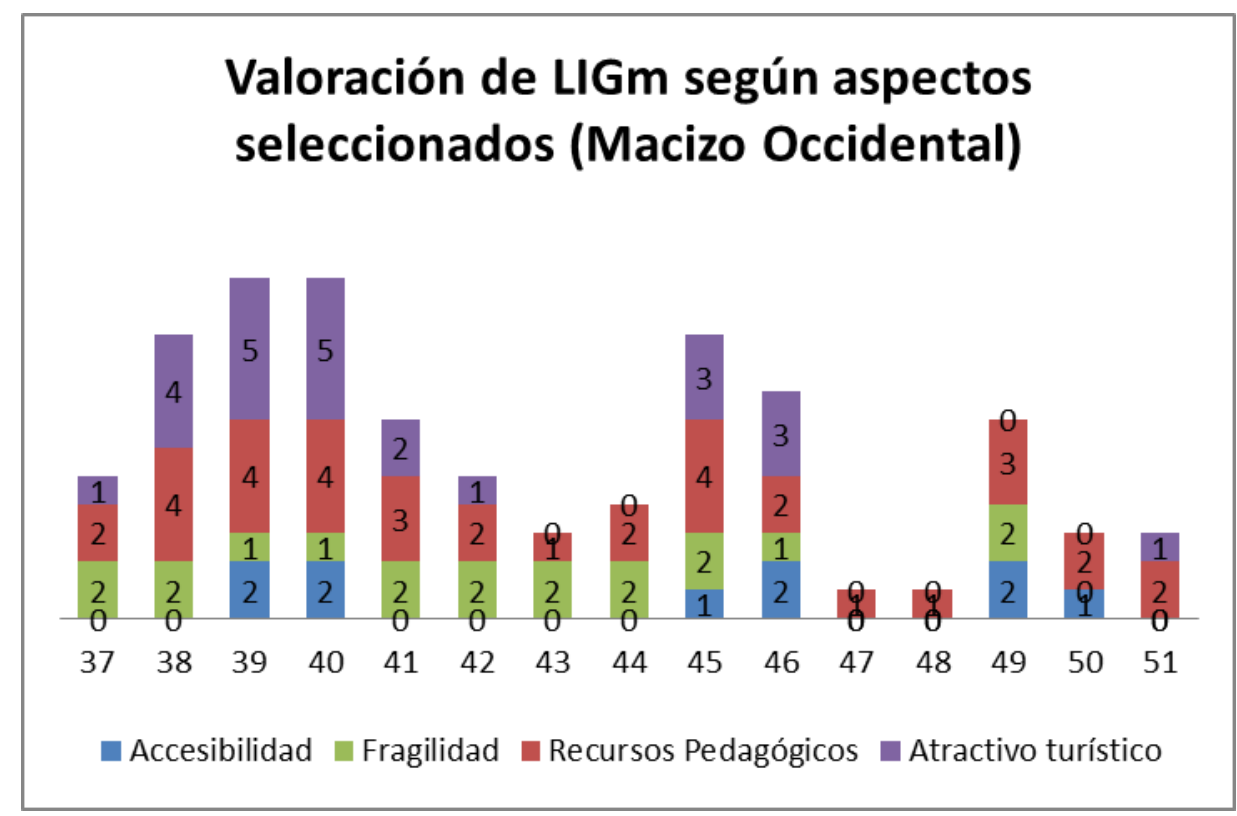

Figura 101. Valoración de LIGm según aspectos seleccionados (Macizo Occidental). Fuente: elaboración propia.

Como en los ejemplos de los Complejos glaciares de Jou Negro y de Trasllambrión, la Garganta de Urdón o el Desfiladero de los Beyos, existen LIGm que poseen una alta valoración como recurso pedagógico o atractivo turístico, pero las dificultades en su acceso o su fragilidad restringen su uso para tales fines. Por este motivo, estos dos criterios se transforman en excluyentes para la selección de los geositios para el uso didáctico y turístico. Por lo tanto y de acuerdo al análisis de la valoración de los LIGm según su accesibilidad, fragilidad, atractivo turístico y calidad como recurso pedagógico se seleccionan 18 geositios para su aprovechamiento didáctico y turístico con principios interpretativos ${ }^{25}$ :

a) Macizo Central o de los Urrielles

05) Complejo glaciar de Fuente Dé-Pido.

06) Circos y morrenas de Áliva

07) Complejo morrénico con glaciar rocoso de Lloroza

13) Garganta fluviokárstica del Cares.

14) Canal de Dobresengos

15) Canal de Asotín

18) Conos y taludes de derrubios de la Vueltona

19) Gonfolitas del Duje

\section{b) Macizo Oriental o de Ándara}

\footnotetext{
${ }^{25}$ No se utilizó la matriz de evaluación del potencial interpretativo (capítulo 2), ya que muchos de los criterios considerados en esa matriz están presentes en la metodología de Serrano y González Trueba (2005).
} 
26) Artesa y lago de Ándara

27) Complejo morrénico de Escarandi

31) Peñas de Brez

33) Canal de las Arredondas

34) Depresión del Sobra

\section{c) Macizo Occidental o del Cornión}

39) Lago y Vega de Enol

40) Complejo morrénico de La Ercina

45) Depresión de Belbín-La Llomba

46) Polje de Comeya

49) Desprendimiento de La Veguina-Llucia

\section{2) Identificación de elementos y atributos tangibles en los LIGm seleccionados}

Como se observó en el Capítulo 2, la Interpretación es un enfoque de la comunicación que es definida por el estilo del lenguaje que se utilice y las técnicas que se apliquen para PROVOCAR EL PENSAMIENTO de las personas y alcanzar los objetivos propuestos. A continuación, se dará respuesta a los interrogantes “¿Qué queremos explicar?” y “¿Qué queremos que la gente sepa?", reconociendo los principales contenidos curriculares relacionados con la geomorfología que pueden desarrollarse en dichos LIGm. De esta forma se identificarán los elementos y atributos tangibles de cada uno de los 18 LIGm seleccionados para la elaboración de la propuesta interpretativa (Tablas 69 a 86 y Figuras 102 a 108).

\subsection{1) Macizo Central (o de los Urrielles)}

Tabla 69. Identificación de elementos tangibles (LIGm 5).

\begin{tabular}{|l|l|}
\hline No y nombre de LIGm & 05) Complejo glaciar de Fuente Dé-Pido. \\
\hline ¿Qué quiero explicar? & Modelado glaciar. \\
\hline $\begin{array}{l}\text { ¿Qué quiero que la } \\
\text { gente sepa? }\end{array}$ & $\begin{array}{l}\text { La gran muralla, de aproximadamente } 750 \text { m de altura, sirvió de tobogán a } \\
\text { los hielos cuaternarios que se acumularon en su base creando una depresión. } \\
\text { Los aludes generaron abanicos de derrubios al pie de la muralla de Fuente-Dé. }\end{array}$ \\
\hline $\begin{array}{l}\text { ¿Qué conceptos } \\
\text { geomorfológicos } \\
\text { puedo explicar? }\end{array}$ & Modelado glaciar en artesas y complejo morrénico frontal. \\
\hline Fuente: elaboración propia.
\end{tabular}




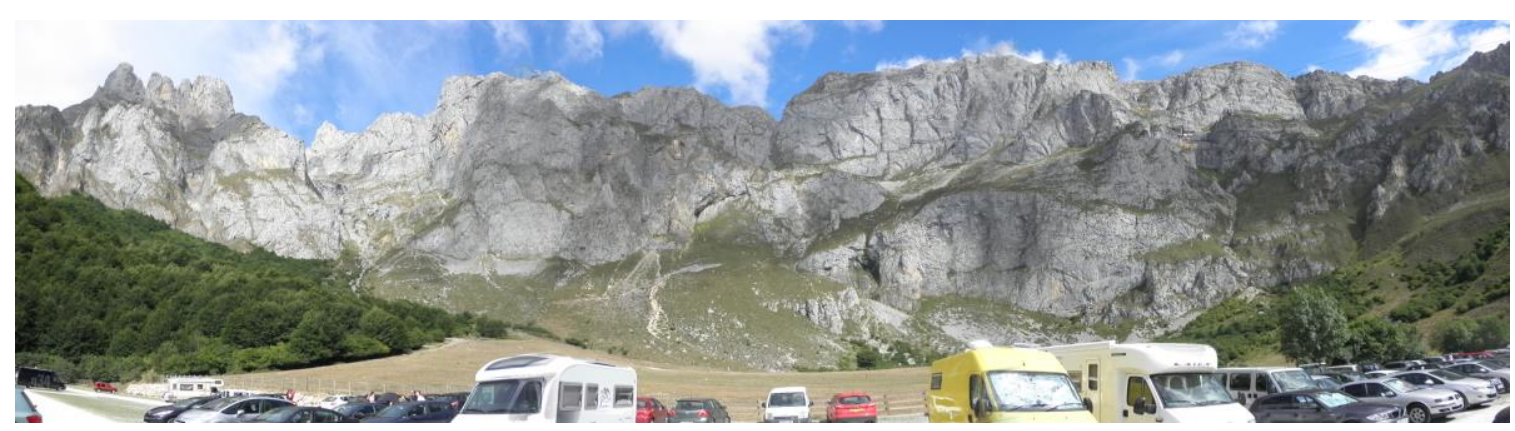

Figura 102. Vista Panorámica del Complejo glaciar de Fuente Dé-Pido.

Fuente: Héctor Bazán.

Tabla 70. Identificación de elementos tangibles (LIGm 6).

\begin{tabular}{|l|l|}
\hline No y nombre de LIGm & 06) Circos y morrenas de Áliva \\
\hline ¿Qué quiero explicar? & Modelado glaciar. \\
\hline $\begin{array}{l}\text { ¿Qué quiero que la } \\
\text { gente sepa? }\end{array}$ & $\begin{array}{l}\text { Es un complejo compuesto de una morrena lateral, con dos complejos de } \\
\text { obturación y un complejo morrénico frontal de } 15 \text { arcos menores con rellanos } \\
\text { lacustres } \\
\text { La Llomba del Toro es la morrena lateral derecha del glaciar del Duje. } \\
\text { Las morrenas de la Llomba y Las Salgardas formaron barreras entre las que } \\
\text { quedó un espacio cerrado. } \\
\text { La Llomba del Toro es la morrena de mayor extensión del PNPE. }\end{array}$ \\
\hline $\begin{array}{l}\text { ¿Qué conceptos } \\
\text { geomorfológicos } \\
\text { puedo explicar? }\end{array}$ & Procesos de erosión y acumulación glaciar. \\
\hline Fuente: elaboración propia.
\end{tabular}

Tabla 71. Identificación de elementos tangibles (LIGm 7).

\begin{tabular}{|l|l|}
\hline № y nombre de LIGm & 07) Complejo morrénico con glaciar rocoso de Lloroza \\
\hline ¿Qué quiero explicar? & Formas de modelado glaciar y periglaciar \\
\hline & $\begin{array}{l}\text { En la gran hondonada de Hoyos de Lloroza tres masas de hielo unían sus } \\
\text { fuerzas para transformar el paisaje rocoso y precipitarse por los escarpes de } \\
\text { Fuente-Dé. } \\
\text { Con la retirada de los glaciares, la disolución kárstica excavó lapiaces. } \\
\text { Una parte del material rocoso que transportaba el glaciar quedó depositado } \\
\text { en la zona formando montículos de derrubios que le proporcionan un aspecto } \\
\text { ondulado. } \\
\text { Los materiales depositados por los glaciares en Lloroza permiten que el agua } \\
\text { líquida permanezca en superficie hasta su evaporación. } \\
\text { ga acción de la gravedad y la crioclastia continuaron la erosión generando } \\
\text { canchales y avalanchas de bloques. }\end{array}$ \\
\hline $\begin{array}{l}\text { ¿Qué conceptos } \\
\text { geomorfológicos } \\
\text { puedo explicar? }\end{array}$ & Morfología glaciar y periglaciar con procesos kársticos asociados. \\
\hline Fuente: elaboración propia. & \\
\hline
\end{tabular}


Tabla 72. Identificación de elementos tangibles (LIGm 13).

\begin{tabular}{|l|l|}
\hline No y nombre de LIGm & 13) Garganta fluviokárstica del Cares. \\
\hline ¿Qué quiero explicar? & $\begin{array}{l}\text { Morfología fluvial y kárstica de torrente de montaña, en combinación con } \\
\text { procesos kársticos y de dinámica de laderas. }\end{array}$ \\
\hline $\begin{array}{l}\text { ¿Qué quiero que la } \\
\text { gente sepa? }\end{array}$ & $\begin{array}{l}\text { El trazado del río Cares responde a un desnivel tectónico originado durante } \\
\text { los movimientos alpinos, excavando su cauce al progresivo levantamiento del } \\
\text { relieve y la erosión kárstica. }\end{array}$ \\
\hline $\begin{array}{l}\text { ¿Qué conceptos } \\
\text { geomorfológicos } \\
\text { puedo explicar? }\end{array}$ & Procesos kársticos y modelado de laderas. \\
\hline Fuente: elaboración propia.
\end{tabular}

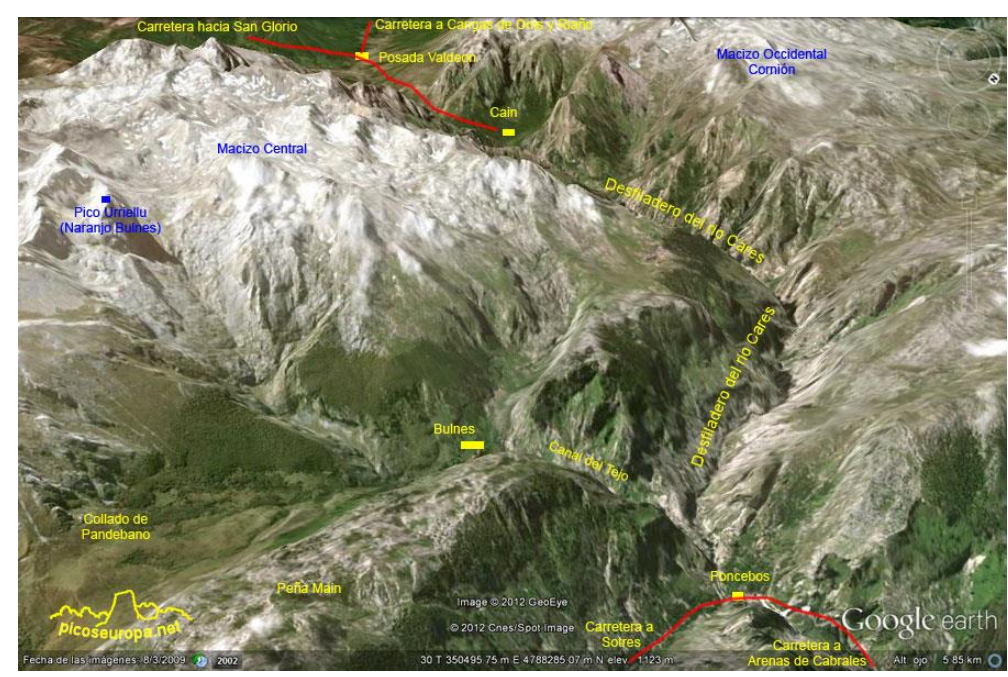

Figura 103. Ubicación del Desfiladero o Garganta del Cares. Fuente: $h t t p: / / w w w . p i c o s e u r o p a . n e t / c a r e s /$

Tabla 73. Identificación de elementos tangibles (LIGm 14).

\begin{tabular}{|l|l|}
\hline No y nombre de LIGm & 14) Canal de Dobresengos \\
\hline ¿Qué quiero explicar? & $\begin{array}{l}\text { Las canales son elementos morfológicos derivados de la combinación de } \\
\text { procesos fluvioglaciares, guiados por las morfoestructuras y la fracturación } \\
\text { local. } \\
\text { Son empinados y estrechos valles laterales que constituyen accesos naturales a } \\
\text { las partes altas de los macizos. La mayoría de ellas tiene una forma rectilínea, } \\
\text { pues se han labrado aprovechando discontinuidades geológicas como fallas o } \\
\text { frentes de cabalgamiento. }\end{array}$ \\
\hline $\begin{array}{l}\text { ¿Qué quiero que la } \\
\text { gente sepa? }\end{array}$ & $\begin{array}{l}\text { Esta canal alcanzó su rasgo actual durante el máximo glaciar del Pleistoceno, } \\
\text { por ensanchamiento del relieve fluviokárstico previo. Luego, los procesos } \\
\text { periglaciares y gravitacionales retocaron este tipo de formas. }\end{array}$ \\
\hline $\begin{array}{l}\text { ¿Qué conceptos } \\
\text { geomorfológicos } \\
\text { puedo explicar? }\end{array}$ & \begin{tabular}{l} 
Modelado mixto (fluvioglaciar) y relieve estructural. \\
\hline Fuente: elaboración propia.
\end{tabular} \\
\hline
\end{tabular}




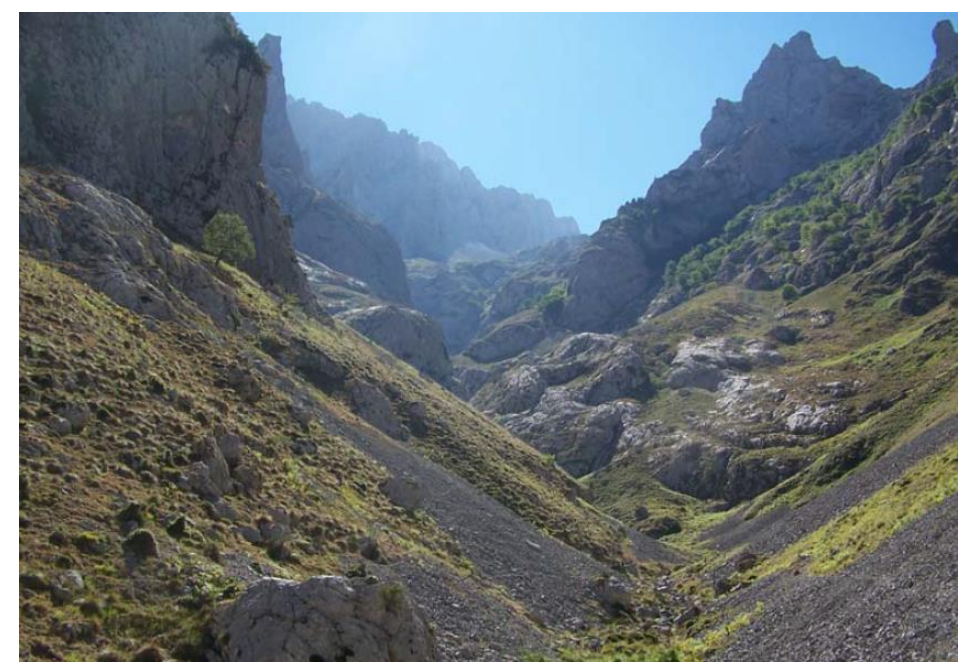

Figura 104. Vista general del tramo medio e inferior de la canal de Dobresengos.

Fuente: González Trueba, 2006.

Tabla 74. Identificación de elementos tangibles (LIGm 15).

\begin{tabular}{|l|l|}
\hline No y nombre de LIGm & 15) Canal de Asotín \\
\hline ¿Qué quiero explicar? & $\begin{array}{l}\text { Las canales son elementos morfológicos de génesis compuesta y son } \\
\text { características del PNPE. }\end{array}$ \\
\hline $\begin{array}{l}\text { ¿Qué quiero que la } \\
\text { gente sepa? }\end{array}$ & $\begin{array}{l}\text { Es una canal de más de } 1000 \text { metros de desarrollo, retocada por el } \\
\text { glaciarismo cuaternario. } \\
\text { Hay un proceso de laderas muy activo en una zona con fuertes pendientes. } \\
\text { Procesos de ladera periglaciar afectan la parte alta de la canal y fluvial en su } \\
\text { parte baja. }\end{array}$ \\
\hline $\begin{array}{l}\text { ¿Qué conceptos } \\
\text { geomorfológicos } \\
\text { puedo explicar? }\end{array}$ & Modelado mixto (glacio-fluvio-kárstico). Procesos de ladera activos. \\
\hline \multicolumn{2}{|l|}{ Fuente: elaboración propia. } \\
\hline
\end{tabular}

Tabla 75. Identificación de elementos tangibles (LIGm 18).

\begin{tabular}{|l|l|}
\hline No y nombre de LIGm & 18) Conos y taludes de derrubios de la Vueltona \\
\hline ¿Qué quiero explicar? & Conos y taludes de derrubios de génesis mixta. \\
\hline $\begin{array}{l}\text { ¿Qué quiero que la } \\
\text { gente sepa? }\end{array}$ & $\begin{array}{l}\text { En este LIGm se produce la combinación de procesos de caída, de crioclastia } \\
\text { (procesos periglaciares) y de redistribución nival. }\end{array}$ \\
\hline $\begin{array}{l}\text { ¿Qué conceptos } \\
\text { geomorfológicos } \\
\text { puedo explicar? }\end{array}$ & Modelado nivoperiglaciar, procesos de ladera. \\
\hline \multicolumn{2}{|l|}{ Fuente: elaboración propia. } \\
\hline
\end{tabular}




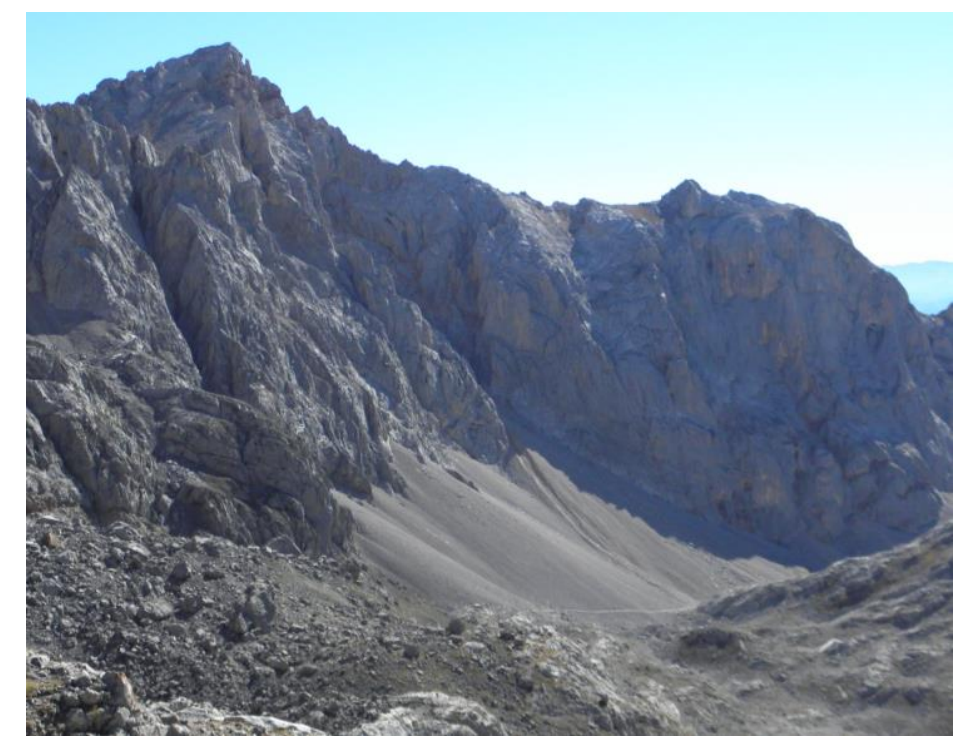

Figura 105. Conos y taludes de la Vueltona (parte central de la imagen).

Foto: Héctor Bazán.

Tabla 76. Identificación de elementos tangibles (LIGm 19).

\begin{tabular}{|l|l|}
\hline № y nombre de LIGm & 19) Gonfolitas del Duje \\
\hline ¿Qué quiero explicar? & $\begin{array}{l}\text { Formas y depósitos como testigos periglaciares, anteriores a la máxima } \\
\text { glaciación. }\end{array}$ \\
\hline $\begin{array}{l}\text { ¿Qué quiero que la } \\
\text { gente sepa? }\end{array}$ & $\begin{array}{l}\text { El derrubio que aflora está formado por un derrubio ordenado de clastos. } \\
\text { Las gonfolitas son derrubios de ladera periglaciares cementados por } \\
\text { carbonatos. }\end{array}$ \\
\hline $\begin{array}{l}\text { ¿Qué conceptos } \\
\text { geomorfológicos } \\
\text { puedo explicar? }\end{array}$ & Modelado periglaciar y de laderas. \\
\hline \multicolumn{2}{|l|}{ Fuente: elaboración propia. } \\
\hline
\end{tabular}


Tabla 77. Identificación de elementos tangibles (LIGm 26).

\begin{tabular}{|l|l|}
\hline No y nombre de LIGm & 26) Artesa y lago de Ándara \\
\hline \multirow{4}{*}{ ¿Qué quiero explicar? } & $\begin{array}{l}\text { Este sitio es un valle glaciokárstico en artesa (U) con depresiones cerradas y } \\
\text { fondo de tendencia plana en la zona del antiguo lago. } \\
\text { En las laderas hay desprendimientos de rocas y morfología kárstica (dolinas y } \\
\text { lapiaces). }\end{array}$ \\
\hline $\begin{array}{l}\text { Las arcillas de descalcificación posibilitaron la obturación de conductos y el } \\
\text { origen del lago de Ándara. } \\
\text { El pulido de las calizas prueba el pasado glaciar de este valle. } \\
\text { ¿n la mayoría de las escamas cabalgantes de Picos de Europa aparecen } \\
\text { gente sepa? }\end{array}$ & $\begin{array}{l}\text { calizas rojas del Carbonífero Inferior. El afloramiento de esta formación suele } \\
\text { revelar la existencia de un cabalgamiento. } \\
\text { La excavación glaciar de la pared de roca que hay sobre el cabalgamiento ha } \\
\text { formado un marcado escarpe. } \\
\text { Entre los depósitos gravitacionales destaca la avalancha de rocas de El } \\
\text { Redondal. } \\
\text { En el fondo del valle de El Redondal afloran pizarras de color oscuro, las que } \\
\text { impermeabilizan el fondo de la cubeta que ocupó el lago de Ándara. }\end{array}$ \\
\hline $\begin{array}{l}\text { ¿Qué conceptos } \\
\text { geomorfológicos } \\
\text { puedo explicar? }\end{array}$ & \begin{tabular}{l} 
Dinámica de laderas. Modelado glaciar y kárstico. \\
\hline Fuente: elaboración propia.
\end{tabular} \\
\hline
\end{tabular}

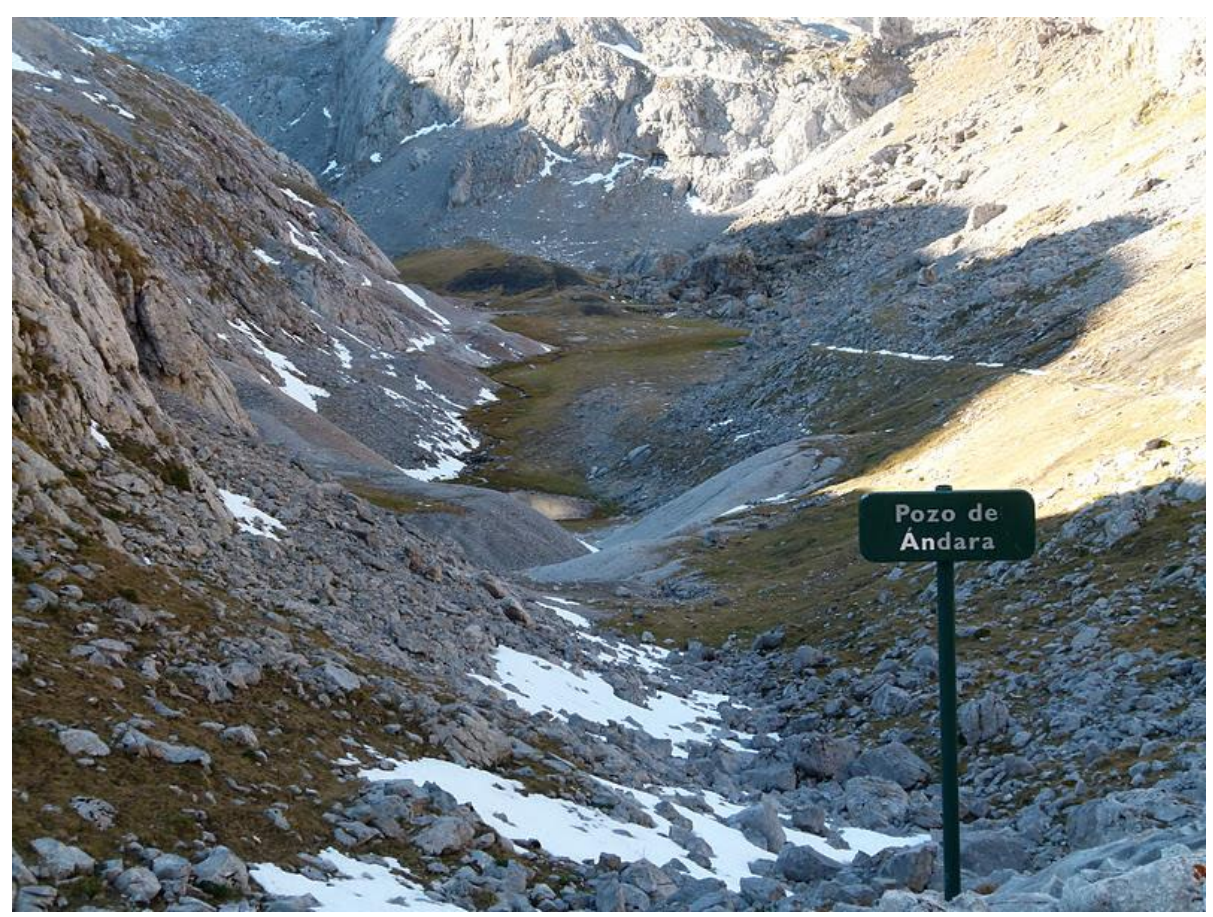

Figura 106. Pozo o Lago de Ándara.

Fuente: http://nieveycumbrescantabricas.blogspot.com.es/2011/11/pozo-de-andaramacizo-oriental.html 
Tabla 78. Identificación de elementos tangibles (LIGm 27).

\begin{tabular}{|l|l|}
\hline No y nombre de LIGm & 27) Complejo morrénico de Escarandi \\
\hline ¿Qué quiero explicar? & Modelado glaciar y till. \\
\hline $\begin{array}{l}\text { ¿Qué quiero que la } \\
\text { gente sepa? }\end{array}$ & $\begin{array}{l}\text { La pista que baja hacia Bejes discurre por lo alto de una loma que } \\
\text { corresponde a una antigua morrena glaciar. En los cortes aflora el till. }\end{array}$ \\
\hline $\begin{array}{l}\text { ¿Qué conceptos } \\
\text { geomorfológicos } \\
\text { puedo explicar? }\end{array}$ & Modelado glaciar. Sedimentos glaciares. \\
\hline \multicolumn{2}{|l|}{ Fuente: elaboración propia. } \\
\hline
\end{tabular}

Tabla 79. Identificación de elementos tangibles (LIGm 31).

\begin{tabular}{|l|l|}
\hline No y nombre de LIGm & 31) Peñas de Brez \\
\hline ¿Qué quiero explicar? & Que este LIGm constituye un ejemplo de activo deslizamiento de laderas. \\
\hline & $\begin{array}{l}\text { Teniendo en cuenta la posición del frente del deslizamiento y la situación } \\
\text { actual del escarpe de los Picos de Europa, se ha estimado un desplazamiento } \\
\text { de más de } 2 \mathrm{~km} .\end{array}$ \\
$\begin{array}{l}\text { ¿Q deslizamiento de Brez se encuentra en proceso de desmantelamiento, lo } \\
\text { gente sepa? }\end{array}$ & $\begin{array}{l}\text { que provoca que haya abundantes caídas de rocas y desprendimientos en su } \\
\text { frente. } \\
\text { Entre los bloques desprendidos destacan dos de gran tamaño situados en el } \\
\text { mismo pueblo de Brez. }\end{array}$ \\
\hline $\begin{array}{l}\text { ¿Qué conceptos } \\
\text { geomorfológicos } \\
\text { puedo explicar? }\end{array}$ & Modelado y dinámica de laderas. \\
\hline \multicolumn{2}{|l|}{ Fuente: elaboración propia. } \\
\hline
\end{tabular}

Tabla 80. Identificación de elementos tangibles (LIGm 33).

\begin{tabular}{|l|l|}
\hline No y nombre de LIGm & 33) Canal de las Arredondas \\
\hline \multirow{4}{*}{ ¿Qué quiero explicar? } & $\begin{array}{l}\text { Las canales son elementos morfológicos derivados de la combinación de } \\
\text { procesos glacio-fluvio-kársticos, guiados por las morfoestructuras y la } \\
\text { fracturación local. } \\
\text { Son empinados y estrechos valles laterales de ríos que constituyen accesos } \\
\text { naturales a las partes altas de los macizos. La mayoría de ellas tiene una } \\
\text { forma rectilinea, pues se han labrado aprovechando discontinuidades } \\
\text { geológicas como fallas o frentes de cabalgamiento. }\end{array}$ \\
\hline $\begin{array}{l}\text { ¿Qué quiero que la } \\
\text { gente sepa? }\end{array}$ & $\begin{array}{l}\text { Como en otras canales, la de las Arredondas alcanzó su rasgo actual durante } \\
\text { fluviokárstico previo. Luego, los procesos periglaciares y gravitacionales la } \\
\text { retocaron. }\end{array}$ \\
\hline $\begin{array}{l}\text { ¿Qué conceptos } \\
\text { geomorfológicos } \\
\text { puedo explicar? }\end{array}$ & Modelado mixto (glacio-fluvio-kárstico) y relieve estructural. \\
\hline Fuente: elaboración propia.
\end{tabular}


Tabla 81. Identificación de elementos tangibles (LIGm 34).

\begin{tabular}{|l|l|}
\hline No y nombre de LIGm & 34) Depresión del Sobra \\
\hline ¿Qué quiero explicar? & $\begin{array}{l}\text { Este LIGm es un polje capturado intramontañoso donde afloran areniscas y } \\
\text { pizarras. }\end{array}$ \\
\hline $\begin{array}{l}\text { ¿Qué quiero que la } \\
\text { gente sepa? }\end{array}$ & $\begin{array}{l}\text { Este sitio tiene una génesis kárstica, a favor de la disolución de las calizas de } \\
\text { montaña y la presencia de pizarras. } \\
\text { Posee una dinámica kárstica y torrencial, con intromisiones de derrubios de } \\
\text { laderas y solifluxión. }\end{array}$ \\
\hline $\begin{array}{l}\text { ¿Qué conceptos } \\
\text { geomorfológicos } \\
\text { puedo explicar? }\end{array}$ & Modelado kárstico y estructural. \\
\hline \multicolumn{2}{|l|}{ Fuente: elaboración propia. } \\
\hline
\end{tabular}

\subsection{3) Macizo Occidental (o del Cornión)}

Tabla 82. Identificación de elementos tangibles (LIGm 39).

\begin{tabular}{|l|l|}
\hline № y nombre de LIGm & 39) Lago y Vega de Enol \\
\hline \multirow{2}{*}{ ¿ué quiero explicar? } & $\begin{array}{l}\text { La erosión glaciar sobre la caliza generó una artesa y una cubeta siendo } \\
\text { afectadas luego por sedimentación glaciar y procesos kársticos. Génesis del } \\
\text { lago. }\end{array}$ \\
\hline $\begin{array}{l}\text { ¿l lago de Enol ocupa una depresión excavada por el hielo en un sustrato } \\
\text { formado por pizarras. La retirada del glaciar formó el lago quedando la } \\
\text { gente sepa? }\end{array}$ & $\begin{array}{l}\text { El valle sobre el que se asientan los lagos tiene forma de U debido a la erosión } \\
\text { glaciar. } \\
\text { Las depresiones subcirculares que abundan en la Vega de Enol son pequeñas } \\
\text { dolinas, formas ligadas a la disolución del sustrato calcáreo. }\end{array}$ \\
\hline $\begin{array}{l}\text { ¿Qué conceptos } \\
\text { geomorfológicos } \\
\text { puedo explicar? }\end{array}$ & Modelado glaciokárstico. \\
\hline \multicolumn{2}{|l|}{ Fuente: elaboración propia. } \\
\hline
\end{tabular}

Tabla 83. Identificación de elementos tangibles (LIGm 40).

\begin{tabular}{|l|l|}
\hline No y nombre de LIGm & 40) Complejo morrénico de La Ercina \\
\hline ¿Qué quiero explicar? & $\begin{array}{l}\text { Este LIGm es un complejo morrénico frontal con un lago de obturación y } \\
\text { presencia de procesos kársticos. }\end{array}$ \\
\hline $\begin{array}{l}\text { ¿Qué quiero que la de la Ercina se asienta sobre un complejo morrénico frontal. } \\
\text { gosee el mismo origen que el lago de Enol. Ambos fueron lenguas glaciares } \\
\text { separadas por una morrena central. } \\
\text { La desaparición de la lengua glaciar provocó la desestabilización del escarpe } \\
\text { rocoso tallado por el hielo, provocando avalanchas de rocas (como el canchal } \\
\text { de la ladera este del Porru Mosquital). }\end{array}$ \\
\hline $\begin{array}{l}\text { ¿Qué conceptos } \\
\text { geomorfológicos } \\
\text { puedo explicar? }\end{array}$ & Modelado glaciokárstico. \\
\hline \multicolumn{2}{|l|}{ Fuente: elaboración propia. } \\
\hline
\end{tabular}


Tabla 84. Identificación de elementos tangibles (LIGm 45).

\begin{tabular}{|l|l|}
\hline No y nombre de LIGm & 45) Depresión de Belbín-La Llomba \\
\hline ¿Qué quiero explicar? & $\begin{array}{l}\text { Este LIGm es una depresión kárstica obstruida por una morrena lateral del } \\
\text { antiguo glaciar de Casaño. }\end{array}$ \\
\hline $\begin{array}{l}\text { ¿Qué quiero que la } \\
\text { gente sepa? }\end{array}$ & $\begin{array}{l}\text { Es una depresión cerrada con fondo plano relleno de arcillas de } \\
\text { Lescalificación. } \\
\text { En esta depresión circula un arroyo que se pierde en un sumidero (ponor). } \\
\text { El polje es una depresión en un macizo calcáreo a modo de valle debido a la } \\
\text { disolución de las calizas por el agua. }\end{array}$ \\
\hline $\begin{array}{l}\text { ¿Qué conceptos } \\
\text { geomorfológicos } \\
\text { puedo explicar? }\end{array}$ & Modelado glaciokárstico. \\
\hline Fuente: elaboración propia.
\end{tabular}

Tabla 85. Identificación de elementos tangibles (LIGm 46).

\begin{tabular}{|c|c|}
\hline № y nombre de LIGm & 46) Polje de Comeya \\
\hline ¿Qué quiero explicar? & $\begin{array}{l}\text { La depresión de Comeya es un polje estructural intramontañoso ampliado por } \\
\text { la actividad kárstica. }\end{array}$ \\
\hline $\begin{array}{l}\text { ¿Qué quiero que la } \\
\text { gente sepa? }\end{array}$ & $\begin{array}{l}\text { El origen de la cuenca de Comeya se encuentra en el funcionamiento de dos } \\
\text { fallas que discurren por sus bordes Norte y Sur, produciendo el hundimiento } \\
\text { del bloque rocoso hace entre } 10 \text { y } 30 \text { millones de años. } \\
\text { Las morrenas de Entrelagos y Buferrera se formaron por la acumulación del } \\
\text { material transportado y depositado por las lenguas glaciares que descendian } \\
\text { de las zonas altas del Cornión. } \\
\text { Al retirarse los glaciares que ocupaban la zona de los lagos, los torrentes } \\
\text { proglaciares desmantelaron buena parte de las morrenas previas y tales } \\
\text { materiales fueron transportados al fondo de Comeya. } \\
\text { El sustrato rocoso del Polje de Comeya está formado por caliza, rocas } \\
\text { arcillosas y cuarcitas. } \\
\text { En la ladera Norte hay abanicos torrenciales y varios flujos de tierra } \\
\text { superficiales. } \\
\text { En la ladera Sur hay desprendimientos y avalanchas de roca. }\end{array}$ \\
\hline $\begin{array}{l}\text { ¿Qué conceptos } \\
\text { geomorfológicos } \\
\text { puedo explicar? }\end{array}$ & Modelado kárstico y relieve estructural. \\
\hline
\end{tabular}

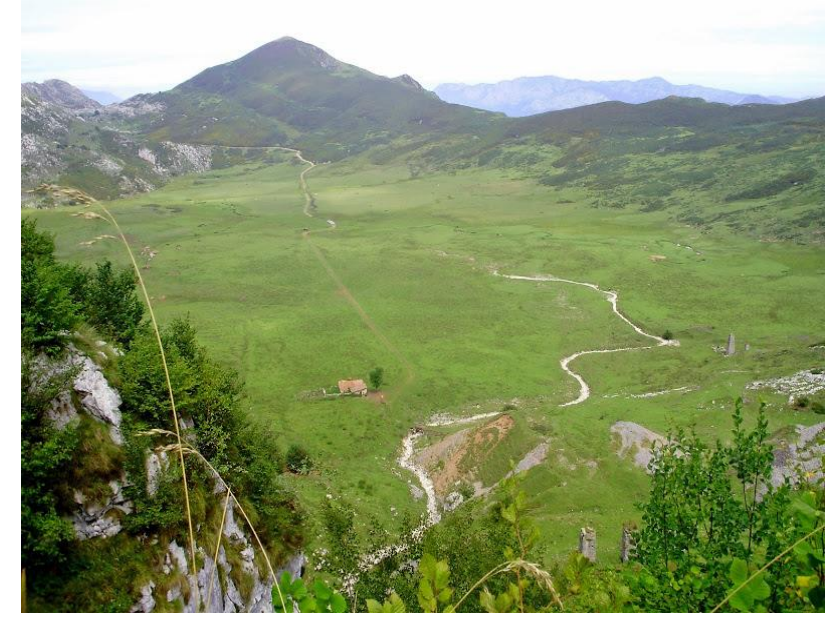

Figura 107. Vista del Polje de Comeya.

Fuente:

http://www.asociacionhubble.org/portal/index.php/for o/viewtopic.php? $f=31 \& t=29218 \&$ start $=10$ 
Tabla 86. Identificación de elementos tangibles (LIGm 49).

\begin{tabular}{|l|l|}
\hline No y nombre de LIGm & 49) Desprendimiento de La Veguina-Llucia: \\
\hline ¿Qué quiero explicar? & Dinámica de laderas, desprendimientos de rocas. \\
\hline $\begin{array}{l}\text { ¿Qué quiero que la } \\
\text { gente sepa? }\end{array}$ & $\begin{array}{l}\text { Que es un cuerpo alargado formado por grandes bloques, con flujo y } \\
\text { reajustes actuales, que termina en una lengua de fuerte pendiente con } \\
\text { grandes bloques de caliza muy inestables y que termina junto a la porción } \\
\text { meridional del lago de la Ercina. } \\
\text { Que es un deslizamiento postglaciar, posiblemente Holoceno, activo en la } \\
\text { actualidad. }\end{array}$ \\
\hline $\begin{array}{l}\text { ¿Qué conceptos } \\
\text { geomorfológicos } \\
\text { puedo explicar? }\end{array}$ & Modelado y dinámica de laderas. \\
\hline Fuente: elaboración propia.
\end{tabular}

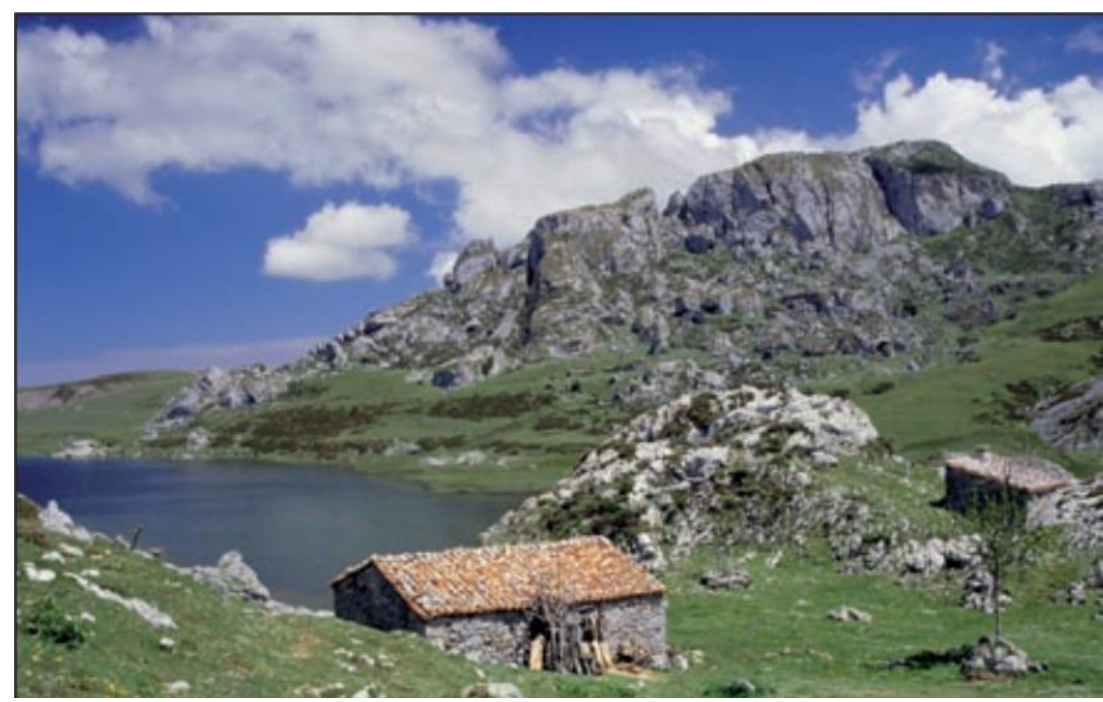

Figura 108. Avalancha de rocas en los escarpes que limitan el lago de la Ercina por el este.

Fuente: Farías y Valderrábano, 2007.

\section{3) Elaboración de tópicos, temas y paneles interpretativos}

De manera general todos los LIGm seleccionados presentan buenas oportunidades para el desarrollo de actividades turísticas y educativas, ya que ofrecen excelentes escenarios para la apreciación y valoración de sus valores patrimoniales. De manera particular, los LIGm considerados pueden ser herramientas para la difusión de mensajes relacionados con la geomorfología en general, el modelado glaciar, la geomorfología periglaciar y los paisajes kársticos, en particular.

Aplicando las recomendaciones para la elaboración de los temas interpretativos en los LIGm seleccionados, surgieron los tópicos relacionados con conceptos geomorfológicos que luego serán utilizados para la elaboración de los mensajes de paneles interpretativos (Tabla 87). 
Tabla 87. Elaboración del tópico general, tópicos específicos y temas interpretativos en los LIGm seleccionados.

\begin{tabular}{|c|c|c|}
\hline \multicolumn{3}{|c|}{ Tópico general } \\
\hline \multicolumn{3}{|c|}{ Geomorfología del PNPE } \\
\hline \multicolumn{3}{|c|}{ Tópicos Específicos } \\
\hline Modelado Periglaciar & Acción de los glaciares en el relieve & Karstificación \\
\hline \multicolumn{3}{|c|}{ Temas } \\
\hline $\begin{array}{l}\text { El hielo y la nieve desgastan } \\
\text { y desintegran las rocas }\end{array}$ & $\begin{array}{l}\text { El paso de los glaciares entre las } \\
\text { montañas formó valles en forma de U. }\end{array}$ & $\begin{array}{l}\text { La acción del agua de } \\
\text { Iluvia en las rocas calizas } \\
\text { creó formas caprichosas. }\end{array}$ \\
\hline $\begin{array}{l}\text { Estos ambientes se } \\
\text { caracterizan por un suelo } \\
\text { congelado y ciclos de helada } \\
\text { y deshielo. }\end{array}$ & $\begin{array}{l}\text { El arrastre del hielo glaciar acarreó } \\
\text { sedimentos que formaron las } \\
\text { morrenas. }\end{array}$ & $\begin{array}{l}\text { El karst de Picos de } \\
\text { Europa es uno de los más } \\
\text { complejos del mundo. }\end{array}$ \\
\hline $\begin{array}{l}\text { El agua de la fusión del hielo } \\
\text { y la nieve modela las } \\
\text { pendientes de las montañas. }\end{array}$ & $\begin{array}{l}\text { Los lagos de Covadonga y de Lloroza se } \\
\text { formaron por la retirada de un frente } \\
\text { glaciar, quedando la morrena frontal } \\
\text { como cerrojo. }\end{array}$ & $\begin{array}{l}\text { Picos de Europa es el } \\
\text { Himalaya de las cuevas. }\end{array}$ \\
\hline
\end{tabular}

El objetivo de la instalación de estos paneles en áreas naturales protegidas es estimular el conocimiento de su patrimonio geomorfológico y minimizar los impactos negativos de los visitantes al comunicar estos aspectos. Para la confección de los mismos se realizaron búsquedas bibliográficas y visitas a la zona de estudio. En todos los casos se trató de utilizar un lenguaje claro y accesible para así alcanzar a una amplia variedad de públicos. Se confeccionó un panel interpretativo de cada uno de los tópicos específicos identificados en el patrimonio geomorfológico del Parque Nacional de los Picos de Europa. Para cada caso, se realizaron bocetos del diseño de cada uno de los paneles interpretativos para la organización gráfica del texto y de las imágenes seleccionadas. A partir de ideas generales sobre el mensaje a transmitir, se redactó una propuesta inicial del texto a colocar en paneles de $40 \times 30 \mathrm{~cm}$ (Figura 109). 


\section{El agua transforma las rocas}

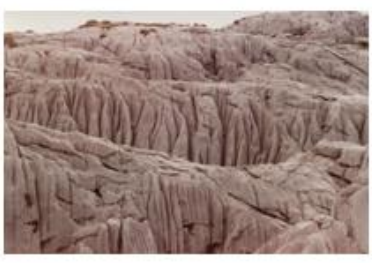

El lapiaz es el primer modeladoque se desarrolla sobre la superficie de los karsts. Se forma por la circulación superficial del agua, su efecto disolvente produce pequeños canales separados por crestas, aveces canalantes agudas. En algunos karsts, los surcos puedentener profundidades superioresa $1 \mathrm{~m}$.

\section{dolina}

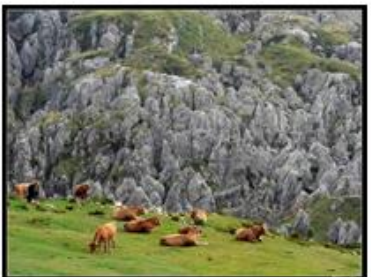

El mode lado kárstico es el que se realiza en los macizos carbonados. Estos macizos están formadosen su mayor parte por un tipo de rocas sedimentarias llamadas rocas carbonadas de las que las calizas y dolomías son ejemplos, Las rocas calizas están compuestas en su mayor parte por calcita, las cuales aunque en principio son compactas e insolubles, son atacadas por el ácido carbónico que se forma al reaccionar el dióxido de carbono disue lto en el agua que discurre por los macizos. Este ácido con la calcita forma bicarbonato que sí se disuelve conel agua.

Figura 109. Boceto de panel interpretativo sobre geomorfología kárstica. Fuente: elaboración propia.

Se analizó el texto original con la ficha elaborada para esta investigación, y se realizaron las modificaciones necesarias para que el mismo se ajustase a las consignas de escritura de textos interpretativos. Se realizó una primera introducción de color en el diseño de los paneles elaborados en planillas de procesador de textos (Figura 110).

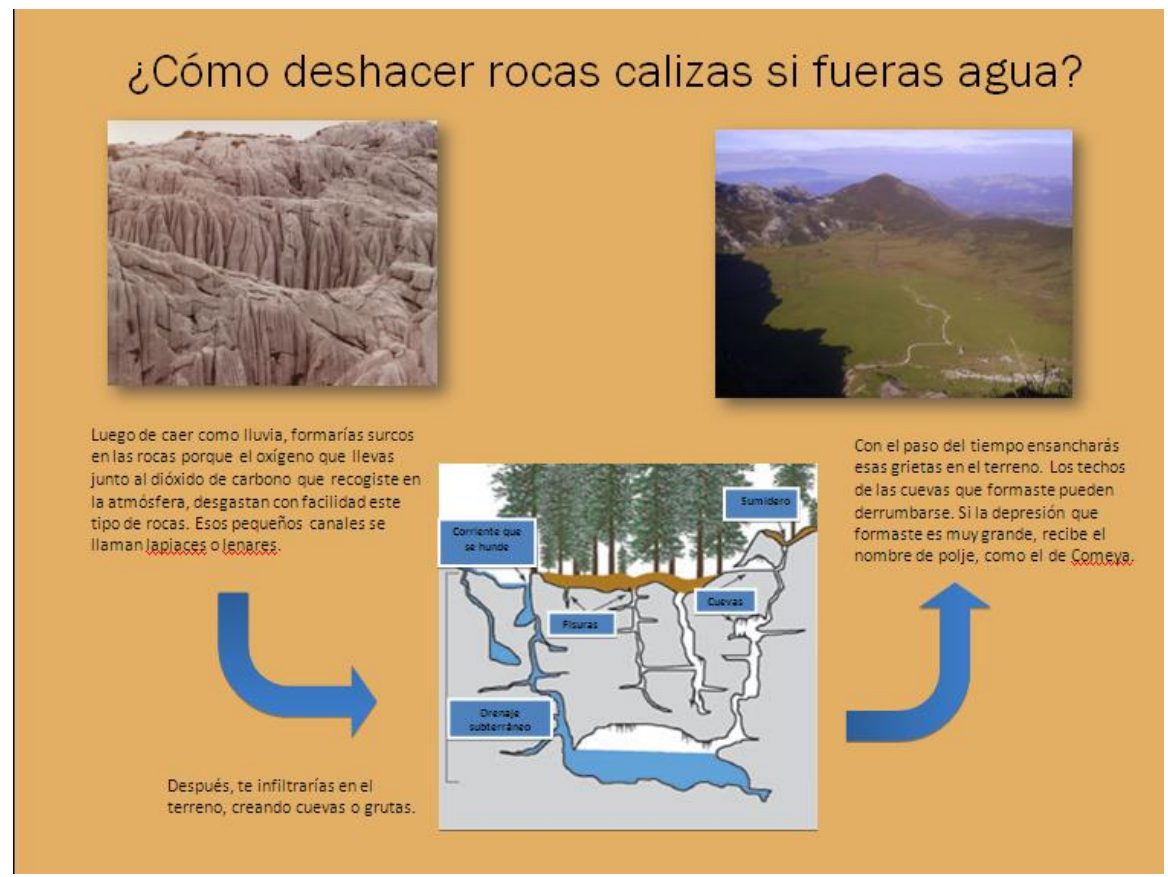

Figura 110. Borrador de panel interpretativo sobre Geomorfología kárstica.

Fuente: elaboración propia. 
La Interpretación del Patrimonio Geomorfológico en los Picos de Europa: una propuesta para su aprovechamiento didáctico y geoturístico

Finalmente, se introducen variantes en el diseño de los paneles al utilizar presentaciones de diapositivas. Se redistribuyen los textos y las imágenes para conseguir una presentación equilibrada (Figura 111) y se aumenta el tamaño de las letras para una mejor lectura del mensaje. Se analizó el texto final del panel interpretativo (Tabla 88) para comprobar que cumpliera con las sugerencias de elaboración del mensaje interpretativo. 


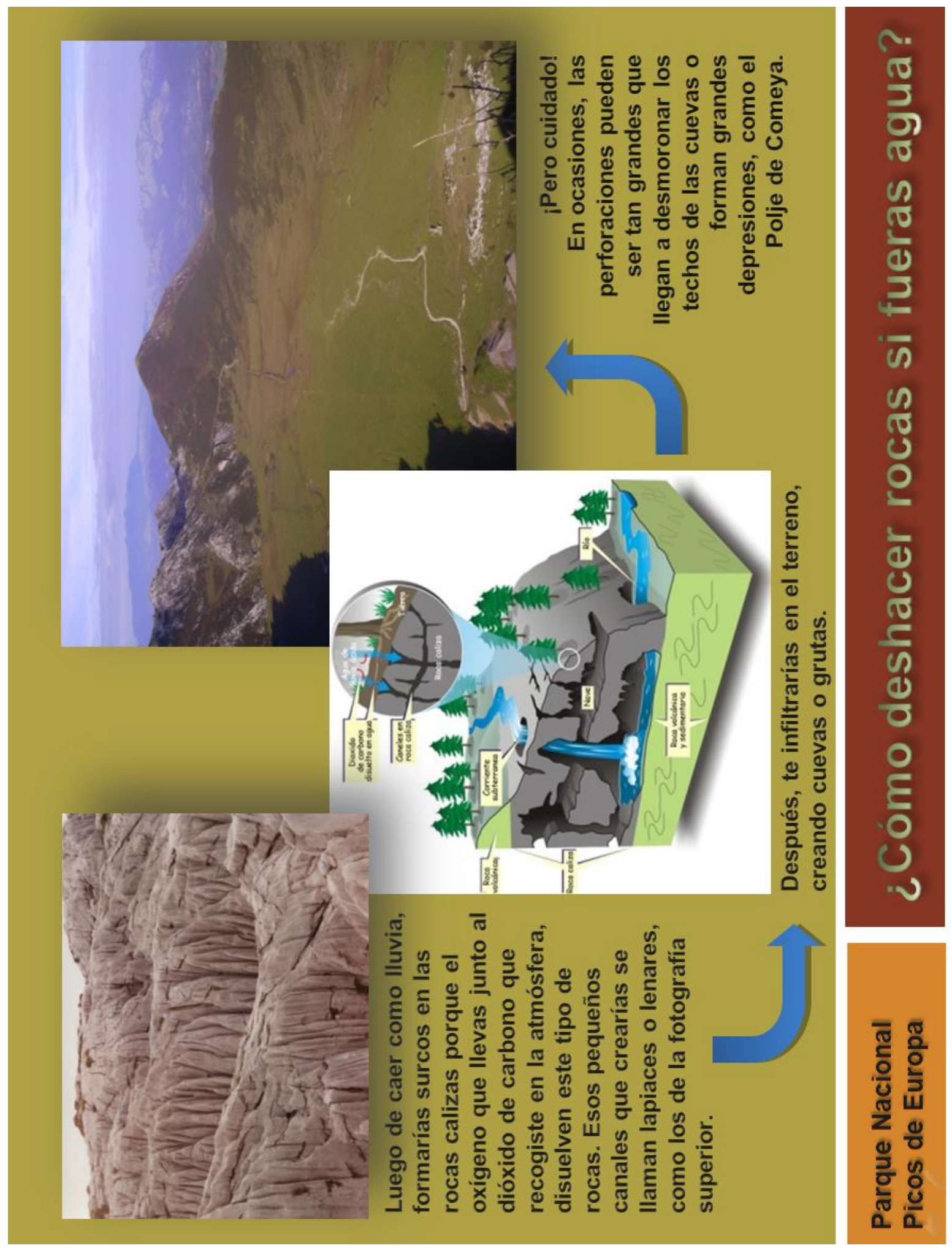

Figura 111. Panel interpretativo sobre geomorfología kárstica.

Fuente: elaboración propia. 
Tabla 88. Análisis de panel interpretativo sobre geomorfología kárstica.

\begin{tabular}{|c|c|c|c|c|}
\hline Título & \multicolumn{4}{|l|}{ ¿Cómo deshacer rocas calizas si fueras agua? } \\
\hline Subtítulo & \multicolumn{4}{|l|}{ No posee } \\
\hline \multirow[t]{2}{*}{ Texto } & \multicolumn{4}{|c|}{$\begin{array}{l}\text { Luego de caer como lluvia, formarías surcos en las rocas calizas porque el oxígeno que llevas } \\
\text { junto al dióxido de carbono que recogiste en la atmósfera, disuelven este tipo de rocas. Esos } \\
\text { pequeños canales que crearías se llaman lapiaces o lenares, como los de la fotografía superior. } \\
\text { Después, te infiltrarías en el terreno, creando cuevas o grutas. } \\
\text { ¡Pero cuidado! En ocasiones, las perforaciones pueden ser tan grandes que llegan a } \\
\text { desmoronar los techos de las cuevas o forman grandes depresiones, como el Polje de Comeya. }\end{array}$} \\
\hline & & & Si & No \\
\hline \multirow{12}{*}{ 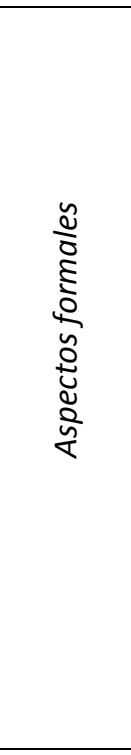 } & $\begin{array}{l}\text { ¿En la lectura del título y/o subtítulo se pu } \\
\text { existencia de una idea clave? }\end{array}$ & de apreciar la & $x$ & \\
\hline & \multirow{2}{*}{\multicolumn{2}{|c|}{$\begin{array}{l}\text { Extensión del texto (se recomienda } 70 \text { palabras en miradores y } \\
\text { paradas de itinerario y } 90 \text { en paneles de exhibición) }\end{array}$}} & \multirow{4}{*}{$\begin{array}{l}\text { Indicar la } \\
\text { cantidad }\end{array}$} & 7 \\
\hline & & & & 85 \\
\hline & \multicolumn{2}{|c|}{ Tipos de fuentes de textos (se recomienda el uso de hasta 2) } & & 1 \\
\hline & \multicolumn{2}{|c|}{ Tamaño de letra (se recomienda el uso de hasta 3) } & & 3 \\
\hline & \multicolumn{2}{|c|}{$\begin{array}{l}\text { El mensaje posee una idea central clara, presentada en forma de } \\
\text { oración, con sujeto, verbo y predicado }\end{array}$} & \multicolumn{2}{|l|}{ Si } \\
\hline & \multicolumn{2}{|c|}{ El mensaje es atractivo, breve, claro y directo } & \multicolumn{2}{|c|}{ Si, en todos los aspectos. } \\
\hline & \multicolumn{2}{|l|}{ Se presenta el todo y no las partes aisladas } & \multicolumn{2}{|c|}{$\mathrm{Si}$} \\
\hline & \multicolumn{2}{|l|}{ ¿Está narrado en primera persona? } & \multicolumn{2}{|l|}{$\mathrm{Si}$} \\
\hline & \multicolumn{2}{|c|}{ En el caso de utilizar tecnicismos, ¿los mismos están explicados? } & \multicolumn{2}{|c|}{$\begin{array}{l}\text { Se explican (ej. lapiaces o } \\
\text { polje). }\end{array}$} \\
\hline & \multicolumn{2}{|c|}{ ¿Se utilizan metáforas, analogías o comparaciones? } & \multicolumn{2}{|c|}{ No } \\
\hline & \multicolumn{2}{|c|}{$\begin{array}{l}\text { ¿Las imágenes utilizadas son apoyos visuales del texto o } \\
\text { redundantes? }\end{array}$} & \multicolumn{2}{|c|}{ Apoyan el texto. } \\
\hline \multirow{8}{*}{ 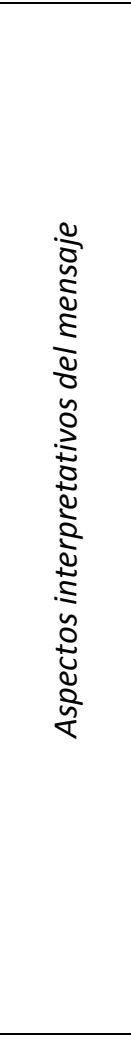 } & $\begin{array}{l}\text { Elementos y atributos tangibles (el mensaje } \\
\text { identifica con claridad los aspectos y } \\
\text { características físicas del rasgo) }\end{array}$ & Rocas calizas, as & ua. & \\
\hline & $\begin{array}{l}\text { Elementos intangibles (ideas abstractas } \\
\text { contenidas en el mensaje que surgen a partir de } \\
\text { los atributos tangibles) }\end{array}$ & Procesos geomo & fológicos. Pai & árstico. \\
\hline & $\begin{array}{l}\text { Conceptos universales (ideas intangibles con un } \\
\text { nivel de relevancia superior para los visitantes. } \\
\text { Surgen del punto anterior) }\end{array}$ & \multicolumn{3}{|l|}{ Erosión. } \\
\hline & $\begin{array}{l}\text { Conexión intelectual con el visitante } \\
\text { (oportunidad que ofrece el mensaje para que el } \\
\text { público comprenda conceptos e ideas) }\end{array}$ & \multicolumn{3}{|c|}{$\begin{array}{l}\text { Si, el mensaje permite que el público } \\
\text { comprenda que el agua de lluvia disuelve las } \\
\text { rocas calizas. }\end{array}$} \\
\hline & $\begin{array}{l}\text { Conexión emocional con el visitante } \\
\text { (oportunidad que ofrece el mensaje para } \\
\text { producir emociones en el público) }\end{array}$ & \multicolumn{3}{|c|}{$\begin{array}{l}\text { Si (posibilidad de asombro al saber que las } \\
\text { rocas pueden romperse por acción del } \\
\text { agua). }\end{array}$} \\
\hline & $\begin{array}{l}\text { Estímulo al pensamiento (capacidad del } \\
\text { mensaje para provocar en el visitante un } \\
\text { pensamiento más profundo) }\end{array}$ & \multicolumn{3}{|l|}{ Sí } \\
\hline & $\begin{array}{l}\text { Actitud de custodia/respeto (actitud que podría } \\
\text { generar el mensaje para que el público aprecie } \\
\text { y contribuya a la salvaguarda del recurso) }\end{array}$ & \multicolumn{3}{|c|}{$\begin{array}{l}\text { Sí, en la medida que se otorgue importancia } \\
\text { al concepto de que el paisaje es producto de } \\
\text { la combinación de elementos y factores que } \\
\text { lo modelaron a través del tiempo. }\end{array}$} \\
\hline & $\begin{array}{l}\text { Idea central (una oración-tema que dé cohesión } \\
\text { a los distintos aspectos tratados) }\end{array}$ & \multicolumn{3}{|c|}{ El agua de lluvia disuelve las rocas calizas. } \\
\hline
\end{tabular}


Para el diseño de los paneles interpretativos referidos a los restantes tópicos específicos sobre el patrimonio geomorfológico del parque (Geomorfología glaciar y periglaciar), se llevó a cabo el procedimiento descrito para el panel sobre geomorfología kárstica. Así es como las Figuras 112 y 113 ilustran los momentos iniciales de la elaboración del panel sobre geomorfología periglaciar.

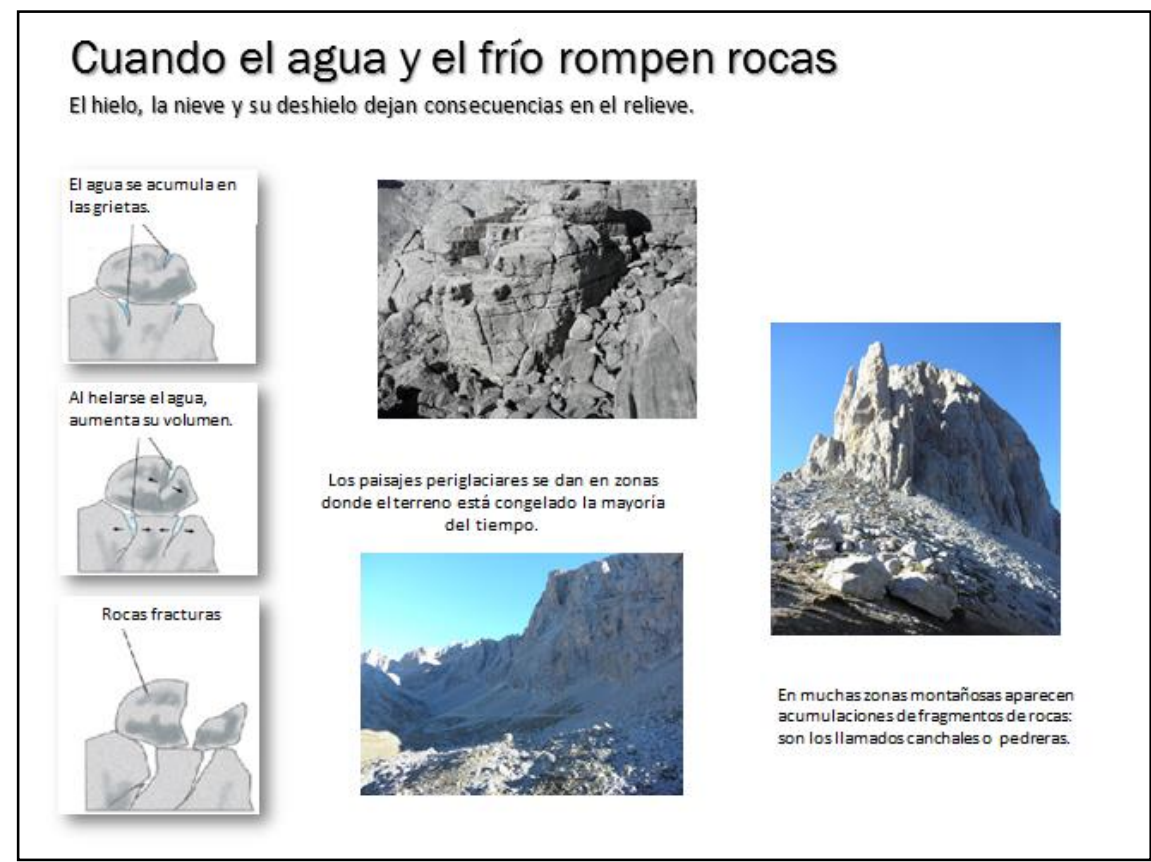

Figura 112. Boceto de panel interpretativo sobre geomorfología periglaciar. Fuente: elaboración propia.

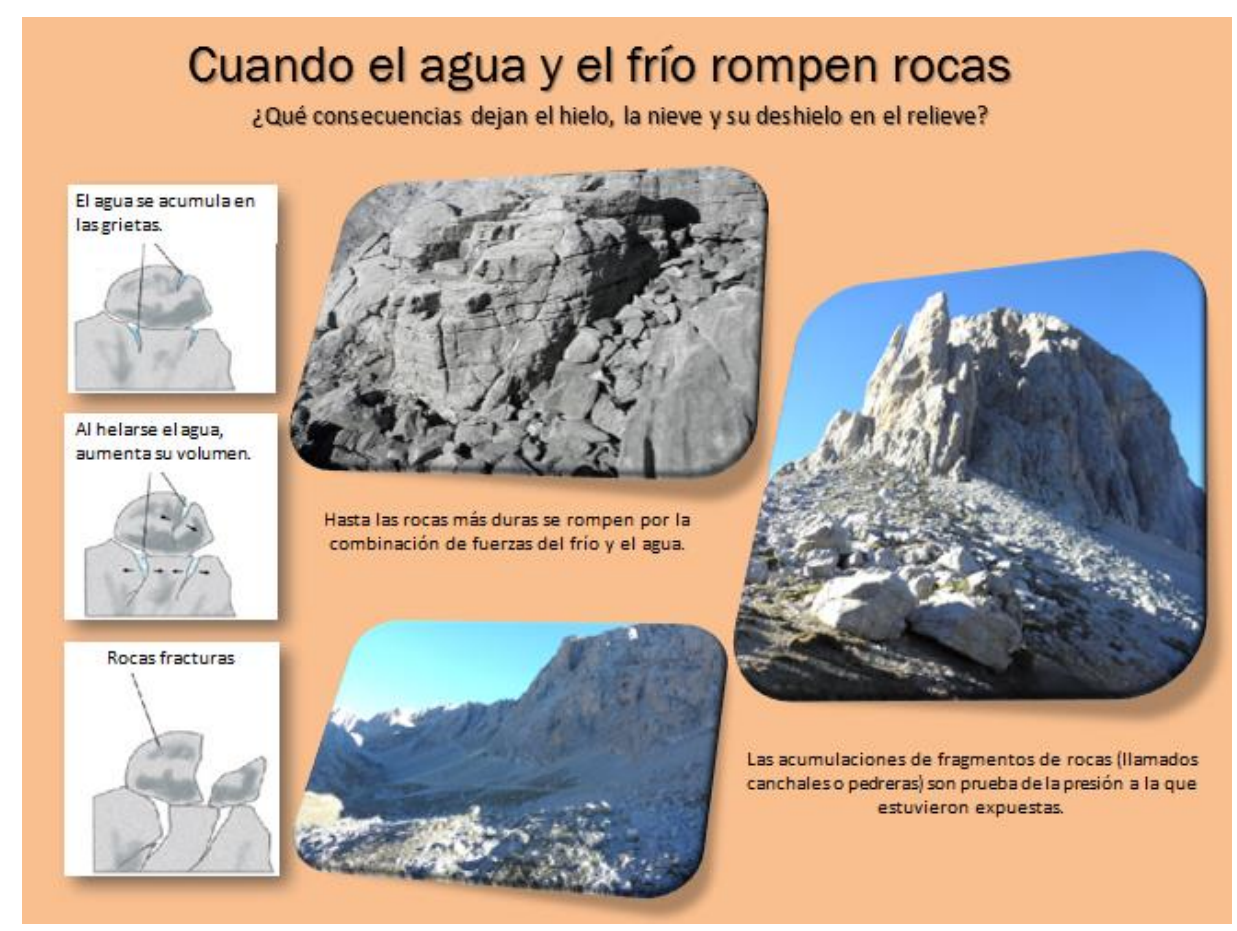

Figura 113. Borrador de panel interpretativo sobre Geomorfología periglaciar. Fuente: elaboración propia. 
Para el diseño final del panel sobre geomorfología periglaciar (Figura 114) se eligió una gama de colores grises y azules metálicos para estar en sintonía con los paisajes rocosos. Se optó por un nuevo título que incluyera conceptos tangibles (agua, rocas) con conceptos universales (poder), eliminando el subtítulo que había sido cambiado en el paso anterior respecto al boceto. Sobre las ilustraciones, se mantuvieron las originales, siendo agregada una imagen de dos manos con rocas que tiene por objetivo apoyar el texto debajo de la misma e invitar al lector del cartel a recoger algunas rocas del suelo para sentir el poder del agua y del frío en ellas. La Tabla 89 recoge el análisis del diseño final del panel interpretativo sobre geomorfología periglaciar. 

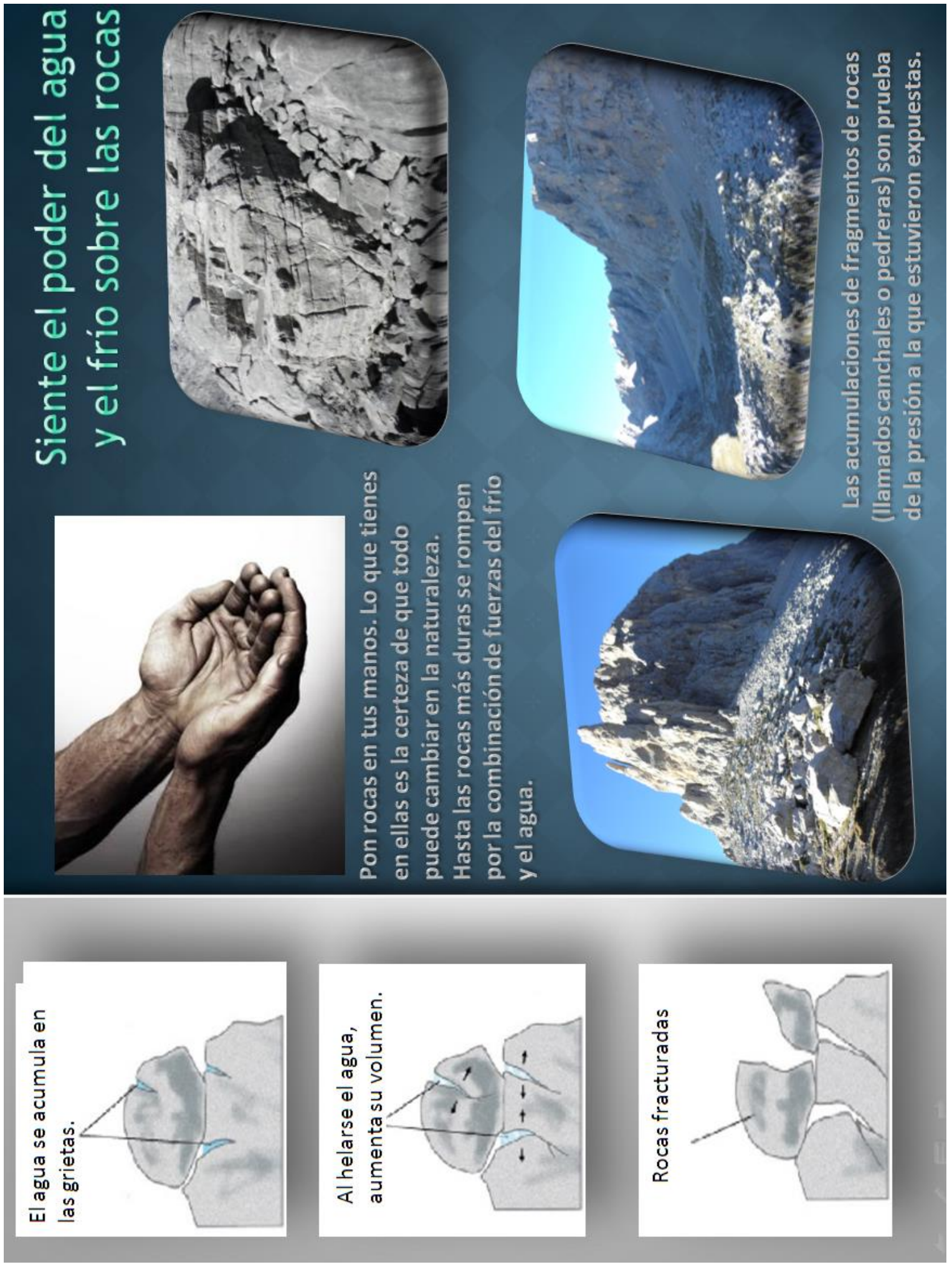

Figura 114. Panel interpretativo sobre geomorfología periglaciar.

Fuente: elaboración propia. 
Tabla 89. Análisis de panel interpretativo sobre geomorfología periglaciar.

\begin{tabular}{|c|c|c|c|c|}
\hline Título & \multicolumn{4}{|l|}{ Siente el poder del frío y del agua en las rocas. } \\
\hline Subtítulo & \multicolumn{4}{|c|}{ No posee. } \\
\hline Texto & \multicolumn{4}{|c|}{$\begin{array}{l}\text { El agua se acumula en las grietas. Al helarse el agua, aumenta su volumen. Rocas fracturadas. } \\
\text { Pon rocas en tus manos. Lo que tienes en ellas es la certeza de que todo puede cambiar en la } \\
\text { naturaleza. Hasta las rocas más duras se rompen por la combinación de fuerzas del frío y el } \\
\text { agua. } \\
\text { Las acumulaciones de fragmentos de rocas (llamados canchales o pedreras) son prueba de la } \\
\text { presión a la que estuvieron expuestas. }\end{array}$} \\
\hline & & & $\mathrm{Si}$ & No \\
\hline \multirow{12}{*}{ 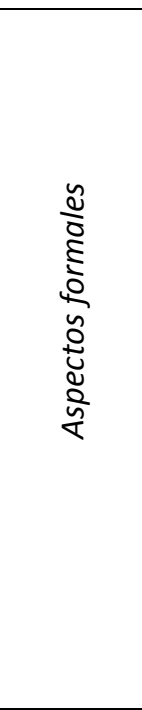 } & $\begin{array}{l}\text { ¿En la lectura del título y/o subtítulo se pu } \\
\text { existencia de una idea clave? }\end{array}$ & de apreciar la & $x$ & \\
\hline & Extensión del título y/o subtítulo & & \multirow{4}{*}{$\begin{array}{l}\text { Indicar la } \\
\text { cantidad }\end{array}$} & 11 \\
\hline & \multicolumn{2}{|c|}{$\begin{array}{l}\text { Extensión del texto (se recomienda } 70 \text { palabras en miradores y } \\
\text { paradas de itinerario y } 90 \text { en paneles de exhibición) }\end{array}$} & & 74 \\
\hline & \multicolumn{2}{|c|}{ Tipos de fuentes de textos (se recomienda el uso de hasta 2) } & & 1 \\
\hline & \multicolumn{2}{|c|}{ Tamaño de letra (se recomienda el uso de hasta 3) } & & 3 \\
\hline & \multicolumn{2}{|c|}{$\begin{array}{l}\text { El mensaje posee una idea central clara, presentada en forma de } \\
\text { oración, con sujeto, verbo y predicado }\end{array}$} & \multicolumn{2}{|l|}{ Si } \\
\hline & \multicolumn{2}{|l|}{ El mensaje es atractivo, breve, claro y directo } & \multicolumn{2}{|c|}{ Si, en todos los aspectos. } \\
\hline & \multicolumn{2}{|l|}{ Se presenta el todo y no las partes aisladas } & \multicolumn{2}{|c|}{ Si } \\
\hline & \multicolumn{2}{|c|}{ ¿Está narrado en primera persona? } & \multicolumn{2}{|l|}{ Si } \\
\hline & \multicolumn{2}{|c|}{ En el caso de utilizar tecnicismos, ¿̇los mismos están explicados? } & \multicolumn{2}{|c|}{ Se explican (ej. canchales). } \\
\hline & \multicolumn{2}{|c|}{ ¿Se utilizan metáforas, analogías o comparaciones? } & \multicolumn{2}{|c|}{ No } \\
\hline & \multicolumn{2}{|c|}{$\begin{array}{l}\text { ¿Las imágenes utilizadas son apoyos visuales del texto o } \\
\text { redundantes? }\end{array}$} & \multicolumn{2}{|c|}{ Apoyan el texto. } \\
\hline \multirow{8}{*}{ 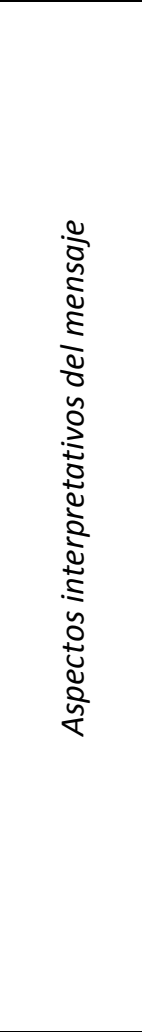 } & \multicolumn{4}{|c|}{\begin{tabular}{l|l}
$\begin{array}{l}\text { Elementos y atributos tangibles ( el mensaje } \\
\text { identifica con claridad los aspectos y } \\
\text { características físicas del rasgo) }\end{array}$ & Rocas, agua, hielo. \\
\end{tabular}} \\
\hline & $\begin{array}{l}\text { Elementos intangibles (ideas abstractas } \\
\text { contenidas en el mensaje que surgen a partir de } \\
\text { los atributos tangibles) }\end{array}$ & \multicolumn{3}{|c|}{$\begin{array}{l}\text { Procesos geomorfológicos. Paisaje } \\
\text { periglaciar. }\end{array}$} \\
\hline & $\begin{array}{l}\text { Conceptos universales (ideas intangibles con un } \\
\text { nivel de relevancia superior para los visitantes. } \\
\text { Surgen del punto anterior) }\end{array}$ & \multicolumn{3}{|c|}{$\begin{array}{l}\text { Distribución de fuerzas (rotura de rocas por } \\
\text { presión del hielo en su interior). }\end{array}$} \\
\hline & $\begin{array}{l}\text { Conexión intelectual con el visitante } \\
\text { (oportunidad que ofrece el mensaje para que el } \\
\text { público comprenda conceptos e ideas) }\end{array}$ & \multicolumn{3}{|c|}{$\begin{array}{l}\text { Si, el mensaje permite que el público } \\
\text { comprenda que la acción combinada del frío } \\
\text { y el agua rompen rocas. }\end{array}$} \\
\hline & $\begin{array}{l}\text { Conexión emocional con el visitante } \\
\text { (oportunidad que ofrece el mensaje para } \\
\text { producir emociones en el público) }\end{array}$ & \multicolumn{3}{|c|}{$\begin{array}{l}\text { Si (posibilidad de asombro al saber que las } \\
\text { rocas pueden romperse por acción del agua } \\
\text { y el frío). }\end{array}$} \\
\hline & $\begin{array}{l}\text { Estímulo al pensamiento (capacidad del } \\
\text { mensaje para provocar en el visitante un } \\
\text { pensamiento más profundo) }\end{array}$ & \multicolumn{3}{|c|}{ ( } \\
\hline & $\begin{array}{l}\text { Actitud de custodia/respeto (actitud que podría } \\
\text { generar el mensaje para que el público aprecie } \\
\text { y contribuya a la salvaguarda del recurso) }\end{array}$ & \multicolumn{3}{|c|}{$\begin{array}{l}\text { Sí, en la medida que se otorgue importancia } \\
\text { al concepto de que el paisaje es producto de } \\
\text { la combinación de elementos y factores que } \\
\text { lo modelaron a través del tiempo. }\end{array}$} \\
\hline & $\begin{array}{l}\text { Idea central (una oración-tema que dé cohesión } \\
\text { a los distintos aspectos tratados) }\end{array}$ & \multicolumn{3}{|c|}{$\begin{array}{l}\text { El efecto combinado del agua y el frío } \\
\text { rompen rocas. }\end{array}$} \\
\hline
\end{tabular}


La Interpretación del Patrimonio Geomorfológico en los Picos de Europa: una propuesta para su aprovechamiento didáctico y geoturístico

Continuando con el proceso de diseño de carteles interpretativos, las Figuras 115 y 116 grafican los primeros momentos de la elaboración del panel sobre geomorfología glaciar.

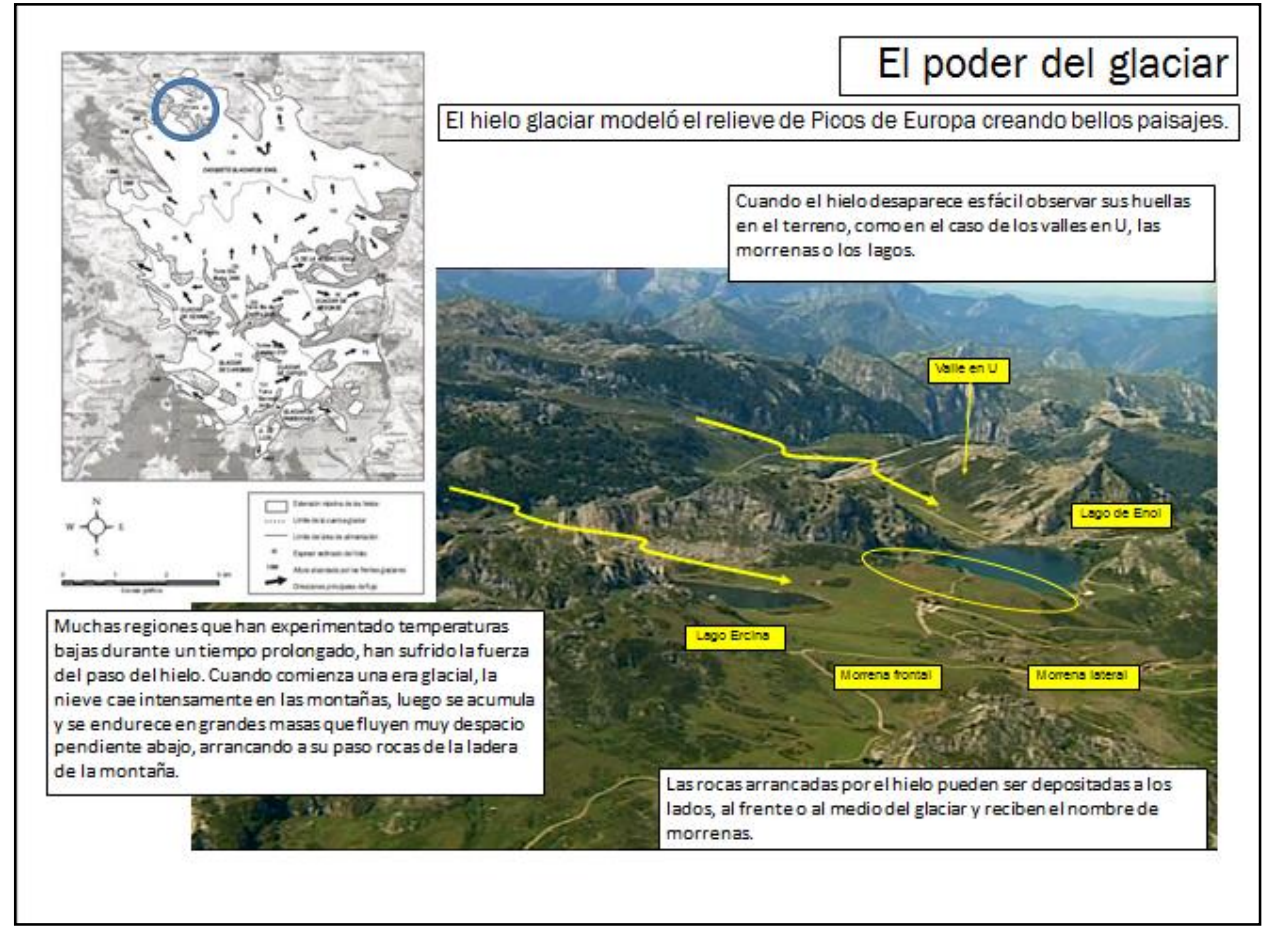

Figura 115. Boceto de panel interpretativo sobre Geomorfología glaciar. Fuente: elaboración propia.

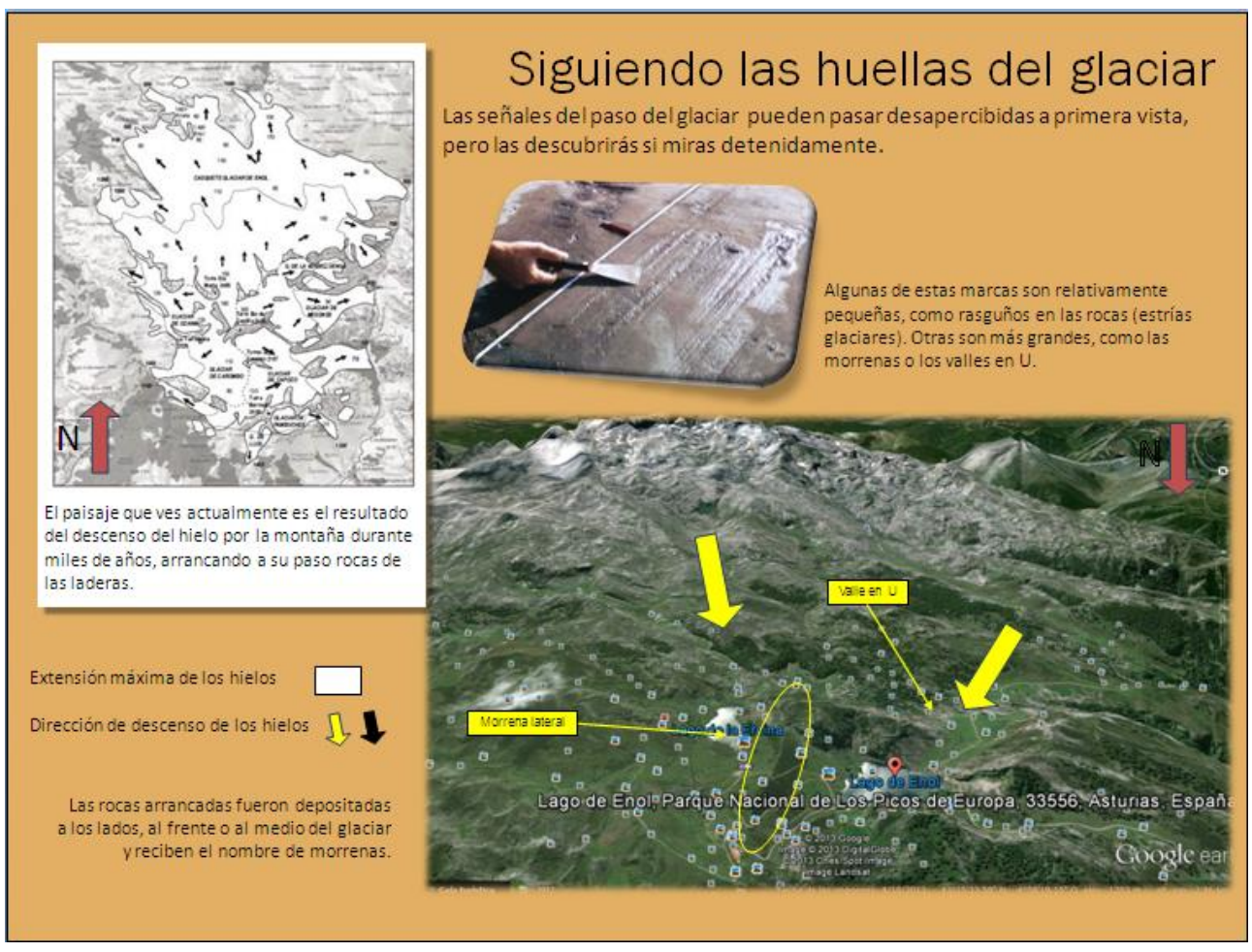

Figura 116. Borrador de panel interpretativo sobre Geomorfología glaciar.

Fuente: elaboración propia. 
El diseño final del panel sobre geomorfología glaciar (Figura 117) mantiene el título y subtítulo del borrador elaborado, pero ahora colocados en la parte inferior del panel. Entre ambos se agregó una imagen de una roca con marcas de erosión glaciar para remarcar la idea de que el terreno posee evidencias visibles del paso del glaciar. Las ilustraciones restantes hacen alusión a la zona cubierta por el hielo glaciar y al aspecto actual con el objetivo de establecer una relación causal entre ambos momentos. Se cambió el mapa del Macizo Occidental con la extensión de los hielos por una imagen panorámica del lago de Enol. De esta forma, esta nueva imagen que acompaña al texto se corresponde con el estilo de escritura del mismo, al permitir "observar el paisaje" en el caso de días nublados o con niebla. Se aumentó el tamaño de las letras para una mejor lectura del mensaje. Como en los casos anteriores, se analizó el texto final del panel interpretativo (Tabla 90) para comprobar que cumple con las sugerencias de elaboración del mensaje interpretativo. 


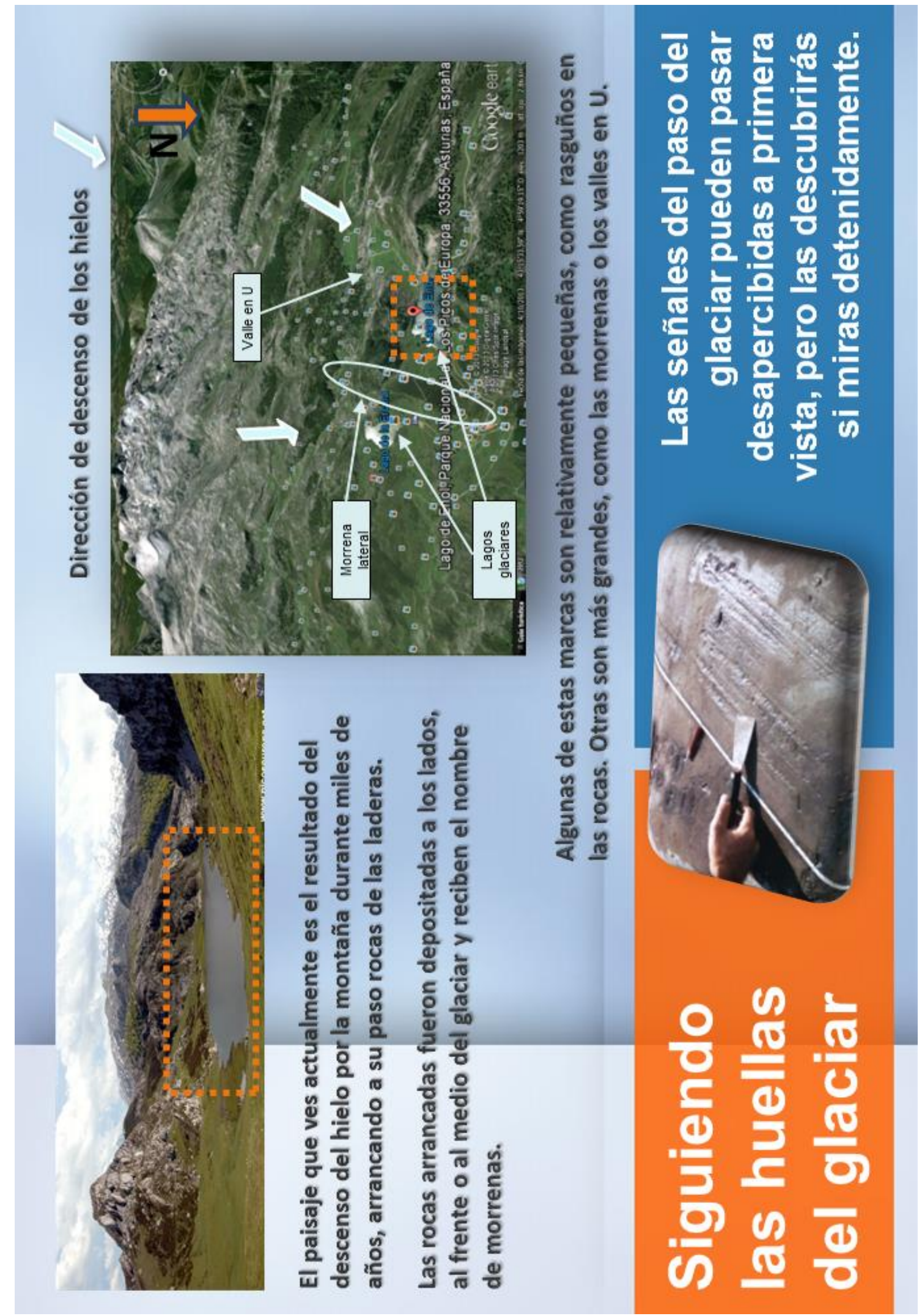

Figura 117. Panel interpretativo sobre Geomorfología glaciar.

Fuente: elaboración propia. 
Tabla 90. Análisis de panel interpretativo sobre geomorfología glaciar.

\begin{tabular}{|c|c|c|c|c|}
\hline Título & \multicolumn{4}{|c|}{ Siguiendo las huellas del glaciar } \\
\hline Subtítulo & \multicolumn{4}{|c|}{$\begin{array}{l}\text { Las señales del paso del glaciar pueden pasar desapercibidas a primera vista, pero las descubrirás } \\
\text { si miras detenidamente. }\end{array}$} \\
\hline Texto & \multicolumn{4}{|c|}{$\begin{array}{l}\text { El paisaje que ves actualmente es el resultado del descenso del hielo por la montaña durante } \\
\text { miles de años, arrancando a su paso rocas de las laderas. } \\
\text { Las rocas arrancadas fueron depositadas a los lados, al frente o al medio del glaciar y reciben el } \\
\text { nombre de morrenas. } \\
\text { Algunas de estas marcas son relativamente pequeñas, como rasguños en las rocas. Otras son } \\
\text { más grandes, como las morrenas o los valles en U. }\end{array}$} \\
\hline & & & Si & No \\
\hline \multirow{12}{*}{ 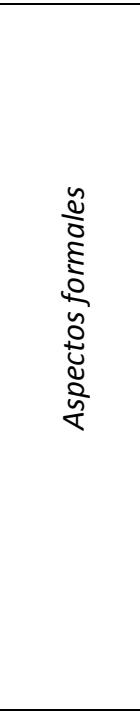 } & \multicolumn{2}{|c|}{$\begin{array}{l}\text { ¿En la lectura del título y/o subtítulo se puede apreciar la existencia } \\
\text { de una idea clave? }\end{array}$} & $x$ & \\
\hline & \multicolumn{2}{|c|}{ Extensión del título y/o subtítulo } & \multirow{4}{*}{$\begin{array}{l}\text { Indicar la } \\
\text { cantidad }\end{array}$} & 23 \\
\hline & \multicolumn{2}{|c|}{$\begin{array}{l}\text { Extensión del texto (se recomienda } 70 \text { palabras en miradores y } \\
\text { paradas de itinerario y } 90 \text { en paneles de exhibición) }\end{array}$} & & 72 \\
\hline & \multicolumn{2}{|c|}{ Tipos de fuentes de textos (se recomienda el uso de hasta 2) } & & 1 \\
\hline & \multicolumn{2}{|c|}{ Tamaño de letra (se recomienda el uso de hasta 3) } & & 3 \\
\hline & \multicolumn{2}{|c|}{$\begin{array}{l}\text { El mensaje posee una idea central clara, presentada en forma de } \\
\text { oración, con sujeto, verbo y predicado }\end{array}$} & \multicolumn{2}{|l|}{ Si } \\
\hline & \multicolumn{2}{|c|}{ El mensaje es atractivo, breve, claro y directo } & \multicolumn{2}{|c|}{ Si, en todos los aspectos. } \\
\hline & \multicolumn{2}{|l|}{ Se presenta el todo y no las partes aisladas } & \multicolumn{2}{|c|}{ Si } \\
\hline & \multicolumn{2}{|l|}{ ¿Está narrado en primera persona? } & \multicolumn{2}{|c|}{ No } \\
\hline & \multicolumn{2}{|c|}{ En el caso de utilizar tecnicismos, ¿̇los mismos están explicados? } & \multicolumn{2}{|c|}{$\begin{array}{l}\text { Se explican (ej. } \\
\text { morrenas). }\end{array}$} \\
\hline & \multicolumn{2}{|l|}{ ¿Se utilizan metáforas, analogías o comparaciones? } & \multicolumn{2}{|c|}{ Si (rasguños). } \\
\hline & \multicolumn{2}{|c|}{$\begin{array}{l}\text { ¿Las imágenes utilizadas son apoyos visuales del texto o } \\
\text { redundantes? }\end{array}$} & \multicolumn{2}{|c|}{ Apoyan el texto. } \\
\hline \multirow{8}{*}{ 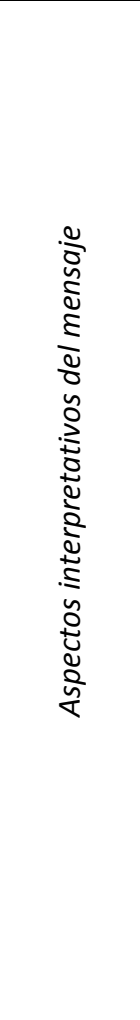 } & \multicolumn{4}{|c|}{\begin{tabular}{l|l} 
Elementos y atributos tangibles ( el mensaje & \\
identifica con claridad los aspectos y características & Montañas, rocas, hielo, nieve, glaciar. \\
físicas del rasgo) &
\end{tabular}} \\
\hline & $\begin{array}{l}\text { Elementos intangibles (ideas abstractas contenidas } \\
\text { en el mensaje que surgen a partir de los atributos } \\
\text { tangibles) }\end{array}$ & \multicolumn{3}{|c|}{$\begin{array}{l}\text { Procesos geomorfológicos. Erosión } \\
\text { glaciar. }\end{array}$} \\
\hline & $\begin{array}{l}\text { Conceptos universales (ideas intangibles con un } \\
\text { nivel de relevancia superior para los visitantes. } \\
\text { Surgen del punto anterior) }\end{array}$ & \multicolumn{3}{|c|}{$\begin{array}{l}\text { Poder (desgaste de rocas por acción del } \\
\text { hielo, desprendimiento de rocas al paso } \\
\text { del glaciar). }\end{array}$} \\
\hline & $\begin{array}{l}\text { Conexión intelectual con el visitante (oportunidad } \\
\text { que ofrece el mensaje para que el público } \\
\text { comprenda conceptos e ideas) }\end{array}$ & \multicolumn{3}{|c|}{$\begin{array}{l}\text { Si, el mensaje permite que el público } \\
\text { comprenda que la acción del hielo modeló } \\
\text { el relieve. }\end{array}$} \\
\hline & $\begin{array}{l}\text { Conexión emocional con el visitante (oportunidad } \\
\text { que ofrece el mensaje para producir emociones en } \\
\text { el público) }\end{array}$ & \multicolumn{3}{|l|}{ No } \\
\hline & $\begin{array}{l}\text { Estímulo al pensamiento (capacidad del mensaje } \\
\text { para provocar en el visitante un pensamiento más } \\
\text { profundo) }\end{array}$ & \multicolumn{3}{|l|}{ Sí } \\
\hline & $\begin{array}{l}\text { Actitud de custodia/respeto (actitud que podría } \\
\text { generar el mensaje para que el público aprecie y } \\
\text { contribuya a la salvaguarda del recurso) }\end{array}$ & \multicolumn{3}{|c|}{$\begin{array}{l}\text { Sí, en la medida que se otorgue } \\
\text { importancia al concepto de que el paisaje } \\
\text { es producto de la combinación de } \\
\text { elementos y factores que lo modelaron a } \\
\text { través del tiempo. }\end{array}$} \\
\hline & $\begin{array}{l}\text { Idea central (una oración-tema que dé cohesión a } \\
\text { los distintos aspectos tratados) }\end{array}$ & \multicolumn{3}{|c|}{$\begin{array}{l}\text { La erosión glaciar modeló el relieve de } \\
\text { Picos de Europa. }\end{array}$} \\
\hline
\end{tabular}




\section{4) Propuestas para el uso didáctico y geoturístico de paneles y \\ LIGm.}

Los paneles interpretativos, al igual que el patrimonio geomorfológico del PNPE, se transforman en medios para la enseñanza según la intencionalidad docente. En el caso particular de los carteles pueden formar parte de una unidad didáctica, de acuerdo a objetivos de aprendizaje, permitiendo introducir un tema, ejemplificar o ejercitar conceptos del mismo o como instancia para consolidar lo aprendido. Dentro de las actividades didácticas a llevar a cabo a partir de la lectura de los paneles, pueden mencionarse el desarrollo de guías de estudio y como ayuda a la observación in situ de procesos geomorfológicos.

Cada geositio es un espacio ideal para el desarrollo de contenidos geomorfológicos específicos. Por lo tanto, relacionando los tópicos sobre geomorfología del Parque (que pueden desarrollarse de manera presencial) con los LIGm elegidos por sus valores para el aprovechamiento turístico y didáctico, se elaboró la Tabla 91.

Tabla 91. Relación de LIGm seleccionados para el uso didáctico y turístico con contenidos geomorfológicos.

\begin{tabular}{|c|c|c|c|c|c|}
\hline \multicolumn{2}{|r|}{ LIGm } & \multirow{2}{*}{$\begin{array}{c}\text { Geomorfología } \\
\text { glaciar }\end{array}$} & \multirow{2}{*}{$\begin{array}{c}\text { Geomorfología } \\
\text { periglaciar }\end{array}$} & \multirow{2}{*}{$\begin{array}{c}\text { Geomorfología } \\
\text { kárstica }\end{array}$} & \multirow{2}{*}{$\begin{array}{c}\text { Otros } \\
\text { conceptos }\end{array}$} \\
\hline № & Nombre & & & & \\
\hline 5 & Complejo glaciar de Fuente Dé-Pido & $x$ & & & \\
\hline 6 & Circos y morrenas de Áliva & $x$ & & & \\
\hline 7 & $\begin{array}{l}\text { Complejo morrénico con glaciar } \\
\text { rocoso de Lloroza }\end{array}$ & $x$ & $x$ & $x$ & \\
\hline 13 & Garganta fluviokárstica del Cares & & & $x$ & \\
\hline 14 & Canal de Dobresengos & $x$ & & $x$ & \\
\hline 15 & Canal de Asotín & $x$ & & $x$ & \\
\hline 18 & $\begin{array}{l}\text { Conos y taludes de derrubios de la } \\
\text { Vueltona }\end{array}$ & & $x$ & & \\
\hline 19 & Gonfolitas del Duje & & $x$ & & \\
\hline 26 & Artesa y lago de Ándara & $x$ & & $x$ & \\
\hline 27 & Complejo morrénico de Escarandi & $x$ & & & \\
\hline 31 & Peñas de Brez & & & & $x$ \\
\hline 33 & Canal de las Arredondas & $x$ & & $x$ & \\
\hline 34 & Depresión del Sobra & & & $x$ & \\
\hline 39 & Lago y Vega de Enol & $x$ & & $x$ & \\
\hline 40 & Complejo morrénico de La Ercina & $x$ & & $x$ & \\
\hline 45 & Depresión de Belbín-La Llomba & $x$ & & $x$ & \\
\hline 46 & Polje de Comeya & & & $x$ & \\
\hline 49 & $\begin{array}{l}\text { Desprendimiento de La Veguina- } \\
\text { Llucia }\end{array}$ & & & & $x$ \\
\hline
\end{tabular}


Cada tópico fue asignado a un color específico: azul para geomorfología glaciar, rojo para la periglaciar y amarillo para la kárstica. El color gris agrupó a otros conceptos sobre geomorfología diferentes a los tópicos seleccionados. Todos los LIGm recibieron el color del tema geomorfológico que puede desarrollarse in situ. Por ejemplo los geositios 5 y 6 fueron coloreados de azul ya que distintos conceptos de geomorfología glaciar pueden ser explicados en ellos. De igual manera se procedió con el resto de LIGm. En el caso de que algún sitio fuera útil para desarrollar dos o más de los temas seleccionados, se los identificó con el color surgido de la fusión de sus componentes. Así es como los geositios que permiten una enseñanza conjunta de conceptos de geomorfología glaciar y kárstica fueron coloreados de verde ya que ese es el color resultante de la mezcla de azul y amarillo, colores que representan a ambos grupos de conceptos geomorfológicos. El LIGm 7 fue pintado de color violeta al permitir la enseñanza de los tres temas geomorfológicos seleccionados y por ser el color que resulta de la mezcla de azul y rojo. Los geositios 31 y 49 fueron coloreados de gris al posibilitar la enseñanza de otros conceptos geomorfológicos distintos a los tres tópicos seleccionados (Figura 118). 


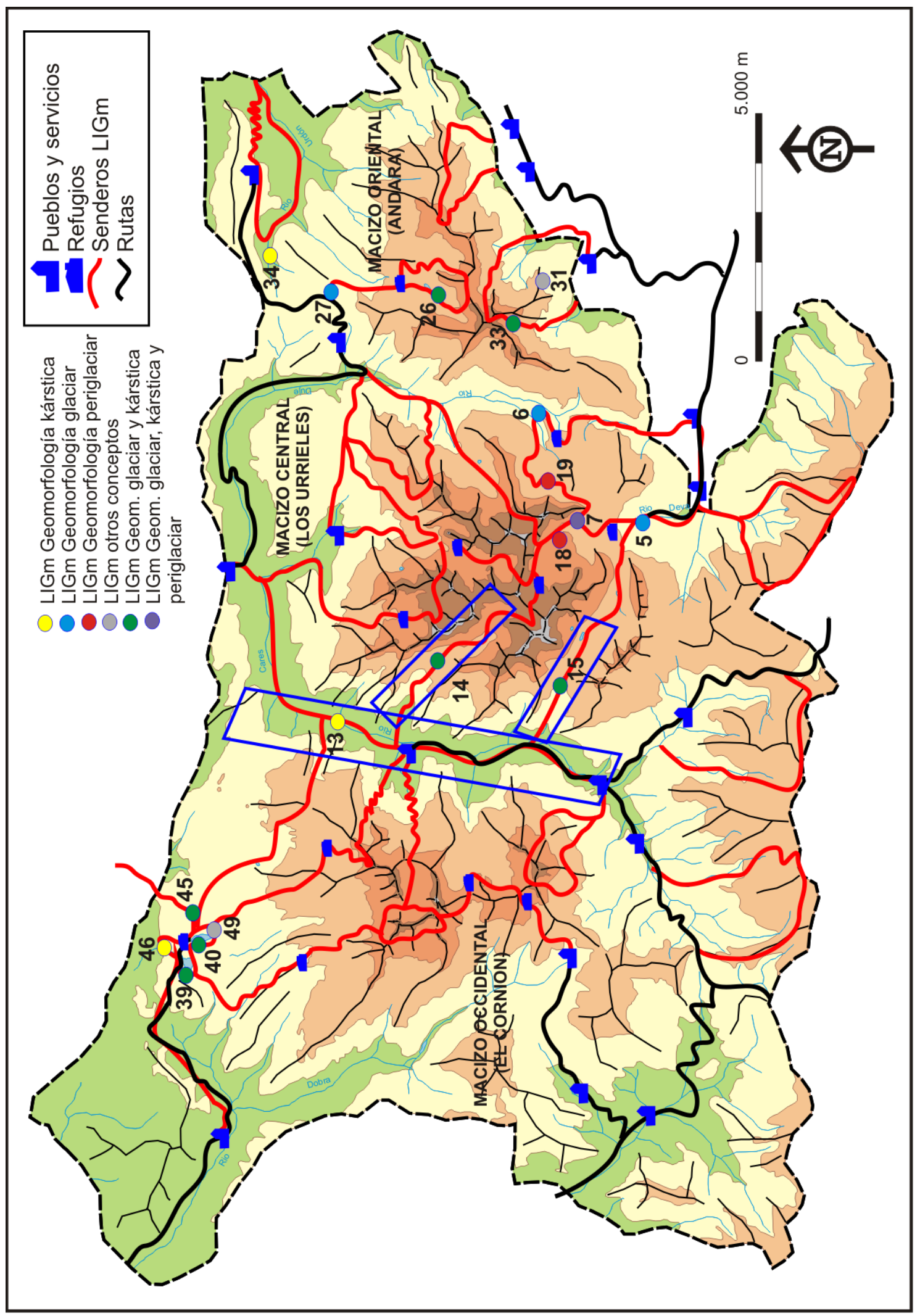

Figura 118. Localización de LIGm del PNPE según tópicos geomorfológicos.

Fuente: elaboración propia. 
Esta identificación y localización de los tópicos permite el desarrollo de actividades interpretativas para el aprovechamiento in situ del patrimonio geomorfológico del PNPE y que las mismas puedan ser utilizadas para la educación y el turismo. Sobre este punto es necesario aclarar que el público de destino de la Interpretación es una audiencia no cautiva y que se encuentra en su tiempo de ocio, mientras que el alumnado constituye un público cautivo y que presenta la obligación de prestar atención porque posiblemente se les evaluará sobre lo aprendido. Por lo tanto la estrategia general de comunicación no puede ser la misma en ambos casos. Es por ello que los paneles elaborados y el patrimonio se convierten en medios para alcanzar objetivos didácticos y turísticos. En tales casos, será la destreza de los gestores de tales actividades (docentes y trabajadores del PNPE) la que convierta estos elementos en medios idóneos para el logro de sus respectivos objetivos. Son varias las propuestas que surgen de la interacción de los valores patrimoniales del PNPE y de los objetivos de gestión del mismo (realización de actividades científicas, educativas, divulgativas y recreativas). Dentro de estos ejemplos se podría nombrar la realización de paseos guiados para la difusión de conceptos relacionados con los tópicos seleccionados (o bien incorporar la Interpretación del Patrimonio Geomorfológico de las zonas visitadas a las visitas guiadas existentes, Figura 119), como así también, la instalación de los paneles interpretativos con tales tópicos sobre Geomorfología del PNPE en senderos que recorran diferentes LIGm.

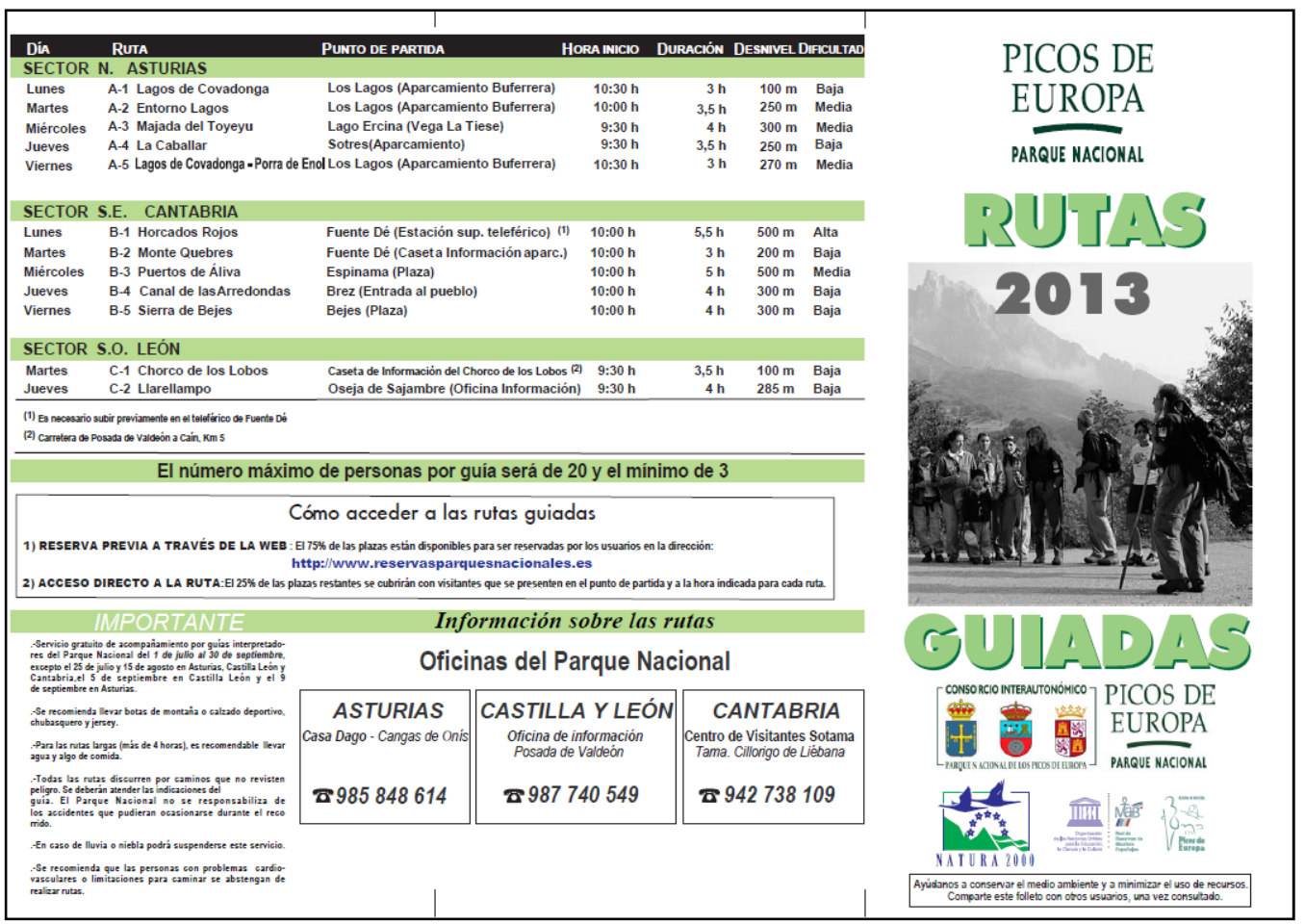

Figura 119. Folleto del PNPE con promoción de rutas guiadas.

Fuente: OAPN. 
Para ambos casos, se podría aprovechar la infraestructura y los servicios existentes en el Parque, para que se incorpore la interpretación del patrimonio geomorfológico como herramienta de gestión, divulgación y conservación de sus valores geomorfológicos. Por ejemplo, se podrían aprovechar los senderos existentes en algunos de los LIGm (por ejemplo, zona de Lagos de Covadonga, Figura 120) para la instalación de paneles interpretativos sobre los procesos geomorfológicos que predominan en ellos. Siguiendo con este ejemplo, los paneles sobre geomorfología glaciar y kárstica podrían instalarse en esta zona, ya que en ella se localizan sitios de génesis predominantemente kárstica (LIGm 46) o combinada con procesos glaciares (LIGm 39, 40, 45).

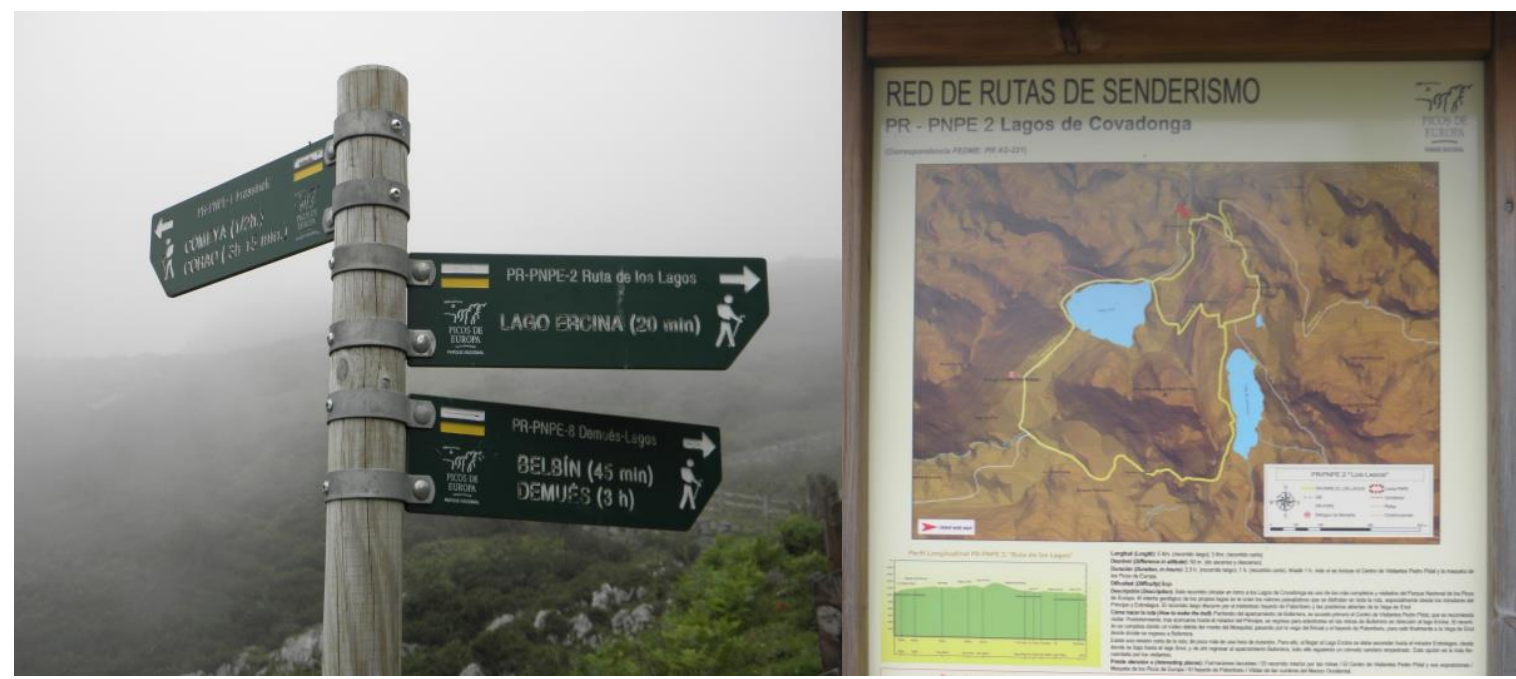

Figura 120. Señalización y panel informativo sobre rutas de senderismo en el PNPE.

Fuente: Héctor Bazán. 
La Interpretación del Patrimonio Geomorfológico en los Picos de Europa: una propuesta para su aprovechamiento didáctico y geoturístico 


\section{Capítulo 8 Conclusiones generales}

El tema de investigación seleccionado, parte de una inquietud por lograr un aprovechamiento didáctico y geoturístico del patrimonio geomorfológico de los Picos de Europa que garantice su sostenibilidad. Si bien la Interpretación del Patrimonio es una disciplina consolidada a nivel nacional e internacional, la mayoría de los trabajos publicados tiene relación con el Patrimonio Cultural o con la biodiversidad del Patrimonio Natural (como lo demuestran las tesis doctorales y de maestría desarrolladas hasta el momento). Al considerar el Patrimonio Geomorfológico del PNPE como el recurso a interpretar, y con el objetivo de lograr un aprovechamiento didáctico y geoturístico del mismo, el presente trabajo adquiere un carácter innovador en la aplicación de las técnicas interpretativas. En este sentido, la presente tesis doctoral ha tratado de reducir las carencias sobre este enfoque.

Algunos de los objetivos de la creación del Parque Nacional de los Picos de Europa fueron la protección de los valores naturales y culturales que lo caracterizan y la realización de actividades de investigación y difusión de sus elementos físicos, biológicos y culturales. Al permitir promover la divulgación y enseñanza de las Ciencias de la Tierra para el público en general, adquiere un papel importante como recurso turístico y educativo.

La metodología desarrollada permitió reflexionar en torno a la contribución de la Interpretación del Patrimonio en la educación y el geoturismo. También, constituyó una ayuda de valor para aportar luz en conceptos que poseen fronteras difusas entre sí, como el ecoturismo, geoturismo y turismo sostenible. Por lo tanto y basándose en el marco conceptual (Interpretación del Patrimonio, Geoturismo, Educación, Lugares de Interés Geomorfológico) propuesto y el análisis de los LIGm del PNPE, el presente trabajo identifica las características geomorfológicas de la zona de estudio y se determinan las oportunidades para las conexiones con los significados de los recursos geomorfológicos para su aprovechamiento didáctico y geoturístico. De lo expuesto hasta aquí, se extraen las siguientes conclusiones generales:

Reconocimiento de la Interpretación del Patrimonio como estrategia comunicativa y herramienta de gestión

Aunque nacida como instrumento de conservación del patrimonio natural, la Interpretación del Patrimonio presenta elementos constitutivos que pueden ser utilizados en el 
ámbito educativo y en el del geoturismo. El estudio de la investigación en Interpretación ha demostrado que esta actividad recogió los avances de otros campos científicos para su conceptualización y el desarrollo de sus modelos de planificación. Por ejemplo, algunas definiciones estuvieron muy influenciadas por la visión de los padres fundadores de la Interpretación (Tilden, Muir), que hacen referencia a ella como una actividad educativa y desarrollada en áreas naturales protegidas. Otros autores incorporaron las investigaciones en comunicación y psicología para presentar estrategias para influir en las emociones y los conocimientos de los visitantes de áreas patrimoniales.

Actualmente se considera a la Interpretación del Patrimonio como un proceso de comunicación que busca, mediante la revelación y la persuasión, mejorar la calidad de la experiencia de los visitantes y de la gestión de un sitio patrimonial. En este proceso de comunicación, las teorías cognitivas y de la conducta proporcionan una guía útil para la toma de decisiones, no sólo en el desarrollo de los temas y enfoques de comunicación, sino también para evaluar la efectividad de la misma.

\section{Conexiones entre Interpretación del Patrimonio, Educación y Geoturismo}

Uno de los momentos cruciales en el proceso interpretativo es el de la elaboración de un mensaje que transmita la esencia del bien patrimonial (transformado en recurso) de una manera amena, relevante, ordenada y temática, adecuándolo a las motivaciones, características y necesidades de los visitantes y a los objetivos interpretativos que se persigan. Al buscar el incremento de la satisfacción y responsabilidad del visitante a un sitio patrimonial se favorece su conservación, resultando un instrumento de planificación, ordenación y gestión territorial. Los paneles interpretativos constituyen una herramienta eficiente para la conservación de los valores patrimoniales de los LIGm, promoviendo su conocimiento y difusión, y posicionándose como estrategias para el aprovechamiento turístico y educativo de tales sitios.

Una de las aplicaciones de la Interpretación del Patrimonio Geomorfológico es el acompañamiento a las actividades educativas y turísticas que se realizan en los LIGm. Como en el caso del docente y el intérprete, es recomendable que el gestor de un servicio turístico aplique los principios interpretativos para elaborar el mensaje a transmitir: necesita conocer a quienes va dirigido el mismo (10 principio interpretativo), reconociendo que existen diversas formas de construir el conocimiento en el interior de las personas (3 principio), que pueden variar según la edad de los turistas (6ำ principio), siendo necesario atraer su atención para que 
se interese en lo que está mirando o escuchando (4o principio), ofreciendo un comunicación de carácter globalizada (5ำ principio) y que no sea sólo mera información (2opincipio).

\section{Valoración y evaluación del patrimonio geomorfológico del PNPE}

La zona de trabajo es uno de los parques nacionales más visitados de España debido a varios factores (históricos, religiosos, paisajísticos). Siguiendo uno de los objetivos propuestos para la presente investigación, el inventario y valoración de los Lugares de Interés Geomorfológico del Macizo de los Picos de Europa ha permitido establecer 51 LIGm. La metodología utilizada se fundamentó en la consideración de tres aspectos: 1ㅇ) valores intrínsecos o científicos, 29) valores añadidos o culturales, y 3) valores de usos y gestión. Esto ha permitido conocer las características geomorfológicas de cada LIGm, valorar otros aspectos complementarios (socioculturales), y estimar sus problemas y potencialidades desde el punto de vista de su uso y gestión dentro del espacio natural protegido en el que se insertan.

Las áreas naturales protegidas son ideales para la realización de proyectos de Interpretación del Patrimonio, ya que pueden ser considerados verdaderos laboratorios vivos que proporcionan un mayor conocimiento y contacto directo con el medio ambiente. Estos proyectos se deben realizar dentro de las directrices establecidas por los planes de gestión. Por lo tanto, las actividades deben estar dirigidas a la planificación y la divulgación de los valores patrimoniales del área en cuestión. El inventario y la valoración de LIGm son tareas necesarias para garantizar un uso sostenible de los mismos a través del desarrollo de actividades científicas, divulgativas y recreativas. Finalmente, cuando se ha estudiado, valorado y desarrollado tales actividades, el elemento geomorfológico adquiere la condición de Patrimonio.

\section{Aprovechamiento didáctico y geoturístico de LIGm}

Analizando la utilidad didáctica de los LIGm en distintos métodos de valoración de estos sitios de interés se llegó a la conclusión de que los mismos no responden a un criterio uniforme ni realizan una metodología estandarizada que sea de utilidad para la práctica pedagógica. Por lo tanto se elaboraron fichas de valoración geomorfológica en general, de geomorfología glaciar, periglaciar y kárstica, considerando la bibliografía referente sobre estos temas $e$ identificando los contenidos geológicos insertos en los diseños curriculares de las comunidades autónomas en las que está inserto el PNPE, necesarios para el desarrollo de contenidos geomorfológicos. 
Considerando la accesibilidad a los mismos y también el grado de fragilidad que presentan, su potencial para el desarrollo de actividades turísticas y su aprovechamiento didáctico se realizó una nueva selección del total de LIGm, lo que permitió identificar 18 LIGm a los que cuales se aplicaron principios teóricos de Interpretación para generar mensajes potentes de cara su utilización en la educación y el geoturismo.

La Interpretación del Patrimonio Geomorfológico, en este sentido, es un aporte fundamental para lograr que los visitantes a las áreas protegidas comprendan, vivan y sientan los valores patrimoniales, enriquezcan sus conocimientos y su conciencia ambiental. Por ello, es importante promover que las personas vinculadas a las actividades turísticas y educativas se formen en interpretación, contribuyendo así a la elevación de la calidad de sus acciones.

Para finalizar, la Interpretación del Patrimonio Geomorfológico representa un potencial insuficientemente utilizado, cuyo uso se podría potenciar de manera importante en un sentido múltiple: difusión atractiva y significativa del patrimonio geomorfológico, lo que redunda en su conservación para generaciones futuras. Así mismo, y a pesar del hecho de que los sistemas nacionales de educación son diferentes de un país a otro, el diseño de la investigación y los recursos producidos pueden ser útiles para inspirar a otras investigaciones e intervenciones educativas dirigidas al aprovechamiento didáctico y turístico del patrimonio geomorfológico. 


\section{Referencias bibliográficas}

AHI (Association Heritage Interpretation) (Reino Unido), What is interpretation? Recuperado de http://www.ahi.org.uk/www/about/what_is_interpretation/

AIP (Asociación para la Interpretación del Patrimonio) (España). La AIP. Recuperado de http://www.interpretaciondelpatrimonio.com/la-aip

Ajzen, I. (1991). The theory of planned behavior. Organizational Behavior and Human Decision Processes, 50 (2), 179-211.

Alcina, A. y Valero, E. (2008). Análisis de las definiciones del diccionario cerámico científicopráctico: sugerencias para la elaboración de patrones de definición. Debate terminológico. Red Iberoamericana de Terminología (RITERM), 4. Recuperado de http://hdl.handle.net/10234/22462

Allan, M. (2011). Toward a better understanding of motivations for a geotourism experience: a self-determination theory perspective. (Tesis de Doctorado). Edith Cowan University, Perth.

Alonso, V. y González Suárez, J.J. (1998). Presencia de hielo glaciar en los Picos de Europa (Cordillera Cantábrica). El helero del jou Negro. Cuaternario y Geomorfología, 12 (1-2), 35-44.

Ander-Egg, E. y Aguilar, M.J. (1996). Cómo elaborar un proyecto. Guía para diseñar proyectos sociales y culturales (13ㅇe edición, ampliada y revisada). Buenos Aires: Lumen/Humanitas.

ANZECC Working Group (1999). Best Practice in Park Interpretation and Education. Victoria: Department of Natural Resources and Environment.

Arguelles, M.; Delgado, J.; Mañana, G.; Laínz, M.; Noval, A. y García, E. (1981). Naturaleza y vida en los Picos de Europa. Madrid: Incafo.

Asociación para la Interpretación del Patrimonio (1999). Conceptos de Interpretación. Definiciones. Boletín de Interpretación, 2, 12.

Asociación para la Interpretación del Patrimonio (2000). Conceptos de Interpretación. Definiciones. Boletín de Interpretación, 3, 15.

Asociación para la Interpretación del Patrimonio (2001a). Conceptos de Interpretación. Definiciones. Boletín de Interpretación, 4, 8.

Asociación para la Interpretación del Patrimonio (2001b). Conceptos de Interpretación. Definiciones. Boletín de Interpretación, 5, 14. 
Asociación para la Interpretación del Patrimonio (2002). Conceptos de Interpretación. Definiciones. Boletín de Interpretación, 6, 17.

Asociación para la Interpretación del Patrimonio (2004). Entrevista a Gianni Netto por Jorge Morales. Boletín de Interpretación, 10, 3-4.

Asociación para la Interpretación del Patrimonio (2006). Recomendaciones para las Buenas Prácticas en Interpretación del Patrimonio Natural y Cultural. Sevilla: Autor

Atkinson, P. y Mullins, G. (1998). Applying social marketing to interpretation. Journal of Interpretation Research, 3 (1), 49-53.

Ayala, C. (2010). Construcción participativa de un Plan de Interpretación y divulgación para la Reserva Forestal Protectora de los ríos Escalerete y San Cipriano, Pacífico colombiano. (Tesis de Maestría). Universidad Internacional de Andalucía: Santa María De La Rábida

Bâca, I. y Schuster, E. (2011). Listing, evaluation and touristic utilisation of geosites containing archaeological artefacts. Case study: Ciceu Ridge (Bistrita-Nasaud County, Romania), Revista Geografica Acadêmica, 5 (1), 5-20.

Ballantyne, R., Hughes, K., Deery, N. y Bond, N. (2007). Meeting visitor needs: a handbook for managers and staff of visitor information centres. Gold Coast: Sustainable Tourism Cooperative Research Centre.

Bao, C. (2009). Entrevista a Jorge Morales Miranda, especialista en interpretación del patrimonio natural y cultural, Lima: Programa Desarrollo Rural Sostenible Recuperado de

http://www.pdrs.org.pe/img upload pdrs/63616e616c6576656e746f7370647273/Entr evista al Prof Jorge Morales Interpretaci n.pdf

Bardin, L. (2002). Análisis de contenido. (3o ed., orig. 1986). Madrid: Akal.

Bazán, H. (2013a). Revelación de significados en Educación e Interpretación. Boletín de Interpretación, 28, 16-21.

Bazán, H. (2013b). El mensaje de los paneles interpretativos y el aprovechamiento turístico y educativo del Patrimonio Natural. Macla, Revista de la sociedad española de mineralogía, 17, 57-58.

Beck, L. y Cable, T. (1998). Interpretation for the 21st Century: fifteen guiding principles for interpreting nature and culture. Urbana: Sagamore Publishing LLC.

Beck, L. y Cable, T. (2011). The Gifts of Interpretation. Fifteen Guiding Principles for Interpreting Nature and Culture. Urbana: Sagamore Publishing LLC.

Benton, G. (2009). From Principle to Practice. Four Conceptions of Interpretation. Journal of Interpretation Research, 14 (1), 7-31. 
Bertonatti, C. (2005). Interpretación y turismo: ¿nos interesa dejar un mensaje al turista? Boletín de Interpretación, 12, 2-4.

Bertrand, C.L. y Bertrand, G. (1971). Le complexe terminal glaciaire du plateau karstique des lacs d'Enol (Picos de Europa, massif cantábrique central, Espagne du nord-ouest, province d'Oviedo). Revue Photointerpretation, 13 (2), 15-18.

Blanco, M. (2008). Guía para la elaboración del plan de desarrollo turístico de un territorio. San José de Costa Rica: Instituto Interamericano de Cooperación para la Agricultura.

Boggino, N. (2005). ¿Problemas de aprendizaje o aprendizaje problemático? Rosario: Homo Sapiens Ediciones.

Boley, B. (2009). Geotourism in the Crown of the Continent: Developing and Testing the Geotourism Survey Instrument (GSI). (Tesis de Maestría). University of Georgia, Atlanta.

Brilha, J. (2005). Património geológico e geoconservação. A conservação da natureza na sua vertente geológica. Braga: Palimage.

Brochu, L. y Merriman T. (2012). Personal Interpretation (Kindle Edition). Fort Collins: Heartfelt Publications.

Bruschi, M. V. y Cendrero, A. (2005). Geosite evaluation; can we measure intangible values? ॥ Quaternario Italian Journal of Quaternary Sciences, 18(1), 293-306.

Bruschi, V. (2007). Desarrollo de una metodología para la caracterización, evaluación y gestión de los recursos de la geodiversidad. (Tesis de Doctorado). Universidad de Cantabria, Santander.

Buckley, R. (2003). Research Note Environmental Inputs and Outputs in Ecotourism: Geotourism with a Positive Triple Bottom Line? Journal of Ecotourism, 2 (1), 76-82.

Buckley, R. (2009): Ecotourism: Principles and Practices. Londres: CABI.

Burbach, M., Pennisi, L., West, C. y Ziegler-Chong, S. (2012). The impact of environmental interpretation in developing a connection to nature in park Visitors. LARNet-The Cyber Journal of Applied Leisure and Recreation Research, 15(4), 13-30.

Cable, T. y Cadden, A. (2006). The Common Roots of Environmental Education and Interpretation. Journal of Interpretation Research, 11 (2), 39-46.

Cacioppo, J. y Petty, R. (1983). Central and peripheral routes to persuasion: Application to advertising. Advertising and consumer psychology, 3-23.

Calonge, A. y Juan, X. (2009). Teaching Geology in Spain: a Teacher's Association view. Teaching Earth Science, 34 (2), 42-47.

Carcavilla, L., Belmonte, A., Durán, J.J. e Hilario, A. (2011). Geoturismo: concepto y perspectivas en España. Enseñanza de las Ciencias de la Tierra, (19.1), 81-94. 
Carcavilla, L., López, J., y Durán, J.J. (2007). Patrimonio geológico y geodiversidad: investigación, conservación, gestión y relación con los espacios naturales protegidos. Madrid: IGME.

Carretero, M. (2006). La comprensión y el aprendizaje de las Ciencias Sociales. Curso de Posgrado de Enseñanza de las Ciencias Sociales: construcción del conocimiento y actualización disciplinar. Buenos Aires: FLACSO-Argentina.

Cartón, A., Ferrari, C., Masé, V., Tomasoni, R. y Zampedri, G. (2012). Parco Naturale Adamello Brenta. Piano d'azione. Recuperado de http://www.pnab.it/uploads/media/090427 PianoAzione AdamelloBrentaGeopark.pdf

Castañón, J.C. y Frochoso, M. (1986). Origen y evolución de unas brechas calcáreas: las gonfolitas del Alto Duje (Picos de Europa-España). Actas symposium sobre fluctuaciones climáticas en las regiones del mediterráneo Occidental, Universidad Autónoma de Madrid.

Castañón, J.C. y Frochoso, M. (1996). Hugo Obermaier y el glaciarismo pleistoceno. En A. Moure (Ed.). El hombre fósil 80 años después. Homenaje a H. Obermaier (pp. 153-175). Universidad de Cantabria: Santander.

Castorina, J. (2006). Adquisición de conocimientos sociales en un programa constructivista. Curso de Posgrado Enseñanza de las Ciencias Sociales: construcción del conocimiento y actualización disciplinar. Buenos Aires: FLACSO-Argentina.

Ceballos-Lascurain, H. (1996). Tourism, ecotourism, and protected areas: The state of naturebased tourism around the world and guidelines for its development. IUCN: Autor.

Cebrián, A. (2011). El turismo de naturaleza en Murcia: la región de los cien humedales. Cuadernos de Turismo, 27, 183-204.

Cendrero, A. (1996a). El patrimonio geológico. Ideas para su protección, conservación y utilización. En MOPTMA (Ed.) El patrimonio geológico. Bases para su valoración, protección, conservación y utilización (pp. 17-28). Madrid: Autor.

Cendrero, A. (1996b). Propuesta sobre criterios para la clasificación y catalogación del patrimonio geológico. En MOPTMA (Ed.) El patrimonio geológico. Bases para su valoración, protección, conservación y utilización (pp. 29-38). Madrid: Autor.

Cendrero, A. y Sainz de Omeñaca, J. (1973). El deslizamiento de la Peña de Brez (Picos de Europa): un caso de incidencia del medio ambiente geológico sobre los asentamientos humanos. Cuadernos de Espeleología, 7, 129-136.

CENEAM (2011). Anexo IV. VI Seminario de Interpretación del Patrimonio Natural y Cultural, Valsaín-Segovia. 
Chen, W. (2003).The Craft and Concepts of Interpretation: A Look at How National Park Service Interpreters Reveal and Facilitate Opportunities for Connections. (Tesis de Doctorado). West Virginia University, Morgantown.

Cho, K. (2005). Developing an interpretative planning model for a National Park System: a stakeholder-based needs assessment study for Korea. (Tesis de Doctorado). The Ohio State University, Columbus.

Colquhoun, F. (2005). Interpretation Handbook and Standard. Distilling the essence. Wellington: Department of Conservation.

Comisión Centroamericana de Ambiente y Desarrollo (2005). Manual de Interpretación Ambiental en Áreas Protegidas de la Región del Sistema Arrecifal Mesoamericano. Proyecto para la conservación y uso sostenible del sistema arrecifal mesoamericano (SAM) Belice - Guatemala - Honduras - México. Belize: Autor.

Comisión Europea (2001). Manual de Gestión del ciclo de un proyecto. Enfoque integrado y Marco Lógico. Serie Métodos e Instrumentos para la gestión del ciclo de un proyecto. Recuperado de http://ec.europa.eu/europeaid/where/latin-america/regionalcooperation/urbal/documents/publications/pcm handbook es.pdf

Consorcio Interautonómico Parque Nacional Picos de Europa (2009). Memoria Anual del Parque Nacional Picos de Europa correspondiente al año 2008. Oviedo: Autor.

Consorcio Interautonómico Parque Nacional Picos de Europa (2010). Memoria Anual del Parque Nacional Picos de Europa correspondiente al año 2009. Oviedo: Autor.

Consorcio Interautonómico Parque Nacional Picos de Europa (2011). Memoria Anual del Parque Nacional Picos de Europa correspondiente al año 2010. Oviedo: Autor.

Consorcio Interautonómico Parque Nacional Picos de Europa (2012a). Memoria Anual del Parque Nacional Picos de Europa correspondiente al año 2011. Oviedo: Autor.

Consorcio Interautonómico Parque Nacional Picos de Europa (2012b). Memoria Anual del Parque Nacional Picos de Europa correspondiente al año 2012. Oviedo: Autor.

Coratza, P. y Giusti, C. (2005). Methodological proposal for the assessment of the scientific quality of geomorphosites. II Quaternario Italian Journal of Quaternary Sciences, 18 (1), 307-313.

Cuenca, J.M. (2002). El patrimonio en la didáctica de las ciencias sociales. Análisis de concepciones, dificultades y obstáculos para su integración en la enseñanza obligatoria. (Tesis de Doctorado). Universidad de Huelva, Huelva.

De Castro, R. (2002). Más que palabras. Comunicación ambiental para una sociedad sostenible. Valladolid: Gea. 
De Miguel, R. (2006). Fundamentos de la comunicación humana. Alicante: Editorial Club Universitario.

De Miró, M. y Domingo, M. (1985). Breviario de geomorfología. Barcelona: Oikos-Tau S.A.

Decreto 40/2007, de 3 de mayo; por el que se establece el Currículo de la Educación Primaria en la Comunidad de Castilla y León. En Boletín Oficial de Castilla y León, 89, 9 de mayo de 2007.

Decreto $42 / 2008$, de 5 de junio, por el que se establece el currículo de bachillerato en la Comunidad de Castilla y León. En Boletín Oficial de Castilla y León, 111, 11 de junio 2008.

Decreto 52/2007, de 17 de mayo, por el que se establece el currículo de la Educación Secundaria Obligatoria en la Comunidad de Castilla y León. En Boletín Oficial de Castilla y León, Suplemento al № 99, 23 de mayo 2007

Decreto 56/2007, de 10 de mayo, por el que se establece el currículo de la Educación Primaria en la Comunidad Autónoma de Cantabria. En Boletín Oficial de Cantabria, 100, 24 de mayo de 2007.

Decreto 56/2007, de 24 de mayo, por el que se regula la ordenación y se establece el currículo de la Educación Primaria en el Principado de Asturias. En Boletín Oficial del Principado de Asturias, 140, 16 de junio de 2007.

Decreto 57/2007, de 10 de mayo, por el que se establece el currículo de la Educación Secundaria Obligatoria en la Comunidad Autónoma de Cantabria. En Boletín Oficial de Cantabria, 101, 25 de mayo de 2007.

Decreto 74/2007, de 14 de junio, por el que se regula la ordenación y establece el currículo de la Educación secundaria obligatoria en el Principado de Asturias. En Boletín Oficial del Principado de Asturias, 162, 12 de julio de 2007.

Decreto 74/2008, de 31 de julio por el que se establece el Currículo del Bachillerato en la Comunidad Autónoma de Cantabria. En Boletín Oficial de Cantabria, 156, 12 de agosto de 2008.

Decreto 75/2008, de 6 de agosto, por el que se establece la ordenación y el currículo del Bachillerato en el Principado de Asturias. En Boletín Oficial del Principado de Asturias, 196, 22 de agosto de 2008.

Delgado, J., Boada, J. y Hernández Pacheco, F. (1932). Guía del Parque de la Montaña de Covadonga. Madrid: Ministerio de Agricultura, Industria y Comercio.

Derruau, M. (1991). Geomorfología. Barcelona: Ariel Geografía.

Diamantis, D. (1999). The Concept of Ecotourism: Evolution and Trends. Current Issues in Tourism, 2, (2-3), 93-122. 
Díaz, F. y Hernández, G. (1999). Estrategias docentes para un aprendizaje significativo. Una interpretación constructivista. México: McGraw-Hill.

Domingues Lagues de Lima, M.F. (2006). Caracterização e estratégias de valorização sutentável de ocorrências geológicas com importância patrimonial. (Tesis de Doctorado). Universidade de Minho, Braga.

Domroese, M. y Sterling, E. (1999). Interpretación de la Biodiversidad. Manual para Educadores Ambientales en los Trópicos. Nueva York: American Museum of Natural History.

Dong, H. (2009): Management Elements for Interpretation Placard System in Mountain Scenic Resort, International Journal of Business and Management, 4 (11), 111-115.

Donohoe, H. y Needham, R. (2006). Ecotourism: The Evolving Contemporary Definition. Journal of Ecotourism, 5 (3), 192-210.

Dowling, R. (2010). Geotourism's Global Growth. Geoheritage, 3, 1-13.

Dowling, R. (2013). The history of ecotourism. En Ballantyne, R. y Packer, J. (Ed.) International handbook of Ecotourism (pp. 15-30). Cheltenham: Edward Elgar Publishing Limited.

Eco, U. (1977). Tratado de semiótica general. Barcelona: Lumen.

Edwards, S., McLaughlin, W. y Ham, S. (2003). A Regional Look at Ecotourism Policy in the Americas. En Fennell, D. y Dowling, R. (Eds.), Ecotourism: Policy and Strategy Issues. (pp. 293-307) Londres: CAB International

Elízaga, E. y Palacio, J. (1996). Valoración de puntos y lugares de interés geológico. En: El Patrimonio Geológico, (pp. 61-78). Madrid: Ministerio de Medio Ambiente

Erhartič, B. y Zorn, M. (2012). Geodiversity and geomorphosite research in Slovenia. Geografski vestnik, 84 (1), 51-63.

Ernst, J. (2005). A formative evaluation of the prairie science class. Journal of Interpretation Research, 10 (1), 9-29.

Estepa, J. Ávila, R. y Ruiz, R. (2007). Concepciones sobre la enseñanza y difusión del patrimonio en las instituciones educativas y los centros de interpretación. Estudio descriptivo. Enseñanza de las Ciencias Sociales, 6, 75-94.

Fabré, J.P. y Fabriol, R. (1984). Resultats de deux traÇages réalisés dans I'anphitheéâtre d’Ozanía (Picos de Europa, Espagne). Karstologie, 14, 35-37.

Farias Arquer, P. y Valderrábano, J. (2007). El Parque Nacional de los Picos de Europa: naturaleza en el entorno de los Lagos de Covadonga. Oviedo: Servicio de Formación del Profesorado, Innovación y Tecnologías Educativas

Farías, G. (2006). La Interpretación del Patrimonio en Brasil. Boletín de Interpretación, 15, 11 13. 
Farías, P., Marquínez, J. y Rodríguez, M.L. (1990). Geomorfología y origen de la depresión de Comeya (Picos de Europa, Asturias). I Reunión Nacional de Geomorfología, Teruel.

Farsani, N. (2012). Sustainable tourism in Geoparks through geotourism and networking. (Tesis de Doctorado). Universidade de Aveiro: Aveiro.

Fennell, D. (2002). Ecotourism programme planning. Londres: CAB International

Fernández Balboa, C. (2007). La Interpretación del Patrimonio en Argentina. Buenos Aires: Editorial Administración de Parques Nacionales.

Fernández Balboa, C. y Taubenschlag, R. (2007). Metodología y práctica de la interpretación del patrimonio. Con especial referencia a la interpretación personalizada. En Fernández Balboa, C. (Comp.), La Interpretación del Patrimonio en Argentina (pp. 25-54). Buenos Aires: Editorial Administración de Parques Nacionales.

Fernández, E. (1992). Las grandes cavidades de Picos de Europa. Kaos de Bloques, 14, 55-57.

Fernández, M. (2009). Enseñanza a partir de la indagación y el descubrimiento. En Moral, C. y Pérez, M. (Coords.), Didáctica. Teoría y práctica de la enseñanza (pp. 209-236). Madrid: Pirámide.

Fernández, M. y Fallas, Y. (2005). ¿Sabe usted qué es Interpretación Ambiental?: Aprendamos de manera fácil y dinámica a explorar la naturaleza. Ponencia en VII Congreso Nacional de Ciencias Exploraciones fuera y dentro del aula para educadores de estudios sociales, ciencias, tecnología, química, biología y física y estudiantes de educación, Santo Domingo de Heredia (Costa Rica).

Fernández, S. (2007). La interpretación como estrategia de manejo ¿Sirve la interpretación como herramienta de manejo? En Fernández Balboa, C. (Comp.), La Interpretación del Patrimonio en Argentina (pp. 55-62). Buenos Aires: Editorial Administración de Parques Nacionales.

Fernández-Martínez, E. (Coord.) (1998). Puntos de interés neoeducativo de la provincia de León. Salamanca: Autor.

Field, D. y Wagar, J. (1984): Visitor groups and interpretation in parks and outdoor leisure settings. En Machlis, G. y Field, D. (Eds.) On interpretation. Sociology for interpreters of natural and cultural history, pp. 11-22, Portland: Oregon State University Press.

Fontan de Negrin, L. (1986). En los Picos de Europa (Asturias). Gijón: GH Editores.

Forte, J.P. (2008). Património geomorfológico da unidade territorial de Alvaiázere: inventariação, avaliação e valorização. (Tesis de Maestría). Universidade de Lisboa, Lisboa. 
Fratto, V. (2007). Planificación interpretativa. En Fernández Balboa, C. (Comp.) La Interpretación del Patrimonio en Argentina (pp. 63-74). Buenos Aires: Editorial Administración de Parques Nacionales.

Fuertes Gutiérrez, I. (2013). Patrimonio geológico y ordenación del territorio. Implicación en la gestión de espacios naturales protegidos. (Tesis de Doctorado) Universidad de León, León.

Fuertes-Gutiérrez, I. y Fernández-Martínez, E. (2010). Geosites Inventory in the Leon Province (Northwestern Spain): A Tool to Introduce Geoheritage into Regional Environmental Management. Geoheritage, 2, 57-75.

Gale, T. y Hill, J. (2009): Ecotourism and Environmental sustainability: an introduction. En Hill, J. y Gale, T. (Eds.) Ecotourism and Environmental Sustainability: Principles and Practice. (pp. 3-16). Surrey: Ashgate Publishing, Ltd.,

Gallego, J.L. y Salvador, F. (2002). Metodología de la acción didáctica. En Medina, A. y Salvador, F. (Coords.) Didáctica General (pp. 155-181). Madrid: Pearson Educación.

Gallegos, J. (2002). Nociones de geología y biología para magisterio. Granada: Grupo Editorial Universitario

Gándara, M. (2003). La interpretación temática: una aproximación antropológica. Antropología y patrimonio: investigación, documentación e intervención, 1, 110-125.

García Cortés, A. (1996). Inventario del Patrimonio Geológico. En: MOPTMA (Ed.), El patrimonio geológico. Bases para su valoración, protección, conservación y utilización (pp. 53-60). Madrid: MOPTMA.

García-Cortés, A. y Carcavilla, L. (2009). Documento metodológico para la elaboración del Inventario Español de Lugares de Interés Geológico (IELIG). Madrid: IGME.

Gardner, H. (1987). Estructuras de la mente: la teoría de las múltiples inteligencias. México: Fondo de Cultura Económica.

Gómez Lende, M. y Serrano, E. (2012). Elementos del patrimonio geomorfológico subterráneo: las cuevas heladas de Picos de Europa (Cordillera Cantábrica). En González Diez, A. (Coord.). Avances de Geomorfología en España, 2010-2012 (pp. 47-50). Santander: Ediciones de la Universidad de Cantabria.

Gómez Lende, M., González García, M. y González Trueba, J.J. (2011). El patrimonio geomorfológico del Cornión: algunos lugares e itinerarios de interés. En González Trueba, J.J. y Serrano, E. (Coords.) (2011), Geomorfología del macizo Occidental del Parque nacional de los Picos de Europa (pp. 165-199). Madrid: OAPN. 
González Cuenca, R. (1992). Picos de Europa y Cordillera Cantábrica. Guía completa de la montaña asturiana. Oviedo: Ediciones Paraíso.

González Fernández, B., Meléndez, M., Meléndez, E. y Gutiérrez Claverol, M. (2006). Propuesta de declaración de Puntos de Interés Hidrogeológico en los acuíferos jurásicos de GijónVillaviciosa (Asturias): nacimiento del río España, nacimiento del río Peña de Francia, cueva del Loviu y fuente de La Ruxidora. Trabajos de Geología, 26, 141-148.

González Méndez, M. (1999). Investigación y puesta en valor del patrimonio histórico: planteamientos y propuestas desde la arqueología del paisaje. (Tesis de Doctorado). Universidad de Santiago de Compostela, Santiago de Compostela.

González Suárez, J.J. (1993). La espeleología en el sector de Cerredo. Sistema del Trave. Torrecerredo, 1993, 57-68.

González Trueba, J.J. (2005). La Pequeña Edad del Hielo en los Picos de Europa (Cordillera Cantábrica, NO de España). Análisis morfológico y reconstrucción del avance glaciar histórico. Revista Cuaternario \& Geomorfología, 19 (3-4), 79-94.

González Trueba, J.J. (2006). El macizo central de los Picos de Europa: geomorfología y sus implicaciones geoecológicas en la alta montaña cantábrica. (Tesis de Doctorado). Universidad de Cantabria, Santander.

González Trueba, J.J. (2007a). Geomorfología del macizo Central del Parque Nacional de los Picos de Europa. Madrid: OAPN.

González Trueba, J.J. (2007b). La Pequeña Edad del Hielo en los Picos de Europa. Santander: Universidad de Cantabria.

González Trueba, J.J. y Serrano, E. (2008). La valoración del patrimonio geomorfológico en espacios naturales protegidos. Su aplicación al Parque Nacional de los Picos de Europa. Boletín de la Asociación de Geógrafos Españoles, 47, 175-194.

González Trueba, J.J. y Serrano, E. (2010a). Geomorfología del macizo Oriental del Parque Nacional de los Picos de Europa. Madrid: OAPN.

González Trueba, J.J. y Serrano, E. (2010b). La nieve en los Picos de Europa. Implicaciones geomorfológicas y ambientales. Cuadernos de investigación geográfica, 36 (2), 61-84.

González Trueba, J.J. y Serrano, E. (Coords.) (2011). Geomorfología del macizo Occidental del Parque Nacional de los Picos de Europa. Madrid: OAPN.

González Trueba, J.J., Ruíz, Y. y Serrano, E. (2002). Huellas morfológicas del glaciarismo histórico. La Pequeña Edad del Hielo en el Macizo Central de los Picos de Europa (Cordillera Cantábrica). En Serrano, E. y García, A. (Eds). Estudios recientes en 
Geomorfología. Patrimonio, montaña y dinámica territorial (pp. 183-192). Valladolid: Sociedad Española de Geomorfología y Universidad de Valladolid.

Guerra, F., Sureda, J. y Castells, M. (2008). Interpretación del Patrimonio. Diseño de programas de ámbito municipal. Barcelona: Editorial UOC.

Guerra. F. (2006). Interpretación do Patrimonio e Educación Ambiental. AmbientalMente sustentable: Revista científica galego-lusófona de educación ambiental, 1-2, 221-227.

Gutiérrez Claverol, M. y Luque Cabal, C. (2000). La Minería En Los Picos De Europa. Oviedo: Ediciones Trea S.L.

Gutiérrez, M. (2001). Geomorfología climática. Barcelona: Omega.

Gutiérrez, M. (2008). Geomorfología. Madrid: Pearson.

Hall, T., Ham, S. y Lacker, B. (2010). Comparative Evaluation of the Attention Capture and Holding Power of Novel Signs Aimed at Park Visitors. Journal of Interpretation Research, 15 (1), 15-36.

Ham, S. (1992). Interpretación Ambiental. Una guía práctica para gente con grandes ideas y presupuestos pequeños. Colorado: North American Press.

Ham, S. (2002). A perspective on the evolution of interpretive research. En Wu, H. (Ed.), Proceedings of Taiwan, U.S., and Australia International Symposium on Environmental Interpretation and Ecotourism (pp.76-92), Taichung city, Taiwan: National Taichung Teachers College.

Ham, S. (2003). Ecotourism-Making a Difference by Making Meaning, Keynote Address to the Ecotourism Association of Australia. Recuperado de http://www.jonkohl.com/publications/n-z/sham-keynote03.pdf

Ham, S. (2007). ¿Puede la Interpretación marcar una diferencia? Respuestas a cuatro preguntas de psicología cognitiva y del comportamiento. Boletín de Interpretación, 17, 10-16.

Ham, S. (2009a). Los Elementos Indispensables en la Formación de Intérpretes, Presentación al Seminario para la Interpretación Natural y Cultural en España. Recuperado de http://www.magrama.gob.es/es/ceneam/grupos-de-trabajo-yseminarios/interpretacion-del-patrimonio-natural-y-cultural/anexo1_sham_tcm713295.pdf

Ham, S. (2009b). From Interpretation to Protection: Is There a Theoretical Basis. Journal of Interpretation Research, 14 (2), 49-57. 
Ham, S. y Krumpe, E. (1996). Identifying Audiences and Messages for Nonformal Environmental Education-A Theoretical Framework for Interpreters. Journal of Interpretation Research, 1 (1), 11-23.

Ham, S. y Weiler, B. (2007). Isolating the Role of On-site Interpretation in a Satisfying Experience. Journal of Interpretation Research, 12 (2), 5-24.

Hammit, W. (1981). A Theoretical Foundation for Tilden's Interpretive Principles. The Journal of Environmental Education, 12 (3), 13-16.

Hammit, W. (1984). Cognitive Processes Involved in Environmental Interpretation. The Journal of Environmental Education, 15 (4), 11-15.

Henao, A. y Osorio, J. (2012). Propuesta Metodológica para la Identificación y Clasificación del Patrimonio Geológico como Herramienta de Conservación y Valoración Ambiental - Caso Específico para Colombia. Congreso Latinoamericano de Prevención de Riesgos y Medio Ambiente, Santiago de Chile.

Hockett, K. y Hall, T. (2007). The Effect of Moral and Fear Appeals on Park Visitors' Beliefs about Feeding Wildlife. Journal of Interpretation Research, 12 (1), 5-27.

Hose, T. (2012). 3gs for modern geotourism. Geoheritage, 4 (1-2), 7-14.

Hughes, M., Ham, S. H., \& Brown, T. (2009). Influencing Park Visitor Behavior: A Belief-based Approach. Journal of Park \& Recreation Administration, 27(4), 38-53.

Ibáñez, G., Ahumada, A. y Páez, S. (2012). Patrimonio geológico en una región de la Sierra de Aconquija, Provincias de Tucumán y Catamarca, Argentina. Pasos Revista de Turismo y Patrimonio Cultural, 10 (1), 75-87.

ICOMOS (International Council on Monuments and Sites) (1999). Carta internacional sobre turismo cultural. La Gestión del Turismo en los sitios con Patrimonio Significativo. Recuperado de http://www.international.icomos.org/charters/tourism_sp.pdf

IGME (2009). Documento metodológico para la elaboración del Inventario Español de Lugares de Interés Geológico (IELIG). Madrid: Autor.

INRENA (Instituto Nacional de Recursos Naturales. Ministerio de Agricultura de Perú) (2006). Interpretación y Educación Ambiental en Áreas Naturales Protegidas. Lima: Biblioteca del Guardaparque.

Interpret Europa What is heritage interpretation? Recuperado de http://www.interpreteurope.net/top/heritage-interpretation.html

Interpretation Australia. What is interpretation? Recuperado de http://interpretationaustralia.asn.au/about-ia/what-is-interpretation 
Interpretation Canada. Our Work Defined. Recuperado de http://www.interpscan.ca/our-workdefined

ISPRA (Istituto Superiore per la Protezione e la Ricerca Ambientale) (2012). Scheda per l'inventario dei geositi italiani. Recuperado de http://www.isprambiente.gov.it/it/progetti/tutela-del-patrimonio-geologico-parchigeominerari-geoparchi-e-geositi/il-censimento-nazionale-dei-geositi/la-scheda-perL2019inventario-dei-geositi-italiani

Jacobson, S. y Marynowski, S. (1998). New Model for Ecosystem management Interpretation: Target Audience on Military Lands. Journal of Interpretation, 3 (1), 1-20.

Jakobson, R. (1985). Ensayos de lingüística general. Barcelona: Planeta.

Jensen, K. (2006). Effects of the artistic design of interpretative signage on attracting power, holding time and memory recall. (Tesis de Maestría). Humboldt State University, Arcata (California)

Jiménez Izarraraz, M. A. (2001). Tesis interpretativa temática: las estrategias de síntesis de la cultura para la difusión de la arqueología. Boletín de Antropología Americana, 37, 99110.

Jiménez Izarraraz, M. A. (2007). Estrategias de planeación para la divulgación del patrimonio. Una introducción. Red Patrimonio, Revista de Estudios en Patrimonio Cultural. Recuperado de http://redcolmich.michoacan.gob.mx/index.php/component/k2/item/108planeaciondivulgacion

Jiménez, C. (1982). Introducción al Estudio de la Teoría Administrativa. México: FCE.

Jorajuria Lara, R. (2007). Caracterización y cartografía de los principales geomorfositios de interés turístico en el corredor de Los Cabos, Baja California Sur. (Tesis de Licenciatura). Universidad Autónoma de Baja California Sur, La Paz.

Juarrero de Varona, C. y Martínez Montero, R. (2003). El camino de la interpretación en Cuba. Boletín de Interpretación, 8, 4-6.

Junta de Andalucía. (2004). Inventario de Georrecursos Culturales, Diagnóstico y Valoración de la Geodiversidad en Andalucía. Sevilla: obra en CD.

Knapp, D. (1997). Environmental education and environmental interpretation: The relationships. National Association for Interpretation, 3, 349-356.

Knopf, R. (1981). Cognitive map formation as a tool for facilitating information transfer in interpretive programming. Journal of Leisure Research, 13 (3), 232-242. 
Krippendorff, K. (1990). Metodología de análisis de contenido. Teoría y práctica. Barcelona: Paidós.

Kuehn, D. (1993). An interpretive planning guide for communities along scenic byways and corridors. Nueva York: NY Sea Grant y Seaway Trail Inc.

Lacreu, H. (2003). Recursos geoambientales y formación ciudadana. Congreso latinoamericano de Educación Superior en el siglo XXI, San Luis (Argentina).

Lancaster County Planning Commission (2007). Telling Our Stories An Interpretation Manual for Heritage Partners. Lancaster: Autor.

Larsen, D. (2003). Meaningful Interpretation. How To Connect Hearts And Minds To Places, Objects, And Other Resources. Maryland: Eastern National.

Lazo Cruz, C. y Arróspide Tehuay, G. (2011). Guías técnicas de proyectos de ecoturismo: Guía de Interpretación del Patrimonio Natural y Cultural. Lima: Ministerio de Comercio Exterior y Turismo de Perú.

Lee, W. y Moscardo, G. (2005). Understanding the Impact of Ecotourism Resort Experiences on Tourists' Environmental Attitudes and Behavioural Intentions. Journal of Sustainable Tourism, 13 (6), 546-565.

Levy Hynes, A. (2002). Guía para la planificación y diseño de actividades y servicios de interpretación. Boletín de Interpretación, 7, 7-9.

Ley 16/1995, de 30 de mayo (Jefatura del Estado). Declaración del Parque Nacional de los Picos de Europa. En Boletín Oficial del Estado, 129, 31 de mayo de 1995.

Ley 2/2006, de 3 de mayo (Jefatura del Estado). Ley Orgánica de Educación. En Boletín Oficial del Estado, 106, 4 de mayo de 2006.

Ley de 22 de julio de 1918. Declaración del Parque Nacional de la Montaña de Covadonga. En Gaceta de Madrid, 24 de julio de 1918.

Littlefair, C. (2003). The effectiveness of Interpretation in reducing the impacts of visitors in National Parks. (Tesis de Doctorado) Griffith University, Brisbane.

López, F. (2002). El análisis de contenido como método de investigación. XXI, Revista de Educación, 4, 167-179.

López-Menchero Bendicho, V. (2001). La presentación e interpretación del patrimonio arqueológico in situ. Los yacimientos arqueológicos visibles en España. (Tesis de Doctorado) Universidad de Castilla La Mancha,

Macklin, E., Hvenegaard, G. y Johnson, P. (2010). Improvisational Theater Games for Children in Park Interpretation. Journal of Interpretation Research, 15 (1), 7-13.

Mäder, U. (1988).Tourism and environment. Annals of Tourism Research, 15 (2), 274-277. 
Madin, E. y Fenton, D. (2004). Environmental Interpretation in the Great Barrier Reef Marine Park: An Assessment of Programme Effectiveness. Journal of Sustainable Tourism, 12 (2), 121-137.

MAGRAMA (Ministerio de Agricultura, Alimentación y Medio Ambiente) (2011). Memoria de la Red de Parques Nacionales. Madrid: OAPN

MAGRAMA (Ministerio de Agricultura, Alimentación y Medio Ambiente) (2012).Memoria de la Red de Parques Nacionales. Madrid: OAPN

Maragliano, M. (2010). Interpretación del Patrimonio: Una experiencia de conocimiento que revela significados. Boletín de Interpretación, 22, 17-20.

Mardones, R. (2012). Valoración de potenciales geositios en el campo volcánico Pali Aike, XII Región de Magallanes y de la Antártida chilena, Chile. (Tesis de Grado). Universidad de Chile, Santiago.

Marquínez, J. (1989). Síntesis cartográfica de la región del Cuera y los Picos de Europa. Trabajos de Geología, 18, 137-144.

Marquínez, J. y Adrados, L. (2000). Geología y relieve de los Picos de Europa. Naturalia Cantabricae, 1, 3-19.

Martín Hernanz, I. (2012). La Interpretación del Patrimonio como herramienta de sostenibilidad turística en áreas rurales. (Tesis de Doctorado). Universidad Autónoma de Madrid, Madrid.

Martín, M. (2007). La difusión del patrimonio. Actualización y debate. Revista electrónica de Patrimonio Histórico e-rph, 1 Recuperado de http://www.revistadepatrimonio.es/revistas/numero1/difusion/estudios/ pdf/difusionestudios.pdf

Martínez-Zavala, L., Jordán, A., Anaya, M., Gómez Parrales, I. y Bellinfante, N. (2005). Clasificación automática de elementos geomorfológicos en la cuenca del río Tepalcatepec (México) a partir de un modelo digital de elevaciones. Revista Cuaternario \& Geomorfología, 19 (3-4), 49-61.

Masters, D. y Carter, J. (1999). What Have We Got And Is It Any Good? A practical guide on how to surveyand assess heritage interpretation. Highland Interpretive Strategy Project. Recuperado de http://www.interpretscotland.org.uk/website/interpretscotland.nsf/byunique/news.ht $\underline{\mathrm{ml} / \text { SFILE/inventorymanual.pdf }}$ 
Mateos, S. (2008). Hacia una comunicación global del patrimonio cultural, o cómo potenciar su uso fomentando su preservación. En Mateos Rusillo, S. (Coord.), La comunicación global del patrimonio cultural (pp. 19-50). Gijón: Ediciones Trea S.L.

Medina, W. (2012). Propuesta Metodológica para el Inventario del Patrimonio Geológico de Argentina. (Tesis de Maestría). Universidad de Minho: Braga.

Mejía, C. (2008). El profesor que enseña: la práctica docente. En Sánchez, J.C. (Coord.), Compendio de Didáctica General (pp. 153-181). Madrid: Editorial CCS.

Mendiburu, I. (2001). Lev S. Vigotsky: la psicología cultural y la construcción de la persona desde la educación. En Trilla, J. (Coord.), El legado pedagógico del siglo XX para la escuela del siglo XXI (pp. 207-228). Barcelona: Graó.

Mendoza-Ontiveros, M., Umbral, M. E. y Arévalo, M. (2011). La interpretación del patrimonio, una herramienta para el profesional del turismo. El Periplo Sustentable, 20, 9-30.

Menéndez, M. (coord.)(2002). Parque Nacional Picos de Europa. Guía de visita. Madrid: OAPN. Miotke, F.D. (1968). Karstmorphologische studien in der glacial-überformten Höhenstufe der Picos de Europa, Nordspanien. Selbtverlag der Geografhischen Gesssellschaft, 4, 144161.

Miró, M. (1997). Interpretación, identidad y territorio. Una reflexión sobre el uso social del patrimonio. PH: Boletín del Instituto Andaluz del Patrimonio Histórico, Especial Monográfico: Patrimonio etnológico, 18, 33-37.

Monteserín, O. (2007). Turismo y desarrollo territorial: los planes de dinamización turística en la Interpretación y puesta en valor del territorio. (Tesis de Doctorado). Universidad Complutense de Madrid, Madrid.

Moore, A. (Ed.) (1993). Manual para la capacitación del personal de áreas protegidas. Washington, D.C: National Park Service.

Moral, C. y Pérez, M. (2009). El profesorado ante la enseñanza. En Moral, C. y Pérez, M. (Coords.), Didáctica. Teoría y práctica de la enseñanza (pp. 19-44). Madrid: Pirámide.

Morales, J. (1998a). Guía Práctica para la Interpretación del patrimonio. El arte de acercar el legado natural y cultural al público visitante. Sevilla: Junta de Andalucía.

Morales, J. (1998b). La interpretación del patrimonio natural y cultural: todo un camino por recorrer. PH: Boletín del Instituto Andaluz del Patrimonio Histórico, Especial Monográfico: Patrimonio y sociedad, 25, 150-157.

Morales, J. (2001). Los objetivos específicos en interpretación (Para saber, sentir y hacer). Boletín de Interpretación, 4, 8-9. 
Morales, J. (2004). La interpretación, en su acepción de comunicación atractiva in situ, Boletín GC: Gestión Cultural. Recuperado de http://www.gestioncultural.org/ficheros/1 1316767039 JMorales-Interpreta.pdf

Morales, J. (2007). La planificación interpretativa asegura la excelencia en interpretación. Una herramienta para el turismo, la difusión in situ del patrimonio y la puesta en valor de lugares de interés: parques naturales, yacimientos arqueológicos, jardines botánicos, $\begin{array}{llll}\text { cascos } & \text { otros. } & \text { Recuperado }\end{array}$ http://www.interpretaciondelpatrimonio.com/docs/pdf/Planificacioninterpretativa.pdf Morales, J. (2008). El sentido y metodología de la interpretación del patrimonio. En Mateos Rusillo, S. (Coord.), La comunicación global del patrimonio cultural (pp. 53-77). Gijón: Ediciones Trea S.L.

Moreira, J. (2008). Património geológico em unidades de conservação: atividades interpretativas, educativas e geoturísticas. (Tesis de Doctorado). Universidade Federal de Santa Catarina, Florianópolis.

Moreira, J. (2012). Interpretative panels about the geological heritage-a case study at the Iguassu Falls National Park (Brazil). Geoheritage, 4(1-2), 127-137.

Moreira-Wachtel, S. y Trellez Solis, E. (2013). La interpretación del patrimonio natural y cultural. Una visión intercultural y participativa. Lima: Ministerio del Ambiente; Deutsche Gesellschaft für Internationale Zusammenarbeit (GIZ)

Moreno, A.; Valero Garcés, B.L., Jiménez, M., Domínguez, M.J., Mata, M.P., Navas, A., González Sampériz, P., Stoll, H., Farias, P., Morellón, M., Corella, J.P., Rico, M.T. (2010). The last glaciation in the Picos de Europa Nacional Park (Cantabrian Mountains, nortern Spain). Journal of Quaternary Science, 25, 1076-1091.

Morgan, M. (2009). Interpretation and Place Attachment. Implications for Cognitive Map Theory. Journal of Interpretation Research, 14 (1), 47-59.

Morgan, M. y Dong, X. (2008). Measuring Passenger Satisfaction of Interpretive Programming on Two Amtrak Trains in the Midwest. Testing the Expectancy Disconfirmation Theory. Journal of Interpretation Research, 13 (2), 43-58.

Morrison, O. (2010). Herramientas de apoyo para la enseñanza de la interpretación ambiental. (Tesis de Licenciatura). Universidad de Costa Rica, San José.

NAI (National Association for Interpretation) (EE.UU.). Mission, vision, and core values. Recuperado de http://www.interpnet.com/nai/About/What We Believe/nai/ About/Mission Vision a nd Core Values.aspx?hkey=ef5896dc-53e4-4dbb-929e-96d45bdb1cc1 
Newsome, D., Dowling, R. y Leung, Y. (2012). The nature and management of geotourism: A case study of two established iconic geotourism destinations. Tourism Management Perspectives, 2-3, 19-27.

NGS (National Geographic Society) (1997). About geotourism. Recuperado de http://travel.nationalgeographic.com/travel/sustainable/pdf/about-geotourism.pdf

Novo, M. (1998). La educación ambiental. Bases éticas, conceptuales y metodológicas. Paris y Madrid: Ediciones UNESCO y Universitas S.A.

NPS (National Park Service) (1997). The Visitor Experience and Resource Protection (VERP) Framework. A Handbook for Planners and Managers. Denver: Autor

NPS (National Park Service) (2000). Comprehensive Interpretive Planning. Recuperado de http://www.nps.gov/hfc/pdf/ip/cip-guideline.pdf

NPS (National Park Service) (2002). The Interpretative Process Model. Recuperado de http://www.nps.gov/idp/interp/101/processmodel.pdf

NPS (National Park Service) (2007). Foundations of Interpretation. Curriculum Content Narrative. http://www.nps.gov/idp/interp/101/FoundationsCurriculum.pdf

Nuche del Rivero, R. (Ed.) (2001). Patrimonio geológico de Castilla y León. Madrid: Enresa.

Obermaier, H. (1988). Estudio de los glaciares de los Picos de Europa. Gijón: Grupo de Montaña de la Calzada (Edición facsímil de la edición de Madrid de 1914 con un prólogo de Patricio Adúriz Pérez).

OMT-PNUMA (2005). Making Tourism More Sustainable - A Guide for Policy Makers. ParisMadrid: Autor.

Orams, M. (1995). Using interpretation to manage nature-based tourism. Journal of Sustainable Tourism, 4(2), 81-92.

Padró, J. (1996). La interpretación un método dinámico para promover el uso social del Patrimonio Cultural y Natural. En Martín, M. y Rodríguez Barberán, J. (Coords.), Difusión del patrimonio histórico (pp. 8-13). Sevilla: Junta de Andalucía.

Panizza, M. (2001). Geomorphosites: concepts, methods and examples of geomorphological survey. Chinese Science Bulletin, 46, 4-6.

Pastor Gascón, E. (2011). Las técnicas interpretativas en la enseñanza de la geología de campo con énfasis ambiental. (Tesis de Doctorado) Universidad de Illes Balears, Palma de Mallorca.

Pedraza, J. (1996). Geomorfología. Principios, métodos y aplicaciones. Madrid: Rueda. 
Pereira, P., Pereira, D. y Caetano, M. (2007a). Geomorphosite assessment in Montesinho Natural Park. Geographica Helvetica, 62 (3), 159-168.

Pereira, P., Pereira, D. y Caetano, M. (2007b). Avaliação do Património Geomorfológico: proposta de metodología. Publicações da Associação Portuguesa de Geomorfólogos, 5, 235-247.

Petty, R., Briñol, P. y Priester, J. (2009). Mass media attitude change: Implications of the Elaboration Likelihood Model of persuasion. En J. Bryant, J. y Oliver, M. (Eds.) Media effects: Advances in theory and research (3 ed., pp. 125-164). Nueva York: Routledge.

Pidal, P. y Zabala, J.F. (1918). Picos de Europa: contribución al estudio de las montañas españolas. Madrid: Club Alpino Español.

Piñuel, J.L. (2002). Epistemología, metodología y técnicas del análisis de contenido. Estudios de Sociolingüística, 3 (1), 1-42.

PNUMA (2002). Declaración de Quebec sobre Ecoturismo. Recuperado de http://www.pnuma.org/eficienciarecursos/documentos/Declaracion\%20De\%20Quebec \%20Sobre\%20E|\%20Ecoturismo.pdf

Portal, C. (2010). Reliefs et patrimoine géomorphologique. Applications aux parcs naturels de la façade atlantique européenne. (Tesis de Doctorado). Université de Nantes, Nantes.

Portillo Stephens, C. (2012). Identidad en tránsito. La interpretación cultural y la puesta en valor del patrimonio intangible. (Tesis de Doctorado) Universidad de Las Palmas de Gran Canaria, Las Palmas.

Powell, R. y Ham, S. (2008). Can Ecotourism Interpretation Really Lead to Pro-Conservation Knowledge, Attitudes and Behaviour? Evidence from the Galapagos Islands. Journal of Sustainable Tourism, 16, 4, 467-489.

Pralong, J.P. (2003). Valorisation et vulgarisation des Sciences de la Terre : les concepts de temps et d'espace et leur application à la randonnée pédestre, in : Géomorphologie et Tourisme, Actes de l'Assemblée annuelle de la Société Suisse de Géomorphologie (SSGm), Finhaut (CH), 21-23 septembre 2001, Eds. E. Reynard, C. Holzmann, D. Guex, N. Summermatter, 115-127.

Pralong, J.P. (2004) Pour une mise en valeur touristique et culturelle des patrimoines de I'espace alpin : le concept d' «histoire totale». En Busset, T., Lorenzetti, L. y Mathieu, J. (Red.), Histoire des Alpes. Tourisme et changements culturels (pp. 301-310). Zurich: Chronos Verlag.

Pralong, J.P. (2005). A method for assessing tourist potential and use of geomorphological sites. Géomorphologie: relief, processus, environnement, 3, 189-196. 
Pralong, J.P. (2006). Géotourisme et utilisation de sites naturels d'intérêt pour les sciences de la Terre: Les régions de Crans-Montana-Sierre (Valais, Alpes suisses) et Chamonix-MontBlanc (Haute-Savoie, Alpes françaises). (Tesis de Doctorado). Université de Lausanne, Lausana.

Programa Leonardo Da Vinci-Proyecto In Nature (2006). La interpretación de la naturaleza y del medio rural: una formación innovadora. León: Gráficas ALSE.

Project Management Institute (2004). Guía de los Fundamentos de la Dirección de Proyectos (Guía del PMBOK ${ }^{\circledR}$ ). Tercera Edición, Four Campus Boulevard, Newtown Square, PA

Proyecto Hicira (2005). Centros de interpretación del patrimonio: un motor para el desarrollo de las áreas rurales de Europa. Barcelona: Diputació de Barcelona.

RAE (Real Academia Española). (2001). Diccionario de la lengua española (22.aed.). Recuperado de http://www.rae.es

Real Decreto 384/2002, de 26 de abril. Por el que se aprueba el Plan Rector de uso y gestión del Parque Nacional de los Picos de Europa. En Boletín Oficial del Estado, 119, 18 de mayo de 2002.

Real Decreto 640/1994, de 8 de abril. Por el que se aprueba el Plan de Ordenación de los Recursos Naturales de Picos de Europa. En Boletín Oficial del Estado, 113, jueves 12 de mayo de 1994

Real Decreto de 17 de agosto de 1918. Límites del Parque Nacional de la Montaña de Covadonga o de Peña Santa, en los Picos de Europa asturiano leoneses. En Gaceta de Madrid, 230, 18 de agosto de 1918.

Regoloni, G. (2011). Cartographier les géomorphosites: objectifs, publics et propositions méthodologiques. (Tesis de Doctorado). Université de Lausanne, Lausana.

Reigner, N. y Lawson, S. (2009). Improving the Efficacy of Visitor Education in Haleakalā National Park Using the Theory of Planned Behavior. Journal of Interpretation Research, $14(2), 21-45$.

Reynard, E. (2004a). Géotopes, géo(morpho)sites et paysages géomorphologiques. En Reynard, E. y Pralong, J.P. (Eds.), Paysages Géomorphologiques (pp. 123-136), Lausana: Université de Lausanne.

Reynard, E. (2004b). La géomorphologie et la création des paysages. En Reynard, E. y Pralong, J.P. (Eds.), Paysages Géomorphologiques (pp. 9-20), Lausana: Université de Lausanne.

Reynard, E. (2005). Géomorphosites et paysages. Géomorphologie: relief, processus, environnement, 3, 181-188. 
Reynard, E. (2006). Fiche d'inventaire des géomorphosites. Université de Lausanne, Lausana Recuperado de http://www.unil.ch/igul/page17893.html

Reynard, E. (2009). The assessment of geomorphosites. En Reynard, E., Coratza, P. y RegoliniBissig (Eds.) Geomorphosites (pp. 63-72) Munich: Pfeil Verlag.

Reynard, E., Fontana, G., Kozlik, L. y Scapozza, C. (2007). A method for assessing <scientific> and <additional values> of geomorphosites. Geographica Helvetica, 62 (3), 148-158.

Rodrigo, M. (2005). Modelos de comunicación. Portal de la Comunicación InCom-UAB: El portal de los estudios de comunicación. Recuperado de http://www.portalcomunicacion.com/uploads/pdf/20_esp.pdf

Ruhanen-Hunter, L. (2006). Sustainable Tourism Planning: An Analysis of Queensland Local Tourism Destinations. (Tesis de Doctorado). The University of Queensland, Brisbane.

Ruiz, A. (2010). Interpretación y difusión: dos formas diferentes de ver el Patrimonio. @rqueología y Territorio, 7, 165-177. Recuperado de http://www.ugr.es/ arqueologyterritorio/PDF7/Parrondo.pdf

Saipradist, A. (2005). A critical analysis of heritage interpretation and development of a guidebook for non-thai cultural tourists at Ayutthaya World Heritage Site. (Tesis de Doctorado). Silpakorn University, Bangkok.

Sánchez Albornoz, C. (1972). Orígenes de la nación española. Estudio crítico sobre la Historia del reino de Asturias. Oviedo: Instituto de Estudios Asturianos.

Sánchez, J.C. (2008). El aprendizaje. En Sánchez, J.C. (Coord.), Compendio de Didáctica General (pp. 73-107). Madrid: Editorial CCS.

Sandoval, L. (1991). Geomorfología. Madrid: Ministerio de Defensa.

Santamarina, B. (2008). De la educación a la interpretación patrimonial: patrimonio, interpretación y antropología. En Pereira, X., Prado, S. y Takenaka, H. (Coords.) Patrimonios culturales: educación e interpretación. Cruzando límites y produciendo alternativas (pp. 39-56). Donostia: Ankulegi Antropologia Elkartea,

Schulz, G. (1858). Descripción geológica de la provincia de Oviedo. Madrid: Imp. José González.

Scottish Natural Heritage. Producing interpretive panels. Recuperado de http://www.snh.gov.uk/policy-and-guidance/heritage-interpretation/producinginterpretive-panels/

Senior, K.J. (1987). Geology and speleogenesis of the MI cave system, Western massif, Picos de Europa, northern Spain. Cave Science, 14, 93-103. 
Serantes, A. (2010). Interpretación del Patrimonio, turismo y Espacios Naturales Protegidos o cómo comunicar el legado natural a nuestros visitantes. TURyDES Revista de investigación en Turismo y Desarrollo Local, 3 (8). Recuperado de http://www.eumed.net/rev/turydes/08/asp.htm

Serrano E., González Trueba. J.J., Pellitero, R., González García, M., Gómez Lende, M. (2013). Quaternary glacial evolution in the central Cantabrian Mountains (Northern Spain). Geomorphology, 196, ,65-82

Serrano, E. (1998). Geomorfología estructural. Una introducción. Santander: TGD.

Serrano, E. y González Trueba, J.J. (2002). Morfología y evolución glaciar en los Picos de Europa. En Redondo, J.M. et al. (Eds.), El modelado de origen glaciar en las montañas leonesas (pp. 249-258). León: Universidad de León.

Serrano, E. y González Trueba, J.J. (2004). Morfodinámica periglaciar en el grupo Peña Vieja (Macizo Central de los Picos de Europa -Cantabria). Revista Cuaternario \& Geomorfología, 18 (3-4), 73-88.

Serrano, E. y González Trueba, J.J. (2005). Assessment of geomorphosites in natural protected areas: the Picos de Europa National Park (Spain). Géomorphologie: relief, processus, environnement, 3, 197-208.

Serrano, E. y González Trueba, J.J. (2011). Environmental education and landscape leisure. Geotourist map and geomorphosites in the Picos de Europa National Park. GeoJournal of Tourism and Geosites, 4 (2), 295-308.

Serrano, E., González Amuchástegui, M. J. y Ruiz Flaño, P. (2009). Gestión ambiental y geomorfología: valoración de los lugares de interés geomorfológico del Parque Natural de las Hoces del Alto Ebro y Rudrón. Revista Cuaternario \& Geomorfología, 23 (3-4), 6582.

Serrano, E., González-Trueba, J.J. y González-García, M. (2012). Mountain Glaciation and paleoclimate reconstruction in the Picos de Europa (Iberian Peninsula, SW Europe). Quaternary Research, 78, 303-314.

Serrano, E., Ruiz Flaño, P., Arroyo, P. y González Trueba, J. J. (2006). Lugares de Interés Geomorfológico. Inventario y valoración aplicada al área de Tiermes Caracena (Provincia de Soria). IX Reunión Nacional de Geomorfología, Santiago de Compostela.

Shannon, C. (1948). A Mathematical Theory of Communication. The Bell System Technical Journal, 27, 379-423, 623-656.

Shulman, L. (1987). Knowledge and teaching: foundations of the new reform. Harvard Educational Review, 57(1), 1-22. Traducción castellana (2005): Conocimiento y 
enseñanza: fundamento de la nueva reforma. Profesorado. Revista de Currículum y Formación de Profesorado, 9(2), 1-30.

Smart, P.L. (1984). The geology, geomorphology and speleogenesis of the eastern massif, Picos de Europa, Spain. Cave Science, 11 (14), 238-245.

Smart, P.L. (1986). Origin and development of glacio-karst closed depressions in the Picos de Europa, Spain. Zeitschrift für Geomorphologie, 30,423-443.

Spangle, P. y Putney, A. (1974). Planificación de Programas Interpretativos, guía para la preparación de programas interpretativos para parques nacionales. Santiago de Chile: Organización de las Naciones Unidas para la Agricultura y la Alimentación, Oficina Regional para América Latina.

Stern, M. y Powell, R. (2013). What leads to better visitor outcomes in live interpretation? Journal of Interpretation Research, 18 (2), 9-43.

Stern, M., Powell, R., McLean, K.; Martin, E., Thomsen, J. y Mutchler, B. (2013). The Difference Between Good Enough and Great: Bringing Interpretive Best Practices to Life. Journal of Interpretation Research, 18 (2), 79-100.

Stokes, A., Cook, S. y Drew, D. (2003). Geotourism: the new trend in travel. Washington: Travel Industry Association of America.

Swarbrooke, J. (1998). Sustainable Tourism Management. Nueva York: CABI Publishing.

Tarlton, J. y Ward. C. (2006). The effect of thematic interpretation on a child's knowledge of an interpretive program. Journal of Interpretation Research, 11 (1), 7-33.

Tilden, F. (2006). La interpretación de nuestro patrimonio. (orig. 1957). Sevilla: Asociación para la Interpretación del Patrimonio.

Torres. M. (2012). El Diseño en la comunicación del patrimonio cultural. (Tesis de Maestría). Universidad de Palermo, Buenos Aires.

Tourism Tasmania (2005). Tasmanian Thematic Interpretation Planning Manual. Hobart: Autor.

Tricart, J. (1963). Géomorphologie des régions froides. Paris: Presses universitaires de France.

Tricart, J. y Cailleux, A. (1967). Le modelé des régions périglaciaires. Paris: Société d'edition d'enseignement supérieur.

Valero, E. (2008). Análisis de las definiciones y elaboración de un patrón definitorio del grupo de términos 'defectos del producto cerámico'. Fòrum de Recerca: XIII Jornadas de Fomento de la investigación en Traducción (Universitat Jaume I), Castellón.

Veverka, J. (1994). Interpretative master planning. Montana: Falcon Press. 
Villa Otero, E. (Dir.) (2010). Parque Nacional Picos de Europa. Guía Geológica. Madrid: OAPNIGME.

Viñals, M., Morant, M. y Quintana, R. (2011). Análisis de los criterios para la valoración turística del patrimonio natural. Investigaciones Turísticas, 1, 37-50.

Voth, A. (2008). Los geoparques y el geoturismo: nuevos conceptos de valoración de recursos patrimoniales y desarrollo regional. XI Coloquio Ibérico de Geografía. Tercera ponencia: Dimensiones sociales y políticas del medio ambiente y la ordenación del territorio, Alcalá de Henares-Pastrana, España

Washburn, A. (1973). Periglacial processes and environments. Londres: Edward Arnold (Publishers) Ltd.

Wearing, S., Archer, D., Moscardo, G. y Schweinsberg, S. (2007). Best practice interpretation research for sustainable tourism. Framework for a New Research Agenda. Gold Coast: Sustainable Tourism Cooperative Research Centre.

Weaver, D. y Lawton, L. (2007). Twenty years on: the state of contemporary ecotourism research. Tourism Management, 28, 1168-1179.

Weiler, B. (1999). Assessing the interpretation competencies of ecotours guides. Journal of Interpretation Research, 4 (1), 80-83.

Wiles, R. y Hall, T. (2005). Can interpretive messages change park visitors' views on wildland fire? Journal of Interpretation Research, 10 (2), 18-35.

Winters, A. (2009). Creation of the Murie Museum Interpretive Plan. (Tesis de Maestría). Utah State University, Logan.

Wood, M. (2002). Ecotourism: principles, practices y policies for sustainability. Paris: UNEP.

Zabala, A. (1995). La práctica educativa. Cómo enseñar. Barcelona: Graó.

Zamora Baño, F. (2002). La gestión del patrimonio cultural en España: presente y futuro. Conferencia pronunciada en el Congreso sobre Patrimonio organizado en el seno de la exposición AR\&PA, Valladolid.

Zouros, N. (2007). Geomorphosite assessment and management in protected areas of Greece. Case study of the Lesvos island - coastal geomorphosites. Geographica Helvetica, 62 (3), 159-180. 
La Interpretación del Patrimonio Geomorfológico en los Picos de Europa: una propuesta para su aprovechamiento didáctico y geoturístico

\section{Anexos}


La Interpretación del Patrimonio Geomorfológico en los Picos de Europa: una propuesta para su aprovechamiento didáctico y geoturístico 


\section{A.1) Currículos oficiales de Educación Primaria, ESO y Bachillerato de Asturias.}

Tabla 92. Principales contenidos geológicos presentes en los currículos oficiales de Asturias de Educación Primaria, ESO y Bachillerato.

\begin{tabular}{|c|c|c|c|}
\hline Escolaridad & & Asignatura & Contenidos \\
\hline \multirow{3}{*}{$\begin{array}{l}\text { Educación } \\
\text { Primaria }\end{array}$} & $\begin{array}{l}\text { Primer } \\
\text { ciclo }\end{array}$ & \multirow{3}{*}{$\begin{array}{l}\text { Conocimiento del } \\
\text { medio natural, } \\
\text { social y cultural. }\end{array}$} & $\begin{array}{l}\text { Bloque 1. El entorno y su conservación } \\
\text { - Observación de las características de rocas por medio de los sentidos. } \\
\text { - Observación y percepción de algunos elementos naturales y humanos de paisajes asturianos del entorno. }\end{array}$ \\
\hline & $\begin{array}{l}\text { Segundo } \\
\text { ciclo }\end{array}$ & & $\begin{array}{l}\text { Bloque 1. El entorno y su conservación. } \\
\text { - Identificación y clasificación elemental de rocas. } \\
\text { - Formas de relieve y accidentes geográficos. Localización de los más relevantes en el entorno próximo, en Asturias y en } \\
\text { España. }\end{array}$ \\
\hline & $\begin{array}{l}\text { Tercer } \\
\text { ciclo }\end{array}$ & & $\begin{array}{l}\text { Bloque 1. El entorno y su conservación. } \\
\text { - Identificación y clasificación de rocas y minerales, observando sus propiedades. } \\
\text { - Valoración de la diversidad y riqueza de los paisajes del territorio asturiano y español e interés por conocer paisajes de } \\
\text { otros lugares. }\end{array}$ \\
\hline \multirow[t]{2}{*}{$\begin{array}{l}\text { Educación } \\
\text { Secundaria } \\
\text { Obligatoria }\end{array}$} & $\begin{array}{l}\text { Primer } \\
\text { año }\end{array}$ & $\begin{array}{l}\text { Ciencias de la } \\
\text { Naturaleza }\end{array}$ & $\begin{array}{l}\text { Bloque } 4 \text { (3o sección): La geosfera. } \\
\text { - Introducción a la estructura interna de la Tierra. } \\
\text { - Diversidad de rocas y minerales y características que permiten identificarlos. Los principales minerales y rocas de } \\
\text { Asturias. } \\
\text { - Importancia y utilidad de los minerales. } \\
\text { - Observación y descripción de las rocas más frecuentes. } \\
\text { - Utilización de claves sencillas para identificar minerales y rocas. } \\
\text { - Importancia y utilidad de las rocas. Explotación de minerales y rocas. } \\
\text { - Yacimientos y explotaciones de minerales y rocas en el Principado de Asturias } \\
\text { Bloque } 5 . \text { Los seres vivos y su diversidad. } \\
\text { Los fósiles y la historia de la vida. }\end{array}$ \\
\hline & $\begin{array}{l}\text { Primer } \\
\text { año }\end{array}$ & $\begin{array}{l}\text { Ciencias Sociales, } \\
\text { Historia y Geografía }\end{array}$ & $\begin{array}{l}\text { Bloque 2. La Tierra y los medios naturales. } \\
\text { Caracterización de los principales medios naturales, identificando los componentes básicos del relieve. }\end{array}$ \\
\hline
\end{tabular}




\begin{tabular}{|c|c|c|}
\hline $\begin{array}{l}\text { Segundo } \\
\quad \text { año }\end{array}$ & $\begin{array}{c}\text { Ciencias de la } \\
\text { Naturaleza }\end{array}$ & $\begin{array}{l}\text { Bloque 4. Transformaciones geológicas debidas a la energía interna de la Tierra. } \\
\text { - Transferencia de energía en el interior de la tierra. } \\
\text { - Las manifestaciones de la energía interna de la Tierra: erupciones volcánicas y terremotos. } \\
\text { - La formación de las rocas magmáticas y metamórficas en el contexto del ciclo de las rocas y de la tectónica de placas. } \\
\text { - Manifestaciones de la geodinámica interna en el relieve terrestre. Identificación de rocas magmáticas y metamórficas y } \\
\text { relación entre su textura y su origen. } \\
\text { - Identificación de algunas de las principales rocas magmáticas y metamórficas utilizadas en el Principado de Asturias. }\end{array}$ \\
\hline $\begin{array}{l}\text { Tercer } \\
\text { año }\end{array}$ & Biología y Geología & $\begin{array}{l}\text { Bloque 4. Transformaciones geológicas debidas a la energía externa. } \\
\text { La actividad geológica externa del planeta Tierra. } \\
\text { - Alteraciones de las rocas producidas por el aire y el agua. La meteorización. } \\
\text { - Los torrentes, ríos y aguas subterráneas como agentes geológicos. La sobreexplotación de acuíferos. La acción geológica } \\
\text { del hielo y el viento. Dinámica marina. } \\
\text { - La formación de rocas sedimentarias. El origen y utilidad del carbón, del petróleo y del gas natural. Valoración de las } \\
\text { consecuencias de su utilización y agotamiento. } \\
\text { - Principales agentes y procesos geológicos externos que actúan en el entorno asturiano. Las principales formas del } \\
\text { relieve. } \\
\text { - Las rocas sedimentarias en el Principado de Asturias }\end{array}$ \\
\hline $\begin{array}{l}\text { Cuarto } \\
\text { año }\end{array}$ & Biología y Geología & $\begin{array}{l}\text { Bloque 2. La Tierra, un planeta en continuo cambio. } \\
\text { - La historia de la Tierra. } \\
\text { El origen de la Tierra. El tiempo geológico: ideas históricas sobre la edad de la Tierra. Principios y procedimientos que } \\
\text { permiten reconstruir su historia. Utilización del actualismo como método de interpretación. } \\
\text { - Los fósiles, su importancia como testimonio del pasado. Los primeros seres vivos y su influencia en el planeta. } \\
\text { - Las eras geológicas: ubicación de acontecimientos geológicos y biológicos importantes. } \\
\text { - Identificación de algunos fósiles característicos. Fósiles y yacimientos fosilíferos del Principado de Asturias. } \\
\text { - Reconstrucción elemental de la historia de un territorio a partir de una columna estratigráfica sencilla. } \\
\text { La tectónica de placas y sus manifestaciones. } \\
\text { - El problema del origen de las cordilleras: algunas interpretaciones históricas. El ciclo de las rocas. } \\
\text { - Pruebas del desplazamiento de los continentes. Distribución de volcanes y terremotos. Las dorsales y el fenómeno de la } \\
\text { expansión del fondo oceánico. } \\
\text { - Interpretación del modelo dinámico de la estructura interna de la Tierra. } \\
\text { - Las placas litosféricas y sus límites. Interacciones entre procesos geológicos internos y externos. Formación de las } \\
\text { cordilleras: tipos y procesos geológicos asociados. } \\
\text { - La tectónica de placas, una revolución en las Ciencias de la Tierra. Utilización de la tectónica de placas para la } \\
\text { interpretación del relieve y de los acontecimientos geológicos. } \\
\text { - Rasgos principales de la evolución geológica de Asturias en el contexto de la Tectónica global. El origen de la cordillera }\end{array}$ \\
\hline
\end{tabular}




\begin{tabular}{|c|c|c|c|}
\hline & & & $\begin{array}{l}\text { Cantábrica. } \\
\text { - Valoración de las consecuencias que la dinámica del interior terrestre tiene en la superficie del planeta. }\end{array}$ \\
\hline & & $\begin{array}{l}\text { Ciencias para el } \\
\text { mundo } \\
\text { contemporáneo } \\
\text { (Materia común) }\end{array}$ & $\begin{array}{l}\text { 2. Nuestro lugar en el universo } \\
\text { - La formación de la Tierra y la diferenciación en capas. La tectónica global de placas y sus manifestaciones. } \\
\text { Interpretación del relieve y acontecimientos geológicos a partir de ortofotografías y mapas topográficos. }\end{array}$ \\
\hline Bachillerato & $\begin{array}{l}\text { Primer } \\
\text { curso }\end{array}$ & $\begin{array}{l}\text { Biología y Geología } \\
\text { (Sólo en Modalidad } \\
\text { Ciencias y } \\
\text { Tecnología) }\end{array}$ & 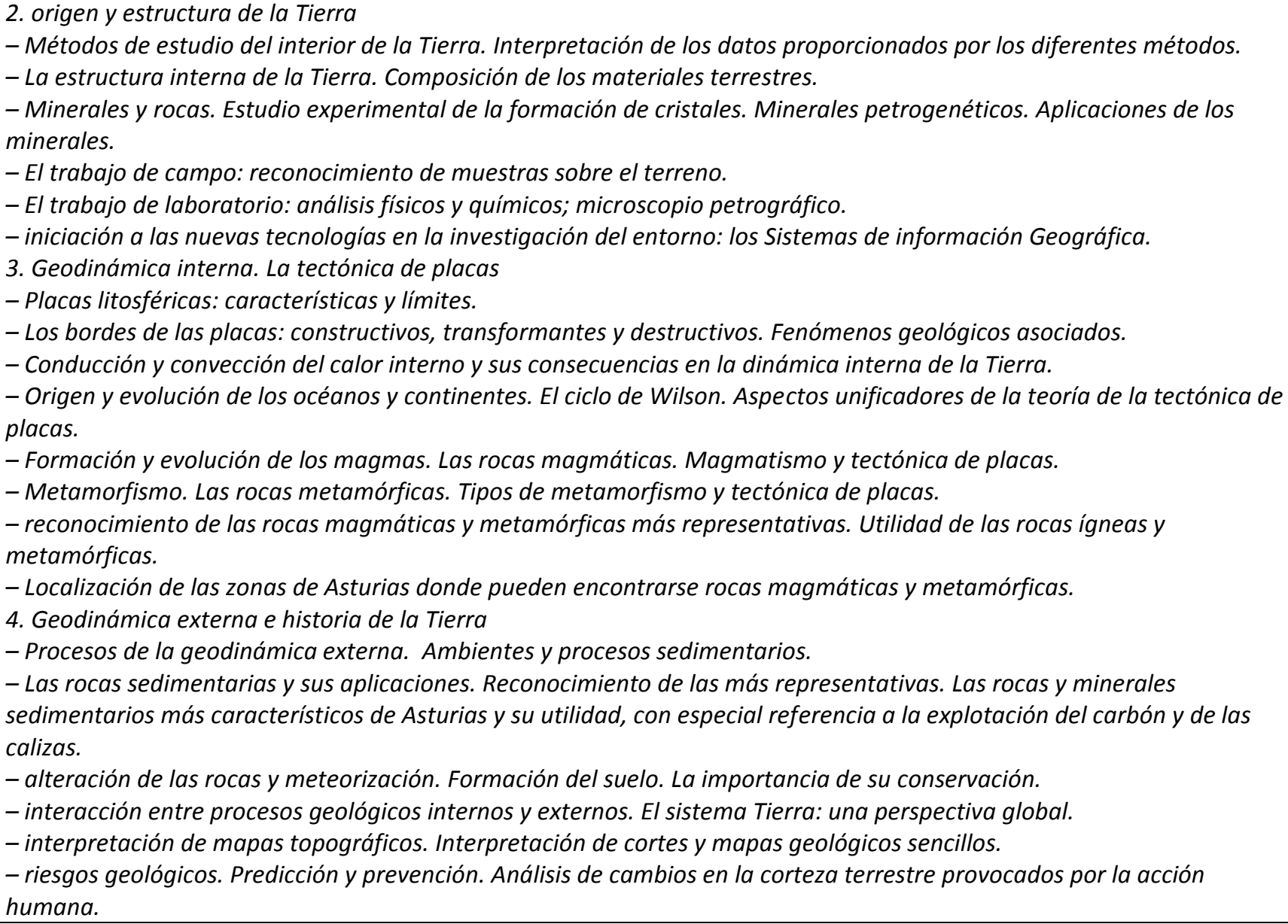 \\
\hline
\end{tabular}




\begin{tabular}{|c|c|c|c|}
\hline & & & $\begin{array}{l}\text { - Procedimientos que permiten la datación y la reconstrucción del pasado terrestre. El tiempo geológico y su división. } \\
\text { Identificación de algunos fósiles característicos. } \\
\text { - Grandes cambios ocurridos en la Tierra. Formación de una atmósfera oxidante. Grandes extinciones. Cambios } \\
\text { climáticos. Cambios en la corteza terrestre provocados por la acción humana. }\end{array}$ \\
\hline & $\begin{array}{c}\text { Segundo } \\
\text { curso }\end{array}$ & $\begin{array}{c}\text { Ciencias de la Tierra } \\
y \\
\text { medioambientales } \\
\text { (Sólo en la } \\
\text { Modalidad Ciencias } \\
\text { y Tecnología) }\end{array}$ & $\begin{array}{l}\text { 4. La geosfera } \\
\text { - Geosfera: formación, estructura y composición. Balance energético de la Tierra. } \\
\text { - origen de la energía interna. La tectónica de placas. Geodinámica interna: procesos magmáticos y metamórficos. } \\
\text { Riesgo volcánico y riesgo sísmico: predicción y prevención. Análisis a partir de mapas estructurales de las causas del } \\
\text { riesgo sísmico y volcánico en el sur de Europa y de las zonas sísmicas de la península ibérica. } \\
\text { - Geodinámica externa: los procesos geológicos externos y el moldeado del relieve. Los procesos de la meteorización. } \\
\text { Sistemas gravitacionales de ladera. } \\
\text { Periglaciarismo y procesos glaciares. La acción geológica de los sistemas fluviales. El relieve como resultado de la } \\
\text { interacción entre la dinámica interna y la dinámica externa de la Tierra. El ambiente sedimentario. Riesgos asociados a } \\
\text { procesos geológicos externos: predicción y prevención. } \\
\text { - recursos de la geosfera y sus reservas. Yacimientos y explotación de recursos minerales. Recursos energéticos } \\
\text { renovables y no renovables. Combustibles fósiles. Energía nuclear. Impactos derivados de la explotación de los recursos } \\
\text { energéticos y minerales. El uso eficiente de la energía. Hábitos de consumo eficiente y responsable de energía. }\end{array}$ \\
\hline
\end{tabular}




\section{A.2) Currículos oficiales de Educación Primaria, ESO y Bachillerato de Cantabria.}

Tabla 93. Principales contenidos geológicos presentes en los currículos oficiales de Cantabria de Educación Primaria, ESO y Bachillerato.

\begin{tabular}{|c|c|c|c|}
\hline Escolaridad & & Asignatura & Contenidos \\
\hline \multirow{3}{*}{$\begin{array}{l}\text { Educación } \\
\text { Primaria }\end{array}$} & $\begin{array}{c}\text { Primer } \\
\text { ciclo }\end{array}$ & \multirow{3}{*}{$\begin{array}{l}\text { Conocimiento del } \\
\text { medio natural, } \\
\text { social y cultural. }\end{array}$} & No presenta \\
\hline & $\begin{array}{l}\text { Segundo } \\
\text { ciclo }\end{array}$ & & $\begin{array}{l}\text { Bloque 1. El entorno y su conservación. } \\
\text { - Principales elementos, características y usos del medio físico. Identificación y clasificación elemental de rocas. } \\
\text { Utilización de técnicas de recogida de muestras de las rocas más frecuentes en el entorno. }\end{array}$ \\
\hline & $\begin{array}{l}\text { Tercer } \\
\text { ciclo }\end{array}$ & & $\begin{array}{l}\text { Bloque 1. El entorno y su conservación. } \\
\text { - Las rocas, minerales y el relieve en la configuración del paisaje. Planificación y realización de experiencias para estudiar } \\
\text { sus propiedades y características. Identificación y clasificación de rocas y minerales. }\end{array}$ \\
\hline \multirow{4}{*}{$\begin{array}{l}\text { Educación } \\
\text { Secundaria } \\
\text { Obligatoria }\end{array}$} & \multirow[t]{2}{*}{$\begin{array}{l}\text { Primer } \\
\text { año }\end{array}$} & \multirow[t]{2}{*}{$\begin{array}{l}\text { Ciencias de la } \\
\text { Naturaleza }\end{array}$} & $\begin{array}{l}\text { Bloque } 3 \text { (3o sección): La geosfera } \\
\text { - Diversidad de rocas y minerales y características que permiten identificarlos. } \\
\text { - Importancia y utilidad de los minerales. } \\
\text { - Observación y descripción de las rocas más frecuentes. } \\
\text { - Utilización de claves sencillas para identificar minerales y rocas. } \\
\text { - Las rocas y minerales como recursos no renovables. } \\
\text { - Importancia y utilidad de las rocas. Explotación de minerales y rocas. } \\
\text { - Introducción a la estructura interna de la tierra. }\end{array}$ \\
\hline & & & $\begin{array}{l}\text { Bloque 4: Los seres vivos y su diversidad } \\
\text { - Los fósiles y la historia de la vida. }\end{array}$ \\
\hline & $\begin{array}{l}\text { Segundo } \\
\quad \text { año }\end{array}$ & $\begin{array}{l}\text { Ciencias de la } \\
\text { Naturaleza }\end{array}$ & $\begin{array}{l}\text { Bloque 4: Transformaciones geológicas debidas a la energía del interior de la Tierra } \\
\text { Transferencia de energía en el interior de la Tierra. } \\
\text { - Las manifestaciones de la energía del interior de la Tierra: erupciones volcánicas y terremotos. } \\
\text { - Identificación de las rocas magmáticas y metamórficas y relación entre su textura y su origen. } \\
\text { - Manifestaciones de la geodinámica interna en el relieve terrestre. }\end{array}$ \\
\hline & $\begin{array}{l}\text { Tercer } \\
\text { año }\end{array}$ & Biología y Geología & $\begin{array}{l}\text { Bloque 7: Transformaciones geológicas debidas a la energía externa } \\
\text { La actividad geológica externa del planeta Tierra. } \\
\text { - Alteraciones de las rocas producidas por el aire y el agua. La meteorización. } \\
\text { - Las aguas salvajes, los torrentes, los ríos y las aguas subterráneas como agentes geológicos. La acción geológica del } \\
\text { hielo y el viento. } \\
\text { Erosión, transporte y sedimentación. }\end{array}$ \\
\hline
\end{tabular}




\begin{tabular}{|c|c|c|c|}
\hline & & & - La formación de rocas sedimentarias. \\
\hline & $\begin{array}{c}\text { Cuarto } \\
\text { año }\end{array}$ & Biología y Geología & $\begin{array}{l}\text { Bloque 2: La Tierra, un planeta en continuo cambio. } \\
\text { La historia de la Tierra. } \\
\text { - El origen de la Tierra. El tiempo geológico: ideas históricas sobre la edad de la Tierra. Principios y procedimientos que } \\
\text { permiten reconstruir su historia. Utilización del actualismo como método de interpretación. } \\
\text { - Los fósiles, su importancia como testimonio del pasado. } \\
\text { - Las eras geológicas: ubicación de acontecimientos geológicos y biológicos importantes. } \\
\text { - Identificación de algunos fósiles característicos. } \\
\text { La tectónica de placas y sus manifestaciones. } \\
\text { - El problema del origen de las cordilleras: algunas interpretaciones históricas. Wegener y la deriva continental. } \\
\text { Pruebas del desplazamiento de los continentes. } \\
\text { - Interpretación del modelo dinámico de la estructura interna de la Tierra. } \\
\text { - La tectónica de placas, una revolución en las Ciencias de la Tierra. Utilización de la tectónica de placas para la } \\
\text { interpretación del relieve y de los acontecimientos geológicos. } \\
\text { - Las placas litosféricas y sus límites. Distribución de volcanes y terremotos. Las dorsales y el fenómeno de la expansión } \\
\text { del fondo oceánico. Las fosas oceánicas y las zonas de subducción. Formación de las cordilleras: tipos y procesos } \\
\text { geológicos asociados. } \\
\text { - Estructuras tectónicas: pliegues, fallas y diaclasas. } \\
\text { - Interacciones entre procesos geológicos internos y externos. El ciclo de las rocas. } \\
\text { - Reconstrucción elemental de la historia de un territorio a partir de un corte geológico sencillo. } \\
\text { - Valoración de las consecuencias que la dinámica del interior terrestre tiene en la superficie del planeta. }\end{array}$ \\
\hline \multirow[b]{2}{*}{ Bachillerato } & \multirow[b]{2}{*}{$\begin{array}{c}\text { Primer } \\
\text { curso }\end{array}$} & $\begin{array}{l}\text { Ciencias para el } \\
\text { mundo } \\
\text { contemporáneo } \\
\text { (Materia común) }\end{array}$ & $\begin{array}{l}\text { 2. Nuestro lugar en el Universo: } \\
\text { - La formación de la Tierra y la diferenciación en capas. } \\
\text { La tectónica global. }\end{array}$ \\
\hline & & $\begin{array}{c}\text { Biología y Geología } \\
\text { (Sólo en Modalidad } \\
\text { Ciencias y } \\
\text { Tecnología) }\end{array}$ & $\begin{array}{l}\text { 1. Origen y estructura de la Tierra: } \\
\text { - Métodos de estudio del interior de la Tierra. Interpretación de los datos proporcionados por los diferentes métodos. } \\
\text { - La estructura interna de la Tierra. Composición de los materiales terrestres. Modelo geoquímico y Modelo dinámico. } \\
\text { - Minerales y rocas. Estudio experimental de la formación de cristales. Minerales petrogenéticos. } \\
\text { - Iniciación a las nuevas tecnologías en la investigación del entorno: los Sistemas de Información Geográfica. } \\
\text { - El trabajo de campo: reconocimiento de muestras sobre el terreno. } \\
\text { - El trabajo de laboratorio: análisis físicos y químicos; microscopio petrográfico. } \\
\text { 2. Geodinámica interna. La tectónica de placas: } \\
\text { - Placas litosféricas: características y límites. Los bordes de las placas: constructivos, transformantes y destructivos. } \\
\text { Fenómenos geológicos asociados. }\end{array}$ \\
\hline
\end{tabular}




\begin{tabular}{|c|c|c|}
\hline & & $\begin{array}{l}\text { - Deformaciones de los materiales terrestres: pliegues, fallas y diaclasas. } \\
\text { - Conducción y convección del calor interno y sus consecuencias en la dinámica interna de la Tierra. } \\
\text { - Origen y evolución de los océanos y continentes. El ciclo de Wilson. Aspectos unificadores de la teoría de la tectónica de } \\
\text { placas. } \\
\text { - Formación y evolución de los magmas. Las rocas magmáticas. Magmatismo y tectónica de placas. } \\
\text { - Metamorfismo. Las rocas metamórficas. Tipos de metamorfismo y tectónica de placas. } \\
\text { Reconocimiento de las rocas magmáticas y metamórficas más representativas. Utilidad de las rocas ígneas y } \\
\text { metamórficas. } \\
\text { 3. Geodinámica externa e historia de la Tierra: } \\
\text { - Procesos de la geodinámica externa: meteorización, erosión, transporte, sedimentación y litificación o diagénesis. } \\
\text { Ambientes sedimentarios. } \\
\text { - Las rocas sedimentarias y sus aplicaciones. Reconocimiento de las más representativas. } \\
\text { - Alteración de las rocas y meteorización. Formación del suelo. El suelo como recurso. La importancia de su conservación. } \\
\text { - Interacción entre procesos geológicos internos y externos. El sistema Tierra: una perspectiva global. } \\
\text { - Riesgos geológicos. Predicción y prevención. } \\
\text { - Procedimientos que permiten la datación y la reconstrucción del pasado terrestre. El tiempo geológico y su división. } \\
\text { Identificación de algunos fósiles característicos. } \\
\text { - Interpretación de mapas topográficos, cortes y mapas geológicos sencillos. } \\
\text { - Grandes cambios ocurridos en la Tierra. Formación de una atmósfera oxidante. Grandes extinciones. Cambios } \\
\text { climáticos. } \\
\text { - Cambios en la corteza terrestre provocados por la acción humana. }\end{array}$ \\
\hline $\begin{array}{l}\text { Segundo } \\
\text { curso }\end{array}$ & $\begin{array}{c}\text { Ciencias de la Tierra } \\
y \\
\text { medioambientales } \\
\text { (Sólo en la } \\
\text { Modalidad Ciencias } \\
\text { y Tecnología) }\end{array}$ & $\begin{array}{l}\text { 4. La geosfera: } \\
\text { - Geosfera: estructura y composición. Balance energético de la Tierra. } \\
\text { - Origen de la energía interna. Geodinámica interna. El papel de la tectónica de placas en la dinámica de los procesos } \\
\text { tectónicos y volcánicos. Riesgo volcánico y sísmico: predicción y prevención. } \\
\text { - Geodinámica externa. Procesos geológicos externos. Sistemas de ladera y sistemas fluviales y la dinámica de sus } \\
\text { procesos. Riesgos asociados: predicción y prevención. El relieve como resultado de la interacción entre la dinámica } \\
\text { interna y la dinámica externa de la Tierra. } \\
\text { - Recursos de la geosfera y sus reservas. Yacimientos minerales. Recursos energéticos. Combustibles fósiles. } \\
\text { Energía nuclear. Impactos derivados de la explotación de los recursos. Gestión sostenible de los recursos y los residuos. }\end{array}$ \\
\hline & $\begin{array}{c}\text { Geología } \\
\text { (Materia optativa) }\end{array}$ & $\begin{array}{l}\text { 2. Mineralogía. } \\
\text { - Concepto de mineral y roca. Formación y crecimiento de los cristales. Composición química de los minerales. } \\
\text { Isomorfismo y polimorfismo. } \\
\text { - Estructura interna de los minerales. Orden y simetría cristalina. Redes cristalinas y elementos de simetría. Sistemas de } \\
\text { cristalización. }\end{array}$ \\
\hline
\end{tabular}




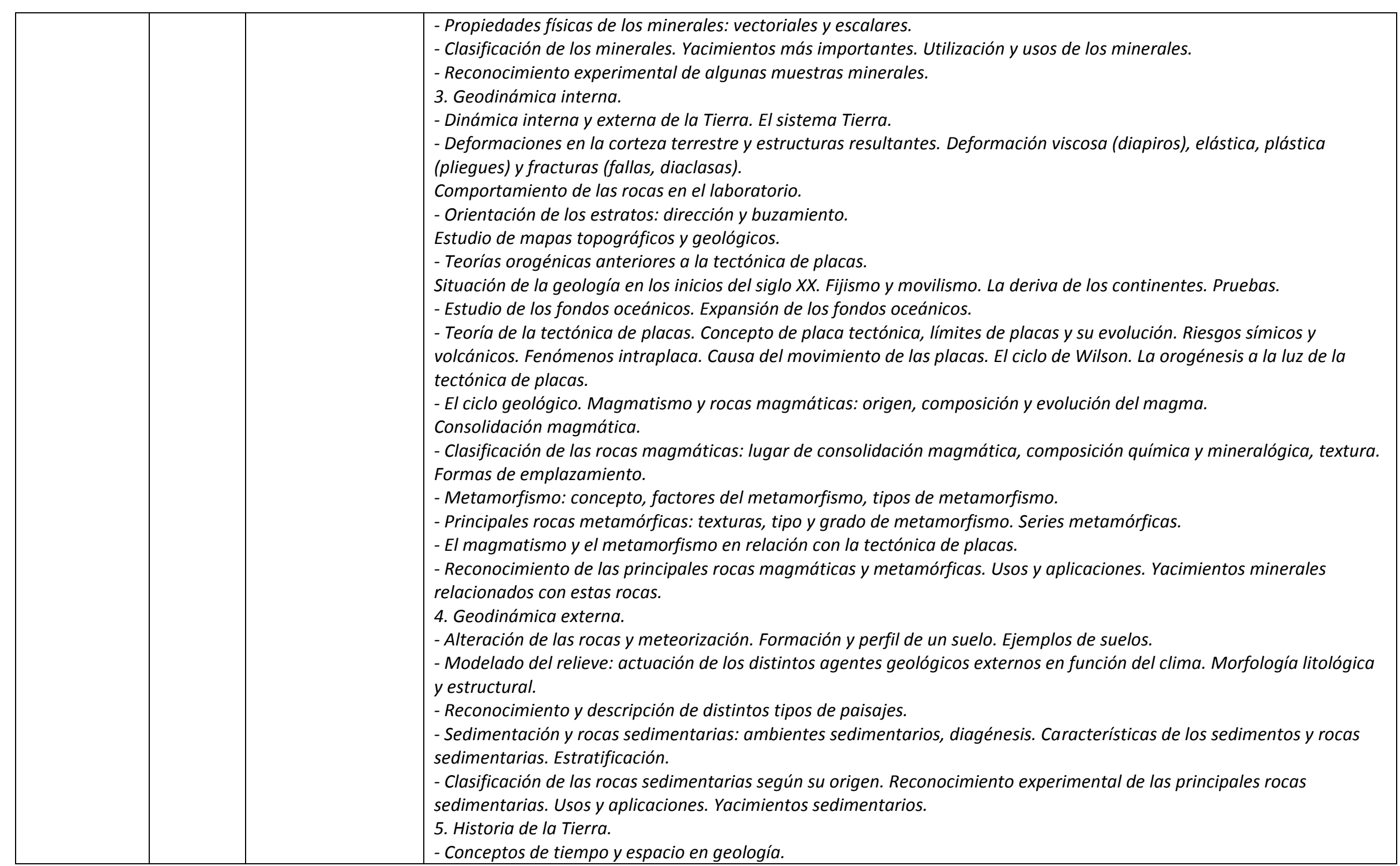




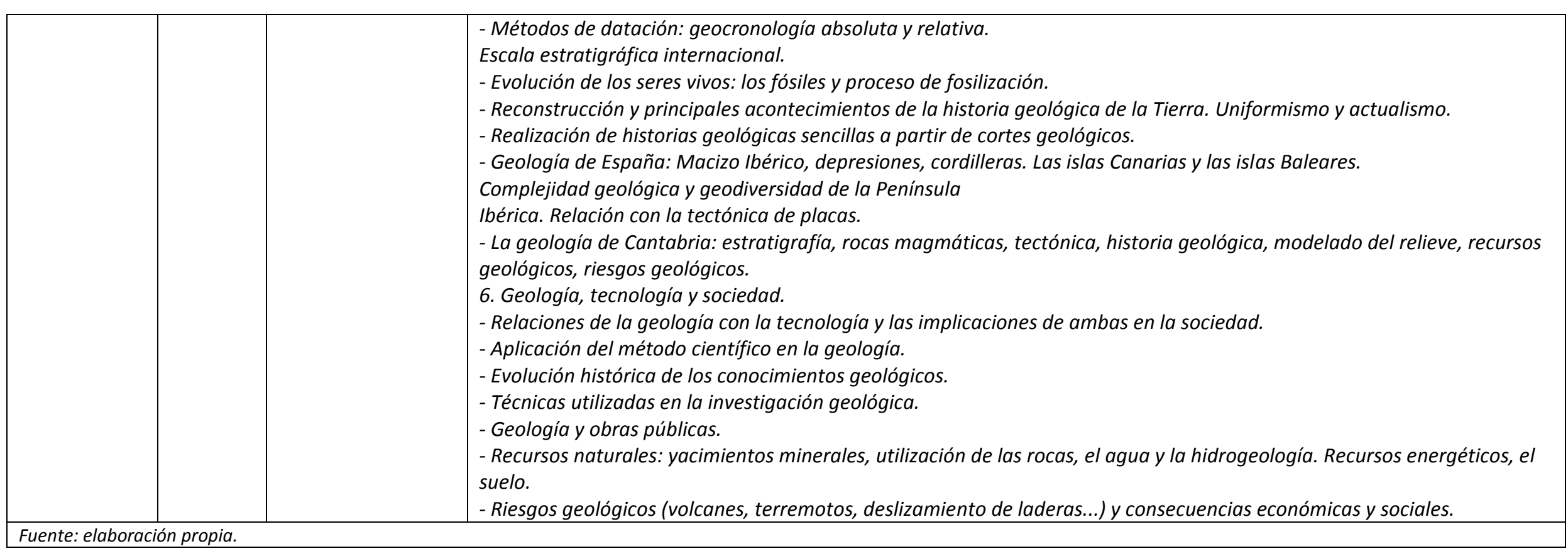




\section{A.3) Currículos oficiales de Educación Primaria, ESO y Bachillerato de Castilla y León.}

Tabla 94. Principales contenidos geológicos presentes en los currículos oficiales de Castilla y León de Educación Primaria, ESO y Bachillerato.

\begin{tabular}{|c|c|c|c|}
\hline Escolaridad & & Asignatura & Contenidos \\
\hline \multirow{3}{*}{$\begin{array}{l}\text { Educación } \\
\text { Primaria }\end{array}$} & $\begin{array}{c}\text { Primer } \\
\text { ciclo }\end{array}$ & \multirow{3}{*}{$\begin{array}{l}\text { Conocimiento del } \\
\text { medio natural, } \\
\text { social y cultural. }\end{array}$} & No presenta \\
\hline & $\begin{array}{l}\text { Segundo } \\
\text { ciclo }\end{array}$ & & $\begin{array}{l}\text { Bloque 1. Geografía. El entorno y su conservación. } \\
\text { - Minerales, rocas y suelos. Recogida, identificación y análisis elemental de muestras sin deteriorar el medio. }\end{array}$ \\
\hline & $\begin{array}{c}\text { Tercer } \\
\text { ciclo }\end{array}$ & & $\begin{array}{l}\text { Bloque 1. Geografía. El entorno y su conservación. } \\
\text { - Minerales y rocas. Identificación y clasificación. Los componentes del suelo. }\end{array}$ \\
\hline \multirow[t]{2}{*}{$\begin{array}{l}\text { Educación } \\
\text { Secundaria } \\
\text { Obligatoria }\end{array}$} & $\begin{array}{l}\text { Primer } \\
\text { año }\end{array}$ & $\begin{array}{l}\text { Ciencias de la } \\
\text { Naturaleza }\end{array}$ & $\begin{array}{l}\text { Bloque } 3 \text { (3o sección): La geosfera. } \\
\text { - Estructura interna de la Tierra. } \\
\text { - La corteza terrestre: su superficie, composición química y elementos geoquímicos. } \\
\text { - Composición química y petrológica de las capas de la Tierra. } \\
\text { - Los minerales y las rocas: concepto de mineral y roca. } \\
\text { - Tipos de rocas: sedimentarias, magmáticas y metamórficas. Importancia y utilidad de las rocas. Observación y } \\
\text { descripción de las rocas más frecuentes. } \\
\text { - Utilidad, importancia y abundancia relativa de los minerales. } \\
\text { Observación y descripción de los minerales más frecuentes. } \\
\text { - Utilización de claves sencillas para identificar minerales y rocas. } \\
\text { - Explotación de minerales y rocas. } \\
\text { - Observación y posterior reconocimiento de los minerales y rocas más representativos del entorno inmediato. } \\
\text { Bloque } 4 \text { (3o sección): El entorno natural inmediato. } \\
\text { - Los accidentes geológicos que conforman el paisaje. } \\
\text { - Rocas y minerales característicos: localización. } \\
\text { - Las principales especies fúngicas y vegetales: descripción y clasificación. } \\
\text { - Las principales especies animales: descripción y clasificación. }\end{array}$ \\
\hline & $\begin{array}{l}\text { Segundo } \\
\quad \text { año }\end{array}$ & $\begin{array}{l}\text { Ciencias de la } \\
\text { Naturaleza }\end{array}$ & $\begin{array}{l}\text { Bloque 4. Transformaciones geológicas debidas a la energía interna de la Tierra. } \\
\text { La energía interna del planeta. } \\
\text { - Las manifestaciones de la energía interna de la Tierra: erupciones volcánicas y terremotos. } \\
\text { - Interpretación del comportamiento de las ondas sísmicas y su contribución al conocimiento del interior de la Tierra. } \\
\text { - Distribución de terremotos y volcanes y descubrimiento de las placas litosféricas. } \\
\text { - Movimientos de los continentes. } \\
\text { - Valoración de los riesgos volcánico y sísmico y de su predicción y prevención. }\end{array}$ \\
\hline
\end{tabular}




\begin{tabular}{|c|c|c|}
\hline \multirow[b]{2}{*}{$\begin{array}{c}\text { Tercer } \\
\text { año }\end{array}$} & & $\begin{array}{l}\text { - Estudio del ciclo de las rocas. } \\
\text { - La formación de rocas magmáticas y metamórficas. Identificación de tipos de rocas y relación entre su textura y origen. } \\
\text { - Interpretación del relieve terrestre como resultado de la acción de las fuerzas internas y externas del planeta. } \\
\text { Bloque } 7 . \text { El entorno natural: la naturaleza en Castilla y León. } \\
\text { - Los accidentes geológicos que conforman el paisaje y el clima. } \\
\text { - Rocas y minerales significativos. } \\
\text { - Especies vegetales configuradoras del paisaje. } \\
\text { - Especies animales significativas. }\end{array}$ \\
\hline & Biología y Geología & $\begin{array}{l}\text { Bloque 7. Transformaciones geológicas debidas a la energía externa. } \\
\text { La actividad geológica externa del planeta Tierra. El ciclo litológico y su imbricación en el ciclo geológico: } \\
\text { - La energía solar en la Tierra. La atmósfera y su dinámica. Interpretación de mapas del tiempo sencillos. El relieve } \\
\text { terrestre y su representación. Los mapas topográficos: lectura. } \\
\text { - Alteraciones de las rocas producidas por el aire y el agua. La meteorización. } \\
\text { - Los torrentes, ríos y aguas subterráneas como agentes geológicos. La sobreexplotación de acuíferos. La acción } \\
\text { geológica del hielo y el viento. Dinámica marina. } \\
\text { - La formación de rocas sedimentarias. Clasificación de las rocas sedimentarias. El origen y utilidad del carbón, petróleo y } \\
\text { gas natural. } \\
\text { Valoración de las consecuencias de su utilización y agotamiento. }\end{array}$ \\
\hline $\begin{array}{c}\text { Cuarto } \\
\text { año }\end{array}$ & Biología y Geología & $\begin{array}{l}\text { Bloque 2. La Tierra, un planeta en continuo cambio. } \\
\text { El modelado del relieve terrestre. } \\
\text { - Concepto de relieve. Agentes y procesos externos: meteorización, erosión, transporte y sedimentación. } \\
\text { - Factores externos del modelado del relieve: litológicos, estructurales, dinámicos, climáticos y antrópicos. El modelado } \\
\text { litoral. El modelado kárstico. } \\
\text { - Los sistemas morfoclimáticos. Clasificación. Los sistemas morfoclimáticos de zonas templadas y de zonas desérticas. } \\
\text { La historia de la Tierra. } \\
\text { - El origen de la Tierra. El tiempo geológico: ideas históricas sobre la edad de la Tierra. Principios y procedimientos que } \\
\text { permiten reconstruir su historia. Utilización del actualismo como método de interpretación. } \\
\text { - Los fósiles, su importancia como testimonio del pasado. Los primeros seres vivos y su influencia en el planeta. } \\
\text { - Reconocimiento de los fósiles guía más importantes. } \\
\text { - Historia geológica de la Tierra: las eras geológicas. Ubicación de los acontecimientos geológicos y biológicos más } \\
\text { significativos. } \\
\text { - Identificación de algunos fósiles característicos. } \\
\text { - Reconstrucción elemental de la historia de un territorio a partir de una columna estratigráfica sencilla. } \\
\text { La tectónica de placas y sus manifestaciones. } \\
\text { - El problema del origen de las cordilleras: algunas interpretaciones históricas. El ciclo de las rocas. }\end{array}$ \\
\hline
\end{tabular}




\begin{tabular}{|c|c|c|c|}
\hline & & & $\begin{array}{l}\text { - Distribución geográfica de terremotos y volcanes. Wegener y la deriva continental. La expansión del fondo oceánico. } \\
\text { Pruebas de la tectónica de placas. } \\
\text { - Las placas litosféricas. Bordes de placa. La formación de cordilleras: tipos y procesos geológicos asociados. } \\
\text { - Fenómenos geológicos asociados al movimiento de las placas: los terremotos. El plano de Benioff. Vulcanismo terrestre. } \\
\text { Las dorsales oceánicas. Las fosas submarinas. La subducción. Las estructuras tectónicas: pliegues, fallas y mantos de } \\
\text { corrimiento. } \\
\text { - La tectónica de placas, una revolución en las Ciencias de la Tierra. Utilización de la tectónica de placas para la } \\
\text { interpretación del relieve y de los acontecimientos geológicos. } \\
\text { - Valoración de las consecuencias que la dinámica del interior terrestre tiene en la superficie del planeta. }\end{array}$ \\
\hline \multirow[b]{2}{*}{ Bachillerato } & \multirow{2}{*}{$\begin{array}{c} \\
\\
\text { Primer } \\
\text { curso }\end{array}$} & $\begin{array}{l}\text { Ciencias para el } \\
\text { mundo } \\
\text { contemporáneo } \\
\text { (Materia común) }\end{array}$ & $\begin{array}{l}\text { 2. Nuestro lugar en el Universo: } \\
\text { La formación de la Tierra y la diferenciación en capas. Lylle y los principios de la geología. Wegener y la deriva de los } \\
\text { continentes. La tectónica global. }\end{array}$ \\
\hline & & $\begin{array}{l}\text { Biología y Geología } \\
\text { (Sólo en Modalidad } \\
\text { Ciencias y } \\
\text { Tecnología) }\end{array}$ & $\begin{array}{l}\text { 1. Origen y estructura de la Tierra: } \\
\text { - Métodos de estudio del interior de la Tierra. Interpretación de los datos proporcionados por los diferentes métodos. } \\
\text { - La estructura interna de la Tierra. Composición de los materiales terrestres. } \\
\text { - Minerales y rocas. Estudio experimental de la formación de cristales. Minerales petrogenéticos. } \\
\text { - Iniciación a las nuevas tecnologías en la investigación del entorno: los Sistemas de Información Geográfica. } \\
\text { - El trabajo de campo: reconocimiento de muestras sobre el terreno. } \\
\text { - El trabajo de laboratorio: análisis físicos y químicos; microscopio petrográfico. } \\
\text { 2. Geodinámica interna. La tectónica de placas: } \\
\text { - Placas litosféricas: características y límites. Los bordes de las placas: constructivos, transformantes y destructivos. } \\
\text { - Fenómenos geológicos asociados. } \\
\text { - Conducción y convección del calor interno y sus consecuencias en la dinámica interna de la Tierra. } \\
\text { - Origen y evolución de los océanos y continentes. El ciclo de Wilson. } \\
\text { Aspectos unificadores de la teoría de la tectónica de placas. } \\
\text { - Formación y evolución de los magmas. Las rocas magmáticas. } \\
\text { Magmatismo y tectónica de placas. } \\
\text { - Metamorfismo. Las rocas metamórficas. Tipos de metamorfismo y tectónica de placas. } \\
\text { - Reconocimiento de las rocas magmáticas y metamórficas más representativas. Utilidad de las rocas ígneas y } \\
\text { metamórficas. } \\
\text { 3. Geodinámica externa e historia de la Tierra: } \\
\text { - Procesos de la geodinámica externa. Ambientes y procesos sedimentarios. } \\
\text { - Las rocas sedimentarias y sus aplicaciones. Reconocimiento de las más representativas. } \\
\text { Alteración de las rocas y meteorización. Formación del suelo. La importancia de su conservación. }\end{array}$ \\
\hline
\end{tabular}




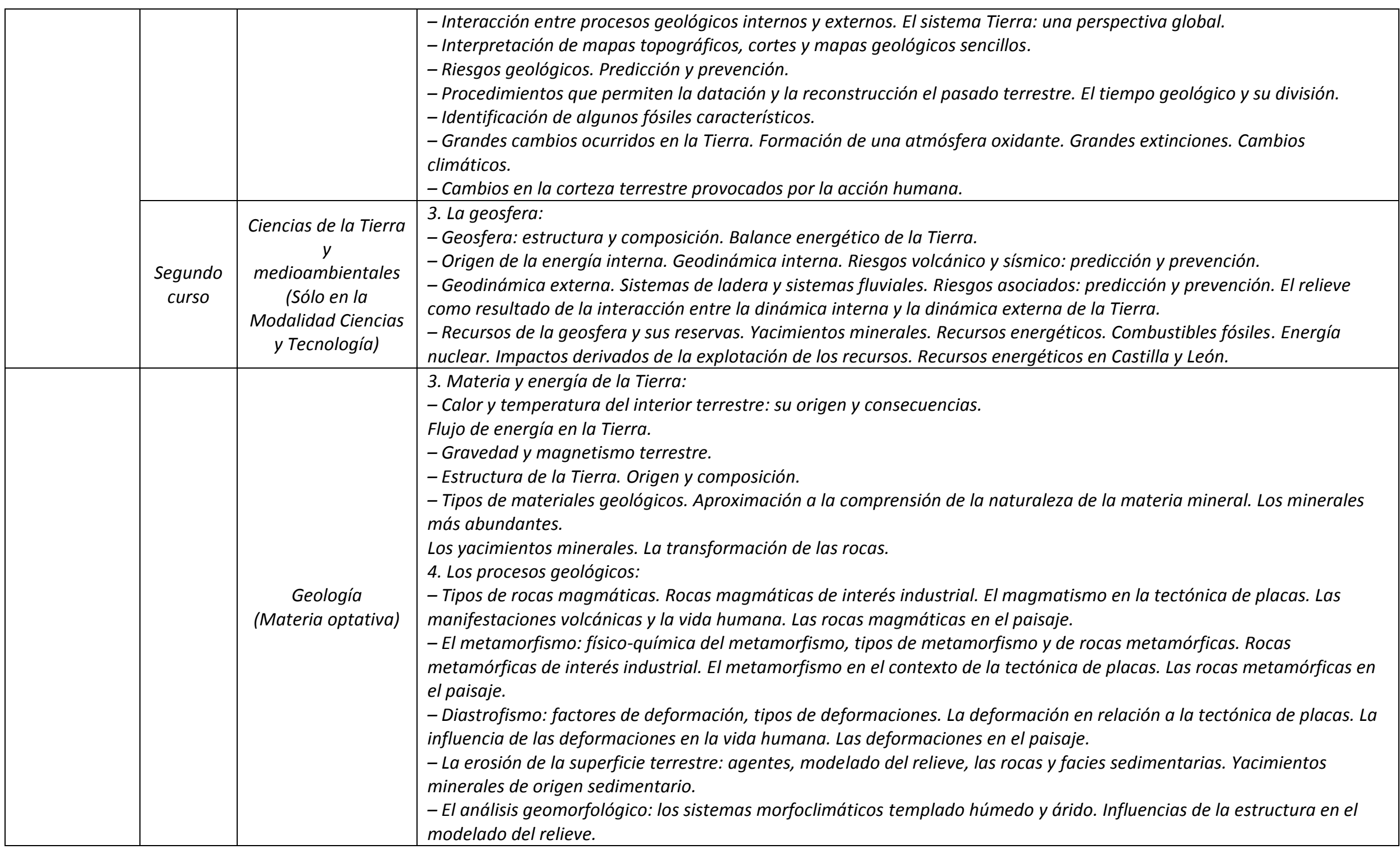




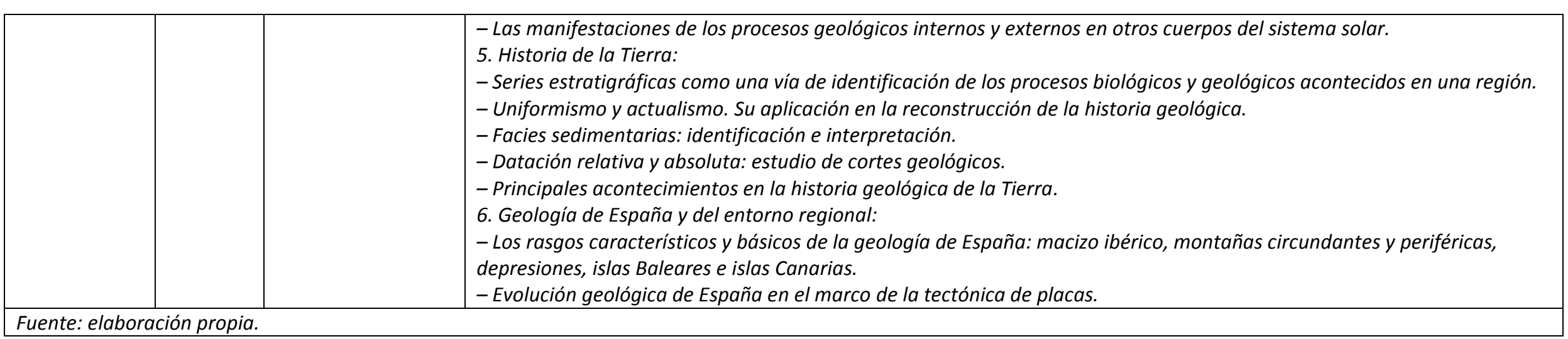




\section{A.4) Grados oficiales de la Universidad de Asturias relacionados con contenidos geomorfológicos.}

Tabla 95. Principales contenidos geológicos y geomorfológicos presentes en grados oficiales de la Universidad de Asturias.

\begin{tabular}{|c|c|c|c|}
\hline \multicolumn{4}{|c|}{ Universidad de Oviedo } \\
\hline Carrera & Curso & Asignatura & Contenido \\
\hline \multirow{2}{*}{$\begin{array}{c}\text { Grado en } \\
\text { Geografía y } \\
\text { Ordenación del } \\
\text { Territorio } \\
\text { (Ciclo 2013- } \\
\text { 2014) }\end{array}$} & 20 & $\begin{array}{l}\text { Geomorfología } \\
\text { estructural }\end{array}$ & $\begin{array}{l}\text { 1. CONCEPTOS Y MÉTODOS BASICOS PARA ANALIZAR E } \\
\text { INTERPRETAR LAS RELACIONES ENTRE ESTRUCTURA Y } \\
\text { RELIEVE TERRESTRE. La naturaleza de los materiales } \\
\text { rocosos (litología) y su disposición interna (tectónica), } \\
\text { dos aspectos estructurales básicos. La noción de forma } \\
\text { estructural, dependiente de los dinamismos interno y } \\
\text { externo de la corteza terrestre: formas primitivas y } \\
\text { formas derivadas. Imágenes y documentos } \\
\text { cartográficos útiles para el análisis de las formas } \\
\text { estructurales. } \\
\text { 2. LITOLOGÍA Y RELIEVES CONTROLADOS POR LA } \\
\text { NATURALEZA DE LAS ROCAS. Principales caracteres } \\
\text { petrográficos y modos de yacimiento de las rocas } \\
\text { magmáticas, sedimentarias y metamórficas. Dos } \\
\text { ejemplos clásicos de la influencia litológica en los } \\
\text { procesos de modelado: los relieves cársticos y } \\
\text { graníticos. }\end{array}$ \\
\hline & 30 & $\begin{array}{l}\text { Dinámica del } \\
\text { modelado }\end{array}$ & $\begin{array}{l}\text { TEMA 2. EL MODELADO ELEMENTAL DE LOS } \\
\text { PROCESOS EROSIVOS. Las características de los } \\
\text { afloramientos rocosos. LOS procesos elementales: } \\
\text { mecánicos y químicos. EI modelado de detalle de los } \\
\text { procesos elementales y las formaciones superficiales. } \\
\text { TEMA 3. LAS FUERZAS MORFODINÁMICAS Y LOS } \\
\text { PROCESOS DE TRANSPORTE Y MODELADO EN LAS } \\
\text { VERTIENTES. Las características de las fuerzas } \\
\text { morfodinámicas: gravedad y convección térmica. Los } \\
\text { desplazamientos gravitatorios y la regularización de las } \\
\text { vertientes. Los desplazamientos en masa. La arroyada } \\
\text { elemental y su acción modeladora. } \\
\text { TEMA 5. EL MODELADO GLACIAR Y EL } \\
\text { PERIGLACIARISMO. El ámbito geográfico de los } \\
\text { glaciares. Tipología de glaciares. La escorrentía glaciar. } \\
\text { Las formas erosivas de origen glaciar. Las formas de } \\
\text { acumulación glaciar. Las formas proglaciares. Las } \\
\text { formas periglaciares. }\end{array}$ \\
\hline \multirow[t]{2}{*}{$\begin{array}{c}\text { Grado en } \\
\text { Geología } \\
\text { (Ciclo 2013- } \\
\text { 2014) }\end{array}$} & 19 & $\begin{array}{l}\text { Geología: } \\
\text { Principios Básicos }\end{array}$ & $\begin{array}{l}\text { Tema 10. Procesos geológicos externos en las áreas } \\
\text { continentales. Concepto y tipos de meteorización. } \\
\text { Meteorización física. Meteorización química. Procesos } \\
\text { edafológicos. Procesos gravitacionales. El ciclo } \\
\text { hidrológico. Aguas de escorrentía superficial. Procesos } \\
\text { cársticos. Aguas subterráneas. Glaciares y } \\
\text { periglaciarismo. }\end{array}$ \\
\hline & 20 & Geomorfología & $\begin{array}{l}\text { BLOQUE 2: Meteorización y suelos } \\
\text { 3. La meteorización. Concepto y tipos. Meteorización }\end{array}$ \\
\hline
\end{tabular}




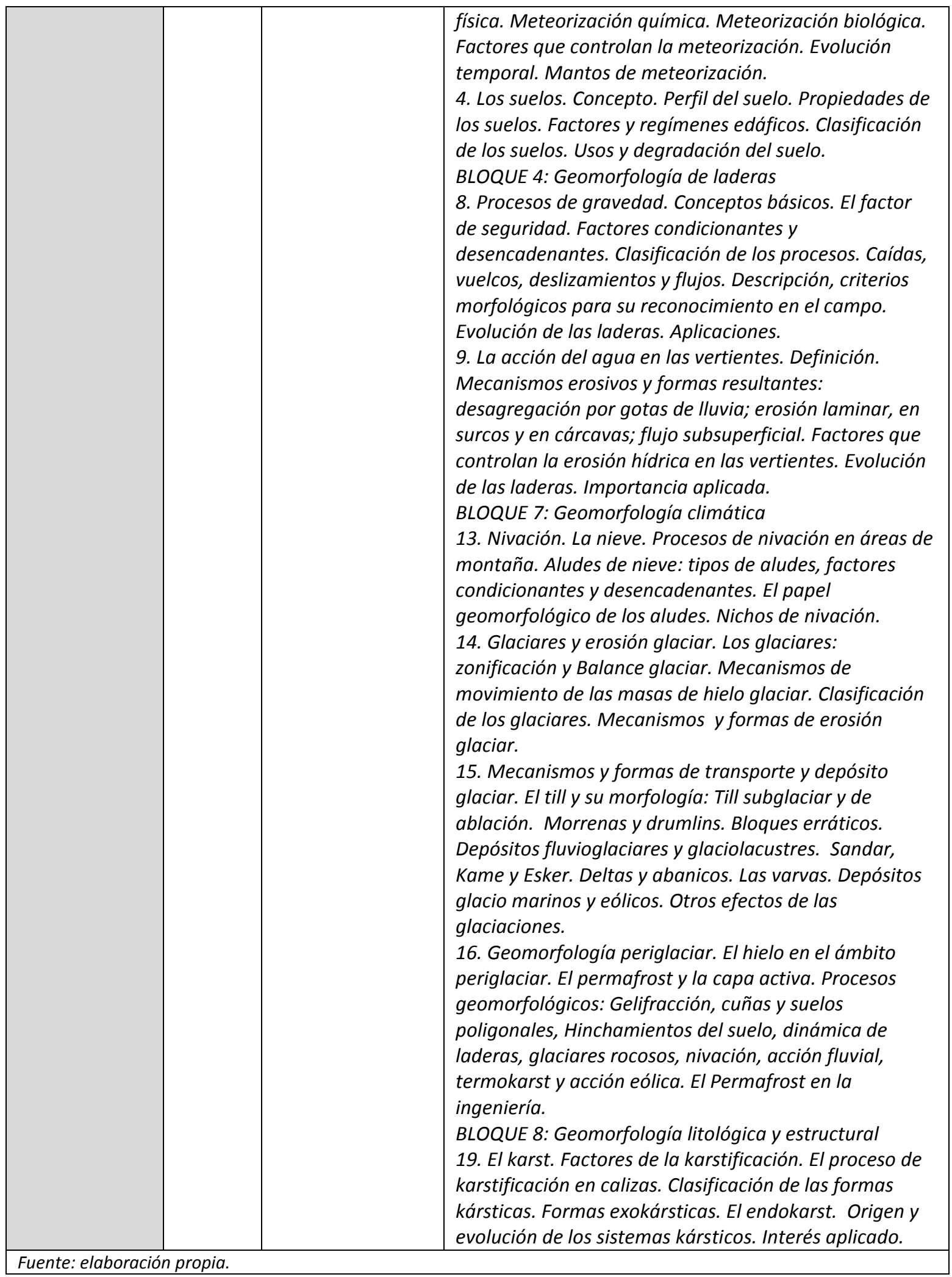




\section{A.5) Grados oficiales de la Universidad de Cantabria relacionados con contenidos geomorfológicos.}

Tabla 96. Principales contenidos geológicos y geomorfológicos presentes en grados oficiales de la Universidad de Cantabria.

\begin{tabular}{|c|c|c|c|}
\hline \multicolumn{4}{|c|}{ Universidad de Cantabria } \\
\hline Carrera & Curso & Asignatura & Contenido \\
\hline & 20 & $\begin{array}{l}\text { Geomorfología } \\
\text { estructural }\end{array}$ & $\begin{array}{l}\text { LOS RELIEVES LITOLÓGICOS } \\
4.1 \text { Relieves kársticos. }\end{array}$ \\
\hline $\begin{array}{c}\text { Grado en } \\
\text { Geografía y } \\
\text { Ordenación del } \\
\text { Territorio } \\
\text { (Ciclo 2013-2014) }\end{array}$ & 20 & $\begin{array}{c}\text { Procesos } \\
\text { Geomorfológicos }\end{array}$ & $\begin{array}{l}\text { 1. Geomorfología y Geografía física. Los procesos de } \\
\text { morfogénesis } \\
\text { La morfogénesis y el tiempo. } \\
\text { Los tipos de procesos y los sistemas morfogenéticos } \\
\text { 2.Los procesos de preparación del material } \\
\text { (meteorización) } \\
\text { Los procesos físico-mecánicos } \\
\text { Los procesos químicos. La alteración } \\
\text { 3. LOS MEDIOS FRÍOS Y LOS MEDIOS ÁRIDOS } \\
\text { 3.1 LoS procesos en los medios glaciares y periglaciares. } \\
\text { Los sistemas morfogenéticos fríos. } \\
\text { 3.3 El papel del viento: Deflación y transporte. Las } \\
\text { acumulaciones eólicas }\end{array}$ \\
\hline $\begin{array}{l}\text { Grado en } \\
\text { Ingeniería de los } \\
\text { Recursos Mineros } \\
\text { (Ciclo 2013-2014) }\end{array}$ & 10 & Geología & $\begin{array}{l}\text { BLOQUE TEMÁTICO 3: PROCESOS GEODINÁMICOS Y } \\
\text { MORFOLOGÍA DEL TERRENO } \\
\text { Tema 6. Geomorfología. Geometría y estructura del } \\
\text { relieve. Meteorización y suelos. Los sedimentos. } \\
\text { Tema 8. Procesos y formas en medios fríos y en medios } \\
\text { áridos. Ambientes, procesos, formas y sedimentos } \\
\text { periglaciares. Ambientes, procesos, formas y sedimentos } \\
\text { glaciares. El viento y los medios áridos. Formas y } \\
\text { sedimentos eólicos. Problemática ingenieril en medios } \\
\text { áridos y fríos. } \\
\text { Tema 10. Aguas subterráneas. Circulación de las aguas } \\
\text { subterráneas. Acuíferos y acuicluidos. Nivel freático. El } \\
\text { karst. Formas y depósitos kársticos superficiales y } \\
\text { subterráneos. Problemática ingenieril de las aguas } \\
\text { subterráneas y del karst. } \\
\text { Tema } 11 . \text { Procesos de ladera. Erosión y evolución de } \\
\text { laderas. Estabilidad e inestabilidad. Factores } \\
\text { condicionantes y desencadenantes. Deslizamientos: } \\
\text { mecanismos y tipos. Problemática ingenieril de laderas y } \\
\text { taludes }\end{array}$ \\
\hline
\end{tabular}




\section{A.6) Grados oficiales de Universidades Públicas de Castilla y León relacionados con contenidos geomorfológicos.}

Tabla 97. Principales contenidos geológicos y geomorfológicos presentes en grados oficiales de la Universidad de Salamanca.

\begin{tabular}{|c|c|c|c|}
\hline \multicolumn{4}{|c|}{ Universidad de Salamanca } \\
\hline Carrera & Curso & Asignatura & Contenido \\
\hline \multirow{5}{*}{$\begin{array}{l}\text { Grado en } \\
\text { Geología } \\
\text { (Ciclo 2012-2013) }\end{array}$} & 10 & $\begin{array}{l}\text { Introducción a la } \\
\text { Geología }\end{array}$ & $\begin{array}{l}\text { Dinámica externa de la Tierra: (...) Glaciares y } \\
\text { glaciaciones, tipos, dinámica, y depósitos glaciares. }\end{array}$ \\
\hline & 20 & Geomorfología & $\begin{array}{l}\text { Módulo II: FASE DE MODELADO: Morfogénesis Básicas. } \\
\text { - Sistema morfogenético glaciar: El hielo como agente } \\
\text { exógeno. Su movimiento. Erosión, transporte y } \\
\text { sedimentación. El modelado glaciar. } \\
\text { Principales formas y depósitos glaciares. Lagos glaciares: } \\
\text { depósitos varvados. Glaciarismo cuaternario. } \\
\text { - Sistema morfogenético periglaciar. Procesos de hielo- } \\
\text { deshielo Formas y depósitos. Fenómenos solifluidales. } \\
\text { Figuras geométricas. } \\
\text { Modulo III: FASE DE MODELADO: Morfogénesis Complejas. } \\
\text { - Modelado litológico. Morfología de las rocas } \\
\text { sedimentarias: formas cársticas. Modelado de las rocas } \\
\text { cristalinas y volcánicas. }\end{array}$ \\
\hline & 20 & Sedimentología & $\begin{array}{l}\text { Ambientes sedimentarios continentales (aluviales, eólicos, } \\
\text { glaciares, lagunares, evaporíticos). }\end{array}$ \\
\hline & $2 \stackrel{0}{2}$ & $\begin{array}{l}\text { Formaciones } \\
\text { superficiales }\end{array}$ & $\begin{array}{l}\text { Formaciones superficiales cársticas. } \\
\text { Formaciones superficiales glaciares, periglaciares y de } \\
\text { gravedad. }\end{array}$ \\
\hline & 30 & $\begin{array}{l}\text { Paleocenografía } \\
\text { y cambio } \\
\text { climático }\end{array}$ & $\begin{array}{l}\text { Bloque cambio climático durante el Cuaternario: las } \\
\text { grandes glaciaciones, el ciclo glacial-interglacial. }\end{array}$ \\
\hline \multirow[b]{2}{*}{$\begin{array}{l}\text { Grado en } \\
\text { Geografía } \\
\text { (Ciclo 2013-2014) }\end{array}$} & 10 & $\begin{array}{l}\text { Fundamentos de } \\
\text { Geología }\end{array}$ & $\begin{array}{l}\text { Tema 7.- Dinámica terrestre. La Litosfera: dinámica y } \\
\text { evolución. Deformación de los materiales terrestres }\end{array}$ \\
\hline & 20 & Geomorfología & $\begin{array}{l}\text { El sistema de meteorización. } \\
\text { El sistema de laderas: procesos y formas } \\
\text { El sistema glaciar: ambientes glaciares, procesos y formas. } \\
\text { El sistema periglaciar: ambientes periglaciares, procesos y } \\
\text { formas. }\end{array}$ \\
\hline \multirow[b]{2}{*}{$\begin{array}{l}\text { Grado en } \\
\text { Ingeniería } \\
\text { Geológica } \\
\text { (Ciclo 2012-2013) }\end{array}$} & 10 & $\begin{array}{l}\text { Introducción a la } \\
\text { Geología }\end{array}$ & $\begin{array}{l}\text { Dinámica externa de la Tierra: (...) Glaciares y } \\
\text { glaciaciones, tipos, dinámica, y depósitos glaciares. }\end{array}$ \\
\hline & 20 & Geomorfología & $\begin{array}{l}\text { Modulo II: FASE DE MODELADO: Morfogénesis Básicas. } \\
\text { - Sistema morfogenético glaciar: El hielo como agente } \\
\text { exógeno. Su movimiento. Erosión, transporte y } \\
\text { sedimentación. El modelado glaciar. Principales formas y } \\
\text { depósitos glaciares. Lagos glaciares: depósitos varvados. } \\
\text { Glaciarismo cuaternario. } \\
\text { - Sistema morfogenético periglaciar. Procesos de hielo- } \\
\text { deshielo Formas y depósitos. Fenómenos solifluidales. } \\
\text { Figuras geométricas. }\end{array}$ \\
\hline & & & \\
\hline
\end{tabular}


Tabla 98. Principales contenidos geológicos y geomorfológicos presentes en grados oficiales de la Universidad de León.

\begin{tabular}{|c|c|c|c|}
\hline \multicolumn{4}{|c|}{ Universidad de León } \\
\hline Carrera & Curso & Asignatura & Contenido \\
\hline $\begin{array}{c}\text { Grado en } \\
\text { Geografía y } \\
\text { Ordenación del } \\
\text { Territorio } \\
\text { (Ciclo 2013-2014) }\end{array}$ & 20 & Geomorfología & $\begin{array}{l}\text { 2. Los relieves derivados de la dinámica interna del } \\
\text { planeta: los relieves estructurales } \\
\text { 2.2. Los relieves kársticos y graníticos } \\
\text { 3. Los relieves controlados por la dinámica externa del } \\
\text { planeta: las formas de modelado } \\
\text { 3.3. La influencia del clima en la morfogénesis: los } \\
\text { modelados glaciar y periglaciar }\end{array}$ \\
\hline $\begin{array}{l}\text { Grado en } \\
\text { Ingeniería Minera } \\
\text { (Ciclo 2013-2014) }\end{array}$ & 20 & Geología & $\begin{array}{l}\text { Bloque V: Las capas fluidas de la tierra y su interacción } \\
\text { con la litosfera } \\
\text { Tema 16. Morfología y dinámica glaciar }\end{array}$ \\
\hline
\end{tabular}

Tabla 99. Principales contenidos geológicos y geomorfológicos presentes en grados oficiales de la Universidad de Valladolid.

\begin{tabular}{|c|c|c|l|}
\hline \multicolumn{4}{|c|}{ Universidad de Valladolid } \\
\hline Carrera & Curso & Asignatura & \multicolumn{1}{c|}{ Contenido } \\
\hline $\begin{array}{c}\text { Grado en Geografía y } \\
\text { Ordenación del Territorio } \\
\text { (Curso 2013-2014) }\end{array}$ & 10 & $\begin{array}{l}\text { Geografía Física y } \\
\text { Medio Ambiente }\end{array}$ & $\begin{array}{l}\text { El relieve como forma exterior de la litosfera y } \\
\text { su carácter de basamento del medio }\end{array}$ \\
\cline { 2 - 4 } & $2 \circ$ & Geomorfología & $\begin{array}{l}\text { La criosfera: los glaciares y el modelado } \\
\text { glaciar. } \\
\text { La criosfera: El modelado periglaciar. }\end{array}$ \\
\hline Fuente: elaboración propia.
\end{tabular}




\section{A.7) Bibliografía de consulta sobre geomorfología glaciar.}

Tabla 100. Principales contenidos sobre geomorfología glaciar presentes en Gutiérrez, 2008 (Capítulo: Geomorfología glaciar I, p. 451-483).

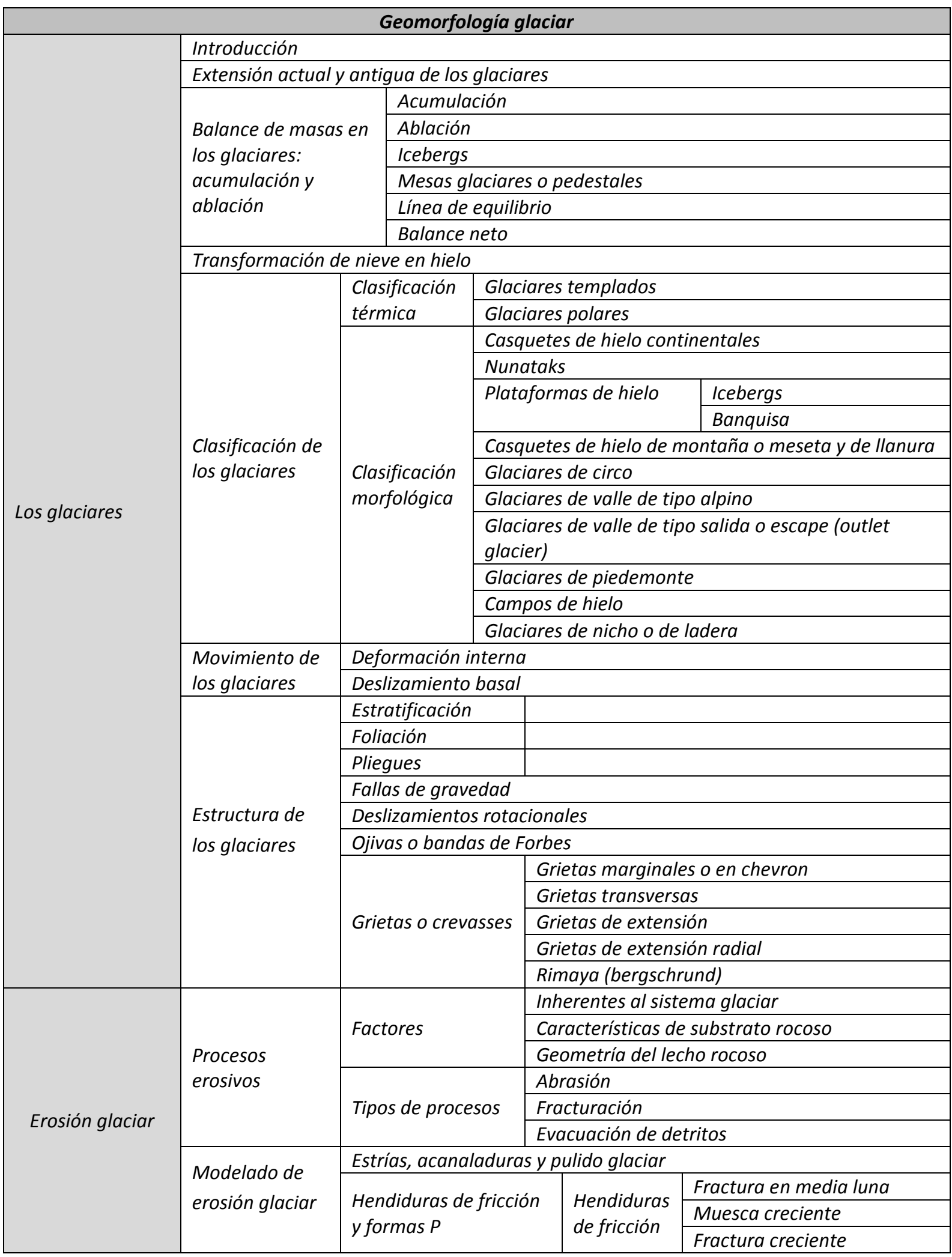


La Interpretación del Patrimonio Geomorfológico en los Picos de Europa: una propuesta para su aprovechamiento didáctico y geoturístico

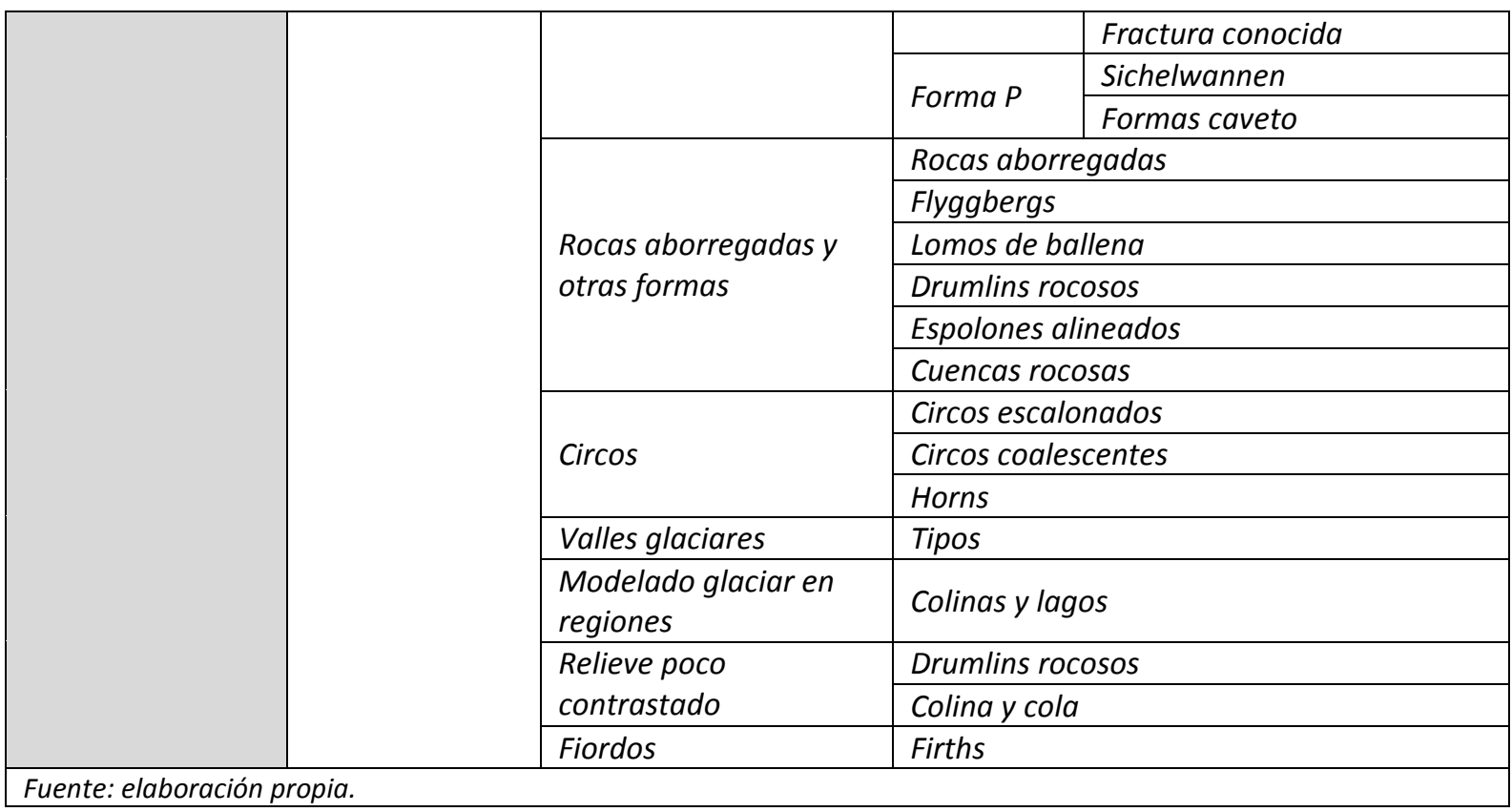

Tabla 101. Principales contenidos sobre geomorfología glaciar presentes en Gutiérrez, 2008 (Capítulo: Geomorfología glaciar II, p. 485-515).

\begin{tabular}{|c|c|c|}
\hline \multicolumn{3}{|c|}{ Geomorfología glaciar } \\
\hline \multirow{16}{*}{$\begin{array}{c}\text { Transporte y sedimentación } \\
\text { glaciar }\end{array}$} & \multirow{3}{*}{$\begin{array}{l}\text { Alimentación y } \\
\text { ambientes glaciares }\end{array}$} & Detritos supraglaciares \\
\hline & & Detritos endoglaciares \\
\hline & & Detritos subglaciares \\
\hline & \multirow{3}{*}{$\begin{array}{l}\text { Mecanismos de } \\
\text { sedimentación } \\
\text { glaciar }\end{array}$} & Deshielo supraglaciar (melt-out) \\
\hline & & Deshielo subglaciar (lodgement) \\
\hline & & Deshielo por deformación \\
\hline & \multirow{3}{*}{ Características del till } & Concepto de till \\
\hline & & Distribución del tamaño de las partículas \\
\hline & & Disposición de las partículas (fábrica) \\
\hline & \multirow{7}{*}{$\begin{array}{l}\text { Modelados } \\
\text { resultantes de la } \\
\text { sedimentación } \\
\text { glaciar }\end{array}$} & Morrenas terminales, laterales y centrales \\
\hline & & Mantos de till (morrena de fondo) \\
\hline & & Morrenas acanaladas \\
\hline & & Drumlins \\
\hline & & Morrenas transversales de valle o morrenas Rogen \\
\hline & & Morrenas de descarga \\
\hline & & Morrenas de empuje \\
\hline \multirow{15}{*}{$\begin{array}{c}\text { Erosión y sedimentación } \\
\text { fluvioglaciares }\end{array}$} & \multirow{7}{*}{$\begin{array}{l}\text { Las aguas de } \\
\text { deshielo }\end{array}$} & Canales marginales y submarginales \\
\hline & & Canales supraglaciares \\
\hline & & Moulins \\
\hline & & Canales intraglaciares \\
\hline & & Canales subglaciares \\
\hline & & Canales proglaciares \\
\hline & & Inundaciones (jökulhlaup) \\
\hline & \multirow{5}{*}{$\begin{array}{l}\text { Formas resultantes } \\
\text { de la erosión } \\
\text { fluvioglaciar }\end{array}$} & Marmitas \\
\hline & & Canales marginales \\
\hline & & Canales subglaciares \\
\hline & & Canales proglaciares \\
\hline & & Canales de desbordamiento \\
\hline & \multirow{3}{*}{$\begin{array}{l}\text { Modelados derivados } \\
\text { de la sedimentación } \\
\text { fluvioglaciar }\end{array}$} & Glaciotectónicas \\
\hline & & Eskers (osar) \\
\hline & & Kames \\
\hline
\end{tabular}




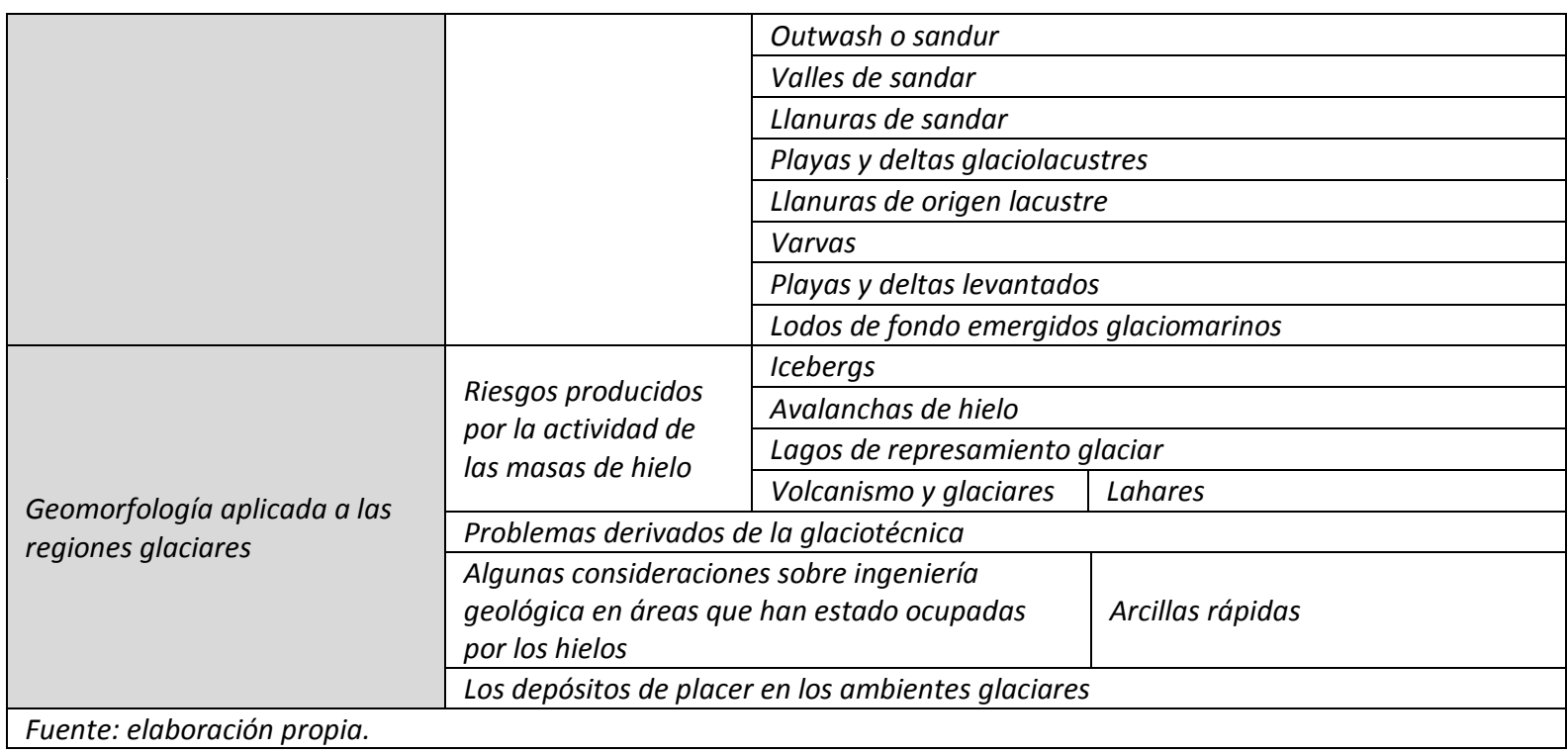

Tabla 102. Principales contenidos sobre geomorfología glaciar presentes en Gutiérrez, 2001.

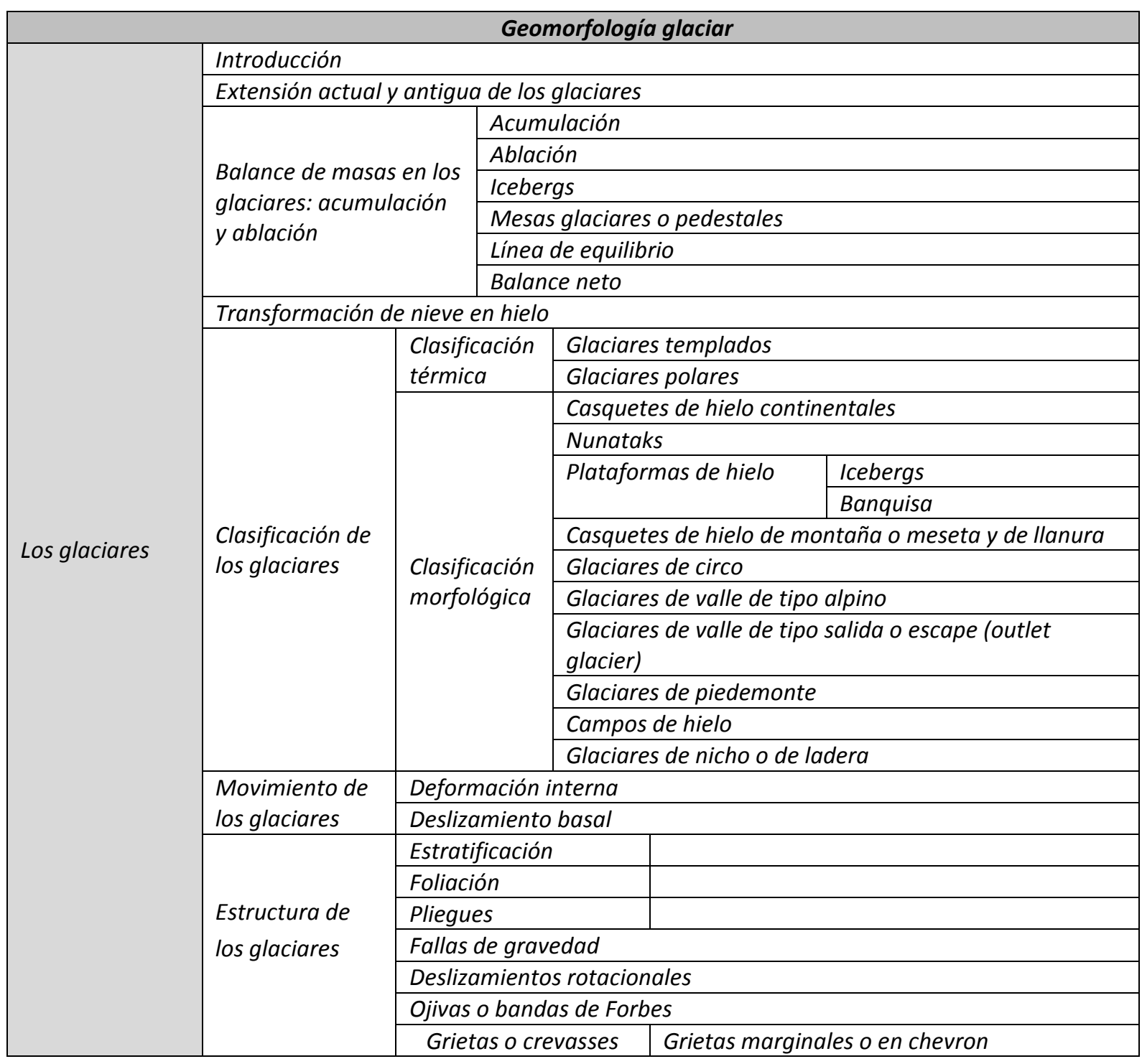


La Interpretación del Patrimonio Geomorfológico en los Picos de Europa: una propuesta para su aprovechamiento didáctico y geoturístico

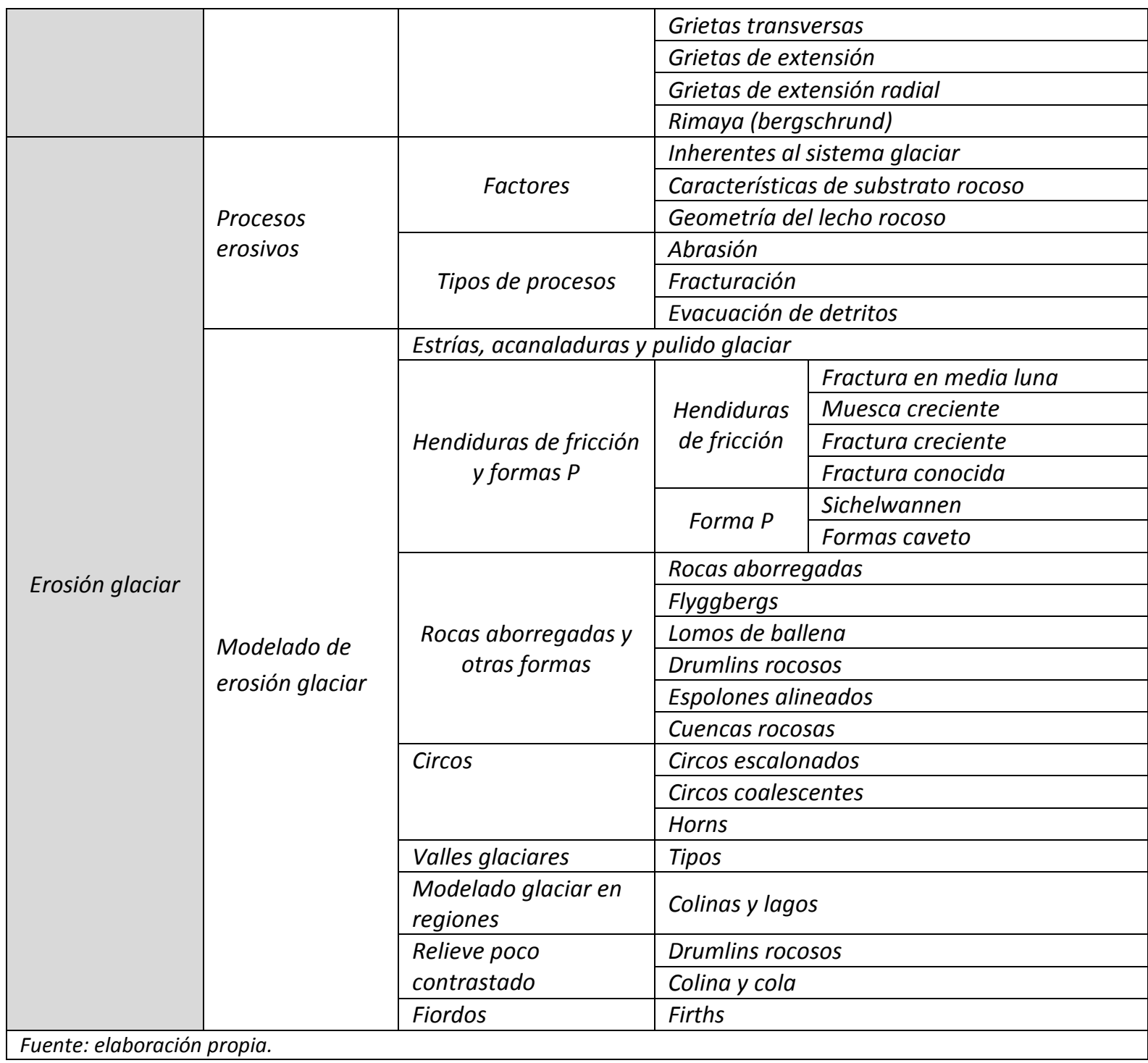

Tabla 103. Principales contenidos sobre geomorfología glaciar presentes en Pedraza, 1996.

\begin{tabular}{|c|c|}
\hline \multicolumn{2}{|r|}{ Procesos glaciares } \\
\hline $\begin{array}{l}\text { Dinámica glaciar: carácter } \\
\text { general }\end{array}$ & $\begin{array}{l}\text { Definición de glaciar, clasificación de glaciares por características del hielo } \\
\text { (clasificación geofísica) y morfología de terreno (clasificación geomorfológica) } \\
\text { Circulación extrusiva y gravitacional } \\
\text { Clasificación geomorfológica de glaciares: } \\
\text { De casquete: coberteras de hielo, domos, campos de hielo, glaciares de } \\
\text { plataforma. } \\
\text { De meseta } \\
\text { De montaña: Monteras de hielo, de piedemonte, de valle o alpino, de ladera o } \\
\text { intermedio, de circo. } \\
\text { Deslizamiento basal } \\
\text { Deformación interna } \\
\text { Deslizamiento planar }\end{array}$ \\
\hline $\begin{array}{l}\text { Dinámica glaciar: balance } \\
\text { de masa }\end{array}$ & $\begin{array}{l}\text { Ablación } \\
\text { Zona de ablación } \\
\text { Centro o zona de acumulación } \\
\text { Cuenca de alimentación }\end{array}$ \\
\hline
\end{tabular}


La Interpretación del Patrimonio Geomorfológico en los Picos de Europa: una propuesta para su aprovechamiento didáctico y geoturístico

\begin{tabular}{|c|c|c|c|c|}
\hline & \multicolumn{4}{|l|}{ Zona de descarga } \\
\hline \multirow{9}{*}{$\begin{array}{l}\text { Acciones elementales de } \\
\text { un glaciar: formas y } \\
\text { depósitos }\end{array}$} & \multirow{3}{*}{\multicolumn{2}{|c|}{ Erosión }} & \multicolumn{2}{|l|}{ Desgaste (abrasión) } \\
\hline & & & \multicolumn{2}{|c|}{ Arranque (pukling) } \\
\hline & & & \multicolumn{2}{|c|}{$\begin{array}{l}\text { Elementos morfológicos derivados: pulidos, estrías, } \\
\text { acanaladuras, rocas aborregadas, cubetas u ombligos, } \\
\text { huellas de arranque y choque, fracturas de empuje }\end{array}$} \\
\hline & \multirow{2}{*}{\multicolumn{2}{|c|}{ Transporte }} & \multirow{2}{*}{$\begin{array}{l}\text { Derrubios } \\
\text { glaciares }\end{array}$} & Modalidad activa \\
\hline & & & & Modalidad pasiva \\
\hline & \multirow{4}{*}{\multicolumn{2}{|c|}{ Sedimentación }} & \multicolumn{2}{|l|}{ Deformación } \\
\hline & & & \multicolumn{2}{|l|}{ Acreción } \\
\hline & & & \multicolumn{2}{|l|}{ Fusión } \\
\hline & & & \multicolumn{2}{|l|}{ Tills (clases de tills) } \\
\hline $\begin{array}{l}\text { Concatenación de } \\
\text { acciones elementales: } \\
\text { formas y depósitos } \\
\text { mayores }\end{array}$ & \multicolumn{4}{|c|}{$\begin{array}{l}\text { Cuencas con cabecera en forma de circo } \\
\text { Valles en artesa hemicilíndrica } \\
\text { Morrenas } \\
\text { Drumlins (campos de drumlins, drumlins rocosos) }\end{array}$} \\
\hline \multirow{5}{*}{$\begin{array}{l}\text { Fenómenos } \\
\text { fluvioglaciares: acción de } \\
\text { las aguas de fusión }\end{array}$} & \multirow{3}{*}{$\begin{array}{l}\text { En contacto } \\
\text { con el hielo o } \\
\text { yuxtaglaciares }\end{array}$} & Sobre & re el hielo & Terrazas de kame \\
\hline & & Dent & tro del hielo & Kame \\
\hline & & Bajo & el hielo & Esquer, varvas \\
\hline & \multirow{2}{*}{$\begin{array}{l}\text { Sin contacto } \\
\text { con el hielo o } \\
\text { proglaciares }\end{array}$} & \multicolumn{2}{|c|}{ De frente de fusión } & $\begin{array}{l}\text { Llanuras aluviales } \\
\text { encajadas, amplias; conos } \\
\text { y abanicos fluvioglaciares }\end{array}$ \\
\hline & & \multicolumn{2}{|c|}{$\begin{array}{l}\text { De frente de desmembramiento } \\
\text { en mares o lagos }\end{array}$} & Deltas y varvas \\
\hline $\begin{array}{l}\text { Variaciones glaciares a lo } \\
\text { largo del tiempo: ritmos } \\
\text { evolutivos }\end{array}$ & \multicolumn{4}{|c|}{$\begin{array}{l}\text { Eras glaciares } \\
\text { Épocas glaciares } \\
\text { Avances-retrocesos absolutos } \\
\text { Avances-retrocesos relativos mayores } \\
\text { Avances-retrocesos relativos menores } \\
\text { Avances-retrocesos continuos }\end{array}$} \\
\hline $\begin{array}{l}\text { Variaciones glaciares a lo } \\
\text { largo del tiempo: causas } \\
\text { más probables }\end{array}$ & $\begin{array}{l}\text { Fenómenos que } \\
\text { pueden influir en } \\
\text { avances y } \\
\text { retrocesos } \\
\text { glaciares }\end{array}$ & & \multicolumn{2}{|c|}{$\begin{array}{l}\text { Orogenias } \\
\text { Ciclos astronómicos (ciclos de Milankovich) } \\
\text { Excentricidad orbital } \\
\text { Inclinación del eje de rotación } \\
\text { Precesión-cabeceo-nutación } \\
\text { Actividad reguladora de los océanos } \\
\text { Actividad solar y volcánica }\end{array}$} \\
\hline $\begin{array}{l}\text { Tendencias evolutivas del } \\
\text { clima a escala global: } \\
\text { hipótesis glaciares }\end{array}$ & \multicolumn{4}{|c|}{$\begin{array}{l}\text { Período pluvial } \\
\text { Período interpluvial } \\
\text { Pequeña Edad Glaciar }\end{array}$} \\
\hline $\begin{array}{l}\text { Cronología y } \\
\text { paleotemperaturas } \\
\text { asociadas al glaciarismo } \\
\text { cuaternario }\end{array}$ & \multicolumn{4}{|c|}{$\begin{array}{l}\text { Cronologías climáticas } \\
\text { Estudio de secuencias morfosedimentarias } \\
\text { Registros térmicos en formaciones geológicas }\end{array}$} \\
\hline
\end{tabular}


La Interpretación del Patrimonio Geomorfológico en los Picos de Europa: una propuesta para su aprovechamiento didáctico y geoturístico

Tabla 104. Principales contenidos sobre geomorfología glaciar presentes en Sandoval, 1991.

\begin{tabular}{|c|c|c|}
\hline \multicolumn{3}{|r|}{ El relieve glaciar } \\
\hline \multirow{4}{*}{ Glaciares actuales } & \multicolumn{2}{|c|}{ Glaciares continentales o inlandsis } \\
\hline & \multirow{3}{*}{$\begin{array}{l}\text { Glaciares de } \\
\text { montaña }\end{array}$} & Glaciares de meseta \\
\hline & & Glaciares de circo \\
\hline & & Glaciares de valle \\
\hline \multirow{7}{*}{$\begin{array}{l}\text { Descripción de un } \\
\text { glaciar }\end{array}$} & \multirow{3}{*}{ Grietas } & Rimaya \\
\hline & & Grietas marginales y transversales \\
\hline & & Serac \\
\hline & \multirow{4}{*}{ Depósitos } & Morrenas laterales \\
\hline & & Morrenas medianas \\
\hline & & Morrenas de fondo \\
\hline & & Morrenas frontales \\
\hline \multirow{4}{*}{ La erosión glaciar } & \multicolumn{2}{|c|}{ Rocas aborregadas } \\
\hline & \multicolumn{2}{|l|}{ Drumlins } \\
\hline & \multicolumn{2}{|l|}{ Valle en $U$} \\
\hline & \multicolumn{2}{|l|}{ Hombrera } \\
\hline Relieve glaciar & \multicolumn{2}{|c|}{ Planicies o glacis aluviales (terrazas fluvioglaciares) } \\
\hline
\end{tabular}

Tabla 105. Principales contenidos sobre geomorfología glaciar presentes en Derruau, 1991.

\begin{tabular}{|c|c|}
\hline \multicolumn{2}{|r|}{ El sistema de erosión glaciar } \\
\hline \multirow{6}{*}{$\begin{array}{l}\text { Los glaciares } \\
\text { actuales }\end{array}$} & Los inlandsis \\
\hline & Casquetes locales (que a veces emiten lenguas glaciares) \\
\hline & Glaciares de circo \\
\hline & Glaciares de valle \\
\hline & Glaciares de piedemonte \\
\hline & Los hielos marinos \\
\hline \multirow{4}{*}{$\begin{array}{l}\text { Los procesos de } \\
\text { erosión glaciar }\end{array}$} & Cristalografía y dinámica de la nieve y del hielo \\
\hline & Ultraglaciaristas, antiglaciaristas y transaccionistas \\
\hline & $\begin{array}{l}\text { El modelado del lecho (estriado, pulimento, arañazos, harina glaciar, rocas } \\
\text { aborregadas) }\end{array}$ \\
\hline & Modelado de los materiales transportados (morrena de fondo, de superficie) \\
\hline \multirow{4}{*}{$\begin{array}{l}\text { Las formas } \\
\text { glaciares }\end{array}$} & El circo (tipos) \\
\hline & Valle glaciar \\
\hline & Llanuras y plataformas glaciares (drumlin, osar, esker, kame) \\
\hline & Problemas del frente glaciar \\
\hline \multicolumn{2}{|c|}{ Las deformaciones glacioistáticas } \\
\hline \multicolumn{2}{|c|}{ Glaciarismo cuaternario y modelado glaciar en España } \\
\hline Fuente: elaboracic & \\
\hline
\end{tabular}


Tabla 106. Principales contenidos sobre geomorfología glaciar presentes en Tricart, 1963.

\begin{tabular}{|c|c|c|}
\hline \multicolumn{3}{|c|}{ Les actions glaciaires } \\
\hline \multirow{6}{*}{$\begin{array}{l}\text { La dynamique } \\
\text { glaciaire }\end{array}$} & \multirow{2}{*}{ De la neige a la glace } & La niege et ses propiétés \\
\hline & & La transfomation de la neige en névé et en glace \\
\hline & \multirow{3}{*}{ L'écoulement glaciaire } & Les faits d'observation \\
\hline & & Les propriétés de la glace \\
\hline & & L'interprétation mécanique \\
\hline & \multicolumn{2}{|c|}{ Les théories de l'érosion glaciaire } \\
\hline \multirow{5}{*}{$\begin{array}{l}\text { Les formes } \\
\text { élémentaires }\end{array}$} & \multirow{2}{*}{$\begin{array}{l}\text { L'action morphologique } \\
\text { de la neige }\end{array}$} & Les avalanches \\
\hline & & Les autres formes d'érosion mécanique de la neige \\
\hline & \multirow{3}{*}{$\begin{array}{l}\text { L'action morphologique } \\
\text { des néves }\end{array}$} & Les cirques: définition et classification \\
\hline & & Les théories: glacialistes et antiglacialistes \\
\hline & & Genèse et évolution des cirques \\
\hline \multirow{7}{*}{$\begin{array}{l}\text { Le façonnement du lit } \\
\text { glaciaire }\end{array}$} & \multirow{2}{*}{$\begin{array}{l}\text { Altération, dépots et } \\
\text { processus }\end{array}$} & Les micro-façonnements \\
\hline & & Les dépots glaciaires \\
\hline & \multirow{3}{*}{$\begin{array}{l}\text { Le façonnement du lit } \\
\text { des inlandsis }\end{array}$} & Les formes élémentaires du relief inlandsisien \\
\hline & & Les adaptations structurales \\
\hline & & $\begin{array}{l}\text { Conclusion: le rôle morphologique de la glace des } \\
\text { inlandsis }\end{array}$ \\
\hline & \multirow{2}{*}{$\begin{array}{l}\text { Le façonnement du lit } \\
\text { des glaciers locaux }\end{array}$} & Les formes caractéristiques du modelé \\
\hline & & Le façonnement des vallées glaciaires \\
\hline \multirow{6}{*}{ La marge glaciaire } & \multirow{2}{*}{ La zone de fusión } & Les eaux au contact de la glace \\
\hline & & L'action morphologique des eaux glaciaires \\
\hline & \multirow{2}{*}{ Le domaine frontal } & Les marges des glaciers locaux \\
\hline & & Les marges des inlandsis \\
\hline & \multirow{2}{*}{ Le domaine proglaciaire } & Les caracteres particuliers de l'écoulement \\
\hline & & Le modelé d'accumulation \\
\hline \multirow{2}{*}{$\begin{array}{l}\text { L'influence } \\
\text { morphogénétique des } \\
\text { séquences glaciaires }\end{array}$} & \multicolumn{2}{|c|}{ Influence d'un englacement glaciaires } \\
\hline & \multicolumn{2}{|l|}{ Les formes de déglaciation } \\
\hline \multirow{2}{*}{$\begin{array}{l}\text { Les conséquences } \\
\text { indirectes des } \\
\text { glaciations }\end{array}$} & \multicolumn{2}{|c|}{ Les phénomenes glacio-eustatiques } \\
\hline & \multicolumn{2}{|c|}{ Les déformations glacio-isostatiques } \\
\hline
\end{tabular}




\section{A.8) Bibliografía de consulta sobre geomorfología periglaciar.}

Tabla 107. Principales contenidos sobre geomorfología periglaciar presentes en Gutiérrez, 2008.

\begin{tabular}{|c|c|c|c|c|c|}
\hline \multicolumn{6}{|c|}{ Geomorfología periglaciar } \\
\hline \multirow{27}{*}{$\begin{array}{l}\text { El dominio } \\
\text { periglaciar }\end{array}$} & \multicolumn{5}{|c|}{ Definición, distinción de tipos de climas periglaciares } \\
\hline & \multirow{6}{*}{ Permafrost } & \multicolumn{4}{|c|}{ Definición, características } \\
\hline & & \multicolumn{4}{|c|}{ Talik } \\
\hline & & \multicolumn{4}{|l|}{ Icings o aufeis } \\
\hline & & \multicolumn{4}{|l|}{ Lentejones de hielo } \\
\hline & & \multicolumn{4}{|c|}{ Venas y cuñas de hielo } \\
\hline & & \multicolumn{4}{|c|}{ Hielo de pingo } \\
\hline & \multirow{20}{*}{$\begin{array}{l}\text { Procesos } \\
\text { periglaciares }\end{array}$} & \multirow{10}{*}{$\begin{array}{l}\text { Acción de } \\
\text { helada }\end{array}$} & \multirow{4}{*}{\multicolumn{2}{|c|}{$\begin{array}{l}\text { Levantamiento } \\
\text { por helada }\end{array}$}} & $\begin{array}{l}\text { Componente vertical } \\
\text { (levantamiento) }\end{array}$ \\
\hline & & & & & Componente horizontal (traslación) \\
\hline & & & & & Agujas de hielo o pipkrake \\
\hline & & & & & Nubbins \\
\hline & & & $\begin{array}{l}\text { Desf } \\
\text { de } m\end{array}$ & $\begin{array}{l}\text { amiento } \\
\text { as }\end{array}$ & $\begin{array}{l}\text { Crioturbaciones o involuciones } \\
\text { periglaciares }\end{array}$ \\
\hline & & & \multirow{2}{*}{\multicolumn{2}{|c|}{$\begin{array}{l}\text { Agrietamiento } \\
\text { por helada }\end{array}$}} & Cuña de hielo \\
\hline & & & & & Cuña de arena \\
\hline & & & \multirow{3}{*}{\multicolumn{2}{|c|}{$\begin{array}{l}\text { Clasificación por } \\
\text { helada }\end{array}$}} & Clasificación vertical \\
\hline & & & & & Clasificación lateral \\
\hline & & & & & Clasificación mecánica \\
\hline & & \multicolumn{4}{|c|}{ Meteorización química } \\
\hline & & \multirow{6}{*}{$\begin{array}{l}\text { Movimiento de } \\
\text { masas }\end{array}$} & \multicolumn{3}{|c|}{ Desprendimientos de rocas (rotura por helada) } \\
\hline & & & \multicolumn{3}{|c|}{ Solifluxión } \\
\hline & & & \multicolumn{3}{|c|}{ Gelifluxión } \\
\hline & & & \multicolumn{3}{|c|}{ Creep de helada } \\
\hline & & & \multicolumn{3}{|c|}{ Bloque de arrastre } \\
\hline & & & \multicolumn{3}{|c|}{ Coladas de barro } \\
\hline & & Procesos nivales & $A v c$ & ichas o alu & es (polvo o placa) \\
\hline & & Actividad fluvial & $\mathrm{Cal}$ & es de ríost & nzados (braided) \\
\hline & & Acción del viento & $P a$ & entos peri & ciares en llanuras aluviales o de till \\
\hline & & Círculos & & & \\
\hline & & Polígonos & & & \\
\hline & Suelos & Redes & & & \\
\hline & ordenados & Césped almohadi & lado & & \\
\hline & & Escalones & & & \\
\hline & & Bandas o suelos & striac & & \\
\hline & Colinas con & Palsas & & & \\
\hline & núcleo de & Pingoce & & Sistema & rado \\
\hline & hielo & PIngos & & Sistema & ierto \\
\hline Formas & & & & Hojas de & lifluxión \\
\hline periglaciares & & laderac de gelifl & vión & Bancos d & gelifluxión \\
\hline & & Laderas ae gelljlu & XIon & Lóbulos o & gelifluxión \\
\hline & Morfología y & & & Regueros & e gelifluxión \\
\hline & evolución de & Terrazas de criop & Ianac & y criopedi & ntos \\
\hline & las laderas & Canchales y cono & sde o & ubios & \\
\hline & & Campos, laderas, & ríoso & osques & \\
\hline & & Glaciares rocosos & & & \\
\hline & & Grèzes litées & & & \\
\hline
\end{tabular}


La Interpretación del Patrimonio Geomorfológico en los Picos de Europa: una propuesta para su aprovechamiento didáctico y geoturístico

\begin{tabular}{|c|c|c|c|c|}
\hline & & Modelado resultante de & Nichos de nivación & \\
\hline & & la nivación & Termociclos & \\
\hline & & & Cordones de nivac & o protalus ramparts \\
\hline & & Evolución de las laderas & Laderas de cantil-t & \\
\hline & & & Laderas abancalac & \\
\hline & & & Laderas & Laderas tripartitas \\
\hline & & & $\begin{array}{l}\text { regularizadaso } \\
\text { convexo-cóncavas }\end{array}$ & $\begin{array}{l}\text { Facetas triangulares de } \\
\text { ladera }\end{array}$ \\
\hline & & Valles asimétricos & & \\
\hline & floderado & Valles en cuna & & \\
\hline & & Valles de fondo plano & & \\
\hline & & Lagos de deshielo & & \\
\hline & & Lagos orientados & & \\
\hline & lermokarst & Pingos colapsados & & \\
\hline & & Desplomes por deshielo & & \\
\hline & & Alas & & \\
\hline & Avalanchas & nieve & & \\
\hline Algunos & Movimientos & e masa & & \\
\hline aspectos sobre & Problemas in & nieriles en las regiones $d$ & suelos helados & \\
\hline Geomorfología & Edificios & & & \\
\hline aplicada a las & Obras lineale & & & \\
\hline regiones & Oleoductosy & aseoductos & & \\
\hline periglaciares & Minería & & & \\
\hline & Otras activid & & & \\
\hline
\end{tabular}

Tabla 108. Principales contenidos sobre geomorfología periglaciar presentes en Gutiérrez, 2001.

\begin{tabular}{|c|c|c|c|c|}
\hline \multicolumn{5}{|c|}{ Geomorfología periglaciar } \\
\hline \multirow{21}{*}{ El dominio periglaciar } & \multicolumn{4}{|c|}{ Definición, distinción de tipos de climas periglaciares } \\
\hline & \multirow{6}{*}{ Permafrost } & \multicolumn{3}{|c|}{ Definición, características } \\
\hline & & \multicolumn{3}{|c|}{ Talik } \\
\hline & & \multicolumn{3}{|c|}{ Icings o aufeis } \\
\hline & & \multicolumn{3}{|c|}{ Lentejones de hielo } \\
\hline & & \multicolumn{3}{|c|}{ Venas y cuñas de hielo } \\
\hline & & \multicolumn{3}{|c|}{ Hielo de pingo } \\
\hline & \multirow{14}{*}{$\begin{array}{l}\text { Procesos } \\
\text { periglaciares }\end{array}$} & \multirow{10}{*}{$\begin{array}{l}\text { Acción de } \\
\text { helada }\end{array}$} & \multirow{4}{*}{$\begin{array}{l}\text { Levantamiento } \\
\text { por helada }\end{array}$} & $\begin{array}{l}\text { Componente vertical } \\
\text { (levantamiento) }\end{array}$ \\
\hline & & & & $\begin{array}{l}\text { Componente horizontal } \\
\text { (traslación) }\end{array}$ \\
\hline & & & & Agujas de hielo o pipkrake \\
\hline & & & & Nubbins \\
\hline & & & $\begin{array}{l}\text { Desplazamiento } \\
\text { de masas }\end{array}$ & $\begin{array}{l}\text { Crioturbaciones o } \\
\text { involuciones periglaciares }\end{array}$ \\
\hline & & & Agrietamiento & Cuña de hielo \\
\hline & & & por helada & Cuña de arena \\
\hline & & & & Clasificación vertical \\
\hline & & & helada & Clasificación lateral \\
\hline & & & & Clasificación mecánica \\
\hline & & Meteorización q & nica & \\
\hline & & Movimiento de & $\begin{array}{l}\text { Desprendimiento } \\
\text { helada) }\end{array}$ & de rocas (rotura por \\
\hline & & masas & Solifluxión & \\
\hline & & & Gelifluxión & \\
\hline
\end{tabular}




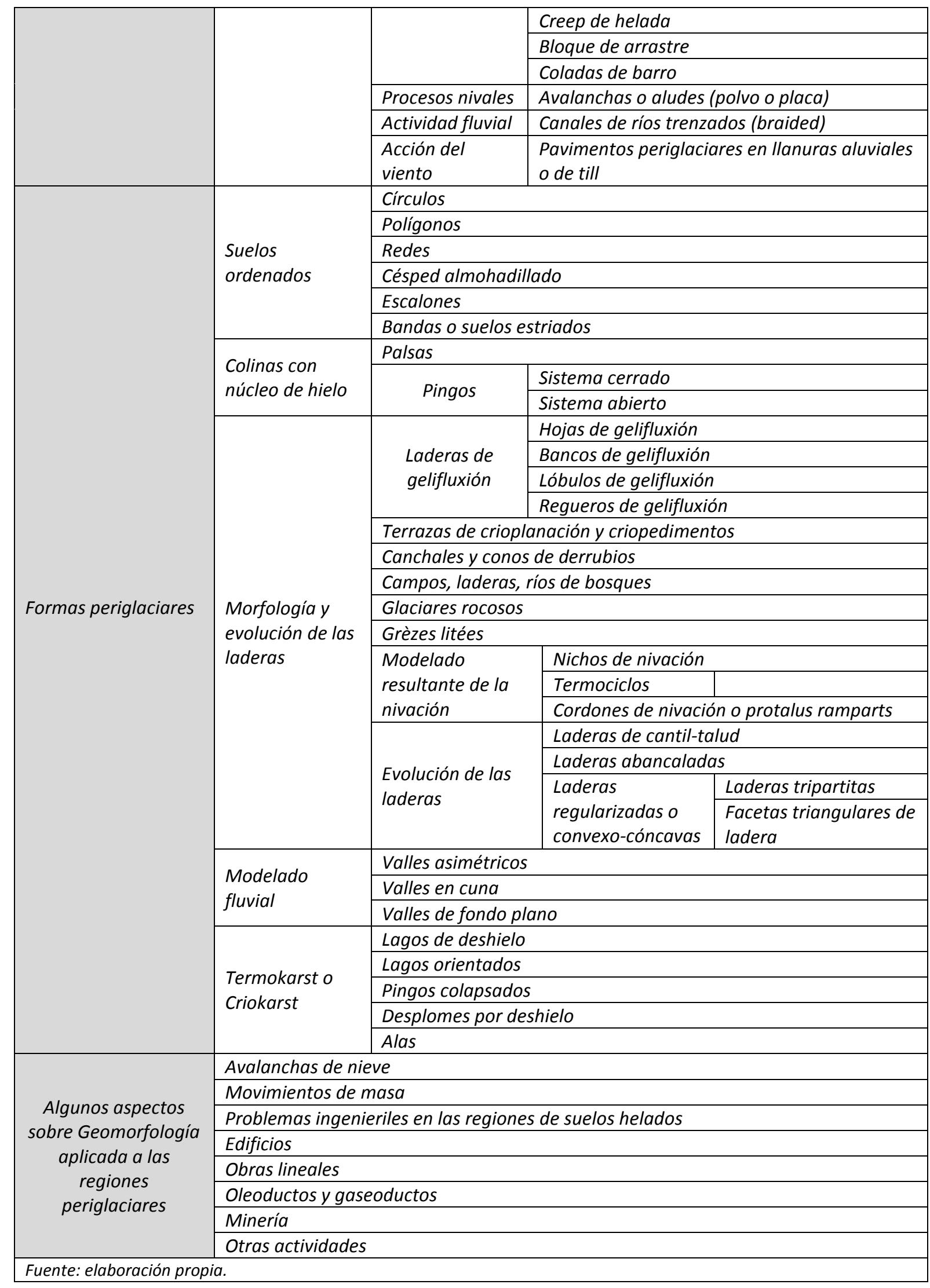


Tabla 109. Principales contenidos sobre geomorfología periglaciar presentes en Pedraza, 1996.

\begin{tabular}{|c|c|c|c|}
\hline \multicolumn{4}{|c|}{ Procesos periglaciares } \\
\hline $\begin{array}{l}\text { Ambientes } \\
\text { periglaciares }\end{array}$ & \multicolumn{3}{|c|}{$\begin{array}{l}\text { Suelos permanentemente helados (permafrost) } \\
\text { Ciclos de helada } \\
\text { Coberteras nivales }\end{array}$} \\
\hline $\begin{array}{l}\text { Acciones } \\
\text { elementales: } \\
\text { dinámica en los } \\
\text { fenómenos hielo- } \\
\text { deshielo }\end{array}$ & \multicolumn{3}{|c|}{$\begin{array}{l}\text { Acuñamiento (frost wedging): gelifracción, congelifracción o crioclastia } \\
\text { Hinchamiento y empuje (heaving y trusting) } \\
\text { Desplazamiento en masa } \\
\text { Agrietamiento (craking) } \\
\text { Segregación (acumulación selectivas de hielo masivo localizadas bajo la superficie } \\
\text { del terreno) }\end{array}$} \\
\hline \multirow{4}{*}{$\begin{array}{l}\text { Productos } \\
\text { periglaciares: } \\
\text { materiales y } \\
\text { formas }\end{array}$} & \multirow{3}{*}{$\begin{array}{l}\text { Formaciones } \\
\text { superficiales }\end{array}$} & $\begin{array}{l}\text { Formaciones } \\
\text { sobre la superficie } \\
\text { del suelo }\end{array}$ & $\begin{array}{l}\text { Morrenas de nevero (cordones, arcos, } \\
\text { vallums, amontonamientos) } \\
\text { Aludes y avalanchas debidas a cornisas de } \\
\text { nieve, placas de hielo, nieve húmeda, nieve en } \\
\text { polvo } \\
\text { Formaciones eólicas (arenas eólicas, loess) } \\
\text { Derrubios de vertiente no ordenados: } \\
\text { corredores rocosos, conos de derrubios, } \\
\text { taludes, campos/rios/mares de bloques } \\
\text { Derrubios de vertientes ordenados } \\
\text { Glaciares rocosos } \\
\text { Canchales o pedreras }\end{array}$ \\
\hline & & $\begin{array}{l}\text { Formaciones en la } \\
\text { superficie del } \\
\text { suelo }\end{array}$ & $\begin{array}{l}\text { Movimientos en masa: Flujo (gelifluxión), } \\
\text { reptación (creep), deslizamientos (avalancha) } \\
\text { Congelifluxión } \\
\text { Gelisolifluxión } \\
\text { Soligelifluxión } \\
\text { Suelos estructurados y ordenados: escalones, } \\
\text { surcos, círculos, polígonos, rosetones, } \\
\text { pavimentos, enlosados, guirnaldas, franjas de } \\
\text { piedra }\end{array}$ \\
\hline & & $\begin{array}{l}\text { Formaciones bajo } \\
\text { la superficie del } \\
\text { suelo }\end{array}$ & $\begin{array}{l}\text { Deformaciones: pliegues, involuciones, } \\
\text { inyecciones, cuñas de hielo } \\
\text { Montículos o hinchamientos: pingos, } \\
\text { hidrolacolitos, palsas y blisters, césped } \\
\text { almohadillado } \\
\text { Montículo helado }\end{array}$ \\
\hline & $\begin{array}{l}\text { Formas de } \\
\text { modelado }\end{array}$ & \multicolumn{2}{|c|}{$\begin{array}{l}\text { Remodelados característicos: vertientes reguladas, fondos de valle } \\
\text { plano, vertientes y valles disimétricos } \\
\text { Termocarst } \\
\text { Formas especificas: perfiles de gelifracción (aristas, agujas, crestas, } \\
\text { tors) } \\
\text { Terrazas de crioplanación, , nichos de nivación, glaciar } \\
\text { embrionario, rellanos escalonados, cicatrices o escarpes, circos } \\
\text { soligelifluidales }\end{array}$} \\
\hline
\end{tabular}


Tabla 110. Principales contenidos sobre geomorfología periglaciar presentes en Derruau, 1991.

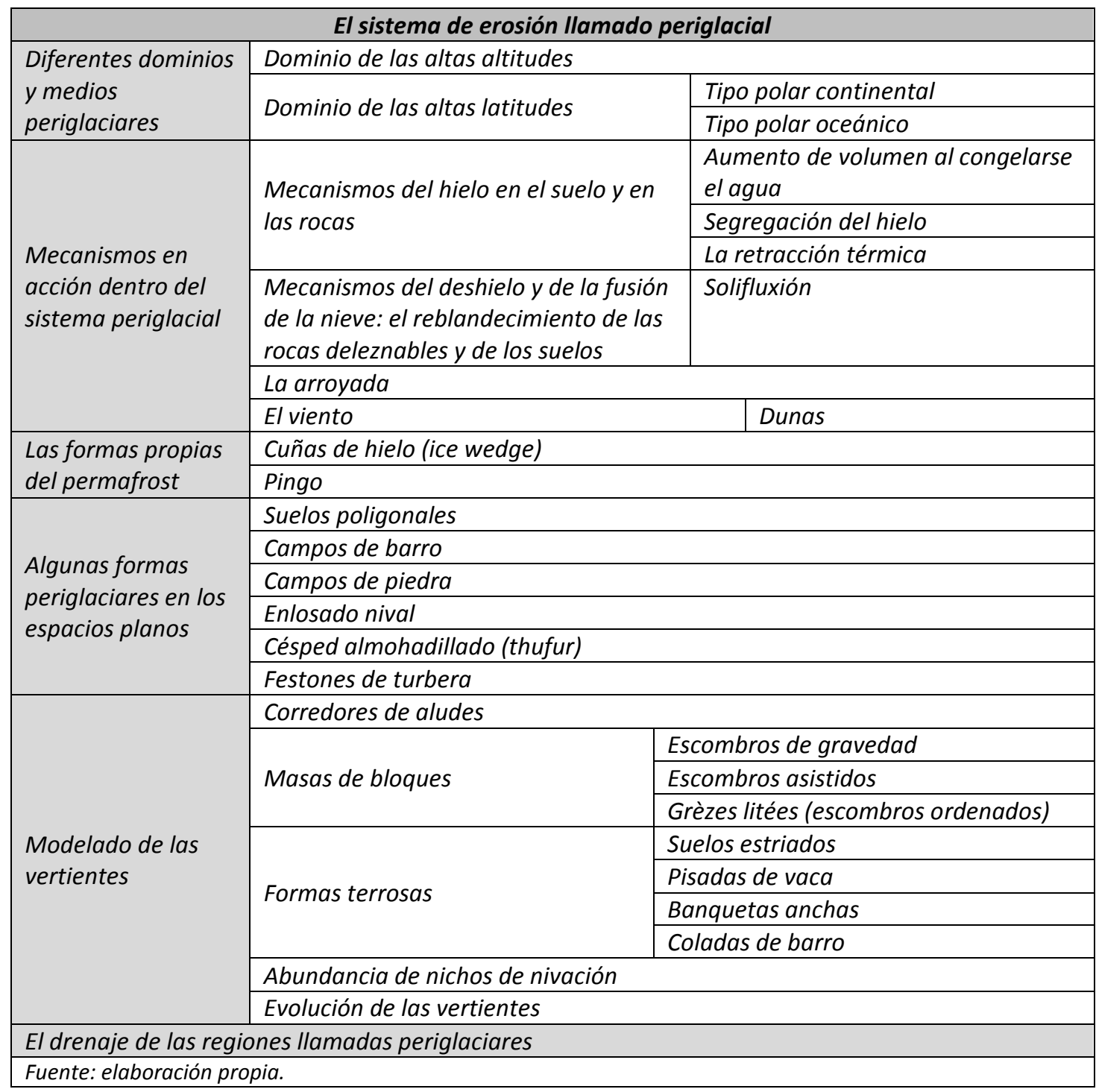

Tabla 111. Principales contenidos sobre geomorfología periglaciar presentes en Washburn, 1973.

\begin{tabular}{|c|c|c|c|}
\hline \multicolumn{4}{|c|}{ Periglacial processes and environments } \\
\hline \multirow{13}{*}{ Introduction } & \multicolumn{3}{|c|}{ Definition of periglacial } \\
\hline & \multicolumn{3}{|c|}{ Objectives } \\
\hline & \multirow{2}{*}{ Processes } & \multicolumn{2}{|c|}{ Frost action } \\
\hline & & \multicolumn{2}{|c|}{ Other processes } \\
\hline & \multirow{4}{*}{ Environments } & \multicolumn{2}{|l|}{ Polar lowlands } \\
\hline & & \multicolumn{2}{|c|}{ Subpolar lowlands } \\
\hline & & \multicolumn{2}{|c|}{ Middle-latitude lowlands } \\
\hline & & \multicolumn{2}{|c|}{ Highlands } \\
\hline & \multirow{5}{*}{ Basic factors } & \multicolumn{2}{|l|}{ Climate } \\
\hline & & \multicolumn{2}{|l|}{ Topography } \\
\hline & & \multirow{3}{*}{ Rock material } & Structure \\
\hline & & & Mineral composition \\
\hline & & & Texture \\
\hline
\end{tabular}


La Interpretación del Patrimonio Geomorfológico en los Picos de Europa: una propuesta para su aprovechamiento didáctico y geoturístico

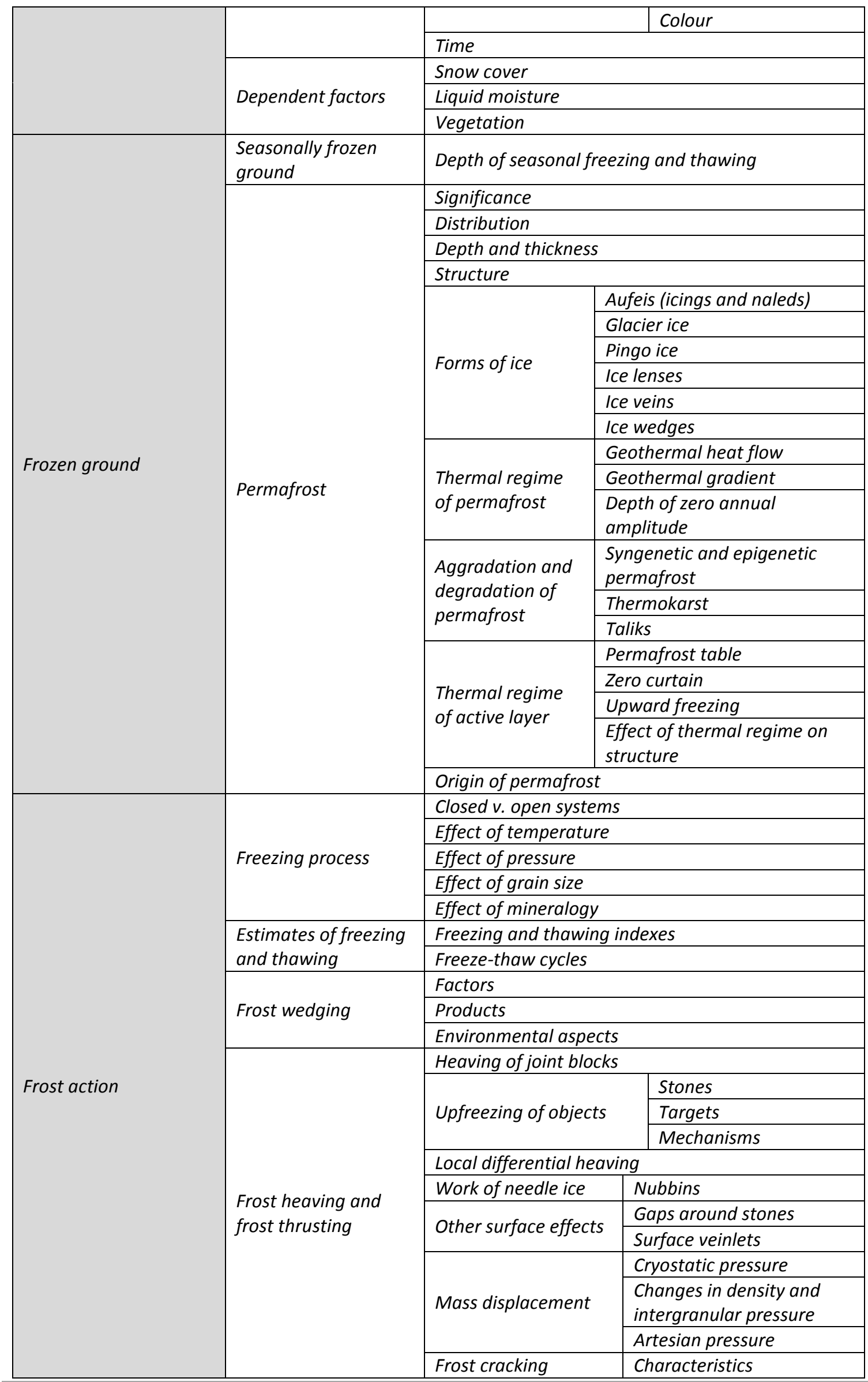


La Interpretación del Patrimonio Geomorfológico en los Picos de Europa: una propuesta para su aprovechamiento didáctico y geoturístico

\begin{tabular}{|c|c|c|c|c|}
\hline & & Sorting by & st action & \\
\hline & & & Nonsortec & circles \\
\hline & & & Sorted cir & \\
\hline & & & Nonsortec & polygons \\
\hline & & & Sorted po & gons \\
\hline & & & Nets & \\
\hline & & & Steps & \\
\hline & & & Nonsortec & stripes \\
\hline & & & Sorted str & \\
\hline & & & Origin & \\
\hline & & & & Desiccation cracking \\
\hline & & & & Dilation cracking \\
\hline & & & & Salt cracking \\
\hline & & Patterned & cracking & Seasonal frost cracking \\
\hline & & ground & & Permafrost cracking \\
\hline & & & & $\begin{array}{l}\text { Frost action along } \\
\text { bedrock joints }\end{array}$ \\
\hline & & & & Primary frost sorting \\
\hline & & & & Mass displacement \\
\hline & & & & Differential frost heaving \\
\hline & & & & Salt heaving \\
\hline & & & non- & $\begin{array}{l}\text { Differential thawing and } \\
\text { eluviation }\end{array}$ \\
\hline & & & & $\begin{array}{l}\text { Differential mass- } \\
\text { wasting }\end{array}$ \\
\hline & & & & Rillwork \\
\hline & & & & Differential weathering \\
\hline & & Involutios & & \\
\hline & & Stone pave & ents & \\
\hline & & String bogs & & \\
\hline & & Palsas & & \\
\hline & & Pingos & & \\
\hline & Avalanching & Snow avalc & ches and $m$ & ed avalanches \\
\hline & Slushflow & & & \\
\hline & Slumping & & & \\
\hline & Frost creep & & & \\
\hline & Gelifluction & & & \\
\hline Mass-wasting & & Sheets, ber & les, lobes a & d streams \\
\hline 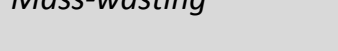 & gelifluction deposits & Block fields & lock slopes & and block streams \\
\hline & & Ploughing & cks & \\
\hline & Rock glaciers & & & \\
\hline & Taluses & & & \\
\hline & Protaluses ramparts & & & \\
\hline & Grèzes litées & & & \\
\hline Nivation & Nivation benches and & ollows & & \\
\hline IVIVCLtion & Altiplanation terraces & & & \\
\hline & Aufies & & & \\
\hline Fluvial action & Break-up phenomena & & & \\
\hline Fluviar acerom & Asymmetric valleys & & & \\
\hline & Dells & & & \\
\hline & & Varves & & \\
\hline Lacustrine ana marine & Lacustrine action & Ice rafti & & \\
\hline & & Ice shou & and ice-shc & e ridges \\
\hline
\end{tabular}


La Interpretación del Patrimonio Geomorfológico en los Picos de Europa: una propuesta para su aprovechamiento didáctico y geoturístico

\begin{tabular}{|l|l|l|}
\hline \multirow{5}{*}{ Wind action } & \multirow{2}{*}{ Marine action } & Ice rafting \\
\cline { 2 - 2 } & & Ice shove and ice-shove ridges \\
\cline { 2 - 2 } & Loess & Striated bedrock \\
\hline \multirow{5}{*}{ Thermokarst } & Dunes \\
\hline & Ventifacts \\
\hline & Linear and polygonal troughs \\
\hline & Collapsed pingos \\
\hline & Beaded drainage \\
\hline & Thaw lakes \\
\hline & Alases \\
\hline Fuente: elaboración propia. & \\
\hline
\end{tabular}

Tabla 112. Principales contenidos sobre geomorfología periglaciar presentes en Tricart, 1963.

\begin{tabular}{|c|c|c|}
\hline \multicolumn{3}{|c|}{ Le modelé périglaciaire } \\
\hline \multirow{3}{*}{$\begin{array}{l}\text { Les particularités de la } \\
\text { pédogenèse dans les } \\
\text { régions périglaciaires }\end{array}$} & \multicolumn{2}{|c|}{ L'occurrence du gel dans le sol } \\
\hline & \multicolumn{2}{|l|}{ L'action du gel dans les sols } \\
\hline & \multicolumn{2}{|c|}{ Les actions biochimiques dans les sols } \\
\hline \multirow{5}{*}{$\begin{array}{l}\text { Sols et microformes } \\
\text { dus à l'action du gel } \\
\text { (cryopédologie) }\end{array}$} & \multirow{3}{*}{$\begin{array}{l}\text { Les divers types. Essai de } \\
\text { classification. }\end{array}$} & Les sols à figures géométriques \\
\hline & & Les sols sans triage \\
\hline & & Les formations de pentes diverses \\
\hline & \multirow{2}{*}{$\begin{array}{l}\text { La répartition des sols et } \\
\text { microformes }\end{array}$} & $\begin{array}{l}\text { Les facteurs de la répartition des types de } \\
\text { sols }\end{array}$ \\
\hline & & $\begin{array}{l}\text { Les associations climatiques des sols et des } \\
\text { microformes }\end{array}$ \\
\hline \multirow{9}{*}{$\begin{array}{l}\text { Le façonnement des } \\
\text { versants }\end{array}$} & \multirow{2}{*}{$\begin{array}{l}\text { Les processus périglaciaires } \\
\text { de façonnement des } \\
\text { versants }\end{array}$} & La fragmentation \\
\hline & & $\begin{array}{l}\text { Le cheminement des débris sur les } \\
\text { versants }\end{array}$ \\
\hline & \multirow{3}{*}{$\begin{array}{l}\text { Evolution des types de } \\
\text { versants zonaux }\end{array}$} & Les versants façonnés par la solifluction \\
\hline & & Les versants à replats-goletz \\
\hline & & Les versants d'éboulis ordonnés \\
\hline & \multirow{2}{*}{$\begin{array}{l}\text { L'intervention des facteurs } \\
\text { azonaux }\end{array}$} & Les éboulis de gravité \\
\hline & & Le ruissellement \\
\hline & \multirow{2}{*}{$\begin{array}{l}\text { Les modalités de l'érosion } \\
\text { différentielle périglaciaire }\end{array}$} & Les influences lithologiques \\
\hline & & Les influences climatiques \\
\hline \multirow{5}{*}{$\begin{array}{l}\text { Les modalités } \\
\text { particulières en zone } \\
\text { froide de l'action } \\
\text { morphogénétique des } \\
\text { mécanismes } \\
\text { plurizonaux }\end{array}$} & \multirow{2}{*}{$\begin{array}{l}\text { L'action particulière des } \\
\text { eaux courantes }\end{array}$} & L'écoulement temporaire des eaux \\
\hline & & $\begin{array}{l}\text { Etude des débits et des coefficients } \\
\text { d'écoulement }\end{array}$ \\
\hline & \multirow{2}{*}{$\begin{array}{l}\text { Les modalités des actions } \\
\text { éoliennes }\end{array}$} & Les modalités banales \\
\hline & & Les modalités zonales d'actions du vent \\
\hline & \multicolumn{2}{|c|}{ Les particuralités de l'évolution littorale } \\
\hline
\end{tabular}




\section{A.9) Bibliografía de consulta sobre geomorfología exokárstica.}

Tabla 113. Principales contenidos sobre geomorfología kárstica presentes en Gutiérrez, 2008.

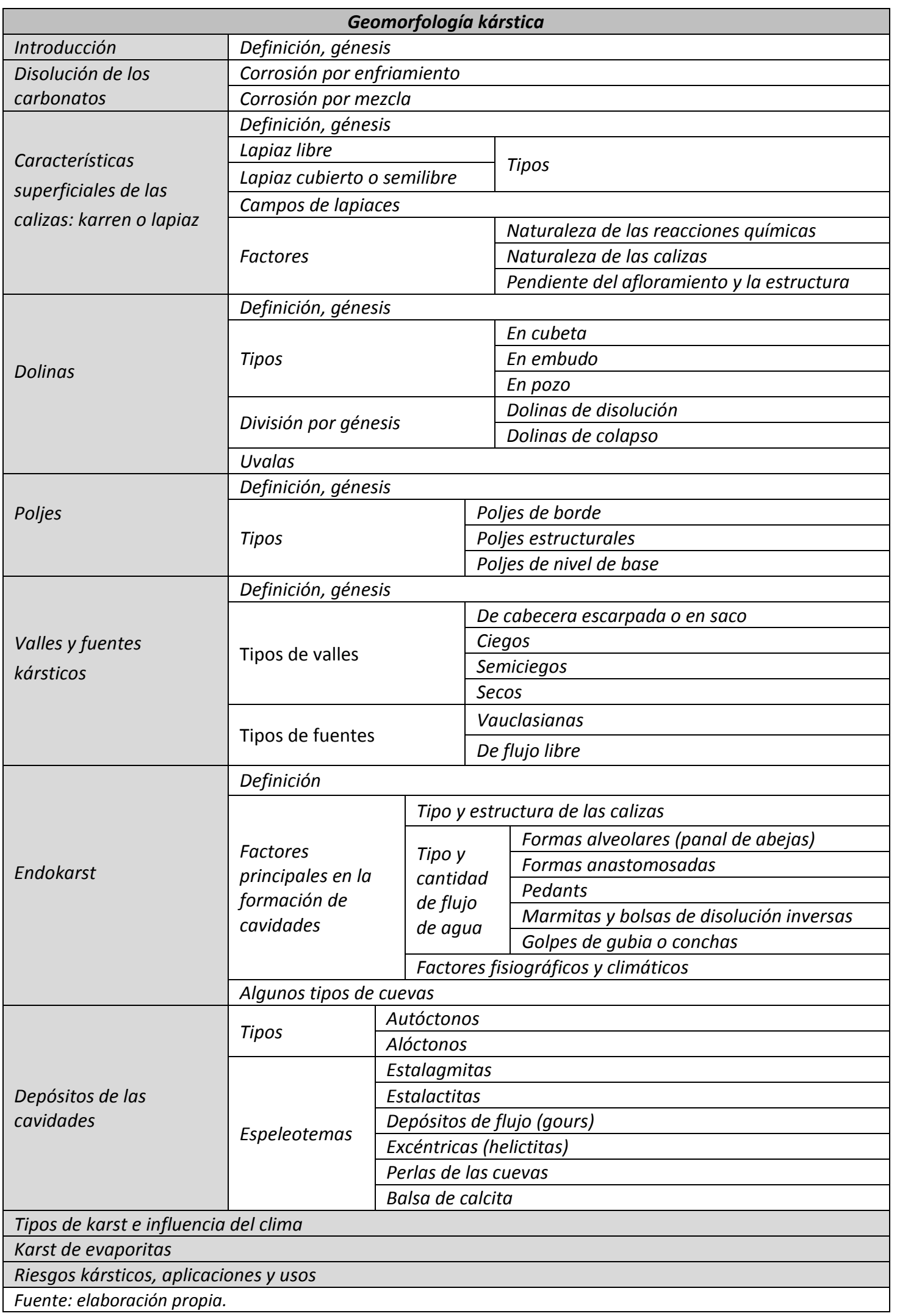


Tabla 114. Principales contenidos sobre geomorfología kárstica presentes en Gutiérrez, 2001.

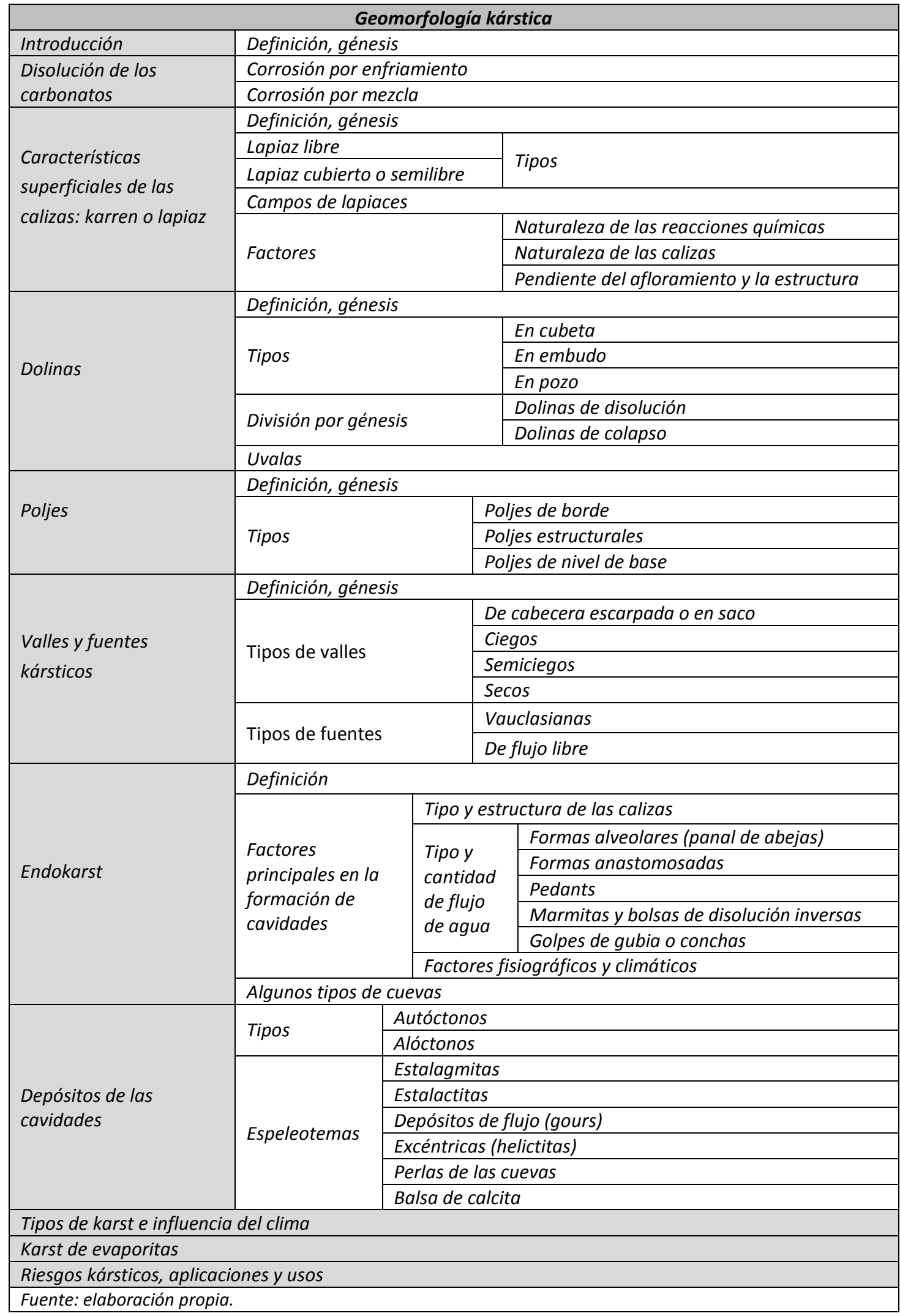


A.10) Fichas de LIGm de los Picos de Europa.

A.10.1) Macizo de los Urrielles

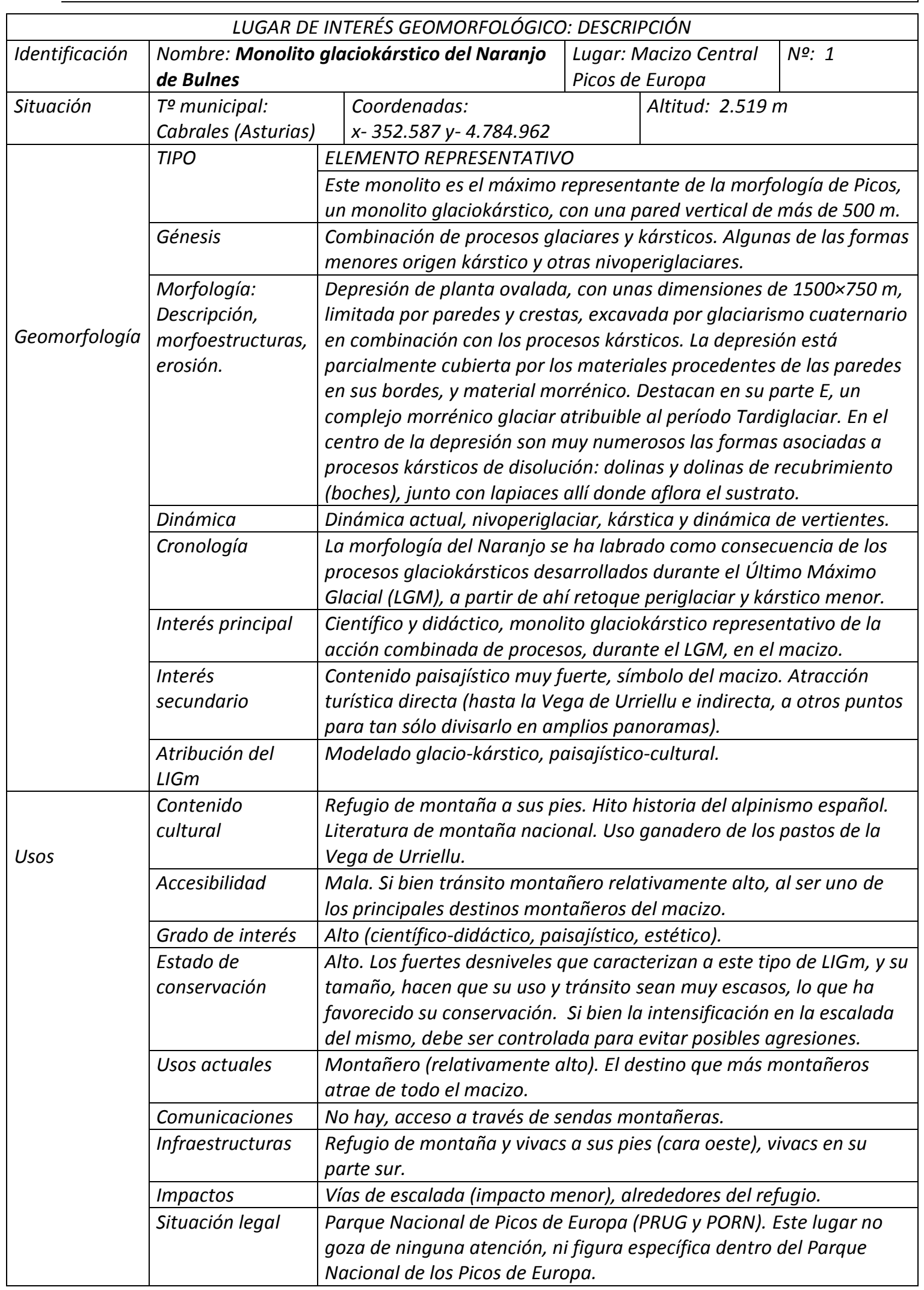




\begin{tabular}{|c|c|c|c|c|}
\hline \multicolumn{5}{|c|}{ LUGAR DE INTERÉS GEOMORFOLÓGICO: DESCRIPCIÓN } \\
\hline Identificación & \multicolumn{2}{|c|}{$\begin{array}{l}\text { Nombre: Morfoestructura cabalgante del Pico } \\
\text { Peña Vieja }\end{array}$} & Lugar: Macizo Central & \multirow[t]{2}{*}{ No: 2} \\
\hline Situación & To municipal: & Coordenadas: & $\begin{array}{l}\text { Altitud: } \\
2613\end{array}$ & \\
\hline \multirow{9}{*}{ Geomorfología } & \multirow[t]{2}{*}{ TIPO } & \multicolumn{3}{|c|}{ ELEMENTO REPRESENTATIVO } \\
\hline & & \multicolumn{3}{|c|}{$\begin{array}{l}\text { Cumbre cuya disposición y morfología está determinada por la } \\
\text { estructura geológica, representativa de las cumbres del macizo, } \\
\text { pero excepcional por su posición exenta y situación. }\end{array}$} \\
\hline & Génesis & \multicolumn{3}{|c|}{$\begin{array}{l}\text { Tectónica, escamas cabalgantes al sur con superposición y } \\
\text { apilamiento de cuatro escamas con buzamiento norte que culminan } \\
\text { en la cumbre. }\end{array}$} \\
\hline & $\begin{array}{l}\text { Morfología: } \\
\text { Descripción, } \\
\text { morfoestructuras, } \\
\text { erosión, erosión. }\end{array}$ & \multicolumn{3}{|c|}{$\begin{array}{l}\text { Frente cabalgante formado por las calizas de montaña, que genera } \\
\text { las grandes paredes y la Fm Picos de Europa, con un nuevo frente en } \\
\text { las Cm que genera la klippe (escama tectónica) de Peña Vieja, por } \\
\text { desconexión con el resto de la porción (Picos de Santa Ana). El Pico } \\
\text { muestra la disimetría, conforme al buzamiento. }\end{array}$} \\
\hline & Dinámica & \multicolumn{3}{|c|}{$\begin{array}{l}\text { Procesos de alta montaña, periglaciares, de ladera, nivales, muy } \\
\text { intensos. }\end{array}$} \\
\hline & Cronología & \multicolumn{3}{|c|}{$\begin{array}{l}\text { Emplazamiento en la orogenia alpina y disposición morfológica } \\
\text { derivada de la erosión glaciar pleistocena. }\end{array}$} \\
\hline & Interés principal & \multicolumn{3}{|c|}{$\begin{array}{l}\text { Morfoestructural, forma derivada de la morfotectónica con gran } \\
\text { importancia paisajística. }\end{array}$} \\
\hline & Interés secundario & \multicolumn{3}{|c|}{ Procesos actuales asociados a la morfoestructura. } \\
\hline & Atribución del LIGm & \multicolumn{3}{|c|}{ Morfoestructural, paisajístico. } \\
\hline \multirow[t]{9}{*}{ Usos } & Contenido cultural & \multicolumn{3}{|c|}{$\begin{array}{l}\text { Ha sido considerada la cumbre más alta de Cantabria hasta 2003, es } \\
\text { un hito montañero por las vías de escalada y constituir un clásico en } \\
\text { las ascensiones a Picos. Uso de cazadero real. }\end{array}$} \\
\hline & Accesibilidad & \multicolumn{3}{|c|}{$\begin{array}{l}\text { Media, pista y senda de montaña -construcción para caza-. } 800 \\
\text { metros desnivel, } 3 \text { horas. }\end{array}$} \\
\hline & Grado de interés & \multicolumn{3}{|c|}{$\begin{array}{l}\text { Elevado por su visibilidad, y ejemplaridad como elemento } \\
\text { morfoestructural. }\end{array}$} \\
\hline & $\begin{array}{l}\text { Estado de } \\
\text { conservación }\end{array}$ & \multicolumn{3}{|c|}{ Alto, no hay agresiones, dadas sus dimensiones y características. } \\
\hline & Usos actuales & \multicolumn{3}{|c|}{ Excursionista y montañero. Alta frecuentación. } \\
\hline & Comunicaciones & \multicolumn{3}{|c|}{ No hay, sólo senda. } \\
\hline & Infraestructuras & \multicolumn{3}{|c|}{ Pista de cazadores construida para el Rey. Muy deteriorada. } \\
\hline & Impactos & \multicolumn{3}{|c|}{--} \\
\hline & Situación legal & \multicolumn{3}{|c|}{ Parque Nacional de Picos de Europa (PRUG y PORN) } \\
\hline
\end{tabular}




\begin{tabular}{|c|c|c|c|c|}
\hline \multicolumn{5}{|c|}{ LUGAR DE INTERÉS GEOMORFOLÓGICO: DESCRIPCIÓN } \\
\hline \multirow{2}{*}{$\begin{array}{l}\text { Identificación } \\
\text { Situación }\end{array}$} & \multicolumn{2}{|c|}{$\begin{array}{l}\text { Nombre: Frente de cabalgamiento Traviesas } \\
\text { de Salinas }\end{array}$} & Lugar: Macizo Central & \multirow[t]{2}{*}{ No: 3} \\
\hline & To municipal: & Coordenadas: & Altitud: & \\
\hline \multirow{9}{*}{ Geomorfología } & \multirow[t]{2}{*}{ TIPO } & \multicolumn{3}{|l|}{ LUGAR REPRESENTATIVO } \\
\hline & & \multicolumn{3}{|c|}{$\begin{array}{l}\text { Frente cabalgante del conjunto de los Picos de Europa sobre } \\
\text { Grupo Mogrovejo, que caracteriza el límite meridional del } \\
\text { macizo central de los Picos de Europa. }\end{array}$} \\
\hline & Génesis & \multicolumn{3}{|c|}{$\begin{array}{l}\text { Tectónica de compresión, cabalgamiento del conjunto de } \\
\text { escamas cabalgantes, con repliegues menores, sobre la unidad } \\
\text { inferior, y erosión diferencial con erosión de los materiales } \\
\text { menos competentes del Grupo Mogrovejo. }\end{array}$} \\
\hline & $\begin{array}{l}\text { Morfología: } \\
\text { Descripción, } \\
\text { morfoestructuras, } \\
\text { erosión, erosión. }\end{array}$ & \multicolumn{3}{|c|}{$\begin{array}{l}\text { Frente de cabalgamiento escalonado por la existencia de } \\
\text { escamas cabalgantes. Las calizas de montaña y la Fm Picos de } \\
\text { Europa generan resaltes verticales y la Fm Lebeña genera } \\
\text { pasillos y fajas de pendiente menor que escalonan la frente. El } \\
\text { contacto mediante la falla inversa está tapizado por derrubios y } \\
\text { materiales morrénicos, y en las paredes se aprecia la estructura } \\
\text { geológica que arma el frente de cabalgamiento. }\end{array}$} \\
\hline & Dinámica & \multicolumn{3}{|c|}{ Dinámica de laderas, taludes, conos y flujos de derrubios. } \\
\hline & Cronología & \multicolumn{3}{|c|}{$\begin{array}{l}\text { Emplazamiento tectónico durante la orogenia alpina y erosión } \\
\text { sintectónica y postectónica hasta la actualidad. }\end{array}$} \\
\hline & Interés principal & \multicolumn{3}{|c|}{ Morfoestructuras cabalgantes en escamas. } \\
\hline & $\begin{array}{l}\text { Interés } \\
\text { secundario }\end{array}$ & \multicolumn{3}{|c|}{ Proceso de laderas y estructuras geológicas visibles. } \\
\hline & $\begin{array}{l}\text { Atribución del } \\
\text { LIGm }\end{array}$ & \multicolumn{3}{|c|}{ Morfoestructural y paisajístico. } \\
\hline \multirow{9}{*}{ Usos } & $\begin{array}{l}\text { Contenido } \\
\text { cultural }\end{array}$ & \multicolumn{3}{|c|}{ Sendas de acceso a Picos de Europa. } \\
\hline & Accesibilidad & \multicolumn{3}{|c|}{ Mala, pistas de montaña y sendas. } \\
\hline & Grado de interés & \multicolumn{3}{|c|}{ Medio, elemento morfoestructural con valor paisajístico. } \\
\hline & $\begin{array}{l}\text { Estado de } \\
\text { conservación }\end{array}$ & \multicolumn{3}{|c|}{ Bueno, dada las dimensiones de la forma. } \\
\hline & Usos actuales & \multicolumn{3}{|c|}{ Excursionista, baja frecuentación. } \\
\hline & Comunicaciones & \multicolumn{3}{|l|}{ Malas, pistas de montaña. } \\
\hline & Infraestructuras & \multicolumn{3}{|l|}{ No existen } \\
\hline & Impactos & \multicolumn{3}{|l|}{ No existen } \\
\hline & Situación legal & \multicolumn{3}{|c|}{ Parque Nacional de Picos de Europa (PRUG y PORN) } \\
\hline
\end{tabular}




\begin{tabular}{|c|c|c|c|c|}
\hline \multicolumn{5}{|c|}{ LUGAR DE INTERÉS GEOMORFOLÓGICO: DESCRIPCIÓN } \\
\hline Identificación & \multicolumn{2}{|c|}{ Nombre: Horn del Pico Tesorero } & $\begin{array}{l}\text { Lugar: Macizo Central } \\
\text { Picos de Europa }\end{array}$ & No: 4 \\
\hline Situación & $\begin{array}{l}\text { To municipal: } \\
\text { Cabrales } \\
\text { (Asturias) } \\
\text { Valdeón (León) } \\
\text { Camaleño } \\
\text { (Cantabria) }\end{array}$ & $\begin{array}{l}\text { Coordenadas: } \\
x-350.027 \\
y-4.782 .789\end{array}$ & \multicolumn{2}{|l|}{$\begin{array}{l}\text { Altitud: } \\
2.570 \mathrm{~m}\end{array}$} \\
\hline & TIPO & \multicolumn{3}{|c|}{ ELEMENTO REPRESENTATIVO } \\
\hline & & \multicolumn{3}{|c|}{$\begin{array}{l}\text { El Pico Tesorero constituye una cumbre con morfología en horn, } \\
\text { que representa el modelo de cumbres labradas prioritariamente } \\
\text { por la acción de los glaciares pleistocenos. }\end{array}$} \\
\hline & Génesis & \multicolumn{3}{|c|}{ Esculpido con forma piramidal de origen glaciar. } \\
\hline Geomorfología & $\begin{array}{l}\text { Morfología: } \\
\text { Descripción, } \\
\text { morfoestructuras, } \\
\text { erosión. }\end{array}$ & \multicolumn{3}{|c|}{$\begin{array}{l}\text { Cumbre en Horn, con forma piramidal típica, labrado por los } \\
\text { glaciares pleistocenos por sus caras E, W y S, mientras que al } \\
\text { norte su ala, desciende hacia la Collada labrada para volver a } \\
\text { ascender hacia la cresta de los Picos de Arenizas. }\end{array}$} \\
\hline & Dinámica & \multicolumn{3}{|c|}{$\begin{array}{l}\text { Dinámica actual nivoperiglaciar, en combinación con procesos } \\
\text { de ladera y karstificación. }\end{array}$} \\
\hline & Cronología & \multicolumn{3}{|c|}{ Último Máximo Glacial (LGM). } \\
\hline & Interés principal & \multicolumn{3}{|c|}{ Cumbre del pico tesorero conforma un modélico horn. } \\
\hline & $\begin{array}{l}\text { Interés } \\
\text { secundario }\end{array}$ & \multicolumn{3}{|c|}{$\begin{array}{l}\text { Elementos secundarios presentes: cubetas, neveros } \\
\text { permanentes, morrenas de nevero, etc. }\end{array}$} \\
\hline & $\begin{array}{l}\text { Atribución del } \\
\text { LIGm }\end{array}$ & \multicolumn{3}{|c|}{ Modelado glaciar. } \\
\hline \multirow{9}{*}{ Usos } & $\begin{array}{l}\text { Contenido } \\
\text { cultural }\end{array}$ & \multicolumn{3}{|c|}{ Punto de reunión de los límites de las tres provincias. } \\
\hline & Accesibilidad & \multicolumn{3}{|c|}{$\begin{array}{l}\text { Mala. Está situada en un sector al que sólo se puede acceder a } \\
\text { través de sendas montañeras durante más de } 4 \text { o } 5 \text { h. }\end{array}$} \\
\hline & Grado de interés & \multicolumn{3}{|c|}{ Medio (didáctico y montañero) } \\
\hline & $\begin{array}{l}\text { Estado de } \\
\text { conservación }\end{array}$ & \multicolumn{3}{|c|}{$\begin{array}{l}\text { Alto. El estado de conservación de este elemento es bueno. Tan } \\
\text { sólo visitado por montañeros, flujo menor. }\end{array}$} \\
\hline & Usos actuales & \multicolumn{3}{|c|}{ Montañero } \\
\hline & Comunicaciones & \multicolumn{3}{|c|}{ No hay, sendas montañeras poco marcadas. } \\
\hline & Infraestructuras & \multicolumn{3}{|c|}{-} \\
\hline & Impactos & \multicolumn{3}{|l|}{ No existentes. } \\
\hline & Situación legal & \multicolumn{3}{|c|}{$\begin{array}{l}\text { Este lugar no goza de ninguna atención, ni figura específica } \\
\text { dentro del Parque Nacional de los Picos de Europa. }\end{array}$} \\
\hline
\end{tabular}




\begin{tabular}{|c|c|c|c|c|}
\hline \multicolumn{5}{|c|}{ LUGAR DE INTERÉS GEOMORFOLÓGICO: DESCRIPCIÓN } \\
\hline Identificación & \multicolumn{2}{|c|}{ Nombre: Complejo glaciar de Fuente De-Pido } & Lugar: Macizo Central & NNo: 5 \\
\hline Situación & To municipal: & Coordenadas: & \multicolumn{2}{|l|}{ Altitud: } \\
\hline \multirow{9}{*}{ Geomorfología } & \multirow[t]{2}{*}{ TIPO } & \multicolumn{3}{|l|}{ LUGAR REPRESENTATIVO } \\
\hline & & \multicolumn{3}{|c|}{$\begin{array}{l}\text { Conjunto compuesto por un complejo morrénico frontal, umbral, cubeta y } \\
\text { artesas (Deva y Liordes) de grandes dimensiones y fuerte desnivel, más de } \\
800 \text { metros, con gran valor paisajístico. Constituye el complejo frontal de } \\
\text { mayor desarrollo y complejidad en cota baja. }\end{array}$} \\
\hline & Génesis & \multicolumn{3}{|c|}{$\begin{array}{l}\text { Modelado glaciar, umbral, cubeta, artesa y morrenas, en un relieve } \\
\text { estructural, el cabalgamiento de las calizas de Picos sobre la Formación } \\
\text { Mogrovejo. Lo acompañan elementos secundarios, deslizamientos de } \\
\text { laderas, flujos de derrubios, taludes. }\end{array}$} \\
\hline & $\begin{array}{l}\text { Morfología: } \\
\text { Descripción, } \\
\text { morfoestructuras, } \\
\text { erosión. }\end{array}$ & \multicolumn{3}{|c|}{$\begin{array}{l}\text { Complejo morrénico frontal compuesto de circo arcos mayores, con vanos } \\
\text { intramorrénicos y llanos de obturación. Cubeta y artesa de Fuente Dé, } \\
\text { limitada por la morrena lateral y con deslizamientos de ladera que retocan } \\
\text { la morfología. Artesa glaciar de la canal de Liordes, de grandes dimensiones, } \\
\text { colgada sobre la de Fuente Dé, presenta una morfología mixta entre artesa } \\
\text { colgada y canal de Picos. Umbral de Fuente Dé, modelado por el } \\
\text { glaciarismo, es un relieve morfoestructural derivado del cabalgamiento de } \\
\text { las calizas de montaña sobre los materiales menos competentes de la } \\
\text { Formación Mogrovejo, presenta canales y proceso activos de alta energía } \\
\text { (aludes, flujos de derrubios, taludes de derrubios). }\end{array}$} \\
\hline & Dinámica & \multicolumn{3}{|c|}{$\begin{array}{l}\text { Fluvial y de laderas, con un amplio abanico de procesos (nivales, aludes, } \\
\text { torrenciales, flujos, deslizamientos) que retocan las formas heredadas. }\end{array}$} \\
\hline & Cronología & \multicolumn{3}{|c|}{$\begin{array}{l}\text { Modelado del LGM con pulsaciones que forman el complejo morrénico, y } \\
\text { retoque posterior de las laderas (finipleistoceno-Holoceno). El relieve } \\
\text { morfoestructural es anterior al glaciarismo (fases orogénicas alpinas). }\end{array}$} \\
\hline & Interés principal & \multicolumn{3}{|c|}{$\begin{array}{l}\text { Modelado glaciar en artesas y complejo morrénico frontal, morfoestructura } \\
\text { de cabalgamiento retocada por el hielo, fuerte contenido paisajístico. }\end{array}$} \\
\hline & Interés secundario & \multicolumn{3}{|c|}{ Dinámica de laderas, procesos actuales en el umbral de Fuente Dé. } \\
\hline & $\begin{array}{l}\text { Atribución del } \\
\text { LIGm }\end{array}$ & \multicolumn{3}{|c|}{ Morfoestructural y modelado glaciar. Paisajístico. } \\
\hline \multirow[t]{9}{*}{ Usos } & Contenido cultural & \multicolumn{3}{|c|}{$\begin{array}{l}\text { Poblamiento actual, Pido, con elementos sobresalientes -viviendas, } \\
\text { estructura del poblamiento, hórreos-, usos tradicionales agroganaderos y } \\
\text { forestal. Restos de minería. Acceso turístico y montañero desde 1960, } \\
\text { complejo turístico, tiendas, bares, camping, teleférico, minizoo, bancos, } \\
\text { aparcamientos, hoteles, restaurantes. }\end{array}$} \\
\hline & Accesibilidad & \multicolumn{3}{|c|}{ Muy buena, carretera C- 621 Pistas. } \\
\hline & Grado de interés & \multicolumn{3}{|c|}{$\begin{array}{l}\text { Alto, sobre todo el complejo morrénico de Pido y la conjunción de elementos } \\
\text { paisajísticos en Fuente Dé. Todo continuo de interés en } 2 \mathrm{~km} \text {. }\end{array}$} \\
\hline & $\begin{array}{l}\text { Estado de } \\
\text { conservación }\end{array}$ & \multicolumn{3}{|c|}{$\begin{array}{l}\text { Bueno, muy utilizado por el hombre, las dimensiones de formas y procesos } \\
\text { impiden un alto deterioro. }\end{array}$} \\
\hline & Usos actuales & \multicolumn{3}{|c|}{$\begin{array}{l}\text { Turístico en Fuente Dé, intenso, es el acceso principal al P.N. Picos de } \\
\text { Europa, con aprox. } 600.000 \text { visitantes al año. Agroganadero en Pido, con } \\
\text { residencias secundarias, pero al margen del flujo turístico masivo. }\end{array}$} \\
\hline & Comunicaciones & \multicolumn{3}{|c|}{ Carretera C-621, Autobús de línea, taxis. } \\
\hline & Infraestructuras & \multicolumn{3}{|c|}{ Teleférico, pistas, carretera, complejo turístico. } \\
\hline & Impactos & \multirow{2}{*}{\multicolumn{3}{|c|}{$\begin{array}{l}\text { Usos masivos del entorno de Fuente Dé, muy puntuales par } \\
\text { mayores en los aspectos biológicos. Moderado en sector de } \\
\text { P.N. Picos de Europa y zona de influencia socioeconómica. }\end{array}$}} \\
\hline & Situación legal & & & \\
\hline
\end{tabular}




\begin{tabular}{|c|c|c|c|}
\hline \multicolumn{4}{|c|}{ LUGAR DE INTERÉS GEOMORFOLÓGICO: DESCRIPCIÓN } \\
\hline Identificación & \multicolumn{2}{|c|}{ Nombre: Circos y morrenas de Áliva } & \begin{tabular}{|l|l|} 
Lugar: Macizo Central & №: 6 \\
\end{tabular} \\
\hline Situación & To municipal: & Coordenadas: & Altitud: \\
\hline \multirow{9}{*}{ Geomorfología } & \multirow[t]{2}{*}{ TIPO } & \multicolumn{2}{|c|}{ LUGAR REPRESENTATIVO } \\
\hline & & \multicolumn{2}{|c|}{$\begin{array}{l}\text { Conjunto de circos y morenas glaciares representativos de la } \\
\text { morfología glaciar del LGM y las fases de retroceso Pleistoceno. }\end{array}$} \\
\hline & Génesis & \multicolumn{2}{|c|}{ Procesos de erosión y acumulación glaciar. } \\
\hline & $\begin{array}{l}\text { Morfología: } \\
\text { Descripción, } \\
\text { morfoestructuras, } \\
\text { erosión, } \\
\text { sedimentación. }\end{array}$ & \multicolumn{2}{|c|}{$\begin{array}{l}\text { Complejo compuesto de una morrena lateral (Lomba de Toro) de } \\
1500 \mathrm{~m} \text { km de longitud, con dos complejos de obturación, un } \\
\text { complejo morrénico frontal compuesto por } 15 \text { arcos menores } \\
\text { con rellanos lacustres. Aguas arriba se sitúan cubetas y umbrales } \\
\text { glaciares, morrenas de retroceso próximas a las paredes y dos } \\
\text { circos en las paredes de Peña Vieja. }\end{array}$} \\
\hline & Dinámica & \multicolumn{2}{|c|}{$\begin{array}{l}\text { Los procesos glaciares no existen. La dinámica actual es } \\
\text { torrencial, nival y solifluidal en el conjunto del LIGm, con } \\
\text { procesos de gravedad, flujos de derrubios y aludes en las } \\
\text { paredes, así como deslizamientos de ladera. }\end{array}$} \\
\hline & Cronología & \multicolumn{2}{|c|}{$\begin{array}{l}\text { Pleistoceno, modelado perteneciente al LGM muy pulsador en } \\
\text { las Salgardas, y a fases de retroceso, con restos de morenas } \\
\text { atribuidos al Tardiglaciar. }\end{array}$} \\
\hline & Interés principal & \multicolumn{2}{|c|}{$\begin{array}{l}\text { Formas de acumulación glaciar inscritas en el paisaje de Picos. } \\
\text { Sobre todo la Lomba de Toro, Las Salgardas y la Morrena de } \\
\text { Peña Vieja. }\end{array}$} \\
\hline & Interés secundario & \multicolumn{2}{|c|}{$\begin{array}{l}\text { Elementos complementarios con los que se relacionan, circos } \\
\text { modelados en las paredes, morrenas de nevero, cubetas de } \\
\text { sobreexcavación, inmersas en un paisaje supraforestal. }\end{array}$} \\
\hline & Atribución del LIGm & \multicolumn{2}{|c|}{ Modelado glaciar. Paisajístico. } \\
\hline Usos & Contenido cultural & \multicolumn{2}{|c|}{$\begin{array}{l}\text { Puertos de montaña, uso tradicional de pastos, ermita; turismo } \\
\text { de montaña tradicional, Chalet del Rey y Hotel. Minería Primeros } \\
\text { estudios de geomorfología en Picos de Europa. }\end{array}$} \\
\hline & Accesibilidad & \multicolumn{2}{|c|}{ Muy buena. Pistas rodadas y sendas fáciles a todos los lugares. } \\
\hline & Grado de interés & \multicolumn{2}{|c|}{$\begin{array}{l}\text { Alto. Constituye el mejor y más didáctico complejo morrénico de } \\
\text { Picos, accesible y muy estudiado desde distintas perspectivas. }\end{array}$} \\
\hline & $\begin{array}{l}\text { Estado de } \\
\text { conservación }\end{array}$ & \multicolumn{2}{|c|}{$\begin{array}{l}\text { Bueno, con agresiones importantes, con contenido paisajístico - } \\
\text { minas de Áliva- y puntuales - pistas, balsas, construcciones y } \\
\text { establos en morrenas-. }\end{array}$} \\
\hline & Usos actuales & \multicolumn{2}{|c|}{$\begin{array}{l}\text { Uso ganadero y turístico ( } 4 \times 4 \text { y senderismo), con muy alta } \\
\text { frecuentación a baja, según los lugares. }\end{array}$} \\
\hline & Comunicaciones & \multicolumn{2}{|c|}{ Taxis $4 \times 4$ con poblaciones cercanas. } \\
\hline & Infraestructuras & \multicolumn{2}{|c|}{$\begin{array}{l}\text { Pistas y construcciones (Hotel, restaurante, Chalet, Ermita). } \\
\text { Caminos mineros y tradicionales abandonados. }\end{array}$} \\
\hline & Impactos & \multicolumn{2}{|c|}{$\begin{array}{l}\text { Pistas, que deterioran las morenas al cruzarlas y atravesarlas, } \\
\text { pero sobre todo el uso libre de todo terrenos, con masificación } \\
\text { estival que dañan pistas y morrenas. Minas abandonadas de } \\
\text { Áliva. }\end{array}$} \\
\hline & Situación legal & \multicolumn{2}{|c|}{ Parque Nacional de Picos de Europa (PRUG y PORN) } \\
\hline
\end{tabular}




\begin{tabular}{|c|c|c|c|c|}
\hline \multicolumn{5}{|c|}{ LUGAR DE INTERÉS GEOMORFOLÓGICO: DESCRIPCIÓN } \\
\hline Identificación & \multicolumn{2}{|c|}{$\begin{array}{l}\text { Nombre: Complejo morrénico con glaciar } \\
\text { rocoso de Lloroza }\end{array}$} & Lugar: Macizo Central & \multirow[t]{2}{*}{ No: 7} \\
\hline Situación & To municipal: & Coordenadas: & Altitud: & \\
\hline \multirow{9}{*}{ Geomorfología } & \multirow[t]{2}{*}{ TIPO } & \multicolumn{3}{|l|}{ LUGAR SINGULAR } \\
\hline & & \multicolumn{3}{|c|}{$\begin{array}{l}\text { Conjunto de morrenas glaciares con lagos estacionales, procesos } \\
\text { kársticos y un glaciar rocoso relicto. La existencia de dos lagos y } \\
\text { el glaciar rocoso hacen de que este lugar sea singular, pues } \\
\text { existen muy pocos lagos en Picos, sólo uno más en el macizo } \\
\text { central, y no hay registrados más glaciares rocosos en Picos. }\end{array}$} \\
\hline & Génesis & \multicolumn{3}{|c|}{$\begin{array}{l}\text { Morfogénesis glaciar y periglaciar con procesos kársticos } \\
\text { asociados. }\end{array}$} \\
\hline & $\begin{array}{l}\text { Morfología: } \\
\text { Descripción, } \\
\text { morfoestructuras, } \\
\text { erosión, } \\
\text { sedimentación. }\end{array}$ & \multicolumn{3}{|c|}{$\begin{array}{l}\text { Complejo compuesto por tres arcos morrénicos que reposas } \\
\text { sobre la parte occidental de la depresión glaciokárstica de los } \\
\text { Hoyos de Lloroza. En las morenas se sitúan, al interior, los dos } \\
\text { lagos glaciares y el glaciar rocoso, que enlazan mediante taludes } \\
\text { de derrubios activos con las paredes calcáreas de Peña Olvidada. }\end{array}$} \\
\hline & Dinámica & \multicolumn{3}{|c|}{ Gravedad, aludes y kárstica. } \\
\hline & Cronología & \multicolumn{3}{|c|}{$\begin{array}{l}\text { Fase de retroceso glaciar posterior al máximo. La existencia de } \\
\text { morenas y glaciar rocoso evoca dos fases, una finipleistocena, } \\
\text { periodo de equilibrio durante el retroceso y otra fría, no glaciar, } \\
\text { que ha sido correlacionada con el Tardiglaciar. }\end{array}$} \\
\hline & Interés principal & \multicolumn{3}{|c|}{ Complejo morrénico intramontañoso y glaciar rocoso. } \\
\hline & $\begin{array}{l}\text { Interés } \\
\text { secundario }\end{array}$ & \multicolumn{3}{|c|}{$\begin{array}{l}\text { Lagos glaciares (intramorrénicos) con dinámica kárstica y } \\
\text { taludes de derrubios semifucionales en marco paisajístico de } \\
\text { alta montaña calcárea. }\end{array}$} \\
\hline & $\begin{array}{l}\text { Atribución del } \\
\text { LIGm }\end{array}$ & \multicolumn{3}{|c|}{ Modelado glaciar y periglaciar. } \\
\hline \multirow{9}{*}{ Usos } & $\begin{array}{l}\text { Contenido } \\
\text { cultural }\end{array}$ & \multicolumn{3}{|c|}{$\begin{array}{l}\text { Turismo de montaña y restos de infraestructuras mineras (pista, } \\
\text { catas...). }\end{array}$} \\
\hline & Accesibilidad & \multicolumn{3}{|c|}{ Muy Buena, teleférico (el cable) -500 m- y pista rodada. } \\
\hline & Grado de interés & \multicolumn{3}{|c|}{$\begin{array}{l}\text { Muy alto, por la excepcionalidad de las formas de acumulación } \\
\text { glaciar intramontanas y la existencia de un glaciar rocoso en un } \\
\text { ámbito muy accesible. }\end{array}$} \\
\hline & $\begin{array}{l}\text { Estado de } \\
\text { conservación }\end{array}$ & \multicolumn{3}{|c|}{$\begin{array}{l}\text { Alto, sólo alterado por una pista en la parte alta y sendas que lo } \\
\text { cruzan. }\end{array}$} \\
\hline & Usos actuales & \multicolumn{3}{|c|}{$\begin{array}{l}\text { Turismo y senderismo. Masificación, dado la proximidad del } \\
\text { Cable. }\end{array}$} \\
\hline & Comunicaciones & \multicolumn{3}{|c|}{ Taxis y teleférico público. } \\
\hline & Infraestructuras & \multicolumn{3}{|c|}{ Pista que lo circunvala. } \\
\hline & Impactos & \multicolumn{3}{|c|}{ Pista en los taludes de derrubios. } \\
\hline & Situación legal & \multicolumn{3}{|c|}{ Parque Nacional de Picos de Europa (PRUG y PORN) } \\
\hline
\end{tabular}




\begin{tabular}{|c|c|c|c|c|}
\hline \multicolumn{5}{|c|}{ LUGAR DE INTERÉS GEOMORFOLÓGICO: DESCRIPCIÓN } \\
\hline Identificación & \multicolumn{2}{|c|}{ Nombre: Complejo Glaciar Jou Negro } & $\begin{array}{l}\text { Lugar: Macizo Central } \\
\text { Picos de Europa }\end{array}$ & NNo: 8 \\
\hline Situación & $\begin{array}{l}\text { To municipal: } \\
\text { Cabrales } \\
\text { (Asturias) }\end{array}$ & $\begin{array}{l}\text { Coordenadas: } \\
x-349.449 \\
y-4.785 .256\end{array}$ & $\begin{array}{l}\text { Altitud: } \\
\text { Entre } 2.220-2.64\end{array}$ & \\
\hline \multirow{9}{*}{ Geomorfología } & \multirow[t]{2}{*}{ TIPO } & \multicolumn{3}{|l|}{ LUGAR SINGULAR } \\
\hline & & \multicolumn{3}{|c|}{$\begin{array}{l}\text { Complejo glaciar que aglutina restos morfológicos glaciares } \\
\text { (morrena y helero residual) de la última pulsación fría acaecida } \\
\text { en época histórica, durante la Pequeña Edad del Hielo. } \\
\text { Enmarcado en un circo y cubeta glaciokárstica del LGM. }\end{array}$} \\
\hline & Génesis & \multicolumn{3}{|c|}{$\begin{array}{l}\text { Glacio-kárstica: guiado por la fracturación local y las } \\
\text { morfoestructuras, los procesos glaciares y kársticas, son los } \\
\text { responsables del relieve actual. }\end{array}$} \\
\hline & $\begin{array}{l}\text { Morfología: } \\
\text { Descripción, } \\
\text { morfoestructuras, } \\
\text { erosión. }\end{array}$ & \multicolumn{3}{|c|}{$\begin{array}{l}\text { Circo labrado sobre dorso de escama cabalgante, y guiado por la } \\
\text { fracturación local, al norte el vaciado de material por el } \\
\text { glaciarismo pleistoceno ha generado el circo y la depresión } \\
\text { glaciokárstica del Jou Negro, en combinación con los procesos } \\
\text { kársticos. El circo está ocupado por un helero, enmarcado en una } \\
\text { morrena (PEH), el fondo del Jou rellenado por material } \\
\text { morrénico de un período anterior, junto con material procedente } \\
\text { de las paredes por caída. Formas de detalle asociadas a procesos } \\
\text { nivoperiglaciares actuales. }\end{array}$} \\
\hline & Dinámica & \multicolumn{3}{|c|}{ Dinámica actual periglaciar, nival, kárstica. } \\
\hline & Cronología & \multicolumn{3}{|c|}{$\begin{array}{l}\text { Circo formado por el glaciarismo pleistoceno, si bien los } \\
\text { elementos singulares contenidos en él, helero, y huellas } \\
\text { morfológicas, son holocenos (PEH). }\end{array}$} \\
\hline & Interés principal & \multicolumn{3}{|c|}{$\begin{array}{l}\text { Presencia de un helero heredado y restos morfológicos glaciares, } \\
\text { tanto huellas de acumulación, como de abrasión, de la Pequeña } \\
\text { Edad el Hielo, muy escasas en el macizo. }\end{array}$} \\
\hline & $\begin{array}{l}\text { Interés } \\
\text { secundario }\end{array}$ & \multicolumn{3}{|c|}{$\begin{array}{l}\text { Elementos complementarios con los que se relacionan, circos } \\
\text { modelados en las paredes, cubeta glaciokárstica, morrena de } \\
\text { ablación tardiglaciar, enmarcado en un paisaje de zona de } \\
\text { cumbres. }\end{array}$} \\
\hline & $\begin{array}{l}\text { Atribución del } \\
\text { LIGm }\end{array}$ & \multicolumn{3}{|c|}{ Modelado glaciar histórico. Científico. } \\
\hline \multirow{9}{*}{ Usos } & $\begin{array}{l}\text { Contenido } \\
\text { cultural }\end{array}$ & \multicolumn{3}{|c|}{$\begin{array}{l}\text { Torre de Cerredo, como techo de los Picos de Europa: historia } \\
\text { montañera, hazañas alpinas, mitos y relatos de montaña. }\end{array}$} \\
\hline & Accesibilidad & \multicolumn{3}{|c|}{$\begin{array}{l}\text { Muy mala. Varias horas desde el refugio más cercano y por } \\
\text { sendas de montaña poco marcadas. }\end{array}$} \\
\hline & Grado de interés & \multicolumn{3}{|c|}{ Muy alto (científico-didáctico). } \\
\hline & $\begin{array}{l}\text { Estado de } \\
\text { conservación }\end{array}$ & \multicolumn{3}{|c|}{$\begin{array}{l}\text { Alto. Los elementos singulares están bien conservados, no han } \\
\text { sufrido impactos antrópicos dada su inaccesibilidad y escaso } \\
\text { tránsito. Elementos con el helero están en desequilibrio natural } \\
\text { con las condiciones climáticas actuales, franca regresión con } \\
\text { posible desaparición en la próxima década. }\end{array}$} \\
\hline & Usos actuales & \multicolumn{3}{|c|}{ Montañero (escaso). } \\
\hline & Comunicaciones & \multicolumn{3}{|c|}{ Sendas montañeras muy poco marcadas. } \\
\hline & Infraestructuras & \multicolumn{3}{|c|}{ Vivacs montañeros de muy bajo impacto. } \\
\hline & Impactos & \multicolumn{3}{|l|}{-} \\
\hline & Situación legal & \multicolumn{3}{|c|}{ Parque Nacional de Picos de Europa (PRUG y PORN). } \\
\hline
\end{tabular}




\begin{tabular}{|c|c|c|c|c|}
\hline \multicolumn{5}{|c|}{ LUGAR DE INTERÉS GEOMORFOLÓGICO: DESCRIPCIÓN } \\
\hline Identificación & \multicolumn{2}{|c|}{ Nombre: Complejo Glaciar Trasllambrión } & $\begin{array}{l}\text { Lugar: Macizo Central } \\
\text { Picos de Europa }\end{array}$ & №: 9 \\
\hline Situación & $\begin{array}{l}\text { To municipal: } \\
\text { Valdeón (León) }\end{array}$ & $\begin{array}{l}\text { Coordenadas: } \\
x-349.583 \\
y-4.782 .107\end{array}$ & $\begin{array}{l}\text { Altitud: } \\
\text { Entre } 2.280-2.642\end{array}$ & \\
\hline \multirow{9}{*}{ Geomorfología } & \multirow[t]{2}{*}{ TIPO } & \multicolumn{3}{|c|}{$\begin{array}{l}\text { LUGAR SINGULAR (lugar representativo con elementos } \\
\text { singulares). }\end{array}$} \\
\hline & & \multicolumn{3}{|c|}{$\begin{array}{l}\text { Complejo glaciar que aglutina restos morfológicos glaciares } \\
\text { (morrena y helero residual) de la última pulsación fría acaecida } \\
\text { en época histórica, durante la Pequeña Edad del Hielo. }\end{array}$} \\
\hline & Génesis & \multicolumn{3}{|c|}{$\begin{array}{l}\text { Glacio-kárstica: guiado por la fracturación local y las } \\
\text { morfoestructuras, los procesos glaciares y kársticas, son los } \\
\text { responsables del relieve actual. }\end{array}$} \\
\hline & $\begin{array}{l}\text { Morfología: } \\
\text { Descripción, } \\
\text { morfoestructuras, } \\
\text { erosión. }\end{array}$ & \multicolumn{3}{|c|}{$\begin{array}{l}\text { Conjunto de circo, depresión glaciokárstica, morrenas y helero, } \\
\text { estos dos últimos heredados del glaciarismo histórico (PEH). } \\
\text { Junto a ello formas asociadas a los procesos periglaciares, } \\
\text { laderas y kársticos son las dominantes. }\end{array}$} \\
\hline & Dinámica & \multicolumn{3}{|c|}{ Dinámica actual periglaciar, nival, kárstica. } \\
\hline & Cronología & \multicolumn{3}{|c|}{$\begin{array}{l}\text { Circo formado por el glaciarismo pleistoceno, si bien los } \\
\text { elementos singulares contenidos en él, helero, y huellas } \\
\text { morfológicas, son de la PEH. }\end{array}$} \\
\hline & Interés principal & \multicolumn{3}{|c|}{ Restos glaciares de la Pequeña Edad del Hielo (interés científico). } \\
\hline & $\begin{array}{l}\text { Interés } \\
\text { secundario }\end{array}$ & \multicolumn{3}{|c|}{$\begin{array}{l}\text { Conjunto morfológico glaciar pleistoceno: circo, cubeta, umbral. } \\
\text { Notable contenido paisajístico. }\end{array}$} \\
\hline & $\begin{array}{l}\text { Atribución del } \\
\text { LIGm }\end{array}$ & \multicolumn{3}{|c|}{ Modelado glaciar. Científico. } \\
\hline \multirow[t]{9}{*}{ Usos } & $\begin{array}{l}\text { Contenido } \\
\text { cultural }\end{array}$ & \multicolumn{3}{|c|}{$\begin{array}{l}\text { Torre del Llambrión y su relación con el descubrimiento y } \\
\text { exploración de los Picos de Europa, Prado y la Historia } \\
\text { montañera. }\end{array}$} \\
\hline & Accesibilidad & \multicolumn{3}{|c|}{ Muy mala. } \\
\hline & Grado de interés & \multicolumn{3}{|c|}{ Muy alto (científico-didáctico). } \\
\hline & $\begin{array}{l}\text { Estado de } \\
\text { conservación }\end{array}$ & \multicolumn{3}{|c|}{$\begin{array}{l}\text { Alto. Los elementos singulares están bien conservados, no han } \\
\text { sufrido impactos antrópicos dada su mala accesibilidad y escaso } \\
\text { tránsito. Elementos con el helero están en desequilibrio natural } \\
\text { con las condiciones climáticas actuales, franca regresión con } \\
\text { posible desaparición en la próxima década. }\end{array}$} \\
\hline & Usos actuales & \multicolumn{3}{|c|}{ Montañero (escaso). } \\
\hline & Comunicaciones & \multicolumn{3}{|c|}{ Sendas montañeras muy poco marcadas. } \\
\hline & Infraestructuras & \multicolumn{3}{|c|}{ Vivacs montañeros de muy bajo impacto. } \\
\hline & Impactos & \multicolumn{3}{|c|}{-} \\
\hline & Situación legal & \multicolumn{3}{|c|}{$\begin{array}{l}\text { Parque Nacional de Picos de Europa (PRUG y PORN) y Parque } \\
\text { Regional de los Picos de Europa (Junta de Castilla León). }\end{array}$} \\
\hline
\end{tabular}




\begin{tabular}{|c|c|c|c|c|}
\hline \multicolumn{5}{|c|}{ LUGAR DE INTERÉS GEOMORFOLÓGICO: DESCRIPCIÓN } \\
\hline \multirow{2}{*}{$\begin{array}{l}\text { Identificación } \\
\text { Situación }\end{array}$} & \multicolumn{2}{|c|}{$\begin{array}{l}\text { Nombre: Complejo Glaciar Torre Blanca-Hoyo } \\
\text { de los Ilagos }\end{array}$} & $\begin{array}{l}\text { Lugar: Macizo Central } \\
\text { Picos de Europa }\end{array}$ & №: 10 \\
\hline & $\begin{array}{l}\text { To municipal: } \\
\text { Valdeón (León) }\end{array}$ & \begin{tabular}{|l|} 
Coordenadas: \\
$x-349.658$ \\
$y-4.781 .563$ \\
\end{tabular} & \multicolumn{2}{|c|}{\begin{tabular}{l|l} 
Altitud: \\
Entre $2.010-2.642 \mathrm{~m}$
\end{tabular}} \\
\hline \multirow{9}{*}{ Geomorfología } & \multirow[t]{2}{*}{ TIPO } & \multirow{2}{*}{\multicolumn{3}{|c|}{$\begin{array}{l}\text { LUGAR REPRESENTATIVO CON ELEMENTOS SINGULARES. } \\
\text { EI LIGm aglutina unas morfologías glaciokársticas } \\
\text { representativas del macizo, como: circos, morrenas, depresión } \\
\text { glaciokárstica, umbral.... Más elementos singulares como las } \\
\text { lagunas que inundan algunas depresiones glaciokársticas. }\end{array}$}} \\
\hline & & & & \\
\hline & Génesis & \multicolumn{3}{|c|}{$\begin{array}{l}\text { Glacio-kárstica: guiado por la fracturación local y las } \\
\text { morfoestructuras, los procesos glaciares y kársticas, son los } \\
\text { responsables del relieve actual. }\end{array}$} \\
\hline & $\begin{array}{l}\text { Morfología: } \\
\text { Descripción, } \\
\text { morfoestructuras, } \\
\text { erosión. }\end{array}$ & \multicolumn{3}{|c|}{$\begin{array}{l}\text { Circo de orientación sur, labrado por el glaciarismo pleistoceno, } \\
\text { guiado por la fracturación local E-W. Los procesos periglaciares } \\
\text { y de laderas posteriores han favorecido la formación de amplios } \\
\text { conos y taludes de derrubios al pie de las paredes, con } \\
\text { elementos menores: flujos de derrubios, morrenas de nevero, } \\
\text { etc. }\end{array}$} \\
\hline & Dinámica & \multicolumn{3}{|c|}{ Dinámica actual nivoperiglaciar, kárstica, y procesos de ladera. } \\
\hline & Cronología & \multicolumn{3}{|c|}{$\begin{array}{l}\text { Circo formado por el glaciarismo pleistoceno, tanto el máximo } \\
\text { formación del circo, como Tardiglaciar, restos morrénicos sobre } \\
\text { el umbral. }\end{array}$} \\
\hline & Interés principal & \multicolumn{3}{|c|}{$\begin{array}{l}\text { Científico, morfologías glaciares representativas del máximo y } \\
\text { Tardiglaciar (científico). }\end{array}$} \\
\hline & $\begin{array}{l}\text { Interés } \\
\text { secundario }\end{array}$ & \multicolumn{3}{|c|}{$\begin{array}{l}\text { Educativo y divulgativo, formas representativas de la zona de } \\
\text { cumbres del macizo: circos con verticales paredones y restos } \\
\text { morfológicos del glaciarismo pleistoceno. }\end{array}$} \\
\hline & $\begin{array}{l}\text { Atribución del } \\
\text { LIGm }\end{array}$ & \multicolumn{3}{|c|}{ Modelado glaciar. } \\
\hline \multirow[t]{9}{*}{ Usos } & $\begin{array}{l}\text { Contenido } \\
\text { cultural }\end{array}$ & \multicolumn{3}{|c|}{$\begin{array}{l}\text { Torre del Llambrión y su relación con el descubrimiento y } \\
\text { exploración de los Picos de Europa, Prado y la Historia } \\
\text { montañera. }\end{array}$} \\
\hline & Accesibilidad & \multicolumn{3}{|c|}{ Muy mala. } \\
\hline & Grado de interés & \multicolumn{3}{|l|}{ Medio (pedagógico). } \\
\hline & $\begin{array}{l}\text { Estado de } \\
\text { conservación }\end{array}$ & \multicolumn{3}{|c|}{$\begin{array}{l}\text { Alto. Los elementos singulares están bien conservados, no han } \\
\text { sufrido impactos antrópicos dada su mala accesibilidad y escasc } \\
\text { tránsito. }\end{array}$} \\
\hline & Usos actuales & \multicolumn{3}{|c|}{$\begin{array}{l}\text { Ganadero (pastos de altura) y Montañero (moderado ruta de } \\
\text { tránsito de Liordes a Collado Jermoso). }\end{array}$} \\
\hline & Comunicaciones & \multicolumn{3}{|c|}{ Sendas montañeras. } \\
\hline & Infraestructuras & \multicolumn{3}{|c|}{-} \\
\hline & Impactos & \multicolumn{3}{|c|}{ Tan sólo una senda de montaña cruza el LIGm. } \\
\hline & Situación legal & \multicolumn{3}{|c|}{$\begin{array}{l}\text { Parque Nacional de Picos de Europa (PRUG y PORN) y Parque } \\
\text { Regional de los Picos de Europa (Junta de Castilla León). }\end{array}$} \\
\hline
\end{tabular}




\begin{tabular}{|c|c|c|c|c|}
\hline \multicolumn{5}{|c|}{ LUGAR DE INTERÉS GEOMORFOLÓGICO: DESCRIPCIÓN } \\
\hline Identificación & \multicolumn{2}{|c|}{ Nombre: Artesa glaciar de Balcosín } & $\begin{array}{l}\text { Lugar: Macizo Central } \\
\text { Picos de Europa }\end{array}$ & №: 11 \\
\hline Situación & $\begin{array}{l}\text { To municipal: } \\
\text { Cabrales } \\
\text { (Asturias) }\end{array}$ & $\begin{array}{l}\text { Coordenadas: } \\
x-352.550 \\
y-4.787 .357\end{array}$ & $\begin{array}{l}\text { Altitud: } \\
\text { Entre } 900-1.100 \mathrm{~m}\end{array}$ & \\
\hline \multirow{9}{*}{ Geomorfología } & \multirow[t]{2}{*}{ TIPO } & \multicolumn{3}{|l|}{ LUGAR SINGULAR } \\
\hline & & \multicolumn{3}{|c|}{$\begin{array}{l}\text { Este elemento es un valle de origen glaciar, su característico } \\
\text { perfil en } U \text {, es representativo de la acción de los glaciares } \\
\text { cuaternarios sobre el macizo. Al interior laderas y el fondo de } \\
\text { valle retocado por procesos periglaciares, kársticos y } \\
\text { torrenciales. }\end{array}$} \\
\hline & Génesis & \multicolumn{3}{|c|}{$\begin{array}{l}\text { Glaciar. Guiado por la fracturación local, fracturas norte sur, } \\
\text { aprovechadas por el glaciarismo pleistoceno. }\end{array}$} \\
\hline & $\begin{array}{l}\text { Morfología: } \\
\text { Descripción, } \\
\text { morfoestructuras, } \\
\text { erosión. }\end{array}$ & \multicolumn{3}{|c|}{$\begin{array}{l}\text { Artesa glaciar, marcado perfil en } U \text {, paredes verticalizadas que } \\
\text { enlazan progresivamente con el fondo plano característico. En la } \\
\text { actualidad drenado por un pequeño arroyo, alimentado por las } \\
\text { surgencias que tienen en el Jou Bajo, su nivel de base. }\end{array}$} \\
\hline & Dinámica & \multicolumn{3}{|c|}{ Dinámica actual nivoperiglaciar y kárstica. } \\
\hline & Cronología & \multicolumn{3}{|c|}{$\begin{array}{l}\text { Forma derivada de la acción erosiva del glaciarismo pleistoceno } \\
\text { (LGM) }\end{array}$} \\
\hline & Interés principal & \multicolumn{3}{|c|}{ Valle en artesa glaciar. } \\
\hline & $\begin{array}{l}\text { Interés } \\
\text { secundario }\end{array}$ & \multicolumn{3}{|c|}{$\begin{array}{l}\text { Retoque periglaciar-kárstico y torrencial posterior y formas } \\
\text { asociadas. }\end{array}$} \\
\hline & $\begin{array}{l}\text { Atribución del } \\
\text { LIGm }\end{array}$ & \multicolumn{3}{|c|}{ Modelado glaciar. } \\
\hline \multirow{9}{*}{ Usos } & $\begin{array}{l}\text { Contenido } \\
\text { cultural }\end{array}$ & \multicolumn{3}{|c|}{$\begin{array}{l}\text { Uso ganadero (pastos de verano, invernales), senderismo y } \\
\text { montañismo. }\end{array}$} \\
\hline & Accesibilidad & \multicolumn{3}{|c|}{ Mala, tan sólo a pie y a través de sendas ganadero-montañeras. } \\
\hline & Grado de interés & \multicolumn{3}{|c|}{ Medio (científico-didáctico) } \\
\hline & $\begin{array}{l}\text { Estado de } \\
\text { conservación }\end{array}$ & \multicolumn{3}{|c|}{$\begin{array}{l}\text { Alto. Su escasa frecuentación e intensidad de uso han favorecido } \\
\text { la conservación del LIGm. }\end{array}$} \\
\hline & Usos actuales & \multicolumn{3}{|c|}{$\begin{array}{l}\text { Ganadero (puertos de altura, pastizales alpinos) y Montañero } \\
\text { (ruta de ascenso hacia Naranjo de Bulnes. }\end{array}$} \\
\hline & Comunicaciones & \multicolumn{3}{|c|}{ No hay, tan sólo acceso a pie. } \\
\hline & Infraestructuras & \multicolumn{3}{|c|}{-} \\
\hline & Impactos & \multicolumn{3}{|l|}{-} \\
\hline & Situación legal & \multicolumn{3}{|c|}{ Parque Nacional de Picos de Europa (PRUG y PORN). } \\
\hline
\end{tabular}




\begin{tabular}{|c|c|c|c|c|}
\hline \multicolumn{5}{|c|}{ LUGAR DE INTERÉS GEOMORFOLÓGICO: DESCRIPCIÓN } \\
\hline \multirow{2}{*}{$\begin{array}{l}\text { Identificación } \\
\text { Situación }\end{array}$} & \multicolumn{2}{|c|}{$\begin{array}{l}\text { Nombre: Complejo morrénico y canales de } \\
\text { Amuesa }\end{array}$} & Lugar: Macizo Central & \multirow[t]{2}{*}{ №: 12} \\
\hline & To municipal: & Coordenadas: & Altitud: & \\
\hline \multirow{9}{*}{ Geomorfología } & \multirow[t]{2}{*}{ TIPO } & \multicolumn{3}{|l|}{ LUGAR REPRESENTATIVO } \\
\hline & & \multicolumn{3}{|c|}{$\begin{array}{l}\text { Canales características de los Picos y collado con complejo } \\
\text { morrénico colgado del máximo glaciar. }\end{array}$} \\
\hline & Génesis & \multicolumn{3}{|c|}{$\begin{array}{l}\text { Fluviokárstico y glaciokárstico, con sedimentación glaciar de } \\
\text { morenas en el collado. }\end{array}$} \\
\hline & $\begin{array}{l}\text { Morfología: } \\
\text { Descripción, } \\
\text { erosión, erosión. }\end{array}$ & \multicolumn{3}{|c|}{$\begin{array}{l}\text { Collado amplio, interfluvio kárstico en el que se deposita el } \\
\text { complejo morrénico de Amuesa, del que parten dos canales, una } \\
\text { al NE, glaciar y otra al NW, hacia el Cares, fluviokárstica. }\end{array}$} \\
\hline & Dinámica & \multicolumn{3}{|c|}{$\begin{array}{l}\text { Kárstica y glaciar, con retoques fluviales menores. En la } \\
\text { actualidad pedreras de gravedad al pie de los escarpes. }\end{array}$} \\
\hline & Cronología & \multicolumn{3}{|c|}{ Preglaciar y Máximo glaciar. } \\
\hline & Interés principal & \multicolumn{3}{|c|}{$\begin{array}{l}\text { Canales características de Picos y complejo morrénico frontal bien } \\
\text { conservado. }\end{array}$} \\
\hline & $\begin{array}{l}\text { Interés } \\
\text { secundario }\end{array}$ & \multicolumn{3}{|l|}{ Proceso kársticos. } \\
\hline & $\begin{array}{l}\text { Atribución del } \\
\text { LIGm }\end{array}$ & \multicolumn{3}{|c|}{ Modelado glaciar y kárstico. } \\
\hline \multirow{9}{*}{ Usos } & $\begin{array}{l}\text { Contenido } \\
\text { cultural }\end{array}$ & \multicolumn{3}{|c|}{$\begin{array}{l}\text { Ruta de la reconquista, seguida por las tropas musulmanas y } \\
\text { reconstruidas por C. Sánchez Albornoz y la ILE. }\end{array}$} \\
\hline & Accesibilidad & \multicolumn{3}{|c|}{ Baja, acceso por sendas a través de las Canales. } \\
\hline & Grado de interés & \multicolumn{3}{|c|}{ Alto, paisajístico, geomorfológico y cultural. } \\
\hline & $\begin{array}{l}\text { Estado de } \\
\text { conservación }\end{array}$ & \multicolumn{3}{|c|}{ Bueno, majadas bien conservadas. } \\
\hline & Usos actuales & \multicolumn{3}{|c|}{ Ganadero y excursionista de baja frecuentación. } \\
\hline & Comunicaciones & \multicolumn{3}{|c|}{ Sendas desde Bulnes y el Cares. } \\
\hline & Infraestructuras & \multicolumn{3}{|c|}{ Cabañas tradicionales (piedra y teja). } \\
\hline & Impactos & \multicolumn{3}{|c|}{ No existen. } \\
\hline & Situación legal & \multicolumn{3}{|c|}{ Parque Nacional de Picos de Europa (PRUG y PORN). } \\
\hline
\end{tabular}




\begin{tabular}{|c|c|c|c|c|}
\hline \multicolumn{5}{|c|}{ LUGAR DE INTERÉS GEOMORFOLÓGICO: DESCRIPCIÓN } \\
\hline Identificación & \multicolumn{2}{|c|}{ Nombre: Garganta Fluviokárstica del Cares } & $\begin{array}{l}\text { Lugar: Macizo Central } \\
\text { Picos de Europa }\end{array}$ & No: 13 \\
\hline Situación & $\begin{array}{l}\text { To municipal: } \\
\text { Cabrales } \\
\text { (Asturias) } \\
\text { Valdeón (León) }\end{array}$ & $\begin{array}{l}\text { Coordenadas: } \\
x-347.145 \\
y-4.790 .568\end{array}$ & $\begin{array}{l}\text { Altitud: } \\
\text { Entre } 220-440 \mathrm{~m}\end{array}$ & \\
\hline \multirow{9}{*}{ Geomorfología } & TIPO & \multicolumn{3}{|l|}{ LUGAR REPRESENTATIVO } \\
\hline & & \multicolumn{3}{|c|}{$\begin{array}{l}\text { LIGm como ejemplo representativo de las gargantas que separan } \\
\text { y limitan el macizo. }\end{array}$} \\
\hline & Génesis & \multicolumn{3}{|c|}{$\begin{array}{l}\text { Combinación de procesos fluviales y kársticos. Dados los fuertes } \\
\text { desniveles destaca el retoque de los procesos de ladera. }\end{array}$} \\
\hline & $\begin{array}{l}\text { Morfología: } \\
\text { Descripción, } \\
\text { morfoestructuras, } \\
\text { erosión. }\end{array}$ & \multicolumn{3}{|c|}{$\begin{array}{l}\text { Garganta fluvial de marcada perfil en } V \text {, fuertes pendientes y } \\
\text { desniveles en ambas márgenes. El fondo de la garganta a unos } \\
400 \mathrm{~m} \text {, en su inicio y } 200 \mathrm{~m} \text {, en la parte final cerca de Poncebos, } \\
\text { conecta mediante empinadas canales, que aprovechan las } \\
\text { morfoestructuras y la fracturación local, con las zonas superiores } \\
\text { del macizo. Morfología fluvial de torrente de montaña, en } \\
\text { combinación con la karstificación y la dinámica de vertientes. }\end{array}$} \\
\hline & Dinámica & \multicolumn{3}{|c|}{ Dinámica actual, fluvial, laderas y kárstica. } \\
\hline & Cronología & \multicolumn{3}{|c|}{$\begin{array}{l}\text { Establecimiento de la red actual preglaciar, guiado por la } \\
\text { fracturación local y el karst preglaciar, desarrollo y profundización } \\
\text { acentuado a partir del LGM, continuado en menor medida hasta } \\
\text { la actualidad a través de la incisión del río Cares. }\end{array}$} \\
\hline & Interés principal & \multicolumn{3}{|c|}{ Garganta fluvio-kárstica de gran desarrollo vertical. } \\
\hline & $\begin{array}{l}\text { Interés } \\
\text { secundario }\end{array}$ & \multicolumn{3}{|c|}{$\begin{array}{l}\text { Desniveles de más de } 2.000 \mathrm{~m} \text {, le dan gran calidad paisajística al } \\
\text { elemento. }\end{array}$} \\
\hline & $\begin{array}{l}\text { Atribución del } \\
\text { LIGm }\end{array}$ & \multicolumn{3}{|c|}{ Garganta fluvio-kárstica. } \\
\hline \multirow{9}{*}{ Usos } & $\begin{array}{l}\text { Contenido } \\
\text { cultural }\end{array}$ & \multicolumn{3}{|c|}{$\begin{array}{l}\text { Núcleos de población (Caín en su inicio y Poncebos al final). } \\
\text { Itinerario histórico: huida de los musulmanes. }\end{array}$} \\
\hline & Accesibilidad & \multicolumn{3}{|c|}{$\begin{array}{l}\text { Buena (Carretera asfaltada por ambas partes, tanto la asturiana } \\
\text { como la leonesa). }\end{array}$} \\
\hline & Grado de interés & \multicolumn{3}{|c|}{ Alto (científico-didáctico, turístico). } \\
\hline & $\begin{array}{l}\text { Estado de } \\
\text { conservación }\end{array}$ & \multicolumn{3}{|c|}{$\begin{array}{l}\text { Medio. Muchos sectores agrestes bien conservados, dada su } \\
\text { dificultad de acceso y escaso tránsito, pero concentración de } \\
\text { impactos en torno al itinerario turístico muy masivo del fondo de } \\
\text { la garganta. }\end{array}$} \\
\hline & Usos actuales & \multicolumn{3}{|c|}{$\begin{array}{l}\text { Turístico y ganadero (más de } 450.000 \text { turistas llegan a los dos } \\
\text { puntos de aproximación a la garganta del Cares). }\end{array}$} \\
\hline & Comunicaciones & \multicolumn{3}{|c|}{$\begin{array}{l}\text { Hasta el inicio carretera asfaltada, dentro de la garganta en su } \\
\text { mayor parte sendas y pistas peatonales. }\end{array}$} \\
\hline & Infraestructuras & \multicolumn{3}{|c|}{ Puentes, casetones y edificaciones ganaderas (invernales). } \\
\hline & Impactos & \multicolumn{3}{|c|}{$\begin{array}{l}\text { La mayor parte de su superficie no, debido a la dificultad de } \\
\text { acceso y escaso tránsito derivado, pero el itinerario del fondo de } \\
\text { la garganta, el recorrido más turístico de todo el macizo, } \\
\text { masificado y con impactos puntuales. }\end{array}$} \\
\hline & Situación legal & \multicolumn{3}{|c|}{ Parque Nacional de Picos de Europa (PRUG y PORN) } \\
\hline
\end{tabular}




\begin{tabular}{|c|c|c|c|c|}
\hline \multicolumn{5}{|c|}{ LUGAR DE INTERÉS GEOMORFOLÓGICO: DESCRIPCIÓN } \\
\hline Identificación & \multicolumn{2}{|c|}{ Nombre: Canal de Dobresengos } & $\begin{array}{l}\text { Lugar: Macizo Central } \\
\text { Picos de Europa }\end{array}$ & №: 14 \\
\hline Situación & $\begin{array}{l}\text { To municipal: } \\
\text { Valdeón (León) }\end{array}$ & \begin{tabular}{|l} 
Coordenadas: \\
$x-348.759$ \\
$y-4.785 .125$
\end{tabular} & \multicolumn{2}{|l|}{$\begin{array}{l}\text { Altitud: } \\
\text { Entre } 440-1.964 \mathrm{~m}\end{array}$} \\
\hline & TIPO & \multicolumn{3}{|c|}{\begin{tabular}{|l|} 
L-4.785.125 \\
LUGAR REPRESENTATIVO
\end{tabular}} \\
\hline & & \multicolumn{3}{|c|}{$\begin{array}{l}\text { Este LIGm abarca toda la Canal de Dobresengos. Las canales son } \\
\text { elementos morfológicos complejos, característicos de Picos de } \\
\text { Europa. }\end{array}$} \\
\hline & Génesis & \multicolumn{3}{|c|}{$\begin{array}{l}\text { Combinación de procesos glacio-fluvio-kársticos. Guiados por las } \\
\text { morfoestructuras y la fracturación local. }\end{array}$} \\
\hline Geomorfología & $\begin{array}{l}\text { Morfología: } \\
\text { Descripción, } \\
\text { morfoestructuras, } \\
\text { erosión. }\end{array}$ & \multicolumn{3}{|c|}{$\begin{array}{l}\text { Guiado por la fracturación local E-O, y por las morfoestructuras } \\
\text { entre el escarpe que da la escama cabalgante en el sector de } \\
\text { Cerredo, y el dorso que se extiende hacia el sur. Relieve abrupto, } \\
\text { grandes desniveles, crestas y paredes que caen hasta el fondo de } \\
\text { la garganta fluvial del Cares. }\end{array}$} \\
\hline & Dinámica & \multicolumn{3}{|c|}{$\begin{array}{l}\text { Dinámica actual, procesos de ladera, nivoperiglaciar en la parte } \\
\text { alta y fluvial en la baja. }\end{array}$} \\
\hline & Cronología & \multicolumn{3}{|c|}{$\begin{array}{l}\text { Canal formado con sus rasgos actuales durante el máximo } \\
\text { glaciar pleistoceno, por ensanchamiento del relieve } \\
\text { fluviokárstico previo. Posteriormente los procesos periglaciares y } \\
\text { gravitacionales han retocado este tipo de formas de origen } \\
\text { mixto complejo. }\end{array}$} \\
\hline & Interés principal & \multicolumn{3}{|c|}{ Cientifico, morfologías glaciares representativas del LGM. } \\
\hline & $\begin{array}{l}\text { Interés } \\
\text { secundario }\end{array}$ & \multicolumn{3}{|c|}{ Educativo y divulgativo. } \\
\hline & $\begin{array}{l}\text { Atribución del } \\
\text { LIGm }\end{array}$ & \multicolumn{3}{|c|}{ Modelado mixto-fluvio-kárstico y estructural. } \\
\hline \multirow{9}{*}{ Usos } & $\begin{array}{l}\text { Contenido } \\
\text { cultural }\end{array}$ & \multicolumn{3}{|l|}{ - } \\
\hline & Accesibilidad & \multicolumn{3}{|c|}{$\begin{array}{l}\text { Media (por su parte alta mala, varias horas a pie, por sendas de } \\
\text { montaña, por abajo, la carretera llega hasta sus pies, pero los } \\
\text { fuertes desniveles a pie hacen de ésta un recorrido poco } \\
\text { frecuentado, incluso por montañeros. }\end{array}$} \\
\hline & Grado de interés & \multicolumn{3}{|c|}{ Medio (científico-didáctico). } \\
\hline & $\begin{array}{l}\text { Estado de } \\
\text { conservación }\end{array}$ & \multicolumn{3}{|c|}{$\begin{array}{l}\text { Alto. Los fuertes desniveles que caracterizan a este tipo de LIGm } \\
\text { hacen que su uso y tránsito sea muy escaso, lo que ha } \\
\text { favorecido su conservación. Si bien por sus características } \\
\text { intrínsecas (fuertes pendientes), cualquier acción modificadora } \\
\text { de la dinámica puede romper su equilibrio natural (laderas). }\end{array}$} \\
\hline & Usos actuales & \multicolumn{3}{|c|}{ Ganadero (pastos de altura) y Montañero (escaso). } \\
\hline & Comunicaciones & \multicolumn{3}{|c|}{ Sendas ganaderas y montañeras. } \\
\hline & Infraestructuras & \multicolumn{3}{|c|}{-} \\
\hline & Impactos & \multicolumn{3}{|l|}{-} \\
\hline & Situación legal & \multicolumn{3}{|c|}{$\begin{array}{l}\text { Parque Nacional de Picos de Europa (PRUG y PORN) y Parque } \\
\text { Regional de los Picos de Europa (Junta de Castilla León). }\end{array}$} \\
\hline
\end{tabular}




\begin{tabular}{|c|c|c|c|c|}
\hline \multicolumn{5}{|c|}{ LUGAR DE INTERÉS GEOMORFOLÓGICO: DESCRIPCIÓN } \\
\hline Identificación & \multicolumn{2}{|c|}{ Nombre: Canal de Asotín } & $\begin{array}{l}\text { Lugar: Macizo Central } \\
\text { Picos de Europa }\end{array}$ & No: 15 \\
\hline Situación & $\begin{array}{l}\text { To municipal: } \\
\text { Valdeón (León) }\end{array}$ & $\begin{array}{l}\text { Coordenadas: } \\
x-347.265 \\
y-4.782 .235\end{array}$ & \multicolumn{2}{|l|}{$\begin{array}{l}\text { Altitud: } \\
\text { Entre } 700-1.850 \mathrm{~m}\end{array}$} \\
\hline \multirow{9}{*}{ Geomorfología } & \multirow[t]{2}{*}{ TIPO } & \multicolumn{3}{|c|}{ LUGAR REPRESENTATIVO } \\
\hline & & \multicolumn{3}{|c|}{$\begin{array}{l}\text { Este LIGm abarca toda la Canal de Asotín. Las canales son } \\
\text { elementos morfológicos de génesis compuesta, característicos } \\
\text { de Picos de Europa. }\end{array}$} \\
\hline & Génesis & \multicolumn{3}{|c|}{$\begin{array}{l}\text { Combinación de procesos glacio-fluvio-kársticos, guiados por las } \\
\text { morfoestructuras y la fracturación local NNO-SSE. }\end{array}$} \\
\hline & $\begin{array}{l}\text { Morfología: } \\
\text { Descripción, } \\
\text { morfoestructuras, } \\
\text { erosión. }\end{array}$ & \multicolumn{3}{|c|}{$\begin{array}{l}\text { Guiado por la fracturación local NNO-SSE. Canal de más de } \\
1.000 \text { de desarrollo, retocada por el glaciarismo pleistoceno. } \\
\text { Fuertes pendientes y paredes, crestas, fondo estrecho y de } \\
\text { fuerte pendiente. Dinámica de laderas muy fuerte. }\end{array}$} \\
\hline & Dinámica & \multicolumn{3}{|c|}{$\begin{array}{l}\text { Dinámica actual, procesos de ladera, nivoperiglaciar en la parte } \\
\text { alta y fluvial en la baja. }\end{array}$} \\
\hline & Cronología & \multicolumn{3}{|c|}{$\begin{array}{l}\text { Canal formado con sus rasgos actuales durante el máximo } \\
\text { glaciar pleistoceno, por ensanchamiento del relieve } \\
\text { fluviokárstico previo. }\end{array}$} \\
\hline & Interés principal & \multicolumn{3}{|c|}{$\begin{array}{l}\text { Morfología de génesis mixta, característica de los Picos de } \\
\text { Europa. }\end{array}$} \\
\hline & $\begin{array}{l}\text { Interés } \\
\text { secundario }\end{array}$ & \multicolumn{3}{|c|}{-} \\
\hline & $\begin{array}{l}\text { Atribución del } \\
\text { LIGm }\end{array}$ & \multicolumn{3}{|c|}{$\begin{array}{l}\text { Modelado glacio-fluvio-kárstico, contenido paisajístico (derivado } \\
\text { de sus fuertes desniveles). }\end{array}$} \\
\hline Usos & $\begin{array}{l}\text { Contenido } \\
\text { cultural }\end{array}$ & \multicolumn{3}{|c|}{$\begin{array}{l}\text { Un refugio de montaña en la parte alta (Refugio. Collado } \\
\text { Hermoso } 2.046 \mathrm{~m} \text { ) y edificaciones de uso ganadero en la parte } \\
\text { baja (invernales de Cordiñanes). }\end{array}$} \\
\hline & Accesibilidad & \multicolumn{3}{|c|}{$\begin{array}{l}\text { Media (el acceso a su parte de cabecera es malo, varias horas a } \\
\text { pie, por sendas de montaña, la parte inferior, se abre al valle de } \\
\text { Valdeón, (carretera llega hasta sus pies), pero los fuertes } \\
\text { desniveles a pie hacen de ésta un recorrido de una frecuentación } \\
\text { media. }\end{array}$} \\
\hline & Grado de interés & \multicolumn{3}{|c|}{ Alto (científico-didáctico). } \\
\hline & $\begin{array}{l}\text { Estado de } \\
\text { conservación }\end{array}$ & \multicolumn{3}{|c|}{$\begin{array}{l}\text { Alto. Los fuertes desniveles que caracterizan a este tipo de LIGm } \\
\text { hacen que su uso y tránsito sea muy escaso, lo que ha } \\
\text { favorecido su conservación. }\end{array}$} \\
\hline & Usos actuales & \multicolumn{3}{|c|}{ Ganadero (pastos de altura) y Montañero (moderado). } \\
\hline & Comunicaciones & \multicolumn{3}{|c|}{ Sendas ganaderas y montañeras. } \\
\hline & Infraestructuras & \multicolumn{3}{|c|}{-} \\
\hline & Impactos & \multicolumn{3}{|l|}{-} \\
\hline & Situación legal & \multicolumn{3}{|c|}{$\begin{array}{l}\text { Parque Nacional de Picos de Europa (PRUG y PORN), Parque } \\
\text { Regional de los Picos de Europa (Junta de Castilla León). }\end{array}$} \\
\hline
\end{tabular}




\begin{tabular}{|c|c|c|c|c|}
\hline \multicolumn{5}{|c|}{ LUGAR DE INTERÉS GEOMORFOLÓGICO: DESCRIPCIÓN } \\
\hline Identificación & \multicolumn{2}{|c|}{$\begin{array}{l}\text { Nombre: Depresión glaciokárstica de los } \\
\text { Boches }\end{array}$} & $\begin{array}{l}\text { Lugar: Macizo Central } \\
\text { Picos de Europa }\end{array}$ & №: 16 \\
\hline Situación & $\begin{array}{l}\text { To municipal: } \\
\text { Cabrales } \\
\text { (Asturias) }\end{array}$ & $\begin{array}{l}\text { Coordenadas: } \\
x-351.426 \\
y-4.782 .995\end{array}$ & \begin{tabular}{|l} 
Altitud: \\
$2.099 m$
\end{tabular} & \\
\hline \multirow{9}{*}{ Geomorfología } & \multirow[t]{2}{*}{ TIPO } & \multicolumn{3}{|c|}{ LUGAR REPRESENTATIVO } \\
\hline & & \multicolumn{3}{|c|}{$\begin{array}{l}\text { Este LIGm aglutina varios elementos geomorfológicos de interés } \\
\text { y representativos de la alta montaña del macizo: depresión } \\
\text { glaciokárstica (Jou), morrenas tardiglaciares, dolinas, pozos de } \\
\text { recubrimiento, taludes y conos de derrubios }\end{array}$} \\
\hline & Génesis & \multicolumn{3}{|c|}{$\begin{array}{l}\text { Combinación de procesos glaciares y kársticos. Algunas de las } \\
\text { formas menores origen kárstico y otras nivoperiglaciares. }\end{array}$} \\
\hline & $\begin{array}{l}\text { Morfología: } \\
\text { Descripción, } \\
\text { morfoestructuras, } \\
\text { erosión. }\end{array}$ & \multicolumn{3}{|c|}{$\begin{array}{l}\text { Depresión de planta ovalada, con unas dimensiones de } \\
1500 \times 750 \text { m, limitada por paredes y crestas, excavada por } \\
\text { glaciarismo cuaternario en combinación con los procesos } \\
\text { kársticos. La depresión está parcialmente cubierta por los } \\
\text { materiales procedentes de las paredes en sus bordes, y material } \\
\text { morrénico. Destacan en su parte E, un complejo morrénico } \\
\text { glaciar atribuible al período Tardiglaciar. En el centro de la } \\
\text { depresión son muy numerosos las formas asociadas a procesos } \\
\text { kársticos de disolución: dolinas y dolinas de recubrimiento } \\
\text { (boches), junto con lapiaces allí donde aflora el sustrato. }\end{array}$} \\
\hline & Dinámica & \multicolumn{3}{|c|}{$\begin{array}{l}\text { Dinámica actual de dominantes nivoperiglaciar y kárstica, en } \\
\text { combinación con procesos de ladera, dadas las fuertes } \\
\text { pendientes existentes en sus márgenes. }\end{array}$} \\
\hline & Cronología & \multicolumn{3}{|c|}{$\begin{array}{l}\text { Formación de la depresión glaciokárstica durante el LGM, y } \\
\text { retoque menor Tardiglaciar, que rellena con material morrénico } \\
\text { parte de la depresión. }\end{array}$} \\
\hline & Interés principal & \multicolumn{3}{|c|}{ Depresión de génesis mixta-compleja glaciokárstica. } \\
\hline & $\begin{array}{l}\text { Interés } \\
\text { secundario }\end{array}$ & \multicolumn{3}{|c|}{$\begin{array}{l}\text { Formas secundarias contenidas: glaciares (morrenas, umbrales), } \\
\text { periglaciares (Taludes de derrubios, solifluxión) y kársticas } \\
\text { (dolinas, pozos cubiertos o boches). }\end{array}$} \\
\hline & $\begin{array}{l}\text { Atribución del } \\
\text { LIGm }\end{array}$ & \multicolumn{3}{|c|}{ Modelado mixto glacio-kárstico. } \\
\hline \multirow{9}{*}{ Usos } & $\begin{array}{l}\text { Contenido } \\
\text { cultural }\end{array}$ & \multicolumn{3}{|l|}{-} \\
\hline & Accesibilidad & \multicolumn{3}{|c|}{ Mala. Si bien el tránsito montañero relativamente es alto } \\
\hline & Grado de interés & \multicolumn{3}{|c|}{ Alto (científico-didáctico). } \\
\hline & $\begin{array}{l}\text { Estado de } \\
\text { conservación }\end{array}$ & \multicolumn{3}{|c|}{$\begin{array}{l}\text { Alto. Los fuertes desniveles que caracterizan a este tipo de LIGm } \\
\text { hacen que su uso y tránsito sea muy escaso, lo que ha } \\
\text { favorecido su conservación. }\end{array}$} \\
\hline & Usos actuales & \multicolumn{3}{|c|}{$\begin{array}{l}\text { Montañero (relativamente alto). Está en una de las rutas de alta } \\
\text { montaña más transitadas del macizo: Fuente De-Naranjo de } \\
\text { Bulnes. }\end{array}$} \\
\hline & Comunicaciones & \multicolumn{3}{|c|}{$\begin{array}{l}\text { No hay, el acceso es únicamente a través de varias horas a pie a } \\
\text { través de sendas de montaña. }\end{array}$} \\
\hline & Infraestructuras & \multicolumn{3}{|l|}{-} \\
\hline & Impactos & \multicolumn{3}{|l|}{-} \\
\hline & Situación legal & \multicolumn{3}{|c|}{ Parque Nacional de Picos de Europa (PRUG y PORN) } \\
\hline
\end{tabular}




\begin{tabular}{|c|c|c|c|c|}
\hline \multicolumn{5}{|c|}{ LUGAR DE INTERÉS GEOMORFOLÓGICO: DESCRIPCIÓN } \\
\hline Identificación & \multicolumn{2}{|c|}{ Nombre: Polje de Liordes } & Lugar: Macizo Central & \multirow[t]{2}{*}{ №: 17} \\
\hline Situación & To municipal: & Coordenadas: & Altitud: & \\
\hline \multirow{9}{*}{ Geomorfología } & \multirow[t]{2}{*}{ TIPO } & \multicolumn{3}{|c|}{ ELEMENTO SINGULAR } \\
\hline & & \multicolumn{3}{|c|}{$\begin{array}{l}\text { Polje intramontañoso, entre dos escamas cabalgantes, que } \\
\text { constituye una forma excepcional en el modelado de los Picos de } \\
\text { Europa. }\end{array}$} \\
\hline & Génesis & \multicolumn{3}{|c|}{$\begin{array}{l}\text { Kárstica, a favor de la disolución de las calizas de montaña y la } \\
\text { presencia de pizarras y esquistos de la formación Lebeña. Polje } \\
\text { estructural. Enmarcado en el modelado glaciokárstico. }\end{array}$} \\
\hline & $\begin{array}{l}\text { Morfología: } \\
\text { Descripción, } \\
\text { morfoestructuras, } \\
\text { erosión. }\end{array}$ & \multicolumn{3}{|c|}{$\begin{array}{l}\text { Depresión glaciokárstica de } 1 \mathrm{~km}^{2} \text { con fondo plano recubierto } \\
\text { por arcillas que se superponen a la Fm Lebeña. En el contacto } \\
\text { fallado se generan las fuentes, que dan lugar a un arroyo que } \\
\text { recorre la depresión y a un ponor en su parte SW. }\end{array}$} \\
\hline & Dinámica & \multicolumn{3}{|c|}{ Kárstica con intromisiones de derrubios de laderas y solifluxión. } \\
\hline & Cronología & \multicolumn{3}{|c|}{$\begin{array}{l}\text { Polje estructural funcional desde su emplazamiento, con retoque } \\
\text { glaciar durante el Pleistoceno. }\end{array}$} \\
\hline & Interés principal & \multicolumn{3}{|c|}{ Formas y procesos kársticos. } \\
\hline & $\begin{array}{l}\text { Interés } \\
\text { secundario }\end{array}$ & \multicolumn{3}{|c|}{$\begin{array}{l}\text { Valor paisajístico y ecológico (uno de los pocos arroyos del } \\
\text { macizo central) }\end{array}$} \\
\hline & $\begin{array}{l}\text { Atribución del } \\
\text { LIGm }\end{array}$ & \multicolumn{3}{|c|}{ Modelado kárstico y estructural. } \\
\hline \multirow{9}{*}{ Usos } & $\begin{array}{l}\text { Contenido } \\
\text { cultural }\end{array}$ & \multicolumn{3}{|l|}{ Poblado minero } \\
\hline & Accesibilidad & \multicolumn{3}{|c|}{$\begin{array}{l}\text { Mala, antiguo camino minero de Liordes, hoy senda ( } 2 \text { horas, } \\
600 \text { metros desnivel). }\end{array}$} \\
\hline & Grado de interés & \multicolumn{3}{|c|}{ Alto, por la excepcionalidad y buena conservación. } \\
\hline & $\begin{array}{l}\text { Estado de } \\
\text { conservación }\end{array}$ & \multicolumn{3}{|c|}{ Muy bueno. } \\
\hline & Usos actuales & \multicolumn{3}{|c|}{ Excursionista, baja frecuentación. } \\
\hline & Comunicaciones & \multicolumn{3}{|c|}{ No hay, senda de montaña. } \\
\hline & Infraestructuras & \multicolumn{3}{|c|}{$\begin{array}{l}\text { Pista minera en estado de abandono, restos de barracones } \\
\text { destruidos. }\end{array}$} \\
\hline & Impactos & \multicolumn{3}{|c|}{--} \\
\hline & Situación legal & \multicolumn{3}{|c|}{ Parque Nacional de Picos de Europa (PRUG y PORN) } \\
\hline
\end{tabular}




\begin{tabular}{|c|c|c|c|c|}
\hline \multicolumn{5}{|c|}{ LUGAR DE INTERÉS GEOMORFOLÓGICO: DESCRIPCIÓN } \\
\hline Identificación & \multicolumn{2}{|c|}{ Nombre: Conos de derrubios de la Vueltona } & $\begin{array}{l}\text { Lugar: Macizo Central } \\
\text { Picos de Europa }\end{array}$ & No: 18 \\
\hline Situación & $\begin{array}{l}\text { To municipal: } \\
\text { Camaleño(Cantabria) }\end{array}$ & $\begin{array}{l}\text { Coordenadas: } \\
x-352.587 \\
y-4.781 .523\end{array}$ & $\begin{array}{l}\text { Altitud: } \\
1.960 \mathrm{~m}\end{array}$ & \\
\hline \multirow{9}{*}{ Geomorfología } & \multirow[t]{2}{*}{ TIPO } & \multicolumn{3}{|c|}{ LUGAR REPRESENTATIVO } \\
\hline & & \multicolumn{3}{|c|}{$\begin{array}{l}\text { Este LIGm aglutina un conjunto de conos y taludes de } \\
\text { derrubios. Es uno de los mejores ejemplos del macizo, tanto } \\
\text { por la dimensión de los elementos, como por su complejidad. }\end{array}$} \\
\hline & Génesis & \multicolumn{3}{|c|}{$\begin{array}{l}\text { Morfología de génesis mixta: combinación de procesos de } \\
\text { caída (procesos de ladera) y crioclastia (procesos } \\
\text { periglaciares). }\end{array}$} \\
\hline & $\begin{array}{l}\text { Morfología: } \\
\text { Descripción, } \\
\text { morfoestructuras, } \\
\text { erosión. }\end{array}$ & \multicolumn{3}{|c|}{$\begin{array}{l}\text { A los pies del escarpe de la escama cabalgante que forma el } \\
\text { Grupo Peña Vieja, se encuentran conos y taludes de } \\
\text { derrubios de amplio desarrollo, que conectan las paredes del } \\
\text { escarpe, con el sector de Lloroza y el Jou Sin Tierra. } \\
\text { Acumulaciones de derrubios en forma de cono, de fuerte } \\
\text { pendiente y clasificación del material a través de procesos de } \\
\text { gravedad. }\end{array}$} \\
\hline & Dinámica & \multicolumn{3}{|c|}{$\begin{array}{l}\text { Dinámica actual nivoperiglaciar, en combinación con } \\
\text { procesos de ladera. }\end{array}$} \\
\hline & Cronología & \multicolumn{3}{|c|}{$\begin{array}{l}\text { Proceso de acumulación tras retirada de los glaciares } \\
\text { pleistocenos, post-Tardiglaciar fundamentalmente }\end{array}$} \\
\hline & Interés principal & \multicolumn{3}{|c|}{$\begin{array}{l}\text { Conos y taludes activos de génesis mixta compleja, de gran } \\
\text { desarrollo. }\end{array}$} \\
\hline & Interés secundario & \multicolumn{3}{|c|}{$\begin{array}{l}\text { Formas secundarias: morrenas de nevero, desprendimientos } \\
\text { de piedras. }\end{array}$} \\
\hline & Atribución del LIGm & \multicolumn{3}{|c|}{ Modelado nivoperiglaciar, procesos de ladera intensos. } \\
\hline Usos & Contenido cultural & \multicolumn{3}{|c|}{$\begin{array}{l}\text { Los conos en su parte este están cortados por una pista en su } \\
\text { origen creada para la explotación minera y el acceso a los } \\
\text { cazaderos reales. }\end{array}$} \\
\hline & Accesibilidad & \multicolumn{3}{|c|}{$\begin{array}{l}\text { Buena. El LIGm está a } 15 \text { min. de la estación superior del } \\
\text { teleférico de Fuente Dé, a través de una pista rodada, en su } \\
\text { parte baja, y una senda montañera, la que sube hacia el } \\
\text { refugio de Cabaña Verónica en su mitad superior. }\end{array}$} \\
\hline & Grado de interés & \multicolumn{3}{|c|}{ Alto (científico - didáctico) } \\
\hline & $\begin{array}{l}\text { Estado de } \\
\text { conservación }\end{array}$ & \multicolumn{3}{|c|}{$\begin{array}{l}\text { Medio. En su parte inferior han sido alterados por la creación } \\
\text { de pistas y sendas. }\end{array}$} \\
\hline & Usos actuales & \multicolumn{3}{|c|}{ Montañero y turístico. } \\
\hline & Comunicaciones & \multicolumn{3}{|c|}{ Sendas y pistas de montaña. } \\
\hline & Infraestructuras & \multicolumn{3}{|l|}{-} \\
\hline & Impactos & \multicolumn{3}{|c|}{$\begin{array}{l}\text { Pistas que cortan las morfologías, impacto paisajístico y } \\
\text { ruptura de la morfodinámica natural. }\end{array}$} \\
\hline & Situación legal & \multicolumn{3}{|c|}{$\begin{array}{l}\text { Este lugar no goza de ninguna atención, ni figura específica } \\
\text { dentro del Parque Nacional de los Picos de Europa. }\end{array}$} \\
\hline
\end{tabular}




\begin{tabular}{|c|c|c|c|c|}
\hline \multicolumn{5}{|c|}{ LUGAR DE INTERÉS GEOMORFOLÓGICO: DESCRIPCIÓN } \\
\hline Identificación & \multicolumn{2}{|c|}{ Nombre: Gonfolitas del Duje } & Lugar: Macizo Central & No: 19 \\
\hline Situación & To municipal: & Coordenadas: & \multicolumn{2}{|l|}{ Altitud: } \\
\hline \multirow{9}{*}{ Geomorfología } & TIPO & \multicolumn{3}{|c|}{ ELEMENTO SINGULAR } \\
\hline & & \multicolumn{3}{|c|}{$\begin{array}{l}\text { Derrubios ordenados cementados característicos de las laderas } \\
\text { de Picos, que fueron denominados así por Obermaier (1914). }\end{array}$} \\
\hline & Génesis & \multicolumn{3}{|c|}{ Derrubios de ladera periglaciares cementados por carbonatos. } \\
\hline & $\begin{array}{l}\text { Morfología: } \\
\text { Descripción, }\end{array}$ & \multicolumn{3}{|c|}{$\begin{array}{l}\text { Laderas regularizadas e incididas en el pie por la acción fluvial y } \\
\text { glaciar. El depósito que aflora está formado por un derrubio } \\
\text { ordenado de clastos heterométricos y aristados. }\end{array}$} \\
\hline & Dinámica & \multicolumn{3}{|c|}{ Derrubios superficiales y karstificación. } \\
\hline & Cronología & \multicolumn{3}{|c|}{ Preglaciar, 70.000 años B.P. } \\
\hline & Interés principal & \multicolumn{3}{|c|}{ Formas y depósitos como testigos preglaciares. } \\
\hline & $\begin{array}{l}\text { Interés } \\
\text { secundario }\end{array}$ & \multicolumn{3}{|c|}{ Relación con arroyos, terrazas y glaciares. } \\
\hline & $\begin{array}{l}\text { Atribución del } \\
\text { LIGm }\end{array}$ & \multicolumn{3}{|c|}{ Modelado periglaciar y preglaciar. } \\
\hline \multirow{9}{*}{ Usos } & $\begin{array}{l}\text { Contenido } \\
\text { cultural }\end{array}$ & \multicolumn{3}{|c|}{ Primeros estudios de geomorfología en Picos de Europa. } \\
\hline & Accesibilidad & \multicolumn{3}{|c|}{ Alta, próximas a pistas. } \\
\hline & Grado de interés & \multicolumn{3}{|c|}{ Medio, formación sedimentaria puntual con reflejo morfológico. } \\
\hline & $\begin{array}{l}\text { Estado de } \\
\text { conservación }\end{array}$ & \multicolumn{3}{|c|}{ Alto, afectación por pistas escasa. Deterioro natural. } \\
\hline & Usos actuales & \multicolumn{3}{|c|}{ Ninguno. } \\
\hline & Comunicaciones & \multicolumn{3}{|c|}{ Pista muy próxima en los invernales de Sotres. } \\
\hline & Infraestructuras & \multicolumn{3}{|c|}{ No existen. } \\
\hline & Impactos & \multicolumn{3}{|c|}{ Los derivados del talud de la pista. } \\
\hline & Situación legal & \multicolumn{3}{|c|}{ Parque Nacional de Picos de Europa (PRUG y PORN). } \\
\hline
\end{tabular}




\begin{tabular}{|c|c|c|c|c|}
\hline \multicolumn{5}{|c|}{ LUGAR DE INTERÉS GEOMORFOLÓGICO: DESCRIPCIÓN } \\
\hline Identificación & \multicolumn{2}{|c|}{ Nombre: Cueva helada de Peña Castil } & $\begin{array}{l}\text { Lugar: Macizo Central } \\
\text { Picos de Europa }\end{array}$ & No: 20 \\
\hline Situación & $\begin{array}{l}\text { To municipal: } \\
\text { Cabrales } \\
\text { (Asturias) }\end{array}$ & $\begin{array}{l}\text { Coordenadas: } \\
x-353.420 \\
y-4.785 .096\end{array}$ & Altitud: & \\
\hline \multirow{9}{*}{ Geomorfología } & TIPO & \multicolumn{3}{|c|}{ ELEMENTO SINGULAR } \\
\hline & & \multicolumn{3}{|c|}{$\begin{array}{l}\text { Si bien las cavidades endokársticas, son un elemento } \\
\text { representativo del relieve del macizo, la cueva de Peña Castil es } \\
\text { un elemento singular, por estar en parte ocupada por una masa } \\
\text { de hielo autóctono y formaciones alóctonas. }\end{array}$} \\
\hline & Génesis & \multicolumn{3}{|c|}{$\begin{array}{l}\text { De origen kárstico, con permanencia de un lentejón de hielo en } \\
\text { su interior que denota unas condiciones ambientales } \\
\text { periglaciares. }\end{array}$} \\
\hline & $\begin{array}{l}\text { Morfología: } \\
\text { Descripción, } \\
\text { morfoestructuras, }\end{array}$ & \multicolumn{3}{|c|}{$\begin{array}{l}\text { Cavidad kárstica, sala y pozo de } 15 \mathrm{~m} \text {. de profundidad, que } \\
\text { contiene una masa de hielo con flujo, taponando la sala, y } \\
\text { formaciones criogénicas estacionales asociadas al régimen } \\
\text { endoclimático. }\end{array}$} \\
\hline & Dinámica & \multicolumn{3}{|c|}{ Kárstica y criokárstica } \\
\hline & Cronología & \multicolumn{3}{|c|}{ Hielo reciente, de la PEH. } \\
\hline & Interés principal & \multicolumn{3}{|c|}{ Formaciones de hielo en una Cueva kárstica } \\
\hline & $\begin{array}{l}\text { Interés } \\
\text { secundario }\end{array}$ & \multicolumn{3}{|c|}{ Formas endokársticas } \\
\hline & $\begin{array}{l}\text { Atribución del } \\
\text { LIGm }\end{array}$ & \multicolumn{3}{|c|}{ MODELADO KÁRSTICO y PERIGLACIAR } \\
\hline \multirow{9}{*}{ Usos } & $\begin{array}{l}\text { Contenido } \\
\text { cultural }\end{array}$ & \multicolumn{3}{|l|}{-} \\
\hline & Accesibilidad & \multicolumn{3}{|c|}{$\begin{array}{l}\text { Mala. Está situada en un sector al que sólo se puede acceder a } \\
\text { través de sendas montañeras durante más de } 2 \text { o } 3 \text { h, desde el } \\
\text { punto más cercano al que se llega a través de pistas. }\end{array}$} \\
\hline & Grado de interés & \multicolumn{3}{|c|}{ Alto (científico) } \\
\hline & $\begin{array}{l}\text { Estado de } \\
\text { conservación }\end{array}$ & \multicolumn{3}{|c|}{$\begin{array}{l}\text { Alto. El estado de conservación de este elemento es bueno, dada } \\
\text { su dificultad de acceso. El incremento de visitas, no sólo por } \\
\text { equipos espeleológicos, puede implicar un deterioro ambiental. }\end{array}$} \\
\hline & Usos actuales & \multicolumn{3}{|c|}{$\begin{array}{l}\text { Ninguno, pues ni siquiera el uso espeleológico es alto, ya que no } \\
\text { es uno de los sistemas endokársticos más explorados. }\end{array}$} \\
\hline & Comunicaciones & \multicolumn{3}{|c|}{-} \\
\hline & Infraestructuras & \multicolumn{3}{|l|}{-} \\
\hline & Impactos & \multicolumn{3}{|c|}{ Visitantes } \\
\hline & Situación legal & \multicolumn{3}{|c|}{$\begin{array}{l}\text { Este lugar no goza de ninguna atención, ni figura específica } \\
\text { dentro del Parque Nacional de los Picos de Europa (PORN y } \\
\text { PRUG). }\end{array}$} \\
\hline
\end{tabular}




\begin{tabular}{|c|c|c|c|c|c|}
\hline \multicolumn{6}{|c|}{ LUGAR DE INTERÉS GEOMORFOLÓGICO: DESCRIPCIÓN } \\
\hline \multirow{2}{*}{$\begin{array}{l}\text { Identificación } \\
\text { Situación }\end{array}$} & \multicolumn{2}{|c|}{ Nombre: Torca del Cerro (-1.589m) } & \multicolumn{2}{|c|}{ Lugar: Macizo Central } & №: 21 \\
\hline & To municipal: & \multicolumn{2}{|l|}{ Coordenadas: } & \multicolumn{2}{|l|}{ Altitud: } \\
\hline \multirow{9}{*}{ Geomorfología } & \multirow[t]{2}{*}{ TIPO } & \multicolumn{4}{|c|}{ ELEMENTO REPRESENTATIVO } \\
\hline & & \multicolumn{4}{|c|}{ Sima kárstica de gran profundidad. } \\
\hline & Génesis & \multicolumn{4}{|l|}{ Karst. } \\
\hline & Morfología: & \multicolumn{4}{|c|}{$\begin{array}{l}\text { Sima vertical que sigue las directrices estructurales a favor de las } \\
\text { calizas de montaña }\end{array}$} \\
\hline & Dinámica & \multicolumn{4}{|c|}{ Kárstica } \\
\hline & Cronología & \multicolumn{4}{|c|}{ Finiterciaria a actual. } \\
\hline & Interés principal & \multicolumn{4}{|c|}{$\begin{array}{l}\text { Kárstico, sima más profunda de España y cuarta del planeta, la } \\
\text { Torca del Cerro, de }-1589 \mathrm{~m} \text {. }\end{array}$} \\
\hline & $\begin{array}{l}\text { Interés } \\
\text { secundario }\end{array}$ & \multicolumn{4}{|c|}{$\begin{array}{l}\text { Endemismos biológicos. Exploraciones SC Seine, Cockteil Club e } \\
\text { Interclub Espeleo Valenciano de espeleología. }\end{array}$} \\
\hline & $\begin{array}{l}\text { Atribución del } \\
\text { LIGm }\end{array}$ & \multicolumn{4}{|c|}{ Modelado endokárstico } \\
\hline \multirow{9}{*}{ Usos } & $\begin{array}{l}\text { Contenido } \\
\text { cultural }\end{array}$ & \multicolumn{4}{|c|}{$\begin{array}{l}\text { Deportivo-espeleológico. Descubrimiento y exploración (1998), } \\
\text { historia reciente de la espeleología en España. }\end{array}$} \\
\hline & Accesibilidad & \multicolumn{4}{|c|}{ Mala, son necesarias técnicas espeleológicas. } \\
\hline & Grado de interés & \multicolumn{4}{|c|}{$\begin{array}{l}\text { Alto: por la singularidad de la sima y la representatividad del } \\
\text { modelado kárstico. }\end{array}$} \\
\hline & $\begin{array}{l}\text { Estado de } \\
\text { conservación }\end{array}$ & \multicolumn{4}{|c|}{ Alto } \\
\hline & Usos actuales & \multicolumn{4}{|c|}{ Deportivo, baja frecuentación. } \\
\hline & Comunicaciones & \multicolumn{4}{|c|}{ No existen } \\
\hline & Infraestructuras & \multicolumn{4}{|l|}{ No existen } \\
\hline & Impactos & \multicolumn{4}{|c|}{ No existen } \\
\hline & Situación legal & \multicolumn{4}{|c|}{ Parque Nacional de Picos de Europa (PRUG y PORN) } \\
\hline
\end{tabular}




\begin{tabular}{|c|c|c|c|c|}
\hline \multicolumn{5}{|c|}{ LUGAR DE INTERÉS GEOMORFOLÓGICO: DESCRIPCIÓN } \\
\hline \multirow{2}{*}{$\begin{array}{l}\text { Identificación } \\
\text { Situación }\end{array}$} & \multicolumn{2}{|c|}{$\begin{array}{l}\text { Nombre: Sistema endokárstico del Trave (- } \\
\text { 1.441) }\end{array}$} & Lugar: Macizo Central & No: 22 \\
\hline & To municipal: & Coordenadas: & \multicolumn{2}{|l|}{ Altitud: } \\
\hline \multirow{9}{*}{ Geomorfología } & \multirow[t]{2}{*}{ TIPO } & \multicolumn{3}{|c|}{ ELEMENTO REPRESENTATIVO } \\
\hline & & \multicolumn{3}{|c|}{$\begin{array}{l}\text { Complejo endokárstico de gran desarrollo y profundidad, con } \\
\text { dominante de las simas verticales. }\end{array}$} \\
\hline & Génesis & \multicolumn{3}{|c|}{$\begin{array}{l}\text { Disolución kárstica en las calizas de montaña, conforme a la } \\
\text { estructura de la unidad. }\end{array}$} \\
\hline & Morfología: & \multicolumn{3}{|c|}{$\begin{array}{l}\text { Sistema kárstico muy complejo, con dominancia de simas que } \\
\text { finaliza en un sifón y una galería horizontal inundada a } 1441 \mathrm{~m} \text {. } \\
\text { de profundidad y } 9 \mathrm{~km} \text { de desarrollo. }\end{array}$} \\
\hline & Dinámica & \multicolumn{3}{|c|}{ Kárstica. } \\
\hline & Cronología & \multicolumn{3}{|l|}{ Finiterciaria a actual. } \\
\hline & Interés principal & \multicolumn{3}{|l|}{ Kárstico, hidrogeológico. } \\
\hline & $\begin{array}{l}\text { Interés } \\
\text { secundario }\end{array}$ & \multicolumn{3}{|c|}{$\begin{array}{l}\text { Las aguas drenadas por este sector resurgen a nivel del Río Cares, } \\
\text { en el impresionante manantial del Farfao de la Viña. Endemismos } \\
\text { biológicos }\end{array}$} \\
\hline & $\begin{array}{l}\text { Atribución del } \\
\text { LIGm }\end{array}$ & \multicolumn{3}{|c|}{ Modelado endokárstico. } \\
\hline \multirow[t]{9}{*}{ Usos } & $\begin{array}{l}\text { Contenido } \\
\text { cultural }\end{array}$ & \multicolumn{3}{|c|}{$\begin{array}{l}\text { Espeleológico: explorado en los } 80 \text { por el Spéléo Club de la Seine, } \\
\text { consiguiendo unir en } 1989 \text { con la colaboración del Interclub } \\
\text { Espeleo Valenciano tres profundas simas en un solo sistema. }\end{array}$} \\
\hline & Accesibilidad & \multicolumn{3}{|c|}{ Mala, son necesarias técnicas espeleológicas. } \\
\hline & Grado de interés & \multicolumn{3}{|c|}{ Alto, por la singularidad del complejo y la representatividad. } \\
\hline & $\begin{array}{l}\text { Estado de } \\
\text { conservación }\end{array}$ & \multicolumn{3}{|l|}{ Alto } \\
\hline & Usos actuales & \multicolumn{3}{|c|}{ Deportivo espeleológico de muy baja frecuencia. } \\
\hline & Comunicaciones & \multicolumn{3}{|l|}{ No existen } \\
\hline & Infraestructuras & \multicolumn{3}{|l|}{ No existen } \\
\hline & Impactos & \multicolumn{3}{|c|}{ No existen } \\
\hline & Situación legal & \multicolumn{3}{|c|}{ Parque Nacional de Picos de Europa (PRUG y PORN) } \\
\hline
\end{tabular}




\begin{tabular}{|c|c|c|c|c|}
\hline \multicolumn{5}{|c|}{ LUGAR DE INTERÉS GEOMORFOLÓGICO: DESCRIPCIÓN } \\
\hline \multirow{2}{*}{$\begin{array}{l}\text { Identificación } \\
\text { Situación }\end{array}$} & \multicolumn{2}{|c|}{ Nombre: Frente cabalgante de Ándara } & $\begin{array}{l}\text { Lugar: Macizo Oriental } \\
\text { de los Picos de Europa }\end{array}$ & \\
\hline & $\begin{array}{l}\text { To municipal: } \\
\text { Camaleño(Cantabria) }\end{array}$ & Coordenadas: & Altitud: & \\
\hline \multirow{9}{*}{ Geomorfología } & \multirow[t]{2}{*}{ TIPO } & \multicolumn{3}{|c|}{ LUGAR REPRESENTATIVO } \\
\hline & & \multicolumn{3}{|c|}{$\begin{array}{l}\text { Representa la ladera meridional del macizo que aglutina los } \\
\text { frentes cabalgantes de la unidad Picos de Europa y genera un } \\
\text { amplio frente sobre la depresión de Liébana. }\end{array}$} \\
\hline & Génesis & \multicolumn{3}{|c|}{$\begin{array}{l}\text { Tectónica. Cabalgamientos hacia el sur y levantamiento de } \\
\text { toda la serie con erosión diferencial respecto a los materiales } \\
\text { no calcáreos. }\end{array}$} \\
\hline & $\begin{array}{l}\text { Morfología: } \\
\text { Descripción, } \\
\text { morfoestructuras, } \\
\text { erosión. }\end{array}$ & \multicolumn{3}{|c|}{$\begin{array}{l}\text { Escarpe de escamas cabalgantes que generan un frente } \\
\text { calcáreo de } 400-800 \text { metros de desnivel sobre la depresión, } \\
\text { caracterizado por la alternancia de facies de Montañas y } \\
\text { facies Picos de Europa, surcado por canales que } \\
\text { individualizan parcialmente el frente }\end{array}$} \\
\hline & Dinámica & \multicolumn{3}{|c|}{$\begin{array}{l}\text { Dinámica de aludes y deslizamientos de ladera activos en } \\
\text { combinación con procesos de ladera. }\end{array}$} \\
\hline & Cronología & \multicolumn{3}{|c|}{$\begin{array}{l}\text { Los materiales de edad carbonífera, el emplazamiento } \\
\text { tectónico Paleozoico y Alpino (mesoterciario), y la erosión } \\
\text { diferencial Terciaria-Cuaternaria. }\end{array}$} \\
\hline & Interés principal & \multicolumn{3}{|c|}{$\begin{array}{l}\text { Paisajístico y estratigráfico, es el límite meridional del macizo } \\
\text { calcáreo. }\end{array}$} \\
\hline & Interés secundario & \multicolumn{3}{|c|}{$\begin{array}{l}\text { Procesos y formas característicos (canales, derrubios, } \\
\text { deslizamientos). }\end{array}$} \\
\hline & Atribución del LIGm & \multicolumn{3}{|c|}{ Morfoestructural. } \\
\hline \multirow[t]{9}{*}{ Usos } & Contenido cultural & \multicolumn{3}{|c|}{$\begin{array}{l}\text { Usos de canales y laderas, con vestigios prehistóricos y } \\
\text { tradicionales en el frente. Cuadro de la canal de Mancorbo, } \\
\text { que ha caracterizado la imagen de los Picos de Europa y } \\
\text { pistas y actividad minera abandonada. }\end{array}$} \\
\hline & Accesibilidad & \multicolumn{3}{|c|}{$\begin{array}{l}\text { Mala. El frente tiene un acceso difícil, por largo, se trata de } \\
\text { un LIGm con contenido paisajistico para ser apreciado desde } \\
\text { lejos. Constituye la línea del cielo del Parque desde el sur. }\end{array}$} \\
\hline & Grado de interés & \multicolumn{3}{|c|}{ Alto (estético-paisajístico). } \\
\hline & $\begin{array}{l}\text { Estado de } \\
\text { conservación }\end{array}$ & \multicolumn{3}{|c|}{$\begin{array}{l}\text { Bueno. En detalle existen explotaciones mineras, y pistas en } \\
\text { avanzado estado de deterioro. }\end{array}$} \\
\hline & Usos actuales & \multicolumn{3}{|c|}{ Montañero y turístico. } \\
\hline & Comunicaciones & \multicolumn{3}{|c|}{ Sendas y pistas de montaña. } \\
\hline & Infraestructuras & \multicolumn{3}{|c|}{ Pistas abandonadas. } \\
\hline & Impactos & \multicolumn{3}{|l|}{-} \\
\hline & Situación legal & \multicolumn{3}{|c|}{$\begin{array}{l}\text { Este lugar no goza de ninguna atención, ni figura específica } \\
\text { dentro del Parque Nacional de los Picos de Europa. }\end{array}$} \\
\hline
\end{tabular}




\begin{tabular}{|c|c|c|c|c|}
\hline \multicolumn{5}{|c|}{ LUGAR DE INTERÉS GEOMORFOLÓGICO: DESCRIPCIÓN } \\
\hline Identificación & \multicolumn{2}{|c|}{ Nombre: Garganta Fluviokárstica de Urdón } & $\begin{array}{l}\text { Lugar: Macizo Oriental } \\
\text { Picos de Europa }\end{array}$ & No: 24 \\
\hline Situación & $\begin{array}{l}\text { To municipal: } \\
\text { Tresviso y Bejés } \\
\text { (Cantabria) }\end{array}$ & Coordenadas: & \multicolumn{2}{|l|}{$\begin{array}{l}\text { Altitud: } \\
\text { Entre } 220-440 \mathrm{~m}\end{array}$} \\
\hline \multirow{9}{*}{ Geomorfología } & TIPO & \multicolumn{3}{|l|}{ LUGAR REPRESENTATIVO } \\
\hline & & \multicolumn{3}{|c|}{$\begin{array}{l}\text { LIGm como ejemplo representativo de las gargantas que limitan } \\
\text { el macizo. }\end{array}$} \\
\hline & Génesis & \multicolumn{3}{|c|}{$\begin{array}{l}\text { Combinación de procesos fluviales y kársticos. Dados los fuertes } \\
\text { desniveles destaca el retoque de los procesos de ladera. }\end{array}$} \\
\hline & $\begin{array}{l}\text { Morfología: } \\
\text { Descripción, } \\
\text { morfoestructuras, } \\
\text { erosión. }\end{array}$ & \multicolumn{3}{|c|}{$\begin{array}{l}\text { Garganta fluvial con perfil complejo en } V \text {, fuertes pendientes y } \\
\text { desniveles en ambas márgenes. El fondo de la garganta, a unos } \\
200 \text { m, conecta con las zonas superiores mediante paredes } \\
\text { verticales y canales que aprovechan las morfoestructuras y la } \\
\text { fracturación local. Morfología fluvial de torrente de montaña, en } \\
\text { combinación con la karstificación y la dinámica de laderas. }\end{array}$} \\
\hline & Dinámica & \multicolumn{3}{|c|}{ Dinámica actual, fluvial y kárstica. } \\
\hline & Cronología & \multicolumn{3}{|c|}{$\begin{array}{l}\text { Establecimiento de la red actual preglaciar, guiado por la } \\
\text { fracturación local y el karst preglaciar, desarrollo y } \\
\text { profundización acentuado a partir del LGM, continuado en } \\
\text { menor medida hasta la actualidad a través de la incisión del río } \\
\text { Urdón. }\end{array}$} \\
\hline & Interés principal & \multicolumn{3}{|c|}{ Garganta fluvio-kárstica de gran desarrollo vertical. } \\
\hline & $\begin{array}{l}\text { Interés } \\
\text { secundario }\end{array}$ & \multicolumn{3}{|c|}{$\begin{array}{l}\text { Desniveles de más de } 400 \text { m, le dan gran calidad paisajística al } \\
\text { elemento. }\end{array}$} \\
\hline & $\begin{array}{l}\text { Atribución del } \\
\text { LIGm }\end{array}$ & \multicolumn{3}{|c|}{ GARGANTA FLUVIO-KÁRSTICA } \\
\hline \multirow{9}{*}{ Usos } & $\begin{array}{l}\text { Contenido } \\
\text { cultural }\end{array}$ & \multicolumn{3}{|c|}{$\begin{array}{l}\text { Núcleo de población. Tresviso y camino minero de Tresviso. } \\
\text { Fonda histórica en la desembocadura del Deva. }\end{array}$} \\
\hline & Accesibilidad & \multicolumn{3}{|c|}{$\begin{array}{l}\text { Mala. Accesible como actividad de aventura, visible desde lo alto } \\
\text { y caminos como el de Tresviso. }\end{array}$} \\
\hline & Grado de interés & \multicolumn{3}{|c|}{ Alto (científico-didáctico, turístico). } \\
\hline & $\begin{array}{l}\text { Estado de } \\
\text { conservación }\end{array}$ & \multicolumn{3}{|c|}{$\begin{array}{l}\text { Medio. Muchos sectores agrestes bien conservados, dada su } \\
\text { dificultad de acceso y escaso tránsito, pero concentración de } \\
\text { impactos en torno a la explotación hidroeléctrica actual y } \\
\text { minera del pasado. }\end{array}$} \\
\hline & Usos actuales & \multicolumn{3}{|c|}{ Excursionista y turístico. } \\
\hline & Comunicaciones & \multicolumn{3}{|c|}{$\begin{array}{l}\text { Hasta el inicio carretera asfaltada, camino minero a Tresviso, en } \\
\text { el interior no hay accesibilidad, en la ladera sur, el camino del } \\
\text { canal. }\end{array}$} \\
\hline & Infraestructuras & \multicolumn{3}{|c|}{ Hidroeléctricas y camino minero. } \\
\hline & Impactos & \multicolumn{3}{|c|}{$\begin{array}{l}\text { La mayor parte de su superficie no, debido a la dificultad de } \\
\text { acceso y escaso tránsito derivado, pero las laderas están } \\
\text { ocupadas por infraestructuras hidroeléctricas. }\end{array}$} \\
\hline & Situación legal & \multicolumn{3}{|c|}{ Parque Nacional de Picos de Europa (PRUG y PORN) } \\
\hline
\end{tabular}




\begin{tabular}{|c|c|c|c|c|}
\hline \multicolumn{5}{|c|}{ LUGAR DE INTERÉS GEOMORFOLÓGICO: DESCRIPCIÓN } \\
\hline Identificación & \multicolumn{2}{|c|}{ Nombre: Nunatak de Macondiú } & $\begin{array}{l}\text { Lugar: Macizo Oriental } \\
\text { Picos de Europa }\end{array}$ & No: 25 \\
\hline Situación & $\begin{array}{l}\text { To municipal: } \\
\text { Bejés (Cantabria) }\end{array}$ & Coordenadas: & \multicolumn{2}{|l|}{$\begin{array}{l}\text { Altitud: } \\
\text { Entre } 220-440 \mathrm{~m}\end{array}$} \\
\hline & TIPO & \multicolumn{3}{|c|}{ LUGAR SINGULAR } \\
\hline & & \multicolumn{3}{|c|}{$\begin{array}{l}\text { Cumbre exenta entre dos artesas glaciares poco frecuente en el } \\
\text { macizo, pero muy característico de los ambientes glaciares. }\end{array}$} \\
\hline & Génesis & \multicolumn{3}{|c|}{ Combinación de morfoestructura y erosión glaciar. } \\
\hline Geomorfología & $\begin{array}{l}\text { Morfología: } \\
\text { Descripción, } \\
\text { morfoestructuras, } \\
\text { erosión. }\end{array}$ & \multicolumn{3}{|c|}{$\begin{array}{l}\text { Cumbre piramidal que refleja la disposición de monoclinal, con } \\
\text { un frente escarpado y un dorso suave, en el que las paredes } \\
\text { están escarpadas por la acción glaciar y fue la zona de división } \\
\text { de las lenguas glaciares que volvían a confluir aguas abajo del } \\
\text { monolito. }\end{array}$} \\
\hline & Dinámica & \multicolumn{3}{|c|}{ No activo. Procesos de ladera y kársticos (lapiaces). } \\
\hline & Cronología & \multicolumn{3}{|c|}{ Emplazamiento tectónico (alpino) y erosión glaciar. Pleistoceno. } \\
\hline & Interés principal & \multicolumn{3}{|c|}{ Elemento glaciar visible y señalado. } \\
\hline & $\begin{array}{l}\text { Interés } \\
\text { secundario }\end{array}$ & \multicolumn{3}{|c|}{ Morfoestructural, y es un mirador privilegiado. } \\
\hline & $\begin{array}{l}\text { Atribución del } \\
\text { LIGm }\end{array}$ & \multicolumn{3}{|c|}{ Nunatak (origen glaciar) } \\
\hline \multirow{9}{*}{ Usos } & $\begin{array}{l}\text { Contenido } \\
\text { cultural }\end{array}$ & \multicolumn{3}{|c|}{ Pistas mineras en sus laderas. } \\
\hline & Accesibilidad & \multicolumn{3}{|c|}{ Buena, a pie. Proximidad de pistas y refugio de Ándara. } \\
\hline & Grado de interés & \multicolumn{3}{|c|}{ Medio (didáctico, turístico) } \\
\hline & $\begin{array}{l}\text { Estado de } \\
\text { conservación }\end{array}$ & \multicolumn{3}{|c|}{$\begin{array}{l}\text { Bueno. La ladera WNW muy deteriorada por la actividad } \\
\text { minera. }\end{array}$} \\
\hline & Usos actuales & \multicolumn{3}{|c|}{ Excursionista y turístico. } \\
\hline & Comunicaciones & \multicolumn{3}{|c|}{ Pista desde Escarandi, y senda hacia la cumbre. } \\
\hline & Infraestructuras & \multicolumn{3}{|c|}{ Camino minero. } \\
\hline & Impactos & \multicolumn{3}{|c|}{ Derivados de la actividad minera y su abandono. } \\
\hline & Situación legal & \multicolumn{3}{|c|}{ Parque Nacional de Picos de Europa (PRUG y PORN) } \\
\hline
\end{tabular}




\begin{tabular}{|c|c|c|c|c|}
\hline \multicolumn{5}{|c|}{ LUGAR DE INTERÉS GEOMORFOLÓGICO: DESCRIPCIÓN } \\
\hline Identificación & \multicolumn{2}{|c|}{ Nombre: Artesa y lago de Ándara } & $\begin{array}{l}\text { Lugar: Macizo Oriental } \\
\text { Picos de Europa }\end{array}$ & \\
\hline Situación & $\begin{array}{l}\text { To municipal: } \\
\text { Bejés (Cantabria) }\end{array}$ & Coordenadas: & \multicolumn{2}{|l|}{\begin{tabular}{l|l} 
Altitud: \\
Entre $220-440 \mathrm{~m}$
\end{tabular}} \\
\hline \multirow{9}{*}{ Geomorfología } & \multirow[t]{2}{*}{ TIPO } & \multicolumn{3}{|c|}{ LUGAR REPRESENTATIVO } \\
\hline & & \multicolumn{3}{|c|}{$\begin{array}{l}\text { LIGm representativo del modelado glaciokárstico del macizo, y } \\
\text { de las agresiones ambientales a los aspectos abióticos de la } \\
\text { minería. }\end{array}$} \\
\hline & Génesis & \multicolumn{3}{|c|}{$\begin{array}{l}\text { Erosión glaciar sobre calizas y pizarras, con comportamiento } \\
\text { diferencial (mecánico y disolución kárstica), cuyos restos, las } \\
\text { arcillas de descalcificación, posibilitaron la obturación de } \\
\text { conductos y la génesis de uno de los pocos lagos de Picos, } \\
\text { desaparecido por la actividad minera. }\end{array}$} \\
\hline & $\begin{array}{l}\text { Morfología: } \\
\text { Descripción, } \\
\text { morfoestructuras, } \\
\text { erosión. }\end{array}$ & \multicolumn{3}{|c|}{$\begin{array}{l}\text { Garganta en artesa (U) con depresiones cerradas y fondo de } \\
\text { tendencia plana en la zona del lago. En las laderas, } \\
\text { desprendimientos y morfología kárstica (dolinas y lapiaces), que } \\
\text { alternan con las formas antrópicas (minería). }\end{array}$} \\
\hline & Dinámica & \multicolumn{3}{|c|}{ Dinámica actual de laderas y kárstica. } \\
\hline & Cronología & \multicolumn{3}{|c|}{$\begin{array}{l}\text { Modelado glaciar Pleistoceno y de laderas Holoceno, destrucción } \\
\text { del lago en los años } 20 \text { del s. XX. }\end{array}$} \\
\hline & Interés principal & \multicolumn{3}{|c|}{$\begin{array}{l}\text { Garganta glacio-kárstica y cubeta lacustre, impacto humano } \\
\text { sobre el relieve. }\end{array}$} \\
\hline & $\begin{array}{l}\text { Interés } \\
\text { secundario }\end{array}$ & \multicolumn{3}{|c|}{ Modelado de laderas. } \\
\hline & $\begin{array}{l}\text { Atribución del } \\
\text { LIGm }\end{array}$ & \multicolumn{3}{|c|}{ Modelado glaciar } \\
\hline \multirow[t]{9}{*}{ Usos } & $\begin{array}{l}\text { Contenido } \\
\text { cultural }\end{array}$ & \multicolumn{3}{|c|}{$\begin{array}{l}\text { Núcleo minero, con restos variados de la ocupación minera. } \\
\text { Escritos, fotografías y pinturas desde el siglo XIX, derivados de la } \\
\text { frecuentación de artistas, naturalistas, geógrafos y educadores } \\
\text { a partir de la actividad minera en Ándara. }\end{array}$} \\
\hline & Accesibilidad & \multicolumn{3}{|c|}{ Buena. Pista desde Escarandi. } \\
\hline & Grado de interés & \multicolumn{3}{|c|}{ Alto (científico-didáctico, turístico y cultural) } \\
\hline & $\begin{array}{l}\text { Estado de } \\
\text { conservación }\end{array}$ & \multicolumn{3}{|c|}{$\begin{array}{l}\text { Malo. Fuerte agresión de la minería, hoy en completo abandono, } \\
\text { con deterioro de formas, génesis de formas y eliminación del } \\
\text { lago. }\end{array}$} \\
\hline & Usos actuales & \multicolumn{3}{|c|}{ Excursionista y turístico. } \\
\hline & Comunicaciones & \multicolumn{3}{|c|}{ Pista minera muy deteriorada. } \\
\hline & Infraestructuras & \multicolumn{3}{|c|}{ Mineras abandonadas. } \\
\hline & Impactos & \multicolumn{3}{|c|}{$\begin{array}{l}\text { Minero. Derivado de las taludes artificiales, y las alteraciones del } \\
\text { relieve. Es un paisaje minero inscrito en un paisaje } \\
\text { geomorfológico. }\end{array}$} \\
\hline & Situación legal & \multicolumn{3}{|c|}{ Parque Nacional de Picos de Europa (PRUG y PORN) } \\
\hline
\end{tabular}




\begin{tabular}{|c|c|c|c|c|}
\hline \multicolumn{5}{|c|}{ LUGAR DE INTERÉS GEOMORFOLÓGICO: DESCRIPCIÓN } \\
\hline Identificación & \multicolumn{2}{|c|}{ Nombre: Complejo morrénico de Escarandi } & $\begin{array}{l}\text { Lugar: Macizo Oriental } \\
\text { Picos de Europa }\end{array}$ & NNo: 27 \\
\hline Situación & $\begin{array}{l}\text { To municipal: } \\
\text { Cabrales (Asturias), } \\
\text { Bejés y Tresviso } \\
\text { (Cantabria). }\end{array}$ & Coordenadas: & \multicolumn{2}{|l|}{$\begin{array}{l}\text { Altitud: } \\
\text { Entre } 220-440 \mathrm{~m}\end{array}$} \\
\hline \multirow{9}{*}{ Geomorfología } & \multicolumn{4}{|c|}{\begin{tabular}{l|l|l} 
(Cantabria). \\
TIPO & LUGAR SINGULAR \\
\end{tabular}} \\
\hline & & \multicolumn{3}{|c|}{$\begin{array}{l}\text { Morrenas laterales de amplio desarrollo, poco frecuentes en los } \\
\text { Picos de Europa, pero características del modelado glaciar. }\end{array}$} \\
\hline & Génesis & \multicolumn{3}{|c|}{$\begin{array}{l}\text { Acumulación glaciar en sus márgenes, con acumulación de finos } \\
\text { en las depresiones y génesis de obturaciones que represaron } \\
\text { lagos durante el periodo glaciar. }\end{array}$} \\
\hline & $\begin{array}{l}\text { Morfología: } \\
\text { Descripción, } \\
\text { morfoestructuras, } \\
\text { erosión. }\end{array}$ & \multicolumn{3}{|c|}{$\begin{array}{l}\text { Arcos morrénicos sucesivos, hasta tres arcos, que delimitan la } \\
\text { zona glaciada durante el Pleistoceno. Entre los arcos rellanos de } \\
\text { obturación con depósitos lacustres. Génesis de acumulación } \\
\text { glaciar del glaciar cuaternario de Valdediezma. }\end{array}$} \\
\hline & Dinámica & \multicolumn{3}{|c|}{ Procesos de ladera, solifluxión y deslizamientos menores. } \\
\hline & Cronología & \multicolumn{3}{|c|}{$\begin{array}{l}\text { Pleistoceno. Atribuidos a una fase previa al LGM europeo, en } \\
\text { torno a } 40.000 \text { años para los arcos externos, con deposición } \\
\text { sucesiva hasta los } 20.000 \text { años. }\end{array}$} \\
\hline & Interés principal & \multicolumn{3}{|c|}{ Morfología glaciar y till. } \\
\hline & $\begin{array}{l}\text { Interés } \\
\text { secundario }\end{array}$ & \multicolumn{3}{|l|}{-} \\
\hline & $\begin{array}{l}\text { Atribución del } \\
\text { LIGm }\end{array}$ & \multicolumn{3}{|l|}{ Modelado glaciar } \\
\hline \multirow{9}{*}{ Usos } & $\begin{array}{l}\text { Contenido } \\
\text { cultural }\end{array}$ & \multicolumn{3}{|c|}{ Usos diferenciados para la ganadería tradicional. } \\
\hline & Accesibilidad & \multicolumn{3}{|c|}{ Buena. Carretera y pista desde el aparcamiento de Escarandi. } \\
\hline & Grado de interés & \multicolumn{3}{|c|}{ Alto (científico-didáctico) } \\
\hline & $\begin{array}{l}\text { Estado de } \\
\text { conservación }\end{array}$ & \multicolumn{3}{|c|}{$\begin{array}{l}\text { Medio. Deterioro por la construcción de pistas, carretera y } \\
\text { aparcamiento }\end{array}$} \\
\hline & Usos actuales & \multicolumn{3}{|c|}{ Ganadero y excursionista. } \\
\hline & Comunicaciones & \multicolumn{3}{|c|}{ Carretera asfaltada y pista. } \\
\hline & Infraestructuras & \multicolumn{3}{|c|}{ Pista minera y edificaciones para ganado. } \\
\hline & Impactos & \multicolumn{3}{|c|}{$\begin{array}{l}\text { Derivados de la construcción y mantenimiento de pistas, así } \\
\text { como del uso del Hill como gravera para la carretera, hoy } \\
\text { abandonado. }\end{array}$} \\
\hline & Situación legal & \multicolumn{3}{|c|}{ Parque Nacional de Picos de Europa (PRUG y PORN) } \\
\hline
\end{tabular}




\begin{tabular}{|c|c|c|c|c|}
\hline \multicolumn{5}{|c|}{ LUGAR DE INTERÉS GEOMORFOLÓGICO: DESCRIPCIÓN } \\
\hline Identificación & \multicolumn{2}{|c|}{ Nombre: Morrenas de El Torno } & $\begin{array}{l}\text { Lugar: Macizo Oriental } \\
\text { Picos de Europa }\end{array}$ & No: 28 \\
\hline Situación & $\begin{array}{l}\text { To municipal: } \\
\text { Bejés (Cantabria) }\end{array}$ & Coordenadas: & \multicolumn{2}{|l|}{$\begin{array}{l}\text { Altitud: } \\
\text { Entre } 220-440 \mathrm{~m}\end{array}$} \\
\hline & TIPO & \multicolumn{3}{|c|}{ LUGAR REPRESENTATIVO } \\
\hline & & \multicolumn{3}{|c|}{$\begin{array}{l}\text { Complejo morrénico frontal de amplio desarrollo, característico } \\
\text { de la última glaciación. }\end{array}$} \\
\hline & Génesis & \multicolumn{3}{|c|}{ Acumulación glaciar frontal de un periodo de retroceso. } \\
\hline Geomorfología & $\begin{array}{l}\text { Morfología: } \\
\text { Descripción, } \\
\text { morfoestructuras, } \\
\text { erosión. }\end{array}$ & \multicolumn{3}{|c|}{$\begin{array}{l}\text { Arcos morrénicos frontales sucesivos, hasta tres arcos, que } \\
\text { delimitan la zona glaciada durante el Pleistoceno. Conectan con } \\
\text { morrenas laterales con rellanos de obturación. }\end{array}$} \\
\hline & Dinámica & \multicolumn{3}{|l|}{ Solifluxión. } \\
\hline & Cronología & \multicolumn{3}{|c|}{$\begin{array}{l}\text { Pleistoceno. Atribuidos a una fase de retroceso, posiblemente } \\
\text { coetánea del LGM europeo, en torno a } 20.000 \text { años, cuando el } \\
\text { glaciar de Ándara aún tenía un amplio desarrollo. }\end{array}$} \\
\hline & Interés principal & \multicolumn{3}{|c|}{ Morfología glaciar y till. } \\
\hline & $\begin{array}{l}\text { Interés } \\
\text { secundario }\end{array}$ & \multicolumn{3}{|c|}{-} \\
\hline & $\begin{array}{l}\text { Atribución del } \\
\text { LIGm }\end{array}$ & \multicolumn{3}{|c|}{ Modelado glaciar } \\
\hline \multirow{9}{*}{ Usos } & $\begin{array}{l}\text { Contenido } \\
\text { cultural }\end{array}$ & \multicolumn{3}{|c|}{ Usos diferenciados para la ganadería tradicional. } \\
\hline & Accesibilidad & \multicolumn{3}{|c|}{ Mala. Pista minera y ganadera, alejada de puntos accesibles. } \\
\hline & Grado de interés & \multicolumn{3}{|c|}{ Alto (científico-didáctico). } \\
\hline & $\begin{array}{l}\text { Estado de } \\
\text { conservación }\end{array}$ & \multicolumn{3}{|c|}{ Alto. Formas bien conservadas. } \\
\hline & Usos actuales & \multicolumn{3}{|l|}{ Ganadero. } \\
\hline & Comunicaciones & \multicolumn{3}{|c|}{ Pista. } \\
\hline & Infraestructuras & \multicolumn{3}{|c|}{ Pista minera y edificaciones para ganado. } \\
\hline & Impactos & \multicolumn{3}{|c|}{ Moderados derivados de la actividad ganadera. } \\
\hline & Situación legal & \multicolumn{3}{|c|}{ Parque Nacional de Picos de Europa (PRUG y PORN). } \\
\hline
\end{tabular}




\begin{tabular}{|c|c|c|c|c|}
\hline \multicolumn{5}{|c|}{ LUGAR DE INTERÉS GEOMORFOLÓGICO: DESCRIPCIÓN } \\
\hline Identificación & \multicolumn{2}{|c|}{$\begin{array}{l}\text { Nombre: Canal del valle y complejo morrénico } \\
\text { de la Aurora. }\end{array}$} & $\begin{array}{l}\text { Lugar: Macizo Oriental } \\
\text { Picos de Europa }\end{array}$ & №: 29 \\
\hline Situación & $\begin{array}{l}\text { To municipal: } \\
\text { Bejés (Cantabria) }\end{array}$ & Coordenadas: & \multicolumn{2}{|l|}{\begin{tabular}{l|l} 
Altitud: \\
Entre $220-440 \mathrm{~m}$
\end{tabular}} \\
\hline & TIPO & \multicolumn{3}{|l|}{ LUGAR REPRESENTATIVO } \\
\hline & & \multicolumn{3}{|c|}{$\begin{array}{l}\text { Canal morfoestructural y complejo morrénico frontal, } \\
\text { característicos de los Picos. }\end{array}$} \\
\hline & Génesis & \multicolumn{3}{|c|}{$\begin{array}{l}\text { Canal morfoestructural en el frente cabalgante y línea de } \\
\text { fractura donde contactan las lutitas y areniscas (Fm Lechada) y } \\
\text { las calizas (Fm Picos de Europa), generando fuentes, con } \\
\text { modelado glaciar y acumulación de morrenas a la salida. }\end{array}$} \\
\hline Geomorfología & $\begin{array}{l}\text { Morfología: } \\
\text { Descripción, } \\
\text { morfoestructuras, } \\
\text { erosión. }\end{array}$ & \multicolumn{3}{|c|}{$\begin{array}{l}\text { Valle de dirección NE, elaborado en las calizas, con dorso al sur y } \\
\text { frente al norte, remodelado por el hielo, en una artesa glaciar } \\
\text { disimétrica. Complejo morrénico frontal, con tres arcos sucesivos } \\
\text { bien conservados. }\end{array}$} \\
\hline & Dinámica & \multicolumn{3}{|c|}{$\begin{array}{l}\text { Procesos kársticos, torrenciales y de ladera (derrubios, conos, } \\
\text { solifluxión y deslizamientos menores). }\end{array}$} \\
\hline & Cronología & \multicolumn{3}{|c|}{$\begin{array}{l}\text { Emplazamiento morfoestructural FiniPaleozoico y Mesoterciario, } \\
\text { modelado del Pleistoceno superior, de la última fase glaciar. } \\
\text { Retoques periglaciares Pleistocenos y Holocenos. }\end{array}$} \\
\hline & Interés principal & \multicolumn{3}{|c|}{ Morfología glaciar y combinación con la morfoestructura. } \\
\hline & $\begin{array}{l}\text { Interés } \\
\text { secundario }\end{array}$ & \multicolumn{3}{|c|}{-} \\
\hline & $\begin{array}{l}\text { Atribución del } \\
\text { LIGm }\end{array}$ & \multicolumn{3}{|c|}{ Morfoestructural y modelado glaciar. } \\
\hline \multirow{9}{*}{ Usos } & $\begin{array}{l}\text { Contenido } \\
\text { cultural }\end{array}$ & \multicolumn{3}{|l|}{ Uso minero abandonado. } \\
\hline & Accesibilidad & \multicolumn{3}{|c|}{$\begin{array}{l}\text { Mala. Senda minera muy alejado de cualquier acceso con } \\
\text { vehículos }\end{array}$} \\
\hline & Grado de interés & \multicolumn{3}{|c|}{ Alto (científico-didáctico) } \\
\hline & $\begin{array}{l}\text { Estado de } \\
\text { conservación }\end{array}$ & \multicolumn{3}{|l|}{ Bueno. } \\
\hline & Usos actuales & \multicolumn{3}{|l|}{ Ganadero. } \\
\hline & Comunicaciones & \multicolumn{3}{|c|}{ Pista minera abandonada y muy deteriorada. } \\
\hline & Infraestructuras & \multicolumn{3}{|l|}{ Pista minera. } \\
\hline & Impactos & \multicolumn{3}{|c|}{ Derivados de la minería, son menores. } \\
\hline & Situación legal & \multicolumn{3}{|c|}{ Parque Nacional de Picos de Europa (PRUG y PORN). } \\
\hline
\end{tabular}




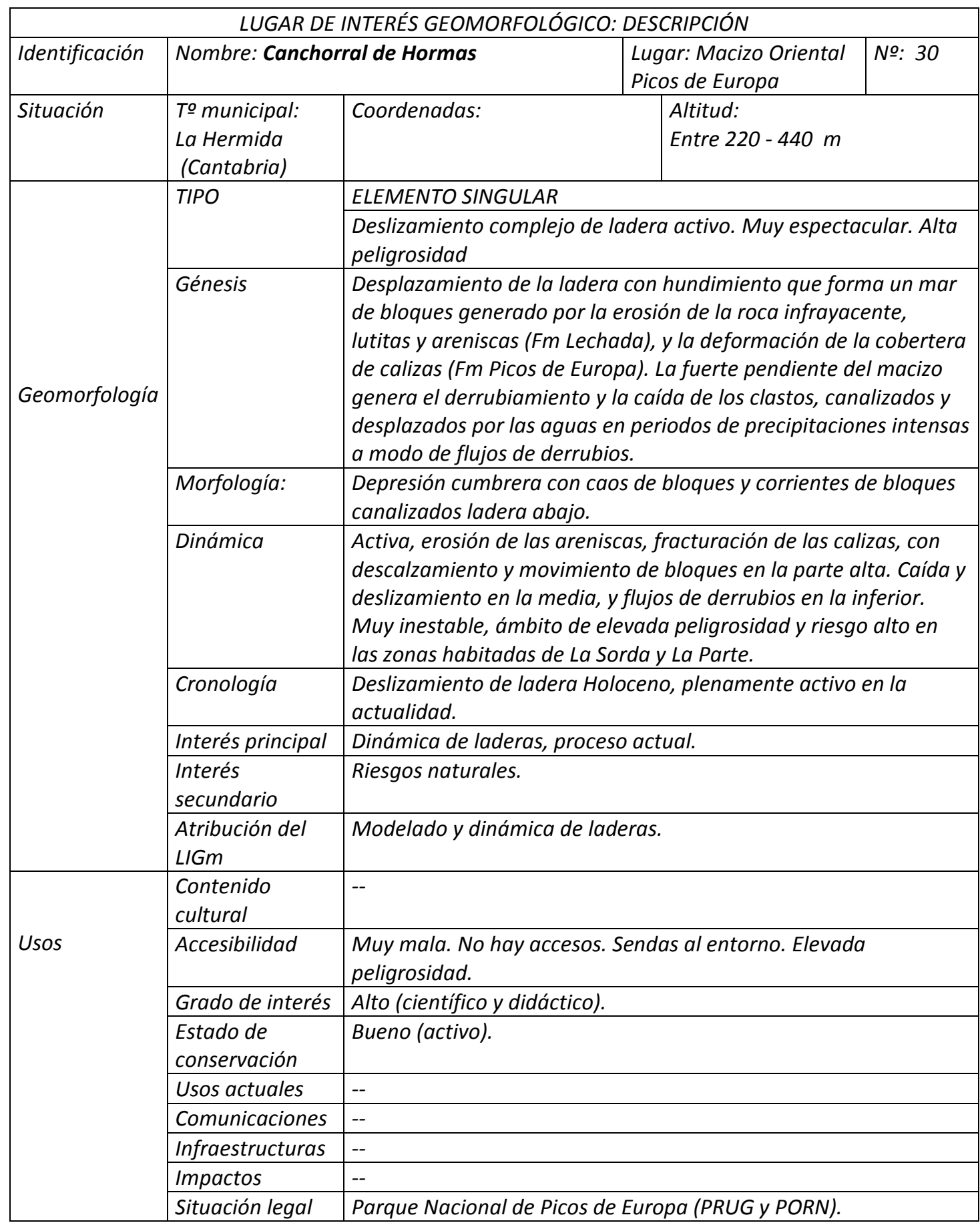




\begin{tabular}{|c|c|c|c|c|}
\hline \multicolumn{5}{|c|}{ LUGAR DE INTERÉS GEOMORFOLÓGICO: DESCRIPCIÓN } \\
\hline Identificación & \multicolumn{2}{|c|}{ Nombre: Peñas de Brez } & $\begin{array}{l}\text { Lugar: Macizo Oriental } \\
\text { Picos de Europa }\end{array}$ & №: 31 \\
\hline Situación & $\begin{array}{l}\text { To municipal: } \\
\text { Camaleño } \\
\text { (Cantabria) }\end{array}$ & Coordenadas: & \multicolumn{2}{|l|}{$\begin{array}{l}\text { Altitud: } \\
\text { Entre } 220-440 \mathrm{~m}\end{array}$} \\
\hline \multirow{9}{*}{ Geomorfología } & \multirow[t]{2}{*}{ TIPO } & \multicolumn{3}{|l|}{ LUGAR SINGULAR } \\
\hline & & \multicolumn{3}{|l|}{ Deslizamiento de ladera activo. } \\
\hline & Génesis & \multicolumn{3}{|c|}{$\begin{array}{l}\text { Deslizamiento rotacional generado por el descalzamiento de la } \\
\text { unidad cabalgante de la Fm Calizas de Montaña a partir de la } \\
\text { erosión de las areniscas y lutitas del Grupo Potes. }\end{array}$} \\
\hline & $\begin{array}{l}\text { Morfología: } \\
\text { Descripción, } \\
\text { morfoestructuras, } \\
\text { erosión. }\end{array}$ & \multicolumn{3}{|c|}{$\begin{array}{l}\text { Nicho de cabecera y cuerpo alargado con flujo actual que } \\
\text { termina en una lengua con fuerte pendiente donde los bloques } \\
\text { de caliza deslizada son muy inestables y caen por la ladera hasta } \\
\text { las proximidades del pueblo. }\end{array}$} \\
\hline & Dinámica & \multicolumn{3}{|c|}{$\begin{array}{l}\text { Deslizamiento rotacional activo con desprendimientos desde el } \\
\text { frente. Muy inestable en el frente y en el cuerpo, agrietado y } \\
\text { formando un caos de bloques. Alta peligrosidad y riesgo elevado } \\
\text { para el pueblo de Brez. }\end{array}$} \\
\hline & Cronología & \multicolumn{3}{|c|}{ Deslizamiento Pleistoceno y Holoceno, activo en la actualidad. } \\
\hline & Interés principal & \multicolumn{3}{|c|}{ Dinámica de laderas, procesos actuales. } \\
\hline & $\begin{array}{l}\text { Interés } \\
\text { secundario }\end{array}$ & \multicolumn{3}{|c|}{ Riesgos naturales. } \\
\hline & $\begin{array}{l}\text { Atribución del } \\
\text { LIGm }\end{array}$ & \multicolumn{3}{|c|}{ Modelado y dinámica de laderas. } \\
\hline \multirow{9}{*}{ Usos } & $\begin{array}{l}\text { Contenido } \\
\text { cultural }\end{array}$ & \multicolumn{3}{|c|}{ Campos de labor, pueblo de Brez. } \\
\hline & Accesibilidad & \multicolumn{3}{|c|}{ Muy Buena. Carretera hasta Brez y pista por el deslizamiento. } \\
\hline & Grado de interés & \multicolumn{3}{|l|}{ Alto (científico, didáctico). } \\
\hline & $\begin{array}{l}\text { Estado de } \\
\text { conservación }\end{array}$ & \multicolumn{3}{|l|}{ Bueno. } \\
\hline & Usos actuales & \multicolumn{3}{|l|}{ Ganadero. } \\
\hline & Comunicaciones & \multicolumn{3}{|l|}{ Carretera y pista. } \\
\hline & Infraestructuras & \multicolumn{3}{|l|}{ Obras de retención en Brez. } \\
\hline & Impactos & \multicolumn{3}{|l|}{-} \\
\hline & Situación legal & \multicolumn{3}{|c|}{ Parque Nacional de Picos de Europa (PRUG y PORN). } \\
\hline
\end{tabular}




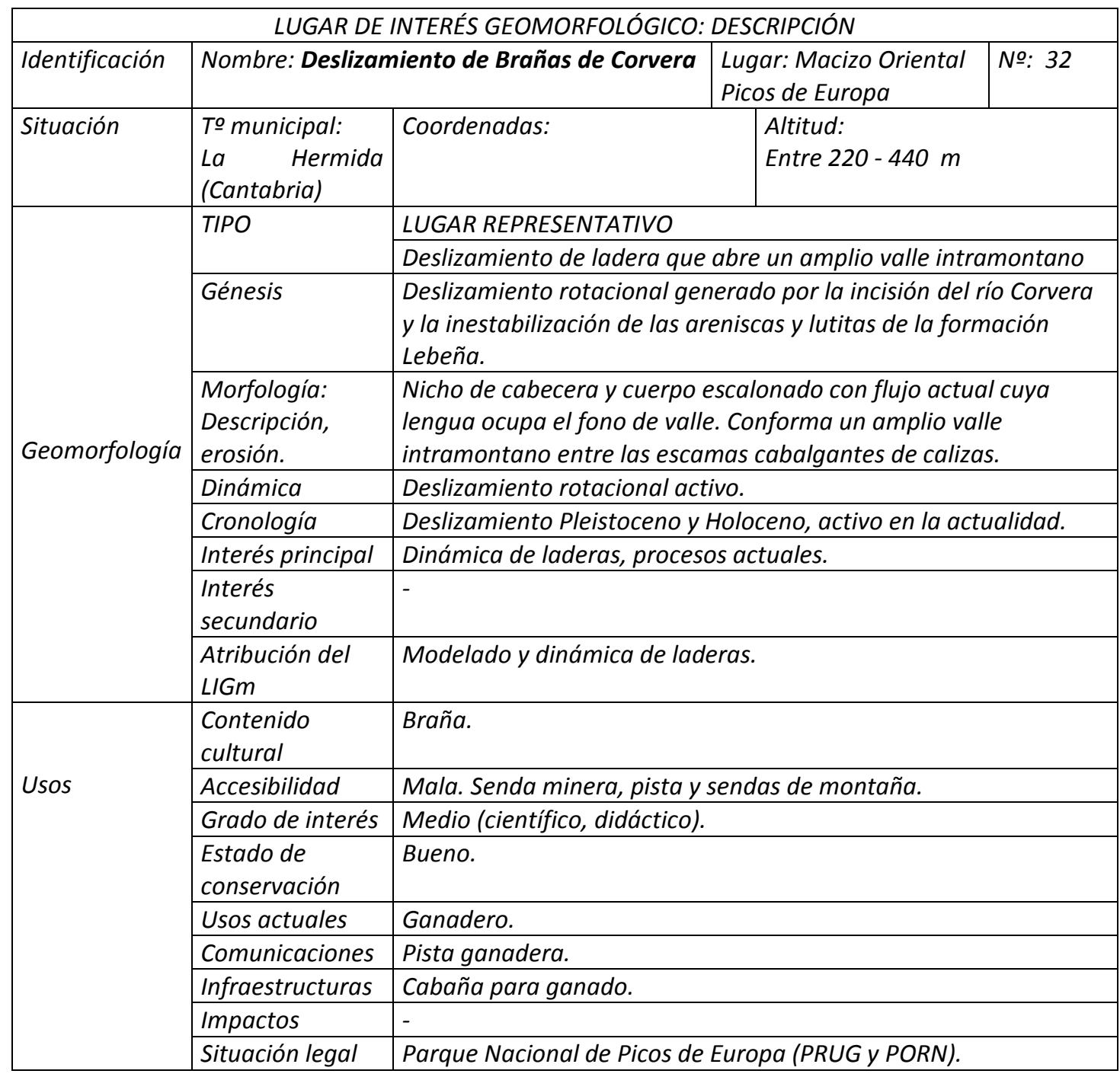




\begin{tabular}{|c|c|c|c|c|}
\hline \multicolumn{5}{|c|}{ LUGAR DE INTERÉS GEOMORFOLÓGICO: DESCRIPCIÓN } \\
\hline \multirow{2}{*}{$\begin{array}{l}\text { Identificación } \\
\text { Situación }\end{array}$} & \multicolumn{2}{|c|}{ Nombre: Canal de Las Arredondas } & $\begin{array}{l}\text { Lugar: Macizo Oriental } \\
\text { Picos de Europa }\end{array}$ & No: 33 \\
\hline & $\begin{array}{l}\text { To municipal: } \\
\text { Camaleño } \\
\text { (Cantabria) }\end{array}$ & Coordenadas: & Altitud: & \\
\hline \multirow{9}{*}{ Geomorfología } & \multirow[t]{2}{*}{ TIPO } & \multicolumn{3}{|c|}{ LUGAR REPRESENTATIVO } \\
\hline & & \multicolumn{3}{|c|}{$\begin{array}{l}\text { Este LIGm abarca toda la Canal de las Arredondas. Las canales } \\
\text { son elementos morfológicos complejos, característicos de Picos } \\
\text { de Europa. }\end{array}$} \\
\hline & Génesis & \multicolumn{3}{|c|}{$\begin{array}{l}\text { Combinación de procesos glacio-fluvio-kársticos. Guiados por las } \\
\text { morfoestructuras y la fracturación local. }\end{array}$} \\
\hline & $\begin{array}{l}\text { Morfología: } \\
\text { Descripción, } \\
\text { morfoestructuras. }\end{array}$ & \multicolumn{3}{|c|}{$\begin{array}{l}\text { Guiado por la fracturación local y por las morfoestructuras, } \\
\text { escarpe de la escama cabalgante frontal. Relieve abrupto de } \\
\text { gran desnivel. }\end{array}$} \\
\hline & Dinámica & \multicolumn{3}{|c|}{$\begin{array}{l}\text { Actualmente procesos de ladera, nivoperiglaciar en la parte alta } \\
\text { y fluvial en la baja, aludes, con elevado riesgo invernal. }\end{array}$} \\
\hline & Cronología & \multicolumn{3}{|c|}{$\begin{array}{l}\text { Canal formado con sus rasgos actuales durante el máximo } \\
\text { glaciar Pleistoceno, por ensanchamiento del relieve } \\
\text { fluviokárstico previo. Posteriormente los procesos periglaciares y } \\
\text { gravitacionales han retocado este tipo de formas de origen } \\
\text { mixto complejo. }\end{array}$} \\
\hline & Interés principal & \multicolumn{3}{|c|}{ Grandes formas, ladera, glaciares. } \\
\hline & $\begin{array}{l}\text { Interés } \\
\text { secundario }\end{array}$ & \multicolumn{3}{|c|}{-} \\
\hline & $\begin{array}{l}\text { Atribución del } \\
\text { LIGm }\end{array}$ & \multicolumn{3}{|c|}{ MODELADO MIXTO GLACIO-FLUVIO-KÁRSTICO Y ESTRUCTURAL } \\
\hline \multirow{9}{*}{ Usos } & $\begin{array}{l}\text { Contenido } \\
\text { cultural }\end{array}$ & \multicolumn{3}{|c|}{$\begin{array}{l}\text { Alusiones montañeras y literarias a las Canales como esencia de } \\
\text { Picos (Bernardo de Quirós, ILE, etc.) }\end{array}$} \\
\hline & Accesibilidad & \multicolumn{3}{|c|}{$\begin{array}{l}\text { Baja (por su parte alta mala, varias horas a pie, por sendas de } \\
\text { montaña, por abajo, llega la pista. Los fuertes desniveles hacen } \\
\text { de ésta un recorrido poco frecuentado. }\end{array}$} \\
\hline & Grado de interés & \multicolumn{3}{|c|}{ Medio (científico paisajístico). } \\
\hline & $\begin{array}{l}\text { Estado de } \\
\text { conservación }\end{array}$ & \multicolumn{3}{|l|}{ Alto. } \\
\hline & Usos actuales & \multicolumn{3}{|c|}{ Ganadero (pastos de altura) y Montañero (escaso). } \\
\hline & Comunicaciones & \multicolumn{3}{|c|}{ Sendas y pista ganadera. } \\
\hline & Infraestructuras & \multicolumn{3}{|c|}{ Restos de minería en la parte alta. } \\
\hline & Impactos & \multicolumn{3}{|c|}{ Mineros abandonados. } \\
\hline & Situación legal & \multicolumn{3}{|c|}{ Parque Nacional de Picos de Europa (PRUG y PORN). } \\
\hline
\end{tabular}




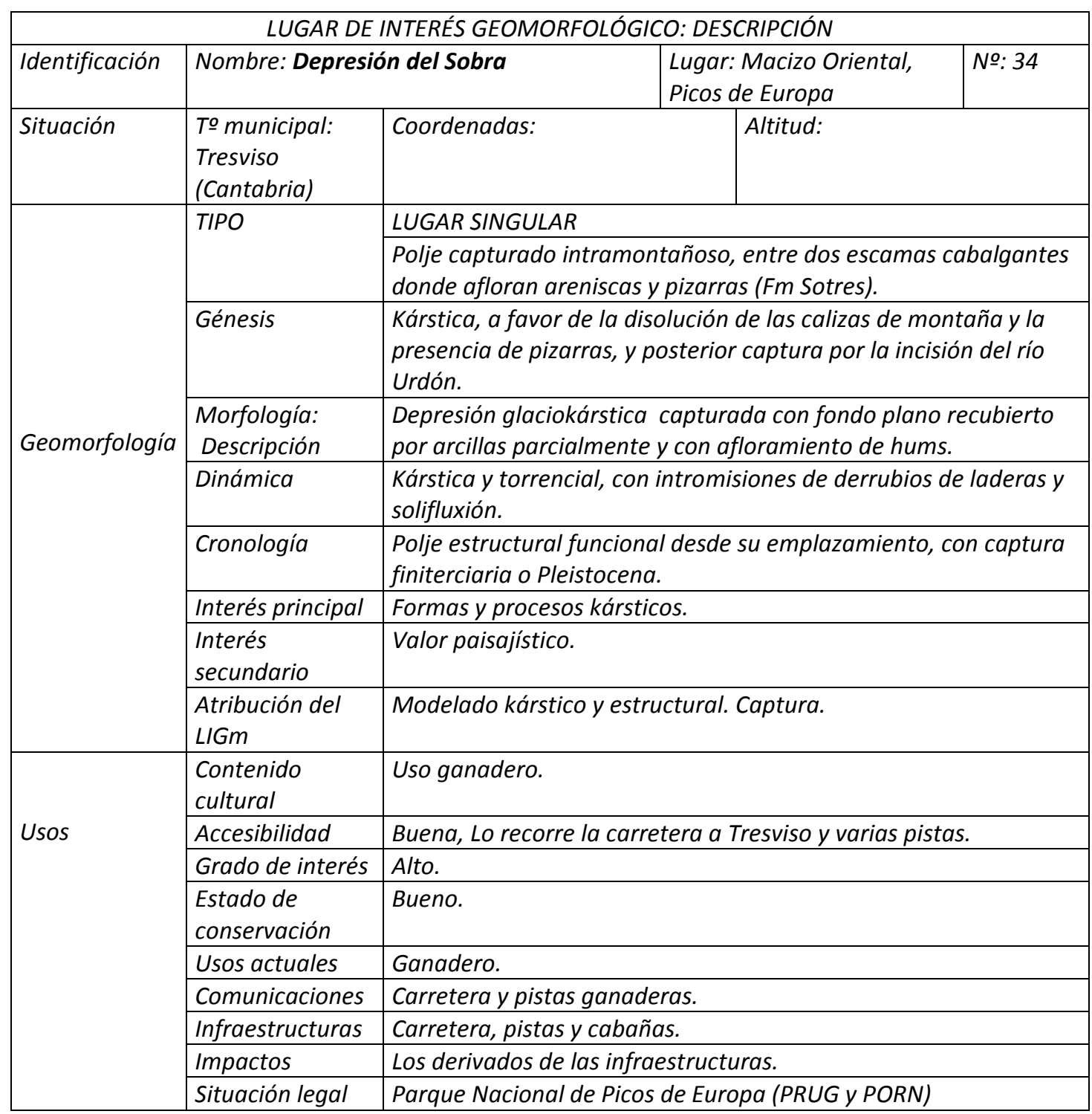




\begin{tabular}{|c|c|c|c|c|c|}
\hline \multicolumn{6}{|c|}{ LUGAR DE INTERÉS GEOMORFOLÓGICO: DESCRIPCIÓN } \\
\hline Identificación & \multicolumn{2}{|c|}{ Nombre: Torca del Cerro (-1.589m) } & \multicolumn{2}{|c|}{$\begin{array}{l}\text { Lugar: Macizo Oriental, } \\
\text { Picos de Europa }\end{array}$} & \multirow[t]{2}{*}{ No: 35} \\
\hline Situación & To municipal: & \multicolumn{2}{|l|}{ Coordenadas: } & Altitud: & \\
\hline \multirow{9}{*}{ Geomorfología } & \multirow[t]{2}{*}{ TIPO } & \multicolumn{4}{|c|}{ Elemento representativo } \\
\hline & & \multicolumn{4}{|c|}{ Sima kárstica de gran profundidad. } \\
\hline & Génesis & \multicolumn{4}{|c|}{ Kárstico. Endokarst. } \\
\hline & Morfología: & \multicolumn{4}{|c|}{$\begin{array}{l}\text { Sima vertical de } 1169 \text { m de profundidad, con sucesión de pozos y } \\
\text { galerías guiadas por la estructura (buzamiento y estratificación) } \\
\text { en las calizas de montaña }\end{array}$} \\
\hline & Dinámica & \multicolumn{4}{|c|}{ Kárstica. } \\
\hline & Cronología & \multicolumn{4}{|c|}{ Finiterciaria a actual. } \\
\hline & Interés principal & \multicolumn{4}{|c|}{ Kárstico, } \\
\hline & $\begin{array}{l}\text { Interés } \\
\text { secundario }\end{array}$ & \multicolumn{4}{|c|}{ Endemismos biológicos. } \\
\hline & $\begin{array}{l}\text { Atribución del } \\
\text { LIGm }\end{array}$ & \multicolumn{4}{|c|}{ Modelado endokárstico. } \\
\hline \multirow{9}{*}{ Usos } & $\begin{array}{l}\text { Contenido } \\
\text { cultural }\end{array}$ & \multicolumn{4}{|c|}{ Deportivo-espeleológico. Descubrimiento y exploración. } \\
\hline & Accesibilidad & \multicolumn{4}{|c|}{ Mala, son necesarias técnicas espeleológicas. } \\
\hline & Grado de interés & \multicolumn{4}{|c|}{$\begin{array}{l}\text { Alto: por la singularidad de la sima y la representatividad del } \\
\text { modelado kárstico. }\end{array}$} \\
\hline & $\begin{array}{l}\text { Estado de } \\
\text { conservación }\end{array}$ & \multicolumn{4}{|c|}{ Alto. } \\
\hline & Usos actuales & \multicolumn{4}{|c|}{ Deportivo, baja frecuentación. } \\
\hline & Comunicaciones & \multicolumn{4}{|c|}{ No existen } \\
\hline & Infraestructuras & \multicolumn{4}{|l|}{ No existen } \\
\hline & Impactos & \multicolumn{4}{|c|}{ No existen } \\
\hline & Situación legal & \multicolumn{4}{|c|}{ Parque Nacional de Picos de Europa (PRUG y PORN) } \\
\hline
\end{tabular}




\begin{tabular}{|c|c|c|c|c|}
\hline \multicolumn{5}{|c|}{ LUGAR DE INTERÉS GEOMORFOLÓGICO: DESCRIPCIÓN } \\
\hline Identificación & \multicolumn{2}{|c|}{ Nombre: Cueva del Nacimiento } & Lugar: Macizo Oriental, & No: 36 \\
\hline Situación & $\begin{array}{l}\text { To Municipal: } \\
\text { La Hermida- } \\
\text { Bejés } \\
\text { (Cantabria) }\end{array}$ & Coordenadas: & Altitud: & \\
\hline \multirow{9}{*}{ Geomorfología } & TIPO & \multicolumn{3}{|l|}{ Elemento singular. } \\
\hline & & \multicolumn{3}{|c|}{$\begin{array}{l}\text { Complejo endokárstico de desarrollo horizontal con salas } \\
\text { escalonadas. }\end{array}$} \\
\hline & Génesis & \multicolumn{3}{|c|}{$\begin{array}{l}\text { Disolución kárstica en las calizas de montaña, conductos dirigidos } \\
\text { por el nivel freático, ligado a las fuentes sobre la garganta de } \\
\text { Urdón. }\end{array}$} \\
\hline & Morfología: & \multicolumn{3}{|c|}{$\begin{array}{l}\text { Sistema kárstico con } 112 \text { kms de desarrollo y dominio de salas, } \\
\text { que recoge las aguas de la mayor parte del macizo de Ándara en } \\
\text { una de las surgencias más importantes de Picos de Europa. }\end{array}$} \\
\hline & Dinámica & \multicolumn{3}{|c|}{ Kárstica. } \\
\hline & Cronología & \multicolumn{3}{|c|}{ Finiterciaria a actual. } \\
\hline & Interés principal & \multicolumn{3}{|c|}{ Kárstico, endokárstico e hidrogeológico. } \\
\hline & $\begin{array}{l}\text { Interés } \\
\text { secundario }\end{array}$ & \multicolumn{3}{|c|}{-} \\
\hline & $\begin{array}{l}\text { Atribución del } \\
\text { LIGm }\end{array}$ & \multicolumn{3}{|c|}{ Modelado endokárstico, fuentes. } \\
\hline \multirow{9}{*}{ Usos } & $\begin{array}{l}\text { Contenido } \\
\text { cultural }\end{array}$ & \multicolumn{3}{|l|}{ Espeleológico. } \\
\hline & Accesibilidad & \multicolumn{3}{|c|}{ Mala, son necesarias técnicas espeleológicas. } \\
\hline & Grado de interés & \multicolumn{3}{|c|}{ Alto, por la singularidad del complejo y la representatividad. } \\
\hline & $\begin{array}{l}\text { Estado de } \\
\text { conservación }\end{array}$ & \multicolumn{3}{|l|}{ Alto } \\
\hline & Usos actuales & \multicolumn{3}{|c|}{ Deportivo espeleológico de muy baja frecuencia. } \\
\hline & Comunicaciones & \multicolumn{3}{|l|}{ No existen } \\
\hline & Infraestructuras & \multicolumn{3}{|l|}{ No existen } \\
\hline & Impactos & \multicolumn{3}{|c|}{ No existen } \\
\hline & Situación legal & \multicolumn{3}{|c|}{ Parque Nacional de Picos de Europa (PRUG y PORN). } \\
\hline
\end{tabular}




\section{A.10.3) Macizo del Cornión}

\begin{tabular}{|c|c|c|c|c|}
\hline \multicolumn{5}{|c|}{ LUGAR DE INTERÉS GEOMORFOLÓGICO: DESCRIPCIÓN } \\
\hline \multirow{2}{*}{$\begin{array}{l}\text { Identificación } \\
\text { Situación }\end{array}$} & \multicolumn{2}{|c|}{$\begin{array}{c}\text { Nombre: FRENTE CABALGANTE } \\
\text { PAMBUCHES }\end{array}$} & $\begin{array}{c}\text { Lugar: Macizo Occidental } \\
\text { Picos de Europa }\end{array}$ & No: 37 \\
\hline & $\begin{array}{l}\text { To municipal: } \\
\text { Valdeón (León) }\end{array}$ & Coordenadas: & \begin{tabular}{l|l} 
Altitud: \\
\end{tabular} & \\
\hline \multirow{9}{*}{ Geomorfología } & TIPO & \multicolumn{3}{|c|}{ LUGAR REPRESENTATIVO } \\
\hline & & \multicolumn{3}{|c|}{$\begin{array}{l}\text { Representa la ladera meridional del macizo que aglutina los } \\
\text { frentes cabalgantes de la unidad Picos de Europa y genera un } \\
\text { amplio frente sobre la depresión de Valdeón. }\end{array}$} \\
\hline & Génesis & \multicolumn{3}{|c|}{$\begin{array}{l}\text { Tectónica. Cabalgamientos hacia el sur y levantamiento de } \\
\text { toda la serie con erosión diferencial respecto a los materiales } \\
\text { no calcáreos. }\end{array}$} \\
\hline & $\begin{array}{l}\text { Morfología: } \\
\text { Descripción, } \\
\text { morfoestructuras, } \\
\text { erosión. }\end{array}$ & \multicolumn{3}{|c|}{$\begin{array}{l}\text { Escarpe de escamas cabalgantes que generan un frente } \\
\text { calcáreo de 400-800 metros de desnivel sobre la depresión, } \\
\text { caracterizado por la alternancia de las Fm Calizas de } \\
\text { Montaña y Fm Picos de Europa, surcado por canales que } \\
\text { individualizan parcialmente el frente. }\end{array}$} \\
\hline & Dinámica & \multicolumn{3}{|c|}{$\begin{array}{l}\text { Dinámica de aludes y deslizamientos de ladera activos en } \\
\text { combinación con procesos de ladera. }\end{array}$} \\
\hline & Cronología & \multicolumn{3}{|c|}{$\begin{array}{l}\text { Los materiales de edad carbonífera, el emplazamiento } \\
\text { tectónico Paleozoico y Alpino (mesoterciario), y la erosión } \\
\text { diferencial Terciaria-Cuaternaria. }\end{array}$} \\
\hline & Interés principal & \multicolumn{3}{|c|}{$\begin{array}{l}\text { Paisajístico y estratigráfico, es el límite meridional del macizo } \\
\text { calcáreo. }\end{array}$} \\
\hline & Interés secundario & \multicolumn{3}{|c|}{$\begin{array}{l}\text { Procesos y formas característicos (canales, derrubios, } \\
\text { deslizamientos). }\end{array}$} \\
\hline & Atribución del LIGm & \multicolumn{3}{|c|}{ Morfoestructural. } \\
\hline \multirow{9}{*}{ Usos } & Contenido cultural & \multicolumn{3}{|c|}{$\begin{array}{l}\text { Usos de canales y laderas, con vestigios prehistóricos y } \\
\text { tradicionales en el frente. }\end{array}$} \\
\hline & Accesibilidad & \multicolumn{3}{|c|}{$\begin{array}{l}\text { Mala. El frente tiene un acceso difícil, por largo, se trata de } \\
\text { un LIGm con contenido paisajístico para ser apreciado desde } \\
\text { lejos. Constituye la línea del cielo del Parque desde el sur. }\end{array}$} \\
\hline & Grado de interés & \multicolumn{3}{|c|}{ Alto (estético-paisajístico) } \\
\hline & $\begin{array}{l}\text { Estado de } \\
\text { conservación }\end{array}$ & \multicolumn{3}{|c|}{ Bueno. } \\
\hline & Usos actuales & \multicolumn{3}{|c|}{ Montañero y turístico } \\
\hline & Comunicaciones & \multicolumn{3}{|c|}{ Sendas y pistas de montaña } \\
\hline & Infraestructuras & \multicolumn{3}{|c|}{ Pistas rurales } \\
\hline & Impactos & \multicolumn{3}{|c|}{-} \\
\hline & Situación legal & \multicolumn{3}{|c|}{$\begin{array}{l}\text { Este lugar no goza de ninguna atención, ni figura específica } \\
\text { dentro del Parque Nacional de los Picos de Europa. }\end{array}$} \\
\hline
\end{tabular}




\begin{tabular}{|c|c|c|c|c|}
\hline \multicolumn{5}{|c|}{ LUGAR DE INTERÉS GEOMORFOLÓGICO: DESCRIPCIÓN } \\
\hline Identificación & \multicolumn{2}{|c|}{ Nombre: DESFILADERO DE LOS BEYOS } & $\begin{array}{l}\text { Lugar: Macizo Occidental } \\
\text { Picos de Europa }\end{array}$ & No: 38 \\
\hline Situación & $\begin{array}{l}\text { To municipal: } \\
\text { Cabrales } \\
\text { (Asturias) } \\
\text { Valdeón (León) }\end{array}$ & $\begin{array}{l}\text { Coordenadas: } \\
x-347.145 \\
y-4.790 .568\end{array}$ & \multicolumn{2}{|l|}{$\begin{array}{l}\text { Altitud: } \\
\text { Entre } 220-440 \mathrm{~m}\end{array}$} \\
\hline \multirow{9}{*}{ Geomorfología } & TIPO & \multicolumn{3}{|c|}{ LUGAR REPRESENTATIVO } \\
\hline & & \multicolumn{3}{|c|}{$\begin{array}{l}\text { LIGm representativo de las gargantas que separan y limitan el } \\
\text { macizo. }\end{array}$} \\
\hline & Génesis & \multicolumn{3}{|c|}{$\begin{array}{l}\text { Garganta Fluvio-kárstica, combinación de procesos fluviales y } \\
\text { kársticos en un contexto tectónico de apilamiento de escamas } \\
\text { tectónicas. Dados los fuertes desniveles destaca el retoque de los } \\
\text { procesos de ladera. }\end{array}$} \\
\hline & $\begin{array}{l}\text { Morfología: } \\
\text { Descripción }\end{array}$ & \multicolumn{3}{|c|}{$\begin{array}{l}\text { Garganta fluvial de marcada perfil en } V \text {, fuertes pendientes y } \\
\text { desniveles en sus laderas. El fondo de la garganta a unos } 400-800 \\
m \text {. Morfología fluvial de torrente de montaña, en combinación } \\
\text { con la karstificación y la dinámica de laderas, donde destacan las } \\
\text { estructuras tectónicas cabalgantes. }\end{array}$} \\
\hline & Dinámica & \multicolumn{3}{|c|}{ Dinámica actual, fluvial, kárstica y de laderas. } \\
\hline & Cronología & \multicolumn{3}{|c|}{$\begin{array}{l}\text { Inicio de la incisión y elaboración de valle inicial Pre-Pleistocena, } \\
\text { guiado por la fracturación local y el karst preglaciar. Desarrollo y } \\
\text { profundización acentuados a partir del Pleistoceno medio y } \\
\text { Superior, postglaciar, con continuidad de procesos hasta la } \\
\text { actualidad. }\end{array}$} \\
\hline & Interés principal & \multicolumn{3}{|c|}{ Garganta fluvio-kárstica. } \\
\hline & $\begin{array}{l}\text { Interés } \\
\text { secundario }\end{array}$ & \multicolumn{3}{|c|}{$\begin{array}{l}\text { Desniveles, calidad paisajística, afloramientos calcáreos y } \\
\text { estructuras tectónicas visibles. }\end{array}$} \\
\hline & $\begin{array}{l}\text { Atribución del } \\
\text { LIGm }\end{array}$ & \multicolumn{3}{|c|}{ GARGANTA FLUVIO-KÁRSTICA. } \\
\hline \multirow{9}{*}{ Usos } & $\begin{array}{l}\text { Contenido } \\
\text { cultural }\end{array}$ & \multicolumn{3}{|c|}{$\begin{array}{l}\text { Núcleos de población en las laderas y vía de comunicación abierta } \\
\text { en } 1886 .\end{array}$} \\
\hline & Accesibilidad & \multicolumn{3}{|c|}{ Buena. Carretera asfaltada. } \\
\hline & Grado de interés & \multicolumn{3}{|c|}{ Alto (científico-didáctico, turístico) } \\
\hline & $\begin{array}{l}\text { Estado de } \\
\text { conservación }\end{array}$ & \multicolumn{3}{|c|}{$\begin{array}{l}\text { Bueno. Dada la escala, existen alteraciones en todo el } \\
\text { desfiladero, que no perturban su valor original. }\end{array}$} \\
\hline & Usos actuales & \multicolumn{3}{|c|}{ Rural tradicional y turístico. } \\
\hline & Comunicaciones & \multicolumn{3}{|l|}{ Carretera nacional. } \\
\hline & Infraestructuras & \multicolumn{3}{|c|}{ Puentes, casetones, poblaciones. } \\
\hline & Impactos & \multicolumn{3}{|c|}{$\begin{array}{l}\text { Derivados del uso y construcción de la carretera, así como de los } \\
\text { usos rurales activos. }\end{array}$} \\
\hline & Situación legal & \multicolumn{3}{|c|}{ Parque Nacional de Picos de Europa (PRUG y PORN). } \\
\hline
\end{tabular}




\begin{tabular}{|c|c|c|c|c|}
\hline \multicolumn{5}{|c|}{ LUGAR DE INTERÉS GEOMORFOLÓGICO: DESCRIPCIÓN } \\
\hline \multirow{2}{*}{$\begin{array}{l}\text { Identificación } \\
\text { Situación }\end{array}$} & \multicolumn{2}{|c|}{ Nombre: LAGO Y VEGA DE ENOL } & $\begin{array}{l}\text { Lugar: Macizo Occidental } \\
\text { Picos de Europa }\end{array}$ & \multirow[t]{2}{*}{ №: 39} \\
\hline & To municipal: & Coordenadas: & \begin{tabular}{l|l} 
& Altitud:
\end{tabular} & \\
\hline \multirow{9}{*}{ Geomorfología } & \multirow[t]{2}{*}{ TIPO } & \multicolumn{3}{|c|}{ LUGAR REPRESENTATIVO } \\
\hline & & \multicolumn{3}{|c|}{$\begin{array}{l}\text { LIGm representativo del modelado glacio-kárstico del macizo, } \\
\text { que contiene el lago de Enol, uno de los elementos hidrológicos y } \\
\text { paisajísticos más representativo del Parque Nacional. }\end{array}$} \\
\hline & Génesis & \multicolumn{3}{|c|}{$\begin{array}{l}\text { Erosión glaciar sobre calizas que genera una artesa y una } \\
\text { cubeta, con sedimentación glaciar (till y morrenas laterales) y } \\
\text { procesos kársticos. }\end{array}$} \\
\hline & $\begin{array}{l}\text { Morfología: } \\
\text { Descripción, } \\
\text { morfoestructuras, } \\
\text { erosión. }\end{array}$ & \multicolumn{3}{|c|}{$\begin{array}{l}\text { Valle en artesa que finaliza en la cubeta glaciokárstica ocupada } \\
\text { por el lago de Enol, represado por dos morrenas frontales. Las } \\
\text { morrenas se alojan en la artesa y en el frente del antiguo } \\
\text { glaciar, y en el Hill del fondo de valle se desarrollan dolinas de } \\
\text { disolución (denominadas localmente boches). }\end{array}$} \\
\hline & Dinámica & \multicolumn{3}{|c|}{ Dinámica actual kárstica y de laderas. } \\
\hline & Cronología & \multicolumn{3}{|c|}{$\begin{array}{l}\text { Modelado glaciar Pleistoceno, elaboración de las grandes } \\
\text { formas, retoque kárstico y de laderas Holoceno y actual. }\end{array}$} \\
\hline & Interés principal & \multicolumn{3}{|c|}{$\begin{array}{l}\text { Valle, lago y morrenas, la morfología glaciar (científico, } \\
\text { pedagógico y turístico) con un importante componente } \\
\text { paisajístico. }\end{array}$} \\
\hline & $\begin{array}{l}\text { Interés } \\
\text { secundario }\end{array}$ & \multicolumn{3}{|c|}{ Modelado kárstico (boches), e hidrología (fuente y lago). } \\
\hline & $\begin{array}{l}\text { Atribución del } \\
\text { LIGm }\end{array}$ & \multicolumn{3}{|c|}{ MODELADO GLACIAR. } \\
\hline \multirow{9}{*}{ Usos } & $\begin{array}{l}\text { Contenido } \\
\text { cultural }\end{array}$ & \multicolumn{3}{|c|}{$\begin{array}{l}\text { Uso ganadero de la Vega y minero del lago y su entorno, con } \\
\text { restos numerosos de ambos usos. }\end{array}$} \\
\hline & Accesibilidad & \multicolumn{3}{|c|}{ Muy Buena. Carretera y pista desde la carretera de fácil tránsito. } \\
\hline & Grado de interés & \multicolumn{3}{|c|}{ Alto (científico-didáctico, turístico y cultural). } \\
\hline & $\begin{array}{l}\text { Estado de } \\
\text { conservación }\end{array}$ & \multicolumn{3}{|c|}{$\begin{array}{l}\text { Bueno. Agresiones mineras hoy parcialmente recuperadas, que } \\
\text { afectan a la porción del lago. }\end{array}$} \\
\hline & Usos actuales & \multicolumn{3}{|c|}{ Excursionista y turístico. } \\
\hline & Comunicaciones & \multicolumn{3}{|c|}{ Carretera de los Lagos. } \\
\hline & Infraestructuras & \multicolumn{3}{|c|}{ Mineras abandonadas, restaurante, aparcamiento y ganadería. } \\
\hline & Impactos & \multicolumn{3}{|c|}{$\begin{array}{l}\text { Minero, hoy en abandono y recuperación, y derivado de la } \\
\text { carretera y el restaurante. }\end{array}$} \\
\hline & Situación legal & \multicolumn{3}{|c|}{ Parque Nacional de Picos de Europa (PRUG y PORN) } \\
\hline
\end{tabular}




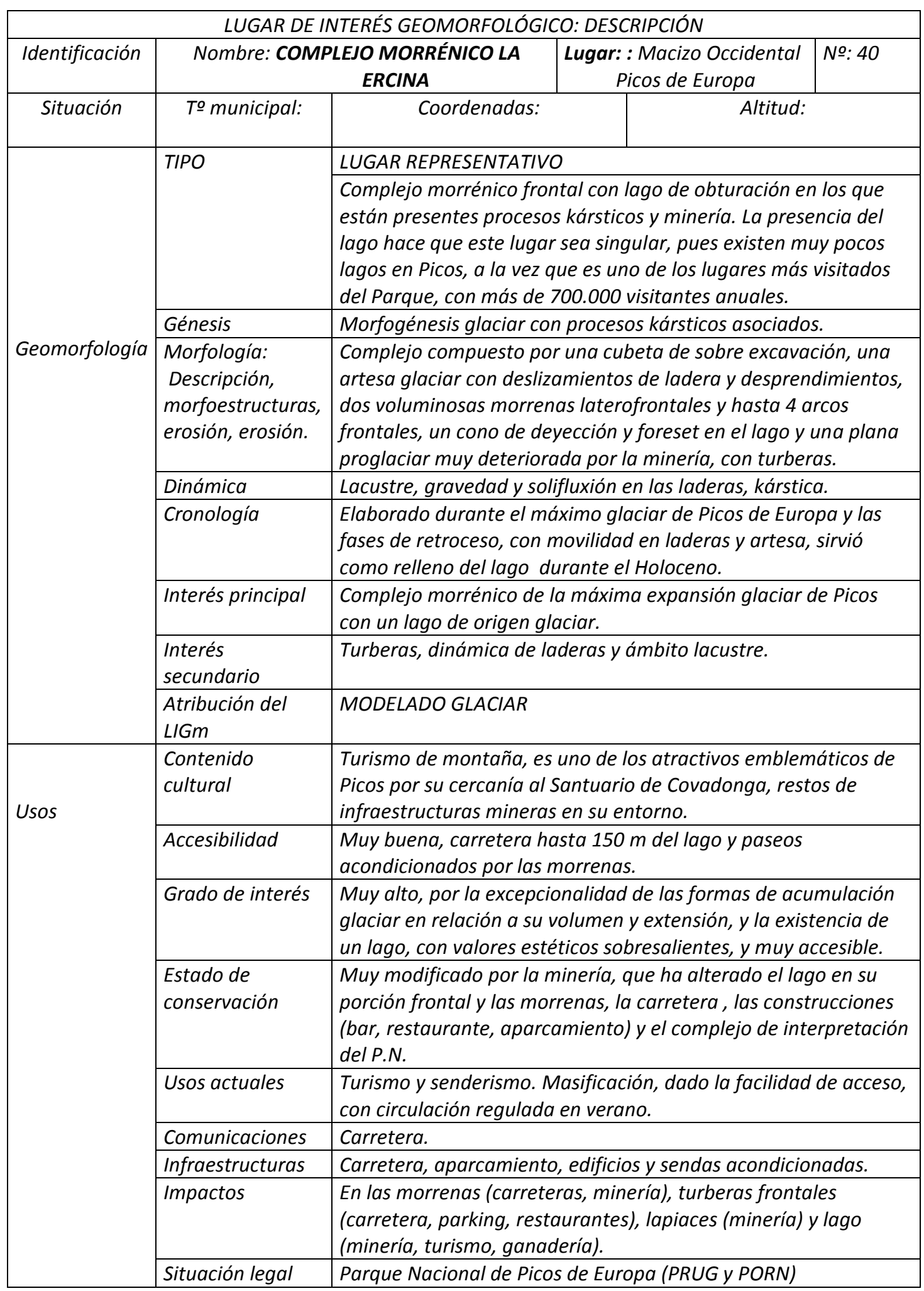




\begin{tabular}{|c|c|c|c|c|}
\hline \multicolumn{5}{|c|}{ LUGAR DE INTERÉS GEOMORFOLÓGICO: DESCRIPCIÓN } \\
\hline Identificación & \multicolumn{2}{|c|}{ Nombre: MORRENAS DE LLÓS } & $\begin{array}{r}\text { Lugar: Macizo Central } \\
\text { Picos de Europa }\end{array}$ & No: 41 \\
\hline Situación & $\begin{array}{l}\text { To municipal: } \\
\text { Valdeón (León) }\end{array}$ & Coordenadas: & Altitud: & \\
\hline \multirow{9}{*}{ Geomorfología } & TIPO & \multicolumn{3}{|c|}{ ELEMENTO REPRESENTATIVO } \\
\hline & & \multicolumn{3}{|c|}{$\begin{array}{l}\text { Conjunto glaciar en el frente cabalgante meridional formado por } \\
\text { un Circo, cubeta y complejo morrénico. }\end{array}$} \\
\hline & Génesis & \multicolumn{3}{|c|}{ Glaciar y glaciokárstica en la cubeta. } \\
\hline & $\begin{array}{l}\text { Morfología: } \\
\text { Descripción, }\end{array}$ & \multicolumn{3}{|c|}{$\begin{array}{l}\text { Circo de orientación sur, labrado por el glaciarismo Pleistoceno, } \\
\text { guiado por la fracturación local NE-SO con una cubeta glaciar y } \\
\text { un complejo morrénico laterofrontal de más de } 1 \mathrm{~km} \text { de longitud } \\
\text { donde se suceden dos arcos morrénicos. }\end{array}$} \\
\hline & Dinámica & \multicolumn{3}{|c|}{ Dinámica actual kárstica, nival (aludes) y de ladera } \\
\hline & Cronología & \multicolumn{3}{|c|}{$\begin{array}{l}\text { Circo y morrenas del Pleistoceno, formado durante el último } \\
\text { máximo glaciar, con retoques Holocenos y actuales. }\end{array}$} \\
\hline & Interés principal & \multicolumn{3}{|c|}{ Científico y didáctico, morfología glaciar. Pleistoceno. } \\
\hline & $\begin{array}{l}\text { Interés } \\
\text { secundario }\end{array}$ & \multicolumn{3}{|c|}{$\begin{array}{l}\text { Formas de modelado complementario, canales de aludes, } \\
\text { derrubios de ladera, canal. }\end{array}$} \\
\hline & $\begin{array}{l}\text { Atribución del } \\
\text { LIGm }\end{array}$ & \multicolumn{3}{|c|}{ MODELADO GLACIAR. } \\
\hline \multirow{9}{*}{ Usos } & $\begin{array}{l}\text { Contenido } \\
\text { cultural }\end{array}$ & \multicolumn{3}{|c|}{ Cabañas ganaderas. } \\
\hline & Accesibilidad & \multicolumn{3}{|c|}{ Mala. } \\
\hline & Grado de interés & \multicolumn{3}{|c|}{ Medio, de carácter pedagógico y científico. } \\
\hline & $\begin{array}{l}\text { Estado de } \\
\text { conservación }\end{array}$ & \multicolumn{3}{|c|}{$\begin{array}{l}\text { Alto. Los elementos singulares están bien conservados, no han } \\
\text { sufrido impactos antrópicos dada su mala accesibilidad y escaso } \\
\text { uso. }\end{array}$} \\
\hline & Usos actuales & \multicolumn{3}{|c|}{$\begin{array}{l}\text { Ganadero (pastos de altura) y montañero-excursionista de } \\
\text { moderada frecuencia. }\end{array}$} \\
\hline & Comunicaciones & \multicolumn{3}{|c|}{ Pista ganadera y sendas montañeras. } \\
\hline & Infraestructuras & \multicolumn{3}{|c|}{ Cabañas ganaderas y pistas. } \\
\hline & Impactos & \multicolumn{3}{|c|}{ Derivadas del uso ganadero y la pista. } \\
\hline & Situación legal & \multicolumn{3}{|c|}{$\begin{array}{l}\text { Parque Nacional de Picos de Europa (PRUG y PORN) y Parque } \\
\text { Regional de los Picos de Europa (Junta de Castilla León). }\end{array}$} \\
\hline
\end{tabular}




\begin{tabular}{|c|c|c|c|c|}
\hline \multicolumn{5}{|c|}{ LUGAR DE INTERÉS GEOMORFOLÓGICO: DESCRIPCIÓN } \\
\hline \multirow{2}{*}{$\begin{array}{l}\text { Identificación } \\
\text { Situación }\end{array}$} & \multicolumn{2}{|c|}{ Nombre: HELERO DE LA FORCADONA } & \multirow{2}{*}{$\begin{array}{l}\begin{array}{c}\text { Lugar: Macizo Occidental } \\
\text { Picos de Europa }\end{array} \\
\text { Altitud: }\end{array}$} & \multirow[t]{2}{*}{ №: 43} \\
\hline & To municipal: & Coordenadas: & & \\
\hline \multirow{9}{*}{ Geomorfología } & \multirow[t]{2}{*}{ TIPO } & \multicolumn{3}{|c|}{ ELEMENTO SINGULAR } \\
\hline & & \multicolumn{3}{|c|}{$\begin{array}{l}\text { Complejo glaciar que incluye el helero cubierto y restos } \\
\text { morfológicos glaciares (morrena y circo) de la última pulsación } \\
\text { fría acaecida en época histórica, la Pequeña Edad del Hielo (PEH). }\end{array}$} \\
\hline & Génesis & \multicolumn{3}{|c|}{$\begin{array}{l}\text { Depresión glacio-kárstica, guiada por la fracturación local y los } \\
\text { procesos glaciares y kársticos, donde se conserva helero, resto de } \\
\text { hielo glaciar de la P.E.H. El helero está en desequilibrio natural } \\
\text { con las condiciones climáticas actuales, en franca regresión y } \\
\text { posible desaparición en la próxima década. }\end{array}$} \\
\hline & $\begin{array}{l}\text { Morfología: } \\
\text { Descripción, }\end{array}$ & \multicolumn{3}{|c|}{$\begin{array}{l}\text { Circo glaciar encajado y depresión glaciokárstica con morrenas } \\
\text { frontales y el helero en su interior, recubierto de clastos } \\
\text { procedentes de las paredes. }\end{array}$} \\
\hline & Dinámica & \multicolumn{3}{|c|}{ Dinámica actual periglaciar, nival, kárstica } \\
\hline & Cronología & \multicolumn{3}{|c|}{$\begin{array}{l}\text { Circo formado por el glaciarismo Pleistoceno, pero los elementos } \\
\text { singulares contenidos en él, helero y morrena son de la PEH (S. } \\
X I V-X I X) \text {. }\end{array}$} \\
\hline & Interés principal & \multicolumn{3}{|c|}{$\begin{array}{l}\text { Hielo relicto de la Pequeña Edad el Hielo (interés científico) y } \\
\text { morrenas de la misma edad. }\end{array}$} \\
\hline & $\begin{array}{l}\text { Interés } \\
\text { secundario }\end{array}$ & \multicolumn{3}{|c|}{$\begin{array}{l}\text { Conjunto morfológico glaciar Pleistoceno y reciente, con procesos } \\
\text { periglaciares y de recubrimiento. }\end{array}$} \\
\hline & $\begin{array}{l}\text { Atribución del } \\
\text { LIGm }\end{array}$ & \multicolumn{3}{|c|}{ Modelado glaciar. } \\
\hline \multirow{9}{*}{ Usos } & $\begin{array}{l}\text { Contenido } \\
\text { cultural }\end{array}$ & \multicolumn{3}{|l|}{--} \\
\hline & Accesibilidad & \multicolumn{3}{|l|}{ Muy mala. } \\
\hline & Grado de interés & \multicolumn{3}{|c|}{$\begin{array}{l}\text { Muy alto (científico-didáctico), por ser una huella de condiciones } \\
\text { climáticas del pasado conservada a favor de las condiciones } \\
\text { topoclimáticas actuales. }\end{array}$} \\
\hline & $\begin{array}{l}\text { Estado de } \\
\text { conservación }\end{array}$ & \multicolumn{3}{|c|}{ Alto. } \\
\hline & Usos actuales & \multicolumn{3}{|l|}{ Montañero (escaso). } \\
\hline & Comunicaciones & \multicolumn{3}{|c|}{ Sendas montañeras muy poco marcadas. } \\
\hline & Infraestructuras & \multicolumn{3}{|c|}{--} \\
\hline & Impactos & \multicolumn{3}{|c|}{$\begin{array}{l}\text { No hay impactos antrópicos dada su mala accesibilidad y escaso } \\
\text { tránsito. }\end{array}$} \\
\hline & Situación legal & \multicolumn{3}{|c|}{ Parque Nacional de Picos de Europa (PRUG y PORN). } \\
\hline
\end{tabular}




\begin{tabular}{|c|c|c|c|c|}
\hline \multicolumn{5}{|c|}{ LUGAR DE INTERÉS GEOMORFOLÓGICO: DESCRIPCIÓN } \\
\hline \multirow{2}{*}{$\begin{array}{l}\text { Identificación } \\
\text { Situación }\end{array}$} & \multicolumn{2}{|c|}{ Nombre: CEMBA VIEYA } & $\begin{array}{l}\text { Lugar: Macizo Occidental } \\
\text { Picos de Europa }\end{array}$ & No: 44 \\
\hline & To municipal: & Coordenadas: & Altitud: & \\
\hline \multirow{9}{*}{ Geomorfología } & \multirow[t]{2}{*}{ TIPO } & \multicolumn{3}{|c|}{ LUGAR SINGULAR } \\
\hline & & \multicolumn{3}{|c|}{$\begin{array}{l}\text { Circo glaciar con morrenas recientes y presencia de un nevero que } \\
\text { se mantiene casi todos los años, tras la desaparición del helero a } \\
\text { principio del s. XXI. }\end{array}$} \\
\hline & Génesis & \multicolumn{3}{|c|}{$\begin{array}{l}\text { Glaciar, guiado por la fracturación local y las morfoestructuras, la } \\
\text { erosión glaciar ha generado el circo y la última fase fría }(P E H) \text { ha } \\
\text { depositado pequeñas morrenas frontales. }\end{array}$} \\
\hline & $\begin{array}{l}\text { Morfología: } \\
\text { Descripción, }\end{array}$ & \multicolumn{3}{|c|}{$\begin{array}{l}\text { Conjunto de circo, depresión y morrenas, estas últimas heredadas } \\
\text { del glaciarismo histórico (PEH). Junto a ello formas periglaciares, } \\
\text { de ladera y kársticas retocan el modelado glaciar. Los procesos } \\
\text { nivales son importantes, así como el nevero que da nombre al } \\
\text { circo. }\end{array}$} \\
\hline & Dinámica & \multicolumn{3}{|c|}{ Dinámica actual nival, periglaciar y kárstica } \\
\hline & Cronología & \multicolumn{3}{|c|}{$\begin{array}{l}\text { Circo formado por el glaciarismo Pleistoceno, pero las morrenas } \\
\text { pertenecen a la PEH (S. XIV-XIX) y el nevero es un elemento } \\
\text { actual. }\end{array}$} \\
\hline & Interés principal & \multicolumn{3}{|c|}{ Nevero semipermanente y restos de la Pequeña Edad el Hielo. } \\
\hline & $\begin{array}{l}\text { Interés } \\
\text { secundario }\end{array}$ & \multicolumn{3}{|c|}{$\begin{array}{l}\text { Conjunto morfológico glaciar Pleistoceno: circo, cubeta, umbral, } \\
\text { con notable contenido paisajístico. }\end{array}$} \\
\hline & $\begin{array}{l}\text { Atribución del } \\
\text { LIGm }\end{array}$ & \multicolumn{3}{|c|}{ MODELADO GLACIAR. } \\
\hline \multirow{9}{*}{ Usos } & $\begin{array}{l}\text { Contenido } \\
\text { cultural }\end{array}$ & \multicolumn{3}{|c|}{$\begin{array}{l}\text { Topónimo relativo a sus contenidos geomorfológicos. Posibles } \\
\text { usos en el pasado. }\end{array}$} \\
\hline & Accesibilidad & \multicolumn{3}{|c|}{ Mala. } \\
\hline & Grado de interés & \multicolumn{3}{|c|}{$\begin{array}{l}\text { Muy alto (científico-didáctico), por la permanencia del nevero y } \\
\text { las condiciones topoclimáticas singulares que han propiciado la } \\
\text { reciente desaparición de un helero y la presencia del nevero. }\end{array}$} \\
\hline & $\begin{array}{l}\text { Estado de } \\
\text { conservación }\end{array}$ & \multicolumn{3}{|l|}{ Alto. } \\
\hline & Usos actuales & \multicolumn{3}{|c|}{ Montañero (escaso). } \\
\hline & Comunicaciones & \multicolumn{3}{|c|}{ Sendas montañeras muy poco marcadas. } \\
\hline & Infraestructuras & \multicolumn{3}{|l|}{--} \\
\hline & Impactos & \multicolumn{3}{|c|}{$\begin{array}{l}\text { No hay impactos antrópicos dada su mala accesibilidad y escaso } \\
\text { tránsito. }\end{array}$} \\
\hline & Situación legal & \multicolumn{3}{|c|}{ Parque Nacional de Picos de Europa (PRUG y PORN). } \\
\hline
\end{tabular}




\begin{tabular}{|c|c|c|c|c|}
\hline \multicolumn{5}{|c|}{ LUGAR DE INTERÉS GEOMORFOLÓGICO: DESCRIPCIÓN } \\
\hline \multirow{2}{*}{$\begin{array}{l}\text { Identificación } \\
\text { Situación }\end{array}$} & \multicolumn{2}{|c|}{ Nombre: DEPRESIÓN DE BELBÍN-LA LLOMBA } & $\begin{array}{l}\text { Lugar Macizo Occidental } \\
\text { Picos de Europa }\end{array}$ & \multirow[t]{2}{*}{ №: 45} \\
\hline & To municipal: & Coordenadas: & Altitud: & \\
\hline \multirow{9}{*}{ Geomorfología } & TIPO & \multicolumn{3}{|c|}{ LUGAR REPRESENTATIVO } \\
\hline & & \multicolumn{3}{|c|}{$\begin{array}{l}\text { Depresión kárstica (polje) y morrena que la cierra por el este, } \\
\text { combinando ambientes glaciados kárstico no glaciados, con } \\
\text { elevado valor paisajístico. }\end{array}$} \\
\hline & Génesis & \multicolumn{3}{|c|}{$\begin{array}{l}\text { Depresión kárstica a favor de una línea de cabalgamiento entre } \\
\text { la Fm Calizas de montaña y la Fm Picos de Europa, obstruida por } \\
\text { la morrena lateral del antiguo glaciar de Casaño. }\end{array}$} \\
\hline & $\begin{array}{l}\text { Morfología: } \\
\text { Descripción, } \\
\text { morfoestructuras, } \\
\text { erosión. }\end{array}$ & \multicolumn{3}{|c|}{$\begin{array}{l}\text { Depresión cerrada con fondo plano relleno de arcillas de } \\
\text { descalcificación, por lo que circula un arroyo que se pierde en el } \\
\text { sumidero (ponor) de Belbín. La porción oriental está formada } \\
\text { por la morrena lateral bien conservada en alto de la artesa de } \\
\text { Casaño (Los Regerones), donde se desdobla en dos arcos. }\end{array}$} \\
\hline & Dinámica & \multicolumn{3}{|c|}{ Procesos kársticos. } \\
\hline & Cronología & \multicolumn{3}{|c|}{$\begin{array}{l}\text { Emplazamiento morfoestructural Finiterciario, modelado } \\
\text { kárstico Finiterciario y Pleistoceno con actividad actual y } \\
\text { modelado glaciar Pleistoceno superior. }\end{array}$} \\
\hline & Interés principal & \multicolumn{3}{|c|}{$\begin{array}{l}\text { Morfología kárstica (amplitud y variedad de formas) y glaciar. } \\
\text { Componente paisajístico de interés. }\end{array}$} \\
\hline & $\begin{array}{l}\text { Interés } \\
\text { secundario }\end{array}$ & \multicolumn{3}{|c|}{ Estructural. } \\
\hline & $\begin{array}{l}\text { Atribución del } \\
\text { LIGm }\end{array}$ & \multicolumn{3}{|l|}{ Modelado kárstico y glaciar. } \\
\hline \multirow{9}{*}{ Usos } & $\begin{array}{l}\text { Contenido } \\
\text { cultural }\end{array}$ & \multicolumn{3}{|c|}{ Invernales de Belbín, uso tradicional, producción quesera. } \\
\hline & Accesibilidad & \multicolumn{3}{|c|}{ Media, pista hasta Belbin y sendas. } \\
\hline & Grado de interés & \multicolumn{3}{|c|}{$\begin{array}{l}\text { Alto (científico y didáctico). Centrado en el polje y su } \\
\text { funcionamiento actual, la morrena como herencia del pasado y } \\
\text { el paisaje. }\end{array}$} \\
\hline & $\begin{array}{l}\text { Estado de } \\
\text { conservación }\end{array}$ & \multicolumn{3}{|l|}{ Bueno. } \\
\hline & Usos actuales & \multicolumn{3}{|l|}{ Ganadero y excursionista. } \\
\hline & Comunicaciones & \multicolumn{3}{|l|}{ Pista ganadera. } \\
\hline & Infraestructuras & \multicolumn{3}{|c|}{ Pista ganadera. } \\
\hline & Impactos & \multicolumn{3}{|c|}{ Derivados de la ganadería y la conservación de la pista. } \\
\hline & Situación legal & \multicolumn{3}{|c|}{ Parque Nacional de Picos de Europa (PRUG y PORN) } \\
\hline
\end{tabular}




\begin{tabular}{|c|c|c|c|c|}
\hline \multicolumn{5}{|c|}{ LUGAR DE INTERÉS GEOMORFOLÓGICO: DESCRIPCIÓN } \\
\hline Identificación & \multicolumn{2}{|c|}{ Nombre: POLJÉ DE COMEYA } & $\begin{array}{c}\text { Lugar: Macizo Occidental } \\
\text { Picos de Europa }\end{array}$ & No: 46 \\
\hline Situación & To municipal: & Coordenadas: & Altituo & \\
\hline \multirow{9}{*}{ Geomorfología } & \multirow[t]{2}{*}{ TIPO } & \multicolumn{3}{|c|}{ LUGAR REPRESENTATIVO } \\
\hline & & \multicolumn{3}{|c|}{$\begin{array}{l}\text { Polje intramontañoso, entre dos escamas cabalgantes, que por su } \\
\text { tamaño es una forma excepcional en el modelado de los Picos de } \\
\text { Europa. }\end{array}$} \\
\hline & Génesis & \multicolumn{3}{|c|}{$\begin{array}{l}\text { Polje estructural, depresión tectónica ampliada por la actividad } \\
\text { kárstica a favor de la disolución de las calizas de montaña en } \\
\text { contacto con las pizarras de la formación Lebeña. }\end{array}$} \\
\hline & $\begin{array}{l}\text { Morfología: } \\
\text { Descripción, }\end{array}$ & \multicolumn{3}{|c|}{$\begin{array}{l}\text { Depresión de 0,8 } \mathrm{km}^{2} \text { con fondo plano recubierto de sedimentos } \\
\text { que reposan sobre las pizarras, por la que circula un río que } \\
\text { desagua en un ponor, en porción NW. El fondo está constituido } \\
\text { por arcillas, lacustres y descalcificación, derrubios de ladera y un } \\
\text { cono de deyección, con turberas en la porción distal de la } \\
\text { depresión. En los contactos fallados se generan las fuentes y el } \\
\text { sumidero. }\end{array}$} \\
\hline & Dinámica & \multicolumn{3}{|c|}{$\begin{array}{l}\text { Kárstica con intromisiones de derrubios de laderas y un cono } \\
\text { aluvial. Desarrollo de turberas. }\end{array}$} \\
\hline & Cronología & \multicolumn{3}{|c|}{$\begin{array}{l}\text { Polje estructural funcional desde su emplazamiento, } \\
\text { funcionamiento lacustre durante el FiniPleistoceno y Holoceno } \\
\text { temprano. }\end{array}$} \\
\hline & Interés principal & \multicolumn{3}{|c|}{ Formas y procesos kársticos. } \\
\hline & $\begin{array}{l}\text { Interés } \\
\text { secundario }\end{array}$ & \multicolumn{3}{|c|}{ Valor paisajístico y ecológico, así como minero. } \\
\hline & $\begin{array}{l}\text { Atribución del } \\
\text { LIGm }\end{array}$ & \multicolumn{3}{|c|}{ MODELADO KÁRSTICO Y ESTRUCTURAL. } \\
\hline \multirow{9}{*}{ Usos } & $\begin{array}{l}\text { Contenido } \\
\text { cultural }\end{array}$ & \multicolumn{3}{|c|}{ Explotaciones mineras, valor arqueológico industrial. } \\
\hline & Accesibilidad & \multicolumn{3}{|c|}{$\begin{array}{l}\text { Media, senda desde el centro de recepción por antiguos caminos } \\
\text { mineros }\end{array}$} \\
\hline & Grado de interés & \multicolumn{3}{|c|}{$\begin{array}{l}\text { Alto, por la excepcionalidad del elemento y la combinación con } \\
\text { aspectos paisajísticos y mineros. }\end{array}$} \\
\hline & $\begin{array}{l}\text { Estado de } \\
\text { conservación }\end{array}$ & \multicolumn{3}{|c|}{ Medio. Muy alterado por la minería. } \\
\hline & Usos actuales & \multicolumn{3}{|c|}{ Excursionista, baja frecuentación. } \\
\hline & Comunicaciones & \multicolumn{3}{|c|}{ Pista y senda de montaña. } \\
\hline & Infraestructuras & \multicolumn{3}{|c|}{ Pista minera, instalaciones mineras. } \\
\hline & Impactos & \multicolumn{3}{|c|}{$\begin{array}{l}\text { Mineros, intensos en el pasado (transformación total del polje, } \\
\text { hoy parcialmente recuperados. }\end{array}$} \\
\hline & Situación legal & \multicolumn{3}{|c|}{ Parque Nacional de Picos de Europa (PRUG y PORN). } \\
\hline
\end{tabular}




\begin{tabular}{|c|c|c|c|c|c|}
\hline \multicolumn{6}{|c|}{ LUGAR DE INTERÉS GEOMORFOLÓGICO: DESCRIPCIÓN } \\
\hline Identificación & \multicolumn{2}{|c|}{$\begin{array}{c}\text { Nombre: SISTEMA DEL XITU- } \\
\text { CULIEMBRO }\end{array}$} & \multicolumn{2}{|c|}{$\begin{array}{l}\text { Lugar: Macizo Occidental } \\
\text { Picos de Europa }\end{array}$} & No: 47 \\
\hline Situación & To municipal: & \multicolumn{2}{|l|}{ Coordenadas: } & \multicolumn{2}{|l|}{ Altitud: } \\
\hline \multirow{9}{*}{ Geomorfología } & \multirow[t]{2}{*}{ TIPO } & \multicolumn{4}{|c|}{ ELEMENTO REPRESENTATIVO } \\
\hline & & \multicolumn{4}{|c|}{ Sima kárstica de gran profundidad (1232 m). } \\
\hline & Génesis & \multicolumn{4}{|c|}{ Endokarst. } \\
\hline & Morfología: & \multicolumn{4}{|c|}{$\begin{array}{l}\text { Sucesión de galerías y pozos escalonados que sigue las directrices } \\
\text { estructurales a favor de las calizas de montaña y conecta con el } \\
\text { sistema de galerías horizontales de las Fuentes de Culimebro, } \\
\text { donde se suceden } 6 \text { sifones. }\end{array}$} \\
\hline & Dinámica & \multicolumn{4}{|c|}{ Kárstica. } \\
\hline & Cronología & \multicolumn{4}{|c|}{ Finiterciaria a actual. } \\
\hline & Interés principal & \multicolumn{4}{|c|}{$\begin{array}{l}\text { Kárstico, sima más profunda del macizo del Cornión, que conecta } \\
\text { con las fuentes en un recorrido de } 15 \mathrm{kms} \text { y } 1232 \mathrm{~m} \text {. de } \\
\text { profundidad, enlazada en } 2010 \text {. Es la principal surgencia del } \\
\text { macizo, con un caudal de } 100-700 \mathrm{l} / \mathrm{s} \text {. }\end{array}$} \\
\hline & $\begin{array}{l}\text { Interés } \\
\text { secundario }\end{array}$ & \multicolumn{4}{|c|}{$\begin{array}{l}\text { Endemismos biológicos. Exploraciones espeleológicas } \\
\text { internacionales. }\end{array}$} \\
\hline & $\begin{array}{l}\text { Atribución del } \\
\text { LIGm }\end{array}$ & \multicolumn{4}{|c|}{ Modelado endokárstico. } \\
\hline \multirow[t]{9}{*}{ Usos } & $\begin{array}{l}\text { Contenido } \\
\text { cultural }\end{array}$ & \multicolumn{4}{|c|}{$\begin{array}{l}\text { Deportivo-espeleológico. Descubrimiento, exploración y conexión } \\
\text { con las fuentes (2010), historia reciente de la espeleología en } \\
\text { España. }\end{array}$} \\
\hline & Accesibilidad & \multicolumn{4}{|c|}{ Muy mala, son necesarias técnicas espeleológicas. } \\
\hline & Grado de interés & \multicolumn{4}{|c|}{$\begin{array}{l}\text { Alto: por la singularidad de la sima y la representatividad del } \\
\text { modelado kárstico. }\end{array}$} \\
\hline & $\begin{array}{l}\text { Estado de } \\
\text { conservación }\end{array}$ & \multicolumn{4}{|l|}{ Alto. } \\
\hline & Usos actuales & \multicolumn{4}{|c|}{ Deportivo, baja frecuentación. } \\
\hline & Comunicaciones & \multicolumn{4}{|c|}{ No existen } \\
\hline & Infraestructuras & \multicolumn{4}{|l|}{ No existen } \\
\hline & Impactos & \multicolumn{4}{|l|}{ No existen } \\
\hline & Situación legal & \multicolumn{4}{|c|}{ Parque Nacional de Picos de Europa (PRUG y PORN). } \\
\hline
\end{tabular}




\begin{tabular}{|c|c|c|c|c|}
\hline \multicolumn{5}{|c|}{ LUGAR DE INTERÉS GEOMORFOLÓGICO: DESCRIPCIÓN } \\
\hline Identificación & \multicolumn{2}{|c|}{$\begin{array}{c}\text { Nombre: SISTEMA ENDOKÁRSTICO } \\
\text { JULTAYU-XITU }\end{array}$} & $\begin{array}{c}\text { Lugar: Macizo Occidental } \\
\text { Picos de Europa }\end{array}$ & No: 48 \\
\hline Situación & To municipal: & Coordenadas: & Altitud: & \\
\hline \multirow{9}{*}{ Geomorfología } & TIPO & \multicolumn{3}{|c|}{ ELEMENTO REPRESENTATIVO } \\
\hline & & \multicolumn{3}{|c|}{$\begin{array}{l}\text { Complejo endokárstico de gran desarrollo horizontal (12,6 kms) } \\
\text { que enlaza con las simas del situ. }\end{array}$} \\
\hline & Génesis & \multicolumn{3}{|c|}{$\begin{array}{l}\text { Disolución kárstica en las calizas de montaña y niveles freáticos } \\
\text { en el pasado. }\end{array}$} \\
\hline & Morfología: & \multicolumn{3}{|c|}{$\begin{array}{l}\text { Sistema kárstico complejo, con dominancia de galerías } \\
\text { condicionadas por la presencia de freáticos, hoy colgados, con } \\
\text { galerías activas y fósiles con } 12,6 \text { kms de desarrollo. }\end{array}$} \\
\hline & Dinámica & \multicolumn{3}{|c|}{ Kárstica. } \\
\hline & Cronología & \multicolumn{3}{|l|}{ Finiterciaria a actual. } \\
\hline & Interés principal & \multicolumn{3}{|c|}{$\begin{array}{l}\text { Kárstico, es el sistema de mayor desarrollo horizontal del macizo. } \\
\text { Hidrogeológico. }\end{array}$} \\
\hline & $\begin{array}{l}\text { Interés } \\
\text { secundario }\end{array}$ & \multicolumn{3}{|c|}{$\begin{array}{l}\text { Endemismos biológicos. Exploraciones espeleológicas } \\
\text { internacionales. }\end{array}$} \\
\hline & $\begin{array}{l}\text { Atribución del } \\
\text { LIGm }\end{array}$ & \multicolumn{3}{|c|}{ Modelado endokárstico. } \\
\hline \multirow{9}{*}{ Usos } & $\begin{array}{l}\text { Contenido } \\
\text { cultural }\end{array}$ & \multicolumn{3}{|c|}{ Deportivo-espeleológico. } \\
\hline & Accesibilidad & \multicolumn{3}{|c|}{ Mala, son necesarias técnicas espeleológicas. } \\
\hline & Grado de interés & \multicolumn{3}{|c|}{ Alto, por la singularidad y representatividad del complejo. } \\
\hline & $\begin{array}{l}\text { Estado de } \\
\text { conservación }\end{array}$ & \multicolumn{3}{|l|}{ Alto. } \\
\hline & Usos actuales & \multicolumn{3}{|c|}{ Deportivo espeleológico de muy baja frecuencia. } \\
\hline & Comunicaciones & \multicolumn{3}{|c|}{ No existen } \\
\hline & Infraestructuras & \multicolumn{3}{|l|}{ No existen } \\
\hline & Impactos & \multicolumn{3}{|c|}{ No existen } \\
\hline & Situación legal & \multicolumn{3}{|c|}{ Parque Nacional de Picos de Europa (PRUG y PORN). } \\
\hline
\end{tabular}




\begin{tabular}{|c|c|c|c|c|}
\hline \multicolumn{5}{|c|}{ LUGAR DE INTERÉS GEOMORFOLÓGICO: DESCRIPCIÓN } \\
\hline Identificación & \multicolumn{2}{|c|}{$\begin{array}{c}\text { Nombre: DESPRENDIMIENTO DE LA } \\
\text { VEGUINA-LLUCIA }\end{array}$} & $\begin{array}{l}\text { Lugar: Macizo Occidental } \\
\text { Picos de Europa }\end{array}$ & \multirow[t]{2}{*}{ No: 49} \\
\hline Situación & To municipal: & Coordenadas: & Altitud: & \\
\hline \multirow{9}{*}{ Geomorfología } & TIPO & \multicolumn{3}{|c|}{ ELEMENTO REPRESENTATIVO } \\
\hline & & \multicolumn{3}{|c|}{ Deslizamiento de ladera activo } \\
\hline & Génesis & \multicolumn{3}{|c|}{$\begin{array}{l}\text { Deslizamiento traslacional generado por la relajación postglaciar } \\
\text { tras la retirada del hielo, en las calizas de la Fm Picos de Europa. }\end{array}$} \\
\hline & $\begin{array}{l}\text { Morfología: } \\
\text { Descripción }\end{array}$ & \multicolumn{3}{|c|}{$\begin{array}{l}\text { Nicho de cabecera en la ladera NW del pico Llucia, y cuerpo } \\
\text { alargado formado por grandes bloques, con flujo y reajustes } \\
\text { actuales, que termina en una lengua de fuerte pendiente con } \\
\text { grandes bloques de caliza muy inestables, que termina junto a la } \\
\text { porción meridional del lago de la Ercina. }\end{array}$} \\
\hline & Dinámica & \multicolumn{3}{|c|}{$\begin{array}{l}\text { Deslizamiento parcialmente activo con desprendimientos desde el } \\
\text { frente. }\end{array}$} \\
\hline & Cronología & \multicolumn{3}{|c|}{$\begin{array}{l}\text { Deslizamiento postglaciar, posiblemente Holoceno, activo en la } \\
\text { actualidad. }\end{array}$} \\
\hline & Interés principal & \multicolumn{3}{|c|}{ Dinámica de laderas, procesos actuales. } \\
\hline & $\begin{array}{l}\text { Interés } \\
\text { secundario }\end{array}$ & \multicolumn{3}{|c|}{ Riesgos naturales. } \\
\hline & $\begin{array}{l}\text { Atribución del } \\
\text { LIGm }\end{array}$ & \multicolumn{3}{|c|}{ Modelado y dinámica de laderas. } \\
\hline \multirow{9}{*}{ Usos } & $\begin{array}{l}\text { Contenido } \\
\text { cultural }\end{array}$ & \multicolumn{3}{|c|}{ Cabañas ganaderas (La Veguina). } \\
\hline & Accesibilidad & \multicolumn{3}{|c|}{ Buena. Senda al borde del lago de la Ercina. } \\
\hline & Grado de interés & \multicolumn{3}{|c|}{ Alto (científico, didáctico). } \\
\hline & $\begin{array}{l}\text { Estado de } \\
\text { conservación }\end{array}$ & \multicolumn{3}{|l|}{ Bueno } \\
\hline & Usos actuales & \multicolumn{3}{|c|}{ Ganadero y excursionista. } \\
\hline & Comunicaciones & \multicolumn{3}{|c|}{ Carretera hasta el lago y senda de montaña (10 min.) } \\
\hline & Infraestructuras & \multicolumn{3}{|c|}{-} \\
\hline & Impactos & \multicolumn{3}{|c|}{-} \\
\hline & Situación legal & \multicolumn{3}{|c|}{ Parque Nacional de Picos de Europa (PRUG y PORN). } \\
\hline
\end{tabular}




\begin{tabular}{|c|c|c|c|c|}
\hline \multicolumn{5}{|c|}{ LUGAR DE INTERÉS GEOMORFOLÓGICO: DESCRIPCIÓN } \\
\hline \multirow{2}{*}{$\begin{array}{l}\text { Identificación } \\
\text { Situación }\end{array}$} & \multicolumn{2}{|c|}{ Nombre: GUEYOS DE JUNJUMIA } & \multirow{2}{*}{$\begin{array}{l}\text { Lugar: Macizo Occidental } \\
\text { Picos de Europa } \\
\text { Altitud: } \\
1390 \mathrm{~m} .\end{array}$} & \multirow[t]{2}{*}{ №: 50} \\
\hline & To Municipal: & $\begin{array}{l}\text { Coordenadas: } \\
43^{\circ} 14^{\prime} 10^{\prime \prime} \\
4059^{\prime} 42^{\prime \prime}\end{array}$ & & \\
\hline \multirow{9}{*}{ Geomorfología } & TIPO & \multicolumn{3}{|c|}{ ELEMENTO SINGULAR } \\
\hline & & \multicolumn{3}{|c|}{ Fuente que drena la porción NW del macizo. } \\
\hline & Génesis & \multicolumn{3}{|c|}{$\begin{array}{l}\text { Surgencia kárstica a favor de contactos tectónicos en la que } \\
\text { afloran las aguas colectadas en la porción noroccidental del } \\
\text { macizo, drenando hacia el Dobra y Sella. }\end{array}$} \\
\hline & Morfología: & \multicolumn{3}{|c|}{$\begin{array}{l}\text { Fuentes dispersas en la ladera, con surgencias variables en } \\
\text { función de la dinámica del freático, que dan lugar al nacimiento } \\
\text { del río Junjumia. }\end{array}$} \\
\hline & Dinámica & \multicolumn{3}{|c|}{ Kárstica. } \\
\hline & Cronología & \multicolumn{3}{|l|}{ Actual } \\
\hline & Interés principal & \multicolumn{3}{|c|}{ Kárstico e hidrológico. } \\
\hline & $\begin{array}{l}\text { Interés } \\
\text { secundario }\end{array}$ & \multicolumn{3}{|l|}{ Ecológico. } \\
\hline & $\begin{array}{l}\text { Atribución del } \\
\text { LIGm }\end{array}$ & \multicolumn{3}{|c|}{ Hidrológico, fuentes. } \\
\hline \multirow{9}{*}{ Usos } & $\begin{array}{l}\text { Contenido } \\
\text { cultural }\end{array}$ & \multicolumn{3}{|c|}{ Uso tradicional, refugio de montaña cercano. } \\
\hline & Accesibilidad & \multicolumn{3}{|c|}{$\begin{array}{l}\text { Media, senda de montaña. Proximidad de refugio de montaña } \\
\text { (Vegarredonda) }\end{array}$} \\
\hline & Grado de interés & \multicolumn{3}{|c|}{$\begin{array}{l}\text { Alto, dada la singularidad de las fuentes en Picos y su } \\
\text { importancia. }\end{array}$} \\
\hline & $\begin{array}{l}\text { Estado de } \\
\text { conservación }\end{array}$ & \multicolumn{3}{|c|}{ Alto } \\
\hline & Usos actuales & \multicolumn{3}{|c|}{ Deportivo, excursionista, ganadero. } \\
\hline & Comunicaciones & \multicolumn{3}{|l|}{ No existen } \\
\hline & Infraestructuras & \multicolumn{3}{|l|}{ No existen } \\
\hline & Impactos & \multicolumn{3}{|c|}{ No existen } \\
\hline & Situación legal & \multicolumn{3}{|c|}{ Parque Nacional de Picos de Europa (PRUG y PORN). } \\
\hline
\end{tabular}




\begin{tabular}{|c|c|c|c|c|}
\hline \multicolumn{5}{|c|}{ LUGAR DE INTERÉS GEOMORFOLÓGICO: DESCRIPCIÓN } \\
\hline \multirow{2}{*}{$\begin{array}{c}\text { Identificación } \\
\text { Situación }\end{array}$} & \multicolumn{2}{|c|}{ Nombre: FUENTE DE LA FARFADA } & \multirow{2}{*}{\begin{tabular}{|} 
Lugar: Macizo Occidental \\
Picos de Europa \\
Altitud: \\
$850 \mathrm{~m}$
\end{tabular}} & \multirow[t]{2}{*}{ No: 51} \\
\hline & To Municipal: & $\begin{array}{c}\text { Coordenadas: } \\
43^{\prime}=11^{\prime} 15^{\prime \prime} \\
\text { 40 55' } 20^{\prime \prime}\end{array}$ & & \\
\hline \multirow{9}{*}{ Geomorfología } & TIPO & \multicolumn{3}{|l|}{ Elemento singular } \\
\hline & & \multicolumn{3}{|c|}{ Surgencia kárstica. } \\
\hline & Génesis & \multicolumn{3}{|c|}{$\begin{array}{l}\text { Surgencia kárstica en el contacto entre las calizas (Fm. Calizas de } \\
\text { Montaña), altamente karstificadas y permeables, y las pizarras } \\
\text { (Gr. Valdeón) infrayacentes, aflorando las aguas colectadas en la } \\
\text { porción sureste del macizo para drenar hacia el Cares. }\end{array}$} \\
\hline & Morfología: & \multicolumn{3}{|c|}{ Fuentes en la ladera, con salida concentrada desde una cavidad. } \\
\hline & Dinámica & \multicolumn{3}{|c|}{ Kárstica. } \\
\hline & Cronología & \multicolumn{3}{|c|}{ Actual. } \\
\hline & Interés principal & \multicolumn{3}{|c|}{ Hidrológico y kárstico. } \\
\hline & $\begin{array}{l}\text { Interés } \\
\text { secundario }\end{array}$ & \multicolumn{3}{|c|}{ Ecológico. } \\
\hline & $\begin{array}{l}\text { Atribución del } \\
\text { LIGm }\end{array}$ & \multicolumn{3}{|c|}{ Hidrológico, fuentes. } \\
\hline \multirow{9}{*}{ Usos } & $\begin{array}{l}\text { Contenido } \\
\text { cultural }\end{array}$ & \multicolumn{3}{|l|}{--} \\
\hline & Accesibilidad & \multicolumn{3}{|c|}{ Mala, senda. } \\
\hline & Grado de interés & \multicolumn{3}{|c|}{ Alto, nacimiento de arroyo y fuentes, poco común en Picos. } \\
\hline & $\begin{array}{l}\text { Estado de } \\
\text { conservación }\end{array}$ & \multicolumn{3}{|c|}{ Alto. } \\
\hline & Usos actuales & \multicolumn{3}{|l|}{--} \\
\hline & Comunicaciones & \multicolumn{3}{|l|}{--} \\
\hline & Infraestructuras & \multicolumn{3}{|l|}{--} \\
\hline & Impactos & \multicolumn{3}{|c|}{--} \\
\hline & Situación legal & \multicolumn{3}{|c|}{ Parque Nacional de Picos de Europa (PRUG y PORN). } \\
\hline
\end{tabular}




\section{A.11) Fichas de valoración de LIGm de los Picos de Europa}

\section{A.11.1) Macizo de los Urrielles}

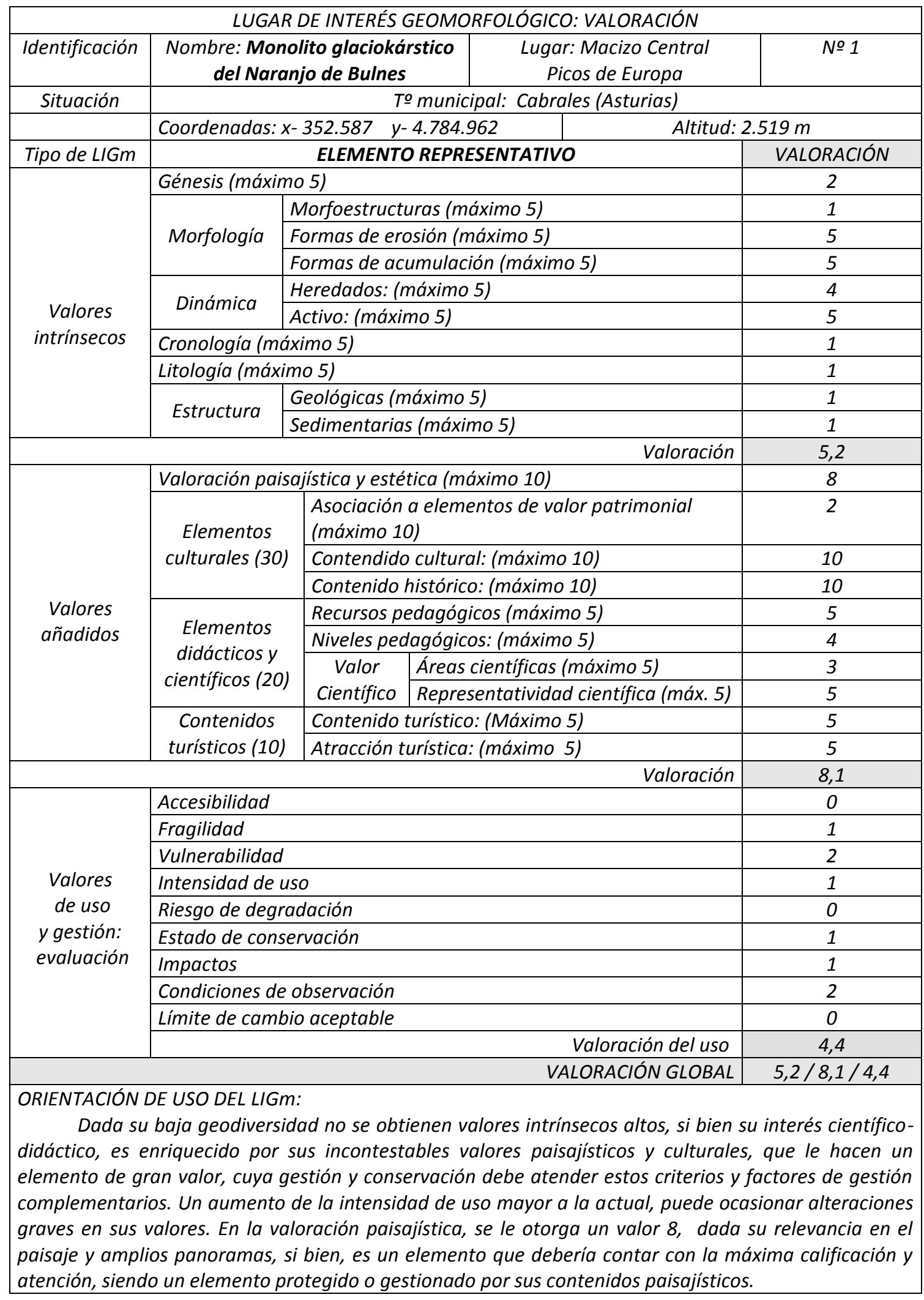




\begin{tabular}{|c|c|c|c|c|c|}
\hline \multicolumn{6}{|c|}{ LUGAR DE INTERÉS GEOMORFOLÓGICO: VALORACIÓN } \\
\hline Identificación & \multicolumn{3}{|c|}{$\begin{array}{l}\text { Nombre: MORFOESTRUCTURA } \\
\text { CABALGANTE DEL PICO PEÑA VIEJA }\end{array}$} & Lugar: Macizo Central & № 2 \\
\hline Situación & \multicolumn{5}{|c|}{ To municipal } \\
\hline & \multicolumn{3}{|l|}{ Coordenadas } & \multicolumn{2}{|l|}{ Altitud 2613} \\
\hline Tipo de LIGm & \multicolumn{4}{|c|}{ ELEMENTO REPRESENTATIVO } & VALORACIÓN \\
\hline \multirow{10}{*}{$\begin{array}{l}\text { Valores } \\
\text { intrínsecos }\end{array}$} & \multicolumn{4}{|c|}{ Génesis (máximo 5) } & 2 \\
\hline & \multirow{3}{*}{ Morfología } & \multicolumn{3}{|c|}{ Morfoestructuras (máximo 5) } & 5 \\
\hline & & Formas de er & sión $(m c$ & ximo 5) & 3 \\
\hline & & Formas de ac & umulació & (máximo 5) & 2 \\
\hline & \multirow[t]{2}{*}{ Dinámica: } & Heredados: ( & náximo 5 & & 2 \\
\hline & & Activo: (máxi & no 5) & & 2 \\
\hline & \multicolumn{4}{|c|}{ Cronología (máximo 5) } & 3 \\
\hline & \multicolumn{4}{|c|}{ Litología (máximo 5) } & 2 \\
\hline & \multirow{2}{*}{ Estructura } & \multicolumn{3}{|c|}{ Geológicas (máximo 5) } & 5 \\
\hline & & \multicolumn{3}{|c|}{ Sedimentarias (máximo 5) } & 0 \\
\hline & & & & Valoración & 5,2 \\
\hline \multirow{10}{*}{$\begin{array}{l}\text { Valores } \\
\text { añadidos }\end{array}$} & \multicolumn{4}{|c|}{ Valoración paisajística y estética (10) } & 8 \\
\hline & \multirow{3}{*}{$\begin{array}{c}\text { Elementos } \\
\text { culturales (30) }\end{array}$} & \multicolumn{3}{|c|}{$\begin{array}{l}\text { Asociación a elementos de valor patrimonial } \\
\text { (máximo 10) }\end{array}$} & 1 \\
\hline & & \multicolumn{3}{|c|}{ Contendido cultural: (Máximo 10) } & 2 \\
\hline & & \multicolumn{3}{|c|}{ Contenido histórico: (máximo 10) } & 1 \\
\hline & \multirow{4}{*}{$\begin{array}{c}\text { Elementos } \\
\text { didácticos y } \\
\text { científicos (20) }\end{array}$} & \multicolumn{3}{|c|}{ Recursos pedagógicos (máximo 5) } & 3 \\
\hline & & \multicolumn{3}{|c|}{ Niveles pedagógicos: (máximo 5) } & 2 \\
\hline & & \multirow{2}{*}{$\begin{array}{l}\text { Valor } \\
\text { Científico }\end{array}$} & Áreas c & entíficas (máximo 5) & 2 \\
\hline & & & Represe & tatividad científica (máx. 5) & 3 \\
\hline & Contenidos & Contenido & turístico: & Máximo 5) & 1 \\
\hline & turísticos (10) & Atracción & urística: & náximo 5) & 2 \\
\hline & & & & Valoración & 3,5 \\
\hline & Accesibilidad & & & & 1 \\
\hline & Fragilidad & & & & 2 \\
\hline & Vulnerabilidad & & & & 0 \\
\hline Valores & Intensidad de $u$ & & & & 1 \\
\hline de uso & Riesgo de degrc & adación & & & 2 \\
\hline y gestión: & Estado de cons & ervación & & & 2 \\
\hline evaluación & Impactos & & & & 2 \\
\hline & Condiciones de & observación & & & 2 \\
\hline & Límite de camb & io aceptable & & & 2 \\
\hline & & & & Valoración del uso & 7,7 \\
\hline VALOI & ACIÓN GLOBAL & & & & $2,6-3,5-7,7$ \\
\hline $\begin{array}{r}\text { ORIENTACIÓN } \\
\text { Valor in } \\
\text { por la escasa a } \\
\text { el conjunto } d \\
\text { favorable haci } \\
\text { locales y puntu }\end{array}$ & $\begin{array}{l}\text { DE USO DEL LIGn } \\
\text { rínseco moderac } \\
\text { ccesibilidad y po } \\
\text { macizo, con } \\
\text { un uso excursi } \\
\text { ales en el tiempo }\end{array}$ & $\begin{array}{l}n \text { : } \\
\text { do, con bajos } \\
\text { tenciado por } \\
\text { componente } \\
\text { ionista, con } \\
\text { o. }\end{array}$ & $\begin{array}{l}\text { valores a } \\
\text { a visibilic } \\
\text { culturo } \\
\text { scasas li }\end{array}$ & $\begin{array}{l}\text { adidos y alto potencial de us } \\
\text { ad externa. Posee un alto valc } \\
\text { es derivados del montañisr } \\
\text { itaciones pues las aglomero }\end{array}$ & $\begin{array}{l}\text { o, desfavorecido } \\
\text { or paisajístico en } \\
\text { mo. Orientación } \\
\text { ciones son muy }\end{array}$ \\
\hline
\end{tabular}




\begin{tabular}{|c|c|c|c|c|c|}
\hline \multicolumn{6}{|c|}{ LUGAR DE INTERÉS GEOMORFOLÓGICO: VALORACIÓN } \\
\hline Identificación & \multicolumn{3}{|c|}{$\begin{array}{l}\text { Nombre: FRENTE DE CABALGAMIENTO } \\
\text { TRAVIESAS DE SALINAS }\end{array}$} & Lugar: Macizo Central & NNo 3 \\
\hline \multirow[t]{2}{*}{ Situación } & \multicolumn{5}{|c|}{ To municipal } \\
\hline & \multicolumn{3}{|l|}{ Coordenadas } & \multirow[t]{2}{*}{ Altitud } & \\
\hline Tipo de LIGm & \multicolumn{3}{|c|}{ LUGAR REPRESENTATIVO } & & VALORACIÓN \\
\hline \multirow{10}{*}{$\begin{array}{l}\text { Valores } \\
\text { intrínsecos }\end{array}$} & \multicolumn{4}{|c|}{ Génesis (máximo 5) } & 3 \\
\hline & \multirow{3}{*}{ Morfología } & \multicolumn{3}{|c|}{ Morfoestructuras (máximo 5) } & 3 \\
\hline & & \multicolumn{3}{|c|}{ Formas de erosión (máximo 5) } & 2 \\
\hline & & \multicolumn{3}{|c|}{ Formas de acumulación (máximo 5) } & 3 \\
\hline & \multirow{2}{*}{ Dinámica } & \multicolumn{3}{|c|}{ Heredados: (máximo 5) } & 2 \\
\hline & & \multicolumn{3}{|c|}{ Activo: (máximo 5) } & 3 \\
\hline & \multicolumn{4}{|c|}{ Cronología (máximo 5) } & 3 \\
\hline & \multicolumn{4}{|c|}{ Litología (máximo 5) } & 2 \\
\hline & \multirow{2}{*}{ Estructura } & \multicolumn{3}{|c|}{ Geológicas (máximo 5) } & 3 \\
\hline & & \multicolumn{3}{|c|}{ Sedimentarias (máximo 5) } & 0 \\
\hline \multirow{11}{*}{$\begin{array}{l}\text { Valores } \\
\text { añadidos }\end{array}$} & \multicolumn{4}{|r|}{ Valoración } & 4,8 \\
\hline & \multicolumn{4}{|c|}{ Valoración paisajística y estética (10) } & 6 \\
\hline & \multirow{3}{*}{$\begin{array}{l}\text { Elementos } \\
\text { culturales (30) }\end{array}$} & \multicolumn{3}{|c|}{$\begin{array}{l}\text { Asociación a elementos de valor patrimonial } \\
\text { (máximo 10) }\end{array}$} & 0 \\
\hline & & \multicolumn{3}{|c|}{ Contendido cultural: (Máximo 10) } & 0 \\
\hline & & Contenido & histórico: ( $m$ & imo 10) & 0 \\
\hline & & Recursos $p$ & edagógicos & áximo 5) & 2 \\
\hline & Elementos & Niveles pec & lagógicos: (1 & ximo 5) & 2 \\
\hline & científicos (20) & Valor & Áreas cien & as (máximo 5) & 2 \\
\hline & & Científico & Represent & idad científica (máx. 5) & 2 \\
\hline & Contenidos & Contenido & urístico: (M & mo 5) & 1 \\
\hline & turísticos (10) & Atracción $t$ & urística: $(m c$ & no 5) & 1 \\
\hline & & & & Valoración & 2,2 \\
\hline & Accesibilidad & & & & 0 \\
\hline & Fragilidad & & & & 2 \\
\hline & Vulnerabilidad & & & & 2 \\
\hline & Intensidad de us & & & & 2 \\
\hline de uso & Riesgo de degra & adación & & & 2 \\
\hline y gestión: & Estado de conse & ervación & & & 2 \\
\hline evaluación & Impactos & & & & 2 \\
\hline & Condiciones de & observación & & & 1 \\
\hline & Límite de cambi & io aceptable & & & 2 \\
\hline & & & & Valoración del uso & 8,3 \\
\hline & & & & VALORACIÓN GLOBAL & $2,4-2,2-8,3$ \\
\hline $\begin{array}{r}\text { ORIENTACIÓN } \\
\text { Valor } \\
\text { desfavorecido } \\
\text { como decorad }\end{array}$ & $\begin{array}{l}\text { DE USO DEL LIGm } \\
\text { trínseco modero } \\
\text { oor la escasa acc } \\
\text { paisajístico del } \mathrm{V}\end{array}$ & $\begin{array}{l}\text { ado, con val } \\
\text { cesibilidad. Or } \\
\text { valle de Valde }\end{array}$ & $\begin{array}{l}\text { ores añadi } \\
\text { ientación } f( \\
\text { ón. }\end{array}$ & $\begin{array}{l}\text { muy bajos y alto po } \\
\text { able hacia un uso excur }\end{array}$ & $\begin{array}{l}\text { tencial de uso, } \\
\text { sionista, y valor }\end{array}$ \\
\hline
\end{tabular}




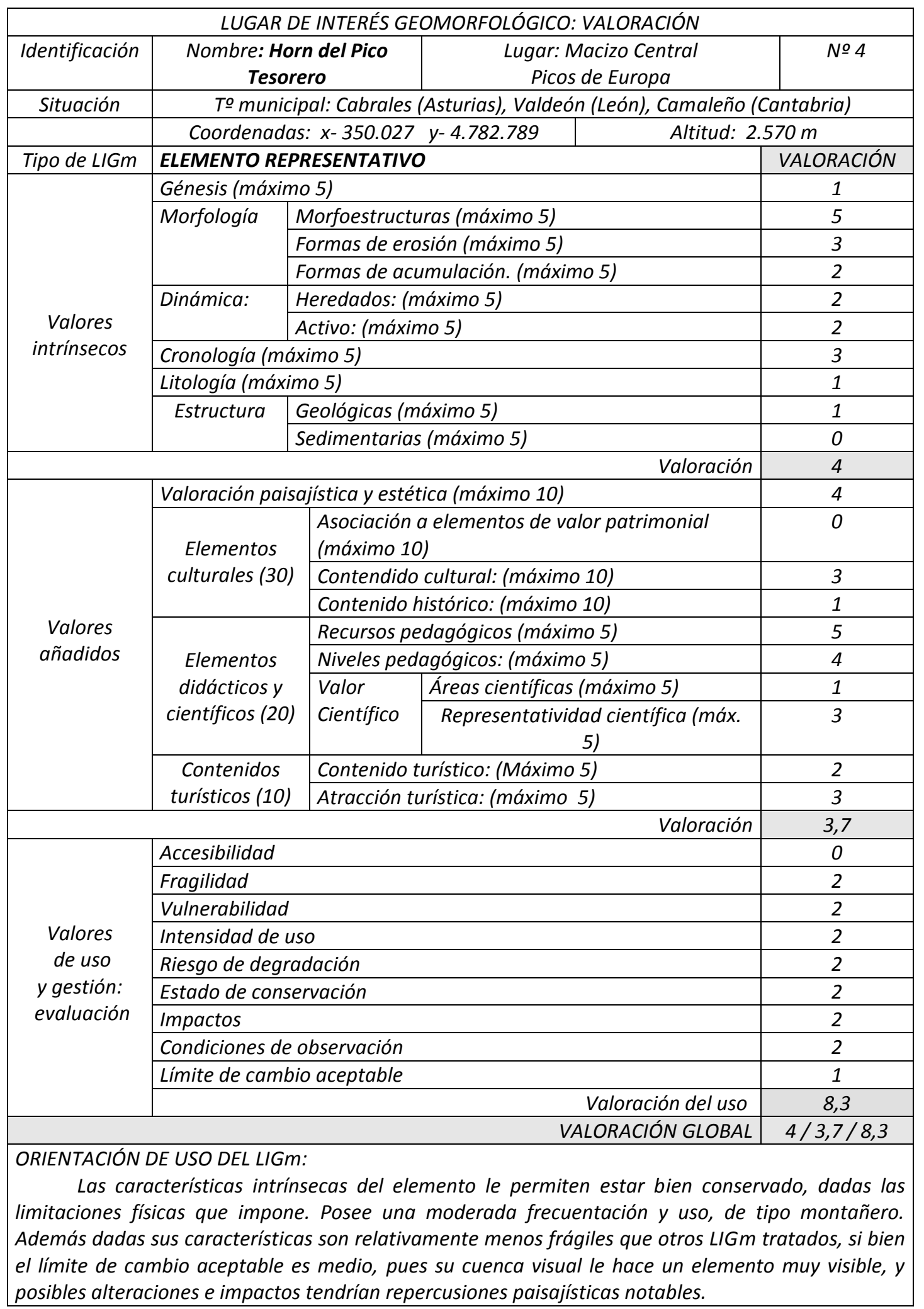




\begin{tabular}{|c|c|c|c|c|}
\hline \multicolumn{5}{|c|}{ LUGAR DE INTERÉS GEOMORFOLÓGICO: VALORACIÓN } \\
\hline Identificación & \multicolumn{2}{|c|}{$\begin{array}{l}\text { Nombre: Complejo glaciar } \\
\text { de Fuente De-Pido }\end{array}$} & Lugar: Macizo Central & № 5 \\
\hline Situación & \multicolumn{4}{|c|}{ To municipal } \\
\hline & \multicolumn{3}{|l|}{ Coordenadas } & Altitud \\
\hline Tipo de LIGm & \multicolumn{3}{|c|}{ LUGAR REPRESENTATIVO } & VALORACIÓN \\
\hline \multirow{10}{*}{$\begin{array}{l}\text { Valores } \\
\text { intrínsecos }\end{array}$} & \multicolumn{3}{|c|}{ Génesis (máximo 5) } & 5 \\
\hline & \multirow[t]{3}{*}{ Morfología } & \multicolumn{2}{|c|}{ Morfoestructuras (máximo 5) } & 2 \\
\hline & & Formas de & erosión (máximo 5) & 3 \\
\hline & & Formas de & acumulación. (máximo 5) & 5 \\
\hline & \multirow[t]{2}{*}{ Dinámica: } & Heredado & : (máximo 5) & 3 \\
\hline & & Activo: $(\mathrm{m}$ & áximo 5) & 3 \\
\hline & \multicolumn{3}{|c|}{ Cronología (máximo 5) } & 3 \\
\hline & \multicolumn{3}{|c|}{ Litología (máximo 5) } & 2 \\
\hline & \multirow[t]{2}{*}{ Estructura } & \multicolumn{2}{|c|}{ Geológicas (máximo 5) } & 3 \\
\hline & & \multicolumn{2}{|c|}{ Sedimentarias (máximo 5) } & 4 \\
\hline \multirow{11}{*}{$\begin{array}{l}\text { Valores } \\
\text { añadidos }\end{array}$} & & & Valoración & 6,6 \\
\hline & \multicolumn{3}{|c|}{ Valoración paisajística y estética (10) } & 10 \\
\hline & \multirow{3}{*}{$\begin{array}{c}\text { Elementos } \\
\text { culturales (30) }\end{array}$} & \multicolumn{2}{|c|}{$\begin{array}{l}\text { Asociación a elementos de valor patrimonial } \\
\text { (máximo 10) }\end{array}$} & 4 \\
\hline & & \multicolumn{2}{|c|}{ Contendido cultural: (Máximo 10) } & 1 \\
\hline & & \multicolumn{2}{|c|}{ Contenido histórico: (máximo 10) } & 2 \\
\hline & \multirow{4}{*}{$\begin{array}{c}\text { Elementos } \\
\text { didácticos y } \\
\text { científicos (20) }\end{array}$} & \multicolumn{2}{|c|}{ Recursos pedagógicos (máximo 5) } & 5 \\
\hline & & \multicolumn{2}{|c|}{ Niveles pedagógicos: (máximo 5) } & 4 \\
\hline & & \multirow{2}{*}{\begin{tabular}{|l|} 
Valor \\
Científico
\end{tabular}} & Áreas científicas (máximo 5) & 5 \\
\hline & & & Representatividad científica (máx. 5) & 5 \\
\hline & Contenidos & Contenido & turístico: (Máximo 5) & 5 \\
\hline & turísticos (10) & Atracción & turística: (máximo 5) & 5 \\
\hline & & & Valoración & 6,5 \\
\hline & Accesibilidad & & & 2 \\
\hline & Fragilidad & & & 2 \\
\hline & Vulnerabilidad & & & 1 \\
\hline Valores & Intensidad de us & & & 0 \\
\hline de uso & Riesgo de degra & dación & & 2 \\
\hline y gestión: & Estado de conse & vación & & 2 \\
\hline evaluación & Impactos & & & 1 \\
\hline & Condiciones de & bservación & & 1 \\
\hline & Límite de cambi & aceptable & & 1 \\
\hline & & & Valoración del uso & 6,5 \\
\hline VALO & ACIÓN GLOBAL & & & $3,5-6,5-6,5$ \\
\hline $\begin{array}{l}\text { ORIENTACIÓN } \\
\text { Valor ir } \\
\text { Orientación fo } \\
\text { de impacto (in } \\
\text { turísticas. }\end{array}$ & $\begin{array}{l}\text { DE USO DEL LIGM } \\
\text { rínseco moderad } \\
\text { orable hacia un } \\
\text { raestructuras) y }\end{array}$ & $\begin{array}{l}\text { amente alto } \\
\text { Iso turísticc } \\
\text { estión de fl }\end{array}$ & $\begin{array}{l}\text { con elevados valores añadidos y alto pa } \\
\text {-cultural y pedagógico, con corrección a } \\
\text { ujos con canalización y control hacia las }\end{array}$ & $\begin{array}{l}\text { tencial de uso. } \\
\text { le los elementos } \\
\text { infraestructuras }\end{array}$ \\
\hline
\end{tabular}




\begin{tabular}{|c|c|c|c|c|}
\hline \multicolumn{5}{|c|}{ LUGAR DE INTERÉS GEOMORFOLÓGICO: VALORACIÓN } \\
\hline Identificación & \multicolumn{2}{|c|}{$\begin{array}{l}\text { Nombre: Circos y morrenas } \\
\text { de Áliva }\end{array}$} & Lugar: Macizo Central & № 6 \\
\hline \multirow[t]{2}{*}{ Situación } & \multicolumn{4}{|c|}{ To municipal } \\
\hline & \multicolumn{3}{|c|}{ Coordenadas } & \\
\hline Tipo de LIGm & \multicolumn{3}{|c|}{ LUGAR REPRESENTATIVO } & VALORACIÓN \\
\hline \multirow{10}{*}{$\begin{array}{l}\text { Valores } \\
\text { intrínsecos }\end{array}$} & \multicolumn{3}{|c|}{ Génesis (máximo 5) } & 4 \\
\hline & \multirow[t]{3}{*}{ Morfología } & \multicolumn{2}{|c|}{ Morfoestructuras (máximo 5) } & 2 \\
\hline & & \multicolumn{2}{|c|}{ Formas de erosión (máximo 5) } & 3 \\
\hline & & \multicolumn{2}{|c|}{ Formas de acumulación. (máximo 5) } & 4 \\
\hline & \multirow[t]{2}{*}{ Dinámica: } & \multicolumn{2}{|c|}{ Heredados: (máximo 5) } & 5 \\
\hline & & \multicolumn{2}{|c|}{ Activo: (máximo 5) } & 3 \\
\hline & \multicolumn{3}{|c|}{ Cronología (máximo 5) } & 3 \\
\hline & \multicolumn{3}{|c|}{ Litología (máximo 5) } & 2 \\
\hline & \multirow[t]{2}{*}{ Estructura } & \multicolumn{2}{|c|}{ Geológicas (máximo 5) } & 2 \\
\hline & & \multicolumn{2}{|c|}{ Sedimentarias (máximo 5) } & 1 \\
\hline \multirow{11}{*}{$\begin{array}{l}\text { Valores } \\
\text { añadidos }\end{array}$} & & & Valoración & 7,2 \\
\hline & \multicolumn{3}{|c|}{ Valoración paisajística y estética (10) } & 6 \\
\hline & \multirow{3}{*}{$\begin{array}{c}\text { Elementos } \\
\text { culturales (30) }\end{array}$} & \multicolumn{2}{|c|}{$\begin{array}{l}\text { Asociación a elementos de valor patrimonial } \\
\text { (máximo 10) }\end{array}$} & 3 \\
\hline & & \multicolumn{2}{|c|}{ Contendido cultural: (Máximo 10) } & 3 \\
\hline & & \multicolumn{2}{|c|}{ Contenido histórico: (máximo 10) } & 2 \\
\hline & & \multicolumn{2}{|c|}{ Recursos pedagógicos (máximo 5) } & 5 \\
\hline & Elementos & Niveles ped & agógicos: (máximo 5) & 4 \\
\hline & 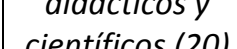 & Valor & Áreas científicas (máximo 5) & 5 \\
\hline & & Científico & Representatividad científica (máx. 5) & 3 \\
\hline & Contenidos & Contenidot & urístico: (Máximo 5) & 4 \\
\hline & turísticos (10) & Atracción ti & Irística: (máximo 5) & 5 \\
\hline & & & Valoración & 5,7 \\
\hline & Accesibilidad & & & 2 \\
\hline & Fragilidad & & & 2 \\
\hline & Vulnerabilidad & & & 1 \\
\hline Valores & Intensidad de us & & & 0 \\
\hline de uso & Riesgo de degra & dación & & 1 \\
\hline y gestión: & Estado de conse & rvación & & 2 \\
\hline evaluación & Impactos & & & 2 \\
\hline & Condiciones de & bservación & & 2 \\
\hline & Límite de cambi & aceptable & & 1 \\
\hline & & & Valoración del uso & 7 \\
\hline & & & VALORACIÓN GLOBAL & $3,6-5,8-7$ \\
\hline $\begin{array}{l}\text { ORIENTACIÓN } \\
\text { Valor in } \\
\text { Valoración del } \\
\text { turístico-pedag } \\
\text { rodado, restos }\end{array}$ & $\begin{array}{l}\text { DE USO DEL LIGm } \\
\text { trínseco modera } \\
\text { paisaje y de los e } \\
\text { ógico, con correc } \\
\text { de minería). }\end{array}$ & $\begin{array}{l}\text { lo, con eleva } \\
\text { lementos que } \\
\text { ción de los e }\end{array}$ & $\begin{array}{l}\text { dos valores añadidos e importante pc } \\
\text { se inscriben en él. Orientación favorak } \\
\text { lementos que impactan (pistas, uso m }\end{array}$ & $\begin{array}{l}\text { tencial de uso. } \\
\text { le hacia un uso } \\
\text { asivo de tráfico }\end{array}$ \\
\hline
\end{tabular}




\begin{tabular}{|c|c|c|c|c|c|}
\hline \multicolumn{6}{|c|}{ LUGAR DE INTERÉS GEOMORFOLÓGICO: VALORACIÓN } \\
\hline Identificación & \multicolumn{3}{|c|}{$\begin{array}{l}\text { Nombre: Complejo morrénico con glaciar } \\
\text { rocoso de Lloroza }\end{array}$} & Lugar: Macizo Central & № 7 \\
\hline Situación & \multicolumn{5}{|c|}{ To municipal } \\
\hline & \multicolumn{3}{|l|}{ Coordenadas } & Altitud & \\
\hline Tipo de LIGm & \multicolumn{4}{|c|}{ LUGAR SINGULAR } & VALORACIÓN \\
\hline \multirow{10}{*}{$\begin{array}{l}\text { Valores } \\
\text { intrínsecos }\end{array}$} & \multicolumn{4}{|c|}{ Génesis (máximo 5) } & 4 \\
\hline & \multirow{3}{*}{\begin{tabular}{|l|} 
Morfología \\
\end{tabular}} & \multicolumn{3}{|c|}{ Morfoestructuras (máximo 5) } & 2 \\
\hline & & Formas de er & sión (máximo & & 2 \\
\hline & & Formas de ac & ımulación. (m & (ximo 5) & 6 \\
\hline & \multirow[t]{2}{*}{ Dinámica: } & Heredados: (1 & náximo 5) & & 3 \\
\hline & & Activo: (máxi & no 5) & & 4 \\
\hline & \multicolumn{4}{|c|}{ Cronología (máximo 5) } & 4 \\
\hline & \multicolumn{4}{|c|}{ Litología (máximo 5) } & 2 \\
\hline & \multirow{2}{*}{\begin{tabular}{|l|l|} 
Estructura & \\
\cline { 2 - 3 }
\end{tabular}} & \multicolumn{3}{|c|}{ Geológicas (máximo 5) } & 2 \\
\hline & & \multicolumn{3}{|c|}{ Sedimentarias (máximo 5) } & 2 \\
\hline \multirow{11}{*}{$\begin{array}{l}\text { Valores } \\
\text { añadidos }\end{array}$} & \multicolumn{4}{|r|}{ Valoración } & 6,4 \\
\hline & \multicolumn{4}{|c|}{ Valoración paisajística y estética (10) } & 2 \\
\hline & \multirow{3}{*}{$\begin{array}{c}\text { Elementos } \\
\text { culturales (30) }\end{array}$} & \multicolumn{3}{|c|}{$\begin{array}{l}\text { Asociación a elementos de valor patrimonial } \\
\text { (máximo 10) }\end{array}$} & 0 \\
\hline & & \multicolumn{3}{|c|}{ Contendido cultural: (Máximo 10) } & 0 \\
\hline & & \multicolumn{3}{|c|}{ Contenido histórico: (máximo 10) } & 0 \\
\hline & \multirow{4}{*}{$\begin{array}{c}\text { Elementos } \\
\text { didácticos y } \\
\text { científicos (20) }\end{array}$} & \multicolumn{3}{|c|}{ Recursos pedagógicos (máximo 5) } & 4 \\
\hline & & \multicolumn{3}{|c|}{ Niveles pedagógicos: (máximo 5) } & 3 \\
\hline & & \multirow{2}{*}{\begin{tabular}{c|} 
Valor \\
Científico \\
\end{tabular}} & \multicolumn{2}{|c|}{ Áreas científicas (máximo 5) } & 4 \\
\hline & & & Representati & idad científica (máx. 5) & 3 \\
\hline & Contenidos & Contenido & urístico: (Máx & mo 5) & 1 \\
\hline & turísticos (10) & Atracción t & urística: (máxi & no 5) & 2 \\
\hline & & & & Valoración & 2,7 \\
\hline & Accesibilidad & & & & 2 \\
\hline & Fragilidad & & & & 1 \\
\hline & Vulnerabilidad & & & & 1 \\
\hline Valores & Intensidad de u & & & & 1 \\
\hline de uso & Riesgo de degr & adación & & & 0 \\
\hline y gestión: & Estado de cons & ervación & & & 1 \\
\hline evaluación. & Impactos & & & & 1 \\
\hline & Condiciones de & observación & & & 2 \\
\hline & Límite de camb & io aceptable & & & 1 \\
\hline & & & & Valoración del uso & 5,5 \\
\hline & & & & VALORACIÓN GLOBAL & $3,1-3,6-5,5$ \\
\hline $\begin{array}{l}\text { ORIENTACIÓN } \\
\text { Valor in } \\
\text { Orientación fa } \\
\text { y gestión de } \\
\text { frecuentación }\end{array}$ & $\begin{array}{l}\text { DE USO DEL LIGn } \\
\text { trínseco modera } \\
\text { orable hacia un } \\
\text { flujos por el LIC } \\
\text { tel entorno. }\end{array}$ & $\begin{array}{l}\text { do, con valor } \\
\text { uso pedagóg } \\
\text { Im para evit }\end{array}$ & $\begin{array}{l}s \text { añadidos } m \\
\text { co, con correc } \\
\text { ar su degrad }\end{array}$ & $\begin{array}{l}\text { dios y un potencial de us } \\
\text { ión de los elementos de } \\
\text { ción potencial derivado }\end{array}$ & $\begin{array}{l}\text { imoderado. } \\
\text { impacto (pistas) } \\
\text { de la elevada }\end{array}$ \\
\hline
\end{tabular}




\begin{tabular}{|c|c|c|c|c|}
\hline \multicolumn{5}{|c|}{ LUGAR DE INTERÉS GEOMORFOLÓGICO: VALORACIÓN } \\
\hline Identificación & \multicolumn{2}{|c|}{$\begin{array}{c}\text { Nombre: Complejo Glaciar } \\
\text { de Jou Negro }\end{array}$} & $\begin{array}{c}\text { Lugar: Macizo Central } \\
\text { Picos de Europa }\end{array}$ & № 8 \\
\hline Situación & \multicolumn{4}{|c|}{ To municipal: Cabrales (Asturias) } \\
\hline & \multicolumn{3}{|c|}{ Coordenadas $x-349.449 y-4.785 .256$} & $0-2.648$ \\
\hline Tipo de LIGm & \multicolumn{3}{|c|}{ LUGAR SINGULAR } & VALORACIÓN \\
\hline \multirow{10}{*}{$\begin{array}{l}\text { Valores } \\
\text { intrínsecos }\end{array}$} & \multicolumn{3}{|c|}{ Génesis (máximo 5) } & 4 \\
\hline & \multirow{3}{*}{ Morfología } & \multicolumn{2}{|c|}{ Morfoestructuras (máximo 5) } & 1 \\
\hline & & Formas de ero & sión (máximo 5) & 5 \\
\hline & & Formas de acu & umulación (máximo 5) & 5 \\
\hline & \multirow[t]{2}{*}{ Dinámica: } & Heredados: $(n$ & náximo 5) & 4 \\
\hline & & Activo: (máxin & no 5) & 5 \\
\hline & \multicolumn{3}{|c|}{ Cronología (máximo 5) } & 3 \\
\hline & \multicolumn{3}{|c|}{ Litología (máximo 5) } & 1 \\
\hline & \multirow{2}{*}{\begin{tabular}{|l|l} 
Estructura & \\
\cline { 2 - 3 } &
\end{tabular}} & \multicolumn{2}{|c|}{ Geológicas (máximo 5) } & 1 \\
\hline & & \multicolumn{2}{|c|}{ Sedimentarias (máximo 5) } & 1 \\
\hline \multirow{11}{*}{$\begin{array}{l}\text { Valores } \\
\text { añadidos }\end{array}$} & & & Valoración & 6 \\
\hline & \multirow{4}{*}{$\begin{array}{c}\text { Valoración paiso } \\
\\
\text { Elementos } \\
\text { culturales (30) }\end{array}$} & sajistica y estét & tica (máximo 10) & 2 \\
\hline & & $\begin{array}{l}\text { Asociación } \\
\text { (máximo } 10\end{array}$ & $\begin{array}{l}\text { a elementos de valor patrimonial } \\
\text { D) }\end{array}$ & 0 \\
\hline & & Contendido & cultural: (máximo 10) & 4 \\
\hline & & Contenido $\mathrm{H}$ & histórico: (máximo 10) & 0 \\
\hline & \multirow{4}{*}{$\begin{array}{c}\text { Elementos } \\
\text { didácticos y } \\
\text { científicos (20) }\end{array}$} & Recursos pe & edagógicos (máximo 5) & 5 \\
\hline & & Niveles ped & lagógicos: (máximo 5) & 5 \\
\hline & & Valor & Áreas científicas (máximo 5) & 5 \\
\hline & & Científico & Representatividad científica (máx. 5) & 4 \\
\hline & \multirow{2}{*}{$\begin{array}{c}\text { Contenidos } \\
\text { turísticos (10) }\end{array}$} & Contenido $t$ & turístico: (Máximo 5) & 2 \\
\hline & & Atracción tc & urística: (máximo 5) & 2 \\
\hline \multirow{11}{*}{$\begin{array}{l}\text { Valores } \\
\text { de uso } \\
\text { y gestión: } \\
\text { evaluación }\end{array}$} & & & Valoración & 4,1 \\
\hline & \multicolumn{3}{|l|}{ Accesibilidad } & 0 \\
\hline & \multicolumn{3}{|l|}{ Fragilidad } & 0 \\
\hline & \multicolumn{3}{|c|}{ Vulnerabilidad } & 2 \\
\hline & \multicolumn{3}{|c|}{ Intensidad de uso } & 2 \\
\hline & \multicolumn{3}{|c|}{ Riesgo de degradación } & 0 \\
\hline & \multicolumn{3}{|c|}{ Estado de conservación } & 2 \\
\hline & Impactos & & & 2 \\
\hline & Condiciones de & observación & & 0 \\
\hline & Límite de cambi & io aceptable & & 1 \\
\hline & & & Valoración del uso & 5 \\
\hline & & & VALORACIÓN GLOBAL & $6 / 4,1 / 5$ \\
\hline $\begin{array}{l}\text { ORIENTACIÓN } \\
\qquad E I \text { LIGm } \\
\text { elementos repr } \\
\text { más alta de toc } \\
\text { morfológicas g } \\
\text { que junto Pirin } \\
\text { frío. Por tanto } \\
\text { frecuentado y } \\
\text { irreversible de } \\
\text { de uso derivad }\end{array}$ & $\begin{array}{l}\text { DE USO DEL LIGm } \\
\text { se encuentra } \\
\text { esentativos de gr } \\
\text { los los Picos de E } \\
\text { laciares de la PEI } \\
\text { eos y Sierra Neva } \\
\text { posee un gran in } \\
\text { bien conservad } \\
\text { sus valores intrín } \\
\text { de su mala acce }\end{array}$ & $\begin{array}{l}\text { en una de la } \\
\text { ran valor, dest } \\
\text { Europa. Su ma, } \\
\text { H, singulares y } \\
\text { ada constituye } \\
\text { nterés científic } \\
\text { to, pero una } \\
\text { secos. Valor in } \\
\text { esibilidad. }\end{array}$ & $\begin{array}{l}\text { I zonas más inaccesibles del macizo } \\
\text { tacan varias morfologías y el hecho de } \\
\text { yor valor intrínseco proviene de la exist } \\
\text { y escasas en Picos de Europa, únicas en } \\
\text { in las tres áreas de montaña con restos } \\
\text { o. Las características del LIGm le hace } \\
\text { llegada masiva de turistas implicar } \\
\text { trínseco y añadido moderado, con un }\end{array}$ & $\begin{array}{l}\text { central, posee } \\
\text { ener la cumbre } \\
\text { ncia de huellas } \\
\text { la Cantábrica y } \\
\text { de este período } \\
\text { un lugar poco } \\
\text { a una pérdida } \\
\text { scaso potencial }\end{array}$ \\
\hline
\end{tabular}




\begin{tabular}{|c|c|c|c|c|c|}
\hline \multicolumn{6}{|c|}{ LUGAR DE INTERÉS GEOMORFOLÓGICO: VALORACIÓN } \\
\hline Identificación & \multicolumn{2}{|c|}{$\begin{array}{c}\text { Nombre: Complejo glaciar } \\
\text { de Trasllambrión }\end{array}$} & \multicolumn{2}{|c|}{$\begin{array}{c}\text { Lugar: Macizo Central } \\
\text { Picos de Europa }\end{array}$} & № 9 \\
\hline Situación & \multicolumn{5}{|c|}{ To municipal: Valdeón (León) } \\
\hline & \multicolumn{3}{|c|}{ Coordenadas: $x-349.583 y-4.782 .107$} & \multicolumn{2}{|c|}{ Altitud: Entre $2.280-2.642 \mathrm{~m}$} \\
\hline Tipo de LIGm & \multicolumn{4}{|c|}{ LUGAR SINGULAR } & VALORACIÓN \\
\hline \multirow{10}{*}{$\begin{array}{l}\text { Valores } \\
\text { intrínsecos }\end{array}$} & \multicolumn{4}{|c|}{ Génesis (máximo 5) } & 5 \\
\hline & \multirow[t]{3}{*}{ Morfología } & \multicolumn{3}{|c|}{ Morfoestructuras (máximo 5) } & 1 \\
\hline & & \multicolumn{3}{|c|}{ Formas de erosión (máximo 5) } & 5 \\
\hline & & \multicolumn{3}{|c|}{ Formas de acumulación. (máximo 5) } & 5 \\
\hline & \multirow[t]{2}{*}{ Dinámica: } & \multicolumn{3}{|c|}{ Heredados: (máximo 5) } & 5 \\
\hline & & Activo: (máxir & no 5) & & 5 \\
\hline & \multicolumn{4}{|c|}{ Cronología ( máximo 5) } & 3 \\
\hline & \multicolumn{4}{|c|}{ Litología (máximo 5) } & 1 \\
\hline & \multirow[t]{2}{*}{ Estructura } & \multicolumn{3}{|c|}{ Geológicas (máximo 5) } & 1 \\
\hline & & \multicolumn{3}{|c|}{ Sedimentarias (máximo 5) } & 1 \\
\hline & & & & Valoración & 6,4 \\
\hline \multirow{10}{*}{$\begin{array}{l}\text { Valores } \\
\text { añadidos }\end{array}$} & \multirow{4}{*}{\begin{tabular}{|c} 
Valoración paisa \\
\\
Elementos \\
culturales (30)
\end{tabular}} & ajística y esté & tica (máximo 10 , & & 4 \\
\hline & & $\begin{array}{l}\text { Asociación } \\
\text { (máximo 1C }\end{array}$ & $\begin{array}{l}\text { a elementos de } \\
\text { D) }\end{array}$ & or patrimonial & 0 \\
\hline & & Contendido & cultural: (máxin & 10) & 4 \\
\hline & & Contenido & histórico: (máxim & & 0 \\
\hline & \multirow{4}{*}{$\begin{array}{c}\text { Elementos } \\
\text { didácticos y } \\
\text { científicos (20) }\end{array}$} & \multicolumn{3}{|c|}{ Recursos pedagógicos (máximo 5) } & 5 \\
\hline & & \multicolumn{3}{|c|}{ Niveles pedagógicos: (máximo 5) } & 5 \\
\hline & & \multirow{2}{*}{\begin{tabular}{|c|} 
Valor \\
Científico
\end{tabular}} & \multicolumn{2}{|c|}{ Áreas científicas (máximo 5) } & 2 \\
\hline & & & Representativic & d científica (máx. 5) & 4 \\
\hline & Contenidos & Contenido & turístico: (Máxim & & 2 \\
\hline & turísticos (10) & Atracción $t$ & uristica: (máximc & & 4 \\
\hline & & & & Valoración & 4,3 \\
\hline & Accesibilidad & & & & 0 \\
\hline & Fragilidad & & & & 0 \\
\hline & Vulnerabilidad & & & & 2 \\
\hline Valores & Intensidad de us & & & & 2 \\
\hline de uso & Riesgo de degra & adación & & & 0 \\
\hline y gestión: & Estado de conse & ervación & & & 2 \\
\hline evaluación & Impactos & & & & 2 \\
\hline & Condiciones de & observación & & & 2 \\
\hline & Límite de cambi & io aceptable & & & 1 \\
\hline & & & & Valoración del uso & 6,1 \\
\hline & & & & ILORACIÓN GLOBAL & $6,4 / 4,3 / 6,1$ \\
\hline $\begin{array}{l}\text { ORIENTACIÓN } \\
\text { EI LIG } \\
\text { elementos rep } \\
\text { cumbre más a } \\
\text { heleros y huel } \\
\text { en la Cantábri } \\
\text { restos de este } \\
\text { hacen un luga } \\
\text { una perdida ir } \\
\text { que los helero } \\
\text { sensibles. }\end{array}$ & $\begin{array}{l}\text { DE USO DEL LIGM } \\
\text { se encuentra e } \\
\text { esentativos de gr } \\
\text { a de todos los Pi } \\
\text { ys morfológicas g } \\
\text { a y que junto PI } \\
\text { eríodo frío. Port } \\
\text { poco frecuentad } \\
\text { eversible de sus } \\
\text { se encuentran e }\end{array}$ & $\begin{array}{l}\text { 7: } \\
\text { en una de lo } \\
\text { ran valor, des } \\
\text { icos de Europo } \\
\text { glaciares de l } \\
\text { irineos y Sier } \\
\text { tanto posee u } \\
\text { to y bien cons } \\
\text { valores intrín } \\
\text { en un estadio }\end{array}$ & $\begin{array}{l}\text { S zonas más in } \\
\text { tacan varias mor } \\
\text { Su mayor valor } \\
\text { a PEH, singulare } \\
\text { a Nevada const } \\
\text { n gran interés ci } \\
\text { ervado, pero un } \\
\text { secos. Su situaci } \\
\text { de fusión termir }\end{array}$ & $\begin{array}{l}\text { cesibles del macizo } \\
\text { logías y el hecho de } \\
\text { trínseco proviene de } \\
\text { escasas en Picos d } \\
\text { yen las tres áreas } \\
\text { tífico. Las caracterís } \\
\text { legada masiva de tu } \\
\text { en claro desequilibr } \\
\text {, le hacen elemento }\end{array}$ & $\begin{array}{l}\text { central, posee } \\
\text { ener la segunda } \\
\text { la existencia de } \\
\text { Europa, únicas } \\
\text { e montaña con } \\
\text { cas del LIGm le } \\
\text { istas implicaría } \\
\text { o natural, dado } \\
\text { especialmente }\end{array}$ \\
\hline
\end{tabular}




\begin{tabular}{|c|c|c|c|c|c|}
\hline \multicolumn{6}{|c|}{ LUGAR DE INTERÉS GEOMORFOLÓGICO: VALORACIÓN } \\
\hline Identificación & \multicolumn{3}{|c|}{$\begin{array}{l}\text { Nombre: Complejo Glaciar Torre } \\
\text { Blanca-Hoyo de los Ilagos }\end{array}$} & $\begin{array}{l}\text { Lugar: Macizo Central } \\
\text { Picos de Europa }\end{array}$ & No 10 \\
\hline Situación & \multicolumn{5}{|c|}{ To municipal: Valdeón (León) } \\
\hline & \multicolumn{3}{|c|}{ Coordenadas: $x-349.658 \quad y-4.781 .563$} & \multicolumn{2}{|c|}{ Altitud: Entre $2.010-2.642 \mathrm{~m}$} \\
\hline Tipo de LIGm & \multicolumn{4}{|c|}{ LUGAR REPRESENTATIVO CON ELEMENTOS SINGULARES } & VALORACIÓN \\
\hline \multirow{10}{*}{$\begin{array}{l}\text { Valores } \\
\text { intrínsecos }\end{array}$} & \multicolumn{4}{|c|}{ Génesis } & 3 \\
\hline & \multirow[t]{3}{*}{ Morfología } & \multicolumn{3}{|c|}{ Morfoestructuras (máximo 5) } & 1 \\
\hline & & \multicolumn{3}{|c|}{ Formas de erosión (máximo 5) } & 5 \\
\hline & & \multicolumn{3}{|c|}{ Formas de acumulación. (máximo 5) } & 5 \\
\hline & \multirow[t]{2}{*}{ Dinámica: } & \multicolumn{3}{|c|}{ Heredados: (máximo 5) } & 2 \\
\hline & & \multicolumn{3}{|c|}{ Activo: (máximo 5) } & 3 \\
\hline & \multicolumn{4}{|c|}{ Cronología (máximo 5) } & 2 \\
\hline & \multicolumn{4}{|c|}{ Litología (máximo 5) } & 1 \\
\hline & \multirow[t]{2}{*}{ Estructura } & \multicolumn{3}{|c|}{ Geológicas (máximo 5) } & 1 \\
\hline & & \multicolumn{3}{|c|}{ Sedimentarias (máximo 5) } & 1 \\
\hline \multirow{11}{*}{$\begin{array}{l}\text { Valores } \\
\text { añadidos }\end{array}$} & & & & Valoración & 4,8 \\
\hline & \multirow{4}{*}{$\begin{array}{c}\text { Valoración paisc } \\
\text { Elementos } \\
\text { culturales (30) }\end{array}$} & sajística y est & tética ( & náximo 10) & 4 \\
\hline & & $\begin{array}{l}\text { Asociación } \\
\text { (máximo } 1\end{array}$ & $\begin{array}{l}\text { a elen } \\
\text { (0) }\end{array}$ & entos de valor patrimonial & 0 \\
\hline & & Contendid & o cultu & al: (máximo 10) & 2 \\
\hline & & Contenido & históri & o: (máximo 10) & 0 \\
\hline & \multirow{4}{*}{$\begin{array}{c}\text { Elementos } \\
\text { didácticos y } \\
\text { científicos (20) }\end{array}$} & \multicolumn{3}{|c|}{ Recursos pedagógicos (máximo 5) } & 5 \\
\hline & & \multicolumn{3}{|c|}{ Niveles pedagógicos: (máximo 5) } & 5 \\
\hline & & \multirow{2}{*}{\begin{tabular}{|c|} 
Valor \\
Científico
\end{tabular}} & Áreas & científicas (máximo 5) & 2 \\
\hline & & & Repre & sentatividad científica (máx. 5) & 3 \\
\hline & Contenidos & Contenido & turístic & o: (Máximo 5) & 2 \\
\hline & turísticos (10) & Atracción & turístic & : (máximo 5) & 3 \\
\hline & & & & Valoración & 3,7 \\
\hline & Accesibilidad & & & & 0 \\
\hline & Fragilidad & & & & 2 \\
\hline & Vulnerabilidad & & & & 2 \\
\hline Valores & Intensidad de u & & & & 2 \\
\hline de uso & Riesgo de degr & adación & & & 0 \\
\hline y gestión: & Estado de cons & ervación & & & 2 \\
\hline evaluación & Impactos & & & & 2 \\
\hline & Condiciones de & observación & & & 1 \\
\hline & Límite de camb & bio aceptable & & & 1 \\
\hline & & & & Valoración del uso & 6,6 \\
\hline & & & & VALORACIÓN GLOBAL & $4,8 / 3,7 / 6,6$ \\
\hline $\begin{array}{r}\text { ORIENTACIÓN } \\
\text { EI LIGm } \\
\text { su mala accesi } \\
\text { obligan a una }\end{array}$ & $\begin{array}{l}\text { DE USO DEL LIGn } \\
\text { posee un interés } \\
\text { ilidad y la fragil } \\
\text { estión conscient }\end{array}$ & $\begin{array}{l}\text { m: } \\
\text { s científico y } \\
\text { lidad de algu } \\
\text { te de tales lir }\end{array}$ & $\begin{array}{l}\text { didácti } \\
\text { nos de } \\
\text { nitacio }\end{array}$ & $\begin{array}{l}\text { o alto. Su estado de conservació } \\
\text { sus elementos, las lagunas espec } \\
\text { es, en el caso de potenciar su fre }\end{array}$ & $\begin{array}{l}\text { es bueno, pero } \\
\text { Imente, } \\
\text { uentación. }\end{array}$ \\
\hline
\end{tabular}




\begin{tabular}{|c|c|c|c|c|}
\hline \multicolumn{5}{|c|}{ LUGAR DE INTERÉS GEOMORFOLÓGICO: VALORACIÓN } \\
\hline Identificación & \multicolumn{2}{|c|}{$\begin{array}{c}\text { Nombre: Artesa glaciar de } \\
\text { Balcosín }\end{array}$} & $\begin{array}{c}\text { Lugar: Macizo Central } \\
\text { Picos de Europa }\end{array}$ & No 11 \\
\hline Situación & \multicolumn{4}{|c|}{ To municipal: Cabrales (Asturias) } \\
\hline & \multicolumn{3}{|c|}{\begin{tabular}{|l|l} 
Coordenadas: $x$ - $352.550 y-4.787 .357$ & Altitud: Entre $900-$
\end{tabular}} & $1.100 \mathrm{~m}$ \\
\hline Tipo de LIGm & \multicolumn{3}{|c|}{ LUGAR REPRESENTATIVO } & VALORACIÓN \\
\hline \multirow{10}{*}{$\begin{array}{l}\text { Valores } \\
\text { intrínsecos }\end{array}$} & \multicolumn{3}{|c|}{ Génesis (máximo 5) } & 1 \\
\hline & \multirow[t]{3}{*}{ Morfología } & \multicolumn{2}{|c|}{ Morfoestructuras (máximo 5) } & 1 \\
\hline & & \multicolumn{2}{|c|}{ Formas de erosión (máximo 5) } & 4 \\
\hline & & \multicolumn{2}{|c|}{ Formas de acumulación. (máximo 5) } & 5 \\
\hline & \multirow[t]{2}{*}{ Dinámica: } & \multicolumn{2}{|c|}{ Heredados: (máximo 5) } & 2 \\
\hline & & \multicolumn{2}{|c|}{ Activo: (máximo 5) } & 5 \\
\hline & \multicolumn{3}{|c|}{ Cronología (máximo 5) } & 1 \\
\hline & \multicolumn{3}{|c|}{ Litología (máximo 5) } & 1 \\
\hline & \multirow[t]{2}{*}{ Estructura } & \multicolumn{2}{|c|}{ Geológicas (máximo 5) } & 1 \\
\hline & & \multicolumn{2}{|c|}{ Sedimentarias (máximo 5) } & 1 \\
\hline \multirow{11}{*}{$\begin{array}{l}\text { Valores } \\
\text { añadidos }\end{array}$} & & & Valoración & 4,4 \\
\hline & \multicolumn{3}{|c|}{ Valoración paisajística y estética (máximo 10) } & 4 \\
\hline & Elementos & \multicolumn{2}{|c|}{$\begin{array}{l}\text { Asociación a elementos de valor patrimonial } \\
\text { (máximo 10) }\end{array}$} & 0 \\
\hline & culturales (30) & \multicolumn{2}{|c|}{ Contendido cultural: (máximo 10) } & 0 \\
\hline & & \multicolumn{2}{|c|}{ Contenido histórico: (máximo 10) } & 0 \\
\hline & & \multicolumn{2}{|c|}{ Recursos pedagógicos (máximo 5) } & 5 \\
\hline & Elementos & \multicolumn{2}{|c|}{ Niveles pedagógicos: (máximo 5) } & 4 \\
\hline & $\begin{array}{l}\text { didacticos y } \\
\text { científicos (20) }\end{array}$ & Valor & Áreas científicas (máximo 5) & 1 \\
\hline & & Científico & Representatividad científica (máx. 5) & 2 \\
\hline & Contenidos & Contenido $t$ & urístico: (Máximo 5) & 2 \\
\hline & turísticos (10) & Atracción tu & urística: (máximo 5) & 3 \\
\hline & & & Valoración & 3 \\
\hline & Accesibilidad & & & 1 \\
\hline & Fragilidad & & & 2 \\
\hline & Vulnerabilidad & & & 2 \\
\hline Valores & Intensidad de u & & & 2 \\
\hline de uso & Riesgo de degr & adación & & 1 \\
\hline y gestión: & Estado de cons & ervación & & 2 \\
\hline evaluación & Impactos & & & 2 \\
\hline & Condiciones de & observación & & 1 \\
\hline & Límite de camb & io aceptable & & 2 \\
\hline & & & Valoración del uso & 7,3 \\
\hline & & & VALORACIÓN GLOBAL & $4,4 / 3 / 7,3$ \\
\hline $\begin{array}{l}\text { ORIENTACIÓN } \\
\text { EI LIGM } \\
\text { valores y carc } \\
\text { aumentarse } m \\
\text { el impacto as } \\
\text { funciona como } \\
\text { didáctico, de } b\end{array}$ & $\begin{array}{l}\text { DE USO DEL LIGn } \\
\text { posee un interé } \\
\text { cterísticas intrín } \\
\text { deradamente. } \\
\text { ociado bajo. SU } \\
\text { elemento de trá } \\
\text { aja intensidad no }\end{array}$ & $\begin{array}{l}\text { n: } \\
\text { is medio (did } \\
\text { Actualmente e } \\
\text { Is valores pai } \\
\text { nsito y no com } \\
\text { conllevaría } u\end{array}$ & $\begin{array}{l}\text { láctico), si bien su buen estado de cor } \\
\text { vierten en un espacio cuyo potencial } \\
\text { el tránsito de montañeros por este LIGm } \\
\text { isajísticos y turísticos son relativame } \\
\text { no destino y atracción directa. Una pote } \\
\text { Ina degradación de sus valores. }\end{array}$ & $\begin{array}{l}\text { servación y sus } \\
\text { de uso podría } \\
\text { es moderado y } \\
\text { te bajos, pues } \\
\text { רciación de uso, }\end{array}$ \\
\hline
\end{tabular}




\begin{tabular}{|c|c|c|c|c|c|}
\hline \multicolumn{6}{|c|}{ LUGAR DE INTERÉS GEOMORFOLÓGICO: VALORACIÓN } \\
\hline Identificación & \multicolumn{3}{|c|}{$\begin{array}{l}\text { Nombre: Complejo morrénico y } \\
\text { canales de Amuesa }\end{array}$} & Lugar: Macizo Central & № 12 \\
\hline \multirow[t]{2}{*}{ Situación } & \multicolumn{5}{|c|}{ To municipal } \\
\hline & \multicolumn{3}{|l|}{ Coordenadas } & \multicolumn{2}{|l|}{ Altitud } \\
\hline Tipo de LIGm & \multicolumn{4}{|c|}{ LUGAR REPRESENTATIVO } & VALORACIÓN \\
\hline \multirow{10}{*}{$\begin{array}{l}\text { Valores } \\
\text { intrínsecos }\end{array}$} & \multicolumn{4}{|c|}{ Génesis (máximo 5) } & 5 \\
\hline & \multirow{3}{*}{ Morfología } & \multicolumn{3}{|c|}{ Morfoestructuras (máximo 5) } & 1 \\
\hline & & Formas de er & ssión & mo 5) & 3 \\
\hline & & Formas de ac & umul & (máximo 5) & 3 \\
\hline & \multirow[t]{2}{*}{ Dinámica: } & Heredados: ( & náxir & & 2 \\
\hline & & Activo: (máxi & no 5 & & 3 \\
\hline & \multicolumn{4}{|c|}{ Cronología (máximo 5) } & 3 \\
\hline & \multicolumn{4}{|c|}{ Litología (máximo 5) } & 1 \\
\hline & \multirow{2}{*}{\begin{tabular}{|l|} 
Estructura \\
\cline { 2 - 3 }
\end{tabular}} & \multicolumn{3}{|c|}{ Geológicas (máximo 5) } & 1 \\
\hline & & \multicolumn{3}{|c|}{ Sedimentarias (máximo (máximo 5)) } & 0 \\
\hline \multirow{11}{*}{$\begin{array}{l}\text { Valores } \\
\text { añadidos }\end{array}$} & & & & Valoración & 4,4 \\
\hline & \multicolumn{4}{|c|}{ Valoración paisajística y estética (10) } & 4 \\
\hline & \multirow{3}{*}{$\begin{array}{l}\text { Elementos } \\
\text { culturales (30) }\end{array}$} & \multicolumn{3}{|c|}{$\begin{array}{l}\text { Asociación a elementos de valor patrimonial } \\
\text { (máximo 10) }\end{array}$} & 1 \\
\hline & & \multicolumn{3}{|c|}{ Contendido cultural: (Máximo 10) } & 2 \\
\hline & & \multicolumn{3}{|c|}{ Contenido histórico: (máximo 10) } & 3 \\
\hline & \multirow{4}{*}{$\begin{array}{c}\text { Elementos } \\
\text { didácticos y } \\
\text { científicos (20) }\end{array}$} & \multicolumn{3}{|c|}{ Recursos pedagógicos (máximo 5) } & 2 \\
\hline & & \multicolumn{3}{|c|}{\begin{tabular}{|l|} 
Niveles pedagógicos: (máximo 5) \\
\end{tabular}} & 3 \\
\hline & & \multirow{2}{*}{\begin{tabular}{c|} 
Valor \\
Científico \\
\end{tabular}} & Áre & tíficas (máximo 5) & 4 \\
\hline & & & Rep & atividad científica (máx. 5) & 2 \\
\hline & Contenidos & Contenido & uríst & (áximo 5) & 0 \\
\hline & turísticos (10) & Atracción $t$ & urísti & áximo 5) & 2 \\
\hline & & & & Valoración & 3,2 \\
\hline & Accesibilidad & & & & 0 \\
\hline & Fragilidad & & & & 2 \\
\hline & Vulnerabilidad & & & & 2 \\
\hline Valores & Intensidad de us & & & & 2 \\
\hline de uso & Riesgo de degra & adación & & & 2 \\
\hline y gestión: & Estado de conse & ervación & & & 2 \\
\hline evaluación & Impactos & & & & 2 \\
\hline & Condiciones de & observación & & & 1 \\
\hline & Límite de cambi & io aceptable & & & 1 \\
\hline & & & & Valoración del uso & 7,7 \\
\hline & & & & VALORACIÓN GLOBAL & $2,2-3,2-7,7$ \\
\hline $\begin{array}{l}\text { ORIENTACIÓN } \\
\text { Valor in } \\
\text { valores añadid } \\
\text { derivado de su } \\
\text { paisajístico mo } \\
\text { LIGm. }\end{array}$ & $\begin{array}{l}\text { DE USO DEL LIGm } \\
\text { trínseco moderao } \\
\text { os, concentrados } \\
\text { conservación y } \\
\text { derado. Orientac }\end{array}$ & $\begin{array}{l}\text { do, con repres } \\
\text { s e los elem } \\
\text { baja fragilida } \\
\text { ción favorable }\end{array}$ & $\begin{array}{l}\text { enta } \\
\text { entos } \\
\text { dest } \\
\text { haci }\end{array}$ & $\begin{array}{l}\text { por la conjunción de eleme } \\
\text { ricos y literarios. El alto pa } \\
\text { avorecido por la escasa acc } \\
\text { so excursionista y cultural. }\end{array}$ & $\begin{array}{l}\text { ntos, pero altos } \\
\text { tencial de uso, } \\
\text { esibilidad. Valor } \\
\text { otenciación del }\end{array}$ \\
\hline
\end{tabular}




\begin{tabular}{|c|c|c|c|c|}
\hline \multicolumn{5}{|c|}{ LUGAR DE INTERÉS GEOMORFOLÓGICO: VALORACIÓN } \\
\hline Identificación & \multicolumn{2}{|c|}{$\begin{array}{c}\text { Nombre: Garganta } \\
\text { fluviokárstica del Cares }\end{array}$} & $\begin{array}{c}\text { Lugar: Macizo Central } \\
\text { Picos de Europa }\end{array}$ & № 13 \\
\hline \multirow[t]{2}{*}{ Situación } & \multicolumn{4}{|c|}{ To municipal: Cabrales (Asturias) y Valdeón (León) } \\
\hline & \multicolumn{3}{|c|}{\begin{tabular}{ll|l} 
Coordenadas: $x-347.145$ & $y$ - 4.790 .568 & Altitud: Entre $220-44$
\end{tabular}} & $40 \mathrm{~m}$ \\
\hline Tipo de LIGm & \multicolumn{3}{|c|}{ LUGAR REPRESENTATIVO } & VALORACIÓN \\
\hline \multirow{10}{*}{$\begin{array}{l}\text { Valores } \\
\text { intrínsecos }\end{array}$} & \multicolumn{3}{|c|}{ Génesis (máximo 5) } & 3 \\
\hline & \multirow{3}{*}{ Morfología } & \multicolumn{2}{|c|}{ Morfoestructuras (máximo 5) } & 5 \\
\hline & & Formas de er & osión (máximo 5) & 4 \\
\hline & & Formas de ac & umulación. (máximo 5) & 4 \\
\hline & \multirow[t]{2}{*}{ Dinámica: } & Heredados: ( & náximo 5) & 1 \\
\hline & & Activo: (máxi & mo 5) & 5 \\
\hline & \multicolumn{3}{|c|}{ Cronología (máximo 5) } & 3 \\
\hline & \multicolumn{3}{|c|}{ Litología (máximo 5) } & 1 \\
\hline & \multirow{2}{*}{ Estructura } & \multicolumn{2}{|c|}{ Geológicas (máximo 5) } & 1 \\
\hline & & \multicolumn{2}{|c|}{ Sedimentarias (máximo 5) } & 1 \\
\hline \multirow{11}{*}{$\begin{array}{l}\text { Valores } \\
\text { añadidos }\end{array}$} & & & Valoración & 5,6 \\
\hline & \multicolumn{3}{|c|}{ Valoración paisajística y estética (máximo 10) } & 8 \\
\hline & \multirow{3}{*}{$\begin{array}{c}\text { Elementos } \\
\text { culturales (30) }\end{array}$} & \multicolumn{2}{|c|}{$\begin{array}{l}\text { Asociación a elementos de valor patrimonial } \\
\text { (máximo 10) }\end{array}$} & 10 \\
\hline & & \multicolumn{2}{|c|}{ Contendido cultural: (máximo 10) } & 3 \\
\hline & & \multicolumn{2}{|c|}{ Contenido histórico: (máximo 10) } & 4 \\
\hline & \multirow{4}{*}{$\begin{array}{c}\text { Elementos } \\
\text { didácticos y } \\
\text { científicos (20) }\end{array}$} & \multicolumn{2}{|c|}{ Recursos pedagógicos (máximo 5) } & 5 \\
\hline & & \multicolumn{2}{|c|}{ Niveles pedagógicos (máximo 5) } & 4 \\
\hline & & \multirow{2}{*}{$\begin{array}{c}\text { Valor } \\
\text { Científico }\end{array}$} & Áreas científicas (máximo 5) & 1 \\
\hline & & & Representatividad científica (máx. 5) & 5 \\
\hline & \multirow{2}{*}{$\begin{array}{l}\text { Contenidos } \\
\text { turísticos (10) }\end{array}$} & Contenido & turístico: (Máximo 5) & 5 \\
\hline & & Atracción t & urística: (máximo 5) & 5 \\
\hline & & & Valoración & 7,1 \\
\hline & Accesibilidad & & & 2 \\
\hline & Fragilidad & & & 1 \\
\hline & Vulnerabilidad & & & 0 \\
\hline Valores & Intensidad de us & & & 0 \\
\hline de uso & Riesgo de degra & adación & & 0 \\
\hline y gestión: & Estado de conse & ervación & & 1 \\
\hline evaluación & Impactos & & & 0 \\
\hline & Condiciones de & observación & & 1 \\
\hline & Límite de cambi & io aceptable & & 0 \\
\hline & & & Valoración del uso & 2,8 \\
\hline & & & VALORACIÓN GLOBAL & $5,6 / 7,1 / 2,8$ \\
\hline $\begin{array}{l}\text { ORIENTACIÓN } \\
\text { EI LIGm } \\
\text { uno de los lugo } \\
\text { sus dos entrad } \\
\text { pendientes y } \\
\text { provocando im } \\
\text { necesaria una } \\
\text { garganta, la af } \\
\text { de salida y dest }\end{array}$ & $\begin{array}{l}\text { DE USO DEL LIGM } \\
\text { posee un valor in } \\
\text { Ires más visitado. } \\
\text { ys por Poncebos y } \\
\text { arreras físicas c } \\
\text { pactos puntuale. } \\
\text { yestión de los fluj } \\
\text { luencia de visitan } \\
\text { ino. }\end{array}$ & $\begin{array}{l}\text { n: } \\
\text { intrínseco mec } \\
\text { os, con flujos } \\
\text { y Caín. Aunqu } \\
\text { que impone } \\
\text { es graves, col } \\
\text { jos de visitant } \\
\text { ntes masiva } 9\end{array}$ & $\begin{array}{l}\text { io, así como un valor añadido alto. En lo } \\
\text { He visitantes por encimad e los } 450.000 / \\
\text { e la mayor parte de la garganta está intc } \\
\text { el medio, la intensidad de uso en el } \\
\text { riesgo de degradación y perdida de s } \\
\text { es concentrados en el itinerario lineal, en } \\
\text { enera además problemas de masificaciór }\end{array}$ & $\begin{array}{l}\text { actualidad es } \\
\text { año, contando } \\
\text { acta, dadas las } \\
\text { recorrido está } \\
\text { sus valores. Es } \\
\text { el fondo de la } \\
\text { en los puntos }\end{array}$ \\
\hline
\end{tabular}




\begin{tabular}{|c|c|c|c|c|}
\hline \multicolumn{5}{|c|}{ LUGAR DE INTERÉS GEOMORFOLÓGICO: VALORACIÓN } \\
\hline Identificación & \multicolumn{2}{|c|}{$\begin{array}{l}\text { Nombre: Canal de } \\
\text { Dobresengos }\end{array}$} & $\begin{array}{l}\text { Lugar: Macizo Central, Picos de } \\
\text { Europa }\end{array}$ & NNo 14 \\
\hline \multirow[t]{2}{*}{ Situación } & \multicolumn{4}{|c|}{ To municipal: Valdeón (León) } \\
\hline & \multicolumn{2}{|c|}{ Coordenadas: $x-348.759$} & \multicolumn{2}{|c|}{ Altitud: Entre $440-1.964 \mathrm{~m}$} \\
\hline Tipo de LIGm & \multicolumn{3}{|c|}{ LUGAR REPRESENTATIVO } & VALORACIÓN \\
\hline \multirow{10}{*}{$\begin{array}{l}\text { Valores } \\
\text { intrínsecos }\end{array}$} & \multicolumn{3}{|c|}{ Génesis (máximo 5) } & 4 \\
\hline & \multirow{3}{*}{ Morfología } & \multicolumn{2}{|c|}{ Morfoestructuras (máximo 5) } & 1 \\
\hline & & \multicolumn{2}{|c|}{ Formas de erosión (máximo 5) } & 5 \\
\hline & & \multicolumn{2}{|c|}{ Formas de acumulación. (máximo 5) } & 5 \\
\hline & \multirow[t]{2}{*}{ Dinámica: } & \multicolumn{2}{|c|}{ Heredados: (máximo 5) } & 2 \\
\hline & & \multicolumn{2}{|c|}{ Activo: (máximo 5) } & 4 \\
\hline & \multicolumn{3}{|c|}{ Cronología (máximo 5) } & 1 \\
\hline & \multicolumn{3}{|c|}{ Litología (máximo 5) } & 1 \\
\hline & \multirow[t]{2}{*}{ Estructura } & \multicolumn{2}{|c|}{ Geológicas (máximo 5) } & 1 \\
\hline & & \multicolumn{2}{|c|}{ Sedimentarias (máximo 5) } & 1 \\
\hline \multirow{11}{*}{$\begin{array}{l}\text { Valores } \\
\text { añadidos }\end{array}$} & & & Valoración & 5 \\
\hline & \multirow{4}{*}{$\begin{array}{c}\text { Valoración paisc } \\
\text { Elementos } \\
\text { culturales (30) }\end{array}$} & sajística y est & ética (máximo 10) & 4 \\
\hline & & $\begin{array}{l}\text { Asociación } \\
\text { (máximo 1C }\end{array}$ & $\begin{array}{l}\text { a elementos de valor patrimonial } \\
\text { D) }\end{array}$ & 1 \\
\hline & & Contendido & cultural: (máximo 10) & 0 \\
\hline & & Contenido & histórico: (máximo 10) & 1 \\
\hline & \multirow{4}{*}{$\begin{array}{c}\text { Elementos } \\
\text { didácticos y } \\
\text { científicos (20) }\end{array}$} & \multicolumn{2}{|c|}{ Recursos pedagógicos (máximo 5) } & 5 \\
\hline & & \multicolumn{2}{|c|}{ Niveles pedagógicos: (máximo 5) } & 4 \\
\hline & & Valor & Áreas científicas (máximo 5) & 3 \\
\hline & & Científico & Representatividad científica (máx. 5) & 4 \\
\hline & Contenidos & Contenido & urístico: (Máximo 5) & 2 \\
\hline & turísticos (10) & Atracción t & urística: (máximo 5) & 3 \\
\hline & & & Valoración & 3,9 \\
\hline & Accesibilidad & & & 2 \\
\hline & Fragilidad & & & 2 \\
\hline & Vulnerabilidad & & & 2 \\
\hline Valores & Intensidad de $u$ & & & 2 \\
\hline de uso & Riesgo de degro & adación & & 1 \\
\hline y gestión: & Estado de conse & ervación & & 2 \\
\hline evaluación & Impactos & & & 2 \\
\hline & Condiciones de & observación & & 1 \\
\hline & Límite de camb & io aceptable & & 1 \\
\hline & & & Valoración del uso & 8,3 \\
\hline & & & VALORACIÓN GLOBAL & $5 / 3,9 / 8,3$ \\
\hline $\begin{array}{l}\text { ORIENTACIÓN } \\
\text { EI LIGm } t \\
\text { y una buena c } \\
\text { pendientes exi } \\
\text { puede tener ir } \\
\text { limitaciones qu } \\
\text { potencial del LI }\end{array}$ & $\begin{array}{l}\text { DE USO DEL LIGm } \\
\text { tiene un valor int } \\
\text { accesibilidad. La } \\
\text { stentes implican } \\
\text { nplicaciones mor } \\
\text { le impone el me } \\
\text { Gm. Ni siquiera e }\end{array}$ & $\begin{array}{l}n: \\
\text { trínseco y aña } \\
\text { intensidad d } \\
\text { una activa } r \\
\text { rfológicas y } \\
\text { edio natural, } \\
\text { el montañero }\end{array}$ & $\begin{array}{l}\text { dido moderado. Posee un buen estado } \\
\text { el uso actual no supone un impacto. Si } \\
\text { norfodinámica, alteración de la pendier } \\
\text { dinámicas muy superiores a lo espera } \\
\text { con desniveles de casi } 2.000 \mathrm{~m} \text {, limita } \\
\text { frecuenta esta canal, el flujo es muy baj }\end{array}$ & $\begin{array}{l}\text { He conservación } \\
\text { bien las fuertes } \\
\text { te de la ladera } \\
\text { to. Además las } \\
\text { mucho el uso }\end{array}$ \\
\hline
\end{tabular}




\begin{tabular}{|c|c|c|c|c|}
\hline \multicolumn{5}{|c|}{ LUGAR DE INTERÉS GEOMORFOLÓGICO: VALORACIÓN } \\
\hline Identificación & \multicolumn{2}{|c|}{ Nombre: Canal de Asotín } & $\begin{array}{l}\text { Lugar: Macizo Central, Picos de } \\
\text { Europa }\end{array}$ & № 15 \\
\hline Situación & \multicolumn{4}{|c|}{ To municipal: Valdeón (León) } \\
\hline & \multicolumn{2}{|c|}{ Coordenadas: $x-347.265$} & \multicolumn{2}{|c|}{ Altitud: Entre $700-1.850 \mathrm{~m}$} \\
\hline Tipo de LIGm & \multicolumn{3}{|c|}{ LUGAR REPRESENTATIVO } & VALORACIÓN \\
\hline \multirow{10}{*}{$\begin{array}{l}\text { Valores } \\
\text { intrínsecos }\end{array}$} & \multicolumn{3}{|c|}{ Génesis (máximo 5) } & 4 \\
\hline & \multirow[t]{3}{*}{ Morfología } & \multicolumn{2}{|c|}{ Morfoestructuras (máximo 5) } & 1 \\
\hline & & Formas de e & rosión (máximo 5) & 4 \\
\hline & & Formas de a & cumulación. (máximo 5) & 5 \\
\hline & \multirow[t]{2}{*}{ Dinámica: } & Heredados: & (máximo 5) & 3 \\
\hline & & Activo: (máx & imo 5) & 5 \\
\hline & \multicolumn{3}{|c|}{ Cronología (máximo 5) } & 1 \\
\hline & \multicolumn{3}{|c|}{ Litología (máximo 5) } & 1 \\
\hline & \multirow{2}{*}{\begin{tabular}{|l|l} 
Estructura \\
\cline { 2 - 3 }
\end{tabular}} & \multicolumn{2}{|c|}{ Geológicas (máximo 5) } & 1 \\
\hline & & \multicolumn{2}{|c|}{ Sedimentarias (máximo 5) } & 1 \\
\hline \multirow{11}{*}{$\begin{array}{l}\text { Valores } \\
\text { añadidos }\end{array}$} & & & Valoración & 5,2 \\
\hline & \multirow{4}{*}{$\begin{array}{c}\text { Valoración pais } \\
\\
\text { Elementos } \\
\text { culturales (30) }\end{array}$} & ajística y est & ética (máximo 10) & 4 \\
\hline & & $\begin{array}{l}\text { Asociación } \\
\text { (máximo 1 } \\
\end{array}$ & $\begin{array}{l}\text { a elementos de valor patrimonial } \\
\text { 0) }\end{array}$ & 2 \\
\hline & & Contendidc & cultural: (máximo 10) & 0 \\
\hline & & Contenido & histórico: (máximo 10) & 1 \\
\hline & \multirow{4}{*}{$\begin{array}{c}\text { Elementos } \\
\text { didácticos y } \\
\text { científicos (20) }\end{array}$} & \multicolumn{2}{|c|}{ Recursos pedagógicos (máximo 5) } & 5 \\
\hline & & \multicolumn{2}{|c|}{ Niveles pedagógicos: (máximo 5) } & 4 \\
\hline & & \multirow{2}{*}{\begin{tabular}{|c|} 
Valor \\
Científico \\
\end{tabular}} & Áreas científicas (máximo 5) & 3 \\
\hline & & & Representatividad científica (máx. 5) & 4 \\
\hline & \multirow{2}{*}{$\begin{array}{c}\text { Contenidos } \\
\text { turísticos (10) }\end{array}$} & \multicolumn{2}{|c|}{ Contenido turístico: (Máximo 5) } & 2 \\
\hline & & \multicolumn{2}{|c|}{ Atracción turística: (máximo 5) } & 4 \\
\hline & & & Valoración & 4,1 \\
\hline \multirow{10}{*}{$\begin{array}{l}\text { Valores } \\
\text { de uso } \\
\text { y gestión: } \\
\text { evaluación }\end{array}$} & Accesibilidad & & & 2 \\
\hline & Fragilidad & & & 2 \\
\hline & Vulnerabilidad & & & 2 \\
\hline & Intensidad de $u$ & & & 1 \\
\hline & Riesgo de degrc & xdación & & 1 \\
\hline & Estado de cons & ervación & & 2 \\
\hline & Impactos & & & 2 \\
\hline & Condiciones de & observación & & 2 \\
\hline & Límite de camb & io aceptable & & 1 \\
\hline & & & Valoración del uso & 8,3 \\
\hline & & & VALORACIÓN GLOBAL & $5,2 / 4,1 / 8,3$ \\
\hline $\begin{array}{l}\text { ORIENTACIÓN } \\
\text { Valor int } \\
\text { Orientación fa } \\
\text { potencial de us }\end{array}$ & $\begin{array}{l}\text { DE USO DEL LIGn } \\
\text { rínseco moderac } \\
\text { Norable hacia un } \\
\text { o. }\end{array}$ & $\begin{array}{l}\text { u, con valor } \\
\text { uso pedagó }\end{array}$ & $\begin{array}{l}\text { es añadidos medios y un potencial de } \\
\text { gico, si bien los fuertes desniveles exist }\end{array}$ & $\begin{array}{l}\text { uso moderado. } \\
\text { entes frenan su }\end{array}$ \\
\hline
\end{tabular}




\begin{tabular}{|c|c|c|c|c|}
\hline \multicolumn{5}{|c|}{ LUGAR DE INTERÉS GEOMORFOLÓGICO: VALORACIÓN } \\
\hline Identificación & \multicolumn{2}{|c|}{$\begin{array}{l}\text { Nombre: Depresión } \\
\text { glaciokárstica de los Boches }\end{array}$} & $\begin{array}{l}\text { Lugar: Macizo Central, Picos de } \\
\text { Europa }\end{array}$ & Noo 16 \\
\hline \multirow[t]{2}{*}{ Situación } & \multicolumn{4}{|c|}{ To municipal: Cabrales (Asturias) } \\
\hline & \multicolumn{2}{|c|}{ Coordenadas: $x-351.426$} & Altitud: $2.099 m$ & \\
\hline Tipo de $L I G m$ & \multicolumn{3}{|c|}{ LUGAR REPRESENTANTIVO } & VALORACIÓN \\
\hline \multirow{10}{*}{$\begin{array}{l}\text { Valores } \\
\text { intrínsecos }\end{array}$} & \multicolumn{3}{|c|}{ Génesis (máximo 5) } & 2 \\
\hline & \multirow{3}{*}{ Morfología } & \multicolumn{2}{|c|}{ Morfoestructuras (máximo 5) } & 1 \\
\hline & & Formas de erc & osión (máximo 5) & 5 \\
\hline & & Formas de ac & umulación. (máximo 5) & 5 \\
\hline & \multirow[t]{2}{*}{ Dinámica: } & Heredados: $(n$ & máximo 5) & 4 \\
\hline & & Activo: (máxir & mo 5) & 5 \\
\hline & \multicolumn{3}{|c|}{ Cronología (máximo 5) } & 2 \\
\hline & \multicolumn{3}{|c|}{ Litología (máximo 5) } & 1 \\
\hline & \multirow{2}{*}{\begin{tabular}{|l|l|} 
Estructura & \\
\cline { 2 - 3 }
\end{tabular}} & \multicolumn{2}{|c|}{ Geológicas (máximo 5) } & 1 \\
\hline & & \multicolumn{2}{|c|}{ Sedimentarias (máximo 5) } & 1 \\
\hline \multirow{11}{*}{$\begin{array}{l}\text { Valores } \\
\text { añadidos }\end{array}$} & & & Valoración & 5,4 \\
\hline & \multicolumn{3}{|c|}{ Valoración paisajística y estética (máximo 10) } & 2 \\
\hline & \multirow{3}{*}{$\begin{array}{c}\text { Elementos } \\
\text { culturales (30) }\end{array}$} & \multicolumn{2}{|c|}{$\begin{array}{l}\text { Asociación a elementos de valor patrimonial } \\
\text { (máximo 10) }\end{array}$} & 0 \\
\hline & & \multicolumn{2}{|c|}{ Contendido cultural: (máximo 10) } & 2 \\
\hline & & \multicolumn{2}{|c|}{ Contenido histórico: (máximo 10) } & 0 \\
\hline & \multirow{4}{*}{$\begin{array}{c}\text { Elementos } \\
\text { didácticos y } \\
\text { científicos (20) }\end{array}$} & \multicolumn{2}{|c|}{ Recursos pedagógicos (máximo 5) } & 5 \\
\hline & & \multicolumn{2}{|c|}{ Niveles pedagógicos: (máximo 5) } & 5 \\
\hline & & Valor & Áreas científicas (máximo 5) & 3 \\
\hline & & Científico & Representatividad científica (máx. 5) & 4 \\
\hline & Contenidos & Contenido ts & urístico: (Máximo 5) & 2 \\
\hline & turísticos (10) & Atracción tu & urística: (máximo 5) & 3 \\
\hline & & & Valoración & 3,7 \\
\hline & Accesibilidad & & & 0 \\
\hline & Fragilidad & & & 2 \\
\hline & Vulnerabilidad & & & 2 \\
\hline Valores & Intensidad de u & & & 1 \\
\hline de uso & Riesgo de degr & adación & & 1 \\
\hline y gestión: & Estado de cons & ervación & & 1 \\
\hline evaluación & Impactos & & & 1 \\
\hline & Condiciones de & observación & & 0 \\
\hline & Límite de camb & bio aceptable & & 1 \\
\hline & & & Valoración del uso & 5 \\
\hline & & & VALORACIÓN GLOBAL & $5,4 / 3,7 / 5$ \\
\hline $\begin{array}{l}\text { ORIENTACIÓN } \\
\text { EI LIGn } \\
\text { escaso potenc } \\
\text { potencial turís } \\
\text { mala accesibili } \\
\text { en la gestiónd }\end{array}$ & $\begin{array}{l}\text { DE USO DEL LIGn } \\
\text { es del tipo de I } \\
\text { al turístico por } \\
\text { ico como es el N } \\
\text { dad y la existenc } \\
\text { el mismo. }\end{array}$ & $\begin{array}{l}\text { los de interés } \\
\text { sí mismo, sin } \\
\text { laranjo. Por ell } \\
\text { cia de un paso }\end{array}$ & $\begin{array}{l}\text { didáctico, con un valor intrínseco y aña } \\
\text { embargo está en la ruta hacia otro el } \\
\text { lo su intensidad de uso y frecuentación } \\
\text { para llegar a su fondo, deben de ser te }\end{array}$ & $\begin{array}{l}\text { dido moderado, } \\
\text { mento de gran } \\
\text { s moderada. La } \\
\text { hidos en cuenta }\end{array}$ \\
\hline
\end{tabular}




\begin{tabular}{|c|c|c|c|c|}
\hline \multicolumn{5}{|c|}{ LUGAR DE INTERÉS GEOMORFOLÓGICO: VALORACIÓN } \\
\hline Identificación & \multicolumn{2}{|c|}{$\begin{array}{l}\text { Nombre: } \\
\text { POLJÉ DE LIORDES }\end{array}$} & $\begin{array}{l}\text { Lugar: Macizo Central } \\
\text { Picos de Europa }\end{array}$ & № 17 \\
\hline \multirow[t]{2}{*}{ Situación } & \multicolumn{4}{|c|}{ To municipal } \\
\hline & \multicolumn{2}{|l|}{ Coordenadas } & Altitud & \\
\hline Tipo de LIGm & \multicolumn{3}{|c|}{ ELEMENTO SINGULAR } & VALORACIÓN \\
\hline \multirow{10}{*}{$\begin{array}{l}\text { Valores } \\
\text { intrínsecos }\end{array}$} & \multicolumn{3}{|c|}{ Génesis (máximo 5) } & 3 \\
\hline & \multirow{3}{*}{\begin{tabular}{|l|} 
Morfología \\
\cline { 2 - 2 }
\end{tabular}} & \multicolumn{2}{|c|}{ Morfoestructuras (máximo 5) } & 3 \\
\hline & & Formas de er & rosión (máximo 5) & 5 \\
\hline & & Formas de ac & cumulación. (máximo 5) & 1 \\
\hline & \multirow[t]{2}{*}{ Dinámica: } & Heredados: ( & (máximo 5) & 2 \\
\hline & & Activo: (máxi & imo 5) & 3 \\
\hline & \multicolumn{3}{|c|}{ Cronología (máximo 5) } & 4 \\
\hline & \multicolumn{3}{|c|}{ Litología (máximo 5) } & 2 \\
\hline & \multirow{2}{*}{\begin{tabular}{|l|l|} 
Estructura & \\
\cline { 2 - 3 } & \\
\end{tabular}} & \multicolumn{2}{|c|}{ Geológicas (máximo 5) } & 3 \\
\hline & & \multicolumn{2}{|c|}{ Sedimentarias (máximo 5) } & 1 \\
\hline \multirow{11}{*}{$\begin{array}{l}\text { Valores } \\
\text { añadidos }\end{array}$} & \multicolumn{3}{|r|}{ Valoración } & 5,2 \\
\hline & \multicolumn{3}{|c|}{ Valoración paisajística y estética (10) } & 2 \\
\hline & \multirow{3}{*}{$\begin{array}{c}\text { Elementos } \\
\text { culturales (30) }\end{array}$} & \multicolumn{2}{|c|}{$\begin{array}{l}\text { Asociación a elementos de valor patrimonial } \\
\text { (máximo 10) }\end{array}$} & 1 \\
\hline & & \multicolumn{2}{|c|}{ Contendido cultural: (Máximo 10) } & 0 \\
\hline & & \multicolumn{2}{|c|}{ Contenido histórico: (máximo 10) } & 1 \\
\hline & \multirow{4}{*}{$\begin{array}{l}\text { Elementos } \\
\text { didácticos y } \\
\text { científicos (20) }\end{array}$} & \multicolumn{2}{|c|}{ Recursos pedagógicos (máximo 5) } & 2 \\
\hline & & Niveles pec & dagógicos: (máximo 5) & 2 \\
\hline & & Valor & Áreas científicas (máximo 5) & 3 \\
\hline & & Científico & Representatividad científica (máx. 5) & 1 \\
\hline & Contenidos & Contenido & turístico: (Máximo 5) & 1 \\
\hline & turísticos (10) & Atracción $t$ & turística: (máximo 5) & 0 \\
\hline & & & Valoración & 1,8 \\
\hline & Accesibilidad & & & 0 \\
\hline & Fragilidad & & & 2 \\
\hline & Vulnerabilidad & & & 2 \\
\hline Valores & Intensidad de us & & & 2 \\
\hline de uso & Riesgo de degra & adación & & 2 \\
\hline y gestión: & Estado de conse & ervación & & 2 \\
\hline evaluación & Impactos & & & 2 \\
\hline & Condiciones de & observación & & 2 \\
\hline & Límite de cambi & io aceptable & & 2 \\
\hline & & & Valoración del uso & 8,8 \\
\hline & & & VALORACIÓN GLOBAL & $2,7-2-8,8$ \\
\hline $\begin{array}{l}\text { ORIENTACIÓN } \\
\text { Valor i } \\
\text { la baja acces } \\
\text { divulgación d }\end{array}$ & $\begin{array}{l}\text { DE USO DEL LIGm } \\
\text { rínseco moderad } \\
\text { ilidad. Uso excu } \\
\text { LIGm. }\end{array}$ & $\begin{array}{l}\text { n: } \\
\text { do, con escasc } \\
\text { ursionista, tu }\end{array}$ & $\begin{array}{l}\text { os valores añadidos y alto potencial de } \\
\text { Irístico y pedagógico de interés local. }\end{array}$ & $\begin{array}{l}\text { 1so, limitado por } \\
\text { Potenciación y }\end{array}$ \\
\hline
\end{tabular}




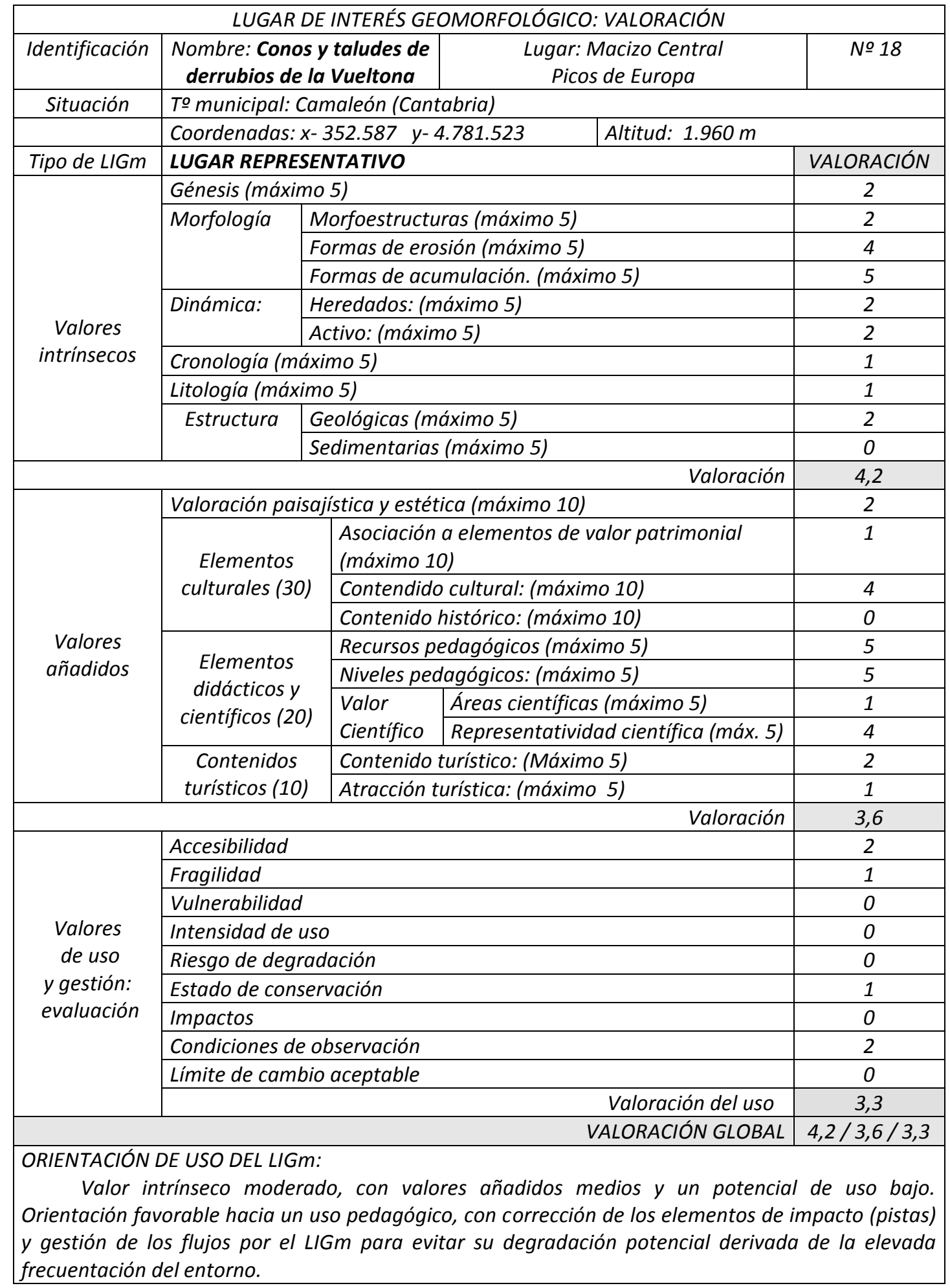




\begin{tabular}{|c|c|c|c|c|c|}
\hline \multicolumn{6}{|c|}{ LUGAR DE INTERÉS GEOMORFOLÓGICO: VALORACIÓN } \\
\hline Identificación & \multicolumn{3}{|c|}{ Nombre: GONFOLITAS DEL DUJE } & Lugar: Macizo central & № 19 \\
\hline \multirow[t]{2}{*}{ Situación } & \multicolumn{5}{|c|}{ To municipal: Sotres } \\
\hline & \multicolumn{3}{|c|}{ Coordenadas } & \multicolumn{2}{|l|}{ Altitud } \\
\hline Tipo de LIGm & \multicolumn{4}{|c|}{ ELEMENTO SINGULAR } & VALORACIÓN \\
\hline \multirow{10}{*}{$\begin{array}{l}\text { Valores } \\
\text { intrínsecos }\end{array}$} & \multicolumn{4}{|c|}{ Génesis (máximo 5) } & 3 \\
\hline & \multirow[t]{3}{*}{ Morfología } & \multicolumn{3}{|c|}{ Morfoestructuras (máximo 5) } & 0 \\
\hline & & \multicolumn{3}{|c|}{ Formas de erosión (máximo 5) } & 2 \\
\hline & & \multicolumn{3}{|c|}{ Formas de acumulación. (máximo 5) } & 2 \\
\hline & \multirow[t]{2}{*}{ Dinámica: } & \multicolumn{3}{|c|}{ Heredados: (máximo 5) } & 4 \\
\hline & & \multicolumn{3}{|c|}{ Activo: (máximo 5) } & 2 \\
\hline & \multicolumn{4}{|c|}{ Cronología (máximo 5) } & 3 \\
\hline & \multicolumn{4}{|c|}{ Litología (máximo 5) } & 1 \\
\hline & \multirow[t]{2}{*}{ Estructura } & \multicolumn{3}{|c|}{ Geológicas (máximo 5) } & 0 \\
\hline & & \multicolumn{3}{|c|}{ Sedimentarias (máximo 5) } & 2 \\
\hline \multirow{11}{*}{$\begin{array}{l}\text { Valores } \\
\text { añadidos }\end{array}$} & & & & Valoración & 3,8 \\
\hline & \multirow{4}{*}{$\begin{array}{l}\text { Valoración pais } \\
\text { Elementos } \\
\text { culturales (30) }\end{array}$} & sajística y est & ética & & 2 \\
\hline & & $\begin{array}{l}\text { Asociación } \\
\text { (máximo 10 }\end{array}$ & $\begin{array}{l}\text { a elen } \\
\text { D) }\end{array}$ & os de valor patrimonial. & 1 \\
\hline & & Contendidc & cultu & (Máximo 10) & 0 \\
\hline & & Contenido & históri & máximo 10) & 0 \\
\hline & \multirow{4}{*}{$\begin{array}{c}\text { Elementos } \\
\text { didácticos y } \\
\text { científicos (20) }\end{array}$} & \multicolumn{3}{|c|}{ Recursos pedagógicos (máximo 5) } & 3 \\
\hline & & \multicolumn{3}{|c|}{ Niveles pedagógicos: (máximo 5) } & 2 \\
\hline & & \multirow{2}{*}{$\begin{array}{c}\text { Valor } \\
\text { Científico } \\
\end{array}$} & Área & ntíficas (máximo 5) & 1 \\
\hline & & & Repr & tatividad científica (máx. 5) & 3 \\
\hline & Contenidos & Contenido & urísti & Máximo 5) & 0 \\
\hline & turísticos (10) & Atracción t & urístic & רáximo 5) & 0 \\
\hline & & & & Valoración & 1,7 \\
\hline & Accesibilidad & & & & 2 \\
\hline & Fragilidad & & & & 1 \\
\hline & Vulnerabilidad & & & & 1 \\
\hline Valores & Intensidad de u & & & & 2 \\
\hline de uso & Riesgo de degr & adación & & & 2 \\
\hline y gestión: & Estado de cons & ervación & & & 2 \\
\hline evaluación & Impactos & & & & 1 \\
\hline & Condiciones de & observación & & & 2 \\
\hline & Límite de camb & io aceptable & & & 1 \\
\hline & & & & Valoración del uso & 7,7 \\
\hline & & & & VALORACIÓN GLOBAL & $1,9-1,7-7,7$ \\
\hline $\begin{array}{r}\text { ORIENTACIÓN } \\
\text { Valor int } \\
\text { por su adscrip } \\
\text { divulgación del }\end{array}$ & $\begin{array}{l}\text { DE USO DEL LIGn } \\
\text { rínseco moderac } \\
\text { ión geomorfoló } \\
\text { LIGm. }\end{array}$ & $\begin{array}{l}\text { n: } \\
\text { do, con muy } \\
\text { gica. Uso c }\end{array}$ & ocos & $\begin{array}{l}\text { res añadidos y alto potencial } \\
\text { pedagógico de interés local. }\end{array}$ & $\begin{array}{l}\text { de uso, limitado } \\
\text { Potenciación y }\end{array}$ \\
\hline
\end{tabular}




\begin{tabular}{|c|c|c|c|c|}
\hline \multicolumn{5}{|c|}{ LUGAR DE INTERÉS GEOMORFOLÓGICO: VALORACIÓN } \\
\hline Identificación & \multicolumn{2}{|c|}{$\begin{array}{l}\text { Nombre: Cueva helada de } \\
\text { Peña Castil }\end{array}$} & $\begin{array}{l}\text { Lugar: Macizo Central, Picos de } \\
\text { Europa }\end{array}$ & NNo 20 \\
\hline \multirow[t]{2}{*}{ Situación } & \multicolumn{4}{|c|}{ To municipal: Cabrales (Asturias) } \\
\hline & \multirow{2}{*}{\multicolumn{3}{|c|}{ 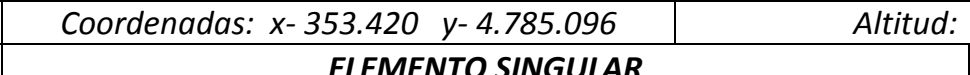 }} & $? m$ \\
\hline Tipo de LIGm & & & & VALORACIÓN \\
\hline \multirow{10}{*}{$\begin{array}{l}\text { Valores } \\
\text { intrínsecos }\end{array}$} & \multicolumn{3}{|c|}{ Génesis (máximo 5) } & 1 \\
\hline & \multirow{3}{*}{ Morfología } & \multicolumn{2}{|c|}{ Morfoestructuras (máximo 5) } & 1 \\
\hline & & \multicolumn{2}{|c|}{ Formas de erosión (máximo 5) } & 2 \\
\hline & & \multicolumn{2}{|c|}{ Formas de acumulación. (máximo 5) } & 4 \\
\hline & \multirow{2}{*}{ Dinámica } & \multicolumn{2}{|c|}{ Heredados: (máximo 5) } & 2 \\
\hline & & \multicolumn{2}{|c|}{ Activo: (máximo 5) } & 3 \\
\hline & \multicolumn{3}{|c|}{ Cronología (máximo 5) } & 2 \\
\hline & \multicolumn{3}{|c|}{ Litología (máximo 5) } & 1 \\
\hline & \multirow{2}{*}{ Estructura } & \multicolumn{2}{|c|}{ Geológicas (máximo 5) } & 1 \\
\hline & & \multicolumn{2}{|c|}{ Sedimentarias (máximo 5) } & 0 \\
\hline \multirow{11}{*}{$\begin{array}{l}\text { Valores } \\
\text { añadidos }\end{array}$} & & & Valoración & 3,4 \\
\hline & \multirow{4}{*}{$\begin{array}{c}\text { Valoración paisa } \\
\text { Elementos } \\
\text { culturales (30) }\end{array}$} & sajística y esté & tica (máximo 10) & 0 \\
\hline & & $\begin{array}{l}\text { Asociación } \\
\text { (máximo } 1 \\
\end{array}$ & $\begin{array}{l}\text { a elementos de valor patrimonial } \\
\text { () }\end{array}$ & 0 \\
\hline & & Contendidc & cultural: (máximo 10) & 1 \\
\hline & & Contenido & histórico: (máximo 10) & 1 \\
\hline & \multirow{4}{*}{$\begin{array}{c}\text { Elementos } \\
\text { didácticos y } \\
\text { científicos (20) }\end{array}$} & \multicolumn{2}{|c|}{ Recursos pedagógicos (máximo 5) } & 2 \\
\hline & & \multicolumn{2}{|c|}{ Niveles pedagógicos (máximo 5) } & 1 \\
\hline & & \multirow{2}{*}{$\begin{array}{c}\text { Valor } \\
\text { Científico }\end{array}$} & Áreas científicas (máximo 5) & 2 \\
\hline & & & Representatividad científica (máx. 5) & 3 \\
\hline & Contenidos & Contenido & urístico: (Máximo 5) & 1 \\
\hline & turísticos (10) & Atracción t & urística: (máximo 5) & 3 \\
\hline & & & Valoración & 2 \\
\hline & Accesibilidad & & & 0 \\
\hline & Fragilidad & & & 0 \\
\hline & Vulnerabilidad & & & 2 \\
\hline Valores & Intensidad de us & & & 2 \\
\hline de uso & Riesgo de degra & adación & & 0 \\
\hline y gestión: & Estado de conse & ervación & & 2 \\
\hline evaluación & Impactos & & & 2 \\
\hline & Condiciones de & observación & & 0 \\
\hline & Límite de cambi & io aceptable & & 0 \\
\hline & & & Valoración del uso & 4,4 \\
\hline & & & VALORACIÓN GLOBAL & $3,4 / 2 / 4,4$ \\
\hline $\begin{array}{l}\text { ORIENTACIÓN } \\
\text { Valor in } \\
\text { estratificado el } \\
\text { por su mala inc } \\
\text { potenciación d } \\
\text { flujo de visitant }\end{array}$ & $\begin{array}{l}\text { DE USO DEL LIGm } \\
\text { trínseco y moder } \\
\text { su interior le do } \\
\text { ccesibilidad. Orie } \\
\text { el LIGm, pues su } \\
\text { es deteriorase su }\end{array}$ & $\begin{array}{l}\text { rado bajo po } \\
\text { a un interés c } \\
\text { ientación dep } \\
\text { u carácter fró } \\
\text { us valores nat }\end{array}$ & $\begin{array}{l}\text { su exclusividad kárstica, si bien la exi } \\
\text { entífico añadido. Su potencial de uso } \\
\text { rtivo-científica favorable a un uso pres } \\
\text { gil podría suponer que un incremento } \\
\text { urales. }\end{array}$ & $\begin{array}{l}\text { tencia de hielo } \\
\text { bajo, limitado } \\
\text { rvacionista, sin } \\
\text { importante del }\end{array}$ \\
\hline
\end{tabular}




\begin{tabular}{|c|c|c|c|c|c|}
\hline \multicolumn{6}{|c|}{ LUGAR DE INTERÉS GEOMORFOLÓGICO: VALORACIÓN } \\
\hline Identificación & \multicolumn{3}{|c|}{ Nombre: Torca del Cerro (-1.589m) } & Lugar: Macizo Central & № 21 \\
\hline \multirow[t]{2}{*}{ Situación } & \multicolumn{5}{|c|}{ To municipal } \\
\hline & \multicolumn{3}{|l|}{ Coordenadas } & \multicolumn{2}{|l|}{ Altitud } \\
\hline Tipo de LIGm & \multicolumn{4}{|c|}{ LUGAR REPRESENTATIVO } & VALORACIÓN \\
\hline \multirow{10}{*}{$\begin{array}{l}\text { Valores } \\
\text { intrínsecos }\end{array}$} & \multicolumn{4}{|c|}{ Génesis (máximo 5) } & 2 \\
\hline & \multirow{3}{*}{ Morfología } & \multicolumn{3}{|c|}{ Morfoestructuras (máximo 5) } & 2 \\
\hline & & \multicolumn{3}{|c|}{ Formas de erosión (máximo 5) } & 2 \\
\hline & & \multicolumn{3}{|c|}{ Formas de acumulación. (máximo 5) } & 2 \\
\hline & \multirow{2}{*}{ Dinámica } & \multicolumn{3}{|c|}{ Heredados: (máximo 5) } & 1 \\
\hline & & \multicolumn{3}{|c|}{ Activo: (máximo 5) } & 3 \\
\hline & \multicolumn{4}{|c|}{ Cronología (máximo 5) } & 1 \\
\hline & \multicolumn{4}{|c|}{ Litología (máximo 5) } & 1 \\
\hline & \multirow{2}{*}{ Estructura } & \multicolumn{3}{|c|}{ Geológicas (máximo 5) } & 1 \\
\hline & & \multicolumn{3}{|c|}{ Sedimentarias (máximo 5) } & 0 \\
\hline & & & & Valoración & 1,5 \\
\hline \multirow{10}{*}{$\begin{array}{l}\text { Valores } \\
\text { añadidos }\end{array}$} & \multicolumn{4}{|c|}{ Valoración paisajística y estética (10) } & 0 \\
\hline & \multirow{3}{*}{$\begin{array}{c}\text { Elementos } \\
\text { culturales (30) }\end{array}$} & \multicolumn{3}{|c|}{$\begin{array}{l}\text { Asociación a elementos de valor patrimonial } \\
\text { (máximo 10) }\end{array}$} & 0 \\
\hline & & \multicolumn{3}{|c|}{ Contendido cultural: (Máximo 10) } & 1 \\
\hline & & \multicolumn{3}{|c|}{ Contenido histórico: (máximo 10) } & 1 \\
\hline & & Recursos $p$ & edagógic & os (máximo 5) & 2 \\
\hline & didácticosy & Niveles pec & lagógico & (máximo 5) & 1 \\
\hline & científicos (20) & Valor & Áreas c & ientíficas (máximo 5) & 2 \\
\hline & & Científico & Represe & ntatividad científica (máx. 5) & 4 \\
\hline & Contenidos & Contenido & turístico: & 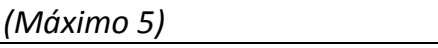 & 0 \\
\hline & turísticos (10) & Atracción $t$ & urística: & (máximo 5) & 1 \\
\hline & & & & Valoración & 1,7 \\
\hline & Accesibilidad & & & & 0 \\
\hline & Fragilidad & & & & 1 \\
\hline & Vulnerabilidad & & & & 2 \\
\hline Valores & Intensidad de us & & & & 2 \\
\hline de uso & Riesgo de degra & adación & & & 0 \\
\hline y gestión: & Estado de conse & ervación & & & 2 \\
\hline evaluación & Impactos & & & & 2 \\
\hline & Condiciones de & observación & & & 0 \\
\hline & Límite de cambi & io aceptable & & & 0 \\
\hline & & & & Valoración del uso & 5 \\
\hline & & & & VALORACIÓN GLOBAL & $1,5-1,7-5$ \\
\hline $\begin{array}{r}\text { ORIENTACIÓN } \\
\text { Valor } \\
\text { valores añadid } \\
\text { los medios sub } \\
\text { sin potenciació }\end{array}$ & $\begin{array}{l}\text { DE USO DEL LIGm } \\
\text { intrínseco modeI } \\
\text { os, y un potencia } \\
\text { terráneos. Orien } \\
\text { n del LIGm. }\end{array}$ & $\begin{array}{l}\text { : } \\
\text { erado por su } \\
\text { al de uso baj } \\
\text { ntación depo }\end{array}$ & $\begin{array}{l}\text { exclusi } \\
\text { o, limita } \\
\text { rtivo-ciel }\end{array}$ & $\begin{array}{l}\text { idad kárstica, muy representc } \\
\text { do por el carácter inaccesible y } \\
\text { tífica favorable hacia un uso c }\end{array}$ & $\begin{array}{l}\text { ivo, con bajos } \\
\text { la fragilidad de } \\
\text { nservacionista, }\end{array}$ \\
\hline
\end{tabular}




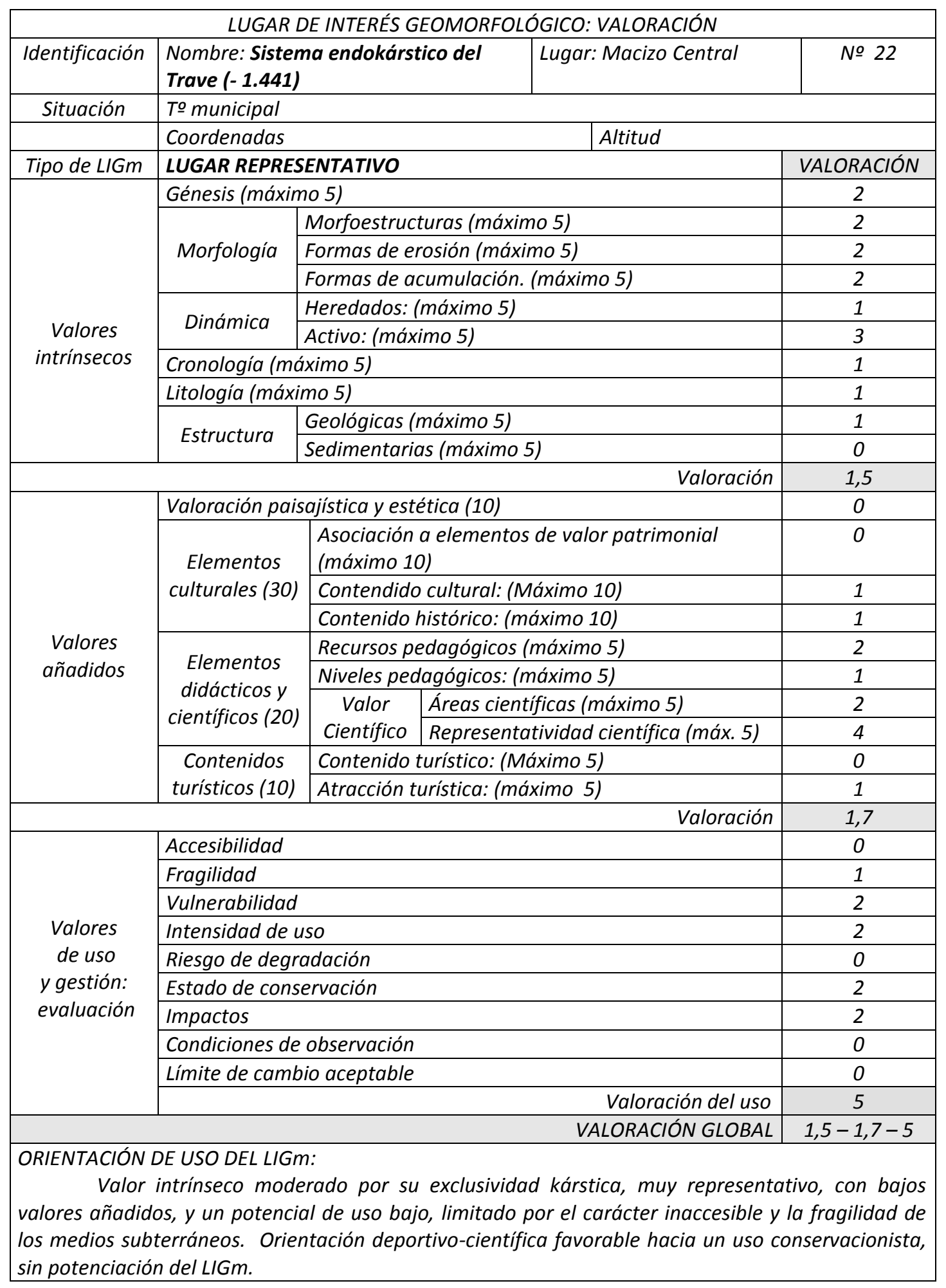




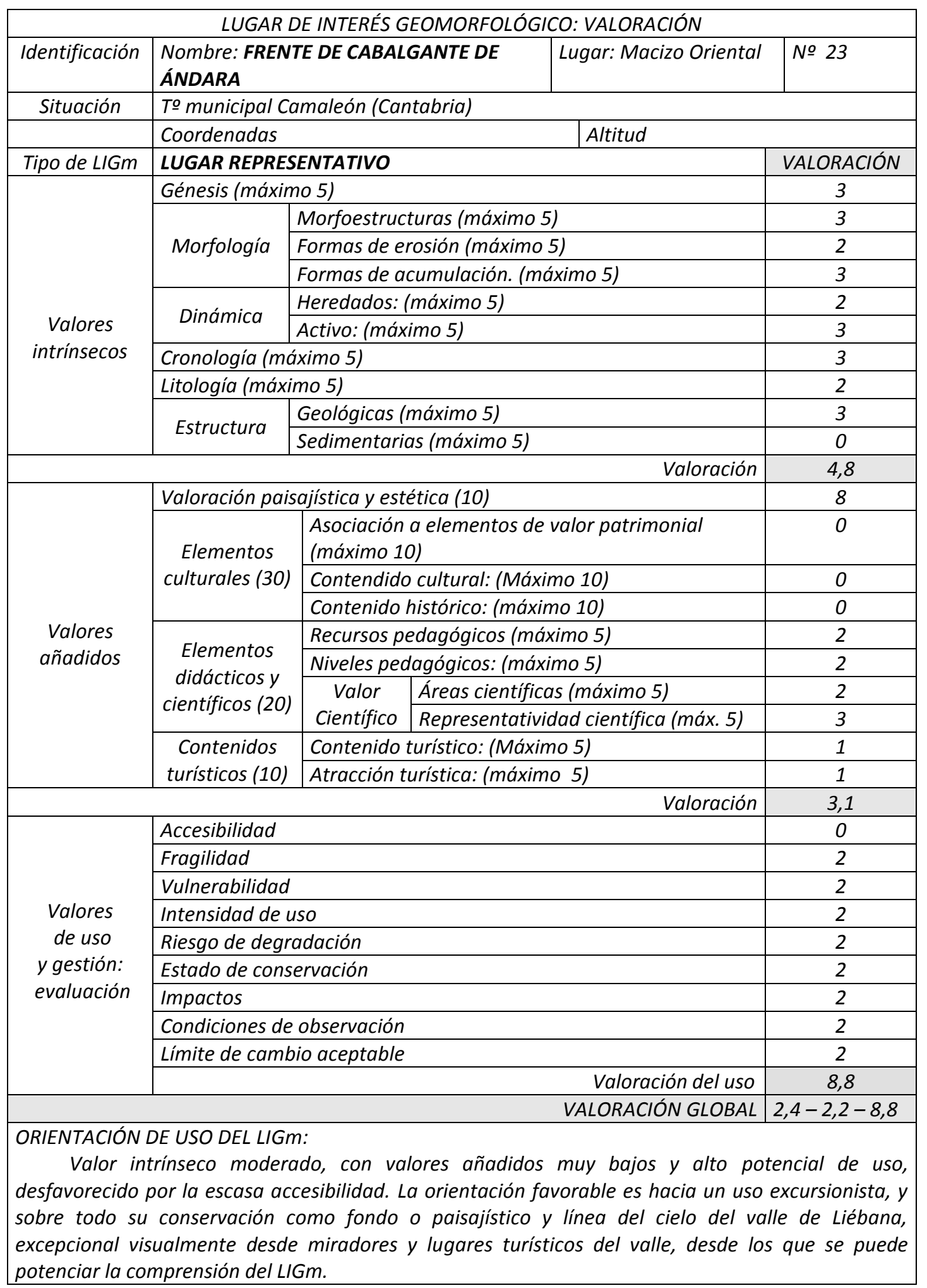




\begin{tabular}{|c|c|c|c|c|c|}
\hline \multicolumn{6}{|c|}{ LUGAR DE INTERÉS GEOMORFOLÓGICO: VALORACIÓN } \\
\hline Identificación & \multicolumn{3}{|c|}{ Nombre: Garganta de Urdón } & $\begin{array}{l}\text { Lugar: Macizo Oriental } \\
\text { Picos de Europa }\end{array}$ & NNo 24 \\
\hline \multirow[t]{2}{*}{ Situación } & \multicolumn{5}{|c|}{ To municipal: La Hermida (Cantabria) } \\
\hline & \multicolumn{3}{|c|}{ Coordenadas } & \multirow[t]{2}{*}{ Altitud: } & \\
\hline Tipo de LIGm & \multicolumn{3}{|c|}{ LUGAR REPRESENTATIVO } & & VALORACIÓN \\
\hline \multirow{10}{*}{$\begin{array}{l}\text { Valores } \\
\text { intrínsecos }\end{array}$} & \multicolumn{4}{|c|}{ Génesis (máximo 5) } & 3 \\
\hline & \multirow{3}{*}{ Morfología } & \multicolumn{3}{|c|}{ Morfoestructuras (máximo 5) } & 5 \\
\hline & & \multicolumn{3}{|c|}{ Formas de erosión (máximo 5) } & 4 \\
\hline & & \multicolumn{3}{|c|}{ Formas de acumulación. (máximo 5) } & 4 \\
\hline & \multirow{2}{*}{ Dinámica } & \multicolumn{3}{|c|}{ Heredados: (máximo 5) } & 1 \\
\hline & & \multicolumn{3}{|c|}{ Activo: (máximo 5) } & 5 \\
\hline & \multicolumn{4}{|c|}{ Cronología (máximo 5) } & 3 \\
\hline & \multicolumn{4}{|c|}{ Litología (máximo 5) } & 1 \\
\hline & \multirow{2}{*}{ Estructura } & \multicolumn{3}{|c|}{ Geológicas (máximo 5) } & 1 \\
\hline & & \multicolumn{3}{|c|}{ Sedimentarias (máximo 5) } & 1 \\
\hline \multirow{11}{*}{$\begin{array}{l}\text { Valores } \\
\text { añadidos }\end{array}$} & \multicolumn{4}{|r|}{ Valoración } & 5,6 \\
\hline & \multicolumn{4}{|c|}{ Valoración paisajística y estética (máximo 10) } & 8 \\
\hline & \multirow{3}{*}{$\begin{array}{l}\text { Elementos } \\
\text { culturales (30) }\end{array}$} & \multicolumn{3}{|c|}{$\begin{array}{l}\text { Asociación a elementos de valor patrimonial } \\
\text { (máximo 10) }\end{array}$} & 6 \\
\hline & & \multicolumn{3}{|c|}{ Contendido cultural: (máximo 10) } & 3 \\
\hline & & Contenido & histórico & imo 10) & 4 \\
\hline & & Recursos p & edagógi & ximo 5) & 4 \\
\hline & Elementos & Niveles peo & agógico & ximo 5) & 3 \\
\hline & científicos (20) & Valor & Áreas C & as (máximo 5) & 2 \\
\hline & & Científico & Repres & idad científica (máx. 5) & 4 \\
\hline & Contenidos & Contenido & turístico & mo 5) & 4 \\
\hline & turísticos (10) & Atracción $t$ & urística: & no 5) & 4 \\
\hline & & & & Valoración & 7 \\
\hline & Accesibilidad & & & & 0 \\
\hline & Fragilidad & & & & 2 \\
\hline & Vulnerabilidad & & & & 2 \\
\hline Valores & Intensidad de u & & & & 1 \\
\hline de uso & Riesgo de degrc & adación & & & 2 \\
\hline y gestión: & Estado de conse & ervación & & & 2 \\
\hline evaluación & Impactos & & & & 1 \\
\hline & Condiciones de & observación & & & 2 \\
\hline & Límite de camb & io aceptable & & & 2 \\
\hline & & & & Valoración del uso & 7,7 \\
\hline & & & & VALORACIÓN GLOBAL & $5,6 / 7 / 7,7$ \\
\hline $\begin{array}{l}\text { ORIENTACIÓN } \\
\text { EI LIG } \\
\text { elemento paiso } \\
\text { la pista minero } \\
\text { que impone e } \\
\text { graves. Es una } \\
\text { valor de sus as }\end{array}$ & $\begin{array}{l}\text { DE USO DEL LIGn } \\
m \text { posee un va } \\
\text { jístico de primer } \\
\text { La mayor parte } \\
\text { medio, aunque } \\
\text { ruta turística lir } \\
\text { ectos intrínseco }\end{array}$ & $\begin{array}{l}\text { lor intrínsec } \\
\text { orden, pero } \\
\text { de la garga } \\
\text { el uso hidr } \\
\text { nitada por lo } \\
\text { s, sólo en los }\end{array}$ & $\begin{array}{l}\text { medic } \\
\text { la dificu } \\
\text { nta estó } \\
\text { peléctric } \\
\text { propia } \\
\text { lugares }\end{array}$ & $\begin{array}{l}\text { adido y de gestión alto. } \\
\text { acceso canaliza la alta fr } \\
\text { a, dadas las pendientes y } \\
\text { a la hidrología con imp } \\
\text { del recorrido que requie } \\
\text { les. }\end{array}$ & $\begin{array}{l}\text { Constituye un } \\
\text { cuentación por } \\
\text { barreras físicas } \\
\text { ctos puntuales } \\
\text { re la puesta en }\end{array}$ \\
\hline
\end{tabular}




\begin{tabular}{|c|c|c|c|c|c|}
\hline \multicolumn{6}{|c|}{ LUGAR DE INTERÉS GEOMORFOLÓGICO: VALORACIÓN } \\
\hline Identificación & \multicolumn{3}{|c|}{ Nombre: Nunatak de Macondiú } & $\begin{array}{l}\text { ar: Macizo Ándara } \\
\text { Picos de Europa }\end{array}$ & NNo 25 \\
\hline Situación & \multicolumn{5}{|c|}{ To municipal: La Hermida (Cantabria) } \\
\hline & \multicolumn{3}{|c|}{ Coordenadas: } & \multicolumn{2}{|l|}{ Altitud: } \\
\hline Tipo de LIGm & \multicolumn{4}{|c|}{ LUGAR REPRESENTATIVO } & VALORACIÓN \\
\hline \multirow{10}{*}{$\begin{array}{l}\text { Valores } \\
\text { intrínsecos }\end{array}$} & \multicolumn{4}{|c|}{ Génesis (máximo 5) } & 4 \\
\hline & \multirow{3}{*}{ Morfología } & \multicolumn{3}{|c|}{ Morfoestructuras (máximo 5) } & 1 \\
\hline & & \multicolumn{3}{|c|}{ Formas de erosión (máximo 5) } & 3 \\
\hline & & \multicolumn{3}{|c|}{ Formas de acumulación. (máximo 5) } & 1 \\
\hline & \multirow{2}{*}{ Dinámica } & \multicolumn{3}{|c|}{ Heredados: (máximo 5) } & 4 \\
\hline & & \multicolumn{3}{|c|}{ Activo: (máximo 5) } & 2 \\
\hline & \multicolumn{4}{|c|}{ Cronología (máximo 5) } & 3 \\
\hline & \multicolumn{4}{|c|}{ Litología (máximo 5) } & 1 \\
\hline & \multirow{2}{*}{ Estructura } & \multicolumn{3}{|c|}{ Geológicas (máximo 5) } & 1 \\
\hline & & \multicolumn{3}{|c|}{ Sedimentarias (máximo 5) } & 2 \\
\hline \multirow{11}{*}{$\begin{array}{l}\text { Valores } \\
\text { añadidos }\end{array}$} & & & & Valoración & 4,4 \\
\hline & \multicolumn{4}{|c|}{ Valoración paisajística y estética (máximo 10) } & 6 \\
\hline & \multirow{3}{*}{$\begin{array}{c}\text { Elementos } \\
\text { culturales (30) }\end{array}$} & \multicolumn{3}{|c|}{$\begin{array}{l}\text { Asociación a elementos de valor patrimonial (máximo } \\
10)\end{array}$} & 1 \\
\hline & & \multicolumn{3}{|c|}{ Contendido cultural: (máximo 10) } & 1 \\
\hline & & \multicolumn{3}{|c|}{ Contenido histórico: (máximo 10) } & 2 \\
\hline & & \multicolumn{3}{|c|}{ Recursos pedagógicos (máximo 5) } & 3 \\
\hline & Elementos & Niveles pedo & ógi & & 3 \\
\hline & científicos (20) & Valor & & áximo 5) & 3 \\
\hline & & Científico & & ientífica (máximo 5) & 2 \\
\hline & Contenidos & Contenido tc & ístic & & 2 \\
\hline & turísticos (10) & Atracción tu & sticc & & 2 \\
\hline & & & & Valoración & 4,3 \\
\hline & Accesibilidad & & & & 1 \\
\hline & Fragilidad & & & & 2 \\
\hline & Vulnerabilidad & & & & 2 \\
\hline Valores & Intensidad de us & & & & 2 \\
\hline de uso & Riesgo de degra & adación & & & 2 \\
\hline y gestión: & Estado de conse & ervación & & & 2 \\
\hline evaluación & Impactos & & & & 1 \\
\hline & Condiciones de & observación & & & 2 \\
\hline & Límite de cambi & io aceptable & & & 2 \\
\hline & & & & Valoración del uso & 8,8 \\
\hline & & & & VALORACIÓN GLOBAL & $4,4-4,3-8,8$ \\
\hline $\begin{array}{l}\text { ORIENTACIÓN } \\
\text { EI LIGm } \\
\text { envergadura, a } \\
\text { mala accesibili } \\
\text { con los elemen } \\
\text { y expresivo. }\end{array}$ & $\begin{array}{l}\text { DE USO DEL LIGm } \\
\text { tiene moderados } \\
\text { sí como relación } \\
\text { dad. Su orientacic } \\
\text { tos culturales (mi }\end{array}$ & $\begin{array}{l}n: \\
\text { s valores intrí } \\
\text { con otros eler } \\
\text { ión es pues ha } \\
\text { nineros de su e }\end{array}$ & $\begin{array}{l}\text { seco } \\
\text { ent } \\
\text { a la } \\
\text { torn }\end{array}$ & $\begin{array}{l}\text { embargo su posición } \\
\text { alto valor de uso, sólc } \\
\text { sajística de educación, } \\
\text { tes } L I G m \text {, desde los qu }\end{array}$ & $\begin{array}{l}\text { en el macizo y } \\
\text { limitado por su } \\
\text { en combinación } \\
\text { e es bien visible }\end{array}$ \\
\hline
\end{tabular}




\begin{tabular}{|c|c|c|c|c|c|}
\hline \multicolumn{6}{|c|}{ LUGAR DE INTERÉS GEOMORFOLÓGICO: VALORACIÓN } \\
\hline Identificación & \multicolumn{3}{|c|}{$\begin{array}{l}\text { Nombre: Artesa glaciokárstica y lago de } \\
\text { Ándara }\end{array}$} & $\begin{array}{l}\text { Lugar: Macizo Ándara } \\
\text { Picos de Europa }\end{array}$ & № 26 \\
\hline \multirow[t]{2}{*}{ Situación } & \multicolumn{5}{|c|}{ To municipal: La Hermida (Cantabria) } \\
\hline & \multicolumn{3}{|c|}{ Coordenadas } & \begin{tabular}{l|l} 
Altitud: \\
\end{tabular} & \\
\hline Tipo de LIGm & \multicolumn{4}{|c|}{ LUGAR REPRESENTATIVO } & VALORACIÓN \\
\hline \multirow{10}{*}{$\begin{array}{l}\text { Valores } \\
\text { intrínsecos }\end{array}$} & \multicolumn{4}{|c|}{ Génesis (máximo 5) } & 5 \\
\hline & \multirow{3}{*}{ Morfología } & \multicolumn{3}{|c|}{ Morfoestructuras (máximo 5) } & 3 \\
\hline & & \multicolumn{3}{|c|}{ Formas de erosión (máximo 5) } & 3 \\
\hline & & \multicolumn{3}{|c|}{ Formas de acumulación. (máximo 5) } & 3 \\
\hline & \multirow{2}{*}{ Dinámica } & \multicolumn{3}{|c|}{ Heredados: (máximo 5) } & 4 \\
\hline & & \multicolumn{3}{|c|}{ Activo: (máximo 5) } & 3 \\
\hline & \multicolumn{4}{|c|}{ Cronología (máximo 5) } & 3 \\
\hline & \multicolumn{4}{|c|}{ Litología (máximo 5) } & 2 \\
\hline & \multirow{3}{*}{ Estructura } & \multicolumn{3}{|c|}{ Geológicas (máximo 5) } & 2 \\
\hline & & \multicolumn{3}{|c|}{ Sedimentarias (máximo 5) } & 3 \\
\hline \multirow{11}{*}{$\begin{array}{l}\text { Valores } \\
\text { añadidos }\end{array}$} & & & & Valoración & 6,2 \\
\hline & \multirow{4}{*}{$\begin{array}{c}\text { Valoración paisc } \\
\text { Elementos } \\
\text { culturales (30) }\end{array}$} & isajistica y esté & ca (máximo & & 8 \\
\hline & & $\begin{array}{l}\text { Asociación o } \\
\text { 10) }\end{array}$ & lementos d & r patrimonial (máximo & 4 \\
\hline & & Contendido & Iltural: (máx & & 4 \\
\hline & & Contenido $h$ & tórico: (máx & & 3 \\
\hline & \multirow{4}{*}{$\begin{array}{c}\text { Elementos } \\
\text { didácticos y } \\
\text { científicos (20) }\end{array}$} & \multicolumn{3}{|c|}{ Recursos pedagógicos (máximo 5) } & 4 \\
\hline & & \multicolumn{3}{|c|}{ Niveles pedagógicos: (máximo 5) } & 4 \\
\hline & & \multirow{2}{*}{$\begin{array}{c}\text { Valor } \\
\text { Científico }\end{array}$} & \multicolumn{2}{|c|}{ Áreas cientificas (máximo 5) } & 5 \\
\hline & & & Represent & ad cientifica (máximo 5) & 4 \\
\hline & Contenidos & Contenido ts & ístico: (Máx & & 4 \\
\hline & turísticos (10) & Atracción tu & stica: (máxil & & 3 \\
\hline & & & & Valoración & 7 \\
\hline & Accesibilidad & & & & 1 \\
\hline & Fragilidad & & & & 2 \\
\hline & Vulnerabilidad & & & & 2 \\
\hline Valores & Intensidad de $u$ & & & & 2 \\
\hline de uso & Riesgo de degro & radación & & & 2 \\
\hline y gestión: & Estado de conse & servación & & & 1 \\
\hline evaluación & Impactos & & & & 0 \\
\hline & Condiciones de & observación & & & 2 \\
\hline & Límite de camb & bio aceptable & & & 2 \\
\hline & & & & Valoración del uso & 7,7 \\
\hline & & & & VALORACIÓN GLOBAL & $6,2-7-7,7$ \\
\hline $\begin{array}{l}\text { ORIENTACIÓN } \\
\text { EI LIGm t } \\
\text { uso deriva de I } \\
\text { dañe un medio } \\
\text { un ejemplo de } \\
\text { recientes de res } \\
\text { puesta en valo } \\
\text { de alta montar } \\
\text { que desvirtúen }\end{array}$ & $\begin{array}{l}\text { E USO DEL LIGm } \\
\text { ene unos elevad } \\
\text { intensa human } \\
\text { ya muy castigad } \\
\text { los impactos } n \\
\text { tauración implic } \\
\text { educativo, cien } \\
\text { a y de la histori } \\
\text { el paisaje o ajarc }\end{array}$ & $\begin{array}{l}\text { m: } \\
\text { dos valores en } \\
\text { nización, con ir } \\
\text { do. Es un paisa } \\
\text { mineros en el } \\
\text { ican un deterio } \\
\text { ntífico y excurs } \\
\text { ia humana y n } \\
\text { dinen la zona. }\end{array}$ & $\begin{array}{l}\text { dos los asp } \\
\text { bactos mine } \\
\text { minero en } \\
\text { nedio y su } \\
\text { de las part } \\
\text { nista-geotu } \\
\text { tura, y en } n\end{array}$ & $\begin{array}{l}\text { con potencialidad de uso. } \\
\text { ue impiden que una eleva } \\
\text { se inserta la destrucción } \\
\text { sibilidad de restauración. } \\
\text { uperadas de modo natura } \\
\text { como modelo de agresión } \\
\text { caso el inicio de trabajos }\end{array}$ & $\begin{array}{l}\text { u alto valor de } \\
\text { frecuentación } \\
\text { I lago. Es pues, } \\
\text { as propuestas } \\
\text { Se aconseja su } \\
\text { la naturaleza } \\
\text { e restauración }\end{array}$ \\
\hline
\end{tabular}




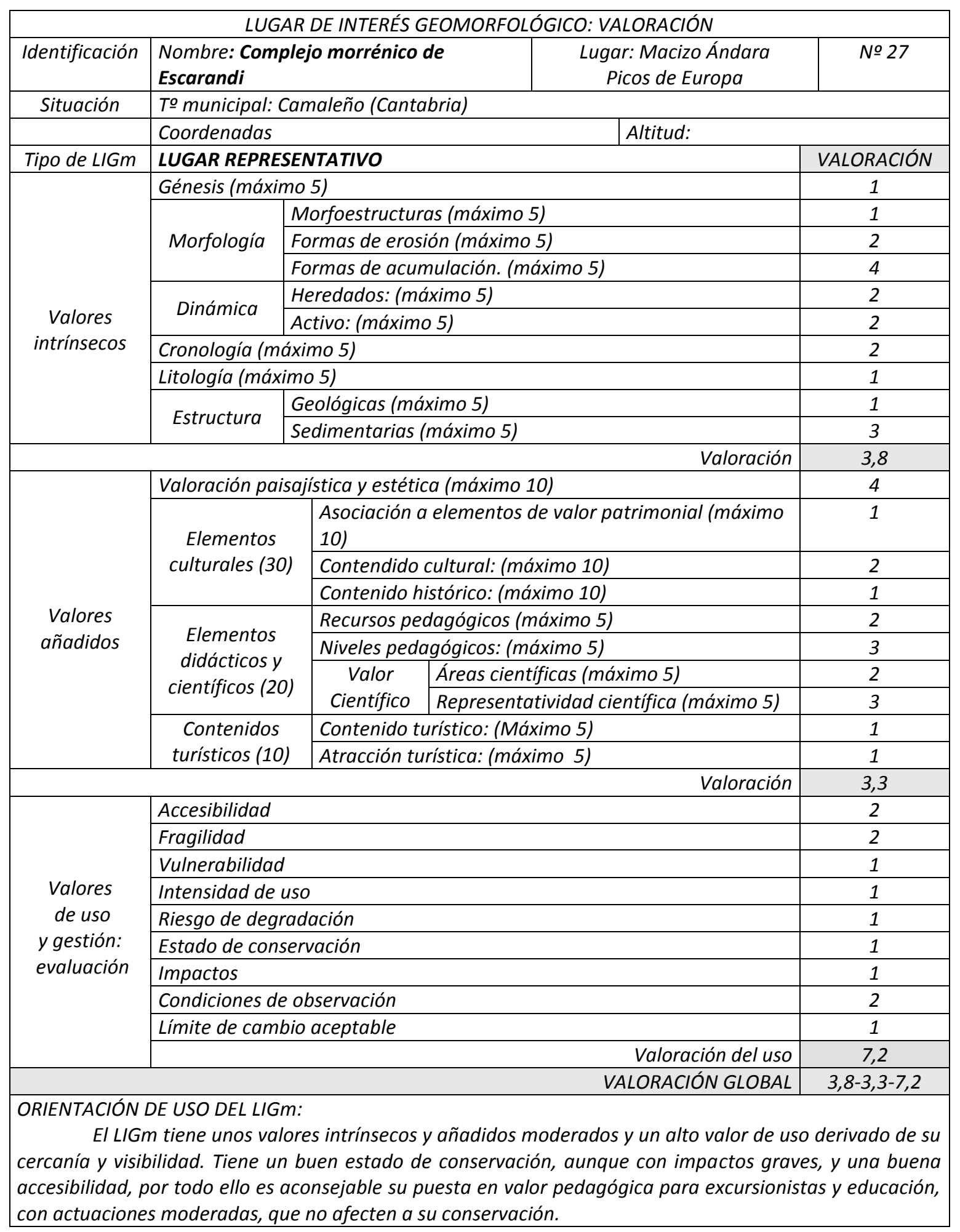




\begin{tabular}{|c|c|c|c|c|c|}
\hline \multicolumn{6}{|c|}{ LUGAR DE INTERÉS GEOMORFOLÓGICO: VALORACIÓN } \\
\hline Identificación & \multicolumn{3}{|c|}{ Nombre: Morrenas de EI Torno } & $\begin{array}{l}\text { r: Macizo Ándara } \\
\text { cos de Europa }\end{array}$ & № 28 \\
\hline Situación & \multicolumn{5}{|c|}{ To municipal: La Hermida (Cantabria) } \\
\hline & \multicolumn{3}{|l|}{ Coordenadas: } & \multicolumn{2}{|l|}{ Altitud: } \\
\hline Tipo de LIGm & \multicolumn{4}{|c|}{ LUGAR REPRESENTATIVO } & VALORACIÓN \\
\hline \multirow{10}{*}{$\begin{array}{l}\text { Valores } \\
\text { intrínsecos }\end{array}$} & \multicolumn{4}{|c|}{ Génesis (máximo 5) } & 1 \\
\hline & \multirow{3}{*}{ Morfología } & \multicolumn{3}{|c|}{ Morfoestructuras (máximo 5) } & 1 \\
\hline & & \multicolumn{3}{|c|}{ Formas de erosión (máximo 5) } & 3 \\
\hline & & \multicolumn{3}{|c|}{ Formas de acumulación. (máximo 5) } & 5 \\
\hline & \multirow{2}{*}{ Dinámica } & \multicolumn{3}{|c|}{ Heredados: (máximo 5) } & 2 \\
\hline & & \multicolumn{3}{|c|}{ Activo: (máximo 5) } & 2 \\
\hline & \multicolumn{4}{|c|}{ Cronología (máximo 5) } & 2 \\
\hline & \multicolumn{4}{|c|}{ Litología (máximo 5) } & 1 \\
\hline & \multirow{2}{*}{ Estructura } & \multicolumn{3}{|c|}{ Geológicas (máximo 5) } & 1 \\
\hline & & \multicolumn{3}{|c|}{ Sedimentarias (máximo 5) } & 3 \\
\hline \multirow{11}{*}{$\begin{array}{l}\text { Valores } \\
\text { añadidos }\end{array}$} & \multicolumn{4}{|r|}{ Valoración } & 4,2 \\
\hline & \multicolumn{4}{|c|}{ Valoración paisajística y estética (máximo 10) } & 2 \\
\hline & \multirow{3}{*}{$\begin{array}{l}\text { Elementos } \\
\text { culturales (30) }\end{array}$} & \multicolumn{3}{|c|}{$\begin{array}{l}\text { Asociación a elementos de valor patrimonial } \\
\text { (máximo 10) }\end{array}$} & 1 \\
\hline & & \multicolumn{3}{|c|}{ Contendido cultural: (máximo 10) } & 1 \\
\hline & & \multicolumn{3}{|c|}{ Contenido histórico: (máximo 10) } & 0 \\
\hline & & Recursos $p$ & edagó & (10 5) & 2 \\
\hline & Elementos & Niveles pe & agógi & 5) & 3 \\
\hline & científicos (20) & Valor & Área & (máximo 5) & 3 \\
\hline & & Científico & Repr & d científica (máx. 5) & 2 \\
\hline & Contenidos & Contenido & turísti & & 0 \\
\hline & turísticos (10) & Atracción & urístic & & 0 \\
\hline & & & & Valoración & 2,3 \\
\hline & Accesibilidad & & & & 1 \\
\hline & Fragilidad & & & & 2 \\
\hline & Vulnerabilidad & & & & 2 \\
\hline Valores & Intensidad de u & & & & 2 \\
\hline de uso & Riesgo de degr & adación & & & 2 \\
\hline y gestión: & Estado de cons & ervación & & & 2 \\
\hline evaluación & Impactos & & & & 2 \\
\hline & Condiciones de & observaciór & & & 2 \\
\hline & Límite de camb & io aceptable & & & 2 \\
\hline & & & & Valoración del uso & 9,4 \\
\hline & & & & ALORACIÓN GLOBAL & $4,2-2,3-9,4$ \\
\hline $\begin{array}{r}\text { ORIENTACIÓN } \\
\text { EI LIG } \\
\text { específico de lo } \\
\text { La orientación } \\
\text { acción de su pu }\end{array}$ & $\begin{array}{l}\text { DE USO DEL LIGn } \\
n \text { tiene unos va } \\
\text { morfología gla } \\
\text { es para la conse } \\
\text { esta en valor. }\end{array}$ & $\begin{array}{l}n: \\
\text { alores intríns } \\
\text { ciar. Es un e } \\
\text { rvación, con }\end{array}$ & $\begin{array}{l}\text { cos } n \\
\text { emplo } \\
\text { un usc }\end{array}$ & $\begin{array}{l}\text { añadidos bajos, lo } \\
\text { bien la lejanía le res } \\
\text { didáctico que conllev }\end{array}$ & $\begin{array}{l}\text { e le hace muy } \\
\text { unosibilidades. } \\
\text { una moderada }\end{array}$ \\
\hline
\end{tabular}




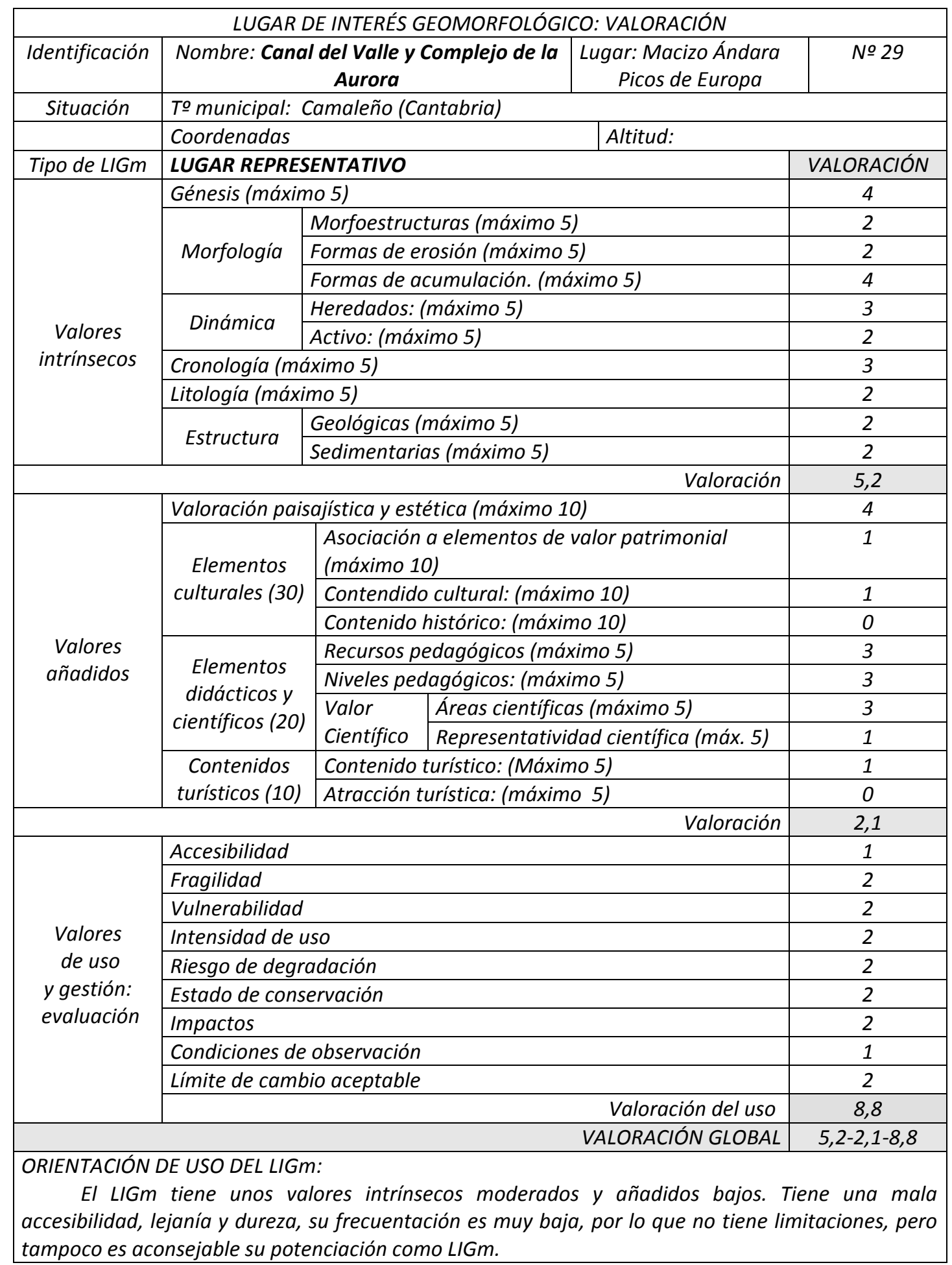




\begin{tabular}{|c|c|c|c|c|c|}
\hline \multicolumn{6}{|c|}{ LUGAR DE INTERÉS GEOMORFOLÓGICO: VALORACIÓN } \\
\hline Identificación & \multicolumn{3}{|c|}{ Nombre: Canchorral de Hormas } & $\begin{array}{l}\text { r: Macizo Ándara } \\
\text { cos de Europa }\end{array}$ & No 30 \\
\hline \multirow[t]{2}{*}{ Situación } & \multicolumn{5}{|c|}{ To municipal: La Hermida (Cantabria) } \\
\hline & \multicolumn{3}{|c|}{ Coordenadas } & \multicolumn{2}{|l|}{ Altitud: } \\
\hline Tipo de LIGm & \multicolumn{4}{|c|}{ LUGAR REPRESENTATIVO } & VALORACIÓN \\
\hline \multirow{10}{*}{$\begin{array}{l}\text { Valores } \\
\text { intrínsecos }\end{array}$} & \multicolumn{4}{|c|}{ Génesis (máximo 5) } & 5 \\
\hline & \multirow{3}{*}{ Morfología } & \multicolumn{3}{|c|}{ Morfoestructuras (máximo 5) } & 2 \\
\hline & & \multicolumn{3}{|c|}{ Formas de erosión (máximo 5) } & 3 \\
\hline & & \multicolumn{3}{|c|}{ Formas de acumulación. (máximo 5) } & 3 \\
\hline & \multirow{2}{*}{ Dinámica } & \multicolumn{3}{|c|}{ Heredados: (máximo 5) } & 2 \\
\hline & & \multicolumn{3}{|c|}{ Activo: (máximo 5) } & 5 \\
\hline & \multicolumn{4}{|c|}{ Cronología (máximo 5) } & 3 \\
\hline & \multicolumn{4}{|c|}{ Litología (máximo 5) } & 3 \\
\hline & \multirow{2}{*}{ Estructura } & \multicolumn{3}{|c|}{ Geológicas (máximo 5) } & 4 \\
\hline & & \multicolumn{3}{|c|}{ Sedimentarias (máximo 5) } & 4 \\
\hline \multirow{11}{*}{$\begin{array}{l}\text { Valores } \\
\text { añadidos }\end{array}$} & & & & Valoración & 6,8 \\
\hline & \multicolumn{4}{|c|}{ Valoración paisajística y estética (máximo 10) } & 4 \\
\hline & \multirow{3}{*}{$\begin{array}{l}\text { Elementos } \\
\text { culturales (30) }\end{array}$} & \multicolumn{3}{|c|}{$\begin{array}{l}\text { Asociación a elementos de valor patrimonial } \\
\text { (máximo 10) }\end{array}$} & 0 \\
\hline & & \multicolumn{3}{|c|}{ Contendido cultural: (máximo 10) } & 0 \\
\hline & & \multicolumn{3}{|c|}{ Contenido histórico: (máximo 10) } & 0 \\
\hline & & Recursos p & edag & imo 5) & 3 \\
\hline & Elementos & Niveles pe & dagó & no 5) & 2 \\
\hline & científicos $(20$ & Valor & Árec & (máximo 5) & 1 \\
\hline & & Científico & $\operatorname{Rep}$ & d científica (máx. 5) & 4 \\
\hline & Contenidos & Contenido & turís & o 5) & 0 \\
\hline & turísticos (10) & Atracción & turíst & 5) & 0 \\
\hline & & & & Valoración & 2,3 \\
\hline & Accesibilidad & & & & 0 \\
\hline & Fragilidad & & & & 2 \\
\hline & Vulnerabilidad & & & & 2 \\
\hline Valores & Intensidad de u & & & & 0 \\
\hline de uso & Riesgo de degr & adación & & & 2 \\
\hline y gestión: & Estado de cons & ervación & & & 2 \\
\hline evaluación & Impactos & & & & 2 \\
\hline & Condiciones de & observación & & & 0 \\
\hline & Límite de camb & io aceptable & & & 2 \\
\hline & & & & Valoración del uso & 6,6 \\
\hline & & & & ALORACIÓN GLOBAL & $6,6-2,3-6,6$ \\
\hline $\begin{array}{r}\text { ORIENTACIÓN } \\
\text { Los } \\
\text { condiciones fa। } \\
\text { riesgo alto tan } \\
\text { Posee alto valo } \\
\text { la gestión de ri }\end{array}$ & $\begin{array}{l}\text { DE USO DEL LIGn } \\
\text { Ialores intrínsec } \\
\text { lorables, si bien } \\
\text { ibién limitan su } \\
\text { r científico, mod } \\
\text { esgo y la no pron }\end{array}$ & $\begin{array}{l}\text { n: } \\
\text { os son altos, } \\
\text { su inaccesibi } \\
\text { uso, más allá } \\
\text { erado pedagó } \\
\text { noción ni pues }\end{array}$ & $\begin{array}{l}\text { es un } \\
\text { lidad } \\
\text { del } \\
\text { gico, } \\
\text { ta en }\end{array}$ & $\begin{array}{l}\text { nuy singular, los aña } \\
\text { difícil uso. El elevado } \\
\text { y control científico } \\
\text { rístico. Su orientación } \\
\text { jm. }\end{array}$ & $\begin{array}{l}\text { idos bajos, con } \\
\text { dinamismo con } \\
\text { e los procesos. } \\
\text { te uso pasa por }\end{array}$ \\
\hline
\end{tabular}




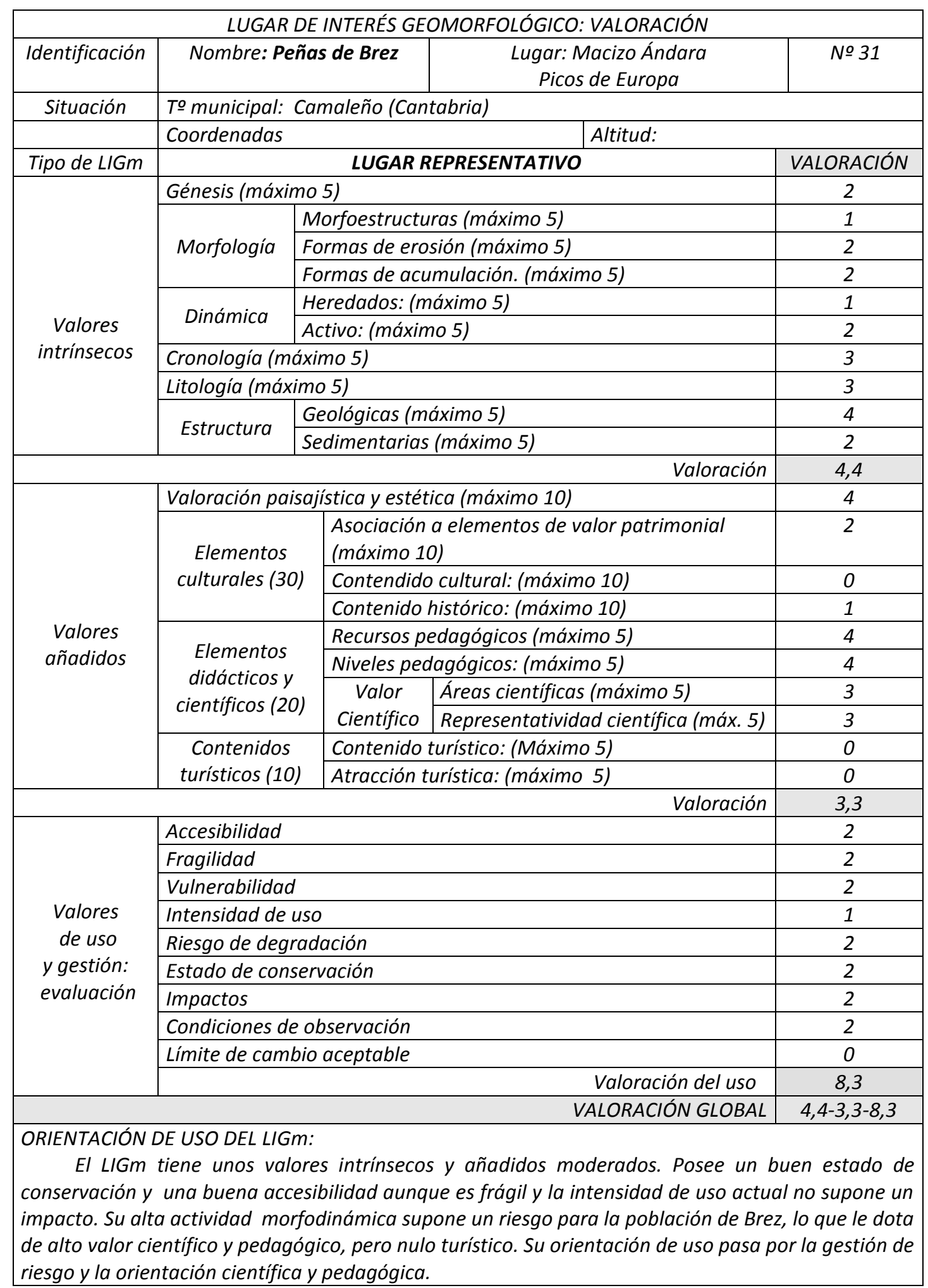




\begin{tabular}{|c|c|c|c|c|c|}
\hline \multicolumn{6}{|c|}{ LUGAR DE INTERÉS GEOMORFOLÓGICO: VALORACIÓN } \\
\hline Identificación & \multicolumn{3}{|c|}{ Nombre: Brañas de Corvera } & $\begin{array}{c}\text { Lugar: Macizo Ándara } \\
\text { Picos de Europa }\end{array}$ & No 32 \\
\hline \multirow[t]{2}{*}{ Situación } & \multicolumn{5}{|c|}{ To municipal: La Hermida-Bejés (Cantabria) } \\
\hline & \multicolumn{3}{|c|}{ Coordenadas } & \multicolumn{2}{|l|}{ Altitud: } \\
\hline Tipo de LIGm & \multicolumn{4}{|c|}{ LUGAR REPRESENTATIVO } & VALORACIÓN \\
\hline \multirow{10}{*}{$\begin{array}{l}\text { Valores } \\
\text { intrínsecos }\end{array}$} & \multicolumn{4}{|c|}{ Génesis (máximo 5) } & 4 \\
\hline & \multirow{3}{*}{ Morfología } & \multicolumn{3}{|c|}{ Morfoestructuras (máximo 5) } & 2 \\
\hline & & \multicolumn{3}{|c|}{ Formas de erosión (máximo 5) } & 3 \\
\hline & & \multicolumn{3}{|c|}{ Formas de acumulación (máximo 5) } & 4 \\
\hline & \multirow{2}{*}{ Dinámica } & \multicolumn{3}{|c|}{ Heredados: (máximo 5) } & 4 \\
\hline & & \multicolumn{3}{|c|}{ Activo: (máximo 5) } & 2 \\
\hline & \multicolumn{4}{|c|}{ Cronología (máximo 5) } & 2 \\
\hline & \multicolumn{4}{|c|}{ Litología (máximo 5) } & 3 \\
\hline & \multirow{2}{*}{ Estructura } & \multicolumn{3}{|c|}{ Geológicas (máximo 5) } & 2 \\
\hline & & \multicolumn{3}{|c|}{ Sedimentarias (máximo 5) } & 4 \\
\hline \multirow{11}{*}{$\begin{array}{l}\text { Valores } \\
\text { añadidos }\end{array}$} & \multirow{2}{*}{\multicolumn{4}{|c|}{ Valoración paisaiística y estética (máximo 10) }} & 6 \\
\hline & & & & & 4 \\
\hline & \multirow{3}{*}{$\begin{array}{c}\text { Elementos } \\
\text { culturales (30) }\end{array}$} & \multicolumn{3}{|c|}{$\begin{array}{l}\text { Asociación a elementos de valor patrimonial } \\
\text { (máximo 10) }\end{array}$} & 1 \\
\hline & & \multicolumn{3}{|c|}{ Contendido cultural: (máximo 10) } & 1 \\
\hline & & Contenido & histó & 10) & 0 \\
\hline & & Recursos p & edag & רo 5) & 2 \\
\hline & Elementos & Niveles peo & lagó & o 5) & 3 \\
\hline & científicos (20) & Valor & Áre & (máximo 5) & 3 \\
\hline & & Científico & Rep & d científica (máx. 5) & 2 \\
\hline & Contenidos & Contenido & turís & & 1 \\
\hline & turísticos (10) & Atracción $t$ & uríst & & 1 \\
\hline & & & & Valoración & 3 \\
\hline & Accesibilidad & & & & 1 \\
\hline & Fragilidad & & & & 2 \\
\hline & Vulnerabilidad & & & & 2 \\
\hline Valores & Intensidad de u & & & & 2 \\
\hline de uso & Riesgo de degr & adación & & & 2 \\
\hline y gestión: & Estado de cons & ervación & & & 2 \\
\hline evaluación & Impactos & & & & 2 \\
\hline & Condiciones de & observación & & & 2 \\
\hline & Límite de camb & io aceptable & & & 2 \\
\hline & & & & Valoración del uso & 9,4 \\
\hline & & & & 'ALORACIÓN GLOBAL & $6-3-9,4$ \\
\hline $\begin{array}{r}\text { ORIENTACIÓN } \\
\text { EI LIGm } \\
\text { estado de cons } \\
\text { Poco frecuenta }\end{array}$ & $\begin{array}{l}\text { DE USO DEL LIGn } \\
\text { tiene un valor in } \\
\text { ervación y una } \\
\text { do, su potencial }\end{array}$ & $\begin{array}{l}n: \\
\text { trínseco moc } \\
\text { accesibilidad } \\
\text { de uso es altc }\end{array}$ & $\begin{array}{l}\text { dera } \\
\text { med } \\
\text {, en }\end{array}$ & $\begin{array}{l}\text { Ialor añadido, aunqu } \\
\text { ad de uso actual no } \\
\text { abinado con otros } L I G\end{array}$ & $\begin{array}{l}\text { tiene un buen } \\
\text { upone impacto. } \\
\text { n próximos. }\end{array}$ \\
\hline
\end{tabular}




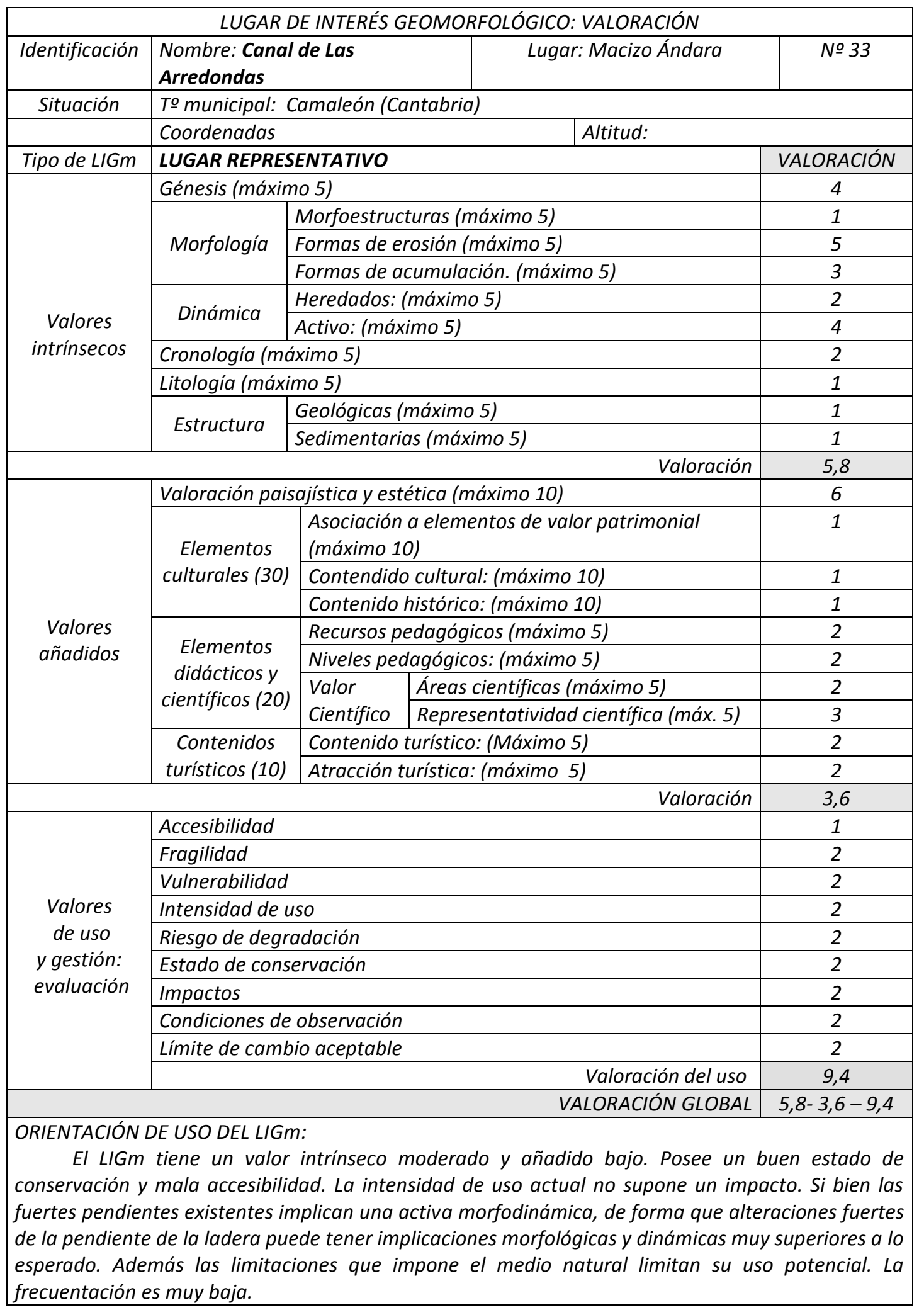




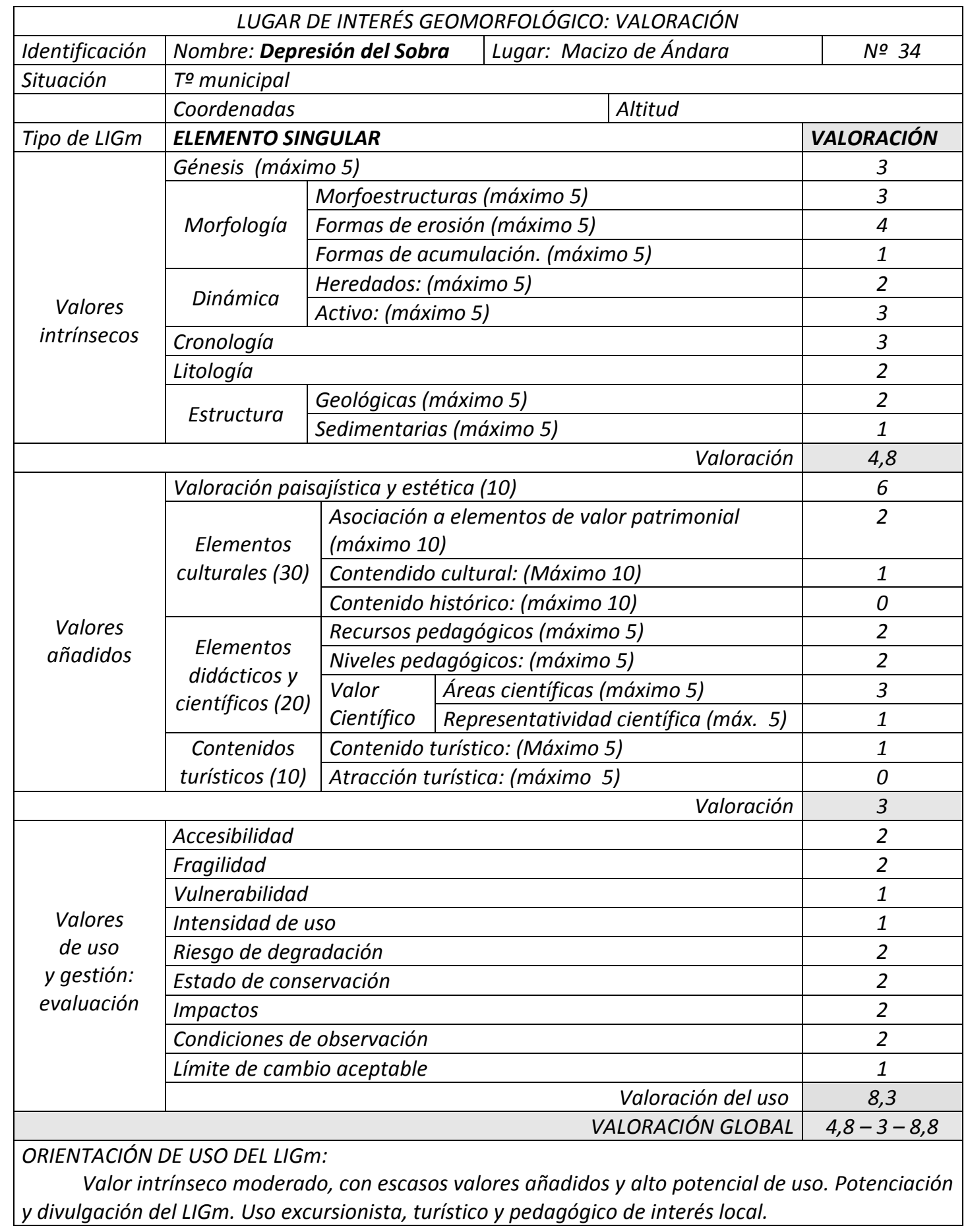




\begin{tabular}{|c|c|c|c|c|}
\hline \multicolumn{5}{|c|}{ LUGAR DE INTERÉS GEOMORFOLÓGICO: VALORACIÓN } \\
\hline Identificación & \multicolumn{3}{|c|}{\begin{tabular}{|l|l|} 
Nombre: Torca S56 & Lugar: Macizo Ándara \\
\end{tabular}} & № 35 \\
\hline \multirow[t]{2}{*}{ Situación } & \multicolumn{4}{|c|}{ To municipal } \\
\hline & \multicolumn{2}{|l|}{ Coordenadas } & Altitud & \\
\hline Tipo de $\mathrm{LIGm}$ & \multicolumn{3}{|c|}{ LUGAR REPRESENTATIVO } & VALORACIÓN \\
\hline \multirow{10}{*}{$\begin{array}{c}\text { Valores } \\
\text { intrínsecos }\end{array}$} & \multicolumn{3}{|c|}{ Génesis (máximo 5) } & 2 \\
\hline & \multirow{3}{*}{ Morfología } & \multicolumn{2}{|c|}{ Morfoestructuras (máximo 5) } & 2 \\
\hline & & \multicolumn{2}{|c|}{ Formas de erosión (máximo 5) } & 2 \\
\hline & & \multicolumn{2}{|c|}{ Formas de acumulación (máximo 5) } & 2 \\
\hline & \multirow{2}{*}{ Dinámica } & \multicolumn{2}{|c|}{ Heredados: (máximo 5) } & 1 \\
\hline & & \multicolumn{2}{|c|}{ Activo: (máximo 5) } & 3 \\
\hline & \multicolumn{3}{|c|}{ Cronología (máximo 5) } & 1 \\
\hline & \multicolumn{3}{|c|}{ Litología(máximo 5) } & 1 \\
\hline & \multirow{2}{*}{ Estructura } & \multicolumn{2}{|c|}{ Geológicas (máximo 5) } & 1 \\
\hline & & \multicolumn{2}{|c|}{ Sedimentarias (máximo 5) } & 0 \\
\hline \multirow{11}{*}{$\begin{array}{l}\text { Valores } \\
\text { añadidos }\end{array}$} & & & Valoración & 3 \\
\hline & \multicolumn{3}{|c|}{ Valoración paisajística y estética (10) } & 0 \\
\hline & \multirow{3}{*}{$\begin{array}{c}\text { Elementos } \\
\text { culturales (30) }\end{array}$} & \multicolumn{2}{|c|}{$\begin{array}{l}\text { Asociación a elementos de valor patrimonial } \\
\text { (máximo 10) }\end{array}$} & 0 \\
\hline & & \multicolumn{2}{|c|}{ Contendido cultural (Máximo 10) } & 1 \\
\hline & & \multicolumn{2}{|c|}{ Contenido histórico (máximo 10) } & 1 \\
\hline & & Recursos pe & dagógicos (máximo 5) & 2 \\
\hline & Elementos & Niveles ped & agógicos (máximo 5) & 1 \\
\hline & didacticos y & Valor & Áreas científicas (máximo 5) & 3 \\
\hline & & Científico & Representatividad científica (máx. 5) & 4 \\
\hline & Contenidos & Contenidot & urístico (Máximo 5) & 0 \\
\hline & turísticos (10) & Atracción tc & urística (máximo 5) & 1 \\
\hline & & & Valoración & 2,1 \\
\hline & Accesibilidad & & & 0 \\
\hline & Fragilidad & & & 1 \\
\hline & Vulnerabilidad & & & 2 \\
\hline Valores & Intensidad de u & & & 2 \\
\hline de uso & Riesgo de degr & adación & & 0 \\
\hline y gestión: & Estado de cons & ervación & & 2 \\
\hline evaluación & Impactos & & & 2 \\
\hline & Condiciones de & observación & & 0 \\
\hline & Límite de camb & io aceptable & & 0 \\
\hline & & & Valoración del uso & 5 \\
\hline & & & VALORACIÓN GLOBAL & $3-2,1-5$ \\
\hline $\begin{array}{l}\text { ORIENTACIÓN } \\
\text { Valor int } \\
\text { añadidos, y ur } \\
\text { medios subterr } \\
\text { potenciación d }\end{array}$ & $\begin{array}{l}\text { DE USO DEL LIGn } \\
\text { rínseco moderac } \\
\text { potencial de u } \\
\text { áneos. Orientac } \\
\text { I LIGm. }\end{array}$ & $\begin{array}{l}\text { do por su excl } \\
\text { Iso bajo, limi } \\
\text { ción deportive }\end{array}$ & $\begin{array}{l}\text { usividad kárstica, muy representativo, co } \\
\text { tado por el carácter inaccesible y la fr } \\
\text {-científica favorable hacia un uso conse }\end{array}$ & $\begin{array}{l}\text { n bajos valores } \\
\text { agilidad de los } \\
\text { rvacionista, sin }\end{array}$ \\
\hline
\end{tabular}




\begin{tabular}{|c|c|c|c|c|c|}
\hline \multicolumn{6}{|c|}{ LUGAR DE INTERÉS GEOMORFOLÓGICO: VALORACIÓN } \\
\hline Identificación & \multicolumn{3}{|c|}{ Nombre: Cueva del Nacimiento } & Lugar: Macizo Ándara & № 36 \\
\hline Situación & \multicolumn{5}{|c|}{ To municipal } \\
\hline & \multicolumn{3}{|l|}{ Coordenadas } & \multicolumn{2}{|l|}{ Altitud } \\
\hline Tipo de $L I G m$ & \multicolumn{4}{|c|}{ ELEMENTO SINGULAR } & VALORACIÓN \\
\hline \multirow{10}{*}{$\begin{array}{l}\text { Valores } \\
\text { intrínsecos }\end{array}$} & \multicolumn{4}{|c|}{ Génesis (máximo 5) } & 2 \\
\hline & \multirow{3}{*}{ Morfología } & \multicolumn{3}{|c|}{ Morfoestructuras (máximo 5) } & 2 \\
\hline & & \multicolumn{3}{|c|}{ Formas de erosión (máximo 5) } & 2 \\
\hline & & \multicolumn{3}{|c|}{ Formas de acumulación. (máximo 5) } & 2 \\
\hline & \multirow{2}{*}{ Dinámica } & \multicolumn{3}{|c|}{ Heredados: (máximo 5) } & 1 \\
\hline & & \multicolumn{3}{|c|}{ Activo: (máximo 5) } & 3 \\
\hline & \multicolumn{4}{|c|}{ Cronología (máximo 5) } & 1 \\
\hline & \multicolumn{4}{|c|}{ Litología (máximo 5) } & 1 \\
\hline & \multirow{2}{*}{ Estructura } & \multicolumn{3}{|c|}{ Geológicas (máximo 5) } & 1 \\
\hline & & \multicolumn{3}{|c|}{ Sedimentarias (máximo 5) } & 0 \\
\hline \multirow{11}{*}{$\begin{array}{l}\text { Valores } \\
\text { añadidos }\end{array}$} & \multicolumn{4}{|c|}{ 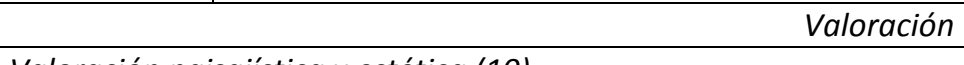 } & 3 \\
\hline & \multicolumn{4}{|c|}{ Valoración paisajística y estética (10) } & 0 \\
\hline & \multirow{3}{*}{$\begin{array}{c}\text { Elementos } \\
\text { culturales (30) }\end{array}$} & \multicolumn{3}{|c|}{$\begin{array}{l}\text { Asociación a elementos de valor patrimonial } \\
\text { (máximo 10) }\end{array}$} & 0 \\
\hline & & \multicolumn{3}{|c|}{ Contendido cultural: (Máximo 10) } & 1 \\
\hline & & \multicolumn{3}{|c|}{ Contenido histórico: (máximo 10) } & 1 \\
\hline & & Recursos $p$ & edagc & máximo 5) & 2 \\
\hline & Elementos & Niveles pec & agóg & רáximo 5) & 1 \\
\hline & aldacticos y & Valor & Árec & íficas (máximo 5) & 3 \\
\hline & crentijicos $(\angle 0)$ & Científico & RepI & tividad científica (máx. 5) & 4 \\
\hline & Contenidos & Contenido & urísti & áximo 5) & 0 \\
\hline & turísticos (10) & Atracción t & urístic & ximo 5) & 1 \\
\hline & & & & Valoración & 2,1 \\
\hline & Accesibilidad & & & & 0 \\
\hline & Fragilidad & & & & 1 \\
\hline & Vulnerabilidad & & & & 2 \\
\hline Valores & Intensidad de u & & & & 2 \\
\hline de uso & Riesgo de degrc & adación & & & 0 \\
\hline y gestión: & Estado de cons & ervación & & & 2 \\
\hline evaluación & Impactos & & & & 2 \\
\hline & Condiciones de & observación & & & 0 \\
\hline & Límite de camb & io aceptable & & & 0 \\
\hline & & & & Valoración del uso & 5 \\
\hline & & & & VALORACIÓN GLOBAL & $3-2,1-5$ \\
\hline $\begin{array}{r}\text { ORIENTACIÓN } \\
\text { Valor int } \\
\text { bajos valores a } \\
\text { de los medios } \\
\text { hacia un uso cc }\end{array}$ & $\begin{array}{l}\text { DE USO DEL LIGn } \\
\text { ínseco moderad } \\
\text { ñadidos, y un po } \\
\text { ubterráneos. La } \\
\text { nservacionista, s }\end{array}$ & $\begin{array}{l}n: \\
\text { lo por ser exc } \\
\text { tencial de us } \\
\text { orientación } \\
\text { sin potenciac }\end{array}$ & $\begin{array}{l}\text { Iusiva } \\
\text { bajc } \\
\text { es de, } \\
\text { ión de }\end{array}$ & $\begin{array}{l}\text { kárstico, aunque muy repre } \\
\text { do por el carácter inaccesib } \\
\text {-científica, de baja frecuent }\end{array}$ & $\begin{array}{l}\text { entativo. Tiene } \\
\text { y la fragilidad } \\
\text { ción, favorable }\end{array}$ \\
\hline
\end{tabular}




\section{A.11.3) Macizo del Cornión}

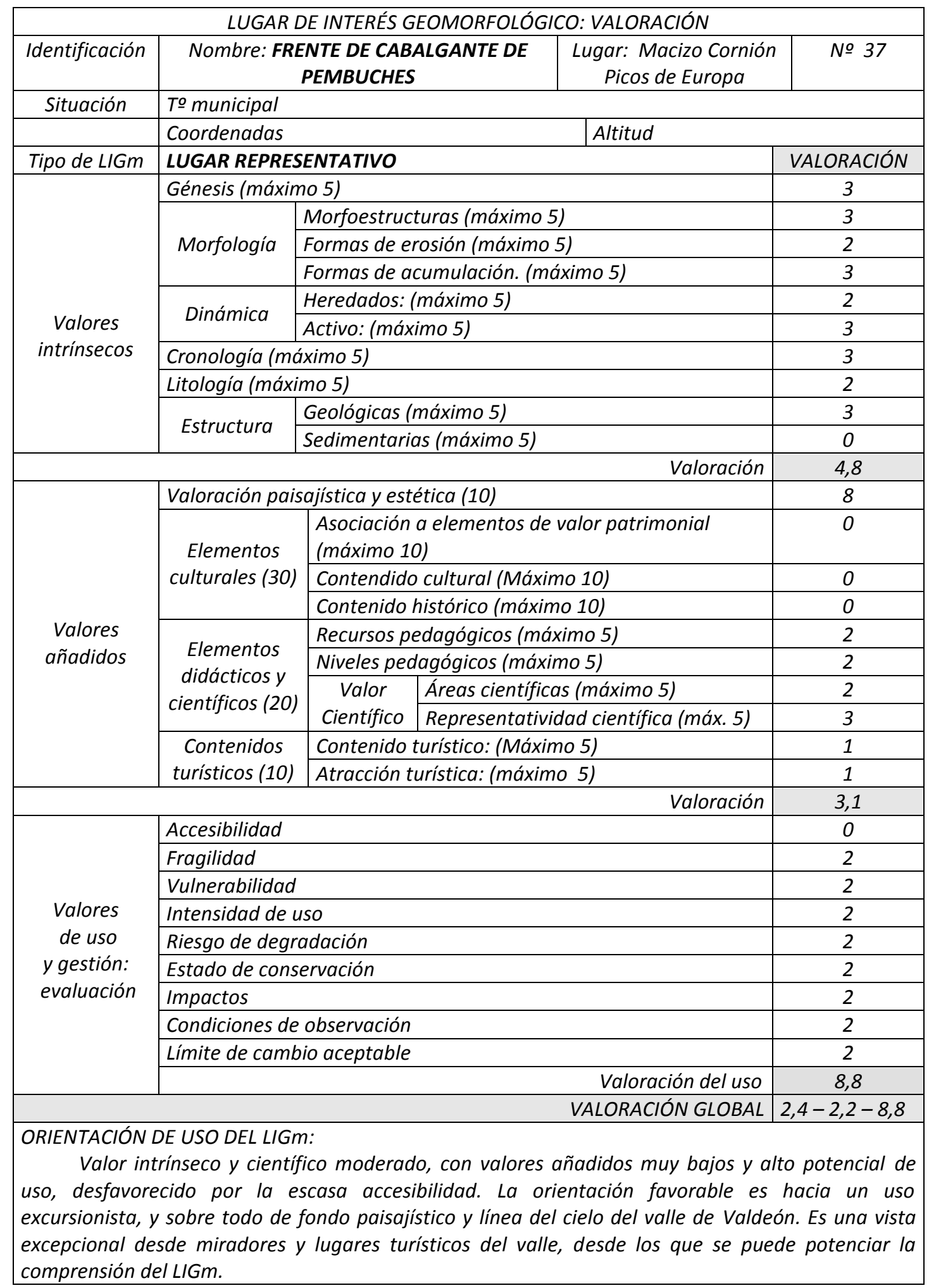




\begin{tabular}{|c|c|c|c|c|c|}
\hline \multicolumn{6}{|c|}{ LUGAR DE INTERÉS GEOMORFOLÓGICO: VALORACIÓN } \\
\hline Identificación & \multicolumn{3}{|c|}{ Nombre: Desfiladero de los Beyos } & $\begin{array}{l}\text { Lugar: Macizo Cornión } \\
\text { Picos de Europa }\end{array}$ & № 38 \\
\hline \multirow[t]{2}{*}{ Situación } & \multicolumn{5}{|l|}{ To municipal: } \\
\hline & \multicolumn{3}{|l|}{ Coordenadas } & \multirow[t]{2}{*}{ Altitud: } & \\
\hline Tipo de LIGm & \multicolumn{3}{|c|}{ LUGAR REPRESENTATIVO } & & VALORACIÓN \\
\hline \multirow{10}{*}{$\begin{array}{l}\text { Valores } \\
\text { intrínsecos }\end{array}$} & \multicolumn{4}{|c|}{ Génesis (máximo 5) } & 3 \\
\hline & \multirow{3}{*}{ Morfología } & \multicolumn{3}{|c|}{ Morfoestructuras (máximo 5) } & 5 \\
\hline & & \multicolumn{3}{|c|}{ Formas de erosión (máximo 5) } & 4 \\
\hline & & \multicolumn{3}{|c|}{ Formas de acumulación. (máximo 5) } & 4 \\
\hline & \multirow{2}{*}{ Dinámica } & \multicolumn{3}{|c|}{ Heredados: (máximo 5) } & 1 \\
\hline & & \multicolumn{3}{|c|}{ Activo: (máximo 5) } & 5 \\
\hline & \multicolumn{4}{|c|}{ Cronología (máximo 5) } & 3 \\
\hline & \multicolumn{4}{|c|}{ Litología (máximo 5) } & 1 \\
\hline & \multirow{2}{*}{ Estructura } & \multicolumn{3}{|c|}{ Geológicas (máximo 5) } & 1 \\
\hline & & \multicolumn{3}{|c|}{ Sedimentarias (máximo 5) } & 1 \\
\hline \multirow{11}{*}{$\begin{array}{l}\text { Valores } \\
\text { añadidos }\end{array}$} & \multicolumn{4}{|r|}{ Valoración } & 5,6 \\
\hline & \multicolumn{4}{|c|}{ Valoración paisajística y estética (máximo 10) } & 8 \\
\hline & \multirow{3}{*}{$\begin{array}{c}\text { Elementos } \\
\text { culturales (30) }\end{array}$} & \multicolumn{3}{|c|}{$\begin{array}{l}\text { Asociación a elementos de valor patrimonial } \\
\text { (máximo 10) }\end{array}$} & 6 \\
\hline & & \multicolumn{3}{|c|}{ Contendido cultural: (máximo 10) } & 3 \\
\hline & & Contenido & histórico: ( & mo 10) & 4 \\
\hline & & Recursos $p$ & pedagógicos & ximo 5) & 4 \\
\hline & Elementos & Niveles pe & dagógicos: & imo 5) & 3 \\
\hline & científicos (20) & Valor & Áreas cient & s (máximo 5) & 2 \\
\hline & & Científico & Representc & lad científica (máx. 5) & 4 \\
\hline & Contenidos & Contenido & turístico: $(\Lambda$ & mo 5) & 4 \\
\hline & turísticos (10) & Atracción & turística: $(m$ & $105)$ & 4 \\
\hline & & & & Valoración & 7 \\
\hline & Accesibilidad & & & & 0 \\
\hline & Fragilidad & & & & 2 \\
\hline & Vulnerabilidad & & & & 2 \\
\hline Valores & Intensidad de u & uso & & & 1 \\
\hline de uso & Riesgo de degrc & adación & & & 2 \\
\hline y gestión: & Estado de conse & ervación & & & 2 \\
\hline evaluación & Impactos & & & & 1 \\
\hline & Condiciones de & observación & & & 2 \\
\hline & Límite de camb & bio aceptable & & & 2 \\
\hline & & & & Valoración del uso & 7,7 \\
\hline & & & & VALORACIÓN GLOBAL & $5,6 / 7 / 7,7$ \\
\hline $\begin{array}{l}\text { ORIENTACIÓN } \\
\text { EI LIGM } \\
\text { paisajístico de } \\
\text { barreras físicas } \\
\text { los impactos de }\end{array}$ & $\begin{array}{l}\text { DE USO DEL LIGn } \\
\text { osee un valor in } \\
\text { orimer orden, co } \\
\text { que impone el } n \\
\text { rivados de actuo }\end{array}$ & $\begin{array}{l}\text { m: } \\
\text { ntrínseco me } \\
\text { on fácil reco } \\
\text { medio. Es un } \\
\text { aciones punt }\end{array}$ & $\begin{array}{l}\text { edio y añad } \\
\text { orrido aunqu } \\
\text { tu ruta turís } \\
\text { tuales par el }\end{array}$ & $\begin{array}{l}\text { de gestión alto. Constitu } \\
\text { fícil visualización, dadas } \\
\text { en coche que requiere esp } \\
\text { smo. }\end{array}$ & $\begin{array}{l}\text { ve un elemento } \\
\text { as pendientes y } \\
\text { ecial atención a }\end{array}$ \\
\hline
\end{tabular}




\begin{tabular}{|c|c|c|c|c|}
\hline \multicolumn{5}{|c|}{ LUGAR DE INTERÉS GEOMORFOLÓGICO: VALORACIÓN } \\
\hline Identificación & \multicolumn{2}{|c|}{ Nombre: Lago y Vega de Enol } & \begin{tabular}{c|c} 
& Lugar: Macizo Cornión \\
& Picos de Europa \\
\end{tabular} & № 39 \\
\hline Situación & \multicolumn{4}{|l|}{ To municipal: } \\
\hline & \multicolumn{2}{|l|}{ Coordenadas } & Altitud: & \\
\hline Tipo de LIGm & \multicolumn{3}{|c|}{ LUGAR REPRESENTATIVO } & VALORACIÓN \\
\hline \multirow{10}{*}{$\begin{array}{l}\text { Valores } \\
\text { intrínsecos }\end{array}$} & \multicolumn{3}{|c|}{ Génesis (máximo 5) } & 4 \\
\hline & \multirow{3}{*}{ Morfología } & \multicolumn{2}{|c|}{ Morfoestructuras (máximo 5) } & 2 \\
\hline & & \multicolumn{2}{|c|}{ Formas de erosión (máximo 5) } & 4 \\
\hline & & \multicolumn{2}{|c|}{ Formas de acumulación. (máximo 5) } & 3 \\
\hline & \multirow{2}{*}{ Dinámica } & \multicolumn{2}{|c|}{ Heredados: (máximo 5) } & 2 \\
\hline & & \multicolumn{2}{|c|}{ Activo: (máximo 5) } & 3 \\
\hline & \multicolumn{3}{|c|}{ Cronología (máximo 5) } & 2 \\
\hline & \multicolumn{3}{|c|}{ Litología (máximo 5) } & 3 \\
\hline & \multirow{2}{*}{ Estructura } & \multicolumn{2}{|c|}{ Geológicas (máximo 5) } & 2 \\
\hline & & \multicolumn{2}{|c|}{ Sedimentarias (máximo 5) } & 3 \\
\hline \multirow{11}{*}{$\begin{array}{l}\text { Valores } \\
\text { añadidos }\end{array}$} & & & Valoración & 5,6 \\
\hline & \multicolumn{3}{|c|}{ Valoración paisajística y estética (máximo 10) } & 6 \\
\hline & \multirow{3}{*}{$\begin{array}{c}\text { Elementos } \\
\text { culturales (30) }\end{array}$} & \multicolumn{2}{|c|}{$\begin{array}{l}\text { Asociación a elementos de valor patrimonial (máximo } \\
\text { 10) }\end{array}$} & 2 \\
\hline & & \multicolumn{2}{|c|}{ Contendido cultural: (máximo 10) } & 2 \\
\hline & & \multicolumn{2}{|c|}{ Contenido histórico: (máximo 10) } & 1 \\
\hline & & \multicolumn{2}{|c|}{ Recursos pedagógicos (máximo 5) } & 4 \\
\hline & Elementos & Niveles pedc & ógicos: (máximo 5) & 5 \\
\hline & científicos (20) & Valor & Áreas científicas (máximo 5) & 4 \\
\hline & & Científico & Representatividad científica (máximo 5) & 4 \\
\hline & Contenidos & Contenido th & stico: (Máximo 5) & 4 \\
\hline & turísticos (10) & Atracción tu & tica: (máximo 5) & 5 \\
\hline & & & Valoración & 5,2 \\
\hline & Accesibilidad & & & 2 \\
\hline & Fragilidad & & & 1 \\
\hline & Vulnerabilidad & & & 1 \\
\hline Valores & Intensidad de u & & & 0 \\
\hline de uso & Riesgo de degr & adación & & 1 \\
\hline y gestión: & Estado de cons & servación & & 1 \\
\hline evaluación & Impactos & & & 1 \\
\hline & Condiciones de & observación & & 2 \\
\hline & Límite de camb & bio aceptable & & 1 \\
\hline & & & Valoración del uso & 5,5 \\
\hline & & & VALORACIÓN GLOBAL & $5,6-5,2-5,5$ \\
\hline $\begin{array}{l}\text { ORIENTACIÓN } \\
\text { EI LIGm t } \\
\text { compensa con } \\
\text { humanización, } \\
\text { castigado. Se } \\
\text { visitas existent }\end{array}$ & $\begin{array}{l}\text { DE USO DEL LIGn } \\
\text { iene valores mec } \\
\text { la elevada frec } \\
\text { con impactos } m \\
\text { conseja su pues } \\
\text { es o en su canaliz }\end{array}$ & $\begin{array}{l}\text { m: } \\
\text { dios, pero sobr } \\
\text { cuentación y u } \\
\text { ineros que im } \\
\text { sta en valor e } \\
\text { zación con obj }\end{array}$ & $\begin{array}{l}\text { ale su alta valoración didáctica, científica y } \\
\text { de la zona. Su mayor valor de uso deriv } \\
\text { den que una elevada frecuentación dañe u } \\
\text { icativo, científico y excursionista-geoturist } \\
\text { vo de conservación. }\end{array}$ & $\begin{array}{l}\text { turística, que se } \\
\text { a de la intensa } \\
\text { medio ya muy } \\
\text { basado en las }\end{array}$ \\
\hline
\end{tabular}




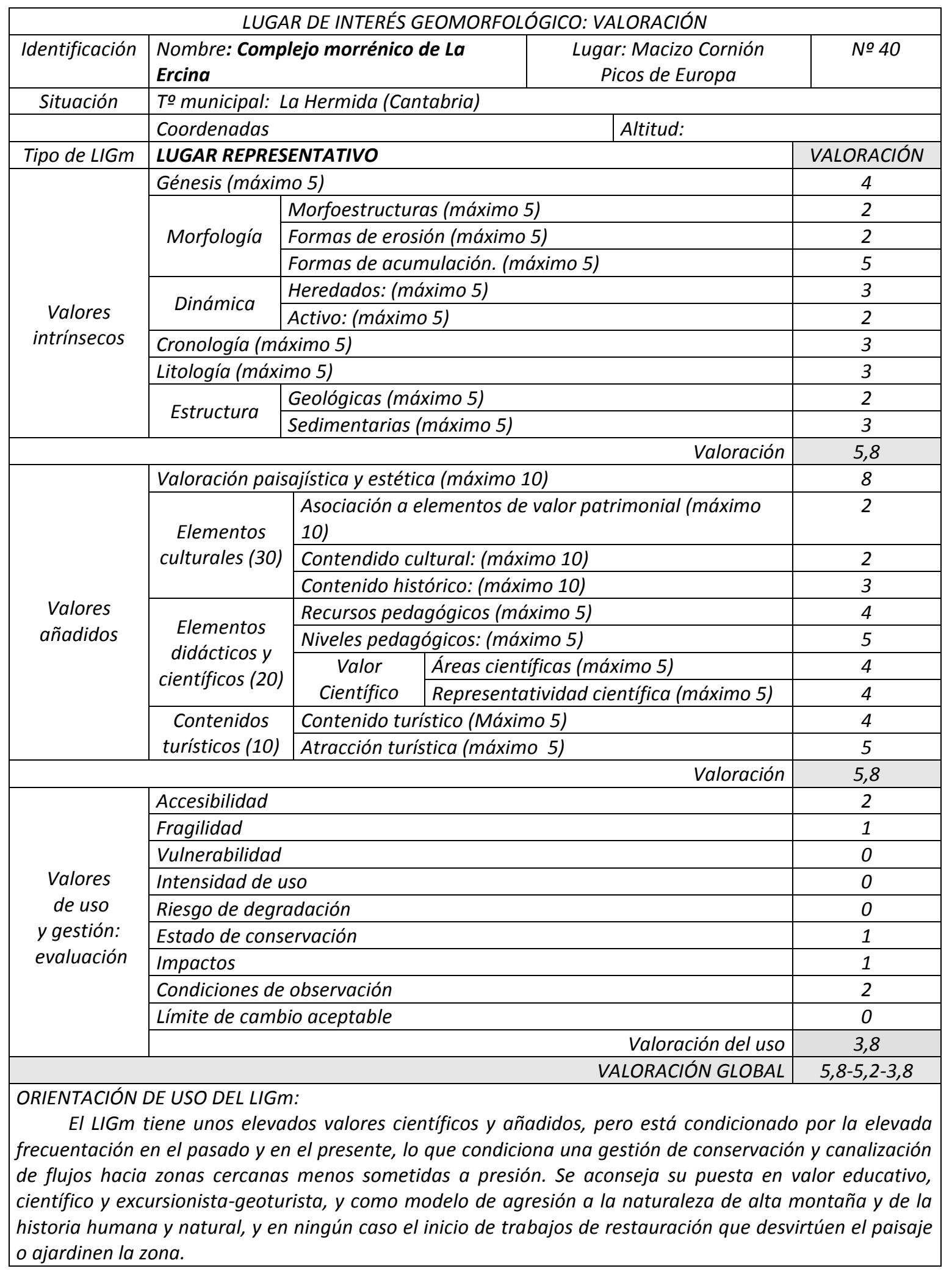




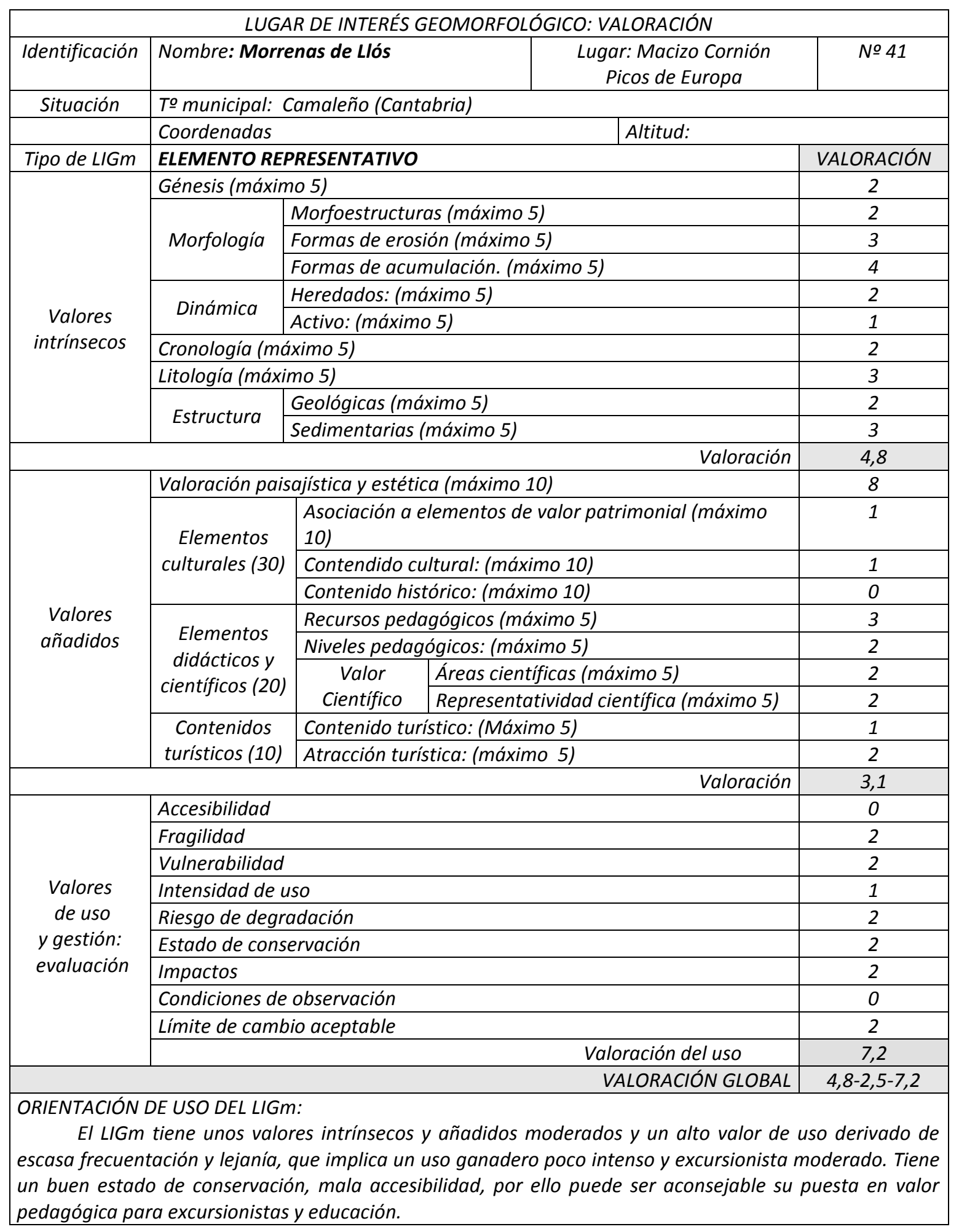




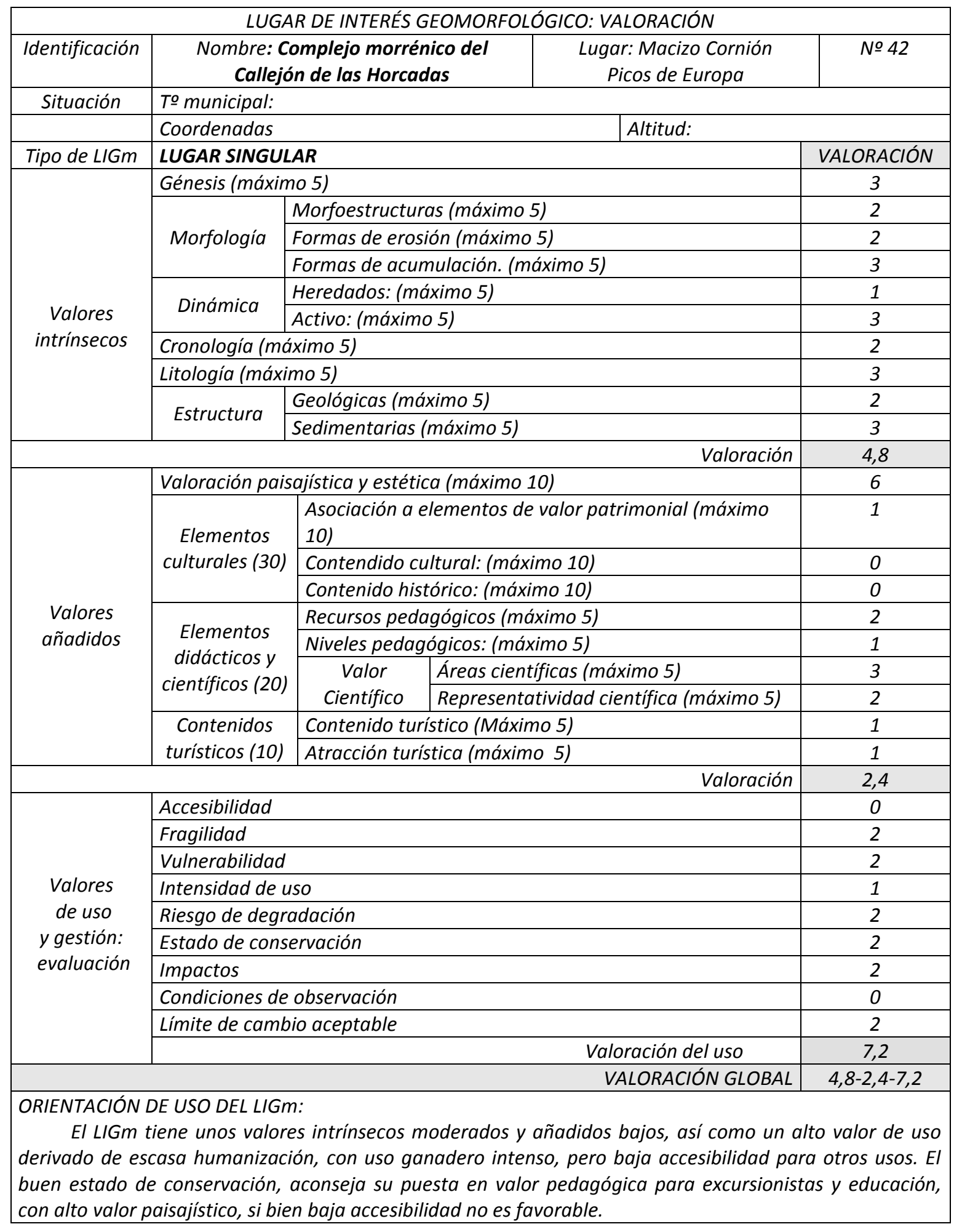




\begin{tabular}{|c|c|c|c|c|c|}
\hline \multicolumn{6}{|c|}{ LUGAR DE INTERÉS GEOMORFOLÓGICO: VALORACIÓN } \\
\hline Identificación & \multicolumn{3}{|c|}{ Nombre: Helero de La Forcadona } & $\begin{array}{l}\text { r: Macizo Cornión } \\
\text { cos de Europa }\end{array}$ & No 43 \\
\hline \multirow[t]{2}{*}{ Situación } & \multicolumn{5}{|l|}{ To municipal: } \\
\hline & \multicolumn{3}{|l|}{ Coordenadas: } & \multicolumn{2}{|l|}{ Altitud: } \\
\hline Tipo de LIGm & \multicolumn{4}{|c|}{ ELEMENTO SINGULAR } & VALORACIÓN \\
\hline \multirow{10}{*}{$\begin{array}{l}\text { Valores } \\
\text { intrínsecos }\end{array}$} & \multicolumn{4}{|c|}{ Génesis (máximo 5) } & 1 \\
\hline & \multirow{3}{*}{ Morfología } & \multicolumn{3}{|c|}{ Morfoestructuras (máximo 5) } & 1 \\
\hline & & \multicolumn{3}{|c|}{ Formas de erosión (máximo 5) } & 2 \\
\hline & & \multicolumn{3}{|c|}{ Formas de acumulación. (máximo 5) } & 2 \\
\hline & \multirow{2}{*}{ Dinámica } & \multicolumn{3}{|c|}{ Heredados: (máximo 5) } & 1 \\
\hline & & \multicolumn{3}{|c|}{ Activo: (máximo 5) } & 2 \\
\hline & \multicolumn{4}{|c|}{ Cronología ( máximo 5) } & 2 \\
\hline & \multicolumn{4}{|c|}{ Litología (máximo 5) } & 2 \\
\hline & \multirow{2}{*}{ Estructura } & \multicolumn{3}{|c|}{ Geológicas (máximo 5) } & 1 \\
\hline & & \multicolumn{3}{|c|}{ Sedimentarias (máximo 5) } & 1 \\
\hline \multirow{11}{*}{$\begin{array}{l}\text { Valores } \\
\text { añadidos }\end{array}$} & \multicolumn{4}{|r|}{ Valoración } & 3 \\
\hline & \multicolumn{4}{|c|}{ Valoración paisajística y estética (máximo 10) } & 4 \\
\hline & \multirow{3}{*}{$\begin{array}{c}\text { Elementos } \\
\text { culturales (30) }\end{array}$} & \multicolumn{3}{|c|}{$\begin{array}{l}\text { Asociación a elementos de valor patrimonial } \\
\text { (máximo 10) }\end{array}$} & 0 \\
\hline & & \multicolumn{3}{|c|}{ Contendido cultural: (máximo 10) } & 0 \\
\hline & & Contenido & istóric & 10) & 1 \\
\hline & & Recursos $p$ & dagós & 10 5) & 1 \\
\hline & Elementos & Niveles pec & agógic & 5) & 2 \\
\hline & $\begin{array}{l}\text { didacticos y } \\
\text { científicos }(20)\end{array}$ & Valor & Área & (máximo 5) & 2 \\
\hline & & Científico & Repr & d científica (máx. 5) & 4 \\
\hline & Contenidos & Contenido & uristic & & 0 \\
\hline & turísticos (10) & Atracción t & urísticc & & 0 \\
\hline & & & & Valoración & 2 \\
\hline & Accesibilidad & & & & 0 \\
\hline & Fragilidad & & & & 2 \\
\hline & Vulnerabilidad & & & & 2 \\
\hline Valores & Intensidad de u & & & & 2 \\
\hline de uso & Riesgo de degr & adación & & & 2 \\
\hline y gestión: & Estado de cons & servación & & & 2 \\
\hline evaluación & Impactos & & & & 2 \\
\hline & Condiciones de & observación & & & 0 \\
\hline & Límite de camb & bio aceptable & & & 2 \\
\hline & & & & Valoración del uso & 7,7 \\
\hline & & & & ALORACIÓN GLOBAL & $3-1,7-7,7$ \\
\hline $\begin{array}{r}\text { ORIENTACIÓN } \\
\text { EI LIGm } \\
\text { intrínseco prov } \\
\text { Picos de Europ } \\
\text { Picos de Europ } \\
\text { escasos. Las } \\
\text { una Ilegada } \\
\text { situación en cl } \\
\text { terminal, le } h \\
\text { posible elevad }\end{array}$ & $\begin{array}{l}\text { DE USO DEL LIGn } \\
\text { e encuentra en } \\
\text { ene de la exister } \\
\text { a sino en toda I } \\
\text { a. Por tanto, pos } \\
\text { racterísticas del } \\
\text { asiva de turista } \\
\text { ro desequilibrio } \\
\text { cen elementos } \\
\text { frecuentación. }\end{array}$ & $\begin{array}{l}\text { m: } \\
\text { una de las z } \\
\text { ncia del heler } \\
\text { la Península } \\
\text { see un gran i } \\
\text { I LIGm le ha } \\
\text { ys implicaría } \\
\text { natural, dao } \\
\text { especialmen }\end{array}$ & $\begin{array}{l}\text { onas } n \\
\text { y la } \\
\text { bérica, } \\
\text { terés } \\
\text { en un } \\
\text { una p } \\
\text { o que } \\
\text { e sen. }\end{array}$ & $\begin{array}{l}\text { bles del macizo occia } \\
\text { a PEH, singulares y es } \\
\text { existen en Pirineos, } \\
\text { ro los restantes valo } \\
\text { frecuentado y bien } \\
\text { ersible de sus valore } \\
\text { e encuentran en un } \\
\text { n su localización le }\end{array}$ & $\begin{array}{l}\text { ntal, y su valor } \\
\text { asas no sólo en } \\
\text { ierra Nevada y } \\
\text { s añadidos son } \\
\text { nservado, pero } \\
\text { intrínsecos. Su } \\
\text { tadio de fusión } \\
\text { rotege de una }\end{array}$ \\
\hline
\end{tabular}




\begin{tabular}{|c|c|c|c|c|}
\hline \multicolumn{5}{|c|}{ LUGAR DE INTERÉS GEOMORFOLÓGICO: VALORACIÓN } \\
\hline Identificación & \multicolumn{2}{|c|}{ Nombre: Cemba Vieya } & $\begin{array}{c}\text { Lugar: Macizo Cornión } \\
\text { Picos de Europa }\end{array}$ & № 44 \\
\hline \multirow[t]{2}{*}{ Situación } & \multicolumn{4}{|l|}{ To municipal: } \\
\hline & \multicolumn{2}{|l|}{ Coordenadas: } & Altitud: & \\
\hline Tipo de LIGm & \multicolumn{3}{|c|}{ LUGAR SINGULAR } & VALORACIÓN \\
\hline \multirow{10}{*}{$\begin{array}{l}\text { Valores } \\
\text { intrínsecos }\end{array}$} & \multicolumn{3}{|c|}{ Génesis (máximo 5) } & 2 \\
\hline & \multirow{3}{*}{ Morfología } & \multicolumn{2}{|c|}{ Morfoestructuras (máximo 5) } & 1 \\
\hline & & \multicolumn{2}{|c|}{ Formas de erosión (máximo 5) } & 1 \\
\hline & & \multicolumn{2}{|c|}{ Formas de acumulación. (máximo 5) } & 2 \\
\hline & \multirow{2}{*}{ Dinámica } & \multicolumn{2}{|c|}{ Heredados: (máximo 5) } & 1 \\
\hline & & \multicolumn{2}{|c|}{ Activo: (máximo 5) } & 2 \\
\hline & \multicolumn{3}{|c|}{ Cronología ( máximo 5) } & 2 \\
\hline & \multicolumn{3}{|c|}{ Litología (máximo 5) } & 1 \\
\hline & \multirow{2}{*}{ Estructura } & \multicolumn{2}{|c|}{ Geológicas (máximo 5) } & 1 \\
\hline & & \multicolumn{2}{|c|}{ Sedimentarias (máximo 5) } & 1 \\
\hline \multirow{11}{*}{$\begin{array}{l}\text { Valores } \\
\text { añadidos }\end{array}$} & & & Valoración & 2,8 \\
\hline & \multirow{4}{*}{$\begin{array}{l}\text { Valoración paise } \\
\text { Elementos } \\
\text { culturales (30) }\end{array}$} & sajística y est & ética (máximo 10) & 8 \\
\hline & & $\begin{array}{l}\text { Asociación } \\
\text { (máximo } 1\end{array}$ & $\begin{array}{l}\text { a elementos de valor patrimonial } \\
\text { D) }\end{array}$ & 0 \\
\hline & & Contendidc & cultural: (máximo 10) & 0 \\
\hline & & Contenido & histórico: (máximo 10) & 1 \\
\hline & \multirow{4}{*}{$\begin{array}{c}\text { Elementos } \\
\text { didácticos y } \\
\text { científicos (20) }\end{array}$} & \multicolumn{2}{|c|}{ Recursos pedagógicos (máximo 5) } & 2 \\
\hline & & \multicolumn{2}{|c|}{ Niveles pedagógicos: (máximo 5) } & 2 \\
\hline & & \multirow{2}{*}{\begin{tabular}{c|} 
Valor \\
Científico
\end{tabular}} & Áreas científicas (máximo 5) & 3 \\
\hline & & & Representatividad científica (máx.5) & 2 \\
\hline & Contenidos & Contenido & turístico: (Máximo 5) & 0 \\
\hline & turísticos (10) & Atracción $t$ & urística: (máximo 5) & 0 \\
\hline & & & Valoración & 2,5 \\
\hline & Accesibilidad & & & 0 \\
\hline & Fragilidad & & & 2 \\
\hline & Vulnerabilidad & & & 2 \\
\hline Valores & Intensidad de u & uso & & 2 \\
\hline de uso & Riesgo de degrc & adación & & 2 \\
\hline y gestión: & Estado de cons & servación & & 2 \\
\hline & Impactos & & & 2 \\
\hline & Condiciones de & observación & & 1 \\
\hline & Límite de camb & bio aceptable & & 2 \\
\hline & & & Valoración del uso & 8 \\
\hline & & & VALORACIÓN GLOBAL & $2,8-2,1-8$ \\
\hline $\begin{array}{l}\text { ORIENTACIÓN } \\
\text { EI LIGm } \\
\text { paisaje, pero r } \\
\text { proviene de la } \\
\text { frecuentado y } \\
\text { accesibilidad. }\end{array}$ & $\begin{array}{l}\text { DE USO DEL LIGn } \\
\text { se encuentra el } \\
\text { nuy inaccesible. } \\
\text { morrenas de Ic } \\
\text { ien conservado }\end{array}$ & $\begin{array}{l}\text { m: } \\
\text { Posee elem } \\
\text { la PEH y la } r \\
\text { por lo que ti }\end{array}$ & $\begin{array}{l}\text { muy visible, constituyendo un lugar e } \\
\text { entos representativos de gran valor, y } \\
\text { eciente desaparición de los glaciares. E} \\
\text { ene un elevado potencial de uso disminu }\end{array}$ & $\begin{array}{l}\text { nblemático del } \\
\text { su mayor valor } \\
\text { un lugar poco } \\
\text { ido por la mala }\end{array}$ \\
\hline
\end{tabular}




\begin{tabular}{|c|c|c|c|c|c|}
\hline \multicolumn{6}{|c|}{ LUGAR DE INTERÉS GEOMORFOLÓGICO: VALORACIÓN } \\
\hline Identificación & \multicolumn{3}{|c|}{$\begin{array}{l}\text { Nombre: Depresión de Belbín- la } \\
\text { Llomba }\end{array}$} & $\begin{array}{l}\text { Lugar: Macizo Cornión } \\
\text { Picos de Europa }\end{array}$ & NNo 45 \\
\hline Situación & \multicolumn{5}{|c|}{ To municipal: } \\
\hline & \multicolumn{3}{|l|}{ Coordenadas } & \multirow[t]{2}{*}{ Altitud: } & \\
\hline Tipo de LIGm & \multicolumn{3}{|c|}{ LUGAR REPRESENTATIVO } & & VALORACIÓN \\
\hline \multirow{10}{*}{$\begin{array}{l}\text { Valores } \\
\text { intrínsecos }\end{array}$} & \multicolumn{4}{|c|}{ Génesis (máximo 5) } & 3 \\
\hline & \multirow{3}{*}{ Morfología } & \multicolumn{3}{|c|}{ Morfoestructuras (máximo 5) } & 3 \\
\hline & & \multicolumn{3}{|c|}{ Formas de erosión (máximo 5) } & 4 \\
\hline & & \multicolumn{3}{|c|}{ Formas de acumulación. (máximo 5) } & 2 \\
\hline & \multirow{2}{*}{ Dinámica } & \multicolumn{3}{|c|}{ Heredados: (máximo 5) } & 2 \\
\hline & & \multicolumn{3}{|c|}{ Activo: (máximo 5) } & 2 \\
\hline & \multicolumn{4}{|c|}{ Cronología (máximo 5) } & 3 \\
\hline & \multicolumn{4}{|c|}{ Litología (máximo 5) } & 2 \\
\hline & \multirow{2}{*}{ Estructura } & \multicolumn{3}{|c|}{ Geológicas (máximo 5) } & 3 \\
\hline & & \multicolumn{3}{|c|}{ Sedimentarias (máximo 5) } & 2 \\
\hline \multirow{11}{*}{$\begin{array}{l}\text { Valores } \\
\text { añadidos }\end{array}$} & & & & Valoración & 5,6 \\
\hline & \multicolumn{4}{|c|}{ Valoración paisajística y estética (máximo 10) } & 6 \\
\hline & \multirow{3}{*}{$\begin{array}{c}\text { Elementos } \\
\text { culturales (30) }\end{array}$} & \multicolumn{3}{|c|}{$\begin{array}{l}\text { Asociación a elementos de valor patrimonial } \\
\text { (máximo 10) }\end{array}$} & 1 \\
\hline & & \multicolumn{3}{|c|}{ Contendido cultural: (máximo 10) } & 1 \\
\hline & & \multicolumn{3}{|c|}{ Contenido histórico: (máximo 10) } & 2 \\
\hline & \multirow{4}{*}{$\begin{array}{c}\text { Elementos } \\
\text { didácticos y } \\
\text { científicos (20) }\end{array}$} & Recursos $p$ & edagóg & náximo 5) & 4 \\
\hline & & Niveles pec & dagógic & áximo 5) & 4 \\
\hline & & Valor & Áreas & icas (máximo 5) & 5 \\
\hline & & Científico & Repres & vidad científica (máx. 5) & 3 \\
\hline & Contenidos & Contenido & turistic & (ximo 5) & 3 \\
\hline & turísticos (10) & Atracción t & turístice & ximo 5) & 3 \\
\hline & & & & Valoración & 4,5 \\
\hline & Accesibilidad & & & & 1 \\
\hline & Fragilidad & & & & 2 \\
\hline & Vulnerabilidad & & & & 2 \\
\hline & Intensidad de u & & & & 1 \\
\hline de uso & Riesgo de degr & adación & & & 1 \\
\hline y gestión: & Estado de cons & ervación & & & 2 \\
\hline evaluación & Impactos & & & & 1 \\
\hline & Condiciones de & observación & & & 2 \\
\hline & Límite de camb & io aceptable & & & 2 \\
\hline & & & & Valoración del uso & 7,7 \\
\hline & & & & VALORACIÓN GLOBAL & $5,6-4,5-7,7$ \\
\hline $\begin{array}{r}\text { ORIENTACIÓN } \\
\text { EI LIGm } \\
\text { media, por la I } \\
\text { que es aconsej }\end{array}$ & $\begin{array}{l}\text { DE USO DEL LIGn } \\
\text { iene unos valor } \\
\text { ejanía, por lo qu } \\
\text { able su potenciac }\end{array}$ & $\begin{array}{l}n: \\
\text { es intrínseco } \\
\text { e posee limit } \\
\text { ción como LIC }\end{array}$ & $\begin{array}{l}\text { s y año } \\
\text { tacione } \\
\text { Gm. }\end{array}$ & $\begin{array}{l}\text { moderados, así como unc } \\
\text { es alto el valor de uso y }\end{array}$ & $\begin{array}{l}\text { accesibilidad } \\
\text { gestión, por lo }\end{array}$ \\
\hline
\end{tabular}




\begin{tabular}{|c|c|c|c|c|}
\hline \multicolumn{5}{|c|}{ LUGAR DE INTERÉS GEOMORFOLÓGICO: VALORACIÓN } \\
\hline Identificación & \multicolumn{2}{|c|}{ Nombre: Polje de Comeya } & \begin{tabular}{|c|c|} 
& $\begin{array}{c}\text { Lugar: Macizo Cornión } \\
\text { Picos de Europa }\end{array}$ \\
\end{tabular} & № 46 \\
\hline Situación & \multicolumn{4}{|c|}{ To municipal: } \\
\hline & \multicolumn{2}{|l|}{ Coordenadas } & \multirow[t]{2}{*}{ Altitud: } & \\
\hline Tipo de LIGm & \multicolumn{2}{|c|}{ LUGAR REPRESENTATIVO } & & VALORACIÓN \\
\hline \multirow{10}{*}{$\begin{array}{l}\text { Valores } \\
\text { intrínsecos }\end{array}$} & \multicolumn{3}{|c|}{ Génesis (máximo 5) } & 4 \\
\hline & \multirow{3}{*}{ Morfología } & \multicolumn{2}{|c|}{ Morfoestructuras (máximo 5) } & 3 \\
\hline & & \multicolumn{2}{|c|}{ Formas de erosión (máximo 5) } & 1 \\
\hline & & \multicolumn{2}{|c|}{ Formas de acumulación. (máximo 5) } & 3 \\
\hline & \multirow{2}{*}{ Dinámica } & \multicolumn{2}{|c|}{ Heredados: (máximo 5) } & 4 \\
\hline & & \multicolumn{2}{|c|}{ Activo: (máximo 5) } & 3 \\
\hline & \multicolumn{3}{|c|}{ Cronología (máximo 5) } & 3 \\
\hline & \multicolumn{3}{|c|}{ Litología (máximo 5) } & 3 \\
\hline & \multirow{2}{*}{ Estructura } & \multicolumn{2}{|c|}{ Geológicas (máximo 5) } & 3 \\
\hline & & \multicolumn{2}{|c|}{ Sedimentarias (máximo 5) } & 4 \\
\hline \multirow{11}{*}{$\begin{array}{l}\text { Valores } \\
\text { añadidos }\end{array}$} & & & Valoración & 5,6 \\
\hline & \multirow{4}{*}{$\begin{array}{c}\text { Valoración paisc } \\
\text { Elementos } \\
\text { culturales (30) }\end{array}$} & sajística y est & ética (máximo 10) & 6 \\
\hline & & $\begin{array}{l}\text { Asociación } \\
\text { (máximo 1 }\end{array}$ & $\begin{array}{l}\text { a elementos de valor patrimonial } \\
\text { ) }\end{array}$ & 3 \\
\hline & & Contendidc & cultural: (máximo 10) & 3 \\
\hline & & Contenido & histórico: (máximo 10) & 2 \\
\hline & \multirow{4}{*}{$\begin{array}{c}\text { Elementos } \\
\text { didácticos y } \\
\text { científicos (20) }\end{array}$} & \multicolumn{2}{|c|}{ Recursos pedagógicos (máximo 5) } & 2 \\
\hline & & \multicolumn{2}{|c|}{ Niveles pedagógicos: (máximo 5) } & 1 \\
\hline & & \multirow{2}{*}{$\begin{array}{c}\text { Valor } \\
\text { Científico }\end{array}$} & Áreas científicas (máximo 5) & 3 \\
\hline & & & Representatividad científica (máx. 5) & 2 \\
\hline & \multirow{2}{*}{$\begin{array}{c}\text { Contenidos } \\
\text { turísticos (10) }\end{array}$} & Contenido & urístico: (Máximo 5) & 3 \\
\hline & & Atracción $t$ & urística: (máximo 5) & 3 \\
\hline & & & Valoración & 4 \\
\hline & Accesibilidad & & & 2 \\
\hline & Fragilidad & & & 1 \\
\hline & Vulnerabilidad & & & 1 \\
\hline Valores & Intensidad de $u$ & & & 2 \\
\hline de uso & Riesgo de degrc & adación & & 2 \\
\hline y gestión: & Estado de cons & ervación & & 2 \\
\hline evaluación & Impactos & & & 1 \\
\hline & Condiciones de & observación & & 2 \\
\hline & Límite de camb & io aceptable & & 1 \\
\hline & & & Valoración del uso & 7,7 \\
\hline & & & VALORACIÓN GLOBAL & $5,6-4-7,7$ \\
\hline $\begin{array}{l}\text { ORIENTACIÓN } \\
\text { Este L } \\
\text { valores, minel } \\
\text { preparación de } \\
\text { hacia un uso } \epsilon \\
\text { conservación } d\end{array}$ & $\begin{array}{l}\text { DE USO DEL LIGn } \\
\text { Gm tiene un mo } \\
\text { os, geomorfolós } \\
\text { la visita minero } \\
\text { ducativo, como } \\
\text { e los elementos } \epsilon\end{array}$ & $\begin{array}{l}n \text { : } \\
\text { oderado valo } \\
\text { gicos, paisaj } \\
\text {, le dotan } d \\
\text { el actual, co } \\
\text { existentes (no }\end{array}$ & $\begin{array}{l}\text { r intrínseco y añadido, pero la compler } \\
\text { ísticos y ambientales, junto a la acc } \\
\text { e un elevado potencial de uso. La orien } \\
\text { extensión a aspectos geomorfológicos } \\
\text { turales y humanos). }\end{array}$ & $\begin{array}{l}\text { nentariedad de } \\
\text { esibilidad y la } \\
\text { ación debe ser } \\
\text { priorizando la }\end{array}$ \\
\hline
\end{tabular}




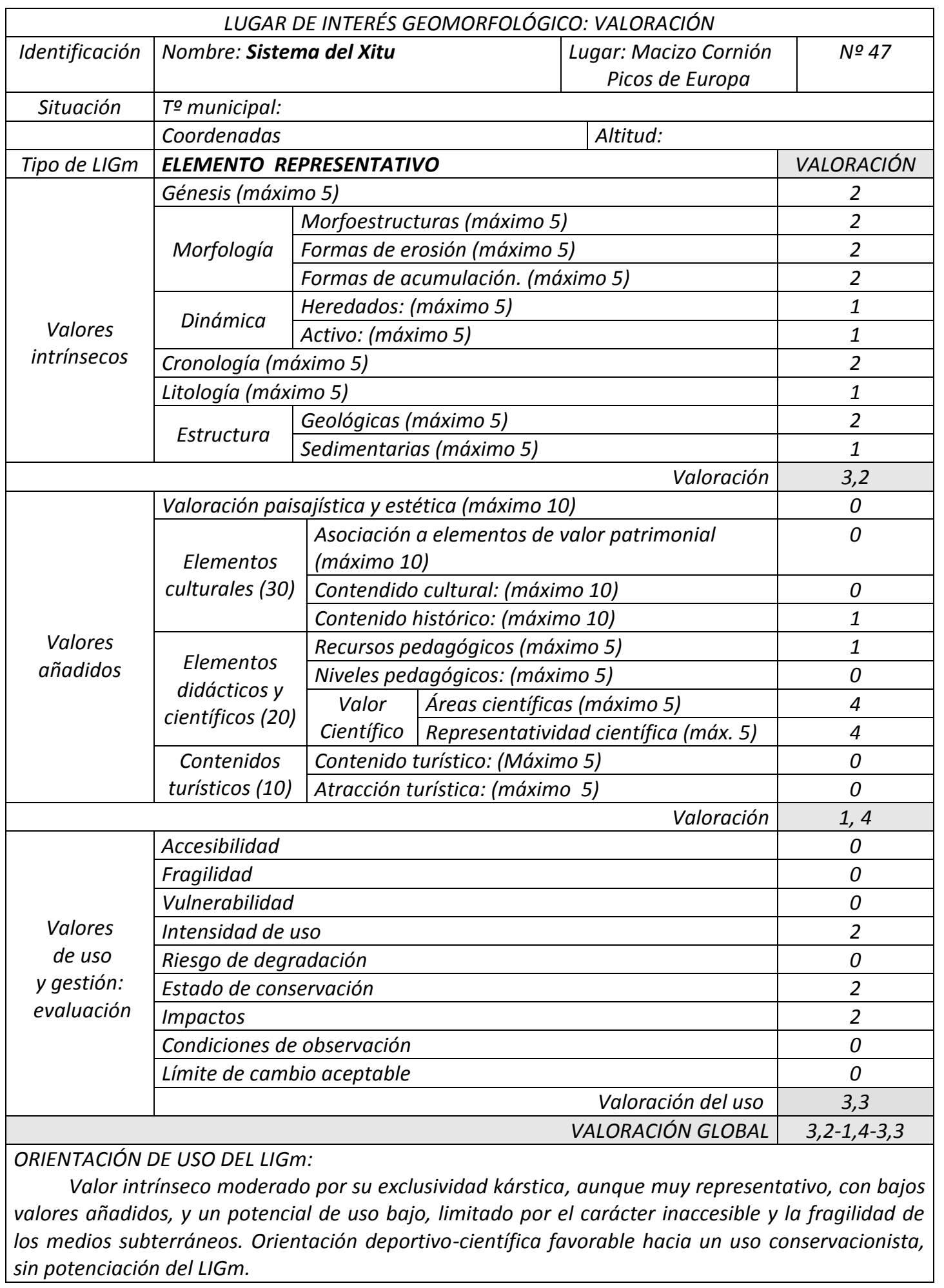




\begin{tabular}{|c|c|c|c|c|}
\hline \multicolumn{5}{|c|}{ LUGAR DE INTERÉS GEOMORFOLÓGICO: VALORACIÓN } \\
\hline Identificación & \multicolumn{2}{|c|}{ Nombre: Sistema Jultayu-Xitu } & \begin{tabular}{|l|c} 
tu & $\begin{array}{c}\text { Lugar: Macizo Cornión } \\
\text { Picos de Europa }\end{array}$ \\
\end{tabular} & No 48 \\
\hline \multirow[t]{2}{*}{ Situación } & \multicolumn{4}{|l|}{ To municipal: } \\
\hline & \multicolumn{2}{|l|}{ Coordenadas } & \multirow[t]{2}{*}{ Altitud: } & \\
\hline Tipo de LIGm & \multicolumn{2}{|c|}{ ELEMENTO REPRESENTATIVO } & & VALORACIÓN \\
\hline \multirow{10}{*}{$\begin{array}{l}\text { Valores } \\
\text { intrínsecos }\end{array}$} & \multicolumn{3}{|c|}{ Génesis (máximo 5) } & 2 \\
\hline & \multirow{3}{*}{ Morfología } & \multicolumn{2}{|c|}{ Morfoestructuras (máximo 5) } & 2 \\
\hline & & \multicolumn{2}{|c|}{ Formas de erosión (máximo 5) } & 2 \\
\hline & & \multicolumn{2}{|c|}{ Formas de acumulación. (máximo 5) } & 2 \\
\hline & \multirow{2}{*}{ Dinámica } & \multicolumn{2}{|c|}{ Heredados: (máximo 5) } & 1 \\
\hline & & \multicolumn{2}{|c|}{ Activo: (máximo 5) } & 1 \\
\hline & \multicolumn{3}{|c|}{ Cronología (máximo 5) } & 2 \\
\hline & \multicolumn{3}{|c|}{ Litología (máximo 5) } & 1 \\
\hline & \multirow{2}{*}{ Estructura } & \multicolumn{2}{|c|}{ Geológicas (máximo 5) } & 2 \\
\hline & & \multicolumn{2}{|c|}{ Sedimentarias (máximo 5) } & 1 \\
\hline & & & Valoración & 3,2 \\
\hline \multirow{10}{*}{$\begin{array}{l}\text { Valores } \\
\text { añadidos }\end{array}$} & \multicolumn{3}{|c|}{ Valoración paisajística y estética (máximo 10) } & 0 \\
\hline & \multirow{3}{*}{\begin{tabular}{|c|} 
Elementos \\
culturales (30)
\end{tabular}} & \multicolumn{2}{|c|}{$\begin{array}{l}\text { Asociación a elementos de valor patrimonial } \\
\text { (máximo 10) }\end{array}$} & 0 \\
\hline & & \multicolumn{2}{|c|}{ Contendido cultural: (máximo 10) } & 0 \\
\hline & & \multicolumn{2}{|c|}{ Contenido histórico: (máximo 10) } & 1 \\
\hline & & Recursos $p$ & dagógicos (máximo 5) & 1 \\
\hline & Elementos & Niveles pec & agógicos: (máximo 5) & 0 \\
\hline & científicos (20) & Valor & Áreas científicas (máximo 5) & 4 \\
\hline & & Científico & Representatividad científica (máx. 5) & 4 \\
\hline & Contenidos & Contenido & urístico: (Máximo 5) & 0 \\
\hline & turísticos (10) & Atracción $t$ & urística: (máximo 5) & 0 \\
\hline & & & Valoración & 1,4 \\
\hline & Accesibilidad & & & 0 \\
\hline & Fragilidad & & & 0 \\
\hline & Vulnerabilidad & & & 0 \\
\hline Valores & Intensidad de u & & & 2 \\
\hline de uso & Riesgo de degro & adación & & 0 \\
\hline y gestión: & Estado de conse & ervación & & 2 \\
\hline evaluación & Impactos & & & 2 \\
\hline & Condiciones de & observación & & 0 \\
\hline & Límite de camb & io aceptable & & 0 \\
\hline & & & Valoración del uso & 3,3 \\
\hline & & & VALORACIÓN GLOBAL & $3,2-1,4-3,3$ \\
\hline $\begin{array}{l}\text { ORIENTACIÓN } \\
\text { Valor in } \\
\text { bajos valores a } \\
\text { de los medi } \\
\text { conservacionis }\end{array}$ & $\begin{array}{l}\text { DE USO DEL LIGm } \\
\text { trínseco modero } \\
\text { ñadidos, y un pot } \\
\text { os subterráneos } \\
\text { a, sin potenciaci }\end{array}$ & $\begin{array}{l}n: \\
\text { ado por su } \\
\text { tencial de us } \\
\text { s. Orient } \\
\text { ión del LIGm. }\end{array}$ & $\begin{array}{l}\text { xclusividad kárstica, aunque muy repr } \\
\text { bajo, limitado por el carácter inaccesibl } \\
\text { ción deportivo-científica favorable }\end{array}$ & $\begin{array}{l}\text { esentativo, con } \\
\text { e y la fragilidad } \\
\text { hacia un uso }\end{array}$ \\
\hline
\end{tabular}




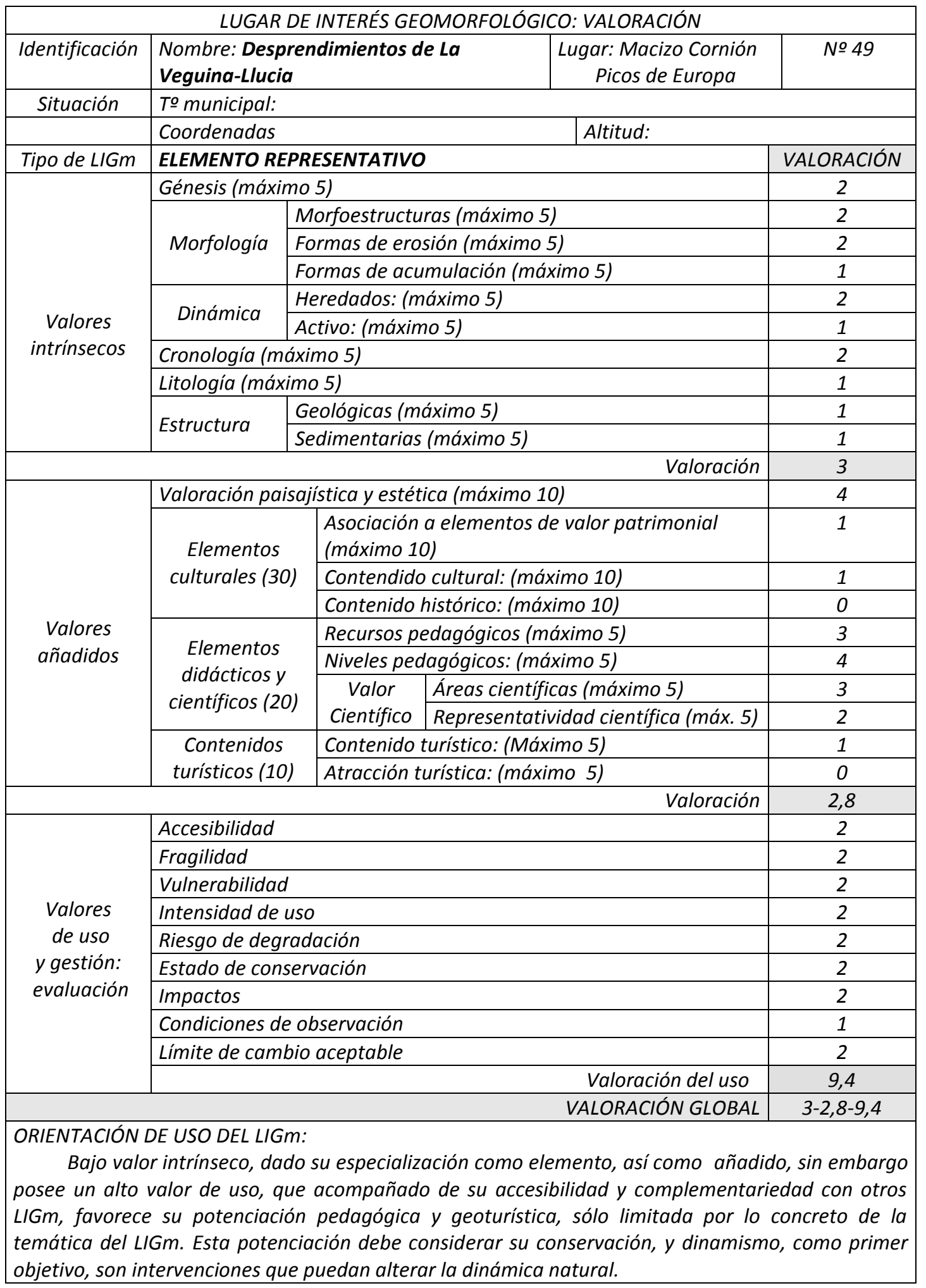




\begin{tabular}{|c|c|c|c|c|}
\hline \multicolumn{5}{|c|}{ LUGAR DE INTERÉS GEOMORFOLÓGICO: VALORACIÓN } \\
\hline Identificación & \multicolumn{2}{|c|}{ Nombre: Gueyos de Junjumia } & \begin{tabular}{l|c} 
a & $\begin{array}{c}\text { Lugar: Macizo Cornión } \\
\text { Picos de Europa }\end{array}$ \\
\end{tabular} & No 50 \\
\hline Situación & \multicolumn{4}{|c|}{ To municipal: } \\
\hline & \multicolumn{2}{|l|}{ Coordenadas } & \multirow[t]{2}{*}{ Altitud: } & \\
\hline Tipo de LIGm & \multicolumn{2}{|c|}{ ELEMENTO SINGULAR } & & VALORACIÓN \\
\hline \multirow{10}{*}{$\begin{array}{l}\text { Valores } \\
\text { intrínsecos }\end{array}$} & \multicolumn{3}{|c|}{ Génesis (máximo 5) } & 1 \\
\hline & \multirow{3}{*}{ Morfología } & \multicolumn{2}{|c|}{ Morfoestructuras (máximo 5) } & 1 \\
\hline & & \multicolumn{2}{|c|}{ Formas de erosión (máximo 5) } & 1 \\
\hline & & \multicolumn{2}{|c|}{ Formas de acumulación. (máximo 5) } & 0 \\
\hline & \multirow{2}{*}{ Dinámica } & \multicolumn{2}{|c|}{ Heredados: (máximo 5) } & 0 \\
\hline & & \multicolumn{2}{|c|}{ Activo: (máximo 5) } & 1 \\
\hline & \multicolumn{3}{|c|}{ Cronología (máximo 5) } & 1 \\
\hline & \multicolumn{3}{|c|}{ Litología (máximo 5) } & 1 \\
\hline & \multirow{2}{*}{ Estructura } & \multicolumn{2}{|c|}{ Geológicas (máximo 5) } & 1 \\
\hline & & \multicolumn{2}{|c|}{ Sedimentarias (máximo 5) } & 0 \\
\hline \multirow{11}{*}{$\begin{array}{l}\text { Valores } \\
\text { añadidos }\end{array}$} & & & Valoración & 1,4 \\
\hline & \multicolumn{3}{|c|}{ Valoración paisajística y estética (máximo 10) } & 2 \\
\hline & \multirow{3}{*}{$\begin{array}{c}\text { Elementos } \\
\text { culturales (30) }\end{array}$} & \multicolumn{2}{|c|}{$\begin{array}{l}\text { Asociación a elementos de valor patrimonial } \\
\text { (máximo 10) }\end{array}$} & 1 \\
\hline & & \multicolumn{2}{|c|}{ Contendido cultural: (máximo 10) } & 1 \\
\hline & & \multicolumn{2}{|c|}{ Contenido histórico: (máximo 10) } & 0 \\
\hline & & \multicolumn{2}{|c|}{ Recursos pedagógicos (máximo 5) } & 2 \\
\hline & Elementos & Niveles ped & agógicos (máximo 5) & 3 \\
\hline & didacticos y & Valor & Áreas científicas (máximo 5) & 2 \\
\hline & & Científico & Representatividad científica (máx. 5) & 1 \\
\hline & Contenidos & Contenido & urístico: (Máximo 5) & 1 \\
\hline & turísticos (10) & Atracción t & urística: (máximo 5) & 0 \\
\hline Valoración & & & & 1,9 \\
\hline & Accesibilidad & & & 1 \\
\hline & Fragilidad & & & 0 \\
\hline & Vulnerabilidad & & & 0 \\
\hline Valores & Intensidad de u & uso & & 2 \\
\hline de uso & Riesgo de degrc & adación & & 0 \\
\hline y gestión: & Estado de cons & servación & & 2 \\
\hline evaluación & Impactos & & & 2 \\
\hline & Condiciones de & observación & & 2 \\
\hline & Límite de camb & bio aceptable & & 1 \\
\hline & & & Valoración del uso & 5 \\
\hline & & & VALORACIÓN GLOBAL & $1,4-1,9-5$ \\
\hline $\begin{array}{r}\text { ORIENTACIÓN } \\
\text { Elementc } \\
\text { con bajos valo } \\
\text { conservación y }\end{array}$ & $\begin{array}{l}\text { E USO DEL LIGn } \\
\text { menor, de valo } \\
\text { res añadidos y } \\
\text { potenciar el uso }\end{array}$ & $\begin{array}{l}\text { m: } \\
\text { r primordialn } \\
\text { moderado } p \\
\text { pedagógico }\end{array}$ & $\begin{array}{l}\text { ente hidrológico, por lo que su valor in } \\
\text { otencial de uso, como elemento debe } \\
\text { n torno a la posible frecuentación desd }\end{array}$ & $\begin{array}{l}\text { rínseco es bajo, } \\
\text { mantenerse su } \\
\text { el refugio. }\end{array}$ \\
\hline
\end{tabular}




\begin{tabular}{|c|c|c|c|c|}
\hline \multicolumn{5}{|c|}{ LUGAR DE INTERÉS GEOMORFOLÓGICO: VALORACIÓN } \\
\hline Identificación & \multicolumn{2}{|c|}{ Nombre: Fuentes de La Farfada } & \begin{tabular}{|c|c} 
Ida & $\begin{array}{c}\text { Lugar: Macizo Cornión } \\
\text { Picos de Europa }\end{array}$ \\
\end{tabular} & № 51 \\
\hline \multirow[t]{2}{*}{ Situación } & \multicolumn{4}{|l|}{ To municipal: } \\
\hline & \multicolumn{2}{|l|}{ Coordenadas } & \multirow[t]{2}{*}{ Altitud: } & \\
\hline Tipo de LIGm & \multicolumn{2}{|c|}{ ELEMENTO SINGULAR } & & VALORACIÓN \\
\hline \multirow{10}{*}{$\begin{array}{l}\text { Valores } \\
\text { intrínsecos }\end{array}$} & \multicolumn{3}{|c|}{ Génesis (máximo 5) } & 2 \\
\hline & \multirow{3}{*}{ Morfología } & \multicolumn{2}{|c|}{ Morfoestructuras (máximo 5) } & 1 \\
\hline & & \multicolumn{2}{|c|}{ Formas de erosión (máximo 5) } & 1 \\
\hline & & \multicolumn{2}{|c|}{ Formas de acumulación. (máximo 5) } & 0 \\
\hline & \multirow{2}{*}{ Dinámica } & \multicolumn{2}{|c|}{ Heredados: (máximo 5) } & 0 \\
\hline & & \multicolumn{2}{|c|}{ Activo: (máximo 5) } & 1 \\
\hline & \multicolumn{3}{|c|}{ Cronología (máximo 5) } & 1 \\
\hline & \multicolumn{3}{|c|}{ Litología (máximo 5) } & 2 \\
\hline & \multirow{2}{*}{ Estructura } & \multicolumn{2}{|c|}{ Geológicas (máximo 5) } & 2 \\
\hline & & \multicolumn{2}{|c|}{ Sedimentarias (máximo 5) } & 2 \\
\hline \multirow{11}{*}{$\begin{array}{l}\text { Valores } \\
\text { añadidos }\end{array}$} & & & Valoración & 2,4 \\
\hline & \multicolumn{3}{|c|}{ Valoración paisajística y estética (máximo 10) } & 0 \\
\hline & \multirow{3}{*}{$\begin{array}{l}\text { Elementos } \\
\text { culturales (30) }\end{array}$} & \multicolumn{2}{|c|}{$\begin{array}{l}\text { Asociación a elementos de valor patrimonial } \\
\text { (máximo 10) }\end{array}$} & 0 \\
\hline & & \multicolumn{2}{|c|}{ Contendido cultural: (máximo 10) } & 0 \\
\hline & & \multicolumn{2}{|c|}{ Contenido histórico: (máximo 10). } & 0 \\
\hline & & Recursos $p$ & edagógicos (máximo 5). & 2 \\
\hline & Elementos & Niveles pec & lagógicos: (máximo 5) & 2 \\
\hline & didacticos y & Valor & Áreas científicas (máximo 5) & 3 \\
\hline & & Científico & Representatividad científica (máx. 5) & 1 \\
\hline & Contenidos & Contenido & turístico: (Máximo 5) & 1 \\
\hline & turísticos $(10)$ & Atracción $t$ & urística: (máximo 5) & 1 \\
\hline & & & Valoración & 1,4 \\
\hline & Accesibilidad & & & 0 \\
\hline & Fragilidad & & & 0 \\
\hline & Vulnerabilidad & & & 0 \\
\hline Valores & Intensidad de $\iota$ & uso & & 2 \\
\hline de uso & Riesgo de degr & radación & & 2 \\
\hline y gestión: & Estado de cons & servación & & 2 \\
\hline evaluación & Impactos & & & 2 \\
\hline & Condiciones de & e observación & & 0 \\
\hline & Límite de camb & bio aceptable & & 0 \\
\hline & & & Valoración del uso & 4,4 \\
\hline & & & VALORACIÓN GLOBAL & $2,4-1,4-4,4$ \\
\hline $\begin{array}{r}\text { ORIENTACIÓN } \\
\text { Element } \\
\text { con bajos valo } \\
\text { su uso y la bc } \\
\text { pedagógico pa }\end{array}$ & $\begin{array}{l}\text { DE USO DEL LIGr } \\
\text { menor, de valo } \\
\text { res añadidos y } n \\
\text { ja frecuentaciór } \\
\text { ra quien accede }\end{array}$ & $\begin{array}{l}m: \\
\text { or primordialme } \\
\text { noderado pote } \\
n, \text { por lo que } \\
\text { a la fuente. }\end{array}$ & $\begin{array}{l}\text { ente hidrológico, por lo que su valor intrí } \\
\text { ncial de uso. La inaccesibilidad, por lejar } \\
\text { debe mantenerse su conservación y po }\end{array}$ & $\begin{array}{l}\text { inseco es bajo, } \\
\text { nía condiciona } \\
\text { tenciar el uso }\end{array}$ \\
\hline
\end{tabular}

